UNIVERSIDADE DE BRASÍLIA

INSTITUTO DE CIÊNCIAS SOCIAIS

DEPARTAMENTO DE SOCIOLOGIA

CONTINUIDADES E RUPTURAS NO MERCADO DA DIFERENÇA: O CASO DA WORLD MUSIC

Autor: Pedro Martins de Menezes

Brasília, 2015 
UNIVERSIDADE DE BRASÍLIA

INSTITUTO DE CIÊNCIAS SOCIAIS

DEPARTAMENTO DE SOCIOLOGIA

CONTINUIDADES E RUPTURAS NO MERCADO DA DIFERENÇA: O CASO DA WORLD MUSIC

Autor: Pedro Martins de Menezes

Dissertação apresentada ao

Departamento de Sociologia da Universidade de Brasília/UnB como parte dos requisitos para a obtenção do título de Mestre.

Brasília, outubro de 2015 


\author{
UNIVERSIDADE DE BRASÍLIA \\ INSTITUTO DE CIÊNCIAS SOCIAIS \\ DEPARTAMENTO DE SOCIOLOGIA \\ PROGRAMA DE PÓS-GRADUAÇÃO EM SOCIOLOGIA
}

DISSERTAC̃̃O DE MESTRADO

\title{
CONTINUIDADES E RUPTURAS NO MERCADO DA DIFERENÇA: O CASO DA WORLD MUSIC
}

Autor: Pedro Martins de Menezes

Orientador: Doutor Edson Silva de Farias (UnB)

Banca: Prof. Doutor Edson Silva de Farias (SOL/UnB)

Prof. Doutor Fabrício Monteiro Neves (SOL/UnB)

Prof. Doutor Anderson Luís Nunes da Mata (TEL/UnB)

Prof. Doutor Stefan Fornos Klein (SOL/UnB) 


\section{AGRADECIMENTOS}

Trabalho de Pesquisa apoiado pelo CNPq.

Durante a escrita desse texto, acumulei dívidas impagáveis com muitas pessoas, e a essas devo meus sinceros agradecimentos.

Agradeço ao Departamento de Sociologia da Universidade de Brasília, por ter apostado nesse projeto de dissertação e ao CNPq pela bolsa de estudos que me concedeu durante o período do mestrado.

Agradeço às pessoas que leram versões preliminares desse trabalho, em congressos ou informalmente, e que me apontaram os caminhos que segui: os professores Elder Maia, Michel Nicolau Netto e Miqueli Michetti, e os amigos de sociologia e de vida Bruno Gontyjo, Danilo Oliveira, Felipe Tartas, Lucas Facó, Maurício Lages e Tiago Rodrigues. Agradeço também aos professores Anderson da Mata, Juliana Brás Dias e Stefan Klein pelas sugestões dadas na banca de qualificação e ao professor Fabrício Neves por ter aceitado participar da banca final.

Agradeço ao professor Edson Farias, que além de um grande orientador, é um grande amigo, que nos dá ânimo para seguir nessa jornada mítica que é a formação em sociologia.

E agradeço principalmente aos meus pais, Daniela e Ricardo, que insensatamente acreditam em mim sempre.

Muito obrigado a todas e todos. 


\section{RESUMO}

A história do conceito de diferença se divide em dois períodos: período exótico-colonial e período da diversidade-global. O primeiro se caracteriza por uma época violenta em que o conceito de diferença se interessou pelas ideias universais de unidade, homogeneidade, pureza e absolutismo. Já o segundo diz respeito a um momento em que se pregou a tolerância e a noção de diferença se aproximou das ideias particulares de multiplicidade, heterogeneidade, hibridismo e relativismo. Debruçando-se sobre essa passagem, o objetivo dessa dissertação é entender que relação se estabelece entre os dois períodos do conceito de diferença: continuidade ou ruptura? Ou seja, intenta-se aqui perceber se exótico-colonial e diversidade-global são momentos iguais ou opostos. O objeto onde se buscou uma resposta para essa pergunta foi a World Music: rótulo criado em 1987 por gravadoras inglesas que se refere à produção musical de países nãoocidentais com o objetivo de apresentá-la para o público ocidental. Sendo um estilo que tematiza não-ocidentais, mas criado por e para ocidentais, pode-se dizer que a World Music se interessa pela diferença. Mas qual conceito de diferença a World Music busca: o do período exótico-colonial ou o do período da diversidade-global? O estilo nasceu no segundo momento, portanto, se usa a ideia de diferença do primeiro, tem-se um indicativo de que há uma continuidade entre eles. Inversamente, se o rótulo evoca a noção de diferença do segundo, pode-se supor que uma ruptura se inscreve entre os dois. Por esse motivo, a World Music se configura como um bom laboratório para chegarmos a uma resposta para a nossa pergunta. $O$ texto que se segue é dividido em duas partes: na primeira é feito um resgate histórico do conceito de diferença, mostrando como essa noção passa de um período exótico-colonial para outro de diversidadeglobal. Na segunda se analisa o campo da World Music com o intuito de descobrir se o estilo adota a diferença do exótico-colonial, sugerindo a continuidade dos períodos, ou se abraça a diferença da diversidade-global em que nasceu, levando-nos a crer que há uma ruptura entre eles. No final, chega-se a conclusão de que a World Music cria uma ambivalência entre os dois períodos do conceito de diferença, mostrando que entre exótico-colonial e diversidade-global há tanto continuidade quanto ruptura.

Palavras-chave: Diferença; Exótico; Diversidade; World Music. 


\begin{abstract}
We can divide the history of the concept of difference in two periods: the colonial-exotic and the global-diversity. The former refers to a time of violence in which the concept of difference was related to the universal ideas of unity, homogeneity, purity, and absolutism. The later stands for a time in which those interested in the concept also advocated for tolerance, thus the concept became close to the particular ideas of multiplicity, heterogeneity, hybridism and relativism. Having this passage in mind, this work aims at understanding the relation between those two periods: is it a continuous movement or is it marked by discontinuities? That is, we intend here to find out if colonial-exotic and global-diversity are the same or opposite. To answer this question, we took World Music as an object of research: genre invented in 1987 by British labels that addresses the musical production of non-western countries. The objective of this name was to make this production consumable by western public. Since it is a genre that thematizes non-westerns, but created by and to westerns, we can say that World Music is interested in difference. But what concept of difference underlies World Music: the exotic-colonial or the global-diversity? The genre was born in the second moment, therefore, if it uses the idea of difference of the first, we can say there is a continuity between them. But if the genre evokes the notion of difference present in the second, we can suppose a discontinuity in this movement. This text consists of two parts: the first draws a historical sketch of the concept of difference. The second analyses the World Music field, aiming to know if the genre adopts the colonial-exotic difference, suggesting the continuity of the periods, or if embraces the global-diversity difference in where it was born, making us believe that there is a discontinuity between them. In the end, we conclude that World Music makes an ambivalence between the two periods of the concept of difference, showing that between colonialexotic and global diversity there is continuity and discontinuity.
\end{abstract}

Key-words: Difference; Exotic; Diversity; World Music. 
A coisa mais estranha em uma terra estranha é o estranho que vai lá visitá-la.

Albert Camus 


\section{Índice}

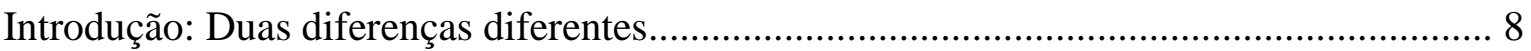

PARTE I: CONTINUIDADES E RUPTURAS NO MERCADO DA DIFERENÇA

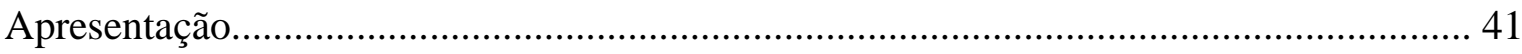

Capítulo 1: O período exótico-colonial do mercado da diferença........................................ 45

Capítulo 2: Transição: o filtro da igualdade....................................................................... 99

Capítulo 3: O período da diversidade-global do mercado da diferença............................ 121

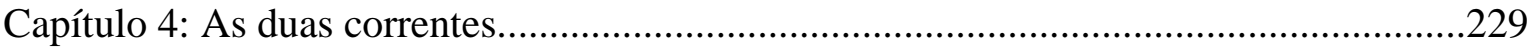

PARTE II: O CASO DA WORLD MUSIC.

Capítulo 5: O mundo da música e a música do mundo................................................... 259

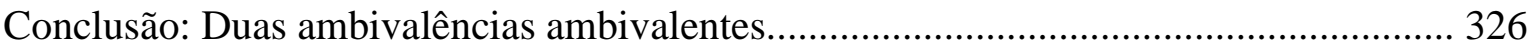

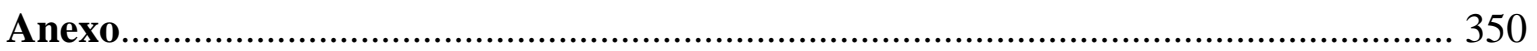

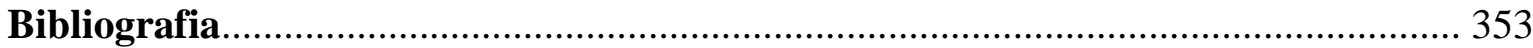




\section{Introdução}

\section{Duas diferenças diferentes}

A trajetória descrita pelo conceito de diferença se divide em dois períodos. $\mathrm{O}$ primeiro diz respeito a uma era colonial em que a diferença operava com uma separação fixa entre "Eu" e "Outro" e se organizava em torno da noção de exótico. Esse é um período em que a diferença estava ocupada das ideias universais de unidade, homogeneidade, pureza e absolutismo. O segundo período se refere a uma era global em que a diferença passa a manejar fluxos contínuos e a se reconhecer na noção de diversidade. Nesse novo momento, o glossário da diferença começa a ser preenchido pelos duplos daqueles antigos signos e, assim, o conceito se aproxima das ideias particulares de multiplicidade, heterogeneidade, hibridismo e relativismo.

Essa mudança no conceito de diferença marcada pela passagem do exótico-colonial para a diversidade-global foi recebida de duas maneiras divergentes: enquanto os que identificavam os dois momentos como opostos enxergavam uma ruptura na noção de diferença, aqueles que consideravam os dois estágios idênticos afirmavam ser contínuo o percurso que ela traçava. Os dois grupos divergiam tanto no plano conceitual quanto no plano político. $\mathrm{Na}$ arena conceitual, a briga se dava porque, de um lado, os defensores da ruptura advogavam que as noções particulares da diversidade-global de multiplicidade, heterogeneidade, hibridismo e relativismo representariam o túmulo das ideias universais do exótico-colonial de unidade, homogeneidade, pureza e absolutismo, e, de outro, aqueles que se filiavam à visão da continuidade achavam que essa nova gramática era apenas uma atualização farsesca da antiga. Já no campo político, a querela se dava em torno da balança liberdade/controle: enquanto o grupo da ruptura acreditava de maneira otimista que a diversidade-global inauguraria uma era de equilíbrio e equivalência, os que se filiavam à continuidade laconicamente diziam que a dominação imperialista do período exóticocolonial se perpetuaria nos anos de diversidade-global sob o abrigo de um novo discurso. Enfim, se para uns a passagem da diferença do exótico-colonial para a diversidade-global era uma revolução, para outros ela não passava de uma repetição.

Recuperando esse debate e conceituando a diferença como um mercado, em termos específicos, o problema de pesquisa dessa dissertação é perceber quais as continuidades e rupturas na noção de diferença quando esta passa de um período exótico-colonial para 
outro de diversidade-global. Em sentido mais amplo, o objetivo desse texto é identificar que relação se estabelece entre colonização e globalização: seriam esses períodos iguais ou diferentes? complementares ou opostos?

O objeto onde quero analisar essa problemática é o campo da World Music: rótulo criado pela indústria fonográfica na Inglaterra do final dos anos 1980 para se referir à produção musical do mundo não ocidental. Assim como a dominação imperialista representa um interesse europeu pelo resto do mundo típico do período exótico-colonial, o caso da World Music encarna uma curiosidade do Ocidente por seus "outros" própria da era da diversidade-global. Por conta disso, o esforço aqui é o de comparar aquele velho projeto político com esse novo fenômeno cultural para que se possa notar quais as proximidades e distâncias entre os dois instantes da ideia de diferença e que tipo de vínculo existe entre colonização e globalização.

O imperativo de se iniciar uma dissertação de mestrado atacando diretamente os pontos centrais da pesquisa me obrigou a reunir concisamente nos primeiros parágrafos as ideias que acompanharão todo o texto, mas, nas páginas seguintes dessa introdução será feita uma análise detalhada do que foi aqui rapidamente apresentando, intentando-se com isso justificar cada escolha teórico-metodológica.

A ideia de discurso é uma das noções mais caras ao glossário das ciências sociais. Se nos dispusermos a buscar a origem do conceito o mais provável é que nos percamos em um caminho tortuoso que conduz à própria origem da disciplina. Ainda que essa névoa espessa paire sobre o nascimento do termo, pode-se dizer que foi com o aparecimento do pós-estruturalismo na arena da investigação social, e mais especificamente com as contribuições trazidas pela obra de Michel Foucault, que o conceito de discurso ganhou a centralidade analítica que tem hoje. Em nossos dias, quando falamos em discurso, é com o pós-estruturalismo que temos que nos mediar e, certamente, dentro dessa bibliografia, Focault se apresenta como uma referência incontornável. A relação entre discurso e poder; o caráter histórico, arbitrário e contingencial da "verdade"; a busca por um "materialismo do incorporal" (2007) que oblitere o hiato entre empírico e simbólico; a reformulação do conceito de autor através de uma crítica à sua imanência atemporal bem como à sua 
anterioridade lógica e cronológica em relação ao texto que escreve (2001); etc. são alguns dos focos do interesse focualtiano. Com o passar do tempo, essas questões colocadas por Foucault se marcaram profundamente nas novas narrativas que surgiam acerca do social: estudos culturais, estudos pós-coloniais, feminismo, dentre outros são exemplos de textos que se debruçaram sobre o legado do filósofo interessados em perceber a dimensão discursiva de seus respectivos objetos de estudo.

Em paralelo a esse prestígio crescente do conceito de discurso, foi aparecendo uma grande inquietação com a ideia de "diferença". A noção de diferença sofreu tantas rearticulações ao longo do tempo que é até difícil conceber que a palavra tenha se conservado a mesma a despeito da infinidade de usos que dela se fez. A ambição de reconstruir a trilha genealógica dessas mudanças, desenhando uma cartografia temporal da diferença, passou a ocupar a cabeça de muitos pesquisadores das ciências sociais. Mesmo que nós ainda vivamos dias em que essa agenda se faz solidamente presente, hoje é possível olhar para o passado e dizer que houve (e ainda há) um imbricamento entre a relevância que a noção de diferença tinha na arena pública e a importância que a mesma ideia ia ganhando no debate das ciências sociais.

Como se pode ver, de um lado havia uma forte valorização do conceito de discurso, de outro, sustentada por uma articulação recíproca entre esfera pública e discussão acadêmica, verificava-se uma preocupação cada vez maior com a noção de diferença e com as mudanças que ela sofreu ao longo do tempo. Como não poderia deixar de ser, não tardaria para que o conceito e a agenda se encontrassem. Quando as duas valências se cruzaram, chegou-se a um cenário em que as várias esferas da vida se viram enredadas pelo que hoje se chama de "discurso da diferença".

Em um brilhante livro recentemente lançado, Nicolau Netto (2014) faz uma reconstrução sócio-genética do discurso da diferença, resgatando a trajetória que o termo descreveu do século XIX até os dias de hoje. De acordo com o autor, a história do discurso da diferença se divide em dois momentos:

O primeiro momento, que vai do final do século XIX até meados do século XX, diz respeito a uma era colonial em que a diferença estava ocupada da ideia de "exótico". Nesse período, o discurso operava com uma rígida fronteira entre "dentro" e "fora" ou "Eu" e 
"Outro". Os dois corpos eram diferentes entre si, mas indiferenciados dentro de seus próprios limites. Por se alicerçar em divisões estritas que demarcavam sólidas oposições binomiais e pares ontológicos imiscíveis, pode-se dizer que na época em que a diferença se organizava em torno da noção colonial de exótico, o discurso se prendia a termos estanques que lhe conferiam certa fixidez. Marcado por uma ideia generalista, totalitária e monista sobre "O Homem", esse era o tempo do universal.

O segundo momento, que começa na segunda metade do século XX e chega até os nossos dias, se configura como uma era global em que a diferença abraçou a noção de "diversidade". Esse é um período em que aqueles limites rigorosos ficaram borrados e se derreteram as velhas díades glaciais para que a antiga inércia do modelo cedesse lugar a um arranjo de fluxos velozes que se territorializavam por todas as partes. Acreditava-se que não havia mais um "lado de cá" e um "lado de lá", um "Eu" e um "Outro" pois os processos não cessavam de circular. Diminuía tanto a diferença que separava um polo do outro quanto a indiferença que constituía cada um dos polos. Nessa segunda era, aquela visão unicista e generalizada de Homem se pulverizava em uma variedade de fragmentos diferentes e idiossincráticos; desse modo, caia a ideia de uma natureza humana totalitária e nascia o interesse pelo específico, o contingencial, o contextual, o étnico, enfim, pelo polifônico. Por isso, ao invés da noção de universal, essa será a era do particular.

Dito de maneira definitiva, a discurso da diferença se dividiria em dois períodos:

(1) Período colonial do exótico ocupado do universal manejando pares conceituais fixos.

(2) Período global da diversidade ocupado do particular manejando grandes fluxos voláteis.

É com essa periodização e com os marcadores lógicos e temporais sugeridos por Nicolau Netto que eu irei trabalhar aqui. Cabe ressaltar que, para o autor, esse arranjo harmônico e simétrico não cumpre a função de uma ferramenta analítica, mas sim de um objeto analisado. Portanto, se aqui me escudo nesse sociólogo, não perco de vista que a "perfeição" da complementaridade dessas duas metades deve causar mais um estranhamento científico do que uma fácil adesão acrítica. As mudanças no discurso da diferença não são uma perspectiva de estudo, mas um tema estudado. 
Retomemos a divisão no discurso da diferença. Como foi dito, o primeiro momento, referente à ênfase colonialista no exótico, se enraizava nas ideias de universal e trabalhava com dois corpos lisos que se diferenciavam entre si para que pudessem se indiferenciar em si (Eu/Outro). Já o segundo momento, marcado por um acento global na diversidade, se aproximava do campo do particular e passava ao largo dos fossos que cindiam ontologias para que pudesse se filiar a um arranjo de processos que cruzavam todas as fronteiras. Quando a percepção dessa virada de página foi se cristalizando na política, na cultura e na universidade, rapidamente essas vozes começaram a atribuir características a cada um dos dois momentos discursivos, intentando compreender o real significado dessa mudança. Tendo em vista os respectivos traços aqui elencados, convencionou-se dizer que a primeira fase do discurso da diferença encarnava uma era universal de unidade, homogeneidade, pureza e absolutismo; em contrapartida, era de se esperar que a segunda fase do discurso da diferença inaugurasse um tempo particular de multiplicidade, heterogeneidade, hibridismo e relativismo. É nesse ponto que disputas acirradas começam a acontecer.

As opiniões acerca da dobra no discurso da diferença foram as mais extremadas possíveis. De um lado, afirmava-se que os dois períodos eram opostos; de outro, insistia-se na ideia de que nada mudou. Alguns "otimistas" enxergavam uma ruptura absoluta entre os dois momentos: para esses, o fim do tempo colonial do exótico representava o ocaso das ideias universais de unidade, homogeneidade, pureza e absolutismo e o início da era global da diversidade celebrava a aurora das noções particulares de multiplicidade, heterogeneidade, hibridismo e relativismo. Todavia, os mais "pessimistas" viam uma continuidade total entre os dois períodos: do ponto de vista desses, a marca universal da unidade, da homogeneidade, da pureza e do absolutismo, própria à era colonial do exótico, continuaria se imprimindo no tempo global da diversidade, e os conceitos particulares de multiplicidade, heterogeneidade, hibridismo e relativismo que tomavam conta dos debates não passavam de antigas fórmulas que se ressemantizavam de seus opostos para que a mágica niveladora e monista continuasse a operar. De um ponto de vista prático, os adeptos dessa corrente não consideravam nem que havia duas metades iguais, mas sim um mesmo continuum que exibia mudanças superficiais com o único intuito de perpetuar velhos mecanismos estruturais. Logicamente, entre essas duas escolas opostas se desenrolava um gradiente de opiniões intermediárias menos peremptórias. 
Se, por um lado, a queda de antigas ordens mundiais gerava alegria, por outro, causava desconfiança o fato de que velhas potencias coloniais estivessem se convertendo no berço da diversidade. Diante dessa disputa, surgiu uma dúvida referente à relação entre o universal (e suas ideias de unidade, homogeneidade, pureza e absolutismo) e o particular (e suas noções de multiplicidade, heterogeneidade, hibridismo e relativismo). Essa primeira interrogação era sustentada por outra de natureza mais política interessada em saber se essa mudança no discurso da diferença represtava a entrada em uma nova era de independência ou se tal virada se prestava apenas a atualizar antigas formas de dominação. Essas duas perguntas eram sintetizadas por uma terceira que questionava o real significado dessa mudança no discurso da diferença de um período colonial do exótico para uma era global da diversidade.

É preciso que olhemos com cuidado para essas três perguntas pois elas acompanharão esse texto até o final. Por isso, a seguir, irei desmembrá-las e fazer um comentário sobre cada uma para que se entenda o argumento. Retomando: dito de forma mais analítica, pode-se dizer que, quando o discurso da diferença passou da fase colonial do exótico para a fase global do diversidade, três perguntas principais surgiram. Chamarei essas perguntas respectivamente de conceitual, política, e sintética. Essas não são três interrogações que se sucedem linearmente, mas três círculos concêntricos de diâmetro crescente. Sendo assim, cada pergunta traz dentro de si a anterior e a última nada mais é que um enunciado abrangente que reúne as outras duas. Isso se dá porque, em último caso, não existe diferença entre esses três termos, já que se tratam de palavras indissociaveis. Mas, por uma questão de organização e para que se perceba o percurso metodológico aqui sugerido, eu optei por desmembrar a questão nessa estrutura espiralada. Dessa maneira, o que se tem aqui não são três perguntas diferentes, mas três entradas diferentes para a mesma pergunta. Todas elas giram em torno das continuidades e rupturas no discurso da diferença quando da passagem do período colonial do exótico para o global da diversidade.

Pergunta conceitual: A passagem do exótico-colonial para a diversidade-global significa uma mudança verdadeira das ideias universais de unidade, homogeneidade, pureza e absolutismo para as ideias particulares de multiplicidade, heterogeneidade, hibridismo e relativismo? 
Essa pergunta conceitual se debruça sobre a morfologia do mundo propriamente dita. Olhando para o conteúdo da história, a pergunta se interessa em saber se a ênfase da diversidade-global nas ideias particulares de múltiplo, heterogêneo, híbrido e relativo intenta construir de fato um mundo com essas características ou se essas palavras são apenas uma nova forma das ideias universais de unidade, homogeneidade, pureza e absolutismo, caras ao período exótico-colonial. De fato, houve uma mudança terminológica: os termos universais uno, homogêneo, puro e absoluto foram substituídos pelas ideias particulares de múltiplo, heterogêneo, hibrido e relativo. Mas que relação o novo glossário guarda com o anterior? Seriam os novos nomes o contrário dos antigos ou apenas um jeito diferente de dizer as mesmas coisas, ou melhor, um caminho obliquo para se atingir o mesmo ponto de antes?

Há uma preocupação epistemológica sublinhando essa dúvida. Como se falou, enquanto o exótico-colonial se enraizava em uma natureza humana única e generalizada, a diversidade-global fragmentava essa natureza obrigatória em uma série de culturas historicamente determinadas diferentes uma das outras. Ora, um discurso só pode versar sobre a materialidade na qual se baseia, portanto, operando esse paralelismo entre as palavras e as coisas, podemos dizer que um mundo onde existe apenas uma mesma natureza humana indiferenciada é dominado também por um único grande discurso sem rugosidades. Em contrapartida, se essa rocha que é a natureza humana for quebrada em uma multiplicidade de culturas diferentes, aquela grande voz monocórdia também se vê obrigada a se desmembrar em uma série de zumbidos heterogêneos. A correlação é muito simples: para uma única, grande e indiferenciada ontologia, um único, grande, e indiferenciado discurso. Do mesmo modo, para várias, pequenas e diferentes ontologias, vários, pequenos e diferentes discursos ${ }^{1}$.

Por causa desse raciocínio, muitos acharam que essa diluição do monolito da natureza humana em uma poeira cultural promovida pela passagem do exótico-colonial para a diversidade-global marcaria a mudança de uma era de grandes teorias únicas e gerais acerca da vida, do devir histórico e das totalizações baseadas em abstrações etéreas como "A Humanidade", "O Povo", "O Homem", "O Mundo", “A Razão” para um tempo

\footnotetext{
${ }^{1}$ Não que haja uma anterioridade lógica ou cronológica da ontologia em relação ao discurso. Para a tradição com que se dialoga aqui, palavra e coisa se constroem mutuamente numa espiral infinita de fabricação recíproca. Só coloquei nos termos acima empregados para que se evidenciasse essa correlação.
} 
de textos autocontidos e efêmeros. Sem o lastro da natureza humana, a grande narrativa fica sem objeto; do mesmo jeito, o aparecimento das várias culturas inaugura uma variedade de outros discursos. Mas, por surgirem enraizados no objeto que tematizam, cada um desses discursos tem a dimensão e a relevância da cultura sobre qual versam, ou seja: são limitados, efêmeros e autocontidos, posto que nenhum deles pode deitar seus enunciados sobre outro fragmento cultural que não o seu. Além disso, da mesma forma que não pode existir hierarquia entre as várias culturas, também não deve ter nenhum desnível nos discursos: por não existir púlpito no parlamento da diversidade, todas as falas são ouvidas no mesmo volume. Se o universalismo único, homogêneo, puro e absoluto da natureza humana se converte no particularismo múltiplo, heterogêneo, híbrido e relativo da variedade cultural, a grande Voz da Verdade se dilui em uma orquestra polifônica de sussurros. Bauman analisa muito bem essa dinâmica quando estuda a passagem do papel do intelectual de legislador para intérprete.

"A estratégia moderna do trabalho intelectual é aquela mais bem-caracterizada pela metáfora do papel do 'legislador'. Consiste em fazer afirmações autorizadas e autoritárias que arbitrem controvérsias de opiniões e escolham aquelas que, uma vez selecionadas, se tornem corretas e associativas. A autoridade para arbitrar é, nesse caso, legitimada por conhecimento (objetivo) superior, ao qual intelectuais têm mais acesso que a parte não intelectual da sociedade. Esse acesso se dá graças a regras de procedimento, garantindo que se alcance a verdade, que se chegue a um juízo moral válido e se selecione um gosto artístico apropriado. (...) [Já o papel do intérprete] Consiste em traduzir afirmações feitas no interior de uma tradição baseada em termos comunais, a fim de que sejam compreendidas no interior de um sistema de conhecimento fundamentado em outra tradição. Em vez de orientar-se para selecionar a melhor ordem social, essa estratégia objetiva facilitar a comunicação entre participantes autônomos (soberanos). Preocupa-se em impedir distorções de significado no processo de comunicação. Para este fim, promove a necessidade de penetrar em profundidade o sistema estrangeiro de conhecimento do qual a tradução deve ser feita (por exemplo, a 'descrição densa' de Geertz) e a necessidade de manter o delicado equilíbrio entre as duas tradições que interagem, indispensável tanto para a mensagem não ser distorcida (com relação ao significado investido pelo remetente) quanto para ela ser compreendida (pelo destinatário).” (BAUMAN, 2010, pp. 19 -21).

Mas, diante desse cenário, algumas interrogações começaram a aparecer: a substituição de uma natureza humana universal única, homogênea, pura e absoluta por uma variedade cultural particular múltipla, heterogênea, híbrida e relativa interessada no específico, no contingencial, no contextual e no étnico representa a queda das narrativas totalitárias e a ascensão de um pluralismo discursivo ou esses modestos relatos nativos 
ainda podem ser abraçados por uma grande teoria niveladora geral? Afinal, qual a relação entre especificidade e generalidade? Seriam esses termos opostos ou complementares? Escolher o específico necessariamente é recusar o geral ou, contrariamente, opta-se pelas especificidades só para que elas possam ser mais facilmente arregimentadas por um grande discurso? O específico é um caminho que nos leva para longe do geral ou uma curva que nos reconduz obliquamente a ele? Os estilhaços culturais que apareceram depois que a natureza humana foi despedaçada são pequenos cristais independentes ou partes de uma nova totalidade?

É esse o debate que alicerça essa pergunta. Recuperando a discussão: com a passagem do discurso da diferença do período exótico-colonial para o da diversidadeglobal, a ênfase depositada nas ideias universais de unidade, homogeneidade, pureza e absolutismo se transfere para as noções particulares de multiplicidade, heterogeneidade, hibridismo e relativismo. Trocando-se o universal pelo particular, a humanidade enterrava a era das grandes narrativas únicas e inaugurava o tempo dos múltiplos relatos contingenciais. Esse deslocamento seria possível porque nesse mesmo período o totem da natureza humana era diluído em um complexo cenário de variedade cultural. Como se acreditava em um paralelismo entre as palavras e as coisas que obrigava os discursos a terem sempre a silhueta da ontologia que tematizam, o despedaçamento da grande, única e homogênea natureza humana em uma nuvem de pequenas, muitas e heterogêneas culturas faria com que aquele texto totalitário e contínuo se quebrasse em uma profusão de metacomentários efêmeros. Diante de uma paisagem em que a fortaleza do monismo cede lugar a uma multiplicidade contingencial, o interesse no universal se transferiria para o particular e, de igual maneira, já que não se tem só uma, mas várias vozes, o absolutismo do monólogo sucumbiria ao relativismo do diálogo. Sai o discurso universal falando da natureza total de forma única, homogênea, pura e absoluta e surgem os discursos particulares falando de culturas parciais enredados no múltiplo, no heterogêneo, no híbrido e no relativo.

Esse raciocínio pode fazer bastante sentido, mas para que se concorde com ele é necessário que se aceite o pressuposto de que a ideia de particular é o oposto da de universal. Mas será que é mesmo? Abraçar um particularismo enraizado na multiplicidade, na heterogeneidade, no hibridismo e no relativismo é refutar um universalismo ocupado da 
unidade, da homogeneidade, da pureza e do absolutismo? E se as diferentes culturas que derivaram da fragmentação da indiferenciada natureza humana começarem a se agrupar em uma nova totalidade orgânica, tudo isso sem se ferir o novo cânone do particular? O interesse particularista pelo étnico e o contingente não pode virar uma nova ortodoxia universalmente cultivada? Da onde vem a certeza de que o particular não pode se converter em uma agenda universal como a natureza humana um dia o foi? Enfim: em linhas gerais, essa pergunta ambiciona descobrir que relação existe entre universal (e seu interesse pela unidade, a homogeneidade, a pureza e o absolutismo) e o particular (e seu apreço pela multiplicidade, a heterogeneidade, o hibridismo e o relativismo): seriam esses termos opostos, complementares, iguais, diferentes, etc.?

Pergunta política: A passagem do exótico-colonial para a diversidade-global significa a mudança de uma era de dominação e controle para um novo período de liberdade $e$ independência?

Baseada naquela alteração conceitual, surge um interesse político nas consequências práticas daquela passagem. Se a mudança no discurso da diferença de um período exótico-colonial para um da diversidade-global marca o abandono das ideias universais de unidade, homogeneidade, pureza e absolutismo em nome de uma preocupação particularista com a multiplicidade, a heterogeneidade, o hibridismo e o relativismo, que implicações políticas se pode esperar dessa virada? Um mundo com essas novas características será mais livre e igualitário que o período anterior, ou seria essa fragmentação o início de uma forma diferente de hegemonia? Novamente aqui se interroga: que relação se estabelece entre liberdade e controle? São termos que rivalizam, que se aproximam, imiscíveis, inseparáveis, etc.?

Pergunta síntese: Afinal, quais são as continuidades e rupturas no discurso da diferença quando da passagem do exótico-colonial para a diversidade-global? Ou seja, que relação se estabelece entre colonização e globalização?

Como pode ser percebido, todas essas perguntas almejam identificar o que muda e o que permanece na passagem de um estado para outro. Tentar descobrir o que fica e o que sai quando se abandona um período e se adentra em outro significa, basicamente, compreender que relação esses dois períodos mantêm entre si. Todas as interrogações se 
debruçam sobre binômios almejando compreender qual a natureza da relação de um polo com o outro: aproximam-se em harmonia e complementaridade ou se distanciam, esgarçando-se em rivalidade?

Pois bem, o caso onde se quer observar essa mudança é o discurso da diferença e as duas partes com as quais esse processo de mutação joga são a fase exótico-colonial e a era da diversidade-global. Quando me interesso aqui pela relação entre os binômios particular/universal e as díades que essa contêm: unidade/multiplicidade, homogeneidade/heterogeneidade, pureza/hibridismo, relativismo/absolutismo, ou sobre a subversão ou a permanência de antigas formas de poder, o que eu quero saber é quais são as continuidades e rupturas no discurso da diferença quando da sua passagem de um período exótico-colonial para uma era da diversidade-global. No fim das contas, dedicar-se a essa tarefa nada mais é que perguntar: que relação se estabelece entre colonização $e$ globalização? Seria a globalização o contrário da colonização ou apenas a atualização daquele período? Entrar na era global significava sair do tempo colonial ou somente adaptá-lo às novas circunstâncias? O que fica e o que muda na passagem de um período para o outro? Enfim (recuperando o mantra de dúvidas) seriam elas iguais ou opostos, complementares ou excludentes, harmonizam-se, rivalizam ou são indiferentes um ao outro? Por isso, essa terceira interrogação não é uma pergunta "a mais", mas apenas uma interrogação síntese que reúne dentro de si as duas anteriores de forma mais abrangente.

Inegavelmente, assistia-se a uma mudança de vocabulário: rearranjos na geopolítica internacional, no debate acadêmico e no campo da cultura se retroalimentavam fazendo com que o dicionário da diferença abandonasse o exótico, o colonial e o universal para aderir à diversidade, ao global e ao particular; mas o que essa virada lexical significava de fato? O diagnóstico acerca do exótico-colonial estava dado, restava saber se a diversidadeglobal seria seu avesso ou sua herdeira. Enquanto para uns a mudança no glossário do discurso da diferença indicava uma passagem, para outros a máquina girava sem sair do lugar.

A partir dessas questões assistiu-se ao nascimento de um debate de enorme profundidade onde as relevantes perguntas levantadas tanto explicavam quanto constituíam o presente. Contudo, e mais uma vez é Nicolau Netto quem chama a nossa atenção para isso, toda a riqueza dessa discussão perde o valor caso não se preste atenção a um elemento 
que subjaz a ela. Sob o risco de realizar uma semeadura no deserto, o pesquisador deve descer um degrau nas suas interrogações para enraizar suas perguntas sóciohistoricamente.

Mas que cuidado é esse que se dever tomar? É necessário que se retroceda um pouco na teoria das ciências sociais para entender: as pesquisas de Durkheim em religião (2003), a obra de Lévi-Strauss sobre pensamento selvagem e totemismo (2011), a Gramatologia de Derrida (2006) e a crítica pós-colonial podem ser narrativas completamente diferentes, mas uma característica que une todos esses projetos e tantos outros é a crença na ideia de que a diferença e os princípios de diferenciação não são algo natural, espontâneo e absoluto, mas sim construções sociais e culturais limitadas por um contexto espaço-temporal específico, e que, por esse motivo, variam dependendo do cenário. Embora muito elementar e importante (ou talvez por isso mesmo) esse preceito é constantemente negligenciado em nosso campo, e quando se esquece dessa lição o pesquisador acaba por cometer uma grande deslize: naturalizar a ideia de diferença. Portanto, se queremos seguir a trilha deixada por esses cânones, não podemos falar da diferença como se ela fosse um ente ahistórico pairando sobre nossas cabeças. Olhando para aquelas três perguntas acima elencadas, percebe-se que antes de fazê-las nós precisamos entender o que é essa diferença sobre a qual versamos, que trama de sentidos a enseja e qual a configuração sócio-histórica a possibilita.

"É necessário se perguntar como se nota a diferença, o que faz, em que momento e em que espaço, que algo seja percebido como diferente a algo. Não há nada de natural na diferença: ela é sempre uma construção que é apenas percebida - tem eficácia - na prática discursiva" (NICOLAU NETTO, 2014, p.9)

Para compreender a relação entre particular/universal, unidade/multiplicidade, homogeneidade/heterogeneidade, pureza/hibridismo, relativismo/absolutismo; para que se chegue a um diagnóstico acerca da balança liberdade/controle; para que se enxergue as continuidades e rupturas entre o período exótico-colonial e a era da diversidade-global; enfim, para entender a mudança no discurso da diferença é preciso saber o que é essa diferença sobre a qual tanto se fala. Levantar essas perguntas tão interessantes sem que primeiro se precise o entendimento que se faz do conceito de diferença não passa de um grande desperdício; e para que se chegue a uma noção clara do que se está chamando de diferença não cabe fazer uma hermenêutica internalista da palavra nem olhar para o céu em 
busca de um sentido atemporal, mas sim mapear a genealogia dos usos que são feitos do termo, situando-o numa configuração sócio-histórica.

Insisti na necessidade de que se conceitue "diferença" antes de se debater seus efeitos, suas características ou as consequências oriundas das mudanças em seu discurso. Porém, para os fins desse texto, esse cuidado deve sempre ser um trabalho de enraizar a diferença na configuração sócio-histórica que a possibilita, e nunca se converter no esforço metafísico que intenta chegar à "essência pura e imanente" da diferença. O simbólico não é uma venda que impede o pesquisador de enxergar o social; na verdade, ele é o aspecto do social que o sociólogo deseja ver ${ }^{2}$. É importante que se retenha essa distinção pois a busca por esse mitológico núcleo duro e por essa virginal concretude sagrada do que seja a diferença "afinal" é justamente o erro que tanto se quer evitar aqui, a saber: a naturalização e a autonomização da diferença.

E como se deve agir quando o que se ambiciona é definir a diferença pelo prisma da configuração que a possibilita sem que se caia no canto de sereia do absolutismo ontológico de uma pureza metafísica? A resposta é muito simples: deve-se identificar $o$ índice de diferença com alto capital de diferenciação e mapear as razões culturais e sóciohistóricas que fizeram com que ele agregasse aquele potencial. Essa sugestão é, para mim, a grande contribuição da obra de Nicolau Netto para esse debate, e munido dela sigo esse texto me acompanhando de outros autores.

Os índices de diferença nada mais são que indicadores de diferença, quer dizer, as variáveis que estão sendo consideradas para que se defina o que é o que não é diferente. Cada índice de diferença carrega em si um potencial variável de gerar diferença, ou seja, uma competência maior ou menor de marcar a diferença: índices de diferença fortes são aqueles que possuem uma grande capacidade de diferenciação; quando aparecem em um fenômeno, eles fazem com que este seja visto como mais diferente e, inversamente, quando esses mesmos elementos se omitem, o evento é tido como mais familiar.

\footnotetext{
${ }^{2}$ Said deixa isso muito claro no seu "Orientalismo": "Está claro, assim espero, que meu interesse pela autoridade não me leva à análise do que está oculto no texto orientalista, mas antes à análise da superfície do texto, sua exterioridade em relação ao que descreve. Nunca é demais enfatizar essa ideia." (SAID, 2013, p. 51)
} 
Por ser um indicador, o índice desliza em um gradiente quantitativo, o que faz com que ele seja um capital, no sentido que Pierre Bourdieu atribuiu ao termo (2007). Tendo isso em vista, podemos ver como é incorreto afirmar que "o índice tem diferença". Primeiro porque o verbo correto não é "tem" mas "provoca", já que estou aqui mais interessado nos efeitos que a diferença causa do que nas fantasmagóricas propriedades internas de um conceito ilhado. Segundo porque causar (alguma) diferença, qualquer coisa que não faça parte do mobiliário do nosso quarto causa. Sendo assim, a diferença não é um traço que "acontece" ou "não acontece" mas que acontece "muito" ou "pouco"; como se disse, tem-se aqui o quantum variável de um capital e não a instantaneidade de uma ontologia fixa. Portanto, ao invés de "o índice tem diferença" devemos dizer "o índice provoca muita diferença" e isso se dá porque ele é um índice de diferenciação forte, ou seja, um traço que carrega em si muito capital de diferenciação.

"A diversidade deve ser vista como um discurso que se baseia em índices de diferenciação que são necessariamente construídos na própria prática discursiva. É por esses índices que as coisas podem ser diferenciadas e, assim, classificadas, hierarquizadas." (NICOLAU NETTO, 2014, p.10)

Contudo, quando o índice de diferenciação é muito forte, a diferença de grau se converte em uma diferença de natureza. Nesses casos, o traço identificado como diferente agrega tanto capital de diferença que uma fenda se abre no tecido liso da homogeneidade, e assim, onde antes havia um mesmo continuum com alterações progressivas, agora se veem dois grupos de conteúdos imiscíveis. Quando um índice de diferença possui um alto capital de diferenciação (um índice forte, portanto) extrapola-se a variação de grau e se passa a uma diferença de substância: essas são as diferenças que fazem diferença. "Há diversas diferenças e similitudes para serem enxergadas entre as coisas, mas apenas algumas se tornam suficientes para gerarem ordenações." (NICOLAU NETTO, 2014, p. 10). É o caso da raça na nossa sociedade, por exemplo. Ainda que um negro e um branco tenham uma série de similaridades e de (outras) diferenças, o fato de a cor da sua pele ser diferente situa-os em dois grupos separados por uma rígida fronteira: negros e brancos. Assim como cor da sua pele, pode ser que o tamanho dos seus braços seja diferente também, mas ainda que seja identificada, essa diferença não é suficiente para situá-los em dois conjuntos opostos. Nesse caso, o tamanho do braço é uma "diferença" e a cor da pele uma "diferença que faz diferença". A nossa sociedade opera esse tipo de classificação porque, devido a razões culturais e sócio-históricas, a raça é considerada um índice de diferença forte, 
enquanto o tamanho do braço seria um bem mais fraco, por isso no segundo caso temos só uma diferença de grau que não enseja novas classificações, e no primeiro essa diferença de grau se converte em uma de natureza, fazendo com que um nome se rasgue em dois (negro e branco), já que uma mesma taxonomia não é mais suficiente para abarcar elementos tidos como tão diferentes. Nos casos em que o índice é excessivamente forte (e sem dúvida esse é o caso da raça em um país como o Brasil), outras características vão sendo atribuídas a cada uma das taxonomias cindidas pelo capital diferenciante do índice, ainda que esses traços não guardem nenhuma relação causal com a característica que primordialmente separa os grupos. Retomando o nosso exemplo: embora neguem que a razão para esse julgamento seja a cor da pele, muitas pessoas "pressupõem" outras características de alguém baseado na raça do sujeito em questão. "Deduz-se" que uma pessoa aja, pense, se comporte, sinta de um determinado jeito por ela ser negra ou branca, ainda que essa crença não tenha o menor lastro na realidade; e, por causa das especificidades culturais e sóciohistóricas da configuração brasileira, os juízos empurram traços pejorativos para os negros, enquanto atribuem características tidas como boas para os brancos. Com o tempo vai se cristalizando uma mentalidade racista que acredita que o termo "negro" é ofensivo. Esse tipo de crença pode ser observado no uso que se faz da palavra "moreno": muitos brancos se referem a negros autodeclarados como morenos por acharem ofensivo chamá-los de negros. Acreditando-se muito polidos e respeitosos por agirem dessa maneira, o que esses brancos estão de fato dizendo é "embora haja um forte índice de diferença que nos situe em dois grupos apartados, eu vou usar um termo mais suave que faz com que nossa diferença pareça apenas de grau, quando na verdade é de natureza", e por causa desses "eufemismos" o fosso que separa os grupos fica cada vez maior. Se nossa história tivesse sido outra, essa diferença poderia ser bem menor ou até nem existir. Logicamente, as pessoas olhariam umas para as outras e veriam que suas peles não seriam iguais, mas, assim como no caso do tamanho dos braços, isso não teria a menor relevância nem criaria a necessidade de que duas palavras diferentes fossem inventadas.

Dando um exemplo forçado só para que se entenda em definitivo o conceito: suponhamos que em um mochilão pela América do Sul, um francês tenha visto muitas araras no Brasil (um bicho que nunca viu na França), mas chegando na Argentina não encontrou nenhuma dessas aves. Quando volta para casa, o viajante conta para seus amigos que achou o Brasil muito diferente e cita as araras, enquanto a Argentina, com suas aves 
"normais", não lhe pareceu tão estranha assim. Certamente, o nosso francês viu várias coisas familiares e estranhas à França tanto no Brasil quanto na Argentina: o corte de cabelo dos brasileiros pode ser parecido com o dos franceses mas o jeito de se vestir não, por exemplo; enquanto na Argentina, o corte de cabelo é que é diferente daqueles feitos na França e as roupas é que são parecidas nos dois lugares. Mas todas essas proximidades e distâncias foram para segundo plano diante da imagem da araras brasileiras. O que essa história deixa claro é que, para esse francês, "arara" é um índice de diferença forte: os países onde ela habita tendem a ser vistos pelo francês como mais diferentes, já aqueles onde ela não vive são mais familiares. Se ao invés da arara, o cabelo fosse um forte índice de diferença, o mesmo francês, tendo visto os mesmos cenários, diria que a Argentina é um país mais diferente da França que o Brasil. Pode ser que, assim como as araras, as aves argentinas também não existam na França, mas o capital de diferenciação que elas carregam não é tão grande quanto o das araras brasileiras: arara = diferença, pois esse traço é um forte índice de diferença. Mas porque a arara e não o cabelo, nem a roupa, nem os pássaros argentinos são índices de diferença tão fortes? Porque todas as similaridades e diferenças entre cabelo, roupa e outras aves não conseguem demarcar essa fronteira entre próximo e distante como as araras conseguem? Certamente porque o capital de diferenciação do índice-arara é maior, fazendo dela um índice mais forte que qualquer outro. Agora, porque o capital diferenciante da arara é maior do que de tudo o mais que o francês viu, isso eu não sei, mas uma coisa é certa: a resposta para essa pergunta deve ser buscada em razões culturais e sócio-históricas. A força que esse índice carrega não tem nada de obrigatório, atemporal ou espontâneo. Esse forte grau de diferenciação poderia estar em outro índice, fazendo com que o diagnóstico do francês sobre a proximidade e a estranheza causadas pelo mesmo Brasil e pela mesma Argentina fosse diametralmente oposto. Se queremos saber porque as araras agregam um potencial de diferenciação tão grande para os franceses, nós devemos olhar para a configuração e o contexto francês, pois foram eles que ensejaram a força desse índice.

A prova de que os índices de diferença e o capital diferenciante que acumulam não são dados absolutos válidos para todos os lugares e todas as épocas pode ser encontrada em várias excelentes etnografias. Tanto em textos clássicos quanto contemporâneos, abundam exemplos de povos que classificam em dezenas de tipos coisas que nós resumimos a um leque restrito de termos ou até que consideramos indivisíveis: neve, mandioca, onça, água, 
etc. Inversamente, a miríade de hierarquias que erigimos forma, para outros, uma grande e indistinta massa homogênea. Embora todos esses princípios classificatórios tenham sido arbitrariamente forjados, quando falamos não parece que estamos obedecendo a atos históricos de categorização, pois tudo soa muito espontâneo e natural. Isso se dá porque esses princípios se internalizaram na nossa prática; a violência dos atos de ordem tende a se esconder na espontaneidade dos atos de fala, mas a eficácia desses princípios classificatórios reside justamente na invisibilidade da qual se vestem quando são evocados. Quanto mais irrefletidamente lidamos com esses princípios, mas eficiente é a sua ordenação, ou seja: quanto mais implícita for a regra, mais explícita é sua eficácia; sendo essa espontaneidade a própria morada de seu arbítrio. Desaparecendo quando aparecem ou sendo esquecidos quando a fala os suscita, os princípios ordenadores participam do jogo exatamente porque parecem não participar dele. Mas ainda se voltará exaustivamente a esse ponto ao longo do texto.

Recusar uma metafísica da diferença que a autonomiza de seu contexto e optar por um estudo dos índices de diferença, do grau de diferenciação que determinada característica traz consigo e dos efeitos que as mudanças nesse discurso causam me parece uma tomada de posição mais adequada aos objetivos desse trabalho. Digo isso porque não ambiciono entender aqui "o que a diferença $e ́$ ", independente de seu contexto cultural e sua configuração sócio-histórico. Almejo antes saber quais são os usos que se fazem da diferença, como seu manejo e seus efeitos variaram ao longo do tempo, e, principalmente qual o valor, a raridade e o prestígio depositados nesse conceito e quais as estratégias empregadas para capitalizar para si a distinção que emana dessa palavra. Inclusive, a descrença na imanência pura da diferença me leva a acreditar que os usos que se fazem dessa palavra e a maneira como a experimentam é que são constitutivas do que a diferença é. Portanto, se queremos penetrar esse conceito, acredito que, ao invés de mergulharmos na suposta metafísica de sua presença ahistórica, devemos atentar para as formas como ele é manipulado e os efeitos de distinção que ele provoca. Se passo ao largo de uma imersão exegética na ontologia de um presente absoluto e opto pelo recorte diacrônico marcado pelas ideias de uso, estratégia, valor, raridade, distinção, prestígio e capital é porque para mim a diferença não é uma coisa, mas um mercado. Como se sabe, em um mercado, nada possui um valor fixado: as mercadorias (que aqui são símbolos) custam o tanto que se acredita que elas custam, e esse preço está sempre sujeito a variações que por sua vez se 
relacionam com uma infinidade de fatores. Por isso, ao invés de me debruçar sobre a materialidade da diferença, eu quero compreender a crença que se investe nela, pois é esse investimento simbólico que a materializa. O conceito de discurso, que nos conduziu até aqui, será abandonado em nome da ideia de "mercado"; a justificativa para essa mudança será dada mais a frente. Sendo assim, para estudar o mercado da diferença (com as circulações infinitas que se operam em seu interior e as mudanças pelas quais ele passa ao longo do tempo) é tarefa fundamental primeiro identificar o índice de diferenciação que carrega consigo um grande capital diferenciante e depois buscar as razões culturais e sóciohistóricas que o investiram daquele poder.

Como agora já deve parecer óbvio, as três perguntas acima elencadas acerca da passagem do mercado da diferença de um período exótico-colonial para um da diversidade-global são extremamente interessantes, mas se não se definir previamente que índice de diferença está sendo considerado e que configuração possibilitou que ele arregimentasse aquele capital diferenciante, o debate perde todo o sentido. Portanto, diante da mudança do exótico-colonial para a diversidade-global, antes de interrogarmos (pergunta 1) o que acontece com os pares universal/particular e as outras díades que carregam consigo: unidade/multiplicidade, homogeneidade/heterogeneidade, pureza/hibridismo e absolutismo/relativismo, ou (pergunta 2) se adentraremos uma era de liberdade ou de controle, ou (pergunta 3) quais continuidades e rupturas existem entre o período exótico-colonial e o da diversidade-global do mercado da diferença, devemos fazer essa pergunta zero: qual índice de diferença está sendo considerado e que trama sóciohistórico-cultural o investiu daquele capital de diferenciação? Assim como o diagnóstico do francês sobre a familiaridade e a estranheza do Brasil e da Argentina mudaria drasticamente caso o índice de diferença forte fosse outro que não as araras, a avaliação que fazemos sobre a silhueta do mundo diante da passagem da colonização para a globalização, sob o risco de se transformar em uma conversa inócua em que qualquer coisa pode ser dita, também precisa se alicerçar em um índice de diferença sócio-historicamente definido.

Sendo assim, diante da mudança no mercado da diferença que sinalizou a passagem do exótico-colonial para a diversidade-global, eu intento fazer a pergunta conceitual, a política e a sintética acima elencadas. Porém, devido às razões analíticas aqui colocadas, 
essas interrogações estarão sempre enraizadas na dúvida zero acerca dos índices de diferenciação e do capital diferenciante que acumulam.

Mas resta ainda dizer sobre qual área esse texto se debruçara para analisar esse deslocamento. Pois bem, o recorte que será feito para que se observe essa mudança no mercado da diferença será o caso da World Music.

Criado em 1987 na Inglaterra, o termo World Music rapidamente começou a aparecer nas prateleiras das lojas de disco, nos catálogos de mais vendidos da Billboard e, em 1992, o novo estilo musical virou até uma categoria do Grammy, o mais prestigiado prêmio da indústria fonográfica. Gravadoras alternativas exclusivamente dedicadas à World Music não paravam de surgir pelos Estados Unidos e pela Europa. Desde que o rótulo nasceu até os nossos dias, a pergunta "o que é World Music?" não cansa de ser ouvida dentro e fora desse universo, mas uma resposta satisfatória ou definitiva nunca foi dada. Assim como acompanhou as últimas décadas, essa dúvida também percorrerá as páginas desse trabalho, portanto, uma definição taxativa não virá agora. Mas uma coisa já pode ser antecipada: a World Music é parte constituinte e constitutiva do mercado da diferença. Ainda que cada gravadora de World Music tenha suas especificidades, pode-se dizer que todas elas estão em busca de um som "diferente" e essa diferença é buscada em países e culturas "distantes", que ocupam a margem tanto do mercado fonográfico quanto da própria geopolítica internacional. Essas músicas do mundo são vagamente definidas como "diferentes", "distantes", "étnicas", "alternativas", "estranhas". Enfim, o que se vê aqui é um interesse pelo lado de lá, pelo longe, pelo estrangeiro, ou seja: pelo Outro.

Mas quem é o Eu interessado e o Outro interessante da World Music? Como havia dito, as gravadoras de World Music, ávidas em conhecer essas culturas estranhas, situam-se nos Estados Unidos e na Europa; em contrapartida, as tais culturas e lugares distantes tematizados por essas gravadoras espalham-se pela América Latina, Caribe, África e Ásia. Em alguns casos, há também uma curiosidade pelo sul negro dos Estados Unidos e pelo leste europeu; em outros, as gravadoras euro-americanas se aproximam dos seus próprios territórios, mas recuam temporalmente, tomando por foco analítico a música folk, a herança dos nativos, as raízes judaicas, a tradição céltica irlandesa, etc. 
Como se pode ver, a linha que separa a cultura das gravadoras da cultura das músicas gravadas é a mesma fronteira que hoje distingue os países desenvolvidos dos países periféricos e que, no passado, com algumas exceções, os dividia entre metrópole e colônia. Como aceitar coincidências não é uma opção, só nos resta voltar para as perguntas de sempre. Cultura das gravadoras e cultura dos gravados: já que há aqui um fenda bem delimitada, pode-se dizer que o índice de diferença com o qual a World Music opera, seja lá qual for, é um daqueles que engendram diferenças que fazem diferença, sendo portanto, um índice com altíssimo capital de diferenciação.

Retomando o fio da meada, iniciei esse texto falando de uma cisão que divide o mercado da diferença em dois: uma era exótico-colonial e um período da diversidadeglobal. Se tivermos que ser taxativos (e portanto simplistas demais) podemos demarcar a virada da década de 1960 para a de 1970, com a independência das últimas colônias portuguesas, como o momento que um segundo período do mercado da diferença fica mais nítido. Ainda que o movimento de transição tenha sido lento e gradativo, acredito que os acontecimentos dos anos 1960 e 1970 (que ainda serão discutidos mais adiante) indicam uma mudança de era, seja lá o que essa passagem queira dizer. Sendo assim, por ter surgido na década de 1980 (portanto, logo que se adentrou na diversidade-global e se deixou o exótico-colonial) e se manter firme e forte até hoje, acredito que o fenômeno da World Music se configura como um bom laboratório para as nossas perguntas acerca das continuidades e rupturas no mercado da diferença. É por isso que tomarei aqui esse caso por objeto.

Eu sei que convém que esse tipo de trabalho exponha logo os pontos que serão discutidos ao longo do texto, mas, de fato, era necessário que se operasse esse resgate para que meus focos de interesse fossem compreendidos. Operada a reconstrução, posso agora mostrar de forma ordenada o que quer essa dissertação, passando em revista o que foi colocado até aqui. Enfim:

O mercado da diferença passou de um período exótico-colonial para outro de diversidade-global. Durante o período colonial, diferença era sinônimo de exótico, o termo se organizava em um binômio fixo (Eu/Outro) e se enredava nas ideias universais de unidade, homogeneidade, pureza a absolutismo. Com a entrada na globalização, o mesmo conceito passou a se referir à diversidade, a lidar com fluxos contínuos e a se ocupar das 
ideias particulares de multiplicidade, heterogeneidade, hibridismo e relativismo. O problema de pesquisa desse texto é compreender o que significa essa passagem, intentando identificar quais são as continuidades e rupturas entre os dois períodos. Traçando um paralelo entre colonização e globalização, almeja-se aqui compreender que relação esses termos mantém entre si: seriam opostos, sinônimos, complementares, uma mesma coisa, etc.? O que muda e o que permanece com a passagem do exótico-colonial para a diversidade-global? O objeto onde se intenta observar esse problema é o fenômeno da World Music. Por ter nascido logo que a passagem se completou e perdurar com fôlego até nossos dias, a World Music se revela um bom recorte para se observar essa mudança. A World Music é um típico fenômeno do segundo momento do mercado da diferença (diversidade-global), portanto, se compararmos esse fenômeno com o primeiro momento (exótico-colonial) atentando para o que ficou e o que mudou, o que sumiu e o que apareceu, o que virou seu oposto e o que se ratificou poderemos perceber que relação se estabelece entre colonização e globalização e quais são as continuidades e rupturas entre os dois momentos.

Valendo-me agora do glossário do problema e do objeto (e sem deixar de lado os cuidados metodológicos aqui levantados), posso finalmente refazer aquelas perguntas do início do trabalho:

Pergunta zero: Com qual índice de diferença a World Music opera e que configuração sócio-histórico-cultural possibilitou que ele arregimentasse tanto capital de diferenciação?

Pergunta conceitual: O fenômeno da World Music gera efeitos universais de unidade, homogeneidade, pureza e absolutismo ou efeitos particulares de multiplicidade, heterogeneidade, hibridismo e relativismo?

Pergunta política: No fenômeno da World Music, as culturas tematizadas são empoderadas pelas gravadoras, ganhando assim maior liberdade e independência, ou seriam elas apenas usadas pela cultura das gravadoras (essa sim a verdadeira vitoriosa), caindo portanto num estado de dependência, dominação e controle?

Pergunta síntese: olhando essa mudança pelo prisma da World Music, quais são as continuidades e rupturas no mercado da diferença quando da passagem do exótico- 
colonial para a diversidade-global? Ou seja, que relação se estabelece entre colonização e globalização?

Movida por essas questões, a dissertação que agora se inicia traça o seguinte percurso: na parte I, farei um resgate histórico do mercado da diferença propriamente dito, analisando a passagem do exótico-colonial para a diversidade-global. Na parte II, eu me dedicarei propriamente à World Music. Ao final dessa trajetória, observando como o problema da mudança no mercado da diferença se deixa ver no objeto da World Music, será dado um esboço de resposta para aquelas perguntas. Como esses esboços não são definitivos, o que esse texto fornece não é um diagnóstico, mas uma (das muitas) porta de entrada no debate. Não foi só a humildade e o imponderável do impossível que tiraram do meu horizonte a vontade de "encerrar a questão"; ainda que esse feito fosse realizável, o que esse texto objetiva é justamente o oposto: não se quer aqui acabar com velhas dúvidas, mas sim suscitar novas. Portanto, quando falo em "dar respostas a perguntas", ao contrário de querer que essas perguntas sumam, o meu esforço é para que elas fiquem mais evidentes. Tendo isso em vista, a conclusão do trabalho não se prestará a passar em revista que interrogações esse texto encerra (pois ele não faz isso com nenhuma), mas sim que veredas podem vir a ser abertas.

Dito isso, algumas opções devem ser justificadas.

A primeira delas é "por que World Music?". De fato, a virada de página no mercado da diferença assinalada pela passagem exótico-colonial para a diversidade-global poderia ser analisada em outros objetos. Mas, já que se quer aqui entender as continuidades e rupturas entre colonialismo e globalização, atentando para rearticulações na balança universal/particular, unidade/multiplicidade, homogeneidade/heterogeneidade, pureza/hibridismo, relativismo/absolutismo, liberdade/controle, eu acredito que o fenômeno da World Music promova um deslocamento interessante. Falo aqui do seguinte: muitas (ótimas) pesquisas interessadas nessas mesmas questões se dedicam a estudar como a cultura de um centro chega às periferias. Também traçando círculos concêntricos que progressivamente vão aumentando de diâmetro, esses trabalhos querem saber como uma cultura legitimada vai se espalhando pelo mundo e quais os efeitos dessa difusão. Nesses textos aprendemos de que maneira o marginal, o étnico e o distante lidam com a pauta normativa e legítima do central. Ainda que coloquem a coroa da reflexividade ora em uma 
cabeça (como o centro chega às periferias), ora na outra (como as periferias recebem o centro), esses são modelos que se dedicam a analisar como os centros saem de si e chegam às periferias. Partindo dessa perspectiva, esses pesquisadores escrevem seus enunciados sobre a natureza universal ou particular, única ou múltipla, homogênea ou heterogênea, pura ou hibrida, absoluta ou relativa, livre ou controlada, do mundo. Mas, no caso da World Music, esse vetor se inverte: os estudos de World Music não se dedicam a entender como o centro chega às periferias, mas como as periferias chegam ao centro. Não se trata aqui de entender os efeitos da política expansionista americana sobre o mundo, as consequências do imperialismo, o significado do fechamento do McDonalds na Bolívia, o consumo de Coca Cola na África do Sul, a audiência de Friends na China, etc., objetiva-se justamente entender que imagem de Bolívia, de África do Sul e de China é feita dentro dos Estados Unidos. Nesse caso, não se almeja observar os impactos do padrão no étnico, mas sim como o padrão se etniza. Portanto, trabalhos desse tipo não são como aqueles sobre a "estadosunização do mundo" ciosos de enxergar como os ecos de americanidade ressoam mundo afora; mas sim esforços para entender como o "mundo afora" adentra os Estados Unidos. Talvez esses dois deslocamentos sejam apenas dois lados da mesma moeda, talvez os rastros que os Estados Unidos fazem quando vão para o resto do mundo sejam só o avesso das pegadas que o resto do mundo deixa indo para os Estados Unidos, talvez o processo de estadosunização do mundo seja o mesmo fenômeno de mundialização dos Estados Unidos... mas ainda que seja, é importante que nós olhemos para o negativo da história para que ela possa ser melhor compreendida. Por serem de uma riqueza inesgotável, muitos estudos que traçaram paralelos entre colonização e globalização se tornaram canônicos e assim, passaram a fazer o oposto do que se propunham: erigir certezas e verdades, criar consensos e aceitações fáceis, encerrar debates. Enfim, eu escolho aqui a World Music como o objeto para observar as continuidades e rupturas no mercado da diferença por acreditar que essa alteração de vetor que ela sugere ajuda a abrir frestas em portas há muito tempo fechadas.

$\mathrm{Eu}$ estou ciente de que essas pesquisas que, ao invés de se interessarem pelos impactos do centro nas especificidades, preferem um estudo acerca do interesse que essas especificidades despertam no centro também não nasceram ontem. Haja visto a profusão de estudos sobre "representação" e de títulos de teses que trazem expressões como "a construção da imagem de...". Hollywood, por exemplo, é constantemente tomada por 
objeto desse tipo de pesquisa. O próprio fenômeno da World Music, inclusive, é vastamente explorado tanto pelas ciências sociais como pela etnomusicologia desde que o termo veio à tona. Isso para não falar da famosa crítica de Edward Said ao Orientalismo (2013), estudo inaugural que salienta justamente como o projeto expansionista do imperialismo se dá através de uma construção da imagem d'O Outro que se está interessado em colonizar. Mesmo assim, acredito que muita coisa ainda precisa ser dita sobre essa mudança de seta. Além disso, o terreno movediço aberto por esse giro exige mais atenção do pesquisador na medida em que denuncia as armadilhas que são as ideias fáceis e a entrega irrefletida às soluções canônicas. Por isso opto por esse caminho.

Olhar as margens indo para o centro ao invés de o centro indo para as margens implica em uma série de mudanças na pesquisa, mas um mesmo elemento se mantém nos dois casos: a assimetria de poder que marca essa relação. "Centro" e "margem" não receberam esses nomes à toa. As pautas normativas tem muito mais trânsito e fluem com mais liberdade do que as periferias, portanto, o que define tanto a visita da cultura legítima aos "outros" quanto a entrada desses "outros" no solo sagrado da legitimidade é o interesse do centro. Mas, a partir dessa constatação, deve-se descobrir que índice demarca essa fronteira e como ele acumulou esse capital diferenciante. Afinal de contas, como todo arranjo assimétrico, essa relação de poder não é natural, mas sim construída.

Como foi dito, essa dissertação intenta analisar as continuidades e rupturas no mercado da diferença quando da passagem do exótico-colonial para a diversidade-global pelo prisma da World Music. Diante disso, é legítimo perguntar: "é possível que um fenômeno tão específico e recente como a World Music dê conta desse problemática mais geral referente à relação entre colonização e globalização?" Sim, é possível. Para isso, basta tratar a World Music como uma figuração, no sentido que Norbert Elias deu ao termo. Para o autor, uma figuração guarda uma relação metonímica com a constelação sócio-histórica que a possibilitou, não sendo portanto nem uma parte, nem uma miniatura, nem uma média, nem uma síntese de uma suposta totalidade maior. Através desse recurso metodológico, um recorte específico do presente concentra dentro de si toda a história passada que o ensejou, de maneira que, atualizado no artefato pontual da figuração, o percurso que o antecedeu se evidencia. Os velhos fluxos se materializam nos momentos de agora e, por esse motivo, uma dinâmica sócio-histórica só pode ser estudada pelo prisma 
da figuração que a coagula hoje. O rio do passado se revela cortado pelo fio da navalha do presente, por isso, para dar conta de um arco, o sociólogo deve observar como ele se inscreve em um dado momento. A linearidade da história fica tridimensional ao se cristalizar em uma figuração do nosso tempo, e é nessa forma objetivada que uma dinâmica se deixa ver. A torrente deságua no instante, o processo todo se inscreve no evento, dessa forma, para o sociólogo alemão, o pesquisador que intenta compreender o tempo deve olhar para a figuração que o imediatiza, pois ele inteiro se presentifica metonimicamente nessa pequena moldura.

Em sua obra mais importante (1990), Elias mostra que o processo civilizador opera tanto como um grande projeto nacional do Ocidente quanto como uma consciência subjetiva. $\mathrm{Na}$ visão do autor, esse arranjo duplex se dá porque a ideia estrutural de civilização se inscreve violenta e silenciosamente na consciência dos indivíduos, e essa inscrição é tão profunda que os externos controles estruturais da civilização, embora sejam arbitrários e históricos, são experimentados pelos que se deixam preencher por eles como internos autocontroles espontâneos e naturais que se evidenciam em economias corporais irreflexivas. Ou seja: no entendimento do sociólogo, civilização é uma espiral entre regra e prática, norma e disposição, nação e consciência. Para dar conta desse arranjo recursivo, Elias se debruçou sobre os hábitos que os nobres mantinham à mesa, tendo por objetivo compreender a dinâmica do processo civilizador. Diante dessa opção metodológica, muitos criticam o autor afirmando que ele "forçou a barra" ou "esticou muito a baladeira" por supostamente ter derivado uma teoria geral da civilização a partir da observação da maneira com que os cortesãos usavam garfo e faca. Mas o que esses críticos não percebem é que Elias trata as tais regras de etiqueta dos nobres como uma figuração do processo civilizador amplamente concebido. Nesse sentido, não há nenhuma generalização forçada, já que, por ser uma figuração, muito longe de se restringir a um epifenômeno do projeto ocidental, esse conjunto de hábitos corporais estabelece uma relação metonímica com a constelação sócio-histórica em que ela se dá. A figuração escolhida por Elias é a imagem que encerra seu modelo, o anteparo onde o tempo se projeta. Anos transcorridos deságuam 
naquelas práticas no exato momento em que elas são acionadas. $\mathrm{Na}$ mesa da corte, o passado se faz presente, história vira disposição, o processo encontra o evento ${ }^{3}$.

Guardadas as devidas proporções e considerando a distância abissal entre o projeto de Elias e esse texto, meu intento aqui é me escudar nos preceitos metodológicos desse autor e assim compreender meu objeto como um figuração. Desse modo, para os fins dessa dissertação, a World Music funcionará como um figuração, ou seja, como um evento que ilustra e contém a dinâmica sócio-histórico que nos interessa, a saber, a trajetória traçada pela ideia de diferença. Conceituar esse fenômeno da indústria fonográfica como uma figuração do mercado da diferença é o mesmo que afirmar que a ancestral trajetória desse conceito se presentifica na contemporaneidade desse estilo musical. Se isso estiver correto, olhar para a World Music é olhar a história da diferença condensada em nossos dias. Diante disso, cabe perguntar: que usos o estilo faz desse conceito? Se a faceta metonímica da figuração for aqui bem explorada, então, penso eu, não há qualquer extrapolação ou simplismo em se falar de World Music para entender o mercado da diferença, de modo que, para mim, o estilo satisfaz os requisitos metodológicos para que se possa acessar a diferença.

Outro autor que pode ajudar a entender as ambições desse texto é Gregory Bateson. Em seu famoso estudo sobre o ritual do Naven entre os povos Iatmul, o antropólogo nos mostra uma sociedade organizada em torno de um "equilíbrio dinâmico" (2008). Recorrendo ao que chama de um "retrato compósito" daquela sociedade, Bateson nos introduz ao conceito de Cismogênese. Escudados nessa noção, aprendemos que permanência e mudança não são termos opostos, uma vez que o funcionamento harmônico de uma sociedade pode estar baseado nas descontinuidades desse arranjo. Isso se dá porque a ordem social e a agregação dos indivíduos (ideias associadas à noção de permanência) podem ser mantidas através de processos evolutivos alicerçados em ciclos cumulativos de estímulos opostos $^{4}$ (ideias associadas à noção de mudança). Nada seria mais incorreto do

\footnotetext{
${ }^{3}$ O mesmo se dá com Mozart. Assim como O Processo Civilizador não é uma micro-história nem uma história dos costumes (como acreditam muitos), Mozart: Sociologia de um gênio (1995) também não é uma biografia, pois, no fim das contas, menos do que um indivíduo, Mozart funciona como uma figuração que encerra em si o arranjo maior que interessa a Elias.

${ }^{4}$ Esses conceitos estão sendo colocados aqui de forma apressada porque essas ideias serão minuciosamente trabalhadas na conclusão. Nesse momento do texto o que me interessa é outra dimensão de Bateson.
} 
que reduzir o argumento de Bateson a uma dialética, pois o caráter circular, cumulativo e autopoiético do Naven leva os conceitos de ordem e reprodução social para um outro nível.

Mas é outro aspecto do Naven que me interessa nesse momento. Assim como no modelo eliasiano, há no ritual Iatmul uma subversão cronológica ou uma preferência do circular-simultâneo em detrimento do linear-sucessivo. Recuperando termos já usados aqui, a relação Sociedade/Naven se dá em termos caros a Elias: o Naven também não é uma metáfora, nem uma maquete e nem um pedaço da sociedade. Da mesma forma, ainda que tenha uma dimensão representativa, não é apenas imitação, mas também não se pode dizer que seja só invenção. Mesmo que hiperbólico, não é a sociedade aumentada, e de forma alguma pode-se afirmar que seja um ritual de passagem.

"A conduta ritualizada do Naven está distante da utilidade e da instrumentalidade cotidianas, porém apresenta elementos comuns a estas: é ocasião de trocas inteiramente situacionais, fluxos de objetos e mensagens, expectativas econômicas e políticas. Se não é prosaico, também não é suplementar, paralelo, derivado, - não é um epifenômeno." (GEIGER. 2008, p. 33)

Embora o Naven aconteça no cento da sociedade Iatmul, envolto por ela, são as ondas concêntricas que reverberam do ritual que constroem essa mesma sociedade que o envolve. Ao tematizar aquela sociedade, o Naven a inventa. No que diz respeito à relação entre a sociedade e o ritual, não se pode dizer quem veio antes e quem veio depois, quem está dentro e quem está fora, qual é o maior e qual o menor... aliás, qual deles é a sociedade e qual é o ritual mesmo? Inútil insistir nessas questões. Nem a sociedade é só uma fixidez imutável, nem o Naven se resume a um desdobramento que a encena. Quando disse que não se podia falar só em imitação ou só em invenção me referia ao fato de que o Naven não é só alegórico, pois ele não apenas dramatiza a sociedade, mas também a instaura. Não há nenhum aspecto cênico do Naven que também não invente o social, da mesma maneira que todo o seu potencial inventivo traz sempre a marca do duplo. Reproduzida no Naven, a sociedade é produzida, pois aquele evento carnavalesco também é fundacional.

"O Naven seria sintoma e sutura desses conflitos. Interpretá-lo, portanto, não significa resolvê-lo. (...) as premissas estruturais decifram o Naven, assim como este as explana. Pois elas são evidenciadas pela própria encenação ritual. (...) Ações padronizadas, que estão referidas a ações passadas e expectativas de ações futuras, implicando muito mais que estímulo resposta; derivam do grupo, por socialização, e repercutem nele, reiteram-no" (GEIGER, 2008, p. 39) 
O que Bateson nos ensina é que certas linguagens só se deixam ver em sua dimensão metalinguística, ou seja, que é se dobrando sobre si mesmo que um texto se escreve. Duplicando-se, o discurso se inaugura.

"Os indivíduos em uma comunidade são padronizados por sua cultura, ao mesmo tempo em que as características gerais que a permeiam, aquelas repetidamente reconhecíveis em seus mais diversos contextos, são uma expressão dessa padronização. Tal hipótese é, em certo sentido, circular; supõese que as características que permeiam a cultura não apenas expressam mas também promovem a padronização dos indivíduos." Grifos meus. (BATESON, 2008, p. 96)

"É evidente que a cerimônia do Naven é expressão e ênfase do laço de parentesco entre o wau e o laua em questão ${ }^{5}$." (BATESON, 2008, p. 143)

Por todos esses motivos, o simbiótico arranjo formado pela Sociedade/Naven funciona como uma espécie de imagem-comentário, quer dizer, uma foto que é também a legenda dessa foto. O ritual é uma seta que aponta para a sociedade, mas, quando chegamos ao final do caminho indicado, ao invés da sociedade, damos de cara novamente com o ritual que nos levou até ali. Como disse Geiger, o Naven "indica e presentifica" (2008, p. 35) a sociedade. A um só tempo pronome pessoal e demonstrativo, a cerimônia se refere aos Iatmul ao mesmo tempo em que é os Iatmul.

Como se pode ver, o Naven guarda muito do arranjo metonímico do quadro de Norbert Elias. Retomando o eixo que nos interessa, pode-se dizer que, para os fins desse trabalho, o caso da World Music está para o mercado da diferença assim como o Naven está para a sociedade Iatmul: quer dizer, a World Music não é fragmento, epifenômeno, nem está dentro desse mercado. Também não podemos dizer que ela é sua miniatura ou sua imitação. Não: o caso da World Music cita o mercado da diferença, e dessa forma o escreve. Ainda que o mercado pareça conter o fenômeno, é a pulsação deste que constrói aquele. Secundando-se enquanto World Music e se deixando atualizar nessa figuração, o mercado da World Music nasce mais uma vez.

Aquela mudança terminológica de discurso para mercado pode agora ser justificada: no início do texto, recuperei a noção foucaultiana de discurso para me referir à diferença, porém, ao longo dessa introdução, a ideia de discurso foi abandonada em nome do termo "mercado", como escrito no título. De fato, a referência a esse conceito se deu

\footnotetext{
${ }^{5}$ Wau e Laua seriam os correlatos de tio e sobrinho no nosso sistema de parentesco.
} 
apenas para que o percurso metodológico pudesse ficar claro, mas daqui sigo sem ele. A escolha por um "mercado da diferença" ao invés de um "discurso da diferença" se deve a dois motivos:

O primeiro é que um estudo sobre a dimensão discursiva da diferença no caso da World Music acabou de ser escrito (atingindo um resultado muito melhor do que essa dissertação poderia ambicionar alcançar). Refiro-me aqui ao já citado livro de Nicolau Netto (2014); trabalho definitivo sobre o assunto com quem tenho uma dívida impagável. Portanto, já que é para frente que o conhecimento deve andar, não quero aqui arremedar toscamente o que ali já está dito de maneira profunda. Logicamente, por me basear nesse autor, referências ao seu livro serão feitas, mas meu recorte, meu objeto e minhas conclusões são outras ${ }^{6}$. Ciente do fato de que adentro em um campo recentemente enriquecido por essa obra, aceito a tarefa de me mediar com ela e, ao invés de repetir, intento escrever algo a partir do que está ali colocado. $\mathrm{O}$ texto que aqui se inicia não ambiciona ir além daquele no sentido de que quer ser mais completo (pois não será), mas apenas na medida em que enxerga o problema pelo prisma do que lá já está posto.

O segundo diz respeito a uma opção metodológica. A ideia de mercado vem aqui ocupar a de discurso porque o diálogo que estabelecerei nessa dissertação não será com Michel Foucault, mas com Roger Chartier. Como se sabe, de Foucault para Chartier há mais uma continuidade e uma releitura do que um corte ou uma oposição de fato. Sendo historiador do livro e do impresso, o que Chartier faz é chamar a nossa atenção para o fato de que a ideia que se constrói em torno de um discurso não emana simplesmente do conteúdo daquele texto, mas também da forma como ele se materializa. Sendo assim, além de nos debruçarmos sobre os discursos, temos que analisar as plataformas sobre a qual eles se inscrevem e se deixam ver, ou seja, as maneiras através das quais esses textos são gravados e absorvidos. Um "mesmo" discurso falado, escrito em rolo ou em códex é, na verdade, três discursos diferentes que forjam subjetividades e são entendidos de maneiras diversas. Diferentes usos podem ser feitos de um discurso: cada maneira diferente de consumir um discurso muda o entendimento que se faz dele e, por isso, muda o discurso

\footnotetext{
${ }^{6}$ Não é por discordância que as conclusões são outras, até mesmo porque abraço integralmente o argumento de Nicolau Netto, mas justamente porque essas alterações no método e no recorte me levaram para outra direção. Não se trata aqui de uma visão diferente sobre a mesma coisa, mas da mesma visão sobre outra coisa. Adotando um caminho diverso, fui conduzido para outro ponto. Só isso.
} 
propriamente dito. Por serem tão constitutivos da substância do discurso, esses meios através dos quais um discurso se deixa ver não são "meros meios", mas elementos importantes formadores da silhueta do discurso. Assim como uma deformação no anteparo provoca distorções na imagem que nele se projeta, mudanças na plataforma onde o discurso se imprime alteram o entendimento que dele se faz. É por isso que, fazendo referência ao texto de Foucault já citado, Chartier irá dizer que tão importante quanto entender a ordem do discurso é compreender a ordem do livro (1994). É claro que Foucault não era um hermeneuta ingênuo que buscava as características intrínsecas e absolutas do discurso em sua ilusória imanência ahistórica. Como é sabido, para Foucault uma formação discursiva geradora de efeito de verdade é construída pela relação que os enunciados estabelecem com as bases materiais da sociedade em uma dada época. Mas essa noção de "base material" ainda é muito difusa para Chartier, por isso, operando um recorte mais específico, esse autor irá se dedicar a mapear a evolução das formas em que os discursos eram inscritos. Para o historiador, as maneiras de se imprimir, as revoluções no mercado editorial, as figuras intermediárias como o livreiro, o copista, as mudanças nas tipografias, as várias formas de se registrar, distribuir, consumir e usar os textos, etc. não são só meios, ferramentas ou vetores inocentes. Mudanças nos discursos se relacionam com alterações nas formas em que eles são inscritos, afinal, além de outras coisas, um discurso é a morfologia em que ele se deixa ver.

Analisar as materialidades em que um discurso se inscreve, os filtros pelos quais ele passa e as ressignificações que ele ganha nas várias formas de ser usado e consumido nada mais é que estudar um mercado. "Mercado" é o nome que se dá para o configuração formada pelo conjunto dessas forças entrelaçadas e para os efeitos de distinção, prestígio e raridade ali negociados. Optei pelo mercado de Chartier ao invés do discurso de Foucault quando percebi que não havia nada interno ou intrínseco às canções de World Music que fizessem delas "canções de World Music". A ideia do que seja World Music é fabricada ao longo do caminho que a música percorre, ou seja: World Music não é só uma coisa que a música é, algo que nasce com ela, mas uma maneira específica de registrar, produzir e consumir determinadas músicas. Nenhuma canção nasce sendo de World Music porque não há nada imamente a ela que a conceitue como tal. A música é significada como sendo de World Music através de um longo processo que atravessa diversos filtros de mediação. Embora nenhuma música nasça sendo de World Music, muitas podem vir a ser uma, ou 
seja, nada é per se World Music, mas diversas composições são uma World Music "em potencial". Fora do mercado da World Music, das suas práticas de registro, distribuição e consumo, aquelas mesmas canções não seriam tidas como tais. Claro que as gravadoras não poderiam escolher qualquer música, mas apenas aquelas que possuem um índice de diferença forte, mesmo assim não podemos ser simplistas e acreditarmos que o trabalho da World Music seja apenas extrativista. Pelo contrário: os filtros mediadores desse mercado submetem o discurso a um processo de ressignificação. Nessa dissertação, além de um estudo da configuração sócio-histórica que forja a World Music, será dada uma atenção à própria materialidade em muitas gravadoras inscrevem suas World Musics: a coletânea.

Muitas gravadoras não lançam discos inteiros de um mesmo artista, mas organizam compilações de diferentes músicas, cada uma escrita por seu respectivo compositor e executada por seu respectivo intérprete. Essas coletâneas são pontuadas por textos e imagens característicos. Como irei tentar mostrar, toda essa embalagem é importante para que as músicas ali reunidas sejam definidas como World Music. Se não fossem aquelas imagens e aqueles textos certamente aquelas composições não seriam definidas como World Music; mas, mais importante, se optasse por lançar um disco contínuo de um mesmo artista, com seu nome e seu rosto na capa, ao invés de fazer um apanhado de vários compositores e intérpretes tão heterogêneos musicalmente falando e os reunir em uma mesma coletânea, seguramente a gravadora não seria tida como uma gravadora de World Music.

Por considerar que a World Music é definida tanto pelo tipo de materialidade em que ela se inscreve quanto por uma série de instâncias externas a seu conteúdo discursivo, essa dissertação se configura mais como um estudo do mercado da diferença do que do discurso da diferença.

Uma última justificativa deve ser dada sobre a função da bibliografia nesse trabalho. Os autores elencados aqui nesse texto não serão tidos apenas como ferramentas para analisar o mercado da diferença, mas também como partes constitutivas e constituintes desse mercado. Nomes como Foucault, Derrida, Deleuze, Said, etc. não são só lentes pelas quais olho as continuidades e rupturas no mercado da diferença, mas são também enunciados internos a esse texto que o escrevem de lá de dentro. Mais a frente, a teoria de alguns autores será minuciosamente apresentada. Mas com esse esforço não 
intento fazer uma exegese desnecessária de textos, mas mapear os caminhos traçados pelo conceito de diferença. Portanto, a narrativa desses teóricos nos interessa não tanto quanto teoria, mas como objeto, ou seja, como o campo em que nosso problema de pesquisa se deixa ver, e é por isso que tantas páginas serão dedicadas a eles. Em paralelo a isso, os etnomusicólogos aqui trazidos não são encarados apenas com analistas externos da World Music, mas vozes contidas nesse mercado que, da mesma forma, o constituem do seu interior. Assim como as gravadoras, os teóricos da World Music (tanto entusiastas quanto críticos) serão tomados aqui como valências que recortam essa trama configuracional. Sendo assim, dito de forma definitiva, esse trabalho não demarca uma fronteira rígida entre marco teórico e objeto teorizado. Para os fins desse texto, as perspectivas analíticas são também corpos analisados já que os pontos de vista podem facilmente se converter em pontos vistos.

Dito tudo isso, acho que já podemos iniciar o trabalho. 


\section{PARTE I:}

CONTINUIDADES E RUPTURAS NO MERCADO DA DIFERENÇA 


\section{Apresentação}

\section{O mercado da diferença}

Como antecipado na introdução, o conceito de diferença se divide em dois momentos. O primeiro dizia respeito a um período colonial em que a diferença operava com o binômio Eu/Outro e se reconhecia sob o signo do exótico. O segundo se estende por uma era global em que a diferença abandona aquela díade estanque para manejar fluxos contínuos e se organizar em torno da noção de diversidade ${ }^{7}$. Como no período exóticocolonial a diferença agregava valor às noções universais de unidade, homogeneidade, pureza e absoluto, criou-se a expectativa de que a era da diversidade-global valorizasse os duplos dessas ideias, ou seja, os conceitos particulares de multiplicidade, heterogeneidade, hibridismo e relativismo. Da mesma forma, como a fase exótico-colonial se caracterizou por um período de dominação e assimetria de poder, a queda das últimas colônias europeias e a entrada em uma nova era de diversidade-global fez crescer a esperança de que se estava inaugurando um tempo de liberdade e equilíbrio.

Diante dessa expectativa, muitas vozes otimistas defenderam a tese de que, realmente, a passagem da fase exótico-colonial para a da diversidade-global representou uma ruptura na ideia de diferença, sendo o segundo momento o oposto do primeiro. Em contrapartida, outros tantos abraçaram o argumento mais sombrio de que a passagem do exótico-colonial para a diversidade-global não abria nenhum hiato no conceito de diferença, pois, já que os dois momentos eram idênticos, a relação que se estabelecia entre eles era mais de continuidade do que de ruptura.

A bem da verdade, deve-se reconhecer que houve uma mudança taxonômica na gramática da diferença; quer dizer, a passagem do exótico-colonial para a diversidadeglobal assinalou o fim de um glossário e o começo de outro. Mas o ponto de divergência entre os teóricos da continuidade e os da ruptura diz respeito ao real significado dessa

\footnotetext{
7 "A diferença no século XIX era discursada a partir de uma relação razoavelmente estável que separava o interno do externo, o próprio do exótico. Na contemporaneidade essa estabilidade se perde. A diferença, então, necessita de um discurso que dê conta do fragmento, da dispersão, dos fluxos globais que se territorializam de diversas maneiras. Esse discurso que organiza a diferença na contemporaneidade é o discurso da diversidade. (...) Desse modo, o exótico, se continua em operação nesse momento (...) não mais é capaz de organizar o discurso da diferença. Em um mundo de relações fragmentadas, será pela diversidade que o discurso da diferença será articulado." (NICOLAU NETTO, 2014, pp. 12, 13).
} 
mudança lexical: enquanto para os primeiros os novos termos representavam uma repetição com ares de farsa dos velhos, para os segundos a mudança na palavra sinalizava uma revolução nas coisas e, assim, a nova agenda da diferença marcava a entrada em uma nova era, oposta à anterior.

Já no Manifesto do Partido Comunista, Marx e Engels apontavam a burguesia como a classe revolucionária por excelência, posto que ela precisa mudar constantemente os modos de vida para que a perenidade das coisas não evidencie as contradições que ela engendra.

\begin{abstract}
"A burguesia não pode existir sem revolucionar permanentemente os instrumentos de produção; portanto, as relações de produção; e assim, o conjunto das relações sociais. Ao contrário, a manutenção inalterada do antigo modo de produção foi a condição precípua de existência de todas as classes industriais do passado. O revolucionamento permanente da produção, o abalo contínuo de todas as categorias sociais, a insegurança e a agitação sempiternas distinguem a época burguesa de todas as precedentes. Todas as relações imutáveis e esclerosadas, com seu cortejo de representações e de concepções vetustas e veneráveis dissolvem-se; as recém constituídas corrompem-se antes de tomarem consistência. Tudo o que era estável e sólido desmancha no ar; tudo o que era sagrado é profanado, e os homens são obrigados a encarar com olhos desiludidos seu lugar no mundo e suas relações recíprocas." (ENGELS \& MARX, 2006, pp. 28, 29).
\end{abstract}

Esse pensamento plantou a semente de uma desconfiança que se manifesta naquelas imagens apocalípticas de que o novo pode ser apenas a esteira sobre a qual vem deslizar o velho, que as revoluções no sistema podem se dar somente em torno de seu próprio eixo, que o mundo muda sem sair do lugar, que a terceira dimensão vertiginosa que o progresso abre é na verdade uma ilusão criada em uma tela plana, que a porta de saída dá para dentro, que a voo é uma queda, etc. Em paralelo a isso, há aqueles que assinalam o que de fato muda com uma mudança, seja celebrando acriticamente os novos tempos de alegria, seja procurando criticamente novas possibilidades de mudança que o futuro nos traz.

Ainda que cortados por uma série de correntes menores, dito de forma ampla, esses são os grupos que se digladiam no diagnóstico sobre a passagem da diferença de uma era exótico-colonial para outra de diversidade-global. Nessa primeira parte, eu intento fazer o resgate histórico dessa mudança mostrando seus efeitos em uma configuração formada pela geopolítica internacional, pela arena cultural e pelo debate acadêmico. Como disse Elias, uma configuração tramada existe porque suas valências se cruzam. Sendo assim, o 
foco do interesse aqui é mais a relação que as reticularidades estabelecem entre si do que suas supostas "naturezas", portanto - já que a intersecção é mais importante que a assepsia - política, cultura e universidade não serão isoladas uma da outra, mas sim aproximadas até que reciprocamente se interpelem. Reconstruindo sociogeneticamente a diferença podemos ter uma pista do caminho que devemos trilhar para chegarmos às respostas das nossas perguntas acerca das continuidades e rupturas que se estabelecem entre o exótico-colonial e a diversidade-global quando da mudança no conceito de diferença e, colocando de maneira ampla, da relação que existe entre colonização e globalização.

Retomando o que já se pontuou anteriormente, tanto as ideias universais de unidade, homogeneidade, pureza e absoluto quanto as noções particulares de multiplicidade, heterogeneidade, hibridismo e relativo são tidos aqui como símbolos cujo valor varia de acordo com as rearticulações que ocorrem na trama configuracional ao longo do tempo: se na era exótico-colonial o prato da balança pendia para os primeiros termos, na fase da diversidade-global foi para o lado dos segundos que ela pesou. Se as ideias em que a diferença está enredada agregam mais ou menos valor, o que se tem aqui é um espaço de produção de prestígio, raridade e distinção, ou seja, um mercado. Sendo assim, a reconstrução histórica que será feita nessa primeira parte se presta a identificar as oscilações no valor que se atribui a determinados símbolos no mercado da diferença. É através desse modelo dinâmico, histórico e processual que se quer identificar as continuidades e rupturas no mercado da diferença quando este deixa o exótico-colonial para entrar na diversidade-global.

Desde o início desse texto eu tenho me preocupado em criar tipificações rigorosas e em demarcar fronteiras claras entre elas (e.g: duas metades do mercado da diferença, dois grupos que divergem acerca dessa passagem, etc.), mas, logicamente, a vida não é tão organizada assim. Como se falou, para os fins dessa pesquisa a diferença é um marcado volátil, uma trama configuracional que se rearticula e muda ao longo do tempo. As categorias sólidas que se erige aqui são apenas sistematizações metodológicas para que se facilite a explicação. Como o mercado da diferença é uma trama que une processo e evento em uma espiral histórica, não podemos acreditar que um acontecimento em específico tenha assinalado definitivamente a passagem de uma fase para a outra, ou que as vozes que divergiam acerca dessa mudança se reuniam em uma assembleia onde de um lado estariam 
sentados os partidários da continuidade e do outro os da ruptura. Claro que não: formalmente, a trama é confusa, mas morfologicamente, a tarefa aqui é a de identificar as silhuetas que essas formas desenham no tecido do simbólico.

Nas paginas seguintes, abordarei primeiro o período exótico-colonial, em seguida passarei para o da diversidade-global, e finalmente chegarei ao debate acerca dos significados dessa mudança, colocando lado a lado as teses da continuidade e da ruptura entre os dois momentos desse mercado da diferença. 


\section{Capítulo 1}

\section{O período exótico-colonial do mercado da diferença}

O primeiro momento do mercado da diferença diz respeito a um período de colonização em que o conceito operava com uma rígida fronteira entre Eu/Outro. Essa bipolarização rigorosa criava ao mesmo tempo efeitos de distinção e indistinção. Por um lado, esse arranjo produzia distinção porque os polos do binômios eram diametralmente opostos; um traço que se verificasse em um obrigatoriamente não existia no outro e viceversa. Por outro, o mesmo modelo produzia indistinção porque cada um dos lados, entendido em seus próprios termos, era liso e indiferenciado. Portanto, pode-se dizer que os corpos se diferenciavam um do outro para que se indiferenciassem em si mesmos, de maneira que uma relação de mutualismo se estabelecia entre distinção e indistinção no binarismo Eu/Outro: o hiato instransponível que separava os dois corpos era sustentado pela homologia completa que reinava dentro deles, e, inversamente, a superfície sem estrias de cada polo da díade era ratificada pela fenda que os alienava. Além de se estender por um período colonial e operar com o par Eu/Outro, outra particularidade do mercado da diferença dessa época é que ele atribuía grande prestígio e raridade aos termos universais de unidade, homogeneidade, pureza e absoluto. Por fim, o que já é quase uma redundância, um traço marcante da era colonial é a dominação imperialista e a assimetria de poder.

Passando tudo em revista, temos um primeiro momento do mercado da diferença marcado então pelas noções de colonização, binarismo, unidade, homogeneidade, pureza, absolutismo, universalidade e dominação. Para que se deixasse reconhecer enquanto um momento específico, esse arrazoado de noções deveria se deixar organizar sob a égide de um mesmo signo, de uma ideia-síntese que evocasse o amálgama de todos esses sentidos difusos: esse signo foi o exótico. Durante o primeiro período do mercado da diferença, o exótico foi o desenho resultante do entrecruzamento de todas aquelas ideias, desempenhando assim o papel de figura do interesse colonial na diferença. Ao mesmo tempo em que continha e proporcionava aquelas ideias, o exótico era composto e ensejado por elas. Portanto, o primeiro momento do mercado da diferença será tido aqui como um período exótico-colonial.

Agora que as características do período exótico-colonial do mercado da diferença já estão conhecidas, resta saber como essas agendas emergiram para constituir esse sentido. 
Para isso, faz-se necessário um resgate sócio-histórico dessa época para que se entenda como tais noções adquiriram esse prestígio e essa eficácia simbólica. É o que será feito agora.

$$
* * *
$$

$\mathrm{O}$ auge da fase exótico-colonial do mercado da diferença foi a era dos grandes empreendimentos imperialistas da Europa. O projeto expansionista europeu de colonização se estendeu durante o período que ficou conhecido como "Longo Século XIX", fase que vai da Revolução Francesa, em 1789, até o começo da Primeira Guerra Mundial, em 1914. Durante esses anos, a Europa ocupou pesadamente diversos territórios, espalhando-se pelo mundo inteiro. Para se ter uma ideia desse empreendimento: em 1815, as colônias europeias correspondiam a 35\% da superfície terrestre; em 1914, esse número havia saltado para $85 \%$. (SAID, 2013.)

Uma ideia-chave muito em voga na época, que ladrilhou o terreno tanto para que as noções típicas do mercado da diferença florescessem quanto para justificar moralmente a dominação imperial, foi a ideia de progresso. Coroado como um dos valores mais importantes da civilização e da natureza humana, o progresso passou a ser a pauta orientadora do expansionismo europeu. Estribada nesse preceito inquestionável, a Europa encarou a conquista de territórios mundo afora como a imagem síntese do seu desenvolvimento.

Mas a justificativa para o expansionismo europeu dada pelo progresso não se restringia apenas a esse ponto. Esse mesmo conceito levava a mentalidade imperial a acreditar que a colonização era algo positivo não só para a Europa, mas para os próprios territórios colonizados. Essa crença se alicerçava na ideia de que os povos subjugados seriam selvagens infantilizados que jamais conseguiriam se desenvolver por eles mesmos. Sendo assim, era completamente estranho ao pensamento europeu a ideia de que o progresso da metrópole implicasse no atraso da colônia; pelo contrário: espalhando-se pelo mundo, a Europa levava o progresso e a civilização para os povos que nunca atingiriam esses estágios sozinhos. Dessa forma, a noção de progresso justificava o imperialismo europeu não só porque alicerçava seu programa político, mas também por ser tida como uma missão civilizatória ou um papel histórico do Ocidente. A base do sistema político- 
econômico europeu era também uma espécie de obrigação filantrópica do continente para com o mundo. Atacando por essas duas frentes, o progresso ia se conformando como um dos princípios mais importantes da colonização.

A crença europeia de que a colonização seria algo positivo para as colônias, uma vez que levaria a civilização e o progresso para elas, expõe uma faceta reveladora do Ocidente: a ideia de que só existe uma única história e uma única direção de desenvolvimento. Como se pode ver, escapava ao colonizador a noção de que "os outros" pudessem estar avançado em um caminho diferente daquele que a Europa escolheu para si, ou até, quem sabe, que a ideia de desenvolvimento não fizesse sentido para a cosmologia local, sem que isso fosse visto como uma falta ou um problema. Não: rasgando o tempo sempre para frente, a seta veloz do progresso levou a Europa a acreditar que sua história seria "A História", ou seja, um processo único que abraçava todas as culturas, arrastandoas na mesma direção. Em nenhum momento se cogitou que as ideias de civilização, desenvolvimento ou progresso fossem preocupações exclusivas da história europeia que violentamente atropelavam outras histórias. Ao invés disso, acreditou-se que aquela era a mesma história que a todos empurrava.

Se ao invés de respectivas histórias e direções de desenvolvimento, o que existia era a mesma história caminhando em uma só direção, então, as diferenças entre os povos não poderiam ser justificadas como sendo contemporâneas especificidades culturais; ao invés disso, aquelas dessemelhanças eram explicadas pelo fato que de que as culturas supostamente se encontrariam estacionadas em diferentes estágios do mesmo processo histórico. Com isso, diferenças contextuais se transmutavam em distanciamentos cronológicos. A partir daí, foi se cristalizando a noção de que o presente da colônia seria uma imagem do passado da metrópole, fazendo assim com que o encontro com o "Outro de hoje" se convertesse em um reencontro com o "Eu de ontem". Desse jeito, a afinidade entre o progresso e o monismo histórico linear teceu uma das ideias mais caras ao pensamento colonial: o evolucionismo.

O século XIX, tomado pelo espírito das luzes, o racionalismo e as novas descobertas, se configurou como um período de muita crença no discurso científico, e a doutrina vigente na ciência da época era justamente o evolucionismo. Deve-se lembrar que, em 1859, foi publicado A Origem das Espécies, livro de Charles Darwin que trouxe a 
teoria biológica da evolução. Nesse contexto, temas gerais próprios à religião, como o homem, a história, a criação, o tempo, o universo, etc., abandonaram o solo sagrado da igreja e adentraram em uma arena científica marcada pela ideia de evolução. Esse acento evolucionista conferido pela laicização racional do debate promoveu uma revolução completa daqueles temas. $\mathrm{O}$ interesse eclesiástico nas causas e nas origines das coisas se transformou na curiosidade científica nas consequências e nos rumos da humanidade. Se para a religião, o homem já nasceu pronto sendo a imagem e semelhança de Deus e se mantinha o mesmo até o presente, para a ciência um longo percurso havia sido traçado para que a humanidade tivesse chegado onde chegou. Se a antropologia a-histórica da igreja fazia com que ela acreditasse que todos eram iguais perante o Pai, uma leitura enviesada da teoria da evolução das espécies fez a ciência achar que os homens eram diferentes uns dos outros, pois já que a evolução se configurava como um processo histórico de mutações, cada um poderia estar passando por um patamar evolutivo diferente.

Se só existe uma única história progredindo teleologicamente em uma linha evolutiva reta, então, mais do que justificada, a intervenção dos povos "mais desenvolvidos" na vida dos "menos desenvolvidos" era quase obrigatória. Situar a Europa no fim de um processo histórico progressivo, único, linear e evolutivo tem uma significação dupla: por um lado, a civilização ocidental se transforma no cânone do desenvolvimento, quer dizer, uma imagem a ser seguida e um ponto para onde todos devem rumar; por outro, os povos colonizados deixam de ser sujeitos do que deveriam ter suas respectivas histórias, para que então sejam vistos como "europeus atrofiados" presos a uma suposta infância antropológica ou a um estágio anterior da evolução que a Europa já teria atravessado há muito tempo.

Progresso, história linear única e evolucionismo formavam o tripé de sustentação do pensamento colonial. Paulatinamente, essas ideias foram se convertendo no gabarito de avaliação de todos os povos. Isso significa que uma teoria ocidental, propondo hierarquias que só faziam sentido para a Europa, se tornou a régua que media todas as culturas do mundo, mesmo que para elas aqueles critérios não significassem nada. Sendo assim, os países eram mais ou menos evoluídos dependendo do quanto parecerem com a Europa: ser evoluído era ser europeu. 
"O progresso então organiza a história - ou mesmo a cria -, reúne seus vários fenômenos e os torna parte de seu próprio movimento universal. (...) A linha da história agora passa a apontar sempre para o futuro, tendo em vista que essa história se torna cumulativa para algo positivo. É com base nisso que será justificado o imperialismo. Afinal, o progresso - e tudo que isso implica - se torna a meta da humanidade. " (NICOLAU NETTO, 2014, pp. 68, 69).

Mas como o ocidente conseguiu prescrever a regra de avaliação de todos os povos? A resposta é: obedecendo-a. Como nos ensina a teoria da prática de Pierre Bourdieu (2009), a subserviência é o lado de uma moeda que tem por outra face a imposição; dessa maneira, aqueles que cegamente se sujeitam a um código estatuído são recompensados com o direito de estatuir esse mesmo código a que se submetem. Situando-se no topo das hierarquia evolutiva, o europeu se fazia apto a legislar a ortodoxia que ele mesmo seguia. Como o que se tem aqui é um jogo onde o que está em jogo são as regras do jogo, o vencedor da partida e o árbitro são sempre a mesma pessoa. Dessa forma, o poder se faz em uma circularidade que se retroalimenta: por ser a cultura mais evoluída do mundo, a Europa adquiria a legitimidade simbólica para dizer o que era evolução e para hierarquizar todas as outras culturas, entronizando-se assim como a cultura mais evoluída do mundo. Quando práticas se sujeitam a um código, o hiato entre elas desaparece, de uma maneira tal que os gestos submissos se confundem com as normas que os submetiam, ensejando-se então um sistema onde as leis são criadas por aqueles que elas criam. Agindo como se deve, o Ocidente dizia como se deveria agir ${ }^{8}$, e desse jeito a mola de reprodução silenciosa e eficaz do habitus seguia se curso gerando as práticas que ela mesma classificava em um campo onde quem faz as regras é aquele que se deixa fazer por elas.

"Uma das coisas mais frequentemente esquecidas é que qualquer pessoa que fale sobre o mundo social deve contar com o fato de que no mundo social falase do mundo social, e para ter a última palavra sobre esse mundo; que o mundo social é o lugar de uma luta pela verdade sobre o mundo social." (BOURDIEU, 1990, p. 116).

Ao se servir do progresso, do monismo histórico linear e do evolucionismo para alicerçar seu empreendimento colonial, a civilização europeia evidencia um tendência recorrente nos projetos de dominação: o casamento entre saber e poder. Recorrer a uma doutrina científica ou a qualquer discurso tido como verdadeiro para que se legitime a barbárie é uma prática comum aos regimes totalitários. Quando faz uso de uma teoria

\footnotetext{
8 "Afinal, o padrão postulado não tem nenhuma realidade empírica, ele é simplesmente um construto imaginado por aqueles que detêm uma posição de poder e que lhes confere uma certa capacidade: a de 'corrigir' os outros." (ORTIZ, 2008, p. 65)
} 
distorcida da evolução para subjugar povos estrangeiros, o imperialismo ocidental mostra como uma dominação epistemológica se converte em uma dominação ontológica, quer dizer: como aquele que tem o poder de criar categorias inventa as coisas que categoriza e assim passa a ser dono de suas invenções. Como num passe de mágica, os enunciados se substancializam nos corpos que eles enunciam e, desse jeito, quem estiver habilitado a falar sobre o mundo pode tê-lo nas mãos. Os que tem a primazia de criar gabaritos e inventar réguas estão sempre no topo das hierarquias que eles mesmos erigem, pois o "Eu" é sempre o metro e o fim dos sistemas que ele próprio instaura. Todo nome inventa uma coisa e toda coisa pertence à voz que a inventou. É por isso que saber e poder andam juntos, pois não há monopólio político que não seja também um monopólio de conhecimento. A Europa do século XIX só podia mandar no mundo porque era ela quem dizia o que o mundo era; em simetria invertida, os povos colonizados eram controlados pois não podiam tecer enunciados sobre as coisas e legislar sobre a história (ainda que fosse uma história própria). Quando criava divisões geográficas e desenhava mapas, o ocidente passava a dominar os territórios que cartografava; da mesma forma, a divisão meridional da Terra, a invenção de uma hora mundial e a teoria científica da evolução coroavam a Europa como a dona do tempo, do progresso e da própria história. As categorias epistemológicas de mundo e de tempo que o ocidente inventou se substancializaram no mundo e no tempo ontologicamente concebidos e, "naturalmente", esses objetos ficaram sob a guarda de seu criador.

O estudo que melhor ilustra esse cruzamento entre erudição e dominação é Orientalismo (2013) , a obra já citada de Edward Said. Debruçando-se sobre o mesmo objeto que por ora nos interessa (o empreendimento colonial europeu do século XIX), Said mostra o paralelismo existente entre o avanço da dominação ocidental sobre o Oriente e o crescimento da doutrina teórica conhecida como Orientalismo. Como o próprio autor define, Orientalismo era "um modo de abordar o oriente que tem como fundamento o lugar especial do oriente na experiência ocidental europeia" (2013, p. 27). Legitimado como um conhecimento sólido, o Orientalismo era um discurso pretensamente científico espalhado pelas mais diversas áreas do saber, que consistia basicamente em uma teoria ocidental que tomava o Oriente por objeto. Quanto mais o Orientalismo se alastrava, mais a Europa dominava o Oriente, e vice-versa; "O alcance do orientalismo correspondia exatamente ao alcance do império" (SAID, 2013, p. 33). Como o autor observou, conhecimento e poder se 
fortaleciam mutuamente: o Orientalismo legitimava a colonização e esta criava a necessidade de um tex to que explicasse aquele novo cenário.

Cada um em sua respectiva área, mas fortalecendo-se reciprocamente, o conquistador militar e o orientalista acadêmico eram vistos como dois salva-vidas civilizatórios responsáveis tanto por garantir o protagonismo europeu no cenário mundial quanto por ajudar o Oriente a sair da treva em que ele se encontrava. Anteriormente, comentei que a Europa justificava sua dominação sobre as colônias afirmando que aquele regime era algo positivo não só para a Europa, mas para a própria colônia, que necessitava de uma intervenção civilizada para abandonar o estágio evolutivo atrasado em que se encontrava. Da mesma forma, o Ocidente se considerava mais habilitado a falar sobre Oriente do que o próprio Oriente justamente porque acreditava que o colonizado não conseguiria teorizar a si mesmo. "O orientalista moderno se considerava um herói resgatando o Oriente da obscuridade, alienação e estranheza que ele próprio cuidava de identificar" (SAID, 2013, p. 176). Dessa forma, tanto no plano político quanto no discursivo, a intervenção do Ocidente no Oriente era encarada como um gesto de filantropia. Não por acaso, as duas arbitrariedades se justificavam mutuamente.

"A exterioridade da representação é sempre regida por alguma versão do truísmo de que, se o Oriente pudesse representar a si mesmo, ele o faria; como não pode, a representação cumpre a tarefa para o ocidente e, faut de mieux, para o pobre Oriente" (SAID, 2013, p. 51)

"Pois o que ele [o orientalista] diz, com efeito, é que, sem pessoas como ele, o Oriente Médio seria negligenciado; e que, sem seu papel de mediador e intérprete, o lugar não seria compreendido (...) porque só o orientalista pode interpretar o Oriente, sendo o Oriente radicalmente incapaz de interpretar a si mesmo." (SAID, 2013, p. 386)

Embora insista que o Oriente seja o tema do Orientalismo, o subtítulo da obra de Said é "O Oriente como invenção do Ocidente". Diante disso, surge a pergunta: como um discurso pode inventar o objeto que tematiza? Essa é a pedra de toque do argumento do autor: para Said, o discurso ocidental sobre o Oriente não está apenas mostrando de maneira desinteressada o Oriente tal como ele é, mas o instaurando de forma interessada de acordo com o que o Ocidente acha que ele seja. Esses inofensivos gestos de classificação, categorização e sistematização possuem um caráter investido de fabricação, invenção e feitura. Para Said, sentidos aparentemente prontos que aguardavam o discurso que os tematizasse foram, na verdade, criados por esses discursos. Esse é o caso do Orientalismo: 
quando lemos o texto desses "eruditos", parece que seus autores passivamente nos mostram toda a concretude virginal de uma realidade nativa tal como ela mesma se define; contudo, para Said, o que esses textos revelam é a visão estrangeira sobre o Outro travestida de visão do Outro sobre si.

"A própria linguagem do Orientalismo mudou radicalmente. O seu realismo descritivo foi aperfeiçoado e tornou-se não apenas um estilo de representação, mas uma linguagem, na verdade, um meio de criação (...) $\mathrm{O}$ oriente foi reconstruído, remontado, moldado, em suma nasceu dos esforços orientalistas." (SAID, 2013, pp. 132, 133).

Como se pode ver, a violência do Orientalismo é dupla: a primeira é o gesto de criar sentidos ativamente, a segunda é fazer esse ativo gesto de criar sentidos parecer um passivo ato de mostrá-los. Empiricamente falando, essa conversão de invenção em tematização se realiza no momento em que o Ocidente faz com que sua imagem estrangeira do Oriente ganhe ares de autoimagem oriental, assim, a fabricação de um discurso externo sobre o Outro parece a simples demonstração de uma voz local. Como deve estar claro, a função do segundo aspecto da violência é apagar o rastro da primeira, e assim permitir que ela opere: é justamente porque os sentidos parecem estar sendo apenas passivamente evidenciados que eles conseguem ser ativamente criados, sem que ninguém interfira no processo.

Sendo assim, a grande contribuição de Said para esse debate foi a ideia de que mediação de sentido também é imputação de sentido. Quer dizer, aqueles intermediários que parecem estar apenas revelando passivamente os sentidos tal como são também instauram ativamente esses sentidos da maneira que acham que eles devam ser. $\mathrm{O}$ mediador se situa entre os sentidos e parece apenas administrá-los. Por desempenhar esse papel meramente administrativo, parece que o mediador não participa do jogo de imputação de sentido. Mas o que Said nos ensina é que essa não participação é uma das formas mais investidas de participar, pois posicionar sentidos também é defini-los. Renunciando a posição de jogador para adotar a de árbitro, o mediador consegue jogar com mais destreza, pois seu juízo parcial acerca do jogo acaba se convertendo na regra imparcial do jogo propriamente dita ${ }^{9}$. Sendo assim, é justamente nesse desinteresse enciclopédico de mediar sentidos que mora a legitimidade simbólica de interessadamente

\footnotetext{
9 "Línguas, raças, tipos, cores, mentalidades, cada categoria sendo menos uma designação neutra que uma interpretação avaliativa." (SAID, 2013, p. 221)
} 
imputá-los. "O silêncio é estratégico e garante a legitimidade do discurso e de quem discursa. (...) Os que se mantém em silêncio são os que mais dizem sobre os outros." (NICOLAU NETTO, 2014, p. 255). Como se falou, o aspecto da mediação apaga as marcas da criação, por isso, os violentos atos de autoria parecem contemplativos gestos de curadoria. Como bem resumiu Bruno Latour, "Cada vez que o trabalho de mediação era concluído, o trabalho de purificação começava" (2009, p. 76)

Ao mostrar como a criação se inscreve dentro da mediação de sentidos, Said revelou como é falsa a anterioridade das coisas em relação às palavras que as suscitam, ou melhor dizendo, dos objetos em relação aos discursos que os tematizam. Para Said, esse gesto supostamente secundário de classificar, categorizar e sistematizar coisas é que enseja os sentidos que parecia estar apenas organizando. Para o autor, a coisa não precisa existir para que só depois seja tematizada, pois é justamente esse gesto aparentemente tardio de tematização que cria a coisa. Não é que o texto exista para ser arquivado, pois é o gesto de arquivamento que escreve o texto. $\mathrm{O}$ manuscrito original já é o verbete do dicionário: inventariar é inventar, citar é falar. Fazendo referência ao mantra bourdiesiano: os gestos de classificação são também os atos de criação.

"O arquivo não é só um lugar que guarda e conserva um conteúdo arquivável do passado que existiria em qualquer caso, com ou sem arquivo. Não, a estrutura técnica de arquivação de um arquivo também determina a estrutura do conteúdo arquivado, inclusive o seu aparecimento e sua relação com o futuro. $\mathrm{O}$ arquivo tanto produz quanto registra o evento" (FEATHERSTONE, 2000, p. 181).

Por isso, no caso que interessa a Said, não é o Oriente que inspira o Orientalismo, é o Orientalismo que inventa o Oriente. A coisa não é a anterior ao discurso que enuncia, o discurso é que vem antes da coisa, pois, na verdade, ele não está só passivamente enunciando-a, mas ativamente a inventando. Paulatinamente, a ficção estrangeira ganha mais legitimidade simbólica que o próprio objeto sobre o qual ela versa, "com o tempo, o Oriente como tal tornou-se menos importante que a entidade em que o orientalista o transformava" (Said, 2013, p. 184), quer dizer, o Orientalismo passa a ser mais real que o Oriente propriamente dito. Como o autor afirma: "O conhecimento britânico do Egito é o Egito" (2013, p. 63). Se a fantasmagoria teórica é mais sólida que a objetividade da empiria, então o Oriente é o que o orientalista disser que ele é. Desse jeito, não importa tanto o que o Oriente seja, mas como o Ocidente o vê, até porque, no fim das contas, a 
visão ocidental sobre Oriente se converte nele propriamente dito. A subjetiva visão estrangeira é recebida como a objetiva realidade nativa ${ }^{10}$.

Mas, uma coisa tem que ser ressaltada a título de esclarecimento: a crítica de Said a uma invenção estrangeira não é, de jeito nenhum, a defesa de uma suposta "verdade nativa". O autor não acredita em uma "essência oriental" que esteja sendo maculada por mãos europeias. Seu pensamento vai justamente contra esse tipo de substancialização: o Orientalismo o incomoda exatamente porque instaura arbitrariamente essa etérea ontologia chamada "O Oriente", uma imagem do Outro fabricada pelo europeu, mas que é vendida como uma autoimagem local.

"Mas o fenômeno do Orientalismo, como eu o estudo aqui, não tem como tema principal uma correspondência entre Orientalismo e Oriente, mas a coerência interna do Orientalismo e suas ideias sobre o Oriente (...) apesar ou além de qualquer correspondência com um Oriente 'real'" (SAID, 2013, p. 32)

"Toda a minha ideia sobre esse sistema não é que seja uma desfiguração de alguma essência oriental - coisa que não acredito nem por um momento -, mas que opere como as representações em geral fazem, para determinado fim, segundo uma tendência, num específico cenário histórico, intelectual e até econômico. ". (SAID, 2013, p. 366).

Depois da obra de Said - e das contribuições de outros autores que serão posteriormente abordados - as ciências sociais aprenderam que a prática inofensiva de selecionar sentidos traz em si o gesto violento de inventá-los. Também ficou claro que é justamente a face passiva do primeiro gesto que garante o caráter ativo do segundo, pois é na natureza pacífica da seleção que se apaga o rastro arbitrário da criação. Ao evidenciar esse mecanismo, Said alterou a maneira de se enxergar a relação entre um discurso e a natureza que ele toma por objeto: durante muito tempo se acreditou em uma anterioridade da natureza em relação ao discurso que a enuncia. Como não se sabia que a função seletiva dos discursos secretava uma inventiva, achava-se que os sentidos selecionados pelo discursos pertenciam à natureza que ele tematizava. Por isso, fundamentalmente seletivo, $\mathrm{o}$ papel de um discurso era passivamente mostrar a natureza tal como ela era. Como se resumia a fotografar a concretude do natural, o discurso era legitimado por essa suposta realidade absoluta que ele discursava. Mas Said mudou o vetor dessa relação: o discurso é

\footnotetext{
10 Ao analisar os mapas produzidos por cartógrafos europeus, Nicolau Netto fala que "mais do que representar o mundo, eles se tornaram o próprio mundo que não podia ser visto em sua plenitude, mas que podia ser apreendido naquele desenho." (2014, p. 255)
} 
que vem antes da natureza, portanto, quando seleciona elementos, ele também os inventa. Ele não estava passivamente mostrando a natureza tal como era, mas ativamente constituindo-a bem como queria. Se os gestos de seleção trazem a marca da invenção, então aqueles sentidos não pertencem a natureza, mas ao discurso; sendo assim, aquilo que parece um natural imagem nativa é, na verdade, um arbitrário olhar estrangeiro. Como a invenção exterior violenta se inscreve na seleção local pacífica, o olhar estrangeiro se converte na coisa olhada, a subjetividade vira a objetividade: não há hiato entre o discurso e a natureza, pois a natureza local objetiva não passa do discurso externo objetivado. No caso de Said, isso significa que o Orientalismo, uma teoria ocidental sobre o Oriente, era o Oriente propriamente dito. Essa doutrina parecia estar só passivamente selecionando sentidos autóctones, mas estava ativamente produzindo sentidos estrangeiros.

Mas ainda é preciso dizer como isso se dava empiricamente, quer dizer, que mecanismo prático é acionado para que a seleção traga a marca secreta da invenção. Ora, a seleção sempre foi uma invenção porque os sentidos eram interessadamente escolhidos. Os traços pinçados do Oriente eram propositalmente selecionados, visando-se um fim específico. Embora parecesse um extrativismo aleatório, o trabalho do orientalista era uma colheita direcionada, um exercício fabril e não casual. O elemento em questão era selecionado, retirado de seu contexto original - o que alterava completamente o sentido tanto do elemento quanto do contexto - e retido. Repetindo esse gesto várias vezes, o orientalista formava um mosaico, ou melhor, um pastiche de fragmentos orientais e dizia que aquilo era $\mathrm{O}$ Oriente. Fora de seu contexto, aquele fragmento não significava nada; inserido em outro, ele significava outra coisa. Apenas por ali haver uma sucessão, pressupunha-se que havia uma ordem, e assim a colagem do Orientalista ganhava um sentido, mas o sentido era dado pelo orientalista que fazia a seleção dos elementos e não pelos elementos orientais selecionados. Achava-se que os sentidos eram nativamente imputados porque o leitor ocidental não via naquilo um amontoado de cacos orientais, mas um sistema inteiriço. $O$ que não se sabia era que essa sistematicidade fora dada pelo orientalista. Como seus arbitrários atos de invenção eram recebidos como tímidos gestos de seleção, não havia razão para não acreditar que aquele Frankenstein na verdade fosse o Oriente em toda a sua ipseidade ontológica. Claro, o que se tem aqui é um finalismo mais prático do que lógico, inspirado por valores, não por uma reflexividade prodigiosa. $\mathrm{O}$ orientalista não era um frio calculista que ouvia todos os ecos simbólicos de seus atos, mas 
também não era de jeito nenhum um caçador de borboletas diletante. Ele tinha um objetivo, mas um objetivo prático.

Fazendo com que seu pastiche de elementos dispersos fosse recebido como uma pátina contínua de sentidos, o orientalista conseguia ressignificar o Oriente da maneira que queria e apresentá-lo a seu público como se aquela fosse uma significação original. Como Said falou, "Uma das principais características do Orientalismo era a acumulação: de conhecimento, pessoas e territórios" (2013, p. 92). Para satisfazer esse "afã classificatório que tomava conta da Europa naquele momento" (NICOLAU NETTO, 2014, p. 67), o Orientalismo inventou um novo gênero: a crestomatia. As crestomatias não passavam de um arrazoado de pedaços de Oriente aleatoriamente compilados em uma obra. A função do organizador era conferir uma sistematicidade àquilo, fazendo com que aquele amontoado parecesse um corpo fechado. Como se pode ver, a sistematicidade era dada pelo ocidental, mas recebida como sendo original do Oriente, por causa disso a crestomatia ilustra tão bem essa articulação entre seleção passiva e invenção ativa. A crestomatia mais famosa na época era a Chrestomathie Arabe, de Sacy. Obra em três volumes definida por seu próprio autor como "Um livro agradável e proveitoso para o aluno estudioso: colige fragmentos de poesia e prosa" (Apud SAID, 2013). Sacy acreditava que sua obra apenas mostrava o Oriente tal como este era, para isso, o autor "fala do seu próprio trabalho como tendo revelado, trazido à luz, resgatado uma vasta quantidade de matéria obscura. Por quê? A fim de colocá-lo diante do estudioso. (...) O conhecimento era essencialmente tornar visível o material" (SAID, 2013, p. 183) [Grifos meus]. Contudo

"A ordem interna de seu conteúdo [das antologias de Sacy], o arranjo de suas partes, a escolha de fragmentos nunca revelam o seu segredo; temos a impressão de que, se os fragmentos não foram escolhidos pela sua importância, pelo seu desenvolvimento cronológico ou por sua beleza estética (como não foram os de Sacy), eles devem ainda assim encarnar uma certa naturalidade oriental, isto é, uma inevitabilidade típica. Mas isso também jamais é dito. Sacy afirma simplesmente ter se esforçado no interesse de seus estudantes, tornando desnecessário que eles comprassem (ou lessem) uma biblioteca grotescamente grande de material oriental. Com o tempo, o leitor esquece o esforço do orientalista e toma a reestruturação do Oriente apontada por uma crestomatia como o Oriente tout court. A estrutura objetiva (a designação do Oriente) e a reestrutura subjetiva (a representação do Oriente pelo orientalista) tornam-se intercambiáveis. $\mathrm{O}$ oriente é sobrecarregado com a 
racionalidade do orientalista; seus princípios se tornam os do orientalista." (SAID, 2013, pp. 185, 186)

Enfim, acumulando fragmentos desordenados e dando a eles uma ordem própria, o orientalista conseguia incutir o ativo gesto de invenção na passiva prática da seleção e assim converter a arbitrariedade de seu olhar estrangeiro na naturalidade do Oriente concreto. Mais adiante, recuperando a obra de Roger Chartier, mostrarei como as opções formais de registro e apresentação de um discurso (crestomatia, por exemplo) são constitutivas do conteúdo desse discurso e das leituras que se fazem dele. Esse caráter cumulativo do Orientalismo, olhado pelo prisma da teoria de Chartier, será importante para que entendamos a opção da World Music por organizar coletâneas que reúnem músicas de diferentes artistas ao invés de lançar discos com um músico só. Mas isso é para depois. Antes de chegarmos aí temos que descobrir o que o orientalista objetivava com esse esforço de produção de um Outro. Como o livro de Said é uma análise canônica do período que me interessa, voltarei constantemente a essa obra para ilustrar a discussão.

Olhando de maneira mais detalhada para as ideias acima sugeridas, podemos observar que o jogo da dominação colonial se baseia na tríade falar, substancializar, possuir. Analisemos então o que cada um desses instantes significa.

"Falar" diz respeito ao momento epistemológico em que é suscitada uma categoria, uma definição ou qualquer gabarito que se preste a construir ordenações e hierarquias: mapas, periodizações, conceitos científicos, por exemplo. "Substancializar" se refere ao instante de transubstanciação em que a categoria ordenadora se transforma na coisa que ela ordenava. É nesse estágio que se dá a mágica fetichista em que os nomes epistemológicos se convertem em artefatos ontológicos: os mapas viram os países, a concepção ocidental de desenvolvimento vira a História, doutrinas pseudocientíficas parciais e arbitrárias acerca do homem e a natureza viram o homem e a natureza propriamente ditos. Enfim, opera-se um processo de ontologização em que discursos subjetivos se cristalizam nas coisas objetivas que eles discursavam. Por fim, "possuir" é a etapa final do processo em que a voz que enunciou o nome e instaurou a coisa passa a ser sua dona legítima: se controla os mapas, as periodizações e os conceitos, a Europa manipula também os países, o tempo e a natureza humana, pois, como foi dito, as categorias avaliadoras se metamorfoseiam nos objetos que categorizam, fazendo com que aquele que domina as regras domine também as coisas que elas regulam. 
Por ser um sistema de dominação, o que marca o compasso dessa valsa colonial é a arbitrariedade e a violência. Fazer com que sua fala instaure os artefatos que ela comenta e, por sua vez, declarar-se o senhor dessas substâncias é, sem dúvida, um gesto de poder reservado a poucos. O poder simbólico de transformar suas palavras em coisas e suas coisas em posses foi adquirido pela Europa porque ela prescrevia a lei evolutiva de hierarquização do mundo; e esse papel de arbitrar normas, por sua vez, só foi a ela concedido porque ela se submeteu ao código que intentava prescrever: sendo o continente mais evoluído do mundo, a Europa definia o conceito de evolução; definindo o conceito de evolução, a Europa se fazia o continente mais evoluído do mundo.

Fecha-se a ciranda colonial: (1) O Ocidente se submete a um código. (2) O código passa a ser controlado pelo Ocidente. (3) Os princípios geradores e classificatórios do códigos são iguais, o que faz com que o código instaure as coisas que avalia. (4) Como o Ocidente maneja esse código por ter a ele se submetido e o código substancializa o mundo que ele codifica, manipulando o código o Ocidente manipula o mundo.

Mas como um sistema tão desigual, arbitrário e violento pôde se transformar em uma ordem mundial aceita? Simples: convertendo desigualdade em fatalismo, arbitrariedade em legitimidade e violência em natureza. Ou seja: todo o poder contingente, artificial e inventando, toda assimetria historicamente forjada, precisou ser percebida não como tal, mas como um estado de coisas normal e incontornável a um só tempo espontâneo e obrigatório. O problema era como fazer isso.

Para que se entenda como esse sistema abusivo de poder se legitima enquanto natureza, faz-se necessário primeiramente compreender que falar, substancializar e possuir não são três gestos, mas um gesto triplo, ou seja, não se tratam aqui de três atos diferentes, mas de três aspectos do mesmo ato: as três ações não se enfileiram em sucessão, mas se imediatizam de forma simultânea. O mundo não é ordenado para que em seguida seja construído e só então conquistado; pelo contrário: falar sobre o mundo é instaurá-lo e mantê-lo sob controle. A esfera da caneta do colonizador rolando no papel do mapa é a própria Terra que gira em torno do seu eixo. A chave colonial que transforma desigualdade, arbitrariedade e violência em fatalismo, legitimidade e natureza reside no 
imediatismo disso que chamarei aqui de um círculo de simultaneidade entre falar, substancializar e possuir ${ }^{11}$.

Não é difícil perceber como a naturalização e a legitimação do domínio se devem a simultaneidade dos gestos: ora, tudo o que é sucessivo é processual, histórico, e o que é histórico é fabricado, criado, inventado, sendo portanto uma contingência fruto de uma vontade arbitrária, de uma antinatureza, enfim, de uma violência. Sendo assim, aquilo que é legítimo, natural e absoluto não pode se reconhecer na horizontalidade causal do artifício histórico. Deus, por exemplo: para os fiéis, Deus não tem antes, durante ou depois, causa ou consequência, ninguém $\mathrm{O}$ inventou, por isso sua legitimidade não carece de exterior e Ele é natural e absoluto em si mesmo. Se aspira ao legítimo e à natureza, o projeto colonial deve, portanto, ter uma silhueta divina, o que significa recusar o sucessivo e abraçar o simultâneo, pois só assim a contingência histórica, o interesse arbitrário e a invenção violenta poderão se converter no purismo da legitimidade natural eterna. É por isso que as etapas de fala, substancialização e domínio que constituem a empresa colonial precisam se imediatizar de forma simultânea ao invés de se prolongarem em uma linearidade causal sucessiva.

Um mundo que precise ser primeiro nomeado, depois construído e em seguida conquistado não pode ser "O Mundo", como ambiciona a mentalidade colonial, mas apenas uma possibilidade entre outras. Por ser histórico, contingencial, arbitrário e violento, um projeto com essas características não consegue se justificar, naufragando na própria ilegitimidade. Sonhando com a naturalidade autolegitimada que só o absolutismo divino possui, o processo colonial se fecha dentro de si mesmo, convertendo-se em uma ontologia adiabática onde as etapas se dão de forma simultânea, legitimando-se reciprocamente. Esse carrossel de autolegitimação só é possível se as instâncias de enunciação, substancialização e conquista se derem ao mesmo tempo. Aquele que ambiciona fechar um circuito entre as

\footnotetext{
${ }^{11}$ O próprio Said chama a nossa atenção para o caráter sistêmico do Orientalismo. Para o autor, o interesse pelo Oriente é muito mais antigo do que o Orientalismo. O traço diferencial dessa escola é seu caráter sistêmico, quer dizer, sua estrutura adiabática de auto-legitimação. "Por Orientalismo quero dizer várias coisas, todas na minha opinião, interdependentes. (...) A unidade do grande conjunto de textos que analiso se deve em parte ao fato de que eles frequentemente se referem um ao outro: o Orientalismo é afinal um sistema para citar obras e autores". (2013, p. 28)
} 
categorias, as coisas categorizadas, e a posse dessas coisas, precisa se entregar às regras para que essas se entreguem a ele.

Passando em revista o que até aqui foi colocado, o quadro que se tem é o seguinte: o projeto colonial era sustentado pelo tripé progresso, história linear única e evolução. Como o ocidente se submeteu a essa ortodoxia (A Europa é a cultura mais evoluída do mundo), essa ortodoxia se submeteu ao ocidente (A Europa diz o que é evolução). As categorias com a qual a ortodoxia trabalhava (mapas, periodizações, conceitos científicos) se coagulavam nas coisas que elas categorizavam (países, História, natureza humana), fazendo com que esses artefatos objetivados fossem retidos pelo ocidente, já que era ele que controlava a doxa (domínio sobre países, a História e a natureza humana). Esse mecanismo desigual, arbitrário e violento adquiria legitimidade, fatalismo e naturalidade porque as instâncias de fala, substancialização e posse - ao invés de se sucederem linearmente evidenciando seu caráter processual, histórico, contingente e artificial - se fechavam em um circuito hermético de simultaneidades em que as três etapas operavam ao mesmo tempo, sustentando-se de maneira recíproca.

É esse arranjo circular e simultâneo entre falar, substancializar e possuir que faz com que sentidos artificiais historicamente constituídos e violentamente imputados apareçam como virginais naturezas intactas. O círculo de simultaneidade causa esse efeito porque os juízos parciais que subjetivamente avaliam o mundo e as fronteiras "imparciais" que "objetivamente" dividem esse mesmo mundo estabelecem um paralelismo tão alinhado que as duas instâncias purificam-se reciprocamente. O processo se dá seguinte maneira: de um lado, há regras (fala) do outro há o mundo sistematizado por aquelas regras (a fala substancializada). Ambos são criados historicamente de maneira violenta e arbitrária. Mas a simetria impecável entre os dois confere tanto fatalismo e a-historicidade ao seu encontro quanto naturalidade à dupla. A afinação entre a regra e o mundo que ela regula se faz tão sublime que ambos se unem em um mesmo corpo sem fissuras, de modo que parece que eles nunca estiveram separados um dia. A perfeição com que palavra e coisa se encaixam, compondo um só artefato, afasta qualquer possibilidade de arbítrio: o encontro "tinha que acontecer". Nesse instante não dá mais para saber o que é regra e o que é mundo, pois o que se tem parece ser um objeto sem começo, meio ou fim: uma natureza absoluta. Errado. 
Como se falou, mundo e regra são igualmente violentos, históricos e inventados. A harmonia que rege o acoplamento das duas instâncias não é um indicativo nem da inevitabilidade a-histórica desse encontro nem da naturalidade dos dois; pelo contrário, é a prova de que tudo foi arbitrariamente forjado. Mas se não foi Deus, nem a natureza, nem o destino, como pode haver um duplo espelhamento tão perfeito entre regra e mundo? É aí que a mágica purificadora do círculo de simultaneidades imediatas opera: regra e mundo tem a mesma silhueta e se encaixam "sem esforço" porque as duas instâncias se construíram mutuamente em um círculo de simetria e reciprocidade, porque a regra é uma fala e o mundo nada mais é que essa fala substancializada. Fazendo seu duplo, cada metade do arranjo faz a si própria. As regras informam o mundo que ratifica essas regras que pesam ainda mais sobre o mundo que confirma com mais vigor essa regras... Mais do que "feitos um para o outro", regra e mundo se fizeram reciprocamente, e por isso elas se parecem tanto. Como se pode ver, a "perfeição" dessa simetria não tem nada de natural, absoluta ou fatal, pelo contrário, trata-se aqui de uma adequação forjada histórica e arbitrariamente em um círculo de simultaneidades onde as instâncias mutuamente se nivelam.

Por me aferrar a esse princípio da simultaneidade e da criação recíproca, eu me separo um pouco de Said e Latour, autores que me trouxeram até aqui. Assim como Said, acredito que as naturezas não antecedem os discursos, mas não seria tão enfático em afirmar o contrário. Acredito mais em um nivelamento recíproco das instâncias do que em uma anterioridade do discurso em relação a natureza. Essa autonomia total do discurso mais transfere o problema de lugar do que o resolve, pois o problema da concretude ahistórica absoluta inscrita na natureza não desaparece, apenas migra dela para o discurso. Esse mesmo círculo de simultaneidades me afasta de Latour, porque enquanto o autor acredita que os gestos arbitrários são primeiro perpetrados para que só então sejam purificados, eu acredito que seja na própria violência dos gestos que se inscreva seu mecanismo de assepsia. Caso contrário, estaríamos diante daquele problema infinito: os gestos são executados, depois o rastro de execução é limpado, depois é limpado o rastro da limpeza, depois se limpa o rastro do rastro da limpeza... Isso não faz sentido. Se o efeito de fatalismo asséptico da classificação não se der junto com a arbitrariedade violenta da invenção, o ato não terá eficácia simbólica porque sua ilegitimidade estará sempre evidente. 
Como se disse, existe uma explicação histórica para a suposta a-historicidade das coisas. Falar sobre algo é instaurar aquilo que se tematiza e vice-versa. A circularidade entre fala e substancialização converte toda violência histórica em natureza eterna, pois a arbitrariedade da invenção contingente de sentido se inscreve na suposta naturalidade com que é suscitado aquele mesmo sentido, assim, a instauração de sentidos históricos e o apagamento do rastro dessa feitura são dois gestos simultâneos, ou melhor, são o mesmo gesto. Sentidos são inventados e praticados; acredita-se que inventá-los seja histórico e violento, mas que praticá-los seja natural. Como os atos de invenção se inscrevem em todos os momentos de execução, o arbítrio da gênese desaparece na espontaneidade da prática não por fugir dela, mas por se marcar em todos os seus momentos, convertendo assim violência em natureza. $\mathrm{O}$ olho tem a mesma idade do mundo que ele olha. Por causa desse parentesco entre visão e vida, os juízos ratificam as coisas e as coisas complementam os juízos em uma espiral de ratificação mútua que só se fortalece: ${ }^{12}$ as "visões de mundo" são as mesmas "divisões de mundo" ${ }^{13}$. As objetividades não passam de subjetividades objetivadas que tiveram seu rastro de objetivação apagado no próprio processo objetivante, fazendo com que as coisas se mostrassem não como algo violentamente objetivado, mas sim naturalmente objetivo. O mutualismo entre essas instâncias é tão fino que a vida já surge limpa sem deixar transparecer sinais de que na verdade foi limpada no momento em que surgia. Os maiores feitos da história não foram seus feitos, mas o apagamento do rastro desse feitos, pois é a invisibilidade dessa feitura produzida no momento em que ele se opera que permite que os feitos se façam. Da mesma forma, nenhuma violência perpetrada pela história é maior do que apagar os indícios de que a história é violenta, pois é fazendo parecer que nada é violento que a história transforma toda violência ilegítima em natureza legítima. Mundo e regra se constroem simultaneamente e assim toda violência e contingência se mostra natural e pura, pois como regra e mundo estão lado a lado, sendo carregadas por um mesmo processo histórico (e também carregam esse processo), para elas parece que estão as duas paradas, da mesma forma que motoristas emparelhados a cem quilômetros por hora podem olhar para o lado e conversar tranquilamente, distinguindo

\footnotetext{
${ }^{12}$ Em sua aula inaugural, Barthes (2008, p. 33) define como uma de suas ambições intelectuais "compreender [...] como uma sociedade produz estereótipos, isto é, cúmulos de artifício que ela consome em seguida como sentidos inatos; isto é, cúmulos de natureza".

${ }^{13}$ Inclusive "Vision of Division" é o nome de uma música que compõe o terceiro álbum de estúdio da banda nova-iorquina The Strokes. Coincidência ou não, o nome do disco é "First Impressions of Earth".
} 
suas silhuetas em repouso enquanto, para quem vê a cena, sentado na calçada, eles são só borrões confusos em movimento. Por mais construído que tenha sido, todo desenlace histórico tende a ser experimentado como destino. Por isso, nenhuma regra que avalie o mundo será tida como injusta, assim como nada no mundo desrespeitará uma regra, pois regra e mundo se constroem em recíproca afinação.

Somando-se à fala e à substancialização, o projeto colonial evidencia o aspecto da posse. Com essa terceira figura completa-se o moinho de simultaneidades do colonialismo: a palavra dita enseja uma substância e a substância pertence à voz que disse a palavra. Por se submeter às hierarquias do progresso, do monismo histórico e da evolução humana, o ocidente passa a manejar tanto essas categorias quanto as ontologias que elas erigem. Logicamente, esse caráter dominador da colonização não se explica só por essas questões conceituais, mas tem suas origens em um cenário geopolítico que vinha sendo rascunhado desde o século XVI: era das navegações, descobrimento, ocupações além-mar, pilhagem de recursos naturais das colônias e toda sorte de vantagem econômica.

O fato é que, controlando as hierarquias a que ela mesma se submetia, a Europa pôs em curso um projeto colonial duradouro cuja eficácia residia na círculo de simultaneidades que enredava os atos de fala, substancialização e posse. Por causa do imediatismo dessas instâncias, toda a carga violenta e histórica do programa colonial era experimentada como algo natural e eterno. Através desse mecanismo, ideias como progresso, monismo histórico linear e evolução, arbitrariamente concebidas e limitadas a um lugar e a uma época, cortavam seu cordão umbilical com qualquer tempo e qualquer espaço, despontando no cenário internacional como noções imortais desenraizadas. Todas as culturas estavam enredadas em suas idiossincrasias e suas respectivas agendas, mas, o Ocidente, colocando em prática essa assepsia, parecia defender ideais supremos aplicáveis a todos os contextos. Com isso, o projeto colonial encontrou uma de suas principais características: o universal.

Estava justificada toda dominação.

$* * *$

O universal é, por definição, algo único, homogêneo, puro e absoluto. Único porque nada é igual a ele. Homogêneo porque sua superfície é lisa e contínua e nela não se pode formar nenhuma relevo, nenhuma rugosidade. Puro porque ele não se deixa marcar pelo 
interesse, a contingência e o arbítrio. O universal não foi inventado, não tem autoria, não tem início, nem antes; nenhum sentido foi imputado, nenhuma violência simbólica foi perpetrada para que ele existisse. A pureza do universal também reside no fato de que ele é um tipo matricial, original e originário; não é parte, nem derivado; é um artefato autocontido, não sendo, portanto, fruto de nenhuma mistura, nenhuma síntese. Absoluto porque é eterno, constante, perene; não se prende a contingências, não é histórico e resiste às mudanças. As coisas mudam mas o universal permanece, pois ele é um círculo encerrado em si mesmo sem finalidade externa, já que sua razão de ser é ele próprio. Sendo único, homogêneo, puro e absoluto, o universal se opõe ao múltiplo, ao heterogêneo, ao híbrido e ao relativo. Aquilo que é idiossincrático, contingente, histórico, diferente, fruto da vontade humana arbitrária é um particular, ou seja, uma degeneração, um desvio em relação ao universal. Sendo assim, o particular tem que reconhecer sua subserviência em relação ao universal. Imanente, a-histórico, eterno e incontornável, o universal é uma natureza legítima. Pelo menos era esse o conceito de universal do período colonial.

As características tidas como universais nessa época (com a licença do paradoxo) eram os traços europeus. Quer dizer, os atributos sem idade nem lugar, incriados, avessos a quaisquer fronteiras, livres das marcas do contingente, do particular, do finalismo arbitrário, enfim, do relativo, nada mais eram que as qualidades de um momento e de uma cultura muito específica, situada em um dado território e em um dado tempo histórico. Esses sentidos violentamente imputados e contextualmente limitados conseguiam se converter em uma natureza legítima porque o rastro da violência e da historicidade que ensejou esses sentidos fora apagado pelo imediatismo das instâncias falar/substancializar/possuir enredadas no círculo de simultaneidade acima descrito.

De fato, o tema do universal se configurou como um agenda na era colonial. Nesse período surgiram os livros de "história universal" e as enciclopédias, cresceu o interesse por sistemas totais, bem como a busca por um idioma universal, um dicionário universal, etc. Essa suposta língua de Deus ora ganhava a forma de um código mínimo e matricial através do qual tudo poderia ser dito ${ }^{14}$ (como uma linguagem de programação de computador), ora se transformava em um glossário infinito que ambicionava ter o tamanho da natureza. É nessa mesma época que florescem narrativas ambiciosas que tematizam

\footnotetext{
${ }^{14}$ Idiomas desse tipo são o tema do ensaio O Idioma Secreto de John Wilkins (2007), de Jorge Luís Borges. Por curiosidade, é nesse ensaio que Foucault se inspira para escrever As Palavras e as Coisas (2007b).
} 
objetos igualmente grandiosos: o Homem, a Natureza, o Mundo, a História, etc. Como se pontuou, a Europa desse período atravessou uma revolução científica onde invenções foram criadas e novas teorias surgiram (como a teoria da evolução, anteriormente comentada). Nesse cenário, temas que eram explicados pela religião passaram para a arena laica da ciência. Na esteira desse movimento, assistiu-se ao aparecimento do racionalismo, do espírito das luzes, do esclarecimento, e de tantos outros discursos. Tudo isso apontando para o universal.

Esse espírito universal que tomava conta da Europa precisava se materializar em alguma instância, quer dizer, era preciso que houvesse uma morfologia que o cristalizasse. O corpo no qual esse discurso se concretizou foi o estado-nação europeu. Dessa forma, encerrando-se dentro do espaço do estado-nação, o espírito universal do período colonial se realizou. Como a palavra e a coisa se constroem reciprocamente e fala e substância são só dois aspectos de um mesmo fenômeno, o discurso do universal e o corpo do estadonação se formavam mutuamente, nivelando-se em uma afinidade eletiva onde cada um se fazia na medida em que fazia o outro.

Mas aqui surge a pergunta: como o discurso do universal, que se pensa como uma natureza a-histórica alheia a quaisquer limites temporais, espaciais e culturais, pode se realizar em um corpo tão específico, datado e marcado por rigorosas fronteiras geográficas como o estado-nação? Na verdade, não há nenhuma incompatibilidade entre as duas coisas. Aliás, pode-se dizer que universal e nação, para a época, eram até complementares. $\mathrm{O}$ trabalho de assepsia que transformou o violento e histórico empreendimento colonial em uma natureza legitimada passa pela ideia de estado-nação. Para que o universal operasse, os territórios fossem conquistados e os projetos locais, arbitrários e finalistas do ocidente ascendessem à legitimidade autojustificada de uma natureza absoluta era preciso que o universal se substancializasse na nação e que a nação refluísse no universal.

Embora se apresentasse como um universal desenraizado sem espaço nem tempo, os valores universais eram valores europeus. Assim, no fundo, o processo de universalização era uma cruzada de europeização. O universal se realizava no contexto ocidental purificando-o, cortando seus laços com aquele cenário circunstancial, e assim fazendo com que ele soasse universal. Mas essa falta de antagonismo entre o diáfano e eterno universal e o limitado e enraizado estado-nação deve ser explicada conceitualmente. 
Para que se entenda a coexistência entre universal e estado-nação deve-se primeiro perceber a diferença entre os binômios local/global e particular/universal. Não raro, vemos autores que tratam as díades como iguais, considerando local sinônimo de particular e global como uma opção a universal, mas a história nos dá exemplo que mostram como essa relação não é obrigatória. Para os fins dessa pesquisa, esses pares serão conceituados da seguinte maneira: local/global diz respeito à presença geográfica e empírica de um fenômeno. Aquilo que estiver restrito a uma parte do globo, a uma cultura específica, será local; já o evento que se espalhou por todo o planeta será aqui tido como global. A dupla particular/universal nada tem a ver com a presença física ou territorial de um fenômeno, pois esses conceitos dizem respeito não ao aparecimento de um traço, mas às pretensões epistemológicas de um discurso. Sendo assim, todo discurso que reunir as características de unicidade, homogeneidade, pureza e absoluto será um discurso universal, não importando o seu espalhamento pelo globo. Textos com essas características que tematizem totalidades abrangentes como o Homem, a Natureza, a Vida, a História serão narrativas universais. Não importa se é localmente ou globalmente aceito: para ser universal um discurso só precisa ser tido como universal dentro de uma comunidade. Mas, no interior desse espaço, ele tem que ser inquestionável, pois isso diz respeito ao princípio da homogeneidade que funda essa característica. Sendo assim, um pequeno grupo que teça um comentário tido por seus membros como unitário, homogêneo, puro e absoluto estará produzindo um discurso universal (e local, no caso). A universalidade de um discurso será definida nesse texto como uma categoria nativa e uma autoimagem; portanto, mesmo que um discurso seja arbitrariamente forjado e logicamente limitado (todos são), se for considerado pelos que o proferem como universal, o discurso será tido aqui como universal. Em contrapartida, um discurso particular é um discurso que se refere diretamente a um contexto específico, ou seja, que quando se apresenta evoca imediatamente um determinado lugar e uma determinada época, um cenário limitado histórica e geograficamente. Embora simbolicamente enraizado, esse discurso pode se espalhar pelo mundo todo (sendo portanto particular e global).

"O universal deve ser entendido como uma proposição que se volta a um todo, seja ele definido ou indefinido, no qual seus elementos aprioristicamente se relacionam independentemente de qualquer condição. Para que o universal exista não importa o alcance de sua proposição, desde que ela seja válida para todos os elementos do todo, ainda que não realizada. $\mathrm{O}$ universal, portanto, não precisa ser global." (NICOLAU NETTO, 2014, p. 57) 
Dito de maneira definitiva: local e global são dois conceitos geográficos e empíricos que medem presença física de um fenômeno no mundo. Particular e universal são dois conceitos epistemológicos que dizem respeito às ambições de validade de um discurso. Ali espalhamento empírico de fenômenos, aqui pretensão epistemológica de discursos. Dando exemplos que cruzam as duas díades, podemos visualizar melhor essas definições:

(A) Local/Particular: Políticas públicas de uma cidade.

Políticas públicas da secretaria de cultura de um município são exemplos de fenômenos locais e discursos particulares. Do ponto de vista do espalhamento empírico do fenômeno, tem-se aqui um evento limitado a uma pequena parcela do globo, sendo portanto local, pois tais políticas públicas estão restritas àquela cidade e não se observam em nenhuma outra do mundo. Do ponto de vista da pretensão epistemológica do discurso, vê-se aqui um texto que se refere a algo limitado e que não aspira à unicidade (convive com outros discursos), à homogeneidade (pode ter muitos aspectos), ao purismo (pode ser multifacetário, diverso) e ao absoluto (pode estar errado, mudar a qualquer momento e se limita a uma constelação histórica). Tais políticas foram elaboradas para uma contingência limitada no tempo e no espaço, pois não se levou em conta os habitantes do passado ou os de um futuro muito longínquo ou os de outras cidades. Além disso, o discurso admite um (ou mais) autores e se sabe algo reflexivamente ensejado decorrente de uma imputação de sentido, não podendo se converter em uma natureza eterna. Por isso o discurso é particular, e não universal.

(B) Global/Particular: MPB

A MPB é um fenômeno global e um discurso particular. Do ponto de vista do espalhamento empírico do fenômeno, têm-se aqui um evento presente em boa parte do globo, que não se limita ao seu lugar de origem, sendo portanto global. Em várias partes do mundo as pessoas conhecem e consomem MPB e os músicos do gênero viajam para fazer shows nesses países. Do ponto de vista da pretensão epistemológica do discurso, vê-se aqui um texto de tema restrito e que não almeja alcançar a unicidade (convive com outros estilos musicais), a homogeneidade (é muito variada), o purismo (tem muitos aspectos) e o absoluto (é uma efemeridade, uma moda enraizada em uma configuração específica). Os 
temas da MPB são agendas restritas a um Brasil de uma determinada época, quer dizer, a uma contingência histórica. MPB não é um discurso de longo alcance sobre a natureza humana, mas um comentário parcial sobre um contexto. Da mesma forma, a MPB é um discurso artificial, inventado, não podendo ser uma natureza imanente. Além disso, MPB é algo que se refere imediatamente ao Brasil (ou seja, a uma contingência), por isso simbólica e epistemologicamente esse é um discurso particular. Ainda que se espalhe pelo mundo todo, é sempre o mesmo Brasil que a MPB evoca. Essa é uma música que "todo mundo" conhece, por isso é global; mas que "todo mundo" conhece como sendo brasileira, por isso é particular. Empiricamente ela se espraia pelo globo, mas epistemologicamente ela se restringe a uma partícula. ${ }^{15}$

(C) Local/Universal: Iluminismo no século XVIII e Jorge Luís Borges.

Quando do seu aparecimento, o iluminismo era um fenômeno local e um discurso universal. Do ponto de vista do espalhamento empírico do fenômeno, o que se tinha aqui era um evento restrito a uma única parcela do globo, sendo portanto local, já que essa doutrina só existia na Europa. Do ponto de vista da pretensão epistemológica do discurso, verifica-se aqui uma narrativa que se queria única (dominava o debate da época), homogênea (seus membros compartilhavam os mesmos preceitos), pura (reconhecia-se como uma doutrina básica, elementar para a vida) e absoluta (acreditava-se de aplicação geral), definindo-se então como universal. Ainda que só fosse cultivado por europeus de um dado tempo (local), o iluminismo tecia comentários sobre todos os povos e todas as épocas (universal). O objeto do interesse dos filósofos iluministas não era o efêmero cidadão europeu do século XVIII, mas a própria natureza humana, a razão, a História e o devir da humanidade. A doutrina não se percebia como um espírito de época, mas como o próprio espelho da natureza. Embora o iluminismo tenha seus autores, estes não se enxergavam como "inventores" de uma teoria, mas como porta-vozes da vida. Quer dizer, não se considerava o iluminismo um sentido arbitrariamente imputado, manchado pelas

\footnotetext{
${ }^{15}$ Imagens que, quando mostradas para várias pessoas do mundo, suscitam imediatamente um mesmo lugar são exemplos de eventos globais e discursos particulares. Pontos turísticos tem esse poder simbólico. Se mostrarmos uma foto da Torre Eiffel para pessoas de diversas culturas e perguntarmos onde a foto foi batida, a maioria saberá dizer que foi em Paris. Por ser reconhecida por pessoas de todo o mundo, a Torre Eiffel é global, mas como se refere imediatamente a Paris, o monumento é local. Empiricamente ela se espalha, mas epistemológica e conceitualmente ela se restringe.
} 
idiossincrasias de seu tempo e espaço e pela subjetividade de seus criadores; pelo contrário, via-se na prédica um tratado acerca do universo.

Ainda que todas essas crenças estejam equivocadas e o iluminismo seja uma parcialidade histórica e uma contingência cultural, o discurso ainda pode ser considerado universal. Digo isso porque o que importa aqui não é o que o discurso "é", mas como ele se enxerga e quais são suas ambições epistemológicas. Nativamente falando, o iluminismo era um discurso universal. O que é universal no discurso é sua autoimagem e a dimensão que ele dava a si mesmo, por isso não há qualquer eurocentrismo em salientar a universalidade desse texto. Por esses mesmos critérios, pode-se considerar também como universais (e locais), por exemplo, as cosmologias ameríndias ou a prédica de Cristo (que hoje se globalizou, mas na época só arregimentou doze pessoas e uma delas ainda traiu o movimento).

$\mathrm{Na}$ ficção, o tema do infinito contido em rígidas arestas é constantemente trabalhado nos contos de Borges, sendo "O Aleph" (2008) o conto que melhor ilustra esse arranjo entre universal e local. $\mathrm{O}$ texto fala de uma esfera de poucos centímetros de diâmetro que guarda dentro de si todas as coisas do universo (e o próprio universo) em tamanho original, vistas de todos os ângulos e simultaneamente.

Enfim, nesse exemplos o que temos são espaços locais que guardam discursos universais, ou, como diria Said, tentativas de "encerrar o infinito numa forma finita" (2013, p. 101).

\section{(D) Global/Universal: Colonialismo}

Como se pôde ver no item anterior, um discurso universal não é algo perigoso ou totalitário em si mesmo, pois, muitas vezes, o traço único, homogêneo, puro e absoluto desses discursos se restringe a um espaço local. Nesse casos, essas narrativas universais fecham-se dentro delas mesmas, criando assim um universo próprio interessado mais em instaurar uma coerência interna do que em transformar aquilo que lhe escapa. Falas universais em espaços locais querem criar um mundo novo sem mudar aquele que já existe. Essa inocência desaparece quando o discurso universal cansa de dialogar consigo mesmo e passa a querer que sua universalidade seja compartilhada por outros universos. 
Nesses casos, o discurso universal deixa de ser local para ser global. É nessa ambição global que mora a violência do discurso universal.

Esse foi o caso do projeto colonial europeu. Inicialmente, os valores ocidentais eram universalidades locais, quer dizer, discursos únicos, homogêneos, puros e absolutos que tematizavam generalidades como a natureza humana e a História, mas que só eram compartilhados pelos europeus, restringindo-se ao continente. Porém, como irá ser trabalhado mais adiante, chegou o momento em que esse discurso universal europeu parou de se limitar à sua localidade e começou a se impor a outros locais, que tinham seus respectivos universais. Inicia-se aqui um programa ocidental de conquista, ocupação e exploração de terras estrangeiras sem par na história. Além de drenar recursos naturais e humanos, o ocidente impunha seu modo de vida aos nativos que espoliava. Enfim, o projeto colonial europeu é o claro exemplo de um discurso universal que ignora seus limites locais para se implementar violentamente em terras estrangeiras, tornando-se global.

"A ligação entre universal e global, embora não necessária, existiu na modernidade pela concordância entre um discurso universal em um contexto imperialista, formando quadros de referência aos quais o exótico se ancorou." (NICOLAU NETTO, 2014, p. 69)

Mas uma nuance deve aqui ser retida. Sim, o discurso universal europeu deixou de se limitar ao continente e se alastrou pelo mundo inteiro, passando assim de local para global. Mas isso não quer dizer que o discurso cortou suas raízes com a Europa para se fixar em outros locais, muito pelo contrário: o discurso se universalizava trazendo consigo a marca da origem europeia. Ou seja: quando o universal europeu aumentava, o local europeu também crescia. A Europa não ambicionava apenas que vários locais compartilhassem seu universal, mas que aqueles locais se anexassem ao território europeu. O discurso do outro deveria virar o discurso europeu, assim como a região do outro deveria virar região europeia. Desse jeito, esse discurso universal não saltou seus muros em busca de outros locais, mas os empurrou a partir de dentro. As fronteiras não foram cruzadas, mas expandidas. O programa imperialista não objetivava apenas um mundo onde muitos locais diferentes entoassem um mesmo discurso, mas um mundo onde um só local único, homogêneo, puro e absoluto entoasse um só discurso único, homogêneo, puro e absoluto. O discurso não cogitava abandonar seu solo para pisar em outros territórios, mas 
pavimentar o mundo inteiro com o seu ladrilho para que o discurso pudesse crescer deslizando no mesmo terreno de sempre.

Por isso, o projeto colonial, ainda que no fim das contas seja um empreendimento global/universal, ainda conserva um ranço local/universal. De um ponto de vista prático, o discurso local virou global; mas, se quisermos insistir em um purismo lógico, podemos dizer que o discurso não se globalizou, o globo é que se "localizou". Como se pode ver, o projeto colonial cria uma distorção nos conceitos: se no espaço de um século (1815 - 1914) a ocupação territorial europeia do planeta passa de $35 \%$ para $85 \%$, então não seria exagero afirmar que o próprio globo deixou de ser um espaço global. Quanto mais o local-Europa dominava o globo, mas o globo se parecia com ele, quer dizer: o projeto de mundialização da Europa não deixa de ser também um esforço de europeização do mundo. O continente não ficava mais cosmopolita, o mundo é que estava mais provinciano. Todavia, para que o percurso aqui traçado faça sentido, eu prefiro criar esse quarto tipo do que considerá-lo uma variante do terceiro. Essa ênfase local nas pretensões globais do universal colonialista será tida aqui como uma faceta ou um aspecto do tipo de espalhamento empírico desse discurso universalista.

No item anterior foi dito que tanto iluminismo quanto as cosmologias ameríndias se aproximavam pelo fato de serem universais locais, quer dizer: discursos únicos, homogêneos, puros e absolutos acerca de grandes questões, mas que se restringiam a seus respectivos territórios, sendo compartilhados apenas por um punhado de indivíduos. Mas no momento agora discutido, a simetria entre esses dois discursos desaparece. Ao contrário dos ameríndios, os europeus empurraram os muros de seu local, fazendo com que seu discurso universal se espraiasse violentamente pelo globo. Espírito das luzes, racionalismo, progresso, história única linear, evolucionismo eram ideias universais contidas na Europa; mas quando o continente abraçou o projeto colonial, aquele discurso universal deixou de ser local e se globalizou ${ }^{16}$.

Pelo prisma do espalhamento empírico do fenômeno, tem-se um evento que se alastra por $85 \%$ do planeta, sendo então global. Pela lente da pretensão epistemológica do

\footnotetext{
16 "Globo", "global", "globalizar" não se referem aqui ao fenômeno da globalização. Esse período ressignifica totalmente essas palavras, mas isso será analisado no capítulo 3.
} 
discurso, vê-se uma narrativa única, homogênea, pura e absoluta. Por isso, o projeto colonial europeu se configura como um global/universal.

Exemplificados os quatro casos, podemos agora retomar o fio do raciocínio. Como dito mais acima, a Europa cultivava um espírito universal que precisava se encarnar em uma morfologia para se realizar; essa morfologia foi o estado-nação. Em uma primeira olhada pode soar paradoxal que um discurso universal se cristalize em algo limitado no tempo e no espaço como o estado-nação, mas, na verdade, essa inadequação é só aparente, pois, ao invés de rivalizarem, os dois entes são mutuamente necessários. A crença errônea nessa incongruência entre o universal e o nacional se alicerça em uma confusão que se faz entre os binômios universal/particular e local/global. Para justificar aquela união, tipifiquei os quatro conceitos, exemplificando todas as combinações possíveis entre eles. Evidenciados os cruzamentos disponíveis entre os quatro termos daqueles pares, cabe responder: a qual dos casos pertence a relação entre discurso universal colonialista e estado-nação europeu?

A relação entre universal e estado-nação na Europa desse período que nos interessa nasce como um cruzamento do tipo (C), mas caminha para o (D). Dito de maneira prolongada: a princípio universal e estado-nação eram um exemplo de universal/particular. O discurso era universal, mas o país um particular, como era no estado que o universal se cristalizava, tinha-se um universal/particular. Mas, quando a expansão colonial começa, a Europa passa a subjugar e espoliar outras culturas, impondo seu modo de vida a elas e anexando seus territórios ao velho mundo. Nesse instante em que o universal não se contém mais no local e o próprio local almeja conquistar outros, o cruzamento que se tem é do tipo universal/global. Entendamos essa transição.

Enquanto o cruzamento entre o discurso e a nação era do tipo universal/particular, as coisas se davam da seguinte maneira: o ocidente havia ensejado um discurso universal baseado nas ideias de progresso, monismo histórico linear e evolução. Por ser universal, esse era um discurso único, homogêneo, puro e absoluto. Esse discurso precisava se encarnar em uma materialidade através da qual pudesse operar, quer dizer, era necessário um anteparo empírico onde os efeitos do discurso fossem sentidos. Essa materialidade foi o estado-nação europeu. A relação que se estabeleceu entre discurso universal e estadonação, nesse momento, foi daquele tipo circular simultâneo: o nome e a coisa se davam 
imediatamente, sendo a fala a dimensão discursiva da substância e a substância o aspecto ontológico da fala. Em outras palavras, isso quer dizer que o discurso universal era o estado enunciado e o estado desempenhava o papel de universal corporificado. Dessa forma, os ideais de progresso, monismo histórico linear e evolução, bem como sua silhueta universal enraizada no único, no homogêneo, no puro e no absoluto deveriam ser características tanto do discurso quanto do estado-nação, já que ambos eram praticamente a mesma coisa.

Se o discurso universal da época pregava o progresso, a história linear única e o evolucionismo, dando a essas características ares universais de unidade, homogeneidade, pureza e absolutismo, também o estado nacional deveria ser um espaço onde o progresso, a história monista linear e a evolução se realizassem alicerçadas nos traços únicos, homogêneos, puros e absolutos que caracterizam o universal. Foi exatamente isso o que aconteceu: a nação era o universal feito corpo, e o universal era a nação discursada, ambos únicos, homogêneos, puros e absolutos.

Como intentava incorporar o discurso universal, a nação deveria então assumir a face única, homogênea, pura e absoluta desse discurso. $\mathrm{O}$ objeto onde esse projeto de universalização da nação se realizou foi a cultura. A nação universal única, homogênea, pura, e absoluta seria aquela detentora de uma cultura universal única, homogênea, pura e absoluta. Implementar esse projeto não era uma tarefa simples: para que esses critérios fossem satisfeitos e pudesse ascender ao universal, cada nação só poderia ter uma única cultura e essa cultura seria um todo (unidade). Porém, não um todo que contém partes diferentes articuladas organicamente, mas sim um que nivele as diferenças, instaurando um monolito cultural, um tecido contínuo que a todos cobrisse sem marcas diferenciais (homogeneidade). A unicidade e a homogeneidade desse corpo não permitia que ele fosse o resultado da soma de elementos ou nem mesmo um amalgama derivado de uma síntese. Não: a cultura era a um só tempo uma matriz originária e um objeto original, acabado. Sua origem, sua natureza e seu futuro não passavam pela ideia de cruzamento, de média ou de resultante pois ela já nasceu pronta (pureza). Por fim, essa rocha única, homogênea e pura que era a cultura da nação não era vista como um sentido violentamente imputado, uma contingência histórica fabricada, enfim, uma parcialidade. Pelo contrário, encarando os 
princípios da universalidade, a cultura da nação parecia uma natureza incriada, objetiva e eterna que negava o artifício e pairava sobre o relativo (absoluto).

Retomando o que até aqui foi colocado, o quadro que se tem é o seguinte: o universal é por definição único, homogêneo, puro e absoluto. O discurso universal se realiza no estado-nação, portanto, esse espaço deve incorporar aquelas características do discurso universal. O objeto onde a nação implementa o discurso universal é a cultura. Sendo assim, universal, nacional e cultura estabelecem um paralelismo, já que os três partilham os mesmos princípios de unidade, homogeneidade, pureza e absolutismo. Sua sintonia é tão fina que falar em universal é falar em uma nação, que por sua ver é se referir a uma cultura. Nivelados pelo paralelismo fruto dessa partilha, as três instâncias se aproximam, formando assim uma cultura nacional universal: o universal se realiza no estado-nação, mais especificamente na sua cultura e é nela que os princípios universais de unidade, homogeneidade, pureza e absoluto devem se marcar.

Obviamente, uma cultura nacional universal enredada nesses princípios rechaçava as ideias particulares de multiplicidade, heterogeneidade, hibridismo e relativismo. Para um estado-nação que objetiva instaurar o universal na sua cultura, essas noções representavam uma espécie de degeneração civilizatória, um atraso que maculava a cultura nacional universal que se queria fundar. Um objeto onde se pode ver claramente essa crença é a língua.

O projeto de fundar uma cultura nacional universal, influenciado por aquelas princípios e pelas quiméricas línguas universais tematizadas por Borges, empreendeu todos os esforços para fundar um monolinguismo em seu território nacional. Como o universal seria atingido pela aceitação do único, do homogêneo, do puro e do absoluto e pela recusa do múltiplo, do heterogêneo, do híbrido e do relativo, a ideia de uma mesma língua sendo falada da mesma maneira em todo o território nacional era um signo de progresso e de evolução, ou seja, de universal; em contrapartida, uma nação fraturada em vários dialetos indicava uma cultura atrasada, distante da aspiração universal. Na verdade, se não havia a língua nacional, também não havia cultura, nem a nação, mas só uma reunião de degenerados. O monolinguismo era um indicativo de progresso e evolução da cultura nacional porque encarnava os ideias de unidade, homogeneidade, pureza e absoluto que 
caracterizavam o tão valorizado universal ${ }^{17}$. "Fraternidade, universalidade, monolinguismo comungam o mesmo ideal" (ORTIZ, 2008, p. 25). Almejando atingir esse patamar civilizatório, verdadeiras chacinas foram cometidas para que a cultura nacional universal fosse falada em apenas um idioma.

\begin{abstract}
"Os projetos de língua universal prezam a unicidade. (...) A planificação busca erradicar a desordem natural do mundo, produz uma peça inteiramente construída que não conhece desgaste e paira acima do convívio humano. Esta vocação asséptica choca-se com a noção de diversidade, que surge como um resíduo a ser eliminado. (...) Ordem e desordem, paz e guerra, universal e particular são antinomias inconciliáveis. A diversidade habita o domínio do irracional, nele a razão tem dificuldade de penetrar" (ORTIZ, 2008, pp. 29,30).
\end{abstract}

Buscava-se uma explicação religiosa que justificasse essa limpeza idiomática. Para esse discurso interessado em estabelecer o universal na cultura do estado-nação, havia dois episódios bíblicos que legitimavam o caráter universal (até divino) do monolinguismo: o Éden e a Torre de Babel. Como diz a Bíblia, o Jardim do Éden era a recriação do paraíso na Terra: o mundo era o espelho do céu. Os bichos, as plantas, e até o homem, que Deus fez sua imagem e semelhança, estavam em um como estavam no outro. Para os defensores do monolinguismo, o Jardim do Éden atestava a naturalidade, o absolutismo e a universalidade do idioma único pois lá reinava um parentesco simpático entre todos os seres, já que todos falavam a mesma língua: Deus falava com Adão, que falava com Eva, que falava com a cobra... todos, divindades, homens, animais, usando a mesma língua. Quando comem o fruto proibido, Adão e Eva cometem um pecado e são expulsos do Éden. O fechamento das portas do Jardim assinala o sepultamento de um monolinguismo divino, natural, absoluto, enfim, universal. Como diz Renato Ortiz, nesse período "a passagem do uno ao diverso é uma queda" (2008, p. 17). Mas o episódio bíblico que melhor ilustra a relação entre polifonia e castigo é a Torre de Babel. A parábola narra a história de uma torre altíssima que os homens queriam construir para chegar até Deus. Irado com a soberba do seu rebanho, o Criador acabou com o plano ao fazer com que cada trabalhador falasse uma língua diferente. Por não se entenderem mais, os homens não conseguiam se organizar para levantar a torre. Nessa parábola, a diversidade dos idiomas é tida como um traço

\footnotetext{
17 "De fato, uma nação se fundaria, especialmente, em torno da língua, o que significa que um espaço no qual há uma profusão de línguas dificilmente seria, ao menos no século XIX, pensado como uma nação. Essa relação entre pureza da língua e pertencimento nacional se coloca agora de forma definitiva." (NICOLAU NETTO, 2014, p. 81)
} 
desagregador: no mundo monoglota os homens se associam, enquanto no poliglota se separam. O fato é que Jardim do Éden e Torre de Babel serão duas imagens bíblicas que o discurso do universal evocará para conceituar o monolinguismo como um presente de Deus natural, eterno e absoluto que une os homens, e a polifonia como um castigo divino desagregador, algo que os separa. Dessa forma, para que a cultura nacional universal vivesse o paraíso da concórdia sem cair nos perigos do dissenso babélico, era preciso que o estado falasse apenas um idioma. O estado-nação que ambicionasse erigir uma cultura alicerçada nos traços universais de unidade, homogeneidade, pureza e absoluto, deveria abraçar o monolinguismo.

Escolhi a língua como exemplo de realização do universal na cultura do estadonação por ser essa uma imagem muito ilustrativa, mas, na verdade, a ideia de erigir uma cultura nacional universal se alastrava por todas as áreas da vida. Para que o espírito universal florescesse, além da língua, o estado, a cultura, a etnia, o sangue, o povo, a tradição, os costumes, a religião etc. deveriam ser únicos, homogêneos, puros e absolutos. Dessa maneira, qualquer desvio, qualquer diferença era visto como um perigo para o projeto de implementar o universal na cultura do estado-nação ${ }^{18}$. Como ameaçava um empreendimento aparentemente tão natural, divino, legítimo e autojustificado, esses desvios (encarados como resíduos anômalos e antinaturais) passaram a ser punidos com interditos, degredos, prisões e até a morte. Essas sanções se viam justificadas pela nobreza do objetivo: se o universal era legítimo em si mesmo, tudo feito em seu nome estava permitido.

Além de únicos, homogêneos, puros, e absolutos, os traços universais que se queria implementar na cultura do estado-nação eram exclusivos; ou seja: uma característica da cultura de um determinado país, além de se alastrar por todo território nacional, pertencia apenas àquela nação, não podendo aparecer em outra. Sendo assim, os atributos de uma cultura nacional universal deveriam, a um só tempo, ser compartilhados por todos contidos nela e não ser compartilhados por ninguém fora dela. Nessa época o termo "identidade"

\footnotetext{
18 "A noção de uniformização das nações deve ser apreendida nesse registro: língua, símbolos, corpos, tudo é único, autêntico, puro, portanto, quando se pensa em nação e a relaciona à diversidade, no século XIX isso não é feito como atualmente: é a pureza de cada cultura nacional que deve ser mantida." (NICOLAU NETTO, 2014, p. 82)
} 
ainda não fazia parte do glossário do mercado da diferença, mas, pode-se dizer que os traços únicos, homogêneos, puros e absolutos da cultura nacional universal, por serem exclusivos dela, fundavam uma espécie de caráter. Esse caráter era o próprio universal, mas também era o caráter nacional que, por sua vez, era o caráter da cultura, já que as três instâncias se fundiam na ideia de cultura nacional universal.

É aqui que surge aquele falso paradoxo que já comentei: como pode um espírito universal se fechar em uma cultura nacional? Como um discurso a-histórico, incriado, sem tempo nem espaço se realiza em algo contingencial, limitado e datado como uma cultura? Além de únicos, homogêneos, puros e absolutos, falou-se que os traços universais eram exclusivos da cultura de cada nação, de maneira tal que a característica de uma não podia existir nas outras. Se cada cultura nacional tem o "seu universal", então o que se tem são várias unicidades? Diferentes homogeneidades? Purezas misturadas? Absolutos relativos? Como isso é possível?

Não há aqui paradoxo nenhum. O que existe é uma distinção entre o que a nação é para si mesma e o que ela é para o mundo, quer dizer, entre a significação de uma cultura nacional encarada nos seus próprios termos e no contexto mundial em que ela se situa. Entendida em si mesma, a nação é um todo autocontido, mas no cenário maior formado por vários países, a nação é a parte de um todo que a contém. A cultura do estado-nação desempenha dois papeis diferentes: da fronteira para dentro, o estado nacional universal marca a indiferença ${ }^{19}$, da fronteira para fora esse mesmo estado marca a diferença. Operando com uma rígida fronteira entre dentro e fora, esse pensamento articula indiferença interna e diferença externa como duas metades de um mesmo binômio. Explicarei adiante.

O espírito universal é único, homogêneo, puro, absoluto e exclusivo. Esse espírito universal se realiza na cultura de um estado-nação. Se olharmos para dentro das fronteiras do estado-nação, veremos que a natureza única, homogênea, pura e absoluta do espírito universal que nele se encarna faz com que sua cultura seja um todo indiferenciado; mas se olharmos para fora das fronteiras do estado-nação, veremos que a natureza exclusiva desse espírito universal faz com que cada cultura seja diferente da outra, e assim a cultura marca

\footnotetext{
${ }^{19}$ A palavra "indiferença" é tomada aqui como o contrário de diferença, ou o sinônimo de indistinção, de homogeneidade, e não no sentido de "alheamento", "equidistância".
} 
uma parte diferencial. A unicidade, a homogeneidade, a pureza e o absolutismo do universal se encarregam de definir o estado-nação como uma indiferença interna, já a exclusividade do universal faz com que esse mesmo estado-nação se configure como uma diferença externa. Em resumo: por ser único, homogêneo, puro e absoluto, o universal marca a indiferença dentro do perímetro do estado-nação; mas por ser exclusivo, cada estado-nação é dono de seu próprio universal e assim um universal não é igual ao outro, fazendo com que fora de seu perímetro, cada estado-nação marque a diferença.

O traço que aparecer em um país tem uma obrigação dupla: (1) verificar-se em todas as partes de dentro da fronteira, fazendo com que o país seja igual para si mesmo. (2) Ausentar-se de todas as partes fora da fronteira, fazendo com que o país seja diferente para o resto do mundo. Como diz Ortiz: "Busca-se a universalidade, mas o caminho passa pela diferença" (ORTIZ, 2008, p. 38).

O limite entre dentro e fora marca diferença e indiferença. Por um lado, a fronteira da cultura nacional universal só permite que dentro dela floresçam traços únicos, homogêneos, puros e absolutos. Por outro lado, essa mesma fronteira contém esses traços, impedindo que eles se realizem fora dela. Sendo assim, unicidade, homogeneidade, pureza e absoluto definem a cultura nacional universal em seus próprios termos como uma totalidade indistinta; já a exclusividade define a cultura nacional universal nos termos do contexto maior que abarca todos os países como uma parcialidade distinta.

O limite do estado-nação permite o universal e o contém. Por permiti-lo, cria-se uma indiferença interna; por contê-lo, instaura-se uma diferença externa. As culturas de cada país são universais, mas como os traços são exclusivos, cada pais é dono do seu respectivo universo. Como na canção de Marisa Monte, cada país é uma espécie de "infinito particular", e cada um dessas universalidades limitadas é igual a si mesma e diferente da outra. É como se existissem vários Alephs: cada um deles contém todo o universo, mas um universo diferente. Para si mesmo, cada Aleph é um todo indivisível, mas para o arranjo que formam, cada um é uma parte dividida. Como se percebe, o que se tem aqui é um cruzamento do tipo (C), ou seja, um universal/local.

Um exemplo pode nos ajudar a visualizar o cenário: a França do século XIX. O estado-nação francês desse período intentava encarnar um espírito universal único, 
homogêneo, puro, absoluto e exclusivo. Como já se comentou, o idioma seria um forte indicativo da presença desse espírito. Para ser único, homogêneo, puro e absoluto, o francês universal deveria ser falado em todo o território francês. Já para ser exclusivo, o francês universal não deveria ser falado fora do território nacional. O princípio de universalidade do idioma se enfraqueceria tanto se a língua nativa de uma parte do país não fosse o francês quanto se a língua nativa de uma parte de outro país fosse. Como se pode ver, dentro das fronteiras do estado-nação, o idioma francês marca uma indiferença, pois traz os traços únicos, homogêneos, puros e absolutos do universal; mas fora dessas fronteiras, esse idioma marca a diferença, pois carrega consigo a exclusividade do universal. É o que se falou: o mesmo universal marca um indistinção se olharmos para a cultura do estado-nação pelo prisma dela mesma e uma distinção se mirarmos o contexto internacional formado por todas essas culturas.

Entendido em si mesmo, o estado-nação cria uma indiferença interna ao se preencher pela natureza única, homogênea, pura e absoluta do universal. Entendido no cenário mundial, o estado-nação cria uma diferença externa devido a exclusividade daqueles traços. A cultura nacional universal indiferencia o interior de suas fronteiras para que possa ser uma diferença fora delas.

Se reunirmos o que até aqui foi colocado, já podemos vislumbrar um rascunho daquela definição do primeiro período do mercado da diferença: já vimos que essa é uma era colonial; que naturaliza num círculo de simultaneidades as noções de progresso, monismo histórico linear e evolução, dando a elas um ar universal; que esse discurso universal se materializa no estado-nação, mais especificamente na sua cultura, criando uma amálgama entre universal, nacional e cultural que instaura uma ideia de cultura nacional universal que vê a si mesma como sendo única, homogênea, pura, e absoluta; que esses traços universais são também exclusivos de cada estado-nação; que se opera com uma rígida separação entre dentro e fora da cultura do estado-nação, pois o lado de dentro marca indiferença e o lado de fora marca a diferença; que isso se dá porque ideias universais de unicidade, homogeneidade, pureza e absolutismo se ocupam da parte de dentro, instaurando uma indiferença interna e a ideia de exclusividade faz com que a universalidade da cultura de cada estado-nação seja diferente da outra, criando-se assim uma diferença externa. Mas ainda resta uma noção síntese que organize sob sua égide esse 
arrazoado de ideias, quer dizer, que dê a sistematicidade que essas ideias precisam para que se convertam em um período nítido do mercado da diferença. É em busca dessa noção síntese que irei agora.

Retomando o raciocínio: o universal se realiza no estado-nação. Os traços de unidade, homogeneidade, pureza e absoluto do universal operam dentro das fronteiras do estado-nação, marcando uma indiferença dentro do seu território, uma indiferença do estado-nação para si mesmo, portanto. O traço de exclusividade do universal opera fora das fronteiras do estado-nação, marcando uma diferença fora do seu território, uma diferença do estado-nação em relação ao outros estados-nação, portanto.

A cultura nacional universal, assim, vê-se munida de um objetivo duplo: marcar a indiferença interna (sendo um todo indistinto autocontido para si mesma), e marcar a diferença externa (sendo a parte distinta contida em um todo formado pelo conjunto das culturas nacionais universais). As duas metades desse objetivo se retroalimentam, quer dizer: quanto mais a cultura nacional universal produz a indiferença em seu território, mais ela cria a diferença fora dele. Voltando ao nosso exemplo: quanto mais a língua francesa se espraia pela França, mais o país se indiferencia para si mesmo e mais se diferencia dos outros, que falam outras línguas.

Enquanto a realização do universal na cultura do estado-nação se deu em um cruzamento do tipo universal/local (tipo C), a Europa se ocupou da primeira metade desse objetivo, fazendo com que a segunda fosse uma decorrência natural desse esforço; quer dizer: enquanto universal/local, os estados-nação europeus abraçavam o caráter único, homogêneo, puro e absoluto do universal, objetivando instaurar uma indiferença interna dentro de seus territórios. Já a natureza exclusiva do universal, responsável por produzir a diferença externa, era tida como um desenlace inevitável; aceitava-se passivamente esse resultado, mas não se procurava por ele ativamente. $\mathrm{O}$ interesse era erigir indiferença interna, a produção de diferença externa era só um efeito colateral dela. Se cada país buscasse suas idiossincrasias e as transformassem em um padrão nacional, naturalmente cada país seria diferente dos outros. Como se falou, um cruzamento universal/local é inofensivo para outros locais, pois as imputações de sentido responsáveis por criar essa universalidade se restringem ao perímetro do local. 
Mas, quando entrou no longo século XIX, a Europa mudou seu comportamento diante desses objetivos. Durante esse século, a assimetria entre as duas metades do objetivo foi desaparecendo, ou seja: os estados-nação não estavam mais interessados em investir todos os seus esforços apenas em um só lado, deixando com que o outro se realizasse por consequência. Não, agora a Europa iria avançar nas duas frentes. As culturas nacionais universais se ocupariam ativamente tanto de produzir a indiferença interna quanto de criar a diferença externa. Para produzir a indiferença interna bastava que os países continuassem a fazer o que já vinham fazendo: pavimentar o território nacional, extirpando dele toda anomalia. A dúvida era como produzir de maneira ativa a diferença externa. Se para produzir ativamente a indiferença interna, o estado-nação se fecha dentro de si mesmo e instaura o "normal", então para fazer com que a diferença externa virasse uma criação ativa e não um desdobramento passivo, a Europa deveria se abrir, sair de seu território, ocupar outro território e lá encontrar o "diferente". O raciocínio era simples: além de ter um interior indiferenciado, o estado-nação queria ser único no contexto mundial, ou seja, marcar-se como uma diferença externa. Para cumprir esse objetivo, o país sempre soube que precisava fomentar a indistinção no seu território, mas agora uma segunda manobra vinha se unir a esta. Objetivando ter uma cultura única no mundo, o estado-nação ocidental passou a manipular a cultura dos outros países. Se todos fossem diferentes dele, ele seria diferente de todos - exclusivo, portanto. Internamente ele seria indiferenciado, mas como os traços que internamente indiferenciava eram exclusividade sua, externamente ele marcaria a diferença. Como se pode ver, para que isso fosse feito, o projeto universal europeu teria que abandonar o seu local e invadir o local de outro universal, alterando o conceito de universalidade que aquela localidade tinha. Dessa maneira, ao ocupar outros locais e adulterar a noção de universal que lá se fazia, a Europa destruiu seu cruzamento universal/local (tipo C) e inaugurou uma fase universal/global (tipo D). A partir daí, a ideia europeia de universalidade deixa de se restringir a seu local e passa a fincar bandeira em outros locais, espalhando-se pelo globo e atropelando qualquer conceito de universalidade que nesses locais houvesse. No momento em que deixa de ser local para se tornar global, o projeto de universal europeu ganha sua silhueta de fato colonizadora, expansionista e violenta. Tem-se aqui o traço da dominação e da assimetria de poder sobre o qual já se falou. Como pontuei anteriormente, as hierarquias criadas pelas noções de progresso, história linear única e evolução - que sempre colocavam a Europa no topo porque eram 
inventadas por ela, e eram inventadas por ela porque a Europa estava no topo justificavam o expansionismo ocidental ao incutir a noção de que as outras culturas estavam atrasadas e precisavam da interferência europeia para atingir seu patamar civilizatório.

A mudança de um cruzamento universal/local para um universal/global marca a passagem de uma fase em que a Europa, em sua busca por universalidade, produzia ativamente apenas a indiferença interna e deixava a diferença externa se realizar como um consequência natural para uma nova era em que o Ocidente investiria esforços em construir tanto a indiferença interna quanto a diferença externa. Dito de forma definitiva, essa virada significava que a busca europeia por um universal não iria mais se restringir a criar apenas o Eu indiferente dentro, mas iria também inventar o Outro diferente fora. Dentro, o Eu realizaria os traços universais marcadores da indiferença: unicidade, homogeneidade, pureza e absolutismo; fora, o Outro marcaria a diferença sublinhando a exclusividade da cultura ocidental. Dever-se-ia marcar o Outro como uma diferença apenas para que ele se contrastasse com o Eu, e assim o Ocidente se marcaria como uma diferença externa, garantindo sua especificidade. Se houvesse um Outro diferente externo, a cultura internamente indiferente do $\mathrm{Eu}$ se mostraria uma exclusividade sua, marcando-se no cenário internacional como uma diferença externa. Dessa forma, o estado-nação do século XIX voa nas duas asas do universal: unidade, homogeneidade, pureza e absolutismo promovendo um indiferença interna; exclusividade promovendo diferença externa.

Essa oposição rigorosa, marcada pela fronteira do estado-nação, entre um Eu indiferente interno e um Outro diferente externo funda todo o projeto. Tanto é que, em sua obra já citada, Said conceituou o Orientalismo como "um estilo de pensamento baseado numa distinção ontológica e epistemológica feita entre o 'Oriente' e o 'Ocidente'" (2013, p. 29) e concluiu que a base do empreendimento colonial era essa "oposição rigidamente binômica de 'nosso' e 'deles', com o primeiro sempre invadindo o último (até o ponto de tornar o 'deles' exclusivamente uma função do 'nosso')" (2013, p. 307). O pensamento colonial operou sempre com o binômio Eu e Outro, duas metades cindidas pela fronteira do estado-nação: dentro um Eu indiferenciado, fora um Outro diferente.

Expostas as duas metades do binômio colonial, resta saber quem ocuparia cada posição. O Eu indiferente interno, logicamente, era o estado-nação europeu, área contida 
dentro da fronteira responsável por encarnar os traços universais de unicidade, homogeneidade, pureza e absoluto. Resta saber quem seria esse Outro diferente externo, aquele que se oporia ao $\mathrm{Eu}$, mostrando a exclusividade dos seus traços e fazendo dele mesmo uma diferença externa. Antes de sabermos quem ele é, devemos descobrir quais funções ele cumpre.

Como foi dito, ambicionando ascender à universalidade, o estado-nação europeu deveria ser único, homogêneo, puro, absoluto e exclusivo. Para tal, unicidade, homogeneidade, pureza e absolutismo produziriam uma indiferença interna e a exclusividade promoveria uma diferença externa. Sendo igual a si mesmo e diferente dos outros, o estado-nação poderia se dizer universal. Se a cultura do estado-nação é exclusividade dele, então ele é diferente dos outros. Durante o longo século XIX, o ideal de universalidade do estado-nação europeu deixa de ser local para se tornar global. Isso quer dizer que a busca ocidental pela universalidade se prestará a criar ativamente tanto indiferença interna quanto diferença externa; ao contrário de antes, quando o Ocidente acreditava que a segunda tarefa seria uma decorrência natural dos esforços para realizar a primeira. Em linhas gerais, essa mudança de postura significava que, para atingir a universalidade, a Europa não produziria apenas um Eu indiferente interno, como também um Outro diferente externo. Nessa cruzada rumo ao universal, o Eu indiferente interno encarnaria os traços de unidade, homogeneidade, pureza e absolutismo; já o Outro diferente externo, teria por função marcar a exclusividade da cultura europeia, fazendo dela própria outra diferença externa. Mas, resgatando a pergunta: que feição deve ter um Outro diferente externo cuja função é salientar a exclusividade dos traços internamente indiferenciados do $\mathrm{Eu}$, mostrando como ele próprio é uma diferença externa? Ora, se sua razão de ser é celebrar a idiossincrasia do Eu indiferente interno, o Outro diferente externo deve ser diametralmente oposto a esse Eu. Para que sublinhe a singularidade da cultura do estado-nação europeu, o Outro terá de cumprir o papel de sua perfeita inversão simétrica, uma espécie de equivalente bárbaro da civilização. Dessa forma, o Outro funcionava como uma antípoda ou grupo controle que se contrastava com a cultura ocidental pra sublinhar sua especificidade. O universal deveria se encarnar em uma cultura nacional única, homogênea, pura, absoluta e exclusiva. Unicidade, homogeneidade, pureza e absolutismo eram garantidos pela produção de um Eu indiferente interno na cultura do estado-nação europeu; mas para que se sentisse um efeito de exclusividade, era necessária a produção de 
um Outro diferente externo. Esse Outro assinalava a exclusividade do Eu porque, como essa alteridade era exatamente o negativo ou o avesso do Eu, depois que o Eu desenhasse a figura do Outro, bastava virar o papel de cabeça para baixo para que tivesse um desenho seu.

Mais do que não ter o que o Eu tem, o Outro tem exatamente o contrário do que tem o Eu. Por ser precisamente o que o Eu não é, o Outro evidencia o que o Eu é, jogando luz sobre a raridade e a exclusividade de seus traços. Portanto, desempenhando o papel de inversão perfeita do $\mathrm{Eu}$, o Outro passa a ser a diferença externa que marca a diferença externa da indiferença interna do Eu. Já que é se contrastando com o Outro que o Eu produz seu efeito de diferença, então para sabermos o que significa diferença nesse período temos que descobrir o que esse Outro representa para o Eu. Ora, para o Eu, o Outro é o contraste, o inverso, o negativo externo responsável por produzir o estranhamento necessário para que o Eu se solidarize consigo mesmo, percebendo sua indiferenciada cultura interna como algo exclusivo, como um diferença externa. Se é estranhamento o que deve causar, então pode-se dizer que o Outro é um exótico para o Eu. Como eu disse que era no papel que o Outro representa para o Eu que iríamos descobrir o que significa diferença nesse período, podemos agora afirmar que essa é uma época em que diferença era sinônimo de exótico. A ideia-síntese que estávamos procurando, aquela que organiza em torno de si todo o conjunto de noções que diz respeito ao universo da diferença no século XIX, é a ideia de exótico. O outro externo, inversão simétrica onde o Eu busca marcar a diferença, é um exótico. Sabemos que o Eu é o Europeu, ainda não sabemos quem é o Outro, mas sabemos que ele é um exótico para o Eu.

Mas afinal, quem é esse Outro diferente externo que encarna o exótico ${ }^{20}$ ? Se o exótico não passa do Eu invertido, então ele não é dono da sua imagem, não é algo per se, mas algo derivado de mim, já que está sempre subordinado ao que eu sou. Como bem resumiu Said, "O islã torno-se uma imagem cuja função era menos representar o islã em si mesmo do que representá-lo para o cristão medieval." (2013, p. 111). Dessa forma, enquanto o $\mathrm{Eu}($ ropeu) era um corpo autocontido cuja única razão de ser era ele mesmo, o Outro era uma simples moldura, uma concavidade, que só existe para jogar luz sobre a Europa. Portanto, enquanto os traços culturais europeus são verdades autoevidentes, as

\footnotetext{
${ }^{20}$ Os substantivos "Outro" e "exótico" serão usados para se referir a mesma coisa.
} 
características exóticas do Outro são simplesmente suas inversões simétricas degeneradas. Por ser o equivalente bárbaro da civilização, o Outro não passava de um lado negro da Europa.

Poder-se-ia alegar que esse é um jogo de mão dupla: se A é o contrário de B, então B é o contrário de A; assim, o Outro seria o duplo da Eu e o Eu seria o duplo do Outro, cada um sendo o Eu de si mesmo e enxergando o exótico como um Outro. Aferrando-se a seu respectivo olhar, cada cultura veria os traços da outra como constructos correspondentes aos seus. Mas essa equivalência some por causa da assimetria de poder entre as duas instâncias. Sim, o Eu sempre será o contrário do Outro e vice-versa, mas quem controla as mudanças é o Eu: ele muda a si e ao Outro a hora que quiser; em paralelo, o Outro não pode nem mudar a própria imagem, nem muito menos a do Eu. Enquanto a razão de ser do Eu é apenas ele mesmo a do Outro é salientar a existência do Eu. A Europa é um texto e o Outro é só o traço que o sublinha. O Eu é a constante em relação a qual o Outro varia. O Outro é consequência do Eu, mas o inverso não é verdadeiro, pois o Eu é sempre a causa do Outro. Como nos lembra Bohlman, os pares que compõem esses binômio não se definem reciprocamente, mas são ambos definidos por um deles, que afirma a natureza tanto de si quanto do duplo contra quem se contrasta.

\footnotetext{
"Dependendo do momento histórico e do foco disciplinar, aparecem as divisões entre culturas 'alta' e 'inferior', 'oral' e 'escrita', 'popular' e 'erudita', povos 'com história' e aqueles 'sem história', 'pré-modernos' e 'modernos', ou, no nosso tempo, 'modernos' e 'pós-modernos'. O paradoxo aqui se torna evidente quando nós percebemos que todos esses termos e os pares conceituais que eles formam foram forjados pelo Ocidente. Nesse pares, um termo é reservado para o observador, fazendo com que o outro se transforme no lugar do observado." (BOHLMAN, 2002, p. 59)
}

Como se pode ver, a busca europeia de uma imagem exótica de Outro não é, de jeito nenhum, uma curiosidade, um interesse pelo Outro ou um exercício de alteridade. Muito pelo contrário: como o Outro é sempre o inverso do Eu, quando se interessa pela figura do exótico, o ocidental objetiva tão somente construir um desenho dele mesmo. A ida até o Outro é só uma oblíqua volta para dentro de si. O Outro não interessa em si mesmo para a Europa, mas apenas na medida em que, contrastada com a civilização, ajuda a construir uma imagem ocidental. É a diferença externa da própria indiferença interna o que se quer produzir quando se busca a diferença externa do Outro."O que importa não era tanto a Ásia como o uso da Ásia para a Europa moderna." (SAID, 2013, p. 168). No tempo 
em que o ocidental se esforçava apenas para fomentar uma indistinção interna do Eu e enxergava a distinção externa do Outro como uma mera consequência dessa clausura homogeneizante, o gesto era de entrar para poder sair. Agora que, além de produzir a mesmidade dentro, o Europeu passou a cultivar uma oposição exótica no Outro, seu movimentou virou no sentido contrário: sai para entrar; ou seja, vai até uma imagem do Outro para produzir a do Eu.

Por ser uma derivação da Europa, o Outro deixa de viver uma história própria para ser a coadjuvante de uma história europeia. A história do ocidente é a história do que o ocidente fez consigo, já a história do Outro é a história dos usos que o Ocidente fez dele, quer dizer, é o anexo da história ocidental. Eventos que são tomados como capítulos da história do Outro são mais reveladores do papel histórico da Europa, que ativamente produziu esses acontecimentos, do que do Outro mesmo, que não pôde escolher participar deles ou não. Em um mundo onde um universal abandona seu local e se torna global, todos os outros projetos locais de universalidades são interrompidos e passam a viver em função da universalidade que os interpelou. Ao invés de ter uma história própria, o Outro participa da história do europeu, mas, o pior de tudo, é que essa violenta história europeia é vivenciada não como tal, mas como uma natural história universal.

Mas para que saibamos o que o Outro é, ontologicamente, é preciso que se veja onde ele se situa, epistemologicamente. Ora, se o Eu precisa do Outro para definir quem ele mesmo é, então podemos dizer que Eu e Outro formam um duplo de tipo muito específico. Normalmente, um duplo se organiza em um intricado jogo de proximidade e distância em que os dois lados se envolvem e se alienam reciprocamente, definindo-se de forma mútua. No caso do duplo formado pelo Eu e o Outro o jogo de proximidade e distância se mantém, mas como a relação dos dois se funda em uma assimetria de poder, então o mutualismo do arranjo desaparece, quer dizer: o espaço entre eles imputa sentido a ambos, a posição do Eu qualifica a posição do Outro e vice-versa; mas os termos não definem suas posições reciprocamente, pois o Eu posiciona os dois lados do binômio. $\mathrm{O}$ Eu é um termo marcado fixo que se situa e situa o Outro no lugar que lhe aprouver. Esse é um caminho de mão única em que há sempre a mesma frente e o mesmo verso e não respectivas frentes que fazem seu duplo de verso. Portanto, a questão deixa de ser "Em que posição Eu e Outro se situam para se definirem reciprocamente?" e passa a ser "Em que 
posição o Eu se situa para se definir e em que posição o Eu situa o outro para ratificar sua definição por contraste?". Como foi dito, para iluminar a posição do Eu, o Outro deve ser seu negativo, sua inversão perfeita, seu exótico. E, no jogo de proximidade e distância que caracteriza a relação entre os pares de um duplo, onde fica essa exótica posição de antípoda? Chego aqui a um ponto muito importante do argumento: para que o Outro desempenhe o papel de exótico, quer dizer, de um mero avesso do Eu e ratifique a exclusividade deste, o Eu não pode fixar o Outro muito próximo de si - pois desse jeito o Outro se confundiria com o Eu, fazendo com que ele perca especificidade - , mas também não pode afastá-lo para muito distante - pois dessa forma a referência contrastante que o Outro deve marcar em relação ao Eu deixa de ser captada, fazendo com que sua especificidade deixe de ser sublinhada -. Como se percebe, a metade da díade que tiver que desempenhar o papel de avesso do seu par para enfatizar os traços desse deve, portanto, conciliar proximidade e distância. Essa é uma característica do duplo Eu/Outro: o Outro é uma alteridade que tem por função garantir as idiossincrasias do Eu. Dessa forma, o Outro é diferente, mas é diferente do Eu. Percebe-se aqui a linha tênue em que o Outro deve se equilibrar em relação ao Eu: por ter que ser diferente, o Outro se distancia do Eu; mas por ter que ser diferente especificamente do Eu, ele se aproxima. O duplo é aquilo que está fora de mim mas sempre em relação a mim. Ele está sempre perto e longe: é o mais próximo dos distante e o mais distante dos próximos. O Outro não pode cruzar a linha que demarca a exclusividade do Eu, por isso não chega muito perto; mas o Outro também não pode parar de se referir a esse limite, por isso não vai para muito longe. O Eu quer ser específico, por isso afasta o Outro diferente, e quer que essa especificidade se contraste com outra para que se evidencie, por isso aproxima o Outro diferente. Quando é fixado pelo Eu nesse ponto de equilíbrio entre proximidade e distância, o Outro consegue desempenhar o papel de inversão simétrica perfeita do $\mathrm{Eu}$, de exótico, ratificando assim sua exclusividade. Falei anteriormente que para que entendêssemos o que o Outro é, ontologicamente, deveríamos descobrir onde ele se posiciona, epistemologicamente. Pois bem: por ter que se equilibrar nessa zona intersticial entre perto e longe em relação ao Eu, pode-se dizer que o Outro exótico ocupa uma posição de ambivalência. É lá que ele está, é isso o que ele é.

O Outro é um mero negativo do Eu, um Não-Eu, portanto. É essa condição de NãoEu que faz dele uma ambivalência entre proximidade e distância: o Outro só sai do Eu com 
a condição de sempre apontar para dentro dele. É justamente por não ser o Eu que o Outro faz com que o Eu o seja. É o mesmo imperativo de ter que se mediar com o Eu que faz com que o Outro esteja ao mesmo tempo perto e longe dele. O Outro é exótico para o Eu: por ser exótico, ele se distancia do $\mathrm{Eu}$, mas como é exótico especificamente para ele, sendo a inversão simétrica apenas do Eu e de ninguém mais, o Outro se aproxima dele. Não se pode dizer que essa seja uma relação só de envolvimento, nem só de alienação, pois o que se tem aqui é um vínculo que se funda na distância, um corte que promove a união, quer dizer, uma ambivalência. Para que se estabeleça nessa posição ambivalente entre perto e longe em relação ao $\mathrm{Eu}$, ratificando sua especificidade ao se fazer de negativo dele, o Outro deve ser fixado "dentro da exterioridade" do Eu. Essa pode parecer uma frase absurda, mas é assim mesmo que os termos se relacionam: o Outro tem que estar fora e ser diferente do Eu para que a exterioridade dessa diferença provoque a exclusividade do seu interior. Falar que o Outro deve estar fora do Eu e ser diferente dele não quer dizer que ele seja um objeto não identificado e sem classificação; muito pelo contrário: ele é identificado e classificado como "O Externo", "O Diferente", enfim "O Exótico". O Eu olha o Outro e identifica nele o exótico, diferente e exterior, e assim, ao perceber que aquilo é o oposto do que ele é, solidariza-se consigo mesmo e indiferencia seu interior. Para causar esse efeito no $\mathrm{Eu}$, o Outro tem que estar fora e ser diferente, mas um fora próximo, uma diferença reconhecível, enfim, tem que estar dentro da exterioridade, ambivalente. Essa ambivalência entre proximidade e distância que faz com que o Outro ratifique a exclusividade do Eu ao desempenhar o papel de sua inversão perfeita faz do Outro um exótico. Mas dizer que o Outro é um exótico para o Eu não é, de forma alguma, dizer que o Eu "não conhece" o Outro; o oposto é verdade: "exótico" é a forma sob a qual o Outro se deixa conhecer pelo Eu. Portanto, a posição ambivalente entre perto e longe que confere exoticidade ao Outro faz com que ele seja um desconhecido que o Eu já conhece, uma novidade pelo qual ele espera, ou, aquilo que Bhabha chama de uma

"forma de crença múltipla e contraditória em seu reconhecimento da diferença e recusa da mesma. Este conflito entre prazer/desprazer, dominação/defesa, conhecimento/recusa, ausência/presença, tem uma significação fundamental para o discurso colonial." (BHABHA, 2013, p. 130)

O estranhamento que o exótico causa no Eu é algo com o qual ele está familiarizado, um choque que ele quer sentir para forjar a própria raridade chocante. Citando Bhabha mais 
uma vez, "O discurso colonial produz o colonizado como uma realidade social que é ao mesmo tempo um 'outro' e ainda assim inteiramente apreensível e visível." (2013, p. 124)

Mas será mesmo que o Outro estaria naturalmente nessa posição ambivalente entre perto e longe em relação ao Eu, ratificando sua idiossincrasia ao desempenhar o papel de seu negativo, marcando-se como exótico? É lógico que não. Seria de uma coincidência incrível que a história ensejasse um espelhamento invertido desses entre dois territórios diferentes. Já que, frustrando as ambições europeias, o Outro não é um intersticial ponto ambivalente que sublinha a exclusividade do $\mathrm{Eu}$ ao se comportar como sua equivalência sombria, enfim já que o Outro não é um exótico perfeito, o que o Eu deve fazer para alcançar a exclusividade de sua indiferença interna e projetá-la externamente como uma diferença? A resposta está em Said: inventar a exoticidade do Outro. Como se falou anteriormente, Eu e Outro não se posicionam reciprocamente, pois como esse duplo se funda em uma relação de poder, o Eu fixa tanto a sua posição quanto a do Outro. Portanto, o Outro não nasce naturalmente nesse lugar ambivalente entre proximidade e distância, enaltecendo a especificidade do Eu ao fazer o papel da sua inversão exótica. Não, é o Eu que coloca o Outro nessa posição, criando arbitrariamente a simplista inversão simétrica da figura do exótico ao resumir toda diferença a uma mera correspondência degenerada do $\mathrm{Eu}$, a um relativo empobrecido de si mesmo. O Eu fixa o Outro em uma posição ambivalente entre proximidade e distância, para que assim o Outro se marque como um exótico que salienta a especificidade da cultura ocidental. Tudo aquilo que está muito perto, se confundindo com o Eu, ou muito longe, não fazendo referência a ele, é arbitrariamente colocado no meio, na posição ambivalente que faz o Exótico não ser o Eu mas sempre referenciá-lo.

Said está se referindo a esse trabalho de aproximar o longe a afastar o perto para fixar o Outro na ambivalência que "nos" especifica quando diz que a função do Orientalismo é "filtrar o Oriente na consciência ocidental" (2013, p. 303). Quando esse esforço está concluído e o Outro fica arbitrariamente fixado nesse interstício perto/longe que aponta para o Ocidente sem sê-lo, cada traço cultural do Outro é visto como um equivalente corrompido de uma característica do Eu. Said traduz muito bem essa terapia da novidade que se presta a manipular o estrangeiro para reduzi-lo a uma mera inversão do Eu na expressão "domesticação do exótico". 
O exótico do Outro é arbitrariamente forjado para criar esse efeito ambivalente de proximidade e distância, esse sensação de novidade pela qual já se espera para iluminar a exclusividade do Eu. Ora, a melhor ferramenta para ensejar um exótico familiar, um diferente que já se conhece é o clichê estereotipado e a hipérbole carnavalesca. Sendo assim, para criar exoticidade ambivalente do Outro necessária para salientar a especificidade de sua cultura, o Eu irá recorrer às pre-noções enviesadas que ele sempre teve acerca daquela exterioridade. Essa zona ambivalente entre perto e longe que faz o Outro se referir a nós sem nos ser é a zona do preconceito. É o preconceito em relação ao Outro que reúne ineditismo e repetição, novidade e reprise. Por causa disso, não importa tanto quem o Outro seja realmente - na verdade, isso até atrapalha - mas sim o uso que o Eu faz do Outro. "O que o orientalista faz é confirmar o Oriente aos olhos de seus leitores; ele não tenta, nem quer desestabilizar convicções já firmes." (SAID, 2013, p. 105). As imagens do Outro que chegam ao Eu são figuras que ele nunca viu, mas são exatamente como ele suspeitava que elas eram. O exótico ambivalente que oscila entre perto e longe e ratifica a unicidade da cultura Europeia não é o Outro, mas é a figura que o Eu faz do Outro. O exótico não nasce exótico, é exotizado. "O seu Oriente não é o Oriente como ele é, mas o Oriente como ele foi orientalizado." (SAID, 2013, p. 155). Como o que se tem aqui é uma relação de poder, a ficção preconceituosa do Eu dominante sobre o Outro dominado tem mais legitimidade do que o que esse Outro de fato é ${ }^{21}$.

"Pois o Oriente ('lá fora' na direção do leste) é corrigido, até penalizado, por se encontrar fora dos limites da sociedade europeia, o 'nosso' mundo; o oriente é assim orientalizado, um processo que não só marca o oriente como a província orientalista, mas também força o leitor ocidental não iniciado a aceitar as codificações orientalistas como o verdadeiro oriente. A verdade, em suma, torna-se uma função do julgamento erudito, e não do próprio material que com o tempo parece dever até sua existência ao orientalista." (SAID, 2013, p. 107)

Sendo assim, de acordo com Said, a era colonial é um período em que o exótico é violentamente inventado, arbitrariamente criado. Nessa época, o Outro não passa de uma fabricação do Eu, uma visão estrangeira propagandeada como teoria nativa. Mas, para Bhabha, a exotização não é uma simples "mentira", é uma estratégia, que, por ser ambivalente, ganha ares de verdade. O estereótipo é pleonástico e lacônico: repete-se

\footnotetext{
${ }^{21}$ Falo aqui no que o Outro é "de fato" ou "realmente" por falta de outra expressão porque, como o próprio Said afirma, essa concretude não existe. Como comentei, a obra do autor não é a defesa da verdade local contra a mentira estrangeira; pelo contrário: o esforço de Said é o de mostrar como o Europeu cria uma ontologia e a traveste de ares nativos.
} 
tantas vezes que se omite em sua repetição, por isso é sólido e etéreo, sempre pode ser visto em sua ausência.

"O ato de estereotipar não é o estabelecimento de uma falsa imagem que se torna o bode expiatório de práticas discriminatórias. É um texto muito mais ambivalente de projeção e introjeção, estratégias metafóricas e metonímicas, deslocamento, sobredeterminação, culpa, agressividade, o mascaramento e a cisão de saberes 'oficiais' e fantasmáticos para construir as posicionalidades e oposicionalidades do discurso racista. (...) O estereótipo é ao mesmo tempo um substituto e uma sombra" (BHABHA, 2013, p. 140)

Por isso, a ambivalente posição do exótico é, ao mesmo tempo, fantasmagórica e concreta, incerta e estável. Dito de maneira direta: o espaço ambivalente é um ponto preciso, mas não se sabe precisamente aonde ele fica. $\mathrm{O}$ exótico deve ocupar um ponto bem específico, mas esse lugar nunca pode ser encontrado, senão a arbitrariedade do jogo se revela. $\mathrm{O}$ estereótipo é nítido porque nunca foi visto.

Nesse jogo de longe e perto, o que se afasta é a presença nativa do Outro e o que se aproxima é o discurso europeu acerca dela. O Outro tal como ele se enxerga é levado para longe da Europa e, para suprir essa falta, o continente elabora uma versão sua do que esse Outro afastado seria. Mas, como a visão europeia sobre o estrangeiro preenche o espaço antes ocupado por ele, esse olhar do velho mundo sobre o Outro acaba sendo recebido como o Outro propriamente dito. Assim, o comentário se converte no artefato comentado. A subjetiva fala europeia sobre uma coisa é tida como a imparcial objetividade dessa coisa, de maneira que a representação externa de uma ausência se transforma na apresentação interna de uma presença. É justamente porque o objeto é afastado que se cria a necessidade de aproximá-lo com uma teoria, mas como a teoria cumpre um papel antes desempenhado pelo objeto, ela passa a se confundir com ele, e é por isso que o texto colonizador acerca do Outro é recebido como se fosse o próprio Outro. No caso estudado por Said, o Oriente é empurrado para longe do Ocidente, incutindo-se a necessidade de um Orientalismo que o traga para perto. Mas depois que o leste é substituído pelo discurso do oeste acerca dele, essa voz europeia sobre o exótico passa a sê-lo, ou seja, o Orientalismo ocidental vira o Oriente oriental.

"Nas discussões sobre o Oriente, o Oriente é uma ausência total, enquanto sentimos o orientalista e o que ele diz como presença; no entanto, não devemos esquecer que a presença do orientalista é possibilitada pela ausência efetiva do Oriente." (SAID, 2013, p. 283) 
Embora já esteja antecipado nas citações, eu ainda não afirmei aqui quem é esse Outro. Como disse, era preciso conhecer suas características e as funções que ele cumpre no mercado da diferença antes de dizermos seu nome. Falou-se que o Outro é o exótico do Eu e que esse corpo que se equilibra em um lugar ambivalente entre perto e longe, sublinhando a especificidade da cultura ocidental. Além disso, foi dito que esse exótico não é natural, tendo que ser arbitrariamente produzido pelo $\mathrm{Eu}$, que está interessado em forjar o grupo controle que realce a idiossincrasia de sua cultura. Já que o Eu é a Europa, não resta muito mistério sobre quem o Outro seja: os únicos territórios do século XIX que estão longe da Europa o suficiente para não pertencerem a ela mas próximas o bastante para com elas se mediarem e sobre quem ela possui plenos poderes são suas colônias alémmar. Por não protagonizar uma história sua, sendo coadjuvante de um projeto ocidental, e por ter sua imagem arbitrariamente inventada pelo europeu, que precisa fazer dele um decalque da civilização que sublinha a unicidade dela, a imagem do colonizado não é uma autoimagem, sua voz não é nativa. O que ele é, na verdade, é um discurso sobre ele, elaborado por outro. Portanto, o Outro que o Eu(ropeu) fixará na ambivalente posição intersticial entre perto e longe com o objetivo de construir violentamente uma figura exótica estereotipada que ratifique a exclusividade da sua cultura fazendo com que indiferença de seus traços internos desfile internacionalmente como uma diferença externa será a colônia.

Como o exótico se realiza na colônia, esse primeiro período do mercado da diferença será chamado aqui de período exótico-colonial do mercado da diferença. Finalmente, reencontramos aqui a definição dada no começo do capítulo: o primeiro período do mercado da diferença se configura como um momento exótico-colonial em que a diferença operava com uma demarcação rigorosa entre Eu/Outro. Essa fronteira produzia simultaneamente distinção externa e indistinção interna, pois as metades do binômio eram opostas uma em relação a outra, mas contínuas para si mesmas. Além disso, esse foi um período em que a diferença valorizava as ideias de unidade, homogeneidade, pureza e absolutismo, contidas na noção de universalidade. Como o nome sugere, essa fase do mercado da diferença se desenrolou em uma era colonial conhecida como Longo Século XIX (1789 - 1914), marcada pela assimetria de poder e pela dominação. A noção em torno da qual se organizavam todas essas características da diferença foi o conceito de exótico. Diferença era sinônimo de exótico, esse era o termo que conduzia e sistematizava o debate. 
Como essa diferença exótica se materializava nas colônias europeias, tem-se aqui um período exótico-colonial do mercado da diferença.

Está mapeado o percurso do primeiro período do mercado da diferença: o espírito universal é, por definição, único, homogêneo, puro, absoluto e exclusivo. Esse espírito se realiza na cultura do estado-nação europeu. Por se materializar em um país, o universal se media com a rígida fronteira nacional dentro/fora. Dentro da fronteira nacional, o universal despeja suas características de unicidade, homogeneidade, pureza e absolutismo; mas, fora da fronteira nacional, o universal aciona a característica da exclusividade, já que cada país tem seu respectivo universal. Por causa dessa separação rigorosa entre dentro e fora do perímetro do estado-nação, os traços universais de unicidade, homogeneidade, pureza e absolutismo criam indiferença dentro da nação; em contrapartida, a exclusividade do universal, cria diferença fora da nação, no contexto mundial que ela forma com as outros países, uma vez que, sendo exclusivo, cada universal é diferente do outro, ou seja, cada cultura nacional universal é única. Um mesmo limite nacional faz o universal marcar indiferença interna e diferença externa. Dado esse quadro, o estado-nação europeu viu que, para encarnar o universal, ele deveria executar um movimento duplo, trabalhando dentro e fora do seu território: dentro, o país deveria ensejar o único, o homogêneo, o puro e o absoluto, produzindo indiferença interna; fora, cada nação tinha que promover a exclusividade, criando diferença externa. Enquanto ainda estavam na fase universal/local, os estados-nação europeus investiram todos os seus esforços no primeiro dos movimentos, acreditando que o segundo seria uma decorrência natural dele, quer dizer: trabalhou-se apenas dentro da fronteira do estado-nação, criando indiferença interna, plasmando o desvio no padrão, e esperando a diferença externa vir por inércia. O estado-nação da época acreditava que, se cada país se ocupasse de homogeneizar a própria cultura, no final das contas haveria um mundo de culturas diferentes: se cada nação se esforçasse por ser monocromática, teríamos um mosaico de azulejos diferentes, pois cada cor seria exclusiva de cada azulejo. No entanto, esse arranjo logo desmoronou no século XIX. Nesse período, os países ocidentais perceberam que não poderiam mais se ocupar apenas de criar indiferença interna e deixar a diferença externa aparecer por si mesma. Era preciso agora agir dentro e fora do limite do estado-nação. A partir daí, o cruzamento universal/local se dissolve e a Europa põe em prática um programa universal/global em que sua visão de mundo começa a se fazer presente, de fato, no mundo inteiro, atropelando as visões de 
mundo próprias aos outros lugares. O trabalho em duas frentes se daria da seguinte maneira: dentro do país, tudo seguiria como antes, instaurar unicidade, homogeneidade, pureza e absolutismo por meio da promoção de indiferença interna. A novidade vinha do fora. Era preciso que as culturas fossem iguais em si mesmas e diferentes uma das outras. Diante disso, os estados-nação europeus puseram em prática o seguinte plano: produziram a sua indiferença interna e outras indiferenças internas a outras culturas, erigindo assim a diferença entre a sua cultura e as demais. Para isso, não bastava que o ocidente manipulasse apenas a sua imagem, fazia-se necessário que ele mexesse na imagem do outro, mostrando como a dele era diferente da sua. Era preciso encontrar uma cultura fora da Europa, mas que se referisse a ela, ratificando sua idiossincrasia. Os territórios que fizeram o papel de grupo controle negativo do Ocidente foram as colônias. Acreditava-se que a cultura da colônia era a exata e simétrica inversão da cultura ocidental, por isso, se o estado-nação europeu queria fundar uma imagem de si, não bastava que se trancasse em seu território e pintasse seu autorretrato, fazia-se necessário criar um imagem da colônia, pois, como essa figura estrangeira era o negativo da figura "civilizada", quando rascunhava esse desenho do outro, o europeu produzia um desenho de si no verso do papel. Sendo assim, fica nítido que esse suposto interesse europeu pelo outro era, na verdade, uma busca por si mesmo, já que a criação de uma imagem estrangeira se prestava única e exclusivamente a erigir uma imagem nativa. Essa dinâmica que faz uma imagem do outro salientar uma imagem de si próprio não é fácil de ser mantida. Para que se realize, esse outro tem que encontrar uma sintonia fina entre longe e perto: longe para que se deixe ver como um outro, um exterior; perto para que seja um outro que não eu, um outro que não é o outro de outro, mas um outro de mim, um outro meu, um outro eu. Por ter que conciliar essa tensão entre perto e longe, eu afirmei aqui que o outro do pensamento colonial europeu se situa em uma posição ambivalente. Criava-se um exterior da cultura europeia exatamente oposto a ela para que se sublinhasse a especificidade do interior dessa cultura. Mas, frustrando as ambições imperialistas, as colônias não se encontravam nesse sutil ponto intersticial entre perto e longe que faria delas inversões perfeitas da Europa. Sem a ambivalência do Outro, a especificidade do Eu não era garantida. Dessa forma, para ter uma alteridade estranha a ele que ratificasse suas idiossincrasias, o Ocidente deveria apagar a figura do colonizado, e inventar, criar, fazer uma imagem do outro posicionada nesse ponto ambivalente. Logicamente, esse ativo gesto de criação não poderia aparecer 
como tal, o Outro tinha que ser inventado pelo Ocidente, mas aquela imagem manipulada deveria aparecer como a própria autoimagem do lugar. Percebe-se aqui a violência desse projeto: a voz não é nativa, o texto que diz o que ele mesmo é foi produzido por alguém que ambicionava instaurar uma imagem estrangeira oposta a sua para que, fazendo o outro, ele obliquamente fizesse a si mesmo. Para criar imagem de Outro que conciliasse de maneira ambivalente proximidade e distância e marcasse a especificidade do criador, o europeu deveria recorrer às pré-noções e aos estereótipos que tinha acerca do Outro. Apenas a caricatura, a hipérbole e o preconceito podem harmonizar o perto e o longe, pois só clichês de alteridade e exterioridades internamente cultivadas tem o poder de ensejar um Outro que esteja fora de mim, mas dentro das minhas expectativas do que ele seja. O lado de dentro e o lado de fora do estado-nação europeu, delimitados pela fronteira do país, dividiam um espaço do "Eu" e um espaço do "Outro", respectivamente, sendo que o Eu protagonizava o binômio, pois o Outro tinha por única função ser um grupo controle que emoldurasse o primeiro. Para ser tido como um padrão normal, o Eu precisa de um Outro desviante. Esse era o papel das colônias: impactar o padrão da metrópole, não para derrubá-lo, mas para evidenciar sua rigidez, quer dizer, um impacto para o qual já se estava preparado. O Eu fixa o Outro como desconhecido, e assim faz de si mesmo um conhecido. É como desconhecido que o Outro se deixa reconhecer; ele é estranho ao Eu, mas um estranho com o qual o Eu está familiarizado, uma vez que o criou como o avesso de sua imagem. Aquilo que é reconhecido com o nome de estranho já é mais familiar do que o que não se deixa reconhecer por nome nenhum. Era em torno dessa figura que o conceito de diferença se organizava: a imagem fabricada de um estranho situado de maneira ambivalente entre perto e longe que salientava a especificidade da cultura ocidental justamente por ser a inversão perfeita dela. A palavra usada na Europa do século XIX para se referir a esse avatar da diferença era o conceito de exótico. "Exótico" é a noção síntese que organiza em torno de si todas as ideias precedentes, é ela que guia o debate colonial acerca da diferença nesse período. Como a imagem dessa diferença exótica se projetava sobre as colônias europeias, o primeiro momento do mercado da diferença será aqui chamado de período exótico-colonial do mercado da diferença. 
Fechado o círculo, algumas noções devem ser esclarecidas. Um ponto importante que precisa ser retido é o seguinte: a natureza ambivalente do exótico, oscilando entre próximo e distante, fazia com que o Eu e o Outro se separassem no conteúdo, mas não na forma. Quando disse que o Outro era a inversão perfeita do Eu, estava falando das suas substâncias, pois estruturalmente eles são simétricos. Quando afirmo que são iguais na forma me refiro ao fato de que tanto metrópole quanto colônia são culturas únicas, homogêneas, puras e absolutas para elas mesmas. Entretanto, o conteúdo que se inscreve nessas categorias formais é diametralmente oposto. Os traços que preenchem as culturas são antípodas, mas as categorias em que se encaixam são as mesmas. Usando aqui uma construção frasal tirada de Viveiros de Castro (2002): os estrangeiros não devem ser "um povo como os europeus", mas tem que ser "um povo, como os europeus". Para que a condição de duplo seja satisfeita, é preciso que a assimetria conteudística seja compensada com um espelhamento formal: caso forma e conteúdo fossem iguais, os dois corpos seriam um só; se fossem ambos diferentes, não haveria termo de comparação possível e o outro não cumpria sua função de iluminar a unicidade do Eu. Por isso, a forma é igual e o conteúdo diferente. Como se pode ver, o rigor da fronteira que separa o Eu do Outro fixa as duas noções, conferindo-lhes estabilidade. Portanto, o período exótico-colonial do mercado da diferença é uma era de ontologias sólidas e estanques. Fluxo, volatilidade, troca, efemeridade, etc. são palavras que não existem no glossário do exótico. Isso serve tanto para o Eu quanto para o Outro.

A princípio, o arranjo causa certa estranheza: um corpo que deseja ser único e total instaura um duplo, uma exterioridade para ter sua unicidade garantida. O quadro pode parecer ambíguo, mas na verdade é ambivalente. Como foi dito na introdução, há certas linguagens que só se deixam ver em sua dimensão metalinguística. Esse é o caso do mercado da diferença: dobrando-se sobre si mesmo, ele nasce. A interioridade do Ocidente é instaurada pela exterioridade da colônia. Retomando uma expressão já usada: duplicando-se, o discurso se inaugura.

Outro elemento que deve ser frisado é: ainda que a Europa tivesse estados-nação diferentes, e que se esforçavam para se diferenciar um dos outros criando respectivas indiferenças internas, o mundo colonial era monolítico. Inglaterra e França, as duas maiores potências coloniais da época, viam suas colônias como uma grande massa 
homogênea sem fronteiras. Da mesma forma, os povos que lá moraram eram um indistinto Outro generalizado. Sobre um orientalista, Said fala:

"Para Cromer, uma das coisas convenientes sobre os orientais era que administrá-los, embora as circunstâncias pudessem diferir um pouco aqui e ali, vinha a ser quase por toda parte mais ou menos a mesma coisa. Assim acontecia, claro, porque os orientais eram quase por toda parte mais ou menos a mesma coisa." (SAID, 2013, p. 70)

Mas ainda voltarei a esse ponto mais tarde

Uma última explicação: falei que a fase violenta, imperialista e colonial do projeto europeu só começou no século XIX, quando seu conceito de universal deixou de ser local para assumir um caráter global. Esse enunciado precisa de reparos, pois, como se sabe, o genocídio dos nativos, a pilhagem de mercadorias, as sanções econômicas e a escravidão aconteciam desde o descobrimento. O mais correto seria dizer que o século XIX inaugura um tipo específico de violência, ou melhor, (já que o chicote dói do mesmo jeito independente da causa da chicotada), uma violência motivada por um novo fim, fim esse quase oposto ao anterior. Até o século XIX, o Ocidente queria instaurar a metrópole na colônia, estender o conceito de Eu aos estrangeiros e conquistar o mundo deixando todos os povos iguais a ele, enfim dominar produzindo indiferença externa. Esse é o tempo das missões religiosas, da catequese dos índios, do ensino forçado das línguas europeias, etc. A partir do século XIX, o objetivo de dominar permanece, mas a estratégia é oposta: criar um mundo colonial que fosse o avesso da metrópole, inventar o Outro, aquele estrangeiro que seria a antípoda do europeu, conquistar o mundo deixando todos os povos diferente dele, enfim dominar produzindo diferença externa. Essa não é mais a época de chamar o estrangeiro para perto, de converter sua alma na "nossa", pelo contrário: o século XIX é o tempo em que o colonizado é fixado como diferente. Antes o europeu achava que ia dominar o mundo se todos ficassem iguais a ele, agora ele percebe que só conseguirá esse objetivo se todos forem diferentes (não diferentes como eles são, mas como o europeu quer que sejam), pois é assim que ele mantém a especificidade que precisa para dominar. Se um dia o ocidente achou que seria soberano caso todos aceitassem sua cultura, no século XIX ficou claro que a glória só seria possível se essa cultura fosse exclusividade dele. Tanto em uma fase como em outra, objetivava-se planificar a cultura estrangeira, transformando-a em um corpo universal único, homogêneo, puro e absoluto para si mesmo. A diferença é que antes do século XIX esse corpo deveria ser idêntico ao do europeu; e depois o esforço 
foi o de torná-lo idêntico apenas a si mesmo, mas diametralmente oposto do europeu, quer dizer, exótico. Como o foco do nosso interesse aqui é o mercado da diferença, essa primeira fase do período colonial não será aqui tematizada.

O tempo estudado aqui foi o primeiro período do mercado da diferença, era colonial enredada nas ideias universais de unidade, homogeneidade, pureza e absolutismo, que trabalhou violentamente com uma divisão estrita entre Eu/Outro, duas ontologias diferentes uma da outra mas iguais em si mesmas, e se organizava em torno da noção de exótico. Essa fase exótico-colonial do mercado da diferença definiu o debate até a Primeira Guerra Mundial, momento em que uma nova ordem emergiu.

É desse novo arranjo que irei me ocupar agora. 


\section{Capítulo 2}

\section{Transição: o filtro da igualdade}

Como é próprio à história, a passagem do período exótico-colonial do mercado da diferença para um de diversidade-global foi lenta e gradativa. Entre essas duas fases, inscreve-se uma etapa transitória responsável por encerrar a primeira e preparar o terreno para a segunda. É importante salientar aqui que, ao contrário dos dois períodos, essa época intermediária não é um momento de valorização da diferença, mas da igualdade. O signo da igualdade cumpriu o papel de segurar uma era exótica-colonial e permitir outra de diversidade-global. Mas ao invés de fechar uma porta para abrir outra, a marca da igualdade faz uma dobradiça. $\mathrm{O}$ mais correto seria dizer que não se tem aqui um terceiro período, mas uma área conurbada entre os dois: menos do que o corredor entre cômodos distantes, a igualdade é o umbral entre quartos contíguos. A igualdade não simplesmente corta, mas também não apenas cola, ela articula o exótico-colonial e a diversidade-global. Ser categórico e afirmar que entre os dois há um hiato ou uma fusão é ver só metade do problema, pois a igualdade afasta e aproxima os dois períodos ao mesmo tempo. As duas diferenças só são separadas pela igualdade na medida em que a compartilham. Não é possível distinguir o crepúsculo do exótico-colonial da aurora da diversidade-global, pois os dois movimentos se inscrevem no mesmo fenômeno. Essa dobradiça da igualdade entre o exótico-colonial e a diversidade-global, que os aliena ao mesmo tempo em que os envolve, é que torna tão difícil afirmar quais as continuidades e rupturas entre os dois períodos do mercado da diferença.

De qualquer forma há que se admitir que essa transição se prestou a acabar com o exótico-colonial e promoveu a diversidade-global, portanto, somos levados a crer que ela teria muito mais afinidade com a segunda do que com o primeiro. Realmente, as políticas da transição intentam extinguir as contradições do mundo antigo e simplesmente administram as do novo. Mas uma coisa deve ser lembrada: é verdade que esse interstício quis acabar com o período exótico-colonial, mas, não se pode dizer que ele racionalmente objetivou ensejar a diversidade-global. Um período se mediou com o istmo da igualdade para continuar existindo e o outro para começar a existir. Toda fronteira é uma porta de entrada, mas é também um lugar de resistência. Sem a igualdade, o exótico-colonial não teria sido freado e a diversidade-global não poderia nascer, mas isso não quer dizer que ela 
não precisou se mediar com esse limite. Foi para esse interstício que o exótico-colonial caminhou e foi desse ponto que a diversidade-global saiu, e se é correto dizer que os valores do mundo vindouro foram aqui cultivados, também é verdadeiro afirmar que foi para cá que o passado nos trouxe.

Tem-se aqui um jogo entre figura e fundo difícil de decifrar: levar a diferença a condição de objeto é se debruçar sobre a morfologia de uma ausência. Como o corpo que nos interessa é um rastro, então essa concavidade emerge e os espaços preenchidos em torno dela recuam. Olhando para o negativo de um problema podemos ver que por mais diferentes que as duas diferenças sejam, elas tem em comum o fato de que são diferenças, e o traço que diferencia uma da outra é a igualdade. A fase intermediária da igualdade não é um terceiro período entre os períodos da diferença, mas também não é uma porta aberta, nem uma porta fechada, ela é uma membrana porosa, um filtro que retém alguns sentidos e deixa outros fluírem. Resta agora descobrir o que ficou de um lado e o que seguiu para o outro.

$* * *$

Como apresentado na seção anterior, o período exótico-colonial do mercado da diferença foi uma era marcada pelas ideias de progresso, história linear única e evolução. Entregando-se a esses princípios, a Europa ganhou o direito de prescrevê-los: por se comportar como a cultura mais desenvolvida do mundo, o ocidente legislava o conceito de desenvolvimento. Já que a história é escrita dentro dela mesma em um círculo de simultaneidades em que o mundo objetivamente concebido e o olhar que subjetivamente o avalia se constroem reciprocamente, então os traços contingenciais e arbitrário da Europa ganhavam ares de naturalidade e fatalismo, quer dizer, de universalidade. Dessa forma, o espírito universal - com seus traços de unidade, homogeneidade, pureza e absolutismo - se encarnava no estado-nação europeu, mais especificamente na sua cultura, forjando assim o que se chamou de cultura nacional universal. Como a violência da fabricação desse universal se apagava na medida em que ele se fazia, a cultura nacional universal do Ocidente surgia como a epítome da civilização, o auge do progresso, do desenvolvimento histórico e da evolução. 
A colonização de outras sociedades era vantajosa para a Europa por dois motivos: primeiro pelas vantagens materiais que ela conseguia pilhando os recursos naturais dessas culturas; segundo porque, manipulando a imagem do estrangeiro, a Europa produzia a figura do exótico em suas colônias, ratificando assim a unicidade da sua própria cultura e se marcando no cenário mundial como uma diferença. No entanto, a crença na universalidade da sua cultura levou a Europa a acreditar que os outros povos não passavam de arremedos do Ocidente, homens primitivos presos a um estágio evolutivo pelo qual ela já teria passado. Sendo assim, ocupar esses territórios passou a ser justificado não só como algo vantajoso para a metrópole, mas para a própria colônia, que carecia do toque de Midas da civilização para amadurecer.

Mas, contrariando a crença disseminada na época, o projeto colonial europeu conduziu o mundo para muito longe dos ideais universais de progresso, evolução e civilidade. Do ponto de vista das colônias, os danos foram óbvios: empiricamente falando, as perdas humanas e materiais foram incalculáveis; no plano simbólico, as colônias tiveram sua história interrompida pelo "contato" com o Ocidente, deixando assim de protagonizar um processo seu para fazer as vezes de anexo ou avesso da história europeia. Ainda que politicamente a independência tenha sido garantida, a defasagem entre as duas metades do mundo parecia incorrigível. Do ponto de vista da Europa, o efeito também foi desastroso. Dos descobrimentos até a independência, a exploração das colônias além-mar foi a base de sustentação das potenciais ocidentais. Entretanto, os conflitos entre os projetos coloniais europeus levaram o continente para uma das mais sangrentas guerras da história: a Primeira Guerra Mundial (1914 - 1918).

Ao final da guerra o quadro era desolador. As consequências imediatas do conflito foram as perdas humanas, a destruição das grandes cidades e uma forte crise econômica; no entanto, com o tempo, os efeitos do episódio se mostraram ainda mais desastrosos. Passada a guerra, a Europa mergulhou em uma grande crise de legitimidade, dentro e fora do seu território. O projeto colonial europeu ambicionava fundar uma cultura universal que representasse os píncaros da evolução e do progresso histórico, mas, ao invés de erigir a civilização, esse caminho só levou à barbárie. As feridas abertas pela Primeira Guerra mostraram para o mundo o lado sombrio do colonialismo: aquele ideal de boa sociedade que aspirava ao universal estava manchado pelo sangue da escravidão, da pilhagem e do 
genocídio. Diante disso, o continente não conseguiu mais que seus atos arbitrários e contingenciais fossem vistos como desenlaces históricos naturais e incontornáveis. Por ter promovido o apocalipse ao invés do progresso, aqueles ideais universais eternos se mostraram interesses locais violentamente universalizados, enfim, princípios que serviam a um lugar e a uma época silenciosamente purificados para serem recebidos como inquestionáveis dogmas de uma natureza universal. De filantropo responsável por colocar o mundo nos trilhos do futuro, o Ocidente passou a ser visto como o grande algoz da história. Dito de maneira definitiva, a conta que o mundo teve que pagar depois da Primeira Guerra mostrou que, fora os danos materiais e humanos, aquele conceito de universal parecia estar em crise. As noções universais de unidade, homogeneidade, pureza e absoluto, que durante o século XIX foram sinônimos de progresso e evolução, passaram a ser vistas com desconfiança depois dos efeitos desastrosos que causaram. Diante desse novo cenário, aquele universal foi perdendo a legitimidade e a eficácia simbólica necessárias para organizar uma ordem mundial.

"O universalismo passou a ser visto como a universalização de um particular europeu, relacionado ao eurocentrismo; tornou-se aquilo que se chamou de 'etnocentrismo da tribo branca'. Em outras palavras, aquilo que fora proposto como válido a todos foi por muitos compreendido como particular dos interesses de alguns, ligados à dominação europeia." (NICOLAU NETTO, 2013, p. 93)

Mas ainda não seria dessa vez que o mundo aprenderia a lição.

Outra consequência da Primeira Guerra foi o aparecimento de uma nova força na geopolítica internacional, uma antiga colônia inglesa que saiu do conflito como a maior credora do mundo: os Estados Unidos. A participação dos Estados Unidos no começo da guerra se restringia ao empréstimo de dinheiro e à venda de equipamentos à Tríplice Entente (França, Grã-Bretanha e Rússia). Como essa conta só seria paga depois do conflito, os Estado Unidos começaram a temer que seus devedores perdessem a guerra e não pudessem honrar suas dívidas. Quando a Rússia abandonou os aliados em 1917, os Estados Unidos tiveram que acabar com sua neutralidade para garantir a vitória de seus parceiros comerciais. Diante disso, a América entrou ativamente no embate de maneira decisiva, assegurando a vitória da Entente. Depois de assinado o armistício, o tabuleiro do mundo estava virado: a Europa, império colonial do século XIX, drenada pela Guerra; os Estados Unidos, antiga colônia europeia, içados à categoria de estado promissor. Além de 
acumular poder econômico e político, os americanos foram despontando como uma influência cultural para o mundo, e é isso que mais nos interessa aqui.

A Alemanha, grande derrotada no conflito, estava despedaçada. Mortes, um cenário urbano destruído, endividamento e uma profunda crise de legitimidade. Para piorar o cenário, o Tratado de Versalhes, assinado depois da guerra, reduziu o país quase a categoria de um estado vassalo. Dentro da Alemanha, reinava a descrença e a humilhação, fora, a nação se via restrita política, econômica e militarmente por um acordo claramente revanchista. Como a história iria provar, essa combinação seria desastrosa. Ao invés de barrar o pan-germanismo, as sanções aplicadas à Alemanha preparam o terreno para o florescimento do nazismo. Em meio à desilusão e à anomia, surgiu a doutrina que fez o país se reerguer e acreditar de novo em si mesma. Das cinzas da Primeira Guerra, subjugada pelo resto do mundo, apareceu uma nova nação disposta a governar o mundo inteiro. Movido por essa injeção de ânimo, a Alemanha deixou o nazismo se espalhar por seu território, conduzindo o mundo para um dos capítulos mais grotescos de sua história: a Segunda Guerra Mundial (1939 - 1945).

Esse período que vai da Primeira Guerra ao fim da Segunda é inesgotável. Apresentei aqui tudo de um jeito muito simplista porque o foco do nosso interesse não é esse momento, mas a ordem mundial que emerge após esses conflitos. Depois que a Alemanha perdeu a guerra e o julgamento de Nuremberg expôs para o mundo os horrores dos campos de concentração e do holocausto, o projeto civilizador se viu confrontado com o seu maior fracasso. As ideias de progresso, história linear única, evolução e as noções universais de unicidade, homogeneidade, pureza e absolutismo, encarnadas na cultura do estado-nação, ao invés de trazerem a tão prometida civilização, perpetraram os espetáculos mais sangrentos da humanidade: uma era de impérios coloniais e duas guerras mundiais, episódios que marcariam o mundo para sempre. Há quem diga de forma apocalíptica que, no fundo, a barbárie que esse programa nos trouxe não foi o fracasso, mas a triste vitória do empreendimento, quer dizer: o espírito universal não desviou sua rota nem produziu algo inesperado, pois era exatamente para essa carnificina que desde o começo ele estava nos conduzindo. Confrontada com os destroços da história, a humanidade teve que admitir sua monstruosidade. Era preciso mudar. 
Elencar as consequências das duas guerras nada mais é que insistir no exercício exaustivo de inventariar tudo o que nós somos, pois é praticamente impossível pinçar um aspecto do social que não seja, de alguma forma, um eco desse período. Mas há duas consequências imediatas do fim da Segunda Guerra que são relevantes especificamente para essa transição no mercado da diferença de uma fase exótico-colonial para outra da diversidade-global: refiro-me aqui a criação da Organização das Nações Unidas (ONU), em reunião realizada em São Francisco no dia 26 de junho de 1945, e da sua divisão interna, a Organização das Nações Unidas para Educação, Ciência e Cultura (UNESCO), em 16 de novembro de 1945, em reunião realizada em Londres.

Os documentos que fundam a ONU e a UNESCO deixam explícito que a criação dessas instituições é uma reação direta às duas guerras mundiais. Os órgãos são feitos para que não restem quaisquer dúvidas sobre as consequências terríveis da guerra, de maneira que novos conflitos possam ser evitados. Há um esforço nos dois textos para mostrar que todas as pessoas e as culturas são iguais, devendo ser igualmente respeitadas. Já que os povos são idênticos e merecem o mesmo tratamento, então a convivência pacífica e a harmonia devem sempre ser buscadas. Assim, igualdade e paz viram princípios inquestionáveis. Nesses documentos as ideias de igualdade e paz oscilam entre o começo e o fim de um processo: há momentos nos textos em que eles parecem uma natureza, um estado original do gênero humano, mas há outros em que eles são metas a serem alcançadas. Seja como marca de nascença, seja como objetivo perseguido, a relevância que ONU e UNESCO conferem a ideia de igualdade e de paz, insistindo mais nas semelhanças entre as pessoas que nas suas diferenças, funda essa grande família chamada Humanidade. Surge uma ideia de pan-humanismo, quer dizer, de uma substância comum a todas as pessoas que as convida a viver harmonicamente em comunidade. Se, no século XIX, por conta de uma leitura enviesada do evolucionismo, não havia nem uma unidade biológica do gênero humano (ou seja, nem havia "gênero humano"), na metade do século XX a ideia de Humanidade instaura um monismo civil do homem. Não faz mais sentido acreditar que uma cultura específica encarna o universal e representa de forma metonímica uma totalidade, fazendo com que as demais pareçam meras degenerações desses eleitos. De agora em diante o todo só se realiza no todo ou em todas as partes, não havendo mais espaço para hierarquias evolutivas. O próprio logotipo da ONU deixa claro esse princípio: a Terra vista de um ponto intermediário e imparcial, sem nenhum território no centro. 
Percebe-se a mudança entre o período exótico-colonial do mercado da diferença e a época que começa a ser burilada. Enquanto aquela era - aferrada as noções de progresso, história linear única e evolução - hierarquizava os povos em diferentes estágios de desenvolvimento e, por isso, julgava natural que culturas "mais desenvolvidas" invadissem, manipulassem e conquistassem as "menos desenvolvidas", esses novos tempos insistiam na igualdade do gênero humano, considerando natural, portanto, a harmonia, a vida comunitária e a paz. Sai a hierarquia evolutiva e a guerra, surge a "Humanidade" e a concórdia.

Na carta de fundação da ONU, pode-se ler o seguinte:

"Preâmbulo

Nós, os povos das nações unidas, resolvidos a preservar as gerações vindouras do flagelo da guerra, que por duas vezes, no espaço da nossa vida, trouxe sofrimentos indizíveis à humanidade, e a reafirmar a fé nos direitos fundamentais do homem, na dignidade e no valor do ser humano, na igualdade de direito dos homens e das mulheres, assim como das nações grandes e pequenas, e a estabelecer condições sob as quais a justiça e o respeito às obrigações decorrentes de tratados e de outras fontes do direito internacional possam ser mantidos, e a promover o progresso social e melhores condições de vida dentro de uma liberdade ampla.

E para tais fins,praticar a tolerância e viver em paz, uns com os outros, como bons vizinhos, e unir as nossas forças para manter a paz e a segurança internacionais, e a garantir, pela aceitação de princípios e a instituição dos métodos, que a força armada não será usada a não ser no interesse comum, a empregar um mecanismo internacional para promover o progresso econômico e social de todos os povos resolvemos conjugar nossos esforços para a consecução desses objetivos. (pp. 3,4) (...)

Propósitos e Princípios

Artigo 1

Os propósitos das Nações unidas são:

1. Manter a paz e a segurança internacionais e, para esse fim: tomar, coletivamente, medidas efetivas para evitar ameaças à paz e reprimir os atos de agressão ou outra qualquer ruptura da paz e chegar, por meios pacíficos e de conformidade com os princípios da justiça e do direito internacional, a um ajuste ou solução das controvérsias ou situações que possam levar a uma perturbação da paz;

2. Desenvolver relações amistosas entre as nações, baseadas no respeito ao princípio de igualdade de direitos e de autodeterminação dos povos, e tomar outras medidas apropriadas ao fortalecimento da paz universal; 
3. Conseguir uma cooperação internacional para resolver os problemas internacionais de caráter econômico, social, cultural ou humanitário, e para promover e estimular o respeito aos direitos humanos e às liberdades fundamentais para todos, sem distinção de raça, sexo, língua ou religião; e

4. Ser um centro destinado a harmonizar a ação das nações para a consecução desses objetivos comuns.

\section{Artigo 2}

A Organização e seus Membros, para a realização dos propósitos mencionados no Artigo 1, agirão de acordo com os seguintes Princípios:

1. A Organização é baseada no princípio da igualdade de todos os seus Membros.

2. Todos os Membros, a fim de assegurarem para todos em geral os direitos e vantagens resultantes de sua qualidade de Membros, deverão cumprir de boa fé as obrigações por eles assumidas de acordo com a presente Carta.

3. Todos os Membros deverão resolver suas controvérsias internacionais por meios pacíficos, de modo que não sejam ameaçadas a paz, a segurança e a justiça internacionais.

4. Todos os Membros deverão evitar em suas relações internacionais a ameaça ou o uso da força contra a integridade territorial ou a dependência política de qualquer Estado, ou qualquer outra ação incompatível com os Propósitos das Nações Unidas." (pp. 5, 6)

\section{E na da UNESCO:}

"Que a grande e terrível guerra que acaba de chegar ao fim foi uma guerra tornada possível pela negação dos princípios democráticos da dignidade, da igualdade e do respeito mútuo dos homens, e através da propagação, em seu lugar, por meio da ignorância e do preconceito, da doutrina da desigualdade entre homens e raças;"

"Paz, para não falhar, precisa ser fundamentada na solidariedade intelectual e moral da humanidade."

"Em conseqüência, eles, por este instrumento criam a Organização das Nações Unidas para a Educação, a Ciência e a Cultura, com o propósito de fazer avançar, através das relações educacionais, científicas e culturais entre os povos do mundo, os objetivos da paz internacional, e do bem-estar comum da humanidade, para os quais foi estabelecida a Organização das Nações Unidas, e que são proclamados em sua Carta."

"O propósito da Organização é contribuir para a paz e para a segurança, promovendo colaboração entre as nações através da educação, da ciência e da cultura, para fortalecer o respeito universal pela justiça, pelo estado de direito, e pelos direitos humanos e liberdades fundamentais, que são afirmados para os povos do mundo pela Carta das Nações Unidas, sem distinção de raça, sexo, idioma ou religião." (p. 1) 
Enfim, nos trechos aqui trazidos e em outros ao longo dos documentos podem-se ler expressões como "Nós, os povos das nações unidas", "povos do mundo", "direitos fundamentais do homem", "dignidade e valor do ser humano", "igualdade de direito dos homens e das mulheres" "interesse comum", "princípio da igualdade de direitos e da autodeterminação dos povos", "paz universal", "harmonizar a ação das nações para consecução desses objetivos comuns", "busca irrestrita da verdade objetiva" "bem estar comum da humanidade", etc. Olhando para esses mantras do filtro da igualdade, nós podemos ver exatamente que noções do período exótico-colonial do mercado da diferença ele retêm e quais deixa passar.

Dois pilares do exótico-colonial são negados: (1) o evolucionismo; a noção de que os povos estariam estacionados em patamares diferentes de desenvolvimento histórico; a crença de que o presente de algumas culturas representa o passado de outras; os gabaritos que hierarquizam e dividem os povos e as culturas, etc. No lugar dessas noções, surge a ideia de igualdade: princípio que instaura esse corpo chamado humanidade, uma grande família humana em que todos os membros são feitos da mesma substância. O século XIX também acreditava n'O Homem, mas enquanto essa narrativa se materializava metonimicamente no europeu e todos os outros povos eram uma tentativa frustrada de encarnar esse arquétipo, agora havia um conceito inscrito em cada um de nós e que ficava mais nítido ainda na união de todos. (2) A violência; o conflito; a guerra; a conquista. Já que os homens deixaram de se separar em hierarquias verticais para se unirem nessa grande família humana, não há mais porque cultivar o dissenso ou ser indiferente ao arbítrio. Ao invés dessas noções, será promovida a paz, a vida comunitária e a simetria.

No entanto, algumas características basilares do período exótico-colonial continuam a ser legitimadas: (1) A natureza humana. (2) O universal (3) A criação de uma ordem mundial a partir de um local. (4) A centralidade do estado-nação.

Esse é mais um daqueles casos em que se muda o conteúdo sem se mudar a forma, quer dizer: as substâncias que preenchem as categorias são opostas, mas as categorias propriamente ditas continuam as mesmas. No caso da natureza humana: durante o século XIX, acreditava-se que os povos se dividiam em patamares evolutivos hierarquizados; já no século XX, passou-se a crer que todos os homens eram iguais. Ideias de natureza humana diametralmente opostas, mas ainda ideias de natureza humana. No caso do 
universal: no século XIX, pensava-se que os povos mais evoluídos podiam subjugar os mais atrasados para ratificar as idiossincrasias de sua própria cultura; no século $\mathrm{XX}$, a irmandade do gênero humano coroava a paz como um valor inestimável. Discursos contrários mas ambos estribados no universal. No caso de uma ordem mundial criada por um local: o século XIX viveu sob a égide da colonização e da assimetria de poder; já o século XX levantou a bandeira da paz e da igualdade como metas incontornáveis da humanidade. Entretanto, as nações que criaram a agenda da colonização no século XIX foram as mesmas (mais os Estados Unidos) que abraçaram o imperativo da igualdade no século XX. Além disso, os criadores das duas pautas normativas, cada um em seu tempo, acreditavam que aquelas políticas eram exatamente o que o mundo precisava, sendo sua criação, portanto, um gesto filantrópico. Nesse caso, tem-se aqui protocolos de conteúdos opostos, mas formalmente ambos são pautas mundiais que não foram mundialmente concebidas, mas forjadas pelo mesmo Ocidente de sempre. Por fim, esses dois projetos tão contrários se materializavam, ambos, na cultura dos estados-nação de suas respectivas épocas. O universal do século XIX, marcado pela ideia de progresso, de história linear única, de evolução, se realizava no estado-nação; da mesma forma, o espírito universal do pós-Segunda Guerra, carregando a paz e a igualdade, desaguava também no estado-nação. Os países sempre foram os cabides dos discursos: a história é escrita por eles e para eles. Passado o período colonial, a guerra das nações foi abominada, mas só a guerra, não as nações; já que foram elas mesmas que se dispuseram a se unir em uma organização: o $\mathrm{N}$ está lá presente em todas as siglas. Por maior que tenha sido a revolução desses conteúdos, é sempre no estado-nação que eles se encarnam. A legitimidade e o poder simbólico dessa materialidade permanecem os mesmos tanto no período exótico-colonial da diferença quanto nesse interstício da igualdade.

Sendo assim, podemos dizer que aquelas ideias de natureza humana, de universalidade, de agendas mundiais localmente forjadas e de estado-nação ruíram, mas as ideias de natureza humana, de universalidade, de agendas mundiais localmente forjadas e de estado-nação permaneceram. Como já falei: os conteúdos mudaram, mas as categorias que preenchem permaneceram as mesmas. Eu não quero aqui parecer um relativista ingênuo e afirmar que "querer o mundo em guerra é a mesma coisa que querer o mundo em paz", claro que não, substancialmente falando, é o contrário inclusive; entretanto, do ponto de vista formal, ainda é "querer alguma coisa para o mundo", e isso não pode ser 
negligenciado. É curioso que uma organização estarrecida com os horrores do passado e disposta a mudar a direção da seta de desenvolvimento histórico tenha conservado categorias fundantes da mentalidade que se queria extinguir, ainda que tenha revolucionado seus conteúdos. Hoje, passados setenta anos da escrita daqueles documentos, é natural que nós tenhamos naturalizado suas soluções, mas se exercitarmos um distanciamento, poderemos notar que, se o ímpeto revolucionário era tão grande, não seria estranho se as coisas tivessem se dado de outra maneira. Quando se confrontou com o sofrimento trazido por um espírito universal encarnado em países que acreditavam que podiam subjugar outros porque seus povos eram naturalmente desiguais, o mundo poderia ter chegado à conclusão que as ideias de natureza, de universal, de ordem mundial e de estado-nação foram responsáveis por aquilo e, portanto, precisavam ser abandonadas. Mas, ao invés disso, as categorias foram conservadas e a crença nelas só aumentou, o que mudou foram os conteúdos nelas investidos. A revolução não foi pequena, foi enorme (abraçou-se o contrário do que se queria antes), mas se restringiu a uma dimensão muito específica do problema. O mais correto seria dizer que a revolução foi profunda, mas limitada a uma área bem localizada. Caminhava-se na direção oposta da mesma rua. Enfim, a escolha por abraçar substâncias opostas de categorias antigas mostra que o mundo perpetrou uma revolução de conteúdos, mas uma conservação das formas. Voltando a questão do início da seção, podemos agora dizer que o filtro da igualdade reteve a morfologia do exótico-colonial, mas deixou que suas categorias fluíssem para a diversidade-global.

Atentemos para os seguintes parágrafos da Carta das Nações Unidas:

5. Todos os Membros darão às Nações toda assistência em qualquer ação a que elas recorrerem de acordo com a presente Carta e se absterão de dar auxílio a qual Estado contra o qual as Nações Unidas agirem de modo preventivo ou coercitivo.

6. A Organização fará com que os Estados que não são Membros das Nações Unidas ajam de acordo com esses Princípios em tudo quanto for necessário à manutenção da paz e da segurança internacionais. (pp. 6, 7)

Recuperando os cruzamentos entre universal/particular e local/global, podemos ver que o que se tem aqui é uma ideia de universal, localmente forjada, tentando se globalizar. Como mostram as passagens, os membros da ONU apoiarão os membros da ONU que agirem de acordo com os princípios da ONU e se absterão de apoiar os estados que ferirem esses 
princípios. Além disso, a Organização se esforçará para que todas as nações compartilhem seus princípios, ainda que não sejam seus membros. Quer dizer, tem-se aqui princípios universais (encarnados nos estados-nação) que, embora tenham sido localmente criados, objetivam se transformar em uma nova ordem mundial, tendo que ser respeitados inclusive por aqueles que não fazem parte da Organização. A liberdade que a ONU quer para as nações não é a liberdade de cada país "ser o que quiser", ou de criar suas respectivas associações e ordens mundiais ${ }^{22}$, muito pelo contrário: foi esse tipo de liberdade que permitiu a colonização, a Primeira Guerra e a ascensão do nazismo. Para a ONU, paz, igualdade e liberdade são pautas normativas universais que devem ser aceitas mundialmente para que funcionem como mecanismos de controle. Fiel a uma ideia de natureza humana e de direitos naturais e universais inquestionáveis, a ONU se projeta sobre o mundo regulando, constrangendo, alterando locais que não compartilham esses princípios. Raça humana, paz, igualdade, comunidade, etc. são princípios universais pétreos que devem ser obedecidos no mundo inteiro. Quando afirma que a liberdade é um valor universal, a ONU não está dizendo que as nações estão liberadas para fazer o que bem entenderem, mas obrigadas a respeitar a liberdade.

Durante o século XIX, um grupo de estados-nação encarnava um espírito universal que fora localmente forjado, mas que se esforçou para se globalizar, atropelando os projetos universais forjados por outras localidades. No século $\mathrm{XX}$, esse mesmo grupo materializava novamente um universal criado por ele mesmo, que também intentou se alastrar pelo mundo inteiro, constrangendo quem se opusesse ao projeto. A diferença brutal é que esses dois princípios universais eram diametralmente opostos: enquanto o primeiro se alicerçava na diferença entre os homens e naturalizava a guerra, o segundo se enraizava na igualdade da família humana, considerando a paz, a igualdade e o respeito entre os povos um dever-ser. De fato, princípios universais contrários, mas ainda princípios universais: diferença de conteúdo com permanência das formas.

Um caso exemplifica muito bem isso: uma das resoluções do Tratado de Versalhes foi a criação da Liga das Nações, órgão internacional responsável por promover a paz mundial. A Segunda Guerra Mundial atestou o fracasso da Liga em cumprir seus objetivos, por conta disso, depois do conflito, a associação transferiu suas responsabilidades para a

\footnotetext{
${ }^{22}$ A ONU jamais conviveria com "outra ONU", por exemplo. Isso seria um acinte aos princípios universais e a natureza humana. A Organização reconhece as muitas nações, mas só uma agremiação pode contemplá-las.
} 
recém-criada ONU, que se comprometeu a continuar o trabalho da Liga. O grande responsável pela criação da Liga das Nações foi Woodrow Wilson, presidente dos Estados Unidos durante a Primeira Guerra Mundial. Por ter fundado a instituição, Wilson recebeu, em 1919, o Nobel da Paz. O curioso dessa história é que o homem que criou o órgão mundial responsável por impedir conflitos e que foi laureado com o prêmio Nobel da Paz tinha acabado de sair vitorioso do que então havia sido a maior guerra conhecida da história. Como foi dito, os Estados Unidos participaram do conflito primeiramente emprestando dinheiro e vendendo equipamentos para Entente e depois, para garantir a vitória de sua devedora, enviando tropas para lutar. Depois disso, o chefe desse país fundou a Liga das Nações, plantando a semente da ONU, e ganhou o Nobel da Paz. Vê-se aqui que, para esse período, as noções de paz, igualdade, comunidade, humanidade eram sim pautas normativas a serem obrigatoriamente obedecidas no mundo inteiro. Em nome da paz, entrava-se em guerra e depois se recebia um prêmio pelo seu pacifismo. Ganhar a guerra era pacificar o mundo. Wilson recebeu o prêmio não tanto por acabar com uma ordem mundial violenta, mas por erigir uma pacífica: a paz tinha um estatuto diferente da guerra, mas ainda tinha um estatuto. No futuro, a academia voltaria a dar o Nobel da Paz para pessoas diretamente envolvidas em guerras, como Henry Kissinger e Barack Obama.

O objetivo desses comentários não foi fazer uma crítica, uma denúncia ou apontar uma contradição no discurso pacifista e igualitário da ONU. Dizer que a paz e a igualdade são, para a instituição, princípios universais que devem ser obrigatoriamente seguidos e que, em nome deles, a Organização interfere em políticas locais não é revelar nenhuma faceta secreta da ONU. Os próprios secretários gerais, ao longo dos anos, insistem nesse caráter e tem muito orgulho dele. Como já pontuado anteriormente, não se quer aqui cair no relativismo inútil que equipara generais colonizadores a embaixadores da paz. Talvez os homens do futuro, vivendo em um mundo ainda mais pacífico e igualitário, vejam com menos nitidez do que nós a diferença entre essas duas figuras, mas eu escrevo do coração do período da diversidade-global do mercado da diferença e, por isso, não tenho o olho treinado para ver as contradições hoje naturalizadas que só o futuro evidenciará. Isso quer dizer que teço afinidades com o meu tempo e por isso prefiro viver nele do que no passado, ainda que as próximas gerações possam sentir uma mesma ojeriza por tudo que as antecedeu. No entanto, hoje, é difícil conceber que mesmo o crítico mais ferrenho dos limites do conceito de liberdade da ONU e do período da diversidade-global (que já irei 
apresentar) prefira viver em um mundo militarmente colonizado ou dominado pelo nazismo. O paralelo aqui estabelecido entre o período exótico-colonial e o filtro da igualdade almejou tão somente mostrar como esse filtro, na tentativa de extinguir os horrores do período que o antecedeu, abraçou conteúdos opostos aos da colonização, mas se aproveitou das suas categorias, conferido a estas o mesmo prestígio. Se queremos descobrir quais são as continuidades e rupturas entre o momento exótico-colonial e o da diversidade global é importante atentarmos para o que fica e o que passa pelo filtro da igualdade, pois é essa membrana que articula os dois períodos do mercado da diferença. Viu-se aqui que o fim de uma era universal não implica no fim do universal, mas apenas na transição de um universal para outro. O conteúdo de cada universal mudou, mas a forma universal continuava. Foi-se a universalidade natural da guerra e da diferença, veio a universalidade natural da paz e da igualdade. Não se vivia mais sob a égide daquela ortodoxia, mas ainda se vivia sob a égide de uma ortodoxia: oposta, mas ainda ortodoxa.

Mas o documento do filtro da igualdade que melhor ilustra essa revolução de conteúdos com permanência das formas é, sem dúvida, a Declaração Universal de Direitos Humanos, de 10 de dezembro de 1948. O termo "direitos humanos" já aparecia nas cartas fundadoras da ONU e da UNESCO, mas só três anos depois surgiu um código exclusivamente destinado a ele. Fica nítida no documento essa seletividade inconsciente do filtro da igualdade, que abraça substâncias opostas às anteriores, mas as posiciona nas mesmas categorias em que as antigas se situavam. A Declaração rejeita a visão de que a violência seria normal porque a natureza humana estaria investida de um espírito universal que a hierarquiza, gerando diferença, e se filia a concepção de que a paz deve ser estabelecida porque, na verdade, a natureza humana se preenche por um espírito universal que a nivela, promovendo a igualdade. Vê-se aqui a revolução dos conteúdos com a conservação das formas: sai o conteúdo da diferença e da violência, vem o da igualdade e o da paz. No entanto, permanecem as formas de natureza humana, de universal, de pauta mundial localmente forjada e de estado-nação. A desigualdade e o conflito são substâncias universais encarnadas em uma natureza humana que se materializa no corpo do estadonação e que tenta se globalizar mesmo tendo sido localmente forjada pelo Ocidente. A igualdade e a paz são substâncias opostas a essas, mas também são substâncias universais encarnadas em uma natureza humana que se materializa no corpo do estado-nação e que 
tenta se globalizar mesmo tendo sido localmente forjada pelo Ocidente. Conteúdos opostos, formas iguais.

Já no título do documento, "Declaração Universal dos Direitos Humanos", ficam explícitas as categorias que ele maneja: a declaração é universal e os direitos são humanos, quer dizer, tem-se ali um discurso desenraizado, que não pode ser relativizado, já que paira acima das parcialidades, e que se materializa em uma natureza humana, uma substância inata que, por se inscrever em todas as pessoas, torna os indivíduos iguais, membros de uma mesma família humana, de uma mesma humanidade. Assim como esse pós-Segunda Guerra cioso de produzir um mundo pacífico, igualitário e liberto, o colonialista século XIX também proferia localmente discursos universais que almejavam espraiar sua ontologia imanente ao ser humano pelo mundo inteiro. A diferença é que enquanto a ONU considera universais a concórdia, o equilíbrio e o respeito, o programa colonial universalizava a hierarquia, a guerra e a conquista. Duas formas igualmente universais acerca da natureza humana localmente forjadas intentando se globalizar por estados-nação com conteúdos opostos.

Ao longo do documento aparecem termos como "dignidade inerente", "essencial", "Família Humana", "consciência da humanidade", "direitos fundamentais do homem", "respeito universal e efetivo dos direitos do homem e das liberdades fundamentais", "todo ser humano" etc. O preâmbulo do texto se encerra da seguinte forma:

"A Assembleia Geral proclama a presente Declaração Universal dos Direitos Humanos como o ideal comum a ser atingido por todos os povos e todas as nações, com o objetivo de que cada indivíduo e cada órgão da sociedade, tendo sempre em mente esta Declaração, se esforce, através do ensino e da educação, por promover o respeito a esses direitos e liberdades, e, pela adoção de medidas progressivas de caráter nacional e internacional, por assegurar o seu reconhecimento e a sua observância universal e efetiva, tanto entre os povos dos próprios Estados-Membros, quanto entre os povos dos territórios sob sua jurisdição." (p. 1)

Como foi dito, é notável aqui a presença das velhas formas de universal, do inatismo, de uma ordem mundial localmente forjada, e da centralidade do estado-nação sustentando os novos conteúdos da paz, da igualdade e da liberdade. Por exemplo:

\section{"Artigo 1:}

Todas os seres humanos nascem livres e iguais em dignidade e direitos. São dotados de razão e consciência e devem agir em relação uns aos outros com espírito de fraternidade." (p. 2) 


\section{"Artigo 15:}

1. Todo ser humano tem direito a uma nacionalidade.

2. Ninguém será arbitrariamente privado de sua nacionalidade, nem do direito de mudar de nacionalidade." (p. 4)

\section{"Artigo 28.}

Todo ser humano tem direito a uma ordem social e internacional em que os direitos e liberdades estabelecidos na presente Declaração possam ser plenamente realizados." (p. 6)

No início dessa seção falei que o filtro da igualdade funciona como uma dobradiça entre os dois períodos do mercado da diferença, quer dizer: a igualdade não simplesmente os separa, nem só os liga, ela articula o exótico-colonial com a diversidade-global. A igualdade não está contida só no primeiro, nem só no segundo, nem é um terceiro espaço, ela é uma membrana porosa entre os dois, alienando-os só na medida em que eles a compartilham, que retêm algumas noções e deixa outras fluir. Como se sabe, a imagem da dobradiça é retirada de Lévi-Strauss (2003). Em sua obra, o autor usa a metáfora pra descrever a função da proibição do incesto na passagem da natureza para a cultura. Recusando tanto uma separação total entre as duas instâncias quanto uma teoria do ponto crítico à maneira de Kroeber (1993), Lévi-Strauss afirma que a proibição do incesto é a dobradiça que articula natureza e cultura: assim como nosso filtro da igualdade em relação aos dois períodos da diferença, o tabu do incesto não é só natural, nem só cultural, nem uma terceira coisa, ela é a fenda cavada no seio da natureza pela qual cultura irá se desenvolver. Articulando a naturalidade do sexo com a racionalidade do veto, o único gesto da proibição do incesto acaba com a endogamia e instaura a exogamia, fazendo assim com que os povos saiam de sua autocontida natureza e se relacionem entre si como culturas. Por marcar a fronteira entre as duas noções, o tabu do incesto separa natureza e cultura, mas também as relaciona para sempre.

Assim como a dobradiça da proibição do incesto pertence tanto a natureza quanto a cultura, esse fole da igualdade também é compartilhado pelas fases exótico-colonial e da diversidade-global do mercado da diferença. Como um filtro, fino mais ainda vazado, a dobradiça da igualdade retém os conteúdos da diferença exótico-colonial, mas ao deixar suas formas seguirem ocas, ela cria a fresta onde a diferença da diversidade-global irá florescer. Portanto, é errado dizer que a igualdade produz ativamente a diversidade-global, pois ela só a habilita obliquamente. $\mathrm{O}$ que acontece é o seguinte: o período exóticocolonial tem um conteúdo que preenche as formas universais de natureza humana 
localmente forjadas que tentam se globalizar por outros estados-nação. Ao passar pelo filtro da igualdade, esse conteúdo do exótico-colonial é contido, e do outro lado aquelas formas de universalidade, natureza humana, ordem mundial e crença no estado-nação saem ocas, sem uma materialidade que as preencha. É nessa concavidade da forma, antes ocupada pelo conteúdo do exótico-colonial, que irá nascer a substância da diversidadeglobal. Por isso, embora o filtro da igualdade não construa o conteúdo da diversidadeglobal, pode-se dizer que seu trabalho é fundamental para o surgimento desse conteúdo, pois se o filtro não neutralizasse o conteúdo do exótico-colonial, o conteúdo da diversidade-global não teria espaço para se desenvolver.

Poder-se-ia alegar que, depois de passarem pelo filtro da igualdade, as formas não estão ocas, mas preenchidas pelo conteúdo da igualdade, e, de fato, foi assim que ela foi aqui conceituada. Mas digamos que a coisa se dê dá seguinte maneira: o filtro da igualdade fornece um certo conteúdo de igualdade, mas não fornece um da diferença; ele limpa as formas de universal, de natureza humana, de pauta mundial e de estado-nação dos conteúdos do período exótico-colonial do mercado da diferença, mas não coloca outro conteúdo de diferença no lugar, deixando assim em aberto o espaço formal para que uma nova diferença se desenvolva. No fim das contas, esse conteúdo de igualdade é o próprio filtro da igualdade, pois é ele que segura o conteúdo exótico-colonial do período da diferença, permitindo que um novo conteúdo surja nas formas que ele deixa fluir. Como nosso objeto é a diferença, o conteúdo da igualdade não nos interessa em si mesmo, mas apenas na medida em que se relaciona com os conteúdos da diferença. A igualdade pode até positivar uma ontologia da igualdade, mas esse corpo só chama nossa atenção porque nega uma ontologia da diferença e abre o espaço para o desenvolvimento de outra. É claro que o mercado da diferença depende das oscilações em outros mercados, mas não nos importa o que essas mudanças são em seus respectivos mercados, mas que mudanças causam no mercado da diferença. Se queremos ver o que a igualdade faz com a diferença, nós temos que olhar para o seu avesso. A igualdade pode ter seu volume convexo, mas queremos saber que concavidade esse volume abre na diferença. A igualdade é uma nova onda, mas que só nos interessa na medida em que muda a frequência da onda da diferença. O filtro da igualdade pode até ensejar uma ontologia da igualdade, mas não erige uma ontologia da diferença; contudo, é essa ontologia da igualdade que livra as formas da velha ontologia da diferença exótica-colonial e assim as deixa preparadas para receber uma nova. 
Por conta disso, a igualdade não nos interessa enquanto uma ontologia da igualdade, mas como um filtro para a diferença.

Voltando para os documentos, podemos ver como se opera esse duplo movimento de conter a diferença exótica-colonial e abrir o corte onde irá repousar a diferença da diversidade-global. Nos três textos aqui apresentados fica claro que, quando se debruça sobre as formas de universalidade, natureza humana, ordem mundial e importância do estado-nação, o filtro da igualdade segura o conteúdo do período exótico-colonial do mercado da diferença, mas não coloca nenhuma outra no lugar, apenas limpa as formas para que elas possam ser preenchidas por um novo conteúdo de diferença. Por um lado, a igualdade se faz presente como uma positivação para apagar o conteúdo da diferença exótica-colonial; por outro, ao invés de sugerir um novo conteúdo de diferença, a igualdade se ausenta como uma negativação, ocupada apenas em preservar as velhas formas, mantendo-as livres dos velhos conteúdos da diferença e garantindo que novos conteúdos preencham esse espaço.

Pode-se ver esse primeiro movimento de negar a diferença exótica-colonial em um termo que aparece ao longo de todos os documentos: "sem distinção".

" (...) promover e estimular o respeito aos direitos humanos e às liberdades fundamentais para todos, sem distinção de raça, sexo, língua ou religião." (ONU, 1945, p. 5)

"os povos do mundo pela Carta das Nações Unidas, sem distinção de raça, sexo, idioma ou religião (...)" (ONU, 1945, p. 13.)

"O propósito da Organização é contribuir para a paz e para a segurança, promovendo colaboração entre as nações através da educação, da ciência e da cultura, para fortalecer o respeito universal pela justiça, pelo estado de direito, e pelos direitos humanos e liberdades fundamentais, que são afirmados para os povos do mundo pela Carta das Nações Unidas, sem distinção de raça, sexo, idioma ou religião." (UNESCO, 1945, p. 2)

\section{"Artigo 2.}

1. Todo ser humano tem capacidade para gozar os direitos e as liberdades estabelecidos nesta Declaração, sem distinção de qualquer espécie, seja de raça, cor, sexo, idioma, religião, opinião política ou de outra natureza, origem nacional ou social, riqueza, nascimento, ou qualquer outra condição.

2. Não será também feita nenhuma distinção fundada na condição política, jurídica ou internacional do país ou território a que pertença uma pessoa, quer se trate de um território independente, sob tutela, sem governo próprio, quer sujeito a qualquer outra limitação de soberania." (ONU, 1948, p. 2)

\section{"Artigo 7.}


Todos são iguais perante a lei e têm direito, sem qualquer distinção, a igual proteção da lei. Todos têm direito a igual proteção contra qualquer discriminação que viole a presente Declaração e contra qualquer incitamento a tal discriminação." (ONU, 1948, p. 7)

\section{"Artigo 16.}

1. Os homens e mulheres de maior idade, sem qualquer restrição de raça, nacionalidade ou religião, têm o direito de contrair matrimônio e fundar uma família. Gozam de iguais direitos em relação ao casamento, sua duração e sua dissolução.

2. O casamento não será válido senão com o livre e pleno consentimento dos nubentes.

3. A família é o núcleo natural e fundamental da sociedade e tem direito à proteção da sociedade e do Estado." (ONU, 1948, p. 4)

Em paralelo a negação da diferença exótico-colonial, há a consciência de que foi a falta de informação e de preparo acerca das diferenças entre povos que conduziram o mundo para a barbárie. Portanto, ao mesmo tempo em que rechaça as velhas ideias de diferença, o filtro da igualdade salienta que é necessário respeitar essa ideia. Cristaliza-se a noção de que $o s$ povos são diferentes, mas devem ser igualmente tratados. Como os trechos a seguir deixam claro, depois de apagar o conteúdo exótico-colonial da diferença, o filtro da igualdade não enseja um novo conteúdo, mas se esforça por garantir esse vazio nas formas para que novos conteúdos possam ali se desenvolver.

"Através da história da raça humana, foi a ignorância sobre as práticas e sobre as vidas uns dos outros uma causa comum da suspeita e da desconfiança entre os povos do mundo, através das quais suas diferenças com enorme frequência resultaram em guerras;" (UNESCO, 1945, p. 2)

7. Nenhum dispositivo da presente Carta autorizará as Nações Unidas a intervirem em assuntos que dependam essencialmente da jurisdição de qualquer Estado ou obrigará os Membros a submeterem tais assuntos a uma solução, nos termos da presente Carta; este princípio, porém, não prejudicará a aplicação das medidas coercitivas constantes do Capitulo VII. [capítulo VII: Ação Relativa a Ameaças à Paz, Ruptura da Paz e Atos de Agressão] (ONU, 1945, p. 7)

3. Com vistas à preservação da independência, da integridade e da diversidade frutífera das culturas e dos sistemas educacionais dos Estados Membros da Organização, fica a ela vedada a intervenção nas questões essencialmente restritas à jurisdição interna desses Estados. (UNESCO, 1945, p. 3)

Trilhado o percurso, podemos entender o papel do filtro da igualdade na passagem do período exótico-colonial do mercado da diferença para o da diversidade-global. No plano do conteúdo, o exótico-colonial se aferrava as ideias de progresso, história linear única, evolução, unidade, homogeneidade, pureza e absolutismo; no plano da forma, essas ideias preenchiam as categorias de universal, de natureza humana, de ordem mundial 
localmente forjada e conferiam centralidade ao estado-nação. Quando o exótico-colonial passa pelo filtro da igualdade seus conteúdos são retidos, mas suas formas fluem para o outro lado. Quer dizer: caem as morfologias do progresso, história linear única, evolução, unidade, homogeneidade, pureza e absolutismo, mas permanecem as categorias de universal, de natureza humana, de ordem mundial localmente forjada e centralidade ao estado-nação. É nessas formas ocas, antes preenchidas pelo conteúdo exótico-colonial da diferença, que irá se inscrever o conteúdo da diversidade-global da diferença. Portanto, a passagem do mercado da diferença pelo filtro da igualdade marca a mudança desse mercado de um período exótico-colonial para outro de diversidade-global, mas como a transição se alicerça em uma revolução dos conteúdos com uma permanência das formas, então se pode dizer que os dois períodos nem se ligam nem se separam completamente, mas se articulam. Resta saber ainda a natureza dessa articulação. Salientei também que, embora o filtro da igualdade seja o responsável por neutralizar os conteúdos da diferença exótica-colonial, nós não podemos dizer que ele tenha erigido diretamente os conteúdos da diferença da diversidade-global; todavia, indiretamente, o filtro da igualdade desempenha um papel vital no aparecimento dos conteúdos da diferença da diversidade-global, pois é varrendo os conteúdos da diferença exótica-colonial que a igualdade deixa as formas limpas para receberem o novo conteúdo da diferença da diversidade-global. Sendo assim, não se pode dizer que o filtro da igualdade encerra um período da diferença e inicia outro, mas sim que ele encerra um período da diferença e cria a possibilidade do outro, abrindo os espaços para que ele surja. Olhando para as cartas de fundação da ONU, da UNESCO e para a Declaração Universal dos Direitos Humanos podemos ver essa dinâmica: se por um lado, os textos se referem diretamente ao período anterior, mostrando seus erros; por outro eles não acrescentam nada sobre o período vindouro, muito embora se esforcem por criar uma concavidade para que algo novo surja. O tipo de conteúdo da diferença do exóticocolonial é ativamente negado, mas ao invés de anunciarem um novo conteúdo, os documentos se limitam a garantir um espaço formal para que ele possa se desenvolver.

Como pontuei, o filtro da igualdade não pertence mais a um período do que a outro, pois ele fica exatamente no meio deles, separando-os na medida em que o compartilham. Como nessa seção explicitei as resistências que o filtro da igualdade impôs à diferença exótica-colonial, é natural que se pense que esse filtro tem mais afinidade com a diferença da diversidade-global, mas isso não é verdade. Se por um lado podemos dizer que o filtro 
da igualdade barrou o primeiro período do mercado da diferença e assim permitiu o florescimento do segundo, por outro também se pode dizer que esse segundo momento teve que brigar com as mesmas ideias do filtro da igualdade que possibilitaram seu nascimento ao neutralizarem o momento anterior. Antecipando aqui elementos do próximo capítulo para que se possa dar um exemplo: a ideia de negar "as distinções de raça, sexo, religião, língua, etc." retém o conteúdo do exótico-colonial e limpa o terreno para o conteúdo da diversidade-global; entretanto, ainda que essa negação tenha sido importante para seu surgimento, é contra essa mesma ideia que o conteúdo da diversidade-global irá lutar, pois ela aparece justamente afirmando essas distinções, mas sem o caráter negativo que o exótico-colonial lhes dava.

É por isso que não considero a igualdade algo próprio só a um período, ou só a outro, ou um terceiro período, mas um filtro intersticial que separa os períodos do mercado da diferença ao mesmo tempo em que os põe em diálogo. Não se marca nenhum conteúdo de diferença no filtro da igualdade, pois ele é um interstício em que os conteúdos da diferença exótica-colonial são contidos e os da diferença da diversidade-global ainda não nasceram, apenas se garantiu a moldura formal onde se fixarão. Pode ser que o filtro da igualdade enseje seu próprio conteúdo, o conteúdo da igualdade, mas ele só nos interessa aqui como a negação de um determinado conteúdo da diferença e a possibilidade de um outro. É tudo um jogo de figura e fundo em que cada lado se vê como figura e vê seu duplo como fundo: a igualdade é desenhada no avesso da tela que nos interessa, por isso tudo o que lá é colorido aqui é branco e vice-versa. Há quem diga que toda música são duas músicas: uma formada pelos sons entre cada silêncio e outra formada pelos silêncios entre cada som. Do lado em que nós estamos a diferença é o som e o silêncio é a igualdade. Daqui, a diferença é o cheio, o convexo, o mercado, e a igualdade é o vazio, o côncavo, o filtro. Viu-se nessa seção que o filtro da igualdade retém conteúdos, mas libera formas, fazendo com que as duas metades do mercado da diferença compartilhem as mesmas categorias mas as preencham com substâncias opostas. Se entre o período exótico-colonial e o da diversidade-global do mercado da diferença existe essa comunhão de formas com essa assimetria de conteúdos, então que tipo de relação as duas metades estabelecem entre si: de continuidade ou de ruptura? 
Para responder essa pergunta é preciso entender o que é o segundo período do mercado da diferença. É o que farei no próximo capítulo. 


\section{Capítulo 3}

\section{O período da diversidade-global do mercado da diferença}

O segundo período do mercado da diferença diz respeito a um momento de globalização em que o mundo se vê cortado por fluxos de informação, pessoas e culturas que se territorializam em lugares diferentes. Nessa era, o conceito de diferença se aproxima das noções particulares de multiplicidade, heterogeneidade, hibridismo e relativismo. Além disso, nessa fase vemos surgir agendas políticas relativas à paz, à tolerância e ao equilíbrio entre os povos. Assim como antes, o mercado da diferença precisa aqui de um termo síntese que organize o debate. O conceito que reúne sob seu abrigo essas ideias constitutivas do segundo período do mercado da diferença é a diversidade. Como se desenrola em um contexto de globalização e se organiza em torno da diversidade, esse segundo momento do mercado da diferença será chamado aqui de período da diversidadeglobal do mercado da diferença.

Percebe-se aqui o contraste desse período com o anterior: se antes a diferença operava com uma divisão rigorosa entre Eu e Outro, sendo cada metade o oposto de seu par mas indiferenciada para si mesma, agora o mundo se vê cortado por fluxos que cruzam todas as fronteiras. O hiato entre as nações desaparece, pois os fluxos (telecomunicações, viagens, trocas comerciais, etc.) levam o fora para dentro e o dentro para fora, confundindo essas noções. Sem a rigidez dessa fronteira, a legitimidade simbólica do estado-nação na definição da diferença é questionada. Como se disse, era no estado-nação que o universal se realizava; desse jeito, quando a morfologia que o cristalizava se enfraquece, aquela própria ideia de universal vê sua autoridade discutida. Com a perda de sustentação daquele universal, esse segundo momento do mercado da diferença começa a se interessar pelo étnico, o específico, o contextual, enfim, pelo particular. Em um cenário em que os fluxos tomam o lugar do estado-nação e o particular cumpre o papel que antes cabia ao universal, o prestígio depositado nas ideias de unicidade, homogeneidade, pureza e absolutismo passa agora a se encarnar nos conceitos de multiplicidade, heterogeneidade, hibridismo e relativismo. $\mathrm{Na}$ esteira dessas mudanças, cresce a expectativa de que a assimetria de poder característica do período colonial ceda lugar a uma maior harmonia entre os povos. Enfim, essa mudança de agendas representa uma troca de ordens mundiais: o mercado da diferença abandona um período exótico-colonial e adentra um de diversidade-global. 
Entretanto, as mudanças acima elencadas dizem respeito a questões terminológicas, conceituais. Resta saber se a releitura dessas ideias aponta uma revolução nas coisas ou se essa nova gramática não passa de uma atualização do antigo glossário. Enfim, ainda precisamos saber que relação esses conceitos estabelecem com os antigos: seriam eles iguais, contrários, complementares, divergentes, etc.? Respondidas essas perguntas, poderemos então descobrir quais as continuidades e rupturas entre os dois períodos do mercado da diferença e que relação afinal existe entre colonização e globalização.

Mas, antes disso, é preciso mapear o período da diversidade-global do mercado da diferença, assim como fiz com o anterior, para que se descubra como emergiram essas agendas. Cronologicamente falando, o cenário começa a mudar depois da Primeira Guerra Mundial. Após esse conflito, o conceito de exótico foi perdendo sua capacidade de organizar o mercado da diferença e uma outra noção foi sendo preparada para desempenhar esse papel. Em torno dessa nova ideia, uma agenda diferente surge. Essa ideia é a diversidade, palavra que vem margeando o debate acerca da diferença até os nosso dias. Nas páginas seguintes tentarei mostrar em que configuração se deu essa transição de um período exótico-colonial do mercado da diferença para um da diversidadeglobal.

$$
* * *
$$

Na seção anterior, falei que os horrores das duas grandes guerras mostraram para o mundo o tamanho do equívoco de seu projeto universal. Diante desse fracasso, o ocidente criou um filtro de igualdade, momento intersticial entre os mercados da diferença, dedicado a abolir o regime anterior e a garantir que o mundo não repetisse os mesmos erros do passado. Quando se abandonou um regime calcado na hierarquia e na guerra para que se adentrasse em um marcado pela igualdade e pela paz, o antigo projeto universal europeu mostrou sua face violenta, interessada e contingencial. Depois que as marcas dos conflitos foram expostas e resoluções estabelecidas pela ONU, pela UNESCO e pela Declaração Universal dos Direitos Humanos abraçaram a igualdade e a paz, ficou difícil defender o empreendimento colonial imperialista e sanguinário do século XIX. As ideias de progresso, história linear única e evolucionismo, fundantes da mentalidade colonial, deixaram de ser vistas como princípios universais naturais, incontornáveis e benéficos e começaram a ser encaradas como arbitrariedades injustificáveis. Enquanto no século XIX 
se acreditava que aquele protocolo era o caminho para a civilização, o século XX percebeu que aquilo era sua sepultura. Quando os princípios universais da colonização deixaram de ser aceitos com naturalidade para serem vistos como violentos, aquela ordem mundial perdeu sua legitimidade e sua eficácia simbólica, sendo substituída por uma agenda da paz e da igualdade. Em meio à descrença no programa colonial, aumentou a pressão por independência. Assim, a independência das colônias europeias foi abalando as certezas do período exótico-colonial da diferença uma a uma.

Primeiro o binômio Eu/Outro. Como se disse, o período exótico-colonial operava com uma rígida separação entre o Eu e Outro. Cada lado dessa díade era diametralmente oposto do seu duplo, mas igual a si mesmo, por isso o par analítico marcava diferença externa e indiferença interna. Nesse arranjo, o Eu manipulava a imagem do Outro, situando-o em uma posição ambivalente entre proximidade e distância para que ele causasse a exoticidade necessária para salientar a especificidade do Eu. Como foi pontuado, esse mundo colonizado habitado pelo Outro era uma grande massa homogênea e indistinta. Para a Europa, o resto do planeta era uma coisa só e os nativos dessa Pangeia também estavam plasmados em um único povo. Com a independência das colônias, esse modelo binomial foi atacado por duas frentes: primeiro pelo princípio de autodeterminação dos povos, depois pelos fluxos de intercâmbios culturais. Estabelecido pela ONU nos documentos do filtro da igualdade, o princípio de autodeterminação dos povos assegura que as culturas possam falar por si e definir quem ela mesmas são, garantindo que não serão silenciadas e definidas por uma voz estrangeira. Conquistada a independência política, as ex-colônias agora estavam em busca de sua independência simbólica e discursiva. Investidas desse poder, as culturas deixaram de ser determinadas pela Europa e passaram a se definir por elas mesmas. Como já era esperado, esses povos não achavam que suas imagens serviam exclusivamente para ratificar a unicidade da cultura Ocidental, e, com isso, se deslocaram daquela posição ambivalente. Além disso, quando passaram a se definir, as ex-colônias mostraram que não eram só diferentes da Europa, mas também diferentes umas das outras, assim, o tecido contínuo d'O Outro se pulverizou em uma infinidade de pequenos fragmentos culturais imiscíveis, irredutíveis a um mesmo termo. Como nome nenhum seria capaz de conter aquela profusão de idiossincrasias, ruiu a ideia pavimentada de Outro. Ora, se a razão de ser do Outro era sublinhar a raridade do Eu, a dissolução daquela ontologia enfraquecia o prestígio dessa. Sem um grupo controle com 
quem se contrastar, a Europa perdeu sua especificidade, tendo que se admitir como uma cultura entre outras. Através do princípio de autodeterminação dos povos, as colônias mostraram que eram tão diferentes uma das outras quanto eram diferentes do Ocidente, e assim aquele mundo binário se transformou em uma nuvem de fragmentos sem centro.

Já os fluxos de intercâmbio cultural dizem respeito ao seguinte aspecto do novo contexto: o século XX assistiu a um grande avanço tecnológico nos transportes, nas telecomunicações e nas trocas comerciais. Vivia-se agora em um mundo que poderia ser atravessado em horas, em que no Brasil se sabe que um golpe de estado no Oriente Médio acabou de acontecer, em que um bem simbólico é feito com peças de vários países, montado em outros e vendido em todos. Desse jeito, pessoas, informações e coisas de outras culturas entram na nossa, assim como elementos da nossa entram nessas outras. Como se pode ver, o princípio de autodeterminação dos povos e os fluxos de intercâmbio cultural abalaram tanto a indiferença interna quanto a diferença externa dos lados daquele binômios. Nesse novo contexto, as culturas estavam menos niveladas e menos distantes uma das outras. Ficou claro que a complexidade do mundo não cabia mais em uma díade estática: agora existiam muitas culturas que mudavam o tempo inteiro. Portanto, ao invés do velho binômio Eu/Outro, o presente passou a operar com a ideia de fluxo.

Com os fluxos de intercâmbios culturais tomando o lugar daquela estável díade colonial, a fronteira, que é o espaço onde as trocas acontecem, passa a ser mais relevante do que o espaço contido nela. Assim, o interstício, o limite, o perímetro onde as trocas se realizam começa a ser visto como um espaço onde sentidos são negociados e imputados, uma arena própria dos novos tempos. Paradoxalmente, o prestígio depositado na fronteira faz com que se evidencie a fraqueza dela. Nesse segundo período do mercado da diferença, as arestas das culturas são tidas como espaços ricos justamente porque são porosas, porque não conseguem conter o que está dentro, nem barrar o que vem de fora. Ao contrário do que se dava no primeiro período do mercado da diferença, essa nova era passará a cultivar identidades polissêmicas.

Depois que os fluxos substituíram o binômio, foi a vez do estado-nação ter seu papel questionado. Ora, que relevância tem a nacionalidade em um mundo que deixou de se organizar em discerníveis ontologias adiabáticas fixas e passou a abraçar uma dinâmica de fluxos ininterruptos? Esses fluxos de intercâmbio de pessoas, conhecimento e bens 
simbólicos cruzam as fronteiras do estado-nação trazendo o fora para dentro e o dentro para fora. Meu país está cheio de estrangeiros e meus compatriotas estão pelo mundo todo; o mesmo jornal fala da novela das oito e do Estado Islâmico; as prateleiras estão abarrotadas de mercadorias chinesas... Enfim, como o perímetro dos territórios nacionais não consegue mais conter a saída da indiferença interna nem barrar a entrada da diferença externa, então a ideia de estado-nação parecia não conseguir mais organizar o debate.

Como exaustivamente pontuado, a cultura do estado-nação era o espaço onde se realizava o universal. Se essa cultura não conseguia mais manter sua especificidade e a própria categoria de estado-nação se via abalada, então aquela noção de universal também começou a perder densidade. Quando cai, o universal leva consigo tanto suas características de unidade, homogeneidade, pureza e absoluto quanto suas ideias de progresso, história linear única e evolução. Ao que tudo indica, o mundo passa por um período de descrença ontológica e epistemológica, quer dizer: se um único e grande bloco se estilhaça em muitos e pequenos fragmentos, também um único e grande discurso se dissolve em muitos e pequenos relatos. No plano ontológico, os fluxos de intercâmbio cultural atestam a incapacidade da fronteira do estado-nação em estabilizar a cultura nacional, mantendo o Eu dentro e o Outro fora. Como "nós" nos dispersamos lá fora e "eles" se misturam conosco aqui dentro, as características universais de unidade, homogeneidade, pureza e absolutismo perdem sua capacidade de explicação para as noções particulares de multiplicidade, heterogeneidade, hibridismo e relativismo. No plano epistemológico, a conquista da independência política e discursiva faz as antigas colônias deixarem de ser coadjuvantes de uma história europeia para que passem a protagonizar suas próprias histórias. Agora que cada um está trilhando seu próprio caminho, as monistas e totalitárias ideias de progresso, história linear única e evolução não conseguem mais dar conta do novo cenário; em seu lugar surge um interesse pelo específico, o étnico, o parcial, o contingente, enfim, o particular. Parece que a complexidade dos novos tempos não pode mais ser explicada por grandes teorias gerais eternas, mas apenas por pequenos relatos contextualizados e efêmeros.

Por fim, depois de trocar o binômio Eu/Outro pela fragmentação, o estado-nação pelo fluxo, e uma teoria universal alicerçada no único, no homogêneo, no puro e no absoluto por relatos parciais múltiplos, heterogêneos, híbridos e relativos, os novos 
tempos, assegurados pelo trabalho do filtro da igualdade, pareciam ter deixado de naturalizar aquela violência colonial para abraçar um tempo pacífico de respeito mútuo.

Bem ou mal, parecia que uma nova fase do mercado da diferença ia ganhando corpo do lado de lá do filtro da igualdade. Paulatinamente, os duplos dos traços exóticocoloniais iam aparecendo depois do filtro: passou-se do binômio Eu/Outro para o fluxo; do universal para o particular; da unidade, homogeneidade, pureza e absolutismo para a multiplicidade, heterogeneidade, hibridismo e relativismo; da guerra para a paz.

Começava a surgir uma vasta literatura denunciando as arbitrariedades do período exótico-colonial do mercado da diferença. Porém, ao invés de acabar com a ideia de diferença, esses textos ambicionavam criar um novo conteúdo de diferença no espaço antes ocupado pelo exótico-colonial. A ideia era fazer com que a diferença deixasse de ser uma régua monopolizada pelo Ocidente, usada para ele exotizar os povos e produzir sua raridade, e se transformasse em uma ferramenta de todas as culturas, para que se afirmassem como bem entendessem. O próprio livro de Said, escrito em 1978, se inscreve nessa tradição. Em um posfácio de 1994, o autor fala:

"Minha meta não era tanto dissipar a própria diferença - pois quem pode negar o papel constitutivo das diferenças nacionais e culturais nas relações entre seres humanos? -, mas questionar a noção de que a diferença implica hostilidade, um conjunto reificado e congelado de essências opostas e todo um conhecimento derivado dessas ideias". (SAID, 2013, p. 465).

Mas, assim como no período anterior, um termo-síntese precisava emergir para organizar em torno de si esse conjunto de ideias. Enfim, já se conheciam os duplos das características do exótico-colonial, mas ainda era preciso saber qual era o duplo do exótico-colonial propriamente dito.

Colocando as coisas nesses termos, os novos tempos pareciam ser o oposto do período anterior, mas não podemos nos reduzir aos termos. É preciso saber o que significam, como são experimentados e que posições ocupam no mercado da diferença para que se possa descobrir se há de fato aqui uma ruptura ou uma continuidade. Os conceitos podem até sugerir uma mudança, mas não podemos esquecer que os sentidos dos conceitos não são imanentes a eles, mas vão sendo adquiridos e negociados ao longo de seus usos, na maneira como são recebidos, enfim, nas práticas. Se por um lado os conceitos indicam uma ruptura, existem outros fatores que apontam para uma continuidade, por 
exemplo: como foi dito, o filtro da igualdade reteve os conteúdos do exótico-colonial, mas deixou fluir as formas de natureza humana, de universal, de ordem mundial localmente forjada e a centralidade do estado-nação. Se, ao contrário dos conteúdos, essas categorias do exótico-colonial não foram negadas pelo filtro da igualdade, mas até afirmadas pelos seus documentos, de que maneira conviverão natureza humana e dispersão? universal e particular? ordem mundial localmente forjada e liberdade? Centralidade do estado-nação e fluxo? Enfim: como um novo conteúdo da diferença pode sair de um filtro da igualdade que deixa fluir velhas formas de diferença? Anteriormente, mostrei como o filtro da igualdade ofereceu resistência ao período exótico-colonial do mercado da diferença, varrendo seus conteúdos e aceitando só suas formas; agora, nessa nova fase que vai surgindo, o quadro evidencia a seguinte dificuldade: (1) ou o novo período também se atritará com o filtro da igualdade, o que nos leva a crer que ele guarda semelhanças com o período anterior, já que o filtro também o desgastou. (2) Ou ele florescerá sem estremecimentos, o que também pode sugerir uma afinidade com o momento de antes, pois, dizer que a nova diferença surgiu tranquilamente significa que os novos conteúdos da diferença se adequaram às antigas formas do exótico-colonial e, de algum jeito, contrariando o tom usado anteriormente, natureza humana e fragmentação, universal e particular, ordem mundial e liberdade, estado-nação e fluxo estariam conseguindo conviver. Se isso for verdade, ainda que tenha havido uma revolução terminológica, é possível que os novos termos ainda estejam sendo usados como os anteriores.

Além desses problemas criados pela porosidade do filtro da igualdade, há a questão da memória, quer dizer: mesmo que o presente rasgue o gabarito do passado e escreva um novo, isso não quer dizer que os ecos daquela velha normatividade não sejam mais ouvidos. Conseguiriam as civilizações fazer tábula rasa da colonização e erigir uma ordem mundial do zero? Tem-se aqui um grande desafio. A história tem sua inércia e as regras não necessariamente espelham a vida que regulam. Tendemos a fazer o que estamos acostumados a fazer, ainda que a norma aponte para outra direção. É claro que as ortodoxias racionais-legais são relevantes, mas eles não são a única instância com a qual nos mediamos: a tradição, o sangue e outros afetos também têm suas densidades. Não me refiro aqui a um comportamento "marginal" ou "fora da lei", muito pelo contrário, mas às maneiras de estar dentro da lei mesmo sem acionar suas regras, ou melhor, acionando regras que não estão escritas, mas que existem, e que são eficientes justamente porque não 
se pode identificá-las nos códigos. Esses mecanismos silenciosos produzem efeitos gritantes e as consequências são claras justamente porque as operações são discretas: resultados visíveis de regras invisíveis. Acontecimentos inevitáveis que tem a solidez de uma rocha justamente porque aparentemente foram produzidos com espontaneidade e desinteresse; aliás, nem parece que foram produzidos, parece que tudo sempre foi assim, por isso "é melhor que continue como está". O mapa só indica um caminho possível, mas isso não que dizer que as pessoas não tenham outros. Essas rotas alternativas não passam por fora do mapa, elas se dão no espaço miniaturizado por ele, só não estão ali desenhadas. Há pegadas que os mapas não mostram, mas que formam hipotenusas com as trilhas ortogonais que ele prescreve. Podemos partir do ponto de partida e chegar no ponto de chegada indicados pelo mapa, mas percorrendo um caminho que, embora seja diferente da indicado, está sempre costurando essa trilha principal. Não é porque não se segue a indicação do mapa que se está fora dele: é possível estar tão dentro dele que se chega a uma espécie de infra-mapa, quer dizer, é possível seguir o mapa do seu jeito. Enfim, acionar regras que não estão no estatuto não é desrespeitá-lo ou se situar fora dele, pelo contrário, somos capazes de estar tão dentro da ortodoxia que conseguimos até encontrar um espaço em branco entre uma regra e outra de onde podemos manipular as leis que nos circundam. Entrar assim nas regras é fazer com que elas entrem em você; é ter o poder de criar o código justamente por obedecê-lo à risca. Dito de forma categórica, uma revolução no conteúdo dos sentidos é um começo, mas o que pode ela sozinha, se os usos que se fazem dos sentidos definem esses conteúdos? Ainda é cedo para dizer que o passado passou.

Uma troca de conceitos indica uma ruptura entre o período exótico-colonial do mercado da diferença e o novo, mas uma dúvida acerca da maneira com que eles estão sendo acionados abre uma fresta para a possibilidade de continuidade. É preciso seguir com a investigação para descobrir o que aconteceu.

$$
* * *
$$

Temos diante de nós um novelo histórico difícil de desenrolar: primeiro um mercado da diferença exótico-colonial que maneja o binômio Eu/Outro, acredita na desigualdade da natureza humana e na violência, confere centralidade ao estado-nação e se alicerça nas ideias universais de unidade, homogeneidade, pureza e absolutismo. Depois 
essa diferença exótico-colonial passa por um filtro de igualdade que retém os conteúdos que preenchiam as categorias de natureza humana, de universalidade, de pauta mundial localmente forjada e de estado-nação, mas deixa que essas categorias propriamente ditas sigam ocas para o lado de lá. Do outro lado do filtro, um mundo diferente parece se reorganizar: fragmentos instáveis tomam o lugar do binômio Eu/Outro e fluxos de intercâmbio cultural atestam a porosidade das fronteiras nacionais. Já que o mundo deixa de se resumir a duas metades externamente opostas e internamente niveladas para se descobrir um amálgama de fluxos que intercambiam milhares de fragmentos diferentes, então aquela agenda do universal, interessada no único, no homogêneo, no puro e no absoluto, perde prestígio para um protocolo do particular, enredado no múltiplo, no heterogêneo, no híbrido e no relativo. Mas aqui surge um grande problema: como se disse, o filtro da igualdade retém os conteúdos do período exótico-colonial, mas deixa que as formas de universalidade, natureza humana, ordem mundial e estado-nação sigam para o futuro. Nas cartas de criação da ONU, da UNESCO e dos Direitos Humanos aqui analisadas fica bem evidente que essas categorias não foram só aceitas, mas fortalecidas. Diante disso, como é que essa nova fase do mercado da diferença irá se mediar com as categorias da velha fase que o filtro da igualdade deixou passar? Dito de maneira explícita: como se concilia fragmentação com natureza humana? fluxos com estado-nação? e, principalmente um discurso da particularidade calcado em multiplicidade, heterogeneidade, hibridismo e relativismo com uma noção de pauta mundial localmente forjada e de uma agenda universalista marcada pelas ideias de unidade, homogeneidade, pureza e absolutismo? Se por um lado tudo parece ter mudado, por outro essas interrogações criam uma certa desconfiança sobre a morte do passado. Na universidade, na política, e nos meios de comunicação as pessoas começam a perguntar: o novo período do mercado da diferença acabará com as formas do antigo que o filtro da igualdade deixou passar ou os velhos hábitos engolirão as novas tendências? Será que os dois discursos podem conviver? Se sim, essa convivência seria tensa ou harmônica? Eles são dois discursos mesmo? Cabe a nós descobrir.

Analisemos o mundo que saía do outro lado do filtro da igualdade, quer dizer, o mundo pós-Segunda Guerra Mundial. De fato, a Europa destruída pela guerra e as revoltas de independência se espalhando pelo mundo inteiro mostravam que o binômio colonial $\mathrm{Eu} /$ Outro não fazia mais muito sentido, no entanto, enquanto aquela velha díade ruía, uma 
nova começava se formar: a bipolaridade Estados Unidos/União Soviética. Se a Primeira Guerra tinha colocado a América no mapa dos países promissores, a Segunda coroou-a de vez como uma grande potência mundial. Por outro lado, a União Soviética também despontava no cenário global como a outra grande influência. Por serem diametralmente opostas, as duas superpotências se sentiam reciprocamente ameaçadas. Temendo perder seu poder para o outro, cada um dos dois países se dedicou a espalhar seu modo de vida para os demais. A nação que conseguisse influenciar o resto do planeta criaria uma ordem mundial idêntica àquela cultivada localmente em seu território e assim se consagraria como um grande império. Sob a égide desses projetos expansionistas rivais, os outros países do mundo viraram peças de uma disputa de poder entre o capitalismo americano e o comunismo soviético. Diante desse cenário, cada cultura se viu encurralada: ou se filiava a um lado ou a outro.

Até aqui, o mundo sentia claramente os efeitos daquelas velhas formas do período exótico-colonial do mercado da diferença que o filtro da igualdade deixara passar: estadosnação imperiais que queriam instaurar sua própria ordem mundial, expandido para os outros países princípios pretensamente universais localmente forjados. Aparentemente, tudo estava igual.

Porém, assim que os efeitos da permissividade formal do filtro da igualdade foram sentidos, logo se pôde perceber a força de sua censura conteudística. Mesmo com todas essas proximidades, as diferenças entre o atual cenário e o período exótico-colonial do mercado da diferença não poderiam ser negligenciadas.

Primeiro deve-se dizer que o que se tinha agora era um conflito entre dois projetos imperiais opostos. Claro que havia atritos entre os estados-nação europeus durante o colonialismo - foram esses embates que conduziram o mundo para a Primeira Guerra, inclusive - mas enquanto lá os países tinham um projeto mundial mais ou menos semelhante e brigavam apenas para descobrir quem lideraria esse processo, agora as culturas viam duas ordens mundiais completamente diferentes tentando se estabelecer. Se no exótico-colonial o mundo se organizava em torno do binômio "Eu dominador" e "Outro dominado", agora a díade era formada por duas culturas tentando ocupar a posição de dominação. A luta entre o Ocidente e suas colônias não era igual a dos Estados Unidos com a União Soviética: enquanto o primeiro caso se configurava como um embate de um 
forte contra um fraco que não tinha o menor interesse no conflito, no segundo tem-se uma disputa entre duas forças que intentam vencer a briga para dominar o resto do globo. $\mathrm{O}$ século XIX estava acostumado com a ideia de um universal localmente forjado virar uma ordem mundial, calando universais modestamente autocontidos, mas nunca tinha visto um duelo de universais em que ambos intentavam virar protocolos globais.

Além disso, o imperativo da paz imposto pelo filtro da igualdade impediu que a tensão entre Estados Unidos e União Soviética caminhasse para aquilo que seria a solução óbvia durante o período exótico-colonial do mercado da diferença: o confronto direto. Esse é um exemplo claro de convivência entre as antigas formas que passaram pelo filtro com as novas agendas que vetaram seus conteúdos: exatamente como no século XIX, o século XX vê estados-nação intentando converter seus respectivos projetos universais localmente forjados em ordens globais inquestionáveis; entretanto, ao contrário do que resolveria o século XIX, para cumprirem seus objetivos, as duas nações não podem entrar em guerra. Esse período de tensão em que os projetos universalistas americano e soviético queriam se converter em ordens mundiais únicas, mas não podiam entrar em confronto direto para atingir seus fins, ficou conhecido como Guerra Fria. A Guerra Fria mostra muito bem a complexidade que o mundo ganha depois de passar pelo filtro poroso da igualdade: de um lado, as formas de natureza humana, universal, pautas mundiais localmente forjadas e centralidade do estado-nação, típicas do período exótico-colonial do mercado da diferença, do outro, o imperativo incontornável da paz, próprio dos novos tempos.

O século XIX foi um período de posições fixas porque o conflito era um estado perene, já o século XX se descobre como uma era de risco justamente porque o conflito, embora seja condenado, está sempre prestes a acontecer. Se a guerra é uma natureza, tudo parece pacífico, mas se a paz é um imperativo, aquela guerra vira uma ameaça constante. Antes a eternidade da guerra era a estabilidade do mundo, agora a perenidade da paz atesta a instabilidade desse mesmo mundo, já que a guerra vira uma promessa que pode se cumprir a qualquer momento. Na era colonial todos despencavam no mesmo abismo, por isso viviam a ilusão de que estavam parados; agora de fato todos pisam no solo firme da paz, mas estão sempre na beira do precipício.

Há que se acrescentar, no entanto, que essa recusa a se entrar em um conflito direto não se devia apenas à ortodoxia da paz criada pelo filtro da igualdade, mas pelo medo de 
uma guerra nuclear que terminaria sem vitoriosos. Os danos irreparáveis das disputas até então travadas nada seriam perto das sequelas de uma guerra com armas nucleares. Desse jeito, essas novas armas criaram, por um lado, um medo mútuo que fortaleceu o dogma da paz, mas, por outro, trouxeram também mais riscos e incertezas para os novos tempos que se iniciavam.

Realmente, ainda que uma segunda organização binomial sugerisse uma continuidade entre o novo mundo e o antigo, as diferenças entre as díades metrópole/colônia e Estados Unidos/União Soviética indicavam uma ruptura; além disso, o recente imperativo da paz deixava claro que nem tudo era como antes. Entretanto, outra característica do novo arranjo mundial parecia desequilibrar a balança em favor da tese da continuidade: ao invés de protagonizarem suas respectivas histórias, os demais países continuavam a ser coadjuvantes de um processo liderado por terceiros, no caso Estados Unidos e União Soviética. Como a história se encarregaria de provar, a frieza da grande guerra entre capitalismo e comunismo foi mantida pelo calor de diversos outros conflitos menores espalhados pelo mundo: para que a paz e a cordialidade pudesse dar a tônica dessa disputa entre duas ordens mundiais, muitos conflitos locais foram travados. Conservava-se a integridade do binômio e de uma suposta história global à custa da destruição de países periféricos e de suas histórias locais. Assim como um jogo de xadrez é uma disputa pacífica para os jogadores, mas pode ser intensa para as peças que se matam no tabuleiro, a Guerra Fria se revelou um conflito em que dois grandes países jogavam sem sujar as mãos justamente porque, ao invés de se enfrentarem diretamente, podiam manipular os países mais fracos, cortando seus universos locais com a lâmina de um universal seja americano, seja soviético que intentava se globalizar. Portanto, assim como a Europa do século XIX fez com que o resto do mundo deixasse de seguir seu caminho para se anexar ao projeto europeu como colônia, agora também Estados Unidos e União Soviética transformavam todos os outros países em peças de seu jogo e todas as suas respectivas histórias em meros capítulos da história da luta entre capitalismo e comunismo. Se antes a autobiografia da América Latina não podia ser escrita porque ela era uma colônia Europeia, no século XX esse texto continua proibido porque no mesmo território os Estados Unidos patrocinam ditaduras militares que se prestam a defender o continente do comunismo. Se antes o Oriente não definia suas especificidades porque o Orientalista o exotizava para salientar as especificidades do Ocidente, agora a União Soviética ocupa 
militarmente esses territórios para que o comunismo se espraie. Enfim: os estados-nação e seus universais localmente forjados que tentam se globalizar são diferentes, mas ainda persiste o velho arranjo em que países dominantes almejam converter agendas próprias em ordens mundiais, transformando os outros países em seus apêndices.

Todavia, os que defendiam uma descontinuidade entre os dois períodos do mercado da diferença insistiam em virar o tabuleiro mais uma vez. Ainda que concordassem que os demais países eram arrastados pela luta entre Estados Unidos e União Soviética, os adeptos da ruptura acreditavam que as tentativas do presente de globalizar um universal localmente forjado eram diferentes daquelas do passado. Para os que se filiavam a essa concepção, a mudança consistia no seguinte: durante o período exótico-colonial do mercado da diferença, a Europa, na tentativa de converter suas particularidades em uma ordem mundial, fazia com que a sua visão de mundo soterrasse as outras visões, de maneira tal que as histórias dos povos deixavam de ser escritas por eles para se transformarem em meras notas de rodapé da história europeia. Contudo, falavam os defensores da ruptura, no período nascente não haveria esse soterramento, pois uma história pretensamente global não mais apagaria as histórias locais, mas refrataria nelas, aclimatando suas ambições totalizadoras às características do lugar. Sim, como as formas do período exótico-colonial do mercado da diferença atravessaram o filtro da igualdade, assim como no passado, nós ainda viveríamos tempos em que um projeto de universal localmente forjado que intenta se transformar em uma ordem mundial; no entanto, como o mesmo filtro reteve os conteúdos daquele período, ao contrário do passado, essa ambição de ascender ao global não teria a legitimidade simbólica de esmagar as várias idiossincrasias locais. Ao invés disso, os projetos totalitários, para se espraiarem, teriam que lidar com traços nativos. Esse poderia até ser um diálogo assimétrico, a voz dominante poderia até falar mais alto que a voz local, mas, ao contrário do que acontecia no período exótico-colonial do mercado da diferença, pela primeira vez havia um diálogo entre as vozes: desleal, mas ainda um diálogo. Uma mesma onda podia emanar de um centro, mas esse gesto único era recebido de maneira diferente em cada cultura que encontrava. Empregando as expressões que Stuart Hall usaria anos mais tarde, tem-se aqui uma polissemia gerada por uma distorção entre a "codificação" e a "decodificação" (2013): há uma só mensagem sendo discursada - uma só voz que, embora seja localmente proferida, quer invadir o global - mas cada lugar ouve essa mensagem da sua respectiva maneira. $\mathrm{O}$ monismo da fala se pulveriza na pluralidade 
das escutas. Não se pode falar em uma pluralidade total, pois só há uma mesma boca, mas também seria errado acreditar em uma unidade absoluta, pois há muitos ouvidos diferentes. A metáfora da refração é a mais adequada: a luz que emana do centro pode ser uma só, mas ela invade líquidos diferentes, e cada um distorce o raio à sua maneira. No período exótico-colonial do mercado da diferença, a Europa pavimentava África, América, Ásia e Oceania em um único, grande e indistinto Outro (que se opunha ao Eu); já no século XX, ainda que a ambição niveladora persista, esse nivelamento tem que se mediar com o relevo local. O mesmo capitalismo americano podia até querer dominar o mundo, mas o capitalismo latino não é igual ao capitalismo asiático, ou africano; do mesmo modo, o comunismo poderia ambicionar ser uma nova ordem mundial, mas seria absurdo dizer que o comunismo russo é igual ao chinês, ou mesmo ao dos demais países soviéticos. Essas especificidades existiriam porque, ainda que um mesmo processo intente se espraiar pelo mundo inteiro, essa narrativa única é apropriada de maneiras diferentes, já que cada território a interpreta do seu jeito, criando-se assim polissemia. Para os teóricos da ruptura, os defensores da continuidade olhavam só para o âmbito da produção dos discursos, mas ignoravam a esfera da recepção: de fato, um único discurso poderia estar sendo proferido, mas muitas eram a formas de recebê-lo. Sendo assim, já que nos novos tempos as tentativas de globalizar um universal localmente forjado refratam nas especificidades locais, já que não conseguem mais esmagá-las como acontecia no período exótico-colonial do mercado da diferença, então vivemos em um período em que mesmo as tentativas de produção de um discurso universal único, homogêneo, puro e absoluto acabam gerando vozes locais, múltiplas, heterogêneas, híbridas e relativas, distorcidas pela polissemia da recepção. Ainda há a produção de um cânone monista, mas que certamente se fragmenta na pluralidade das recepções. Uma única luz reta que serpenteia irregular pelos vários líquidos diferentes.

Como se pode ver, a Guerra Fria mostrou toda a complexidade do mundo que ia surgindo. Não era fácil vaticinar se a fase do mercado da diferença que ganhava corpo do outro lado do filtro da igualdade era a repetição ou a inversão do período anterior: se por um lado a organização binomial do mundo convive com os fluxos, por outro não se pode dizer que ela seja do tipo Eu/Outro. Se ainda há uma ideia de universal localmente forjada querendo se transformar em uma ordem mundial, por outro deve-se lembrar que a alternativa da guerra está vetada. Em compensação pode-se alegar que essa terceira guerra 
mundial é evitada às custas de várias guerras locais que fazem com que os países periféricos continuem sendo satélites de algum centro. Entretanto, mesmo que a história de um local se converta em uma história global que subjuga os outros locais, essa voz dominadora deve se ambientar aos vários e diferentes territórios das dominadas, já que não consegue mais nivelá-los completamente. Desse jeito, ainda que, no âmbito da produção, um discurso monista se esforce por construir um mundo governado por um universal único, homogêneo, puro e absoluto, no plano da recepção, as várias apropriações desse discurso unívoco se encarregam por criar leituras particulares múltiplas, heterogêneas, híbridas e relativas. De todo modo, é difícil bater o martelo e dizer se entre os dois períodos do mercado da diferença há continuidade ou ruptura.

A partir dos anos 1960, aumentaram os atritos entre as velhas formas do período exótico-colonial do mercado da diferença que o filtro da igualdade deixara passar e os novos conteúdos que eram ensejados. A percepção de que os novos tempos ainda conviviam com categorias antigas cultivou uma insatisfação com as soluções do filtro da igualdade. Por um lado, essa membrana tinha deixado algo de velho entrar no novo, por outro, suas soluções para a paz e a igualdade não se mostraram de todo eficientes. Mesmo que alguns hábitos tenham sido perdidos, a virada da década de 1960 para a de 1970 viu os sonhos do filtro da igualdade de paz e equilíbrio se despedaçarem: Guerra do Vietnam, ditaduras militares por toda a América Latina, crise do petróleo e outros tantos conflitos quentes que garantiam a frieza da guerra entre Estados Unidos e União Soviética. Mas, de todos esses eventos, o acontecimento que melhor ilustra a tensão entre os dois projetos de ordem mundial concorrentes foi, sem dúvida, a construção do Muro de Berlim. Em 1961 a cidade de Berlim foi dividida por uma barreira física que demarcava, de um lado, uma porção ocidental capitalista, do outro, uma oriental comunista. Por ser uma divisão do mundo entre capitalismo e comunismo sólida, empírica e visível, o Muro de Berlim foi tido como o símbolo mais ilustrativo da Guerra Fria. Além disso, se por um lado o filtro da igualdade estimulou os processos de independência das antigas colônias europeias, por outro, o mundo que esses países recém libertos encontravam não era nada promissor. Em 1975, Moçambique e Angola ficaram independentes de Portugal e deram adeus ao velho período colonial, contudo, tiveram que entrar no fim da fila do novo capitalismo. Como se pode ver, ainda que o filtro da igualdade tenha resolvido velhos problemas, isso não quer dizer que ele não tenha criado novos. Aos poucos foi se cristalizando a ideia de que 
abandonar um mundo corrompido não significava entrar em outro saudável. Os fluxos ensejavam novos tipos humanos que não se sentiam representados pela bandeira da igualdade. Esse incômodo com a suposta permanência de formas arcaicas e a descrença na agenda da igualdade fez crescer uma demanda por uma nova política da diferença, uma agenda de fato revolucionária. Em maio de 1968, só vinte anos depois de a igualdade ser louvada como princípio universal, as ruas de Paris foram tomadas por jovens gritando "viva a diferença". Não se pedia um retorno daquela diferença anterior ao filtro da igualdade, mas o florescimento de uma nova diferença, capaz de corrigir as distorções criadas pela antiga e pelo próprio filtro. $\mathrm{O}$ mundo não havia partido de um velho conceito de diferença para estacionar na igualdade, mas para ascender a uma diferença nova; a igualdade seria só o filtro que faria a mediação entre as duas. Paulatinamente a silhueta de um segundo período do mercado da diferença ia sendo rascunhada.

Foi na esteira desses acontecimentos que dois projetos intelectuais repensaram a ideia de diferença: o Capitalismo e Esquizofrenia $(2010 ; 2011)$ de Deleuze e Guattari e a Gramatologia (2006) de Derrida. Ainda que se separem em pontos importantes, há um mesmo incômodo que une os dois texto. Cada um a sua maneira, esses autores propuseram uma revolução na ideia de diferença, fazendo com que o conceito se aproximasse da polissemia e do fluxo, afinando-se assim com os princípios particulares de multiplicidade, heterogeneidade, hibridismo e relativismo.

Os dois projetos criticam o autoritarismo, o fascismo e as tentativas arbitrárias de totalização. Mas, para desestabilizar esse grande mau, os textos atacaram o que para eles era a raiz do problema: a ideia de uma metafísica da presença, de uma noção estável, adiabática e convexa de coisa. Para os autores, essa metafísica tem nome: o sujeito e a dimensão inata, universal e egocentrada de cognição que ele traz consigo. É esse relevo metafísico e bruto do sujeito que sustenta e naturaliza os programas totalitários que tomaram conta da história. Para corroer seu inimigo verdadeiro, essa metafísica subjetivada que alicerça a institucionalização da barbárie, os autores elencam seus inimigos estratégicos: a psicanálise freudiana no caso de Deleuze e Guattari, a ideia estruturalista de linguagem no caso de Derrida. Depois de Capitalismo e Esquizofrenia e Gramatologia, a diferença se distancia dos princípios universais de unidade, homogeneidade, pureza e absolutismo e se abre para um novo período. Analisemos os dois quadros analíticos. Para 
mapear o modelo de cada autor, eu usarei muitas citações, mas como os textos estão sendo levados aqui à categoria de objeto, trazer as palavras dos filósofos acaba sendo a maneira mais eficiente de recuperar esse percurso.

Capitalismo e Esquizofrenia se divide em dois tomos: O Anti-Édipo (2010) e Mil Platôs (2011). No primeiro tomo, como já sugerido no título, Deleuze e Guattari centram fogo na psicanálise de Freud e sugerem seu próprio método: a esquizoanálise. Na visão dos autores, a psicanálise faz uma leitura equivocada e sobretudo violenta do inconsciente. Para Deleuze e Guattari, Freud trata o inconsciente como uma coisa, uma forma chapada: Édipo. A partir daí, a psicanálise nos ensina que o inconsciente edipiano (no fim das contas: nós) deseja matar o pai e retornar à mãe para sarar uma fratura originária; quer dizer, o inconsciente já nasce com uma falta, uma lacuna aberta que precisa ser preenchida, sendo, portanto, defeituoso, ou melhor, complexado. Mas, infelizmente, esse desejo do inconsciente de matar o pai e voltar à mãe, essa vontade que ele precisa saciar para se saber inteiro, está a ele vetada, pois se trata de um tabu, aliás d'O Tabu por excelência: a proibição do incesto. O que $O$ Anti-Édipo irá mostrar é que essa visão psicanalítica de inconsciente é errada e perigosa.

Primeiro, afirmam os autores, o inconsciente não é uma coisa, uma ontologia ou uma metafísica, mas um fluxo. Aliás, um não, vários, espraiando-se em todas as direções e arrastando o que encontram pela frente, corroendo as margens e transformando tudo em fluxo. São só agenciamentos maquínicos se articulando, e não há coisas se articulando, mas apenas articulação de articulações, formando uma grande tecnosfera. Segundo, é errado dizer que o fluxo inconsciente deseja matar o pai e desposar a mãe. É verdade que ele deseja, inclusive ele é puro desejo, um fluxo desejante contínuo. Mas não se trata de um desejo transitivo, uma torrente que almeja alcançar uma forma exterior a ela (matar pai, casar mãe, ou qualquer outra figura), mas sim um desejo pré-figurativo, uma força cuja razão de ser não é um êxtase metafísico externo e teleológico, mas o próprio devir desejante, uma corrente de querência que só quer continuar querendo a sua própria vazão. Não se trata aqui de uma busca agonística, o fluxo não procura nada que esteja fora dele, não se tem aqui um rio que só estará completo quando desembocar no mar, pois não há mar, não há desembocadura, só rio. O fluxo querente não quer algo fora do fluxo, só quer continuar fluindo. $\mathrm{O}$ clímax não está em estacionar lá fora, mas em fluir aqui dentro. $\mathrm{O}$ 
desejo é intransitivo: não se deseja algo, algo que trará satisfação lá, apenas se deseja, e a satisfação está aí, ou melhor, aqui. Freud erra ao colocar as figuras de Édipo, da mãe e do pai dentro do inconsciente pois, com se falou, o inconsciente é fluxo pré-figurativo. Lá não há forma, coisa e imagem desejadas, objetos de desejos, só torrente de desejo que deseja desejar. O fluxo inconsciente não para, não se coagula em imagens frutos de desejo, o desejo não se tematiza, só segue. Édipo, mãe, pai... são formas históricas, secundárias, arbitrariamente forjadas que Freud enfia na naturalidade do desejo inconsciente, mas é impossível que um fluxo de vontade puro, natural e intransitivo queira algo externo e posterior a ele; aliás, é impossível que ele queira algo, pois ele só quer, só conhece a si mesmo, e assim ele está bem, já nasce bem, ele é o bem. O inconsciente, fluxo e não coisa, pré-figurativo e não imagético, não espelha dentro de si formas exteriores que ele deseja, mas erige interiormente não formas, mas o próprio desejo que, do começo ao fim, é o que ele é. No inconsciente não há mímese, metáfora, duplo, fantasma, enfim, não há a repetição de formas externas, apenas a criação de mecanismos internos. Ou, para falar como os autores: o inconsciente não é teatro, mas usina. Édipo, mãe, pai... nada disso faz sentido para o inconsciente, justamente porque são "isso's", são coisas, formas, exterioridades, história, violência, tema, fim, e o inconsciente é fluxo de desejo, um desejo tão primário e intenso que nem deseja nada, só desejar, e não há a agonística busca pelo fim exterior, pois o desejo interno já é a razão de ser do fluxo. A psicanálise aprisiona o desejo, tematiza-o, contém todo o fluxo e o direciona para um fim imagético: Édipo, mãe, pai. Freud transitiva o inconsciente, canaliza-o para um telos pictórico fora. Mas a violência psicanalítica vai além: depois de criar um objeto para o desejo, Freud nos ensina que esse objeto não pode ser desejado. Quer dizer: primeiro o psicanalista inventa arbitrariamente uma forma para o desejo e, ato contínuo, diz que essa forma que ele nos ensinou a desejar não pode ser desejada. Freud nos vicia na mesma droga que proíbe. O objeto desejado já chega como veto, o que queremos é exatamente o que não podemos ter, por isso o inconsciente freudiano é lacunoso, incompleto, doente e complexado. Só um remédio pode corrigir essa falta original, curar o inconsciente e deixá-lo completo: o tratamento psicanalítico. Eis a ciranda adiabática em que Freud nos fecha: primeiro diz que o inconsciente é a forma Édipo; depois fala que Édipo deseja matar o pai e casar com a mãe; em seguida ensina que Édipo não pode matar o pai nem casar com a mãe; por fim, para suprir esse desejo que não pode ser suprido, Freud oferece o método psicanalítico, o tratamento que vai desfazer o 
problema que ele mesmo criou, o antídoto para o veneno que ele mesmo nos deu. O mapa para o labirinto está dentro dele: entre para descobrir como sair. A promessa da psicanálise é fazer o inconsciente se reencontrar com sua verdadeira natureza, preencher a fenda que corta sua superfície. Mas, para a esquizoanálise, Freud faz o contrário: desnaturaliza o inconsciente, transforma-o em outra coisa, faz com que ele seja o que ele não é. Fluxo vira forma, interno vira externo, usina vira teatro, imanência vira transcendência, e assim, a violência se naturaliza, descaracterização parece conservação, o controle soa como liberdade e a doença é tida como cura. Freud tranca a torrente desejante do fluxo dentro das paredes do triângulo psicanalítico Édipo-Mãe-Pai e explica, oferece, proíbe e resolve o problema que ele mesmo criou.

Para Deleuze e Guattari o carrossel freudiano é o modus operandi de todo fascismo. Transformar fluxos em coisas e desejos livres em vontades dirigidas, tratar o poiético como mimético, jogar para uma inatingível transcendência exterior um êxtase que era atingido em uma imanência interior, e, depois de naturalizar a arbitrariedade da falta, despontar como a cura para os males que se criou. O Édipo inventa o mito do uno, do indivisível, do liso, da metafísica convexa e presente, quer dizer, das ideias universais de unidade, homogeneidade, pureza e absolutismo. Mas o inconsciente não é Édipo, eu não sou uma coisa monista, eu não sou nem coisa, nem monista, eu não sou nem eu na verdade. Não há essa mônada do sujeito cognitivo figurativo desejando figuras fora dele, mas só fluxos e agenciamentos de agenciamentos desejantes represados na pictografia de Édipo. Nada de universal, nem unidade, nem homogeneidade, nem pureza, nem absolutismo; fluxos devindo, engolindo formas, desejando num plano de consistência imanente. Os fluxos não partem de um ponto para chegar a outro, eles engolem os pontos até não haver mais pontos, só fluxos.

"Freud tentou abordar os fenômenos da multidão desde o ponto de vista do inconsciente, mas ele não viu bem, não via que o inconsciente era antes de mais nada uma multidão." (DELEUZE \& GUATTARI, 2010, p. 56)

Sendo assim, é preciso fazer com que os fluxos desejantes sangrem as paredes da barragem edipiana que os represa. É preciso empurrar para longe essas figuras e explodir em uma supernova de desejos fluidos. A usina está pulsando dentro do triângulo, um dia ela vai derrubá-lo. É isso o que propõe a esquizoanálise. Não se trata mais de apreender formas que domestiquem o fluxo, mas libertar o fluxo das formas que o aprisionam. 
Para que se ascenda a esse nível de liberdade, deve-se primeiro entender que as ortodoxias não antecedem as práticas que regulamentam, quer dizer, os esquemas normativos não nascem antes dos elementos que engendram. Como já se comentou, por mais que pareça natural, toda sistematização é arbitrária. Para esses autores, antes de qualquer lógica, há a imanência do fluxo autossuficiente. Qualquer gabarito que pareça têlo ensejado é, na verdade, uma formalização tardia que intenta dominá-lo. A lógica funcionalista universal não é uma ordem natural, mas uma doxa secundária que sorrateiramente se apresenta como matricial. Para a esquizoanálise, é preciso varrer essa antinatureza sistêmica e atingir a imanência dos fluxos desejantes.

"Não existe lógica proposicional universal, nem gramaticidade em si, assim como não existe significante por si mesmo. 'Por detrás' dos enunciados e das semiotizações, existem apenas máquinas, agenciamentos, movimentos de desterritorialização que percorrem a estratificação dos diferentes sistemas e escapam às coordenadas de linguagem assim como de existência. É porque a pragmática não é o complemento de uma lógica, de uma sintaxe ou de uma semântica, mas, ao contrário, o elemento de base do qual depende todo o resto" (DELEUZE \& GUATTARI, 2011, vol.2 p. 107).

Em Mil Platôs, as armas contra Édipo se apresentam. Como já sinalizado em outro texto (2000), para Deleuze e Guattari fazer filosofia é criar conceitos. No segundo tomo de Capitalismo e Esquizofrenia os autores se servem largamente dessa ideia e inventam um glossário enorme de termos: hecceidade, devir, rizoma, corpo sem órgãos, plano de consistência, etc. Dar uma definição precisa de cada um desses conceitos é uma tarefa tanto impossível quanto equivocada, pois as noções de Deleuze e Guattari não são pontos fixos, mas linhas por onde o sentido escorrega. Na maioria dos autores, os conceitos são como portas de um corredor que se abrem para salas que secretam sentidos. Mas, no caso dos filósofos aqui trabalhados, as portas se abrem para outros corredores, com mais portas. Além disso, os conceitos aqui não cumprem a função de separar sentidos, mas justamente de fazer com que deslizem para um cruzamento. Sendo assim, pode-se dizer que a hecceidade é um devir, que o devir é um rizoma, que o rizoma é um corpo sem órgãos, que o corpo sem órgãos é um plano de consistência, que o plano de consistência é um devir, e assim infinitamente. Ainda assim tentarei dar um panorama desse glossário para mostrar como ele evoca noções caras ao segundo período do mercado da diferença.

Para desconstruir Édipo (ou tudo o que assuma a sua lógica: o sujeito, o nazismo, o estado, etc.), o arsenal conceitual de Mil Platôs irá centrar fogo nas ideias universais de 
unidade, homogeneidade, pureza e absolutismo próprias ao primeiro período do mercado da diferença e trará a ideia de diferença para perto de outras noções, mais particulares.

Primeiro, contra a unidade, surge uma defesa da multiplicidade.

\begin{abstract}
"As multiplicidades são a própria realidade, e não supõem nenhuma unidade, não entram em nenhuma totalidade e tampouco remetem a um sujeito. As subjetivações, as totalizações, as unificações são, ao contrário, processos que se produzem e aparecem nas multiplicidades. Os princípios característicos das multiplicidades concernem a seus elementos, que são singularidade, a suas relações, que são deviris; a seus acontecimentos, que são hecceidades (quer dizer, individuações sem sujeito); a seus espaços-tempos, que são espaços e tempos livres; a seu modelo de realização, que é o rizoma (por oposição ao modelo da árvore); a seu plano de composição, que constitui platôs (zonas de intensidade contínua); aos seus vetores que as atravessam, e que constituem territórios e graus de desterritorialização." (DELEUZE \& GUATTARI 2011, vol. 1.pp. 10,11)
\end{abstract}

Essa multiplicidade, como já foi dito, é uma força intransitiva, não tem começo, nem fỉm, nem ruma em uma direção específica almejando alcançar uma figura exterior. "Uma multiplicidade não tem sujeito nem objeto, mas somente determinações, grandezas, dimensões que não podem crescer sem que mudem de natureza" (DELEUZE \& GUATTARI 2011, vol. 1. p. 23). Da mesma forma, não se pode dizer que existam "coisas múltiplas" ou formas puras multiplicadas, mas apenas multiplicidades. A dimensão mais "atômica" ainda é o cruzamento de fluxos de multiplicidades heterogêneos. Nada de coisas multiplicando, só multiplicidades multiplicando-se. "Existem unicamente multiplicidades de multiplicidades que formam um mesmo agenciamento, que se exercem no mesmo agenciamento." (DELEUZE \& GUATTARI, 2011, vol. 1, p. 62)

Para os autores, o mito do sujeito é uma das maiores violências edipianas. Essa ideia de um único corpo fechado, autocontido, impermeável a tudo que lhe seja externo, com uma inteligência dentro é uma desnatureza. $\mathrm{O}$ rosto é uma violência. Ele remete ao uno, ao indivisível; mas sob o rosto há uma multiplicidade de fluxos que se esforçam por derrubá-lo. Como já apontaram antes, o próprio inconsciente é multidão. Não há sujeito, só articulações arbitrariamente reunidas sob a égide dessa ontologia.

"Não existe sujeito, mas somente agenciamentos coletivos de enunciação, sendo a subjetivação apenas um dentre eles, e designando por isso uma formalização da expressão ou um regime de signos, não uma condição interior da linguagem" (DELEUZE \& GUATTARI, 2011, vol. 2 p. 85.) 
Contra essa visão ontológica, estável e indivisível de sujeito surge a noção de hecceidade. Hecceidades são processos de subjetivação sem sujeito, quer dizer, processos puros, intransitivos que não se prestam a ensejar um sujeito formal exterior a eles, mas a se intensificarem em sua duração. Graus, dias, horas, estações do ano são hecceidades. Grandezas que não carecem de uma figura, réguas que medem a si mesmas.

"Há um modo de individuação muito diferente daquele de uma pessoa, um sujeito, uma coisa ou uma substância. Nós lhe reservamos o nome de hecceidade. Uma estação, um inverno, um verão, uma hora, uma data têm uma individualidade perfeita, à qual não falta nada, embora ela não se confunda com a individualidade de uma coisa ou de um sujeito. São hecceidades, no sentido de que tudo aí é relação de movimento e de repouso entre moléculas ou partículas, poder de afetar e ser afetado." (DELEUZE \& GUATTARI, 2011, vol. 4, p. 47).

"Não é o mesmo plano: plano de consistência ou de composição de hecceidades num caso, que só conhece velocidades e afectos; plano inteiramente outro da formas, das substâncias e dos sujeitos, no outro caso. (...) Em suma, a diferença não passa absolutamente entre o efêmero e o duradouro, nem mesmo entre o regular e o irregular, mas entre dois modos de individuação, dois modos de temporalidade." (DELEUZE \& GUATTARI, 2001, vol. 4, p. 49)

O apelo de Deleuze e Guattari é para que os indivíduos deixem de se perceber como tais, como ontologias pictóricas inteligentes derivadas de um processo de subjetivação que se esforçou por criar uma metafísica exterior a ele, e passem a se perceber como um cruzamento de hecceidades. Nós não somos uma coisa, única, homogênea, pura e absoluta, mas uma encruzilhada de grandezas, de graus, de intensidades, de vetores que, equivocadamente, se enxerga como um sistema adiabático liso. Nós não somos o fruto de um processo de subjetivação que acabou quando nos fez, mas sim a interseção de vários processos de subjetivação que não começam nem acabam nunca, que sempre seguem pois sua razão de ser é o movimento interno. Assim como um dia, por exemplo, é uma subjetividade oca atravessada por acontecimentos variados, o tal "sujeito" também é uma interface de vetores diferentes. Não é que o Eu tenha que começar a se perceber desse jeito, ele tem que parar de perceber, parar de ser Eu e se diluir nesses fluxos para, finalmente, fluir.

"Você é longitude e latitude, um conjunto de velocidades e lentidões entre partículas não formadas, um conjunto de afectos não subjetivados. Você tem a individuação de um dia, de uma estação, de um ano, de uma vida (independentemente da duração), de um clima, de um vento, de uma neblina, de um enxame, de uma matilha (independentemente da regularidade). (...) É todo o agenciamento em seu conjunto individuado que é uma hecceidade, é ele que 
se define por uma longitude e uma latitude, por velocidades e afectos, independentemente das formas e dos sujeitos que pertencem tão somente a outro plano" (DELEUZE \& GUATTARI, vol. 4, p. 49)

O ponto é uma violência contra a linha. Um cruzamento de hecceidades é uma intersecção de linhas, não um ponto. Freud se debruça sobre uma encruzilhada de hecceidades e dá a ela o nome de Édipo. Parece que nada veio antes, nada virá depois, só existe esse ponto, essa coisa estável. Mas só há linhas, linhas de fuga, de segmentaridade, de desterritorialização, de estratificação, acelerando e desacelerando, mudando de natureza sempre que crescem. "Uma hecceidade não tem começo nem fim, nem origem nem destinação; está sempre no meio. Não é feita de pontos, mas apenas de linhas. Ela é rizoma." (DELEUZE \& GUATTARI, 2011, vol. 4, p. 50).

O rizoma é o conjunto formado por esse emaranhando de linhas de hecceidades. "Ele não é feito de unidades, mas de dimensões, ou antes de direções movediças. Ele não tem começo, nem fim, mas sempre um meio pelo qual ele cresce e transborda." (DELEUZE \& GUATTARI, 2011, vol. 1, p. 43). O arranjo rizomático é uma opção à estrutura arbórea. A árvore tem um tronco vertical, linear, quer dizer, um organismo central, organizado, uma hierarquia. O rizoma é um emaranhando de linhas sem pontos, e se não há ponto, não há centro. Qualquer lugar de um rizoma é seu meio, é espaço de interseção, troca de fluidos. Na árvore, monolito, fechamento, verticalidade, hierarquia e estabilidade; no rizoma, polifonia, abertura, horizontalidade, equilíbrio e volatilidade. A árvore é filiação, é ser; o rizoma é aliança, é "e".

"Um rizoma não começa nem conclui, ele se encontra sempre no meio, entre as coisas, inter-ser, intermezzo. A árvore é filiação, mas o rizoma é aliança, unicamente aliança. A árvore impõe o verbo 'ser', mas o rizoma tem como tecido a conjunção 'e... e... e...'. Há nesta conjunção força suficiente para sacudir e desenraizar o verbo ser. Para onde vai você? De onde você vem? Aonde quer chegar? São questões inúteis. Fazer tábula rasa, partir ou repartir de zero, buscar um começo ou um fundamente, implicam uma falsa concepção da viagem e do movimento (metódico, pedagógico, iniciático, simbólico). (...) O meio não é uma média; ao contrário, é o lugar onde as coisas adquirem velocidade. Entre as coisas não designa uma correlação localizável que vai de uma para outra reciprocamente, mas uma direção perpendicular, um movimento transversal que as carrega uma e outra, riacho sem início nem fim, que rói suas duas margens e adquire velocidade no meio." (DELEUZE \& GUATTARI, 2011, vol. 1, p. 11)

Essas linhas de hecceidade que se deixam emaranhar em rizomas são devires. A linha do devir não nasce de um ponto, não segue para um ponto, não é formada de pontos, 
nem liga pontos, ela está entre pontos, perpendicular a eles, arrastando-os consigo. Tal qual um rio que corrói suas margens, transformando-as em mais rio, o devir rasga o espaço entre os pontos e os carrega em seu fluxo. $\mathrm{Na}$ área de vizinhança entre os pontos passa o devir, que os une, nivela-os no fluxo, deixando-os indiscerníveis. O devir sempre relaciona mais de um elemento, mas, uma vez relacionados, os elementos viram devir, uma mesma torrente desejante sem hierarquias ou arestas, só vontade. Depois de arrastado por um devir, um elemento não é mais o que era antes. Mas um elemento não engole o outro, o devir é que arrasta a todos, borrando suas fronteiras. Entretanto, não é porque chama tudo para si que o devir produz mesmidade, pois essa torrente é um rizoma volátil de trocas infinitas.

"Uma linha de devir não se define nem por pontos que ela liga nem por pontos que a compõem: ao contrário, ela passa entre os pontos, ela cresce pelo meio, e corre numa direção perpendicular aos pontos que distinguimos primeiro, transversal à relação localizável entre pontos contíguos ou distantes. Um ponto é sempre de origem. Mas uma linha de devir não tem nem começo nem fim, nem saída nem chegada, nem origem nem destino; e falar de ausência de origem, erigir a ausência de origem em origem, é um mau jogo de palavras. Uma linha de devir só tem meio. o meio não é uma média, é um acelerado, é a velocidade, absoluta do movimento. Um devir está sempre no meio, só se pode pegá-lo no meio. Um devir não é nem um, nem dois, nem relação de dois, mas entre-dois, fronteira ou linha de fuga, de queda, perpendicular aos dois. Se o devir é um bloco (bloco-linha), é porque ele constitui uma zona de vizinhança e de indiscernibilidade, uma relação não localizável arrastando os dois pontos distantes ou contíguos, levando um para a vizinhança do outro - e a vizinhançafronteira é tão indiferente à contiguidade quanto a distância. (...) Ela (a linha) passa entre as duas, levando-as para uma vizinhança comum onde desaparece a discernibilidade dos pontos. O sistema-linha (ou bloco) do devier opões-se ao sistema-ponto da memória. O devir é um movimento pelo qual a linha libera-se do ponto e torna os pontos discerníveis: rizoma da arborescência. O devir é uma anti-memória." (DELEUZE \& GUATTARI, 2011, vol. 4, pp. 91, 92).

"Enfim, devir não é uma evolução, ao menos uma evolução por dependência e filiação. O devir nada produz por filiação; toda filiação seria imaginária. O devir é sempre de uma ordem outra que a da filiação. Ele é da ordem da aliança. Se a evolução comporta verdadeiros devires, é no vasto domínio das simbioses que coloca em jogo seres de escalas e reinos inteiramente diferentes, sem qualquer filiação possível. (...) Devir é um rizoma, não é uma árvore classificatória nem genealógica. Devir não é certamente imitar, nem identificar-se; nem regredir progredir; nem corresponder, instaurar relações correspondentes; nem produzir, produzir uma filiação, produzir por filiação. Devir é um verbo tendo toda sua consistência; ele não se reduz, ele não nos conduz a 'parecer', nem 'ser', nem 'equivaler', nem 'produzir'." (DELEUZE \& GUATTARI, 2011, vol. 4, p. 19) 
Os devires, fluindo e compondo rizomas, nunca redundam em ontologia, apenas se entrelaçam formando uma malha de grandezas, de fluxos que não rumam para lugar nenhum, apenas fluem e se interpelam. Essa trama de devires forma um plano de consistência.

"Aqui não há mais absolutamente formas e desenvolvimento de formas; nem sujeitos e formações de sujeitos. Não há nem estrutura nem gênese. Há apenas relações de movimento e repouso, de velocidade e lentidão entre elementos não formados, ao menos relativamente não formados, moléculas e partículas de toda espécie. Há somente hecceidades, afectos, individuações sem sujeito, que constituem agenciamentos coletivos. Nada se desenvolve, mas coisas acontecem com atraso ou adiantadas e formam esse ou aquele agenciamento de acordo com suas composições de velocidade. Nada se subjetiva, mas hecceidades formam-se conforme as composições de potências ou de afectos não subjetivados. A este plano, que só conhece longitudes e latitudes, velocidades e hecceidades, damos o nome de consistência ou de composição (por oposição ao plano de organização e desenvolvimento) (...) O plano de consistência só contém hecceidades segundo linhas que se entrecruzam." DELEUZE \& GUATTARI, 2011, vol. 4, p. 33)

Esses planos de consistência compostos por rizomas de devires é que são os platôs. "Chamamos de 'platô' toda multiplicidade conectável com outras hastes subterrâneas superficiais de maneira a formar e estender um rizoma" DELEUZE \& GUATTARI, 2011, vol. 1, p. 41). Cunhada por Bateson, a ideia de platô está intimamente ligada à noção (do mesmo autor) de cismogênese, ciclos cumulativos de intensidade que, embora carreguem mais energia a cada volta do circuito, nunca explodem, estabilizando-se em seu progresso, fazendo da mudança um sistema equilibrado. O platô é rasgado por linhas de intensidade, aliás, ele nada mais é que a trama dessas linhas, esse rizoma de devires. Fluxos pulsantes de desejo compõem um platô, no entanto, essa vontade latejante não caminha para um ápice, para uma satisfação posterior, para um clímax fora do platô; pelo contrário, o desejo se encerra nessa trama e tudo acontece lá dentro. É como se não houvesse satisfação ou como se ela se realizasse todo tempo. Não há diferença entre caminhar para o prazer e senti-lo, os fluxos de desejo se realizam intransitivamente na própria imanência de seu devir. Édipo criou a separação arbitrária entre processo e telos, entre estímulo e saciedade, entre desejar o prazer e senti-lo, apenas para adiar o fim para um ponto que nunca chega e assim nos prender em seu labirinto. Mas essa separação é espúria, não faz sentido para um inconsciente esquizo: a satisfação está em desejá-la, alcançamos o prazer quando procuramos por ele, porque ele não está fora, mas dentro. "Região contínua de intensidades.", "pedaço de imanência" zona de "estabilização intensiva", o platô é uma 
superfície pulsante composta por desejos que desejam desejar, que não querem transcender a nenhuma figura externa, mas fluir na imanência interna.

"Um platô está sempre no meio, nem início, nem fim. Um rizoma é feito de platôs. Gregory Bateson serve-se da palavra 'platô' para designar algo muito especial: uma região contínua de intensidades, vibrando sobre ela mesma, e que se desenvolve evitando toda orientação sobre um ponto culminante ou em direção a uma finalidade exterior." (DELEUZE \& GUATTARI, 2011, vol. 1, p. 44)

"Um tipo de platô contínuo de intensidade substitui o orgasmo, a guerra ou um platô culminante. É um traço deplorável do espírito ocidental referir as expressões e as ações a fins exteriores ou transcendentes em lugar de considerálos num plano de imanência segundo seu valor em si" DELEUZE \& GUATTARI, 2011, vol. 1 p. 47)

"Bateson denomina platôs as regiões de intensidade contínua, que são construídas de tal maneira que não se deixam interromper por uma terminação exterior, como também não se deixam ir em direção a um ponto culminante: são assim certos processos sexuais ou agressivos na cultura balinesa. Um platô é um pedaço de imanência." (DELEUZE \& GUATTARI, 2011, vol. 3, p. 23)

Outra importante contribuição do projeto de Deleuze e Guattari foi uma revisão dos conceitos de "maioria" e "minoria". Para os autores, maioria e minoria não são quantidades, mas modos. "O modo maior e o modo menor são dois tratamentos da língua: um consistindo em extrair dela constantes; outro, em colocá-la em variação contínua" (DELEUZE \& GUATTARI, 2011, vol. 2, p. 54). Sendo assim, a questão não é numérica, a diferença entre a maioria e a minoria não é que a primeira tem mais elementos que a segunda (pode ter até menos, inclusive), mas que a maioria tende à estabilidade, ao controle e à ordem, enquanto a minoria chama para o movimento, para a mudança. Como as maiorias são fixas e as minorias fluidas, os devires, em sendo processos, só podem ser minoritários, nunca majoritários. Grandes ou pequenas, maiorias são sempre mesuráveis, porque são feitas de quantidades; já minorias são sempre incomensuráveis, pois não são feitas de quantidades, mas de intensidades, velocidades, são devir.

"Porque há tantos devires do homem, mas não um devir homem? É primeiro porque o homem é majoritário por excelência, enquanto que os devires são minoritários, todo devir é um devir-minoritário" (DELEUZE \& GUATTARI, 2011, vol. 4, p. 87)

Essa ordem que vem com a maioria é tanto obedecida quando exercida por ela, na verdade, a ordem é a maioria. É isso o que caracteriza uma maioria, o fato de ela se dar duplamente: como norma e como elemento, como gabarito de classificação e como exemplar 
classificado. Um homem branco heterossexual é sempre duas coisas: um dever-ser e um ser, uma ortodoxia e um tipo, uma regra e um indivíduo. Mesmo que numericamente existissem mais mulheres negras lésbicas, os homens brancos heterossexuais ainda seriam maioria devido a duplicidade de sua existência, quer dizer, por serem a régua e o traço.

\begin{abstract}
"Maioria e minoria não se opõem apenas de uma maneira quantitativa. Maioria implica uma constante, de expressão ou de conteúdo, como um metro padrão em relação ao qual ela é avaliada. (...) É evidente que 'o homem' tem a maioria, mesmo se é menos numeroso que os mosquitos, as crianças, as mulheres, os negros, os camponeses, os homossexuais... etc. É porque ele aparece duas vezes, uma vez na constante, uma vez na variável de onde se extrai a constante. A maioria supõe um estado de poder e de dominação, não o contrário. Supõe o metro padrão e não o contrário." (DELEUZE \& GUATTARI, 2011, vol. 2, p. 52)
\end{abstract}

"O que define então uma minoria não é o número, são as relações interiores ao número. Uma minoria não pode ser numerosa ou mesmo infinita; do mesmo modo uma maioria. $\mathrm{O}$ que as distingue é que a relação interior ao número constitui no caso no caso de uma maioria um conjunto finito ou infinito, mas sempre numerável, enquanto que a minoria se define como conjunto nãonumerável, qualquer que seja o número de seus elementos. O que caracteriza o inumerável não é nem o conjunto nem os elementos; é antes a conexão, o 'e', que se produz entre os elementos, entre os conjuntos e que não pertence a qualquer dos dois, que lhes escapa e constitui uma linha de fuga." (DELEUZE \& GUATTARI, 2011, vol. 5, p. 186)

Essa assimetria que garante a dominação da maioria sobre a minoria pode ser usada por esta para virar o jogo. Por ser dupla, por ser regra e coisa, a maioria é lenta, pesada, e por ser heterodoxa, a minoria é veloz, fluida, ou, como dizem os autores, nômade. Esse traço nomádico pode fazer as minorias subverterem a dominação. Os fluxos nômades de devir minoritário podem desterritorializar a estabilidade da terra majoritária. $\mathrm{O}$ caule se reparte em rizoma e o que está parado é arrastado pela torrente do devir. Não se trata simplesmente de virar o jogo, colocar os debaixo em cima, mas acabar com todas as hierarquias, os pontos, os centros, os édipos, as ontologias... fazendo com que sejam engolidas pelo fluxo desejante do devir. Aí sim teremos apenas agenciamento de desejos, não coisas em articulação, mas articulação de articulações, voláteis, intensas e rápidas. Não mais um universal, único, homogêneo, puro e absoluto, mas uma fluida tecnosfera.

A crítica de Deleuze e Guattari promove um deslocamento na ideia de diferença. Para o projeto Capitalismo e Esquizofrenia, a diferença não é uma lâmina exotizante que a maioria usa para nivelar a minoria, mas um mecanismo da minoria para abalar as estruturas da maioria. Ao longo do texto os autores vão demonstrando como a lógica de Édipo vai 
penetrando em várias esferas da vida, até chegar ao estado. Por conta disso, a obra se transforma em um grande manifesto contra as instituições e o próprio estado-nação. A ênfase no fluxo, na volatilidade e no movimento nômade vem para desterritorializar a estabilidade do território nacional, uma ontologia que, tal qual Édipo, assume a lógica totalitária de um universal único, homogêneo, puro e absoluto. Além disso, a obra faz uma crítica severa ao binômio Eu/Outro, a ideia de que o mundo se organiza em dois polos opostos entre si e lisos em si mesmos. $\mathrm{O}$ ataque a esse modelo não se alicerça apenas na defesa do múltiplo, do desontológico, e do movimento, mas também porque o livro é um verdadeiro manifesto em defesa do meio, do entre. Tudo o que interessa a Deleuze e Guattari está entre coisas extremas, aproximando-as e fazendo com que deixem de ser coisas, liquefazendo-se nesse grande fluxo central. O rizoma cresce a partir do meio, o devir é um fluxo de fuga entre dois pontos, etc. Arestas, polos, bordas, limites, perímetros que definem territórios adiabáticos são fascismos de Édipo engolidos a partir de um fluxo de intensidades que passa entre eles. O rio corrói as margens.

Como se pode ver, uma nova ideia de diferença é gestada, uma diferença menos universal, única, homogênea, pura e absoluta, menos totalitária, menos estável, menos binomial. Essa também é a direção escolhida por Derrida.

Derrida também se opõe à ideia de uma metafísica da presença e à crença em uma origem morfológica, uma matriz concreta, um começo substancial e ahistórico da história, enfim, a uma anterioridade da coisa presente em relação a uma ausência possibilitadora. Assim como para Deleuze e Guattari, para Derrida a realização mais pura desse mito de uma metafísica presente é o sujeito e sua cognição egocentrada. A ideia de um homem universal, único, homogêneo, puro e absoluto dotado de uma inteligência trancafiada em sua cabeça é a celebração da convexidade bruta, de um corpo original e originário concreto de onde a história nasce e parte sempre em linha reta. Mas enquanto aqueles filósofos atacavam a psicanálise freudiana para desconstruir a metafísica subjetivada, Derrida, para derreter a mesma ontologia, centra fogo no estruturalismo, tanto na linguística de Saussure quanto na antropologia de Lévi-Strauss. Para desconstruir essa substância presente do sujeito, o filósofo defende a anterioridade da ideia côncava e ausente de rastro. Mas não se tem aqui uma anterioridade simples, pois como o tempo de Derrida não é nem linear nem sucessivo, o rastro é uma origem que chega depois, que suplementa a origem, mas por isso 
mesmo a possibilita e passa a sê-la, pois não é um elemento a mais, mas um elemento que insere a fenda onde os elementos irão se inscrever, que faz do começo um anti-começo e da presença uma ausência. Olhemos com cuidado seu quadro analítico.

Para Derrida, como se falou, o pensamento ocidental sempre se prendeu a ideia de coisa, e essa coisa sempre foi o homem racional. Portanto, a história das ideias está marcada por uma metafísica antropocêntrica e logocêntrica. O pensamento ocidental se ancorou na noção de um corpo puro e presente que acabou construindo a imagem de sujeito que temos hoje: um artefato autocontido, convexo e pensante. "O logocentrismo é uma metafísica etnocêntrica, num sentido original e não 'relativista'. Está ligado à história do Ocidente" (DERRIDA, 2006, p. 98). O estruturalismo, na visão de Derrida, acreditou que um elemento específico atestaria a assepsia, o hermetismo e a presença dessa metafísica humana reflexiva: a fala.

Para o método estrutural, a fala é o espelho da alma e da consciência humanas. Não há mediação ou exterioridade na fala; a relação entre existir, pensar e falar é simultânea: a fala não é secundária em relação ao pensamento, não é outra coisa derivada do saber, mas sim a própria reflexão em sua forma acústica, a inteligência humana (e a própria humanidade) saindo de dentro de nós pela boca. "É no sistema da língua associado à escritura fonética - alfabética que se produziu a metafísica logocêntrica determinando o sentido do ser como presença." (DERRIDA, 2006, p. 53) A fala é a forma audível do logos, o logos é a forma reflexiva do homem, e o homem é a forma antropocêntrica da coisa. Fala, logos, homem e coisa são tidos como naturais, presentes, originais e originários, e cada uma dessas instâncias naturaliza as demais.

"A escritura natural está imediatamente unida à voz e ao sopro. Sua natureza não é gramatológica, mas pneumatológica. É hierática, bem próxima da santa voz interior da profissão de fé, da voz que se ouve ao se entrar em si: presença plena e veraz da fala divina ao nosso sentimento interior." (DERRIDA, 2006, p. 21)

A metafísica presente do homem reflexivo é uma forma primeira, matricial e natural. Por atestar essa ontologia antropológica, a voz também passa a ser vista como uma manifestação espontânea, imediata e imaculada. A ênfase estruturalista na naturalidade da fala acaba atirando a escrita no reino do arbítrio e do artifício. Se a fala é o som da alma 
humana interior universal, única, homogênea, pura e absoluta, a escrita passa a ser vista como uma exterioridade violenta que macula a virgindade da voz.

"A escritura como intrusão da técnica artificiosa, efratura de uma espécie totalmente original, violência arquetípica: irrupção do fora no dentro, encetando a interioridade da alma" (DERRIDA, 2006, p. 42)

"Ora, o logos apenas pode ser infinito e presente a si, apenas pode produzir-se como autoafeção, através da voz: ordem de significante pelo qual o sujeito sai de si em si, não toma fora de si o significante que ele emite e que o afeta ao mesmo tempo. Tal é pelo menos a experiência - ou a consciência - da voz: do ouvir-se-falar. Ela vive-se e diz-se como exclusão da escritura, a saber, do apelo a um significante 'exterior', 'sensível', 'especial', interrompendo a presença de si" (DERRIDA, 2006, p. 130)

Entre ser, pensar e falar não há qualquer filtro, falar não é uma ferramenta externa ao Eu por ele instrumentalizada, uma técnica do logos, mas o próprio Eu fluindo num sopro, o próprio logos ressoando no mundo. Já a escrita não: ao contrário do que se dá com o falar, há um hiato entre a presença da reflexão humana e o grafismo. O homem trai sua humanidade oral para virar escrita. Fala é natureza e liberdade, escrita é afetação estilística, violência, história. "A escritura vela a visão da língua: ela não é uma vestimenta e sim uma travestimenta. (...) Não seriamos, pois, cegos ao visível, mas sim, cegados pelo visível, ofuscados pela escritura" (DERRIDA, 2006, p. 46). É o enviesamento da voz, a humanidade se distanciando de sua condição original, traindo-se. "A época do logos, portanto, rebaixa a escritura, pensada como mediação da mediação e queda na exterioridade do sentido." (DERRIDA, 2006, p. 77). Para os estruturalistas, a passagem da fala para a escrita representa uma decadência: de homem a grafia, de natureza a contingência, de liberdade a violência, de imediatismo a mediação. Como diz Saussure, há uma "tirania da letra" (2006, p. 31) sobre a espontaneidade da fala. Voz é vida, letra é morte. Por isso que, para os estruturalistas, para que se entenda o humano e a estrutura de seu logos é preciso estudar a fonética, pois, como a fala é a próprio presença ontológica da razão humana, a ciência da voz é a ciência do homem. Com a escrita, o sentindo, que sempre esteve colado na presença metafísica do homem reflexivo, se distancia dele para chegar depois. Como, para o estruturalismo, "a voz é o que está mais próximo do significado" (DERRIDA, 2006, p. 89), quando se cala e escreve, o homem deixa de ser um corpo irradiador de sentido e joga a significação para um exterior gráfico que nunca aparece junto com ele. 
Para os estruturalistas, a escrita é uma cortina de fumaça que impede que o homem acesse a metafísica presente do seu ser pensante, sendo assim, de acordo com o estruturalismo, faz-se necessário virar as costas para a intoxicação exterior da escrita e retornar para a interioridade sagrada da fala.

"Tudo ocorre, então, como se Saussure quisesse ao mesmo tempo demonstrar a alteração da fala pela escritura, denunciar o mal que esta faz àquela, e sublinhar a independência inalterável e natural da língua. 'A língua independe da escritura' (p. 34), tal é a verdade da natureza. E, no entanto, a natureza é afetada - de fora - por uma perturbação que a modifica no seu dentro, que a desnatura e obriga-a a afastar-se de si mesma. A natureza desnaturando-se a si mesma, afastando-se de si mesma, acolhendo naturalmente seu fora no seu dentro, é a catástrofe, evento natural que perturba a natureza, ou a monstruosidade, afastamento natural na natureza." (DERRIDA, 2006, p. 50)

Para Derrida, o mesmo mal de Saussure afeta Lévi-Strauss, antropólogo que cava um fosso entre língua e escrita, fazendo da primeira um atestado da presença da metafísica humana e da segunda um distanciamento em relação a essa natureza, uma desumanidade, portanto. Como o próprio afirma na sua famosa introdução à obra de Mauss, "a linguagem não pôde nascer senão instantaneamente" (2007, p. 27). Por ser mediada e levar o sentido para fora do sujeito, a escrita não é uma linguagem, mas uma anti-humanidade.

A tese de Derrida é de que essas metafísica presente da reflexividade humana atestada pela fala não tem nada de natural e eterna; muito pelo contrário, assim como Édipo para Deleuze e Guattari, essa ontologia não passa de um mito arbitrariamente forjado cujo rastro de feitura foi apagado no próprio desenrolar de sua produção, sendo portanto tido como espontâneo e obrigatório. Ao contrário do que defendem os estruturalistas, a convexidade do logocentrismo humano não é uma natureza redentora, mas um artifício que aprisiona; sendo assim, para nos emanciparmos dela, é preciso desconstruí-la. Se essa metafísica do homem pensante que se quer destruir é afirmada pela fala e corroída pela escrita, então é a letra que temos que abraçar para que encerremos a ditadura da metafísica da presença e possamos ascender a uma verdadeira liberdade.

"Nossa justificativa seria a seguinte: este índice e alguns outros (de modo geral, o tratamento do conceito de escritura) já nos dão o meio seguro para encetar a desconstrução da totalidade maior - o conceito de epistemé e a metafísica logocêntrica - em que se produziram sem jamais colocar a questão radical da escritura, todos os métodos ocidentais de análise, de explicação, de leitura ou de interpretação" (DERRIDA, 2006, p. 56) 
Para fazer com que a escrita roa a metafísica presente do sujeito cognitivo sublinhada pela fala é preciso, primeiramente, tirar a escrita desse estado de pura exterioridade que os estruturalistas lhe deram. A escrita não está só fora, mas também dentro, e é justamente lá de dentro que será realizado seu trabalho de erosão. A escrita vai "deixar no texto um sulco" (DERRIDA, 2006, p. 75) e é por essa fenda, rasgada na superfície lisa da voz, que a ontologia do homem reflexivo irá escorrer. Assim como o platô anti-edipiano é um "pedaço de imanência" pulsante que inscreve o clímax externo em uma duração interna, a escritura de Derrida também chama o fora para dentro e desontologiza a ontologia por implosão.

"Os movimentos de desconstrução não solicitam as estruturas de fora. Só são possíveis e eficazes, só ajustam seus golpes se habitam estas estruturas. Se as habitam de uma certa maneira, pois sempre se habita, e principalmente quando nem se suspeita disso. Operando necessariamente do interior, emprestando da estrutura antiga todos os recursos estratégicos e econômicos da subversão, emprestando-os estruturalmente, isto é, sem poder isolar seus elementos e seus átomos, o empreendimento de desconstrução é sempre, de um certo modo, arrebatado pelo seu próprio trabalho." (DERRIDA, 2006, p. 30)

"O fora mantém com o dentro uma relação que, como sempre, não é nada menos que uma simples exterioridade. O sentido do fora sempre foi no dentro, prisioneiro fora do fora, e reciprocamente." (DERRIDA, 2006, p. 43)

Desse jeito, a escrita deixa de ser exterior e secundária em relação à metafísica presente do sujeito pensante (separação criada pelo estruturalismo) e adentra essa ontologia antropocêntrica, abrindo no meio de seu tecido um corte que terminará por engolir toda a substância presente desse corpo onde ela mesma se inscreve. Não há para onde o Eu fugir, pois as coisas não se dão como se a nave fosse sugada por um buraco negro no universo, mas como se um buraco negro começasse a se formar no interior da nave e a consumisse de lá de dentro. E o que sobra depois que a escrita engolir toda a presença metafísica do ser cognitivo? Sobra o rastro da escritura. Eis a ontologia desontológica que Derrida erige (ou deveria dizer "cava"?), a metafísica não metafísica, a presença ausente, o ser que é nada: a fenda côncava da escrita. Quando a escrita termina seu trabalho interno de corrosão, onde antes havia a metafísica presente do homem reflexivo agora só existe o oco que um dia ele ocupou. $\mathrm{Na}$ origem de tudo havia a coisa-ser, mas essa originalidade só era mantida às custas da expulsão da escrita; quando inserida na anterioridade da coisa-ser, a escrita, antes secundária e externa, a consome, fazendo com que a origem deixe de ser uma metafísica 
presente humana e reflexiva e se descubra um rastro ausente gramático e vazio. Na origem não há mais a coisa-ser, mas o nada-não ser.

Inserir a exterioridade da escrita na interioridade do ser de maneira que um rastro se abra nele nada mais é que produzir a diferença onde antes havia a mesmidade. $\mathrm{O}$ liso fica estriado, a continuidade se rasga, a coisa dá lugar ao próprio lugar, à presença ausente do nada, ao rastro. O texto de Derrida é, portanto, uma defesa da diferença e da desconstrução que ela opera.

"O rastro não é somente a desaparição da origem, ele quer dizer aqui (...) que a origem não desapareceu sequer, que ela jamais foi reconstituída a não ser por uma não-origem, o rastro, que se torna, assim, a origem da origem. Desde então, para arrancar o conceito de rastro ao esquema clássico que o faria derivar de uma presença ou de um não-rastro originário e que dele faria uma marca empírica, é mais do que necessário falar de rastro originário ou de arqui-rastro. E, no entanto, sabemos que este conceito destrói seu nome e que, se tudo começa pelo rastro, acima de tudo não há rastro originário." (DERRIDA, 2006, pp. 75, 76)

"A diferença inaudita entre o aparecendo e o aparecer (entre o 'mundo' e o 'vivido') é a condição de todas as outras diferenças, de todos os outros rastros, e ela já é um rastro. Assim, este último conceito é absolutamente e de direito 'anterior' a toda problemática fisiológica sobre a natureza do engrama ou metafísica sobre o sentido da presença de que o rastro se dá, desta forma, a decifrar. $\mathrm{O}$ rastro é verdadeiramente a origem absoluta do sentido em geral. $\mathrm{O}$ que vem afirmar, mais uma vez, que não há origem absoluta do sentido em geral. O rastro é a diferência que abre o aparecer e a significação." (DERRIDA, 2006, p. 80)

Percebe-se aqui a delicadeza do modelo de Derrida: o que era externo se internaliza para acabar com as ideias de dentro e fora, o que era derivado retorna ao começo para mostrar como não existe a separação entre matriz e série. A fenda ausente gramatológica do nada tardiamente se acopla à originária metafísica presente cognitiva do ser e, depois de consumi-la, toma o seu lugar, roubando a anterioridade do corpo ao qual ela mesma se associa. A escrita pousa depois na metafísica da presença e a substitui, mostrando que quem veio antes não foi a metafísica, o ser, mas a escrita, o nada.

Mas como algo consegue substituir aquilo que deveria apenas sublinhar? Como um anexo pode inaugurar o corpo ao qual posteriormente se anexou? Como o nada pode se considerar originário se nada se originou? A resposta para essas perguntas não será encontrada em uma filosofia logocêntrica amarrada a uma metafísica da presença subjetivada e interessada pelo problema do sentido, mas apenas por uma teoria que passa 
ao largo dessa metafísica para chegar ao rastro diferenciante da escritura e que, ao invés de tomar o sentido como uma morfologia universal e eterna, enxerga-o primeiro como uma imputação violenta e histórica para em seguida tentar compreender justamente como essa barbárie se naturalizou. "Nenhum conceito da metafísica pode descrever o rastro" (DERRIDA, 2006, p. 77). A filosofia faz sentido, a teoria que responderá essas perguntas desfaz sentido, chega ao oco onde o sentido se situa e mostra que sua presença ali não é espontânea e obrigatória, mas arbitrária e contingencial, evidenciando assim que na origem não havia sentido, mas o oco, que é uma não-origem, uma presença ausente, um volume negativo. A primeira coisa que existiu nem foi primeira, nem coisa, nem existiu, pois foi agregada, côncava e imaterial, foi a possibilidade da existência das coisas: foi a diferença. Derrida repisa essa tensão ao longo de todo o texto: "A diferença é, portanto, a formação da forma." (2006, p. 77) "A significação, assim, não se forma senão no oco da diferença: da descontinuidade e da discrição, do rapto e da reserva do que não aparece." (2006, p. 85) "Origem obliterada da ausência e da presença. (...) a diferença, em seu movimento ativo, é que não só precede a metafísica mas também transborda o pensamento do ser" (2006, p. 176). Um pensamento metafísico, antropocêntrico e logocêntrico jamais entenderá o problema da diferença. A denúncia dessa violência ancestral não será feita por um resgate histórico, pois a própria história já está contaminada pela presença metafísica desse sentido egocentrado $^{23}$, mas pela teoria que inserir o exterior no interior, o nada no ser, a ausência na presença, a diferença no logos, a escrita na fala. Só essa teoria poderá responder aquelas interrogações. Essa teoria não é a filosofia, mas a gramatologia: pensamento que não se baseia na presença metafísica da reflexão humana, mas no rastro aberto da escritura, que não conclui fechando, mas cavando rupturas na continuidade, abrindo feridas no mesmo, enfim, instaurando a diferença.

Eis a revisão gramatológica: no princípio havia a coisa: a metafísica presente do sujeito logocêntrico. Para que a unidade, a homogeneidade, a pureza e o absolutismo desse sólido universal fossem asseguradas era preciso que a escrita diferenciante se mantivesse longe dele. Porém uma ausência secundária se anexa a essa presença primária e acaba

\footnotetext{
23 "A ciência da escritura deveria, portanto, ir buscar seu objeto na raiz da cientificidade. A história da escritura deveria voltar-se para a origem da historicidade. Ciência da possibilidade da ciência? Ciência da ciência que não mais teria a forma da lógica mas sim da gramática? História da possibilidade da história que não mais seria uma arqueologia, uma filosofia da história ou uma história da filosofia?" (DERRIDA, 2006, p.201)
} 
tomando o seu lugar, de maneira que o que era para complementar passa a substituir, fazendo com que derivado vire inicial e o nada ausente ocupe a posição do ser presente. Olhando agora pelo prisma da gramatologia e não da filosofia, retomemos aquelas perguntas: que conceito é esse que assume o papel do corpo ao qual deveria estar só se agregando? Que se proclama matricial mesmo sendo tardio? Que é tido como uma origem ainda que seja o nada? A resposta de Derrida é: o conceito de suplemento originário.

"O mortal redobramento - desdobramento - o representativo constituía o presente vivo, sem se acrescentar simplesmente; ou antes, o constituía, paradoxalmente, acrescentando-se a ele. Trata-se, pois, de um suplemento originário, se se pode arriscar esta expressão absurda, inteiramente inaceitável numa lógica clássica. Ou antes, suplemento de origem: que supre a origem desfalecente e que, contudo, não é derivado; este suplemento é, como se diz de uma peça, de origem." (DERRIDA, 2006, p. 383)

O suplemento originário é o apêndice posterior e vazio que se acopla na origem primeira e metafísica e assim passa a sê-la, mostrando que, na verdade, não existe origem primeira metafísica. Se a derivação futura e côncava substitui o começo matricial convexo ao se agregar a ele, então não há começo matricial convexo. Como falei anteriormente: a primeira coisa que existiu não foi primeira nem, nem coisa nem existiu. O pensamento ocidental se acostumou com a ideia de que primeiro houve o sentido, e ele era uma coisa humana e reflexiva, e depois foram surgindo outros sentidos, outras coisas derivadas dessa. Sendo assim, para essa filosofia, as coisas são anteriores à diferença entre as coisas: é preciso haver partes para que elas se relacionem, objetos para que haja espaço entre objetos. O que Derrida faz é subverter essa lógica, jogando a diferença - que o ocidente sempre conceituou como externa à coisa, tardia, complementar e inócua - para a origem, transformando a origem em uma não-origem já que o começo é sempre uma inscrição do nada secundário no ser primário. $\mathrm{O}$ autor diz que "a alteração pela escritura é uma exterioridade originária. Ela é a origem da linguagem." (2006, p. 385), ou seja, inicia mesmo estando fora, inaugura mesmo sendo alteração, é mesmo não sendo.

"Enquanto substituto, não se acrescenta simplesmente à positividade de uma presença, não produz nenhum relevo, seu lugar é assinalado na estrutura pela marca de um vazio. Em alguma parte, alguma coisa não pode-se preencher de si mesma, não pode efetivar-se a não ser deixando-se colmar por signo e procuração. O signo é sempre o suplemento da própria coisa. (...) Acrescentando-se ou substituindo-se, o suplemento é exterior, fora da positividade à qual se ajusta, estranho ao que, para ser por ele substituído, deve ser distinto dele. Diferentemente do complemento, afirmam os dicionários, o suplemento é uma 'adição exterior'." (DERRIDA, 2006, p. 388) 
O suplemento originário gramatológico, inimaginável para uma filosofia metafísica, possibilita que uma ausência secundária se torne uma presença primeira, roubando sua anterioridade ao substituí-la em sua condição de origem no momento em que tardiamente a ela se agrega. Essa ideia de que complementar é ser o corpo que se complementa, de que o traço que sublinha a frase se torna ela, nada mais é que a noção de que duplicando-se um discurso se inaugura, que o texto nasce quando se dobra sobre si mesmo. Mas como a origem pode estar na repetição? Como algo se dá pela primeira vez quando se dá pela segunda vez? Novamente aqui não se pode contar com sucessão linear, mas com uma simultaneidade circular. Não por acaso, a cruzada de Derrida contra uma metafísica da presença centrada no homem racional foi também uma crítica à linearidade. Para o autor, há um "esquema linear de desenrolamento da presença" (DERRIDA, 2006, p. 106), ou seja, uma horizontalidade sucessiva de construção metafísica que para ele representava uma "redução da história". Como o próprio afirma: "A 'linha' representa apenas um modelo particular, qualquer que seja seu privilégio. Este modelo veio a ser modelo e conservar-se, enquanto modelo, inacessível." (2006, p. 107) Contra a tirania da linearidade sucessiva, parcialidade que constrói metafísicas presentes logocêntricas e humanas, Derrida evoca a liberdade da circularidade simultânea, estratégia que corrói sentidos e abre rastros diferenciantes de escrita.

A ideia de que um discurso nasce ao se duplicar é a completa obliteração da diferença entre matriz originária e série derivada, entre início e caminho; uma revolução que só pode acontecer se a linearidade sucessiva for trocada por uma circularidade simultânea. Para explicar essa mudança, Derrida recorre à arte, servindo-se, ainda que não de maneira direita, da teoria de Walter Benjamin (2012).

Nas primeiras páginas de seu ensaio canônico, Benjamin afirma: “A obra de arte sempre foi, por princípio, reprodutível. O que os homens fizeram sempre pôde ser imitado por homens" (2012, p. 13). Essa frase que a princípio soa inocente é, na verdade, muito reveladora, pois afirmar que o "princípio" da arte é "reprodutível” sugere um nó lógico que, paradoxal à primeira vista, se mostra de fato bastante inspirador. Segundo Benjamin, a origem da arte é sua multiplicação, ou seja, o seu início já é a duplicidade. Quando ainda é una, a arte já é múltipla. Sendo assim, seria incorreto afirmar que primeiro houve a matriz imaculada e original e, a partir dela, teria surgido a série de reproduções secundárias; pelo 
contrário: a origem já é reprodução e, inversamente, toda repetição traz em si a marca do nascimento. Surgir já é duplicar-se e se deixar ver em múltiplos também é atualizar infinitamente o nascimento. Toda origem é reprodução e todo espelhamento é uma estreia. Em Benjamin, mimesis e poiesis se confundem já que produção e reprodução aparecem sempre juntas. Nenhuma instância é só matriz ou só réplica, pois todas são ambas. Surgir e deixar-se ver se imbricam continuamente: a essência é uma representação e a representação é uma essência. Como disse Foucault sobre a literatura:

"É importante se dar conta de que a literatura, a obra literária, não vem de uma espécie de brancura anterior à linguagem, mas justamente da repetição contínua da biblioteca, da impureza letal da palavra." (2005, p. 146)

Como o "princípio" da arte já é a "reprodução", no monismo da origem já se inscrevia a polissemia da série. Seria incorreto pensar que a santidade da aura antecedeu a laicização da cópia, pois origem e multiplicação mantêm uma relação ambivalente: as reproduções maculam a aura, desgastam seu brilho ao esgarçarem o tecido do sudário, mas ao mesmo tempo, é nessas cópias que sobrevive essa autoridade ancestral. Quanto mais a arte se deixa reproduzir, mais seu brilho se apaga, mas mais distante ele chega: sempre mais fraco porque sempre mais longe. A relação da aura com suas versões é como a de uma voz e seus ecos: embora vá se apagando na medida em que se propaga, é sempre mais além que ele está chegando. Embora distorça a mensagem original, é no eco que a voz subsiste. Aqui se encontra a circularidade do modelo de Benjamin: sem o grito primordial não haveria eco, mas sem o eco este também estaria morto. Para quem ouve aquela mensagem em uma distância enorme já não faz sentido a distinção entre eco e grito; a reciprocidade que mantêm é tão afinada que, nesse estado de mutualismo, não se pode tecer uma causalidade linear entre os dois mas sim uma simultaneidade recursiva: voz e eco se constroem um ao outro em simetria. Assim se dão as coisas na arte de Benjamin: o anteparo da aura é as reproduções e essas se multiplicam porque carregam um pouco da autoridade originária. A aura não pode ser vista simplesmente olhando-se para o céu, deve haver uma reprodução ali que atualize o mito originário. Sem a reprodução a aura não é vista, e sem a aura a reprodução não tem brilho. É o próprio Benjamin quem afirma que a categoria de pinturas de "virgens originais da idade média" surgiu no século XIX: as obras de fato foram pintadas na idade média, mas o ato de demarcá-las como matrizes artísticas imaculadas surgiu apenas séculos depois como uma necessidade advinda das incessantes 
reproduções dessas virgens. Antes que se delimitasse a fronteira aural originária houve um pesado trabalho de reprodutibilidade técnica, mas só existe reprodução técnica de uma origem imaculada. A literatura se aproveitou imensamente desse problema da réplica inaugural. Nos seus estudos sobre Kafka, Borges afirma que, ao usá-los e os sistematizar em seus textos, todo autor inventa suas influências, pois, se não estivessem elas ali secundadas naquela obra, essas influências não teriam sua anterioridade salientada (2007). Da mesma forma, Todorov escreve: 'Balzac 'cria' mais suas personagens do que as descobre, mas uma vez criadas, elas se introduzem na sociedade contemporânea e, a partir daí, não cessamos de cruzar com elas pelas ruas." (2009, p. 65.) Como se pode ver, a circularidade do modelo impede que teçamos anterioridades cronológicas na relação aura/reprodução; como foi dito, aqui não tem linearidade sucessiva, mas circularidade simultânea. Escudado nisso, Derrida afirma

"Nascendo a arte da imitação, só pertence à obra propriamente dita o que pode ser retido na estampa, na impressão reprodutora dos traços. Se o belo nada perde em ser reproduzido, se é reconhecido em seu signo, nesse signo do signo que é a cópia, é porque na 'primeira vez' de sua produção ele era já essência reprodutiva. A estampa, que copia os modelos da arte, não deixa de ser o modelo da arte. (...) Se a origem da arte é a possibilidade da estampa, a morte da arte e a arte como morte são prescritas desde o nascimento da obra. O princípio de vida, uma vez mais, confunde-se com o princípio de morte." (DERRIDA, 2006, p. 254)

A reprodução perfeita da coisa em si desaparece quando cumpre sua missão. Ao representar perfeitamente o original, a reprodução se apaga nela mesma, deixando o original reinar absoluto. Isso porque a coisa em si não carece de imagem ou de representação para se deixar ver, ela é nela mesma: a representação evoca a origem ao mesmo tempo em que some, aparece desaparecendo; por isso, a vitória de toda representação que se quer perfeita é a morte. A cópia é começo e fim da arte: instaura-a ao mesmo tempo em que a desgasta. Mas se for assim, então se deve admitir que, além de originária, a origem também é posterior a suas reproduções: o original atualizado no presente pelas reproduções apagadas no passado agora se refere a elas, atualizando-as; o contrário do que se dava antes. As coisas trocam de papel e não cessam de se alternar em uma espiral diabólica: origem e reprodução constantemente cambiando de posição. Ser uma já implica transformar-se na outra e voltar a ser aquela, infinitamente.

"A representação perfeita deveria re-presentar perfeitamente. Ela restaura a presença e apaga-se como representação absoluta. Este movimento é necessário. O telos da imagem é a sua própria imperceptibilidade. Ao cessar, imagem 
perfeita, de ser outra que a coisa, ela respeita e restitui a sua presença originária. Ciclo indefinido: a fonte - representada - da representação, a origem da imagem pode por sua vez representar seus representantes, substituir seus substitutos, suprir seus suplementos. Dobrada, retornando a si mesma, representando-se a si mesma, soberana, a presença não é então - e ainda - mais que um suplemento do suplemento." (DERRIDA, 2006, pp. 363, 364).

A virgindade imaculada do original é uma narrativa instaurada pela sucessão incansável das reproduções que ela instaura. Assim como as hélices girando rapidamente dão a impressão de estarmos vendo um círculo parado, é a série contínua das reprodutibilidades técnicas que rascunha a silhueta estática da origem, e é essa matriz que informa o caminho traçado pela série. Não existe arte pura, mas purificada, e ela se purifica justamente se deixando sujar pelas reproduções. O que deveria suplementar o original passa a constituílo. Por isso, repisando o que já se falou, o discurso se dá pela primeira vez quando se duplica: repetindo-se, a origem se inaugura. A fala original foi uma citação, ou, como diz Derrida, "a primeira linguagem teve de ser figurada" (2006, p. 291). No princípio havia o verbo, e ele já era uma metáfora.

"Uma linguagem justa e exata deveria ser absolutamente unívoca e própria: não metafórica. A língua escreve-se, pro-regride à medida que domina ou apaga em si a figura. Isto é, sua origem. Pois a linguagem é originalmente metafórica. (...) A metáfora é o traço que reporta a língua à sua origem. A escritura seria, então, a obliteração desse traço." (DERRIDA, 2006, p. 330)

"Só se pode superar essa alternativa restituindo-se um não dito: a representação pura, sem deslocamento metafórico, a pintura puramente reflexionante é a primeira figura. Nela, a coisa mais fielmente representada já não está presente propriamente. O projeto de repetir a coisa corresponde já a uma paixão social e comporta, pois, uma metaforicidade, uma translação elementar. Transformata-se a coisa no seu duplo (isto é, já numa idealidade) para um outro, e a representação perfeita é desde sempre outra, em relação ao que ela duplica e representa. Começa aí a alegoria. É por isso que não há escritura verdadeira. A duplicação da coisa na pintura, e já no clarão do fenômeno onde ela está presente, guardar e resguardar, mantida por pouco que seja em olhar e sob o olhar, abre o aparecer como ausência da coisa a seu próprio e à sua verdade. Nunca há pintura da coisa mesma, e antes de mais anda porque não há coisa mesma. Supondo-se que tenha um estágio primitivo e pictórico, a escritura acusa esta ausência, este mal ou este recurso que desde sempre trabalha a verdade do fenômeno: a produz e certamente a supre. A possibilidade original da imagem é o suplemento: que se acrescenta sem nada acrescentar para preencher um vazio que no pleno pede para se deixar substitui. A escritura como pintura é, pois, simultaneamente o mal e o remédio." (DERRIDA, 2006, pp. 356, 357).

Essa simultaneidade circular do suplemento originário, que inscreve o começo do discurso em sua repetição, já estava presente no ritual do Naven, comentado na introdução 
desse texto. Como já se disse, o Naven não é uma miniatura da sociedade, mas um metacomentário que a instaura. Produzindo os Iatmul na medida em que os reproduz, o ritual cria aquilo que espelha.

No entanto, esse mesmo arranjo de circularidade simultânea e a sua ideia de que a sistematização de um discurso é também sua escrita foi aqui evocado para descrever o modus operandi do período exótico-colonial do mercado da diferença. É essa circularidade simultânea que está presente no efeito de fatalismo histórico do habitus, que gera as práticas que classifica, ou no texto do Orientalismo, discurso que fez com que a imagem caricaturada do Oriente ganhasse mais realidade que o Oriente propriamente dito, sendo portando uma representação secundária que roubou a anterioridade da coisa representada. Sendo assim, como pode uma estratégia tão arbitrária servir a projetos de emancipação como Capitalismo e Esquizofrenia e Gramatologia? A resposta para essa pergunta é uma faceta muito interessante da revolução que esses autores intentavam promover: como se disse, primeiramente a ideia de diferença viveu uma fase exótica-colonial, ocupada das noções universais de unidade, homogeneidade, pureza e absolutismo. A bandeira defendida por Deleuze, Guattari e Derrida não é o abandono do conceito de diferença, muito pelo contrário, eles se abraçam com o termo e o defendem, mas justamente para se apropriar dessa ideia, alterando seu sentido e fazendo com que sirva a um novo fim. Se no períodoexótico colonial, a diferença era controlada por dominadores que faziam com que o arranjo circular simultâneo de duplicação criativa ensejasse discursos totalitários, agora, há um esforço para que a diferença passe para a mão dos dominados, tornando-se uma estratégia de libertação.

Se Deleuze e Guattari defendem o rizoma em detrimento do modelo arbóreo, preso a uma linearidade gerativista, se dizem que "um rizoma não pode ser justificado por nenhum modelo estrutural ou gerativo. Ele é estranho a qualquer ideia de eixo genético ou de estrutura profunda" (2011, vol. 1, p. 29), se afirmam "não procure a raiz, siga o canal" (2011, vol. 1, p. 41) e defendem que "todo discurso é indireto" (2011, vol. 2, p. 13, ) e que "é sempre o imitador quem cria seu modelo e o atrai." (2011, vol. 1 p. 31), se Derrida defende a natureza originária da suplência, enfim, se criticam uma linearidade sucessiva e defendem uma circularidade simultânea, esses autores só o fazem porque sabem que estão transferindo para um novo dono o princípio de que um discurso nasce quando se duplica. Quem agora irá ensejar discursos na própria duração deles são as minorias deleuzianas 
(não numéricas, mas processuais), os devires tramados em rizomas, os anti-édipos, os suplementos originários de Derrida, os rastros ausentes de escritura. Enfim, a missão dessas teorias não é acabar com o conceito de diferença, mas deslocá-la, fazer com que deslize, ressignifique-se, busque a liberdade e não a conquista, e aponte para um novo caminho.

Quando defendem o fluxo contra a estática e conferem à polissemia uma importância antes dada a uma metafísica monolítica, quando trocam os polos pelos meios e substituem o debate da origem pela agenda do movimento, o que os autores objetivam é revolucionar a ideia de diferença, tentando fazer com que o conceito abandone as ideias universais de unidade, homogeneidade, pureza e absolutismo, a mentalidade binomial e a violência e busque outra direção. Enfim, a missão de Deleuze, Guattari e Derrida é fazer com que a diferença deixe a fase exótico-colonial e se abra para um novo período, mais dinâmico, mais fluido e mais livre.

Mas olhemos o impacto desse deslocamento naquela nação que saiu do outro lado do filtro da igualdade como a maior potência mundial do seu tempo: os Estados Unidos. Se o período que imediatamente se seguiu à Segunda Guerra Mundial foi de abundância e alegria para os Estados Unidos, a passagem dos anos 1960 para os 1970 foi de muita descrença e ilegitimidade institucional. Como se sabe, desde que chegaram lá, os Estados Unidos nunca abandonaram sua posição de líderes mundiais, entretanto, de 1945 até hoje, houve períodos em que o país se sentiu ameaçado e temeu perder sua posição de soberania. A virada de 1960 para 1970 foi certamente um desses períodos.

Uma série de eventos ocorridos nessa época ajudou a corroer a imagem de vitoriosos que os Estados Unidos vinham construindo para si desde o fim da Primeira Guerra Mundial. Alguns desses eventos não atestavam diretamente um fracasso americano nem ameaçavam sua soberania internacional, mas certamente influenciavam na vida doméstica do país e na crença dos cidadãos no caminho que a nação tinha escolhida para si.

Já em 1961, no início do governo do democrata John Kennedy, houve o fracasso da invasão da Baia dos Porcos. No episódio, um grupo de exilados cubanos amparado pelo governo dos Estados Unidos foi derrotado pelo exército de Cuba quando tentava derrubar o 
regime de Fidel Castro. Quatro meses depois foi construído o Muro de Berlim, outra grande ameaça ao projeto de expansão capitalista. No ano seguinte, a União Soviética instalou em Cuba mísseis nucleares apontados para os Estados Unidos, dando início a um dos momentos mais tensos da Guerra Fria: a Crise dos Mísseis. O tão temido conflito nuclear parecia estar mais próximo do que nunca. Embora a tensão tenha sido contornada e os mísseis não tenham sido lançados, o episódio mostrou a fragilidade daquela que se acreditava a maior potência do mundo: em um ano os Estados Unidos fracassaram em depor Fidel Castro e no ano seguinte sua ilha está com mísseis nucleares apontados para o territórios americano. Em 1963, uma tragédia: o presidente Kennedy é assassinado a tiros no Texas na frente das câmeras. As razões que motivaram o crime são bastante nebulosas e até hoje se multiplacam teorias conspiratórias sobre as causas do atentado, mas o fato é que Lee Harvey Oswald, o assassino, era americano. É claro que estamos falando aqui de um louco, mas quando viram seu presidente ser morto por um americano dentro do território nacional, os Estados Unidos se confrontaram com a descrença e a ilegitimidade institucional que se espalhava pelo país. Quando assumiu a presidência, Lyndon Johnson, vice de Kennedy, oficializou aquilo que seu falecido antecessor já havia iniciado: a entrada dos Estados Unidos na Guerra do Vietnam. O Vietnam foi um labirinto que drenou as forças americanas até a última gota. Não cabe aqui entrar nos detalhes do episódio, mas, como o futuro se encarregaria de provar, o conflito foi um dos maiores fracassos bélicos dos Estados Unidos, tendo deixado um rastro de dívidas e cadáveres. Depois de Johnson, Richard Nixon assumiu a presidência em 1969. Cacique do partido republicano, vicepresidente durante os dois mandatos de Eisenhower e quase tendo derrotado Kennedy nas eleições de 1960, Nixon parecia reunir todas as características para recuperar a fé dos americanos em sua nação. As coisas começaram bem, mas o resultado não poderia ter sido mais frustrante. Durante a disputa presidencial de 1972, quando Nixon tentava se reeleger, o complexo Watergate, sede do partido democrata (oposição a Nixon), foi invadido por homens que tentavam fotografar documentos e instalar escutas no prédio. Nixon obteve uma vitória avassaladora sobre o democrata George Mcgovern e se reelegeu presidente dos Estados Unidos. Contudo, o jornal Washington Post descobriu as ligações entre a Casa Branca e a invasão de Watergate. Quando se provou que Nixon tinha conhecimento das operações de espionagem, não houve outra alternativa senão renunciar ao cargo de presidente. A explosão daquele que ficou conhecido como o "Caso Watergate" fez a fé dos 
americanos em suas instituições despencar. Nixon era o segundo presidente eleito seguido que não concluía o seu mandato. Para piorar, a já citada crise do petróleo levou o preço da mercadoria para níveis estratosféricos, complicando ainda mais as finanças americanas, já bastante comprometidas pela Guerra do Vietnam. O quadro era tão desolador que o vice de Nixon, Gerald Ford, teve que declarar quando assumiu a presidência: "Eu devo dizer que o estado da nossa nação não é bom". A Guerra do Vietnam, que se estendia desde as manobras de Kennedy, já chegou nas mãos de Ford como um caso perdido. Depois de ter consumido o dinheiro e a vida dos americanos, o conflito passou a ser pessimamente recebido pela opinião pública, não deixando outra opção a Ford senão retirar as tropas americanas de lá e assumir o retumbante fracasso da empreitada. Foi a pá de cal na fé americana. A crise estava tão acentuada que em 1975 Ford sofreu dois atentados (doze anos depois do assassinato de Kennedy). No ano seguinte, o democrata Jimmy Carter venceu as eleições presidenciais e com ele a América finalmente entrou na década de 1980.

Como falei, os fracassos acumulados durante os anos 1960 e 1970 fizeram com que as instituições e a política americana perdessem legitimidade. A descrença no país era tão grande que isso acabou alterando a autoimagem dos americanos. Como bem disse Borstelmann "Em meados dos anos 1970, os americanos não se viam mais como escolhidos, mas como sobreviventes" (2012, p. 15). Esse sentimento negativo se espalhou pelas várias esferas do país, alterando o modo de vida americano tanto em grande escala, quanto no âmbito doméstico e até mesmo psicológico.

Em 1969 foi lançado o primeiro disco dos Stooges, banda americana pré-punk liderada pelo ainda desconhecido Iggy Pop. O disco é um retrato fiel do negativismo que tomava conta dos Estados Unidos àquela época. Já na faixa de abertura, batizada com o nome do ano corrente, pode-se perceber essa falta de perspectiva:

Bom, é 1969. Tudo bem.

Por todos os Estados Unidos

É um outro ano para mim e para você.

Um outro ano sem nada para fazer.

Ano passado eu tinha vinte e um

Eu não tive muita diversão

Agora eu vou fazer vinte e dois

E eu digo "nossa, que coisa" 
O lado B do disco é aberto com a não menos depressiva No Fun

\author{
No Fun \\ Sem diversão, minha querida, sem diversão. \\ Sem diversão de sair por aí \\ Sentindo-me daquele jeito de sempre \\ Sem diversão de sair por aí \\ Desesperado por um dia diferente \\ Sem diversão, minha querida, sem diversão \\ Sem diversão de estar por aí \\ Andando sozinho \\ Sem diversão de ficar sozinho \\ Sem amar ninguém mais \\ Talvez eu saia, talvez eu fique em casa \\ Talvez eu ligue para minha mãe no telefone.
}

Como é comum nesses momentos de desânimo, as desestruturas institucionais foram lentamente penetrando na vida cotidiana da sociedade. Não era só a posição mundial dos Estados Unidos que parecia estar em risco, mas o próprio american way of life e a fé dos americanos neles mesmos. Na virada da década de 1960 para 1970, a participação social e o engajamento da população em atividades comunitárias caiu drasticamente. Ainda que demonizassem o comunismo, os americanos sempre se orgulharam de seu espírito comunitário, gregário, e por isso, mesmo que não pusesse em prática planos estruturais de resolução das desigualdades, o povo sempre se preocupou em criar uma sociedade orgânica, filantrópica e fraterna. Mas os tropeços do país acabaram desgastando esse espírito solidário e assim as pessoas se retiraram de sua vida comunitária, fechando-se em suas casas, ou até em si mesmos. O prestígio depositado na ideia de comunidade acabou se transferindo para a noção de indivíduo, e assim, o esforço de criar uma sociedade harmônica foi substituído por um solitário mergulho interior. Não por acaso, Tom Wolfe definiu os anos 1970 como "a década do Eu" (1988).

Como a família era considerada a base da sociedade americana, o esgarçamento do tecido social foi acompanhado de uma corrosão da vida doméstica. O lar, cultuado como um verdadeiro santuário, começou a ruir. Milhares de pais, filhos e maridos que eram os pilares de suas famílias morreram na Guerra do Vietnam, deixando lares despedaçados. Esse cenário apontava uma mudança no papel da mulher: até os anos 1960, os homens haviam desempenhado o papel de provedores da família, enquanto às mulheres foi 
delegada a função de cuidar da casa. Como os maridos ganhavam dinheiro e as esposas ficavam encasteladas em seus lares no subúrbio, então apenas os homens participavam ativamente da vida em sociedade como sujeitos, enquanto as mulheres se restringiam à esfera doméstica. Esse arranjo conferiu um protagonismo aos papeis masculinos e subordinou as mulheres a uma posição de dependência que as colocava sempre à sombra de seus maridos. No entanto, a morte desses homens na Guerra do Vietnam deixou uma lacuna aberta na família e assim a antiga função doméstica das mulheres perdeu sua razão de existir. Ao matar os maridos provedores, pais zelosos e filhos protegidos, a guerra destruiu aquela estrutura familiar, criando uma legião de viúvas, órfãs e mães arrasadas que agora precisavam encontrar uma nova posição na sociedade. Antes bem recebida na população estadunidense como uma ofensiva a favor dos Estados Unidos e contra o comunismo, a Guerra do Vietnam passou a ser encarada como uma máquina de matar americanos. Jovens promissores que não tinham o menor interesse naquela luta eram obrigados a abandonar suas famílias para morrer do outro lado do mundo. Quando o Vietnam começou a cobrar seu preço econômico e humano, o conflito passou a ser rechaçado não só pelos setores pacifistas mais à esquerda que criticavam a política externa do seu país, mas pelas próprias famílias típicas que eram estioladas por uma guerra que dizia protegê-las. Secundarizadas por uma estrutura patriarcal, essas esposas, filhas e mães, agora sem seus homens, se descobriram coadjuvantes sem seus protagonistas, quer dizer: as mulheres viraram uma classe marginalizada sem direitos mínimos garantidos e sem papel definido na nova sociedade despedaçada que emergia. Era preciso se reorganizar.

O enfraquecimento da célula familiar podia ser observado no aumento do número de divórcios, na queda do número de casamentos e da taxa de natalidade registrados na época. Aos poucos foi surgindo uma nova classe de mães solteiras, mulheres divorciadas e garotas que não queriam casar. Essas mulheres sofreram muito preconceito e passaram a ser encaradas como uma ameaça à família tradicional americana. Diante dessa hostilidade, esse novo grupo percebeu que precisava lutar para ser reconhecido.

A tragédia americana na geopolítica internacional, que invadiu a vida doméstica do país, não tardou a penetrar na arena psíquica de seus habitantes. Na passagem dos anos 1960 para 1970, os Estados Unidos estavam psicologicamente doentes e, por isso, os americanos passaram a buscar amparo em substâncias psicoativas. Durante essa época, o 
consumo de maconha e LSD nas grandes cidades americanas cresceu vertiginosamente. Em 1972, Lou Reed, ex-Velvet Underground, lançou Transformer, seu segundo disco solo. No álbum se pode encontrar o maior sucesso da carreira do músico: Take a Walk on the Wild Side, verdadeiro hino daqueles melancólicos anos 1970. Retrato fiel de uma geração sem esperança, a canção elenca uma série de tipos americanos marginalizados que não sabem o que fazer das suas vidas. Na última estrofe da música, Reed canta:

Jackie está só indo embora

Pensou ser James Dean por um dia

Então achei que ela tinha que bater

Valium teria ajudado nisso

Hey, baby

Dê uma caminha pelo lado selvagem.

A referência ao Valium não foi à toa: o remédio foi o mais vendido da década de 1970 , sendo 90 milhões de prescrições só em 1978. Até Betty Ford, primeira dama dos Estados Unidos de 1974 a 1977, admitiu ser dependente do remédio. Em 1980, a Associação Americana de Psiquiatria incluiu "transtorno de estresse pós-traumático" no Manual de Diagnósticos de Problemas Mentais, uma espécie de catálogo que reúne todas as enfermidades psíquicas conhecidas. Assim que o novo rótulo foi incluído no manual, diversos militares que sobreviveram ao Vietnam passaram a receber esse diagnóstico. Em pouco tempo, vários civis que nada tinha a ver com a guerra foram diagnosticados com o mesmo transtorno.

Recuperando o que aqui foi dito, podemos notar que as derrotas acumuladas pelos Estados Unidos durante os anos 1960 e 1970 abalaram a imagem vitoriosa que o país vinha construído desde o fim da Primeira Guerra Mundial. Ao invés daquele otimismo, a América foi invadida por um sentimento de descrença e ilegitimidade institucional que tomou de conta tanto da esfera política, quanto da vida cotidiana e até da psique dos habitantes. A autoimagem dos Estados Unidos estava abalada.

Contudo, não se pode dizer que a descrença e a ilegitimidade institucional que se espalhou pelos Estado Unidos na passagem dos anos 1960 para os 1970 produziu uma época de anomia e descrença generalizada. Muito pelo contrário: a América nunca acreditou tanto quanto nesse período. Mas se não acreditavam nas instituições, os americanos acreditavam em que? Simples: em tudo aquilo que fosse contra as instituições. 
Quando mais o prestígio das instituições desabava, mais aumentava a fé em discursos que criticavam os excessos e a falência das ortodoxia. Esse movimento que se rebelou contra os dogmas dos anos 1960 e 1970 ficou conhecido como contracultura. A contracultura objetivava derrubar os pilares da antiga sociedade americana e erigir um novo estilo de vida no país, um estilo de vida enraizado em valores opostos àqueles que a América vinha cultivando desde Segunda Guerra Mundial. Esse sentimento anti-institucional, que crescia na ordem inversa do prestígio depositado nas instituições, ganhou as mais diferentes feições ao longo do país. A cultura hippie tomou de conta dos Estados Unidos, principalmente da Califórnia, promovendo uma revolução na música, nas roupas, nos comportamentos e no estilo de vida. Pregando a paz e amor - ideias bem representados no festival de Woodstock de 1969 - os jovens defendiam um retorno a uma vida mais simples e lúdica, que muitas vezes só era encontrada dentro deles mesmos. A crença na Guerra do Vietnam e na política expansionista americana iam aos poucos sendo corroídas pela fé na harmonia e na união.

Como não poderia deixar de ser, o desejo hippie de fugir desse mundo e construir outro foi aproveitado das mais diferentes maneiras. Muitos foram os caminhos tomados para se chegar a esse "outro mundo". Primeiro, as drogas: como se falou, o fim dos anos 1960 e o começo da década de 1970 foi um período de grande consumo de substâncias psicoativas. Abrir as portas da percepção, voltar para dentro de si mesmo, etc. eram mantras correntes na época. Segundo, a tecnologia: o discurso da contracultura sempre esteve intimamente ligado com o interesse pelo computador e pela internet. Além de criar uma curiosidade pelas drogas, o tédio que tomava conta do "mundo real" fez nascer o desejo de uma fuga para o "virtual". Bill Gates, Steve Jobs e a mítica em torno do Vale do Silício foram forjados nesse contexto. Em Vício Inerente, livro de Thomas Pynchon ambientado na Califórnia de 1970, o diálogo entre tecnologia e contracultura é constantemente evocado. No romance, Fritz e Sparky são dois hippies que exploraram a ARPAnet, espécie de mãe da internet que conhecemos hoje. Em uma passagem, Sparky diz: "O Fritz disse que depois que ele ficava um tempo na rede era como se estivesse usando psicodélicos" (2010, p. 454). Terceiro, as seitas: por toda a costa oeste dos Estados Unidos, jovens abandonavam as casas confortáveis do subúrbio onde moravam com seus pais e passavam a se agrupar em acampamentos afastados onde um estilo de vida alternativo era cultivado. Nessas comunidades, os jovens defendiam princípios mais 
gregários e naturais, completamente opostos aos ideias de consumo e guerra compartilhados pela classe média e pelo governo. Infelizmente, essa geração inexperiente acabou se transformando em uma argila mole nas mãos de homens insanos. Muitos desses jovens içaram pessoas perigosas de retórica mais sofisticada à condição de profetas, o que acabou convertendo essas comunidades alternativas em verdadeiras seitas religiosas organizadas em torno de um líder criminoso. O exemplo mais famoso é o da seita de Charles Manson. No final dos anos 1960, hippies que viviam isolados em uma comunidade se deixaram seduzir por Charles Manson, um homem que defendia uma teoria estapafúrdia de que uma guerra racial entre negros e brancos estava prestes a explodir. A guerra seria vencida pelos negros, mas, como eles supostamente não teriam capacidade para gerir o novo mundo, o grupo vitorioso precisaria recorrer à seita de Manson, que se manteria retirada durante a guerra esperando o momento em que os vencedores solicitassem sua ajuda. Entronizado pelos negros vitoriosos como guias da nova sociedade, Manson e sua trupe dominariam o mundo. Tudo isso regado a muito Beatles com LSD. Inspirado por essa teoria alucinada, Manson insuflou seus seguidores a cometerem uma série de assassinatos, sendo o mais famoso deles o de Sharon Tate, esposa do cineasta Roman Polanski, morta pelos jovens quando estava grávida de oito meses. Por ter sido considerado o mentor intelectual do crime, Manson foi condenado à prisão perpétua e até hoje, com 80 anos, ainda se encontra preso.

Enfim, como mostra a fuga interior proporcionada pelas drogas, ou a busca de um mundo virtual prometido pela tecnologia, ou a entrega acrítica ao discurso de um líder carismático louco, a passagem dos anos 1960 para os anos 1970 foi um período de crença e de fé. De fato, as instituições e o velho estilo de vida americano perderam legitimidade, mas nenhuma posição ficou vazia, pois quando esses discursos começaram a ruir, o prestígio anteriormente depositado na esfera institucional se transferiu para tudo aquilo que parecesse anti-institucional. A América não via só um velho mundo se despedaçar, mas viu outro aparentemente novo nascer. Por ter feito um discurso se fortalecer em detrimento de outro, a virada dos anos 1960 para os 1970 não pode ser definida como um momento de anomia, mas sim como um período em que a crença mirou um novo alvo. O descrédito na antiga cultura foi compensando com uma aceitação cega da jovem contracultura. 
Resta descobrirmos de que maneira essa contracultura ajudou a construir um segundo período no mercado da diferença. Olhando para essa revolução que se processava nos Estados Unidos na passagem da década de 1960 para a de 1970, podemos perceber três narrativas aparentemente opostas que se entrelaçarem graças àquela porosidade do filtro da igualdade que barrou os conteúdos do primeiro período do mercado da diferença mas deixou que suas velhas formas passassem para o outro lado. Essas três narrativas são: (1) direito das minorias, (2) igualdade, (3) liberalismo. Como falei, essas narrativas parecem contrárias, mas se fortaleceram mutuamente no período que aqui nos interessa. Cada uma a sua maneira, a luta das minorias, a bandeira da igualdade e liberalismo se opunham ao discurso institucional defendido pelo estado, e, dessa maneira, ao se deixarem amalgamar nesse objetivo anti-institucional comum, essas três narrativas foram tecendo um novo período do mercado da diferença nos Estados Unidos. Olhemos com atenção para cada uma delas.

(1) Direito das minorias:

Na virada da década de 1960 para a de 1970, os grupos minoritários americanos passaram a lutar por direitos de maneira mais organizada. Aquelas mulheres sem lugar na sociedade sobre quem já falei começaram a desenvolver um novo feminismo; um novo movimento negro também se articulava e grupos como os Panteras Negras nasceram; a comunidade LGBT (que ainda não se reconhecia sob a égide dessa sigla) se uniu nas grandes cidades americanas. A luta desses grupos por direitos básicos era uma cruzada para sair da marginalidade, quer dizer, era um esforço para que suas diferenças fossem reconhecidas e respeitadas.

(2) Igualdade

De fato, a luta das minorias contra a discriminação era uma cruzada para que suas diferenças deixassem de ser negligenciadas e começassem a ser olhadas com dignidade. No entanto, o movimento das minorias pelo reconhecimento e pelo respeito de suas diferenças era, fundamentalmente, uma batalha para que suas diferenças fossem aceitas. Ou seja: o que as minorias queriam era entrar para o seio da sociedade americana e se plasmar na comunidade nacional. Os grupos marginalizados não salientavam suas diferenças para criar uma ruptura entre eles e o resto da sociedade, mas justamente para 
denunciar que esse corte já existia e que ele era danoso. Com a bandeira do preconceito hasteada, as minorias sentiam a necessidade de balançar suas bandeiras identitárias, mas o objetivo dessa guerra de bandeiras era que no futuro todas elas fossem abaixadas: responder discriminação com identidade e quem sabe um dia viveremos em um mundo sem preconceituosos e sem culturalistas. As minorias tinham a consciência de que todos eram iguais, mas como os preconceituosos não pensavam assim, era preciso ratificar as diferenças para que elas fossem aceitas. A balança estava desequilibrada, por isso era necessário que mais peso fosse depositado de um lado para que finalmente os dois pratos se nivelassem. Portanto, a luta pelo reconhecimento das diferenças era um caminho oblíquo para que se chegasse à igualdade.

Diferença e igualdade podem parecer termos diametralmente opostos, mas aquela porosidade do filtro da igualdade que aceitou antigas formas de diferença mas reteve seus conteúdos foi produzindo esse tipo de configuração em que a diferença funciona como um caminho que ruma para aquilo que deveria ser seu oposto, a igualdade.

Um objeto que ilustra bem essa articulação entre diferença e igualdade é o discurso de John Lennon durante os anos 1970. Ao longo da década (a sua última), Lennon se comportou simultaneamente tanto como um enfurecido defensor das diferenças quanto como um pacifista profeta da igualdade. Um compacto do músico lançado no Reino Unido em 1975 evidencia a tensa harmonia entre essas duas valências: Working Class Hero no lado A e Imagine no lado B.

Working Class Hero é um denúncia dos abusos sofridos pelos trabalhadores marginalizados. Diante dessa injustiça, Lennon salienta a importância de se ser um herói da classe trabalhadora e convoca a massa a segui-lo nessa luta.

"Um herói da classe trabalhadora é algo que se deve ser. Se você quiser ser um herói, bem, siga-me."

Já Imagine defende um mundo homogêneo, pacífico, sem quaisquer fronteiras, identidades ou diferenças.

"Imagine que não há paraiso

É fácil se você tentar

Nenhum inferno abaixo de nós

Sobre nós, só o céu 
Imagine todas as pessoas

Vivendo o hoje

Imagine que não há países

Não é difícil fazer isso

Nenhum motivo para matar ou morrer

E nenhuma religião também

Imagine todas as pessoas

Vivendo a vida em paz

Você pode dizer que eu sou um sonhador

Mas eu não sou o único

Eu espero que algum dia você se junte a nós

E o mundo será um

Imagine nenhuma posse

Eu imagino se você consegue

Nenhum motivo para ganância ou fome

Uma irmandade de homens

Imagine todas as pessoas

Compartilhando todo o mundo"

Working Class Hero nos convida a levantar a bandeira identitária do grupo marginalizado ao qual pertencemos e a lutar contra a opressão imposta pela sociedade. A mensagem aqui é para que nos fechemos em nosso pequeno gueto oprimido pela sociedade e duelemos contra essa maioria que nos marginaliza. Em Imagine, o oposto é sugerido: devemos derrubar as fronteiras dessas pequenas comunidades que nos dividem (religiões, países, dinheiro, etc.), pois no fundo somos todos seres humanos vivendo em um mundo homogêneo. Ali, acabar com a sociedade existente; aqui, entrar nela. Se no lado A, Lennon defende a importância dos heróis, das ideologias e da luta da minoria contra a maioria, no lado B o mesmo músico sonha com um mundo sem líderes, sem credos e sem guerras, pois todos são iguais e vivem em harmonia.

A ambivalência do discurso de Lennon, bem encarnada nesse EP, é a tensão que atravessa toda a década de 1970: de um lado, diferença e luta, de outro, igualdade e paz. Porém, o mais curioso é que essas concepções não se encarnam em grupos opostos, mas se inscrevem nos mesmos entes: na mesma geração, na mesma pessoa, no mesmo disco (compacto, diga-se). Na virada de década de 1960 para a de 1970, os Estados Unidos veem o texto da igualdade e da diferença se entrelaçarem para forjar um segundo período do 
mercado da diferença. Não há aqui um envolvimento total, mas também não se pode dizer que haja apenas alienação. As duas narrativas repousam na tensão em que se articulam, produzindo assim um equilíbrio a um só tempo harmônico e instável.

Seria incorreto dizer que a bandeira americana da igualdade se opunha ao "viva a diferença" dos franceses do maio de 1968. Os Estados Unidos só estavam complexificando um pouco a luta da França: assim como os franceses, os americanos também buscavam o reconhecimento da diferença, entretanto, esse esforço para que as particularidades fossem respeitadas se inscrevia em um gesto maior de reunir cada um desses fragmentos em uma mesma comunidade orgânica e indiferenciada: levantar bandeira para abaixá-las. A igualdade americana não negava a diferença francesa, mas a continha em um quadro mais amplo. Em ambos os países, havia uma busca pela diferença, mas no caso americano esse interesse pelo diferente estava a serviço da formação de um todo igualitário. O que os negros, as mulheres e os gays americanos dos anos 1970 queriam era ter os mesmos direitos que os brancos, os homens e os heterossexuais. Quando lutavam para que a sociedade percebesse suas diferenças e o estado de marginalidade em que se encontravam, as minorias intentavam tão somente sair dessa posição periférica e ser incluídas na comunidade americana. $\mathrm{O}$ tenso equilíbrio entre diferença e igualdade é o típico fruto de um mercado da diferença que passou por um filtro da igualdade que reteve os conteúdos do período anterior mas deixou que as velhas formas fluíssem.

No entanto, uma terceira valência viria emaranhar ainda mais a trama.

\section{(3) Liberalismo.}

O governo, o estado e as instituições americanas não estavam em guerra apenas com o povo, mas também com o mercado. Desse jeito, assim como os jovens hippies, a própria economia começou a ver o governo como um inimigo. Quanto mais o estado se desprestigiava, mais aumentava a fé em um mercado livre da regulação estatal. Tudo indicava que a solução não viria da Casa Branca, mas da iniciativa privada. "A confiança nos mecanismos de oferta e demanda tomou o lugar da confiança da gestão governamental" (BORSTELMANN, 2012, p. 5).

Nada parecia mais antiquado que as soluções keynesianas do New Deal. Se os problemas da nação partiam justamente do estado e das instituições, então a resposta não 
viria de lá, mas somente da sociedade civil. Disseminou-se a crença de que a economia ia mal por causa do governo, portanto, foi se cristalizando a ideia de que o mercado precisava se libertar do estado para entrar nos eixos. Era o liberalismo econômico que ia tomando conta da América.

\begin{abstract}
"A maioria dos americanos acreditava que o mercado resolveria os problemas promovendo incentivos para a produção do que quer que fosse necessário. Por todo o espectro político, de republicanos a democratas, o setor privado foi associado à virtude da eficiência, enquanto o setor público do governo parecia defender apenas a si mesmo." (BORSTELMANN, 2012, p. 5).
\end{abstract}

Direito das minorias, igualdade e liberalismo podem se separar em pontos importantes: o primeiro luta por um reconhecimento da diferença, o segundo quer homogeneizar todas as pessoas e o terceiro se aferra a princípios próprios do mercado. Enquanto as minorias pregam a especificidade e a particularidade, a igualdade se interessa por aquilo que está presente em todos os seres humanos e os nivela em uma mesma massa indistinta, já o liberalismo vende o mercado como um espaço de equivalências mas paulatinamente produz suas próprias assimetrias econômicas. Se por um lado, a tensão diferença/igualdade se organizava em torno da contracultura e criticava o consumismo, o liberalismo, por sua vez, se refugiava no mercado e levantava a bandeira do capital.

Mas, ainda com todas essas diferenças, alguns traços eram comuns às três narrativas: cada uma delas foi uma resposta a uma crise de ilegitimidade institucional, por exemplo. O inimigo das três narrativas era as mesmas instituições americanas. Mesmo que as especificidades de cada um apontasse uma rota de fuga diferente, a ojeriza comum que sentiam pela esfera institucional acabou por tecer afinidades entre esses três textos. Além do que, havia um ruído presente em maior ou menor escala na luta das minorias, na bandeira da igualdade e no liberalismo econômico: o individualismo.

Ainda que fosse uma cruzada pela autonomização de um grupo, a luta das minorias para ter sua diferença reconhecida estava também intimamente ligada a questão das liberdades individuais a ao respeito a direitos inalienáveis da pessoa humana. Além de se enxergarem como coletivos e batalharem por questões estruturais, negros, gays e mulheres tinham demandas que influenciavam diretamente sua vida doméstica e psíquica. Como essas agendas resvalavam na esfera subjetiva desses grupos, essas pessoas começaram a se enxergar não só como partes de um estrato marginalizado, mas como indivíduos 
autônomos que precisavam ter sua intimidade respeitada. Como o reconhecimento da diferença era um caminho que visava a igualdade, não tardou para que essa preocupação das minorias com o indivíduo penetrasse no debate acerca dos direitos iguais. Aos poucos, os Estados Unidos foram percebendo que a nova sociedade não deveria ter apenas grupos iguais, mas indivíduos iguais. Era preciso aumentar o grau da homogeneidade e erigir um país em que não só todos os segmentos, mas também todas as pessoas fossem tratadas da mesma maneira. Se olharmos novamente para o filtro da igualdade, podemos perceber que a preocupação da Declaração Universal dos Direitos Humanos em construir uma sociedade homogênea livre das distinções espúrias feitas pelo nazismo e pela colonização passa por um respeito pelas liberdades individuais e até mesmo pela propriedade privada.

\section{"Artigo 12.}

Ninguém será sujeito à interferências em sua vida privada, em sua família, em seu lar ou em sua correspondência, nem a ataques à sua honra e reputação. Todo ser humano tem direito à proteção da lei contra tais interferências ou ataques." (p. 4)

\section{"Artigo 17}

1. Todo ser humano tem direito à propriedade, só ou em sociedade com outros.

2. Ninguém será arbitrariamente privado de sua propriedade." (p. 4)

Mesmo quando salienta as obrigações que cada indivíduo tem com sua sociedade, a Declaração não vê a comunidade como um espaço que tenha que ser per se protegido, mas como uma arena que precisa ser defendida na medida em que é nela que a personalidade do indivíduo irá se desenvolver. Ou seja, a comunidade é valiosa porque o indivíduo está nela:

\section{"Artigo 29.}

1. Todo ser humano tem deveres para com a comunidade, em que o livre e pleno desenvolvimento de sua personalidade é possível." (p. 6)

Esse mesmo individualismo presente na luta das minorias pela diferença e na defesa da igualdade era a base de sustentação do liberalismo econômico. Contra a tirania de um estado que taxa o cidadão e de uma imagem de comunidade despedaçada, surge a mítica do indivíduo autônomo que só precisa de um mercado livre do governo para que possa vencer na vida. A figura do self-made man, do homem que vence sozinho na vida superando todas os obstáculos que o estado coloca diante dele, aparece como um tipo ideal americano. O individualismo do liberalismo econômico injeta ânimo na população ao incutir a ideia de que os Estados Unidos são a terra das oportunidades: para vencer aqui, basta você querer. 
É verdade que a contracultura enredada em torno dos direitos da minorias e da promoção da igualdade e os defensores do liberalismo econômico tinham uma relação complicada. Se por um lado os dois grupos se aproximavam na medida em que ambos se opunham as instituições governamentais estadunidenses, por outro lado hippies e yuppies ${ }^{24}$ divergiam no que dizia respeito à sociedade de consumo: enquanto os primeiros criticavam o capitalismo e se voltavam para uma vida comunitária mais tradicional, os segundos eram soldados de Wall Street que só pensavam em ganhar dinheiro. Os revolucionários se identificavam com os liberais na sua ojeriza ao estado, mas discordavam deles quando o assunto era o capital. Mas a pergunta que fica é: nesse jogo de proximidade e distância, como a contracultura via aquele individualismo tão caro aos liberais? Ora, o movimento hippie sempre teve por lastro o indivíduo. O que aquela prédica buscava era um retiro interior e uma redescoberta do Eu. A propriedade privada dos liberais era criticada na medida em que desvirtuava o sujeito do seu reencontro com sua própria natureza. A nova sociedade que a contracultura queria erigir e a revolução nos costumes que aqueles jovens intentavam promover passavam por uma redescoberta de si mesmo e por um retraimento subjetivo. A maconha e o LSD eram consumidos para que se pudesse atingir um novo nível de consciência e para que as portas da percepção fossem abertas. As letras dos Stooges acima comentadas refletem muito mais um salto para dentro do que um investimento do lado de fora. Assim como os liberais, os hippies podiam até ser gregários e orgânicos, mas não eram de forma alguma comunistas nem se identificavam com a maquina burocrática da União Soviética. Referindo-se a esses jovens, um personagem de Philip Roth diz: "Dançar twist e gritar, agitar-se freneticamente: isso, e não a Internacional, era o seu hino" (2013, p. 53). O Eu era o alfa e o ômega tanto de liberais como de revolucionários. Abismado com as contradições de uma garota que rotula como "póshippie new age", um personagem de David Foster Wallace descreve aquela como sendo uma geração de "cativos interiores", que se homogeneízam ao tentarem se diferenciar:

\footnotetext{
"A hipocrisia, a tosca autocontradição, o jeito como você sabe de cara que vai encarar os entusiasmos de praxe pela floresta tropical, pela coruja malhada, pela meditação criativa, pela psicologia do bem-estar, pela macrobiótica e a desconfiança radical pelo que consideram autoridade sem evidentemente nem parar para pensar no rígido autoritarismo implícito na rígida uniformidade do entre aspas uniforme não conformista, no vocabulário, nas atitudes. Na posição de alguém que passou pela faculdade e agora já está há dois anos na pós-
}

\footnotetext{
${ }^{24}$ Como eram conhecidos os jovens que trabalhavam no mercado financeiro.
} 
graduação tenho de confessar uma distância quase... esses meninos ricos de jeans rasgado cujo jeito de protestar contra o apartheid foi boicotar a maconha sul-africana. Silverglade chama essa gente de Cativo Interior. A ingenuidade arrogante, a condescendência na entre aspas compaixão que sentem por aqueles que estão entre aspas presos ou escravos das escolhas do estilo de vida ortodoxo americano. E por aí vai. $\mathrm{O}$ fato de os Cativos Interiores nunca considerarem que é a probidade e economia do re... não ocorre a eles que eles próprios transformaram a eles próprios no destilado de toda a cultura que ridicularizam e contra a qual se declaram, o narcisismo, o materialismo, a complacência e a conformidade inconsciente - nem a ironia de que a risonha teleologia dessa entre aspas iminente New Age é exatamente o mesmo deslize permissivo que foi o Manifest Destiny, ou o Reich, ou a dialética do proletariado, ou a Revolução Cultural - tudo a mesma coisa. E nem ocorre a eles nunca que a certeza de que são diferentes é o que faz ele serem iguais." (WALLACE, 2005, p 336)

Por ser enviesado e carregado de valor, o depoimento exagerado do personagem não pode ser tomado como um retrato imparcial daquela geração, mas certamente reflete a opinião de uma parcela da população, além de funcionar como contraponto para a imagem que os hippies faziam deles mesmos.

Eis o individualismo da contracultura: não era necessário que os sonhos cultivados na mente se realizassem no mundo, pois essa viagem subjetiva já era concreta e objetiva o suficiente para os hippies. Para fazer, bastava querer; mas não porque o querer é précondição para fazer, mas justamente porque querer já é fazer. Como a vida que se queria construir era interior, sonhar com a revolução não antecipava o ato de realizá-la, pois, já que a revolução é subjetiva, é sonhando-a que a excutamos. Tudo começava e terminava no indivíduo. $\mathrm{O}$ mundo que a contracultura quis construir não foi erigido sobre aquele que já existia, mas no espírito de cada um dos hippies. Eles estavam sendo sinceros quando disseram que queriam mudar o mundo, e até conseguiram: lá dentro, e já estava ótimo. A revolução da contracultura sempre foi uma revolução interior. Seu projeto de mundo era, fundamentalmente, um projeto de consciência. Portanto, assim como os liberais, os hippies eram extramente individualistas.

Em 1977, o punk apareceu na costa leste americana defendendo o lema "do it yourself" [faça você mesmo]. Quando esse mantra refratou na cultura hippie da costa oeste, surgiu na América uma geração de jovens que odiava o governo, não acreditava na sociedade e estava disposta a se fechar em sua própria consciência e fazer tudo do seu jeito. Pensando bem, qual a pessoa mais indicada pra levar uma vida do it yourself que um self-made man? Seja cheirando cocaína de gravata ou tomando LSD de chinela, os jovens 
americanos só queriam a liberdade para levar a vida da sua maneira longe das regras de um estado falido e de uma sociedade antiquada. Como falei, os hippies não eram descrentes ou anômicos, pelo contrários, eram uma geração devota, apenas acreditavam em outras coisas. Esse traço investido dos hippies acabou sendo aproveitado pelo próprio establishment e suas mentes fiéis acabaram se transformando em uma massa de modelar na mão do que chamavam de sistema. Não por acaso, toda a fúria contracultural dos anos 1970 acabou desaguando em uma década de 1980 dominada pelo liberalismo republicano de Ronald Regan.

Em um nível mais subjetivo, mas que ilustra esse movimento maior, o já citado Thomas Pynchon mostra os hippies como marionetes do velho american way of life. Como se revela no final de Vício Inerente, durante toda a trama o detetive particular hippie Larry "Doc" Sportello estava sendo manipulado pelo detetive de polícia careta Pé-Grande, que usou o seu duplo maconheiro para descobrir quem havia matado seu parceiro na polícia. Em Vineland, obra do mesmo autor, a fórmula também aparece: a militante universitária aspirante a cineasta Frenesi Gates era um títere do promotor de justiça Brock Vond. O pulo do gato de Vond foi ter justamente percebido que aquela não era uma geração descrente, como muitos pensavam, mas completamente crédula, bastava ser "bem aproveitada".

"O gênio de Brock foi ter enxergado nas atividades da esquerda dos anos 60 não ameaças à ordem mas uma oculta ânsia por ela. Enquanto o Tubo [a televisão] proclamava a revolução juvenil contra os pais de todos os tipos, e a maioria dos observadores aceitava essa história, Brock enxergava a profunda - a tocante, se ele se permitisse tal sentimento - vontade de permanecer criança para sempre, em segurança no seio de uma ampla família nacional. Ele apostava no palpite de que esses guris rebeldes, já mais pra lá do que pra cá aliás, iriam facilmente virar a casaca e não seria caro desenvolvê-los. Era só que eles andavam ouvindo a música errada, aspirando a fumaça errada, admirando as personalidades erradas. Precisavam de um certo recondicionamento." (PYNCHON, 1990, p. 280)

O fato é que a luta das minorias, a igualdade e o liberalismo produziram uma mescla inusitada entre um gregarismo orgânico e um individualismo egóico que marcaria a cultura americana para sempre. Para ficarmos com os romancistas estadunidenses, aquele mesmo personagem de Roth analisa assim esse cruzamento inesperado:

"Havia duas tendências na turbulência: o libertarismo que concedia permissão orgiástica ao indivíduo e era contrário aos interesses tradicionais da comunidade, mas com ele, e frequentemente aliado a ele, havia a virtuosidade comunal acerca dos direitos cívicos e contra a guerra, a desobediência, cujo 
prestígio moral é transmitido por Thoreau. E a intercomunicação das duas tendências tornava difícil desacreditar a orgia" (2013, p. 52)

Essa tríade direitos particulares/igualdade/liberalismo, ideias aparentemente antagônicas, começou a dar uma cara para o segundo período do mercado da diferença. Dito de maneira simplista, essas três valências formaram uma configuração em que primeiramente as diferenças deveriam ser reconhecidas, em seguida todas deveriam ser tratadas de forma igual e, finalmente, quando se atingisse essa arena em que cada especificidade estivesse nivelada em uma mesma totalidade, cada indivíduo estaria livre para fazer o que bem entendesse, pois cada parte estaria participando do todo em iguais condições. Como o futuro se encarregaria de provar, esse arranjo acabou por produzir um individualismo exacerbado bem distante da utopia dos anos 1970.

Mesmo que o resultado trazido pela configuração não tenha sido previsto, talvez não se possa falar que o plano dos Estados Unidos tenha dado errado, talvez a América estivesse caminhando sonâmbula para esse ponto desde o começo. Em Watchmen, HQ de Alan Moore e Dave Gibbons, há uma passagem ambientada no final dos anos 1970 em que Coruja e Comediante, dois heróis que um dia nasceram para proteger a população, estão contendo um protesto de civis durante uma greve da polícia. Espantado com o que havia se transformado, Coruja pergunta "O que aconteceu conosco? O que aconteceu com o sonho americano?", ao que o Comediante responde, enquanto atira nos manifestantes, "O que aconteceu com o sonho americano? Ele virou realidade. Você está olhando para ele!" (2014, p. 71).

"Esse foi o momento em que os Estados Unidos abraçaram dois valores antagônicos: igualdade formal e completa fé no mercado. Juntos, essas arquetípicas crenças americanas criaram uma sociedade comprometida a tratar todo mundo de maneira igual, ao mesmo tempo em que se tornava profundamente desigual. Hiperindividualismo foi o resultado: todo mundo poderia e deveria competir na busca de vantagens e felicidades pessoais." (BORSTELMANN, 2012, p. 4)

"Uma sociedade comprometida em tratar todos de forma igual estava se tornando, na prática incrivelmente desigual. Na verdade, essa tal inclusão trouxe o véu que cobria a desigualdade econômica; os indivíduos eram responsabilizados por diferenças entre suas circunstâncias pessoais. Políticas de identidade acabaram mascarando diferenças de classe. (...) A nova igualdade não mudou o sistema, mas incluiu tudo dentro dele, um cenário marcado pela escolha individual e pela lógica do consumo capitalista: bem vindo, e agora você está por sua conta."(BORSTELMANN, 2012, p. 6) 
Eu não abraço totalmente a leitura de Borstelmann, primeiramente porque ele não problematiza a tensão entre o reconhecimento do direito das minorias e a bandeira da igualdade, fazendo parecer que tudo se reúne pacificamente sob a égide do conceito de igualdade; e também porque o autor entende que a igualdade é uma falsa consciência que encobriria uma suposta realidade concreta e danosa do individualismo liberal, enquanto para essa dissertação não há nenhum gradiente de veracidade entre direito das minorias, igualdade e liberalismo: as três valências estavam em um mesmo patamar epistemológico, tramando-se para que um segundo período do mercado da diferença pudesse nascer. No entanto, a versão desse observador atento da década de 1970 não deixa de ser valiosa para nós.

Como foi dito, reconhecimento da diferença das minorias, igualdade e liberalismo econômico eram três narrativas que constantemente se aproximavam e se distanciavam. Essas valências não se encarnavam em três segmentos diferentes da sociedade, mas se inscreviam nos mesmos corpos, formando um arranjo delicado. Os vetores de alienação tinham a mesma força que os de envolvimento, por isso a tensão do modelo fazia com que ele se equilibrasse na própria instabilidade. Por apontarem para direções contrárias, as setas se anulavam, fazendo com que o sistema repousasse no seu conflito. Era tão difícil dizer se as três forças só se complementavam ou só rivalizavam, que já não era possível diagnosticar se o resultado que esse cruzamento trouxe representou a vitória ou o fracasso do empreendimento. Esse emaranhado complexo formado pelo reconhecimento dos direitos das minorias, a luta pela igualdade e o liberalismo econômico é o típico cenário que nasceria daquela seletividade inconsciente que o filtro da igualdade operou no mercado da diferença. A paz e a igualdade impostas pelo filtro retiveram os conteúdos do primeiro período do mercado da diferença: o progresso, a evolução, a história linear única, a violência e todas as noções universais de unidade, homogeneidade, pureza e absoluto que giravam em torno da ideia de exótico. No entanto, o filtro deixou que as formas em que aquelas velhos conteúdos do mercado da diferença se inscreviam passassem para o outro lado. Assim, do lado de lá, as categorias de natureza humana, de universal, de ordem mundial localmente forjada e de estado-nação ${ }^{25}$ continuavam a existir, coroadas agora pelos princípios da paz e da igualdade. Esse arranjo esquisito, em que velhas formas se

\footnotetext{
${ }^{25}$ Embora aquele tipo de estado-nação estivesse em descrédito, a fórmula estado-nação ainda operava. Como os anos 1980 provaram, o estado-nação não desapareceu, apenas um outro modelo do conceito emergiu.
} 
faziam aptas a receber novos conteúdos, produziu esse cenário americano complexo em que diferença, igualdade e liberalismo harmonicamente competiam. Paulatinamente, um segundo período do mercado da diferença ia se formando do outro lado do filtro da igualdade. Os anos 1980 se encarregariam de continuar o trabalho.

Depois de toda a rebeldia dos anos 1960 e 1970, a década de 1980 foi tomada pelo liberalismo do partido republicano. A contracultura não conseguiu derrubar o sistema, mas isso não quer dizer que ela não tenha conseguido alterá-lo. O mais correto seria dizer que, ao invés derrubar o establishment, as demandas dos jovens acabaram penetrando nele, ou seja: a contracultura passou a ser parte constitutiva da cultura americana. O sonho de acabar com as instituições não se realizou, mas certamente as instituições incorporaram alguns dos valores que anteriormente foram usados para criticá-las. Como sempre, é simplista dizer de maneira taxativa se isso representou a vitória de um dos polos. O mais correto seria acreditar que as reticularidades se entrecruzaram, dando uma nova cara à configuração. O tão demonizado governo ainda estava lá, mas as questões relativas ao reconhecimento dos direitos das minorias, à igualdade entre as pessoas e à garantia das liberdades individuais se transformaram em agendas políticas incontornáveis.

Quando começaram os anos 1980, uma palavra passou a tomar conta da política, da cultura e da academia: globalização. O termo, que já era sussurrado nos anos anteriores por economistas, cientistas políticos e homens de negócios, entrou de vez para o glossário das outras ciências sociais e da opinião pública na década de 1980. A popularização do conceito ressignificou a ideia que se tinha sobre o globo: o mundo, que sempre fora encarado como "a Terra", quer dizer, como um planeta, um corpo celeste, passou a ser visto também como um espaço social, uma arena em que indivíduos e culturas interagiam. Com essa mudança de prisma, o mundo deixou de ser um objeto estudado exclusivamente pelas ciências naturais e passou a ser foco de interesse da sociologia e dos estudos culturais.

O debate acerca da globalização levou às últimas consequências o problema dos fluxos. Nesse novo mundo globalizado, as trocas proporcionadas pelo turismo, as migrações, as telecomunicações e o comércio atingiram níveis inéditos. Por causa dos intercâmbios promovidos pelos fluxos globais, elementos de dentro iam para fora e outros de fora vinham para dentro. Diante desse cenário, as fronteiras do estado-nação foram 
perdendo sua rigidez. O conceito de país ainda gozava de muito prestígio no debate político, cultural e acadêmico, mas certamente essa não era mais a única ideia a ser considerada. Em um mundo globalizado, o estado-nação precisava se mediar com outras instâncias que não paravam de surgir. Esses fluxos de trocas que traziam o estrangeiro para o interior e levavam o doméstico para o exterior criavam identidades infra e supra nacionais: na globalização, os lugares teciam afinidades com outros tanto porque elementos de fora vinham para cá quanto características locais iam para lá. Conterrâneos espalhados pelo mundo criavam elos mundiais, enquanto estrangeiros de vários lugares em um mesmo país promoviam cortes no tecido outrora contínuo da nação. Sendo assim, os fluxos globais fizeram com que aquele velho binômio Eu/Outro, que criava pares opostos entre si mas idênticos em si, perdesse completamente a razão de ser. O Outro está aqui, Eu estou lá, todos estamos em todos os lugares. Com a queda desse binômio, a ideia de exótico perde sua sustentação.

\begin{abstract}
"Surge um outro espaço que ultrapassa a nação, que é o próprio espaço global. (...) Dessa forma, a dicotomia interno/externo não se opera mais, como o fazia na era nacional. Estamos todos nos relacionando em espaços atravessados pela globalização. (...) Nesses processos, culturas começam a habitar espaços que antes lhes eram alienígenas; culturas não ocidentais passam a ser internas ao ocidente, tanto quanto as ocidentais ocupam espaços do oriente, sendo evidente que as condições para tanto não são justamente distribuídas. De qualquer modo, a separação que tornava o exótico em externo, sendo sua internalidade apenas temporária, se quebra, tombando assim uma outra referência, em relação à nação, na qual o exótico se ancorava. Hoje, o de fora está definitivamente dentro, ele é o estrangeiro de Simmel, que 'hoje vem e amanha permanece'". (NICOLAU NETTO, 2014, p. 97)
\end{abstract}

Depois que as trocas de pessoas, informações e mercadorias promovidas pelos fluxos substituíram o binômio Eu/Outro, depois que as últimas colônias europeias declararam independência, depois que a contracultura chamou a atenção para o reconhecimento do direito das minorias e da igualdade, depois que o capitalismo entrou em sua fase neoliberal centrada no indivíduo, o mundo já não se resumia mais a um punhado de territórios universais únicos, homogêneos, puros e absolutos como no período exóticocolonial do mercado da diferença. Como já se comentou anteriormente, os discursos têm a mesma dimensão da materialidade que tematizam. Sendo assim, a ruína daquele mundo estável e monista supostamente marcaria também o ocaso dos "grandes relatos" e das teorias abrangentes que teciam enunciados sobre todos os lugares e todas as épocas. Quer dizer, quando o mercado da diferença abandou as noções universais de unidade, 
homogeneidade, pureza e absolutismo, o mundo já não poderia ser explicado pelas ideias ambiciosas e violentas de progresso, evolução e história linear única. Para dar conta da complexidade da nova paisagem de fluxos globais era preciso se recorrer a uma narrativa que explicasse não mais as ideias universais de unidade, homogeneidade, pureza e absolutismo, próprias ao período exótico-colonial do mercado da diferença, mas sim as noções particulares de multiplicidade, heterogeneidade, hibridismo e relativismo.

Em busca de uma narrativa que explique o étnico, o específico e o contingente, a UNESCO alia suas pesquisas sobre cultura ao seu Instituto de Estatística e lança, em 1986, o Framework for Cultural Statistics.

"O Framework fornece as bases conceituais para que se avaliem as contribuições econômicas e sociais da cultura. É uma ferramenta que visa ajudar os Estamos Membros a organizar a coleta e a disseminação de suas estatísticas culturais. O documento irá permitir a produção de dados tanto nacionais como transnacionais que podem vir a ser usados pela UNESCO" (p. 1)

Vê-se aqui como a concepção de cultura do Framework se distancia dos ideias universais de unidade, homogeneidade, pureza e absolutismo caras ao período exótico-colonial do mercado da diferença. Ao dar uma abordagem estatística e matemática ao problema, a UNESCO fragmenta a cultura em índices, gráficos e intensidades, mostrando que ela não é um corpo contínuo e inteiriço. Além disso, ao se debruçar sobre as "contribuições econômicas e sociais da cultura", o Framework mostra que, ao contrário do que se pensava no século XIX, a cultura não é mais uma esfera autônoma, imaculada e adiabática, muito pelo contrário: ela está na história, dialoga com outras áreas, tem causas anteriores e consequências que lhe escapam. Depois de situada no tempo, a cultura não é mais tida como um fato absoluto, universal ou dado por Deus, e começa a ser encarada como uma configuração arbitrariamente forjada. Da mesma forma, vista em sua diacronia, a cultura deixa de ser um fim em si mesmo, um corpo fechado cuja única razão de ser é se perpetuar, e passa a ser pensada como algo que gera efeitos práticos externos que influenciam outras esferas da vida. Além disso, ao insistir nas conexões nacionais e transnacionais, o Framework iça o fluxo a uma posição antes ocupada pelo binômio Eu/Outro. Diluída em números, mediando-se com regras do mercado, deixando-se influenciar pelo que a precedeu, mirando um tempo por vir, e se espalhando por todos os territórios, a cultura se torna mensurável, histórica, terrena e fluida; características aparentemente bem distantes 
dos ideias universais de unidade, homogeneidade, pureza e absolutismo que se fechavam no espaço do estado-nação durante o período exótico-colonial do mercado da diferença.

Na virada da década de 1980 para a de 1990, um novo regime parece dar conta da complexidade desse mundo globalizado: o multiculturalismo. A globalização, as trocas proporcionadas pelos fluxos, a efemeridade das narrativas e a mudança de prestígio das ideias universais de unidade, homogeneidade, pureza e absolutismo para as noções particulares de multiplicidade, heterogeneidade, hibridismo e relativismo ensejaram o multicultural.

A velocidade desses intercâmbios atesta o fracasso das fronteiras nacionais em conter o mesmo dentro e manter o diferente fora. Diante de um cenário de fluxos globais de pessoas, informações e mercadorias em que o estrangeiro está dentro e o conterrâneo está fora, o estado-nação não pode mais dizer que cultiva em seu território uma cultura universal única, homogênea, pura e absoluta. $\mathrm{O}$ filtro da igualdade parecia ter cumprido seu papel, pois tudo indicava que aqueles conteúdos do período exótico-colonial do mercado da diferença tinham ficado no passado e um novo mundo multicultural emergia.

A ascensão do multiculturalismo dava a entender que uma inversão de valores em relação ao passado estava se operando: as ideias de universais de unidade, homogeneidade, pureza e absolutismo, antes defendidas a ferro e fogo, agora seriam índices de pobreza cultural; em contrapartida, as noções particulares de multiplicidade, heterogeneidade, hibridismo e relativismo, demonizadas no século XIX, se transformavam nas novas metas das culturas do mundo globalizado.

Essa troca de guarda promoveu uma revolução no papel do país: o estado-nação, que no século XIX foi o espaço onde uma cultura monista se realizava, passou a cultivar a pluralidade cultural dentro do seu território. Aquele velho jogo exótico-colonial de produzir indiferença interna para se marcar como diferença externa parecia superado: os países não queriam mais ser sistemas fechados iguais a si mesmos e diferentes de tudo o que estivesse fora deles. A riqueza cultural estava agora naquele que deixava o fora entrar e o dentro sair. Nessa nova era, o estado-nação queria tanto que a cultura do seu território se espalhasse pelo resto do mundo quanto que a cultura do resto do mundo se reunisse em seu território. 
Com o multiculturalismo se transformando em motivo de orgulho nacional, a virada dos anos 1980 para os 1990 cunhou uma expressão para os estados-nação que seria absurda no século XIX: identidade multicultural. Na esteira do binômio Eu/Outro e de acordo com os princípios universais de unidade, homogeneidade, pureza a absolutismo, o termo "identidade" sempre serviu para designar uma totalidade inteiriça e estável. Durante o período exótico-colonial do mercado da diferença, a ideia de identidade se alicerçava naquela correspondência 1 cultura $=1$ país $=1$ universal, responsável por forjar uma cultura nacional universal. Agora, nos últimos anos do século $\mathrm{XX}$, o que ontem era paradoxo, hoje é não só possível, como também desejado: a ideia de identidade passa a se harmonizar com a de pluralidade, e assim as culturas nacionais passam a buscar a polissemia. Se há muitas culturas dentro da cultura de um país, o estado-nação pode dizer que possui uma identidade multicultural, e isso passa a ser um signo de distinção.

Desde o filtro da igualdade - com a criação da ONU, da UNESCO e da Declaração Universal dos Direitos Humanos - que os conteúdos do período exótico-colonial do mercado da diferença eram criticados. No entanto, até a década de 1970, a solução posta em prática para erradicar a intolerância cultural que imperou até a Segunda Guerra foi o assimilacionismo. Países assimilacionistas eram aqueles que recebiam estrangeiros em seu território desde que, uma vez estabelecidos, esses recém-chegados abandonassem seu estilo de vida original e assimilassem os hábitos da cultura local que os hospedava ${ }^{26}$. Com o aparecimento do multiculturalismo no final dos anos 1980, essa condição assimilacionista desapareceu, e assim os imigrantes passaram a recriar seus velhos hábitos nativos no novo território. Mais do que liberar, os países anfitriões estimulavam seus imigrantes a cultivar suas culturas originárias no solo que os recebia. Quanto mais culturas diferentes existissem dentro de um território, mais multicultural aquele país era, e mais rica era sua identidade.

A língua sempre foi um espaço onde os projetos de identidade nacional se evidenciaram. Ao apresentar o período exótico-colonial do mercado da diferença, mostrei como - na ambição de erigir uma cultura nacional universal única, homogênea, pura e absoluta que fosse internamente indiferenciada e externamente diferente de tudo - os países se ocuparam em fazer com que apenas um único idioma fosse falado em todo o seu território. Cem anos depois, quando o multiculturalismo passou a dar as cartas - na

\footnotetext{
${ }^{26}$ Como vaticinou Bhabha, "A época de 'assimilar' as minorias em noções holísticas e orgânicas de valor cultural já passou." (2013, p. 44)
} 
tentativa de construir uma cultura nacional particular múltipla, heterogênea, híbrida e relativa que reunisse o mundo dentro de si e espalhasse seu interior pelo mundo - os países começaram a trabalhar para que muitas línguas fossem faladas dentro de suas fronteiras. Houve aqui uma revolução na ideia de identidade: no século XIX, ser monoglota era indicativo de civilização, enquanto ser poliglota era sinal de barbárie; já no fim do século $\mathrm{XX}$, muitos idiomas em um mesmo território nacional faziam com que o país tivesse uma identidade rica, enquanto aqueles onde apenas uma língua era falada passaram a ser tidos como provincianos, isolados, à margem dos fluxos de trocas globais. A Torre de Babel, antes tida como um castigo, passou a ser vista como uma dádiva.

\begin{abstract}
"A aspiração ao monolinguismo, visto como condição sine qua non para a concórdia entre os homens, na situação de globalização, transformou-se num pesadelo assustador." (ORTIZ, 2008, p. 64.)

"Há uma inversão das expectativas. O diverso é sinônimo de riqueza, patrimônio intocável. As noções de confusão e incompreensão, intrínsecas à polêmica anterior, são substituídas por outras, elas agora prezam o diverso e o plural. A ideia de unificação associa-se, então, a de pesadelo, o declínio da vida humana. (...) Ocorre assim a ressemantização do mito de Babel. Suas qualidades nefastas transmutam-se em positividade. Pluralidade significa riqueza e a proliferação de idiomas é o sinal de sua manifestação. Em contrapartida, o unilinguismo associa-se à ideia de restrição, ele empobreceria a mente e as experiências culturais." (ORTIZ, 2008, p. 38).
\end{abstract}

Said, no já citado posfácio, fala sobre a influência do multiculturalismo nas universidades durante os anos 1980. Segundo o autor, ao longo dessa década, intelectuais de grupos minoritários foram aparecendo na bibliografia dos cursos no lugar dos antigos "pensadores" orientalistas.

"Nos campi americanos e europeus da década de 1980, estudantes e professores trabalhavam assiduamente para expandir o foco acadêmico dos currículos. de modo a incluir textos escritos por mulheres, artistas e pensadores não europeus, subalternos. Isso era acompanhado por mudanças importantes na abordagem dos estudos de área, havia muito tempo nas mãos dos orientalistas clássicos e seus equivalentes de outros campos. A antropologia, a ciência política, a literatura, a sociologia e sobretudo a história sentiam os efeitos da crítica de amplo alcance às fontes, da introdução de novas teorias e da renovação da perspectiva eurocêntrica" (2013, p. 464).

No entanto, o modelo herdado dos anos 1970, composto por reconhecimento dos direitos das minorias, igualdade, e liberalismo econômico - ainda que tensamente conseguisse se equilibrar -, se revelou complexo demais para se abrigar sob a égide do multiculturalismo. Ao longo dos anos 1990, ficou claro que esse conceito não conseguia 
mais organizar as disputas entre diferença, igualdade e liberalismo, e assim, críticas ao multiculturalismo começaram a aparecer tanto da direita quanto da esquerda. No fundo, conversadores e progressistas estavam olhando para o mesmo problema, mas cada grupo temia consequências diferentes.

O problema central do multiculturalismo, percebido pela direita e pela esquerda, era o seguinte: países multiculturais recebiam culturas estrangeiras em seu território, porém, ao invés de penetrarem na nação, ou deixarem a nação penetrar nelas, ou se interpenetrarem, essas culturas se fechavam dentro delas mesmas. Estrangeiros em terras multiculturais montavam comunidades que nem adotavam a cultura local (como queria o assimilacionismo), nem deixavam que a cultura local conhecesse a cultura estrangeira, nem interagiam umas com as outras. Dessa forma, os países multiculturais se viam fragmentados por sistemas adiabáticos de culturas diferentes, ilhas de costumes que não dialogavam nem entre si nem com o país que as abrigava. Com o tempo, percebeu-se que o multiculturalismo produzia guetos ou nichos de culturas encerrados dentro de suas fronteiras que só interagiam consigo mesmos. Esse defeito do multiculturalismo ficou conhecido como tribalização. O diferente que estava fora era trazido para dentro, mas no interior das fronteiras do estado-nação as culturas permaneciam imiscíveis. Não havia dúvida que as grandes cidades americanas dos anos 1990 eram multiculturais, pois havia gente do mundo inteiro morando nelas; mas elas estavam divididas em bairro chinês, bairro latino, bairro dos negros, bairro dos gays, bairro judeu... e, obviamente, o grande bairro americano que os continha. Como esses guetos não interagiam nem entre si nem com a comunidade nacional, não havia diálogos entre os grupos. Por causa dessa falta de trocas, as comunidades não se conheciam. Mas a maior lástima dessa falta de conversa multicultural não era que uma cultura não pudesse adotar a outra, mas que juntas elas não pudessem dar ensejo a uma terceira coisa. A era universalista da unidade, da homogeneidade, da pureza e do absolutismo havia passado, portanto, o grande problema do multiculturalismo não era que o Outro não virava o Eu nem que o Eu não virava o Outro, mas sim que Eu e Outro não pudessem construir um terceiro elemento, um corpo novo que derivasse do seu contato mas que não se resumisse a nenhum deles isoladamente. Enfim, seja uma média, uma soma, uma mistura ou um vértice, o grande defeito do multiculturalismo foi que ele não produziu o híbrido. 
Por ser uma política própria da globalização, o multiculturalismo defendia a ideia de fluxos de troca em detrimento da concepção exótico-colonial de um binômio Eu/Outro cujos pares eram opostos entre si mas indiferenciados em si. Porém, infelizmente, o multiculturalismo não conseguiu estimular os fluxos. Seria desonesto dizer que tudo continuava como nos tempos do binômio, pois duas mudanças importantes foram conquistadas: primeiro, não havia mais um único e indistinto Outro, mas vários Outro's; segundo, a fronteira do território nacional havia sido rompida e os Outros estavam dentro do Eu. Mas, mesmo ocupando um só território, as culturas não se misturavam: houve uma superação da distância geográfica sem uma redução da distância simbólica. Novos fluxos não eram promovidos, os círculos estavam apartados como antes; só que ao invés de lado a lado, os Outros estavam dentro do Eu. O estranho estava mais variado, mais perto, mas ainda era estranho.

Como falei, essa tendência do multiculturalismo à tribalização foi mal recebida tanto pela direita quanto pela esquerda. Conservadores e progressistas perceberam que o multicultural não promovia trocas culturais dentro do país, pois fraturava o território nacional em diferentes grupos autocontidos. Ainda que seus diagnósticos sobre o multiculturalismo tenham sido idênticos, direita e esquerda temiam efeitos da tribalização bem diferentes.

A direita, defensora tanto do microcosmo do indivíduo quanto do macrocosmo da nação, temia que a centralidade que o multiculturalismo conferia à instância intermediária da tribo deslegitimasse os extremos individuais e nacionais. Legitimando esse mediador tribal em detrimento dos polos individual e nacional, o multiculturalismo encarnava um risco duplo.

Por colocar a tribo antes do indivíduo, o multiculturalismo abria uma margem para que pessoas dentro do grupo fossem oprimidas pela própria cultura. Como há uma anterioridade do grupo em relação a seus membros, tudo feito em nome do coletivo, ainda que ofenda o pessoal, estará respaldado. Um relativismo multicultural exacerbado faria com todos os excessos tribais fossem justificados como costumes locais que só diziam respeito ao grupo. Assim, essa maior tolerância cultural traria uma maior aceitação dos abusos dos grupos, criando-se dessa forma um mundo mais omisso e condescendente com a violência. Por exemplo: o multiculturalismo faria com que uma dada comunidade 
religiosa, sempre marginalizada, fosse agora vista com maior prestígio. No entanto, a nova legitimidade desse grupo poderia funcionar como uma venda para os costumes misóginos praticados em seu interior. Por respeito ao grupo religioso, deixaríamos ele desrespeitar suas mulheres; quer dizer: em nome da tribo, toleramos arbitrariedades contra indivíduos da tribo.

Por colocar o indivíduo também antes da nação, o multicultural criava outros problemas para a direita. Para os nacionalistas, as diferentes comunidades culturais fechadas que se espalhavam pelo território fragmentavam o país, impedindo o surgimento de uma identidade nacional comum, de leis gerais e de uma ideia unívoca e fraterna de povo. Por causa da subdivisão em guetos, a ideia de uma única e vasta nação carregada por uma mesma irmandade de homens, ainda que culturalmente diferentes, se diluía em tribos autocontidas. Nessa onda nacionalista contra o multicultural podemos notar a sobrevivência das velhas formas do período exótico-colonial do mercado da diferença que passaram pelo filtro da igualdade. Universalidade, natureza humana e nacionalidade ainda são sentimentos vivos na memória das pessoas. Entretanto, não se pode falar em uma continuidade total, pois o dogma da paz ensejado pelo filtro da igualdade anula a solução que seria posta em prática no período exótico-colonial: o genocídio das comunidades. Como o pacifismo do filtro da igualdade tenta impedir que esse sentimento descambe para a destruição das minorias, essa vontade de nação e de povo, ao invés de exterminar guetos, tende apenas a enfatizar as semelhanças entre as tribos em detrimento de atentar para as suas diferenças. Ainda que saibam que cada comunidade tem suas idiossincrasias culturais, os nacionalistas de direita acreditam que a busca por uma consanguinidade subjacente a todas essas diferenças é importante para que uma comunidade nacional possa surgir.

Os problemas que o multiculturalismo criou para o indivíduo e para a nação também incomodaram a esquerda, mas não da maneira que o fizeram com a direita. Para os setores mais progressistas da opinião pública, da cultura e da academia, a tendência tribal do multiculturalismo de criar comunidades autocontidas também foi recebida com maus olhos.

Ainda que essas tribos fossem recortadas por diferenças internas, percebeu-se que, de fora, as comunidades eram vistas como um espaço indiferenciado e nivelado. Sabia-se que os grupos eram diferentes de tudo o que estava fora deles, mas parecia que eles eram 
indiferenciados lá dentro. Enfim, os guetos começaram ser estereotipados. Essa estereotipia prejudicava os indivíduos porque, devido a essa planificação identitária, apenas aquelas pessoas que se encaixavam na imagem caricata do membro daquela comunidade eram vistas como tais pelos de fora. Para pertencer "de verdade" a um grupo era preciso encarnar todo o arsenal carnavalesco de signos que indicasse que se pertencia àquele grupo. Satisfazer as pré-noções clichês dos membros de fora da comunidade acerca do que ela seria virou condição necessária para que indivíduos passassem a ser tidos como exemplares de seus grupos. Os componentes de comunidades culturais (e elas próprias) viraram corpos sem história congelados em uma caricatura da própria tradição. Mudar hábitos ou agregar valores externos passou a ser sinônimo de "traição" e um indicativo de que se estava "perdendo a cultura" ou a "essência". Quem se arriscava a sair da rígida moldura do clichê era desautorizado enquanto membro daquela comunidade. Enfim, os membros das comunidades estavam sendo exotizados. Para a esquerda, a exotização era um típico problema surgido do isolamento tribal provocado pelo multiculturalismo. Se as comunidades estivesses mais misturadas entre si e com a sociedade anfitriã, certamente essas imagens estereotipadas não existiriam.

$\mathrm{Na}$ esteira desse problema, a falta de contato das culturas entre si e com a comunidade nacional acabou aumentando o preconceito, a intolerância e a discriminação. Em pouco tempo, as tribos criadas pelo multiculturalismo viraram guetos marginalizados e os moradores dessas comunidades começaram a ser vistos com maus olhos. Para resolver esse cenário, não bastava que as culturas se aproximassem geograficamente (elas já ocupavam as mesmas cidades), mas simbolicamente. Era preciso haver diálogo, trânsito, troca, enfim, era preciso haver os fluxos de intercâmbio cultural próprios à globalização; mas, infelizmente, esses deslocamentos não viriam de uma agenda tribalista como o multiculturalismo.

Outra limitação do multicultural foi sua natureza ideológica. Para alguns segmentos, o multiculturalismo era uma alegria que mascarava problemas maiores. Governantes se satisfaziam com o fato de que muitas culturas moravam em seu país, mas negligenciavam as condições precárias em que essas culturas se encontravam e o forte preconceito que sofriam. Além das assimetrias propriamente culturais, havia as diferenças econômicas que acabavam sendo eclipsadas por essa festa da multiplicidade cultural. 
O incômodo da direita e da esquerda com os novos tempos deixava claro: no multiculturalismo não havia lugar para o híbrido. A tribalização, essa tendência do multiculturalismo de criar redutos culturais adiabáticos, produziu ilhas de cultura fixas e incomunicáveis. Como as culturas não dialogavam nem entre si nem com a nação, não havia troca de experiências e, sem essa troca, a multiplicidade de culturas não conseguiu ensejar nem algo que fosse a soma de suas partes, nem uma média entre elas, nem uma síntese, nem algo que as arregimentasse, nem que fosse subjacente a elas, enfim, não houve hibridismo. O fracasso de produzir o híbrido, ou de abrigar os híbridos existentes, trouxe todos esses problemas apontados por conservadores e progressistas: opressão do indivíduo, esfacelamento da nação, exotização, descriminação, etc. Para que esses problemas fossem contornados era preciso abandonar o multiculturalismo e encontrar uma narrativa que desse conta do híbrido.

A busca pelo híbrido trouxe teorias como a de Homi Bhabha para o centro do debate. Para Bhabha, o contato entre o Eu e o Outro produz um terceiro espaço, uma zona intersticial ambivalente entre colonizador e colonizado onde cada um dos dois tenta imputar seus respectivos sentidos.

Durante o período exótico-colonial do mercado da diferença, essa área fronteiriça foi dominada pelo Eu, cenário que garantiu sua supremacia sobre o Outro. Quando apresentei esse período, falei que, para a mentalidade colonial, a função do Outro era ratificar a idiossincrasia do Eu. Para que esse jogo se realizasse, o Outro não poderia nem estar muito perto do Eu, para não se confundir com ele, nem longe demais, para que não o referenciasse, mas sim fixado em uma posição ambivalente entre perto e longe, ou seja, em um ponto dentro da exterioridade do colonizador. Pregado nessa ambivalência entre proximidade e distância, o Outro funciona como uma espécie de simétrico invertido ou negativo do $\mathrm{Eu}$, e, desse modo, já que o ser do colonizado não passa do não-ser do colonizador, o Outro se transforma em uma mera linha que assinala a realidade do Eu. Esse espaço ambivalente entre perto e longe onde o Eu fixa o Outro para que ele sublinhe sua especificidade é, justamente, o espaço do exótico. O exótico nada mais é que o nosso duplo invertido, a figura que conhecemos como "o desconhecido", a novidade pela qual já se espera, a imagem que cumpre todas as nossas expectativas do que uma surpresa deva ser, enfim, um corpo ambivalente entre perto e longe que, em sendo exatamente o que não 
somos, positiva a nossa existência se negativando. Pois bem, o terceiro espaço intersticial entre colonizador e colonizado sobre o qual Bhabha fala é exatamente essa área de ambivalência entre perto e longe onde, durante o período exótico-colonial do mercado da diferença, o Eu fixou o Outro para fazer dele uma inversão exótica que jogasse luz sobre sua existência.

Hoje, quando um segundo período do mercado da diferença é gestado, o colonizado deve virar o jogo, tomando do colonizador esse terceiro espaço intersticial ambivalente que ele governou durante o período exótico-colonial do mercado da diferença. No passado, para conquistar esse terreno, o Eu usou uma metáfora, sendo assim, para fincar no presente sua bandeira lá, o Outro deve usar uma catacrese. Entendamos a diferença.

Uma metáfora é um termo figurado secundário usado para se referir a algo; já a catacrese ocorre quando a metáfora desliza para dentro do objeto que ela designava e passa a ser o próprio nome literal daquela coisa. Por exemplo: chamar o apoio da cadeira de "braço", inicialmente, é uma metáfora, pois aquilo não é um braço. Contudo, como "braço" parece ser o nome mais adequado para se referir àquilo, o nome do objeto passa a ser braço mesmo: isso é uma catacrese. É nesse momento em que a figura se naturaliza e a imagem secundária vira a literalidade primária que a metáfora vira catacrese. Retomando daí: para conquistar o terceiro espaço ambivalente entre Eu e Outro, o Eu aplicou a metáfora do exótico ao Outro. "Exótico" não é nem uma categoria nativa nem um nome de batismo, mas uma expressão controlada pelo Eu para fixar o Outro no epitélio ambivalente que disputam. Por ser figurativo, secundário e externo, o "exótico" é uma metáfora que o Eu inventou para aprisionar o Outro. Contra a captura metafórica, o Outro deve acionar uma libertação catacrética e assim conquistar esse terceiro espaço de conurbação. Para Bhabha, nada seria mais ineficiente que tentar esquecer que fomos chamados de exóticos, empurrando esse sentido para longe, seja no tempo, seja no espaço. Muito pelo contrário: a saída catacrética consiste em trazer o sentido para perto de si e então dominá-lo e ressignificá-lo para que o imputemos da nossa maneira. Essa é a passagem da metáfora para a catacrese: fazer a ideia de exótico sair da boca do europeu e passar para a narrativa do colonizado. Em nossa posse, a palavra pode significar o que nós quisermos, inclusive nada. Nós não nascemos nem quisemos ser exóticos, mas já que disseram que éramos, tomemos para nós esse sentido e digamos nós, os exóticos, o que ser exótico significa. A 
passagem da metáfora para a catacrese é um deslizamento de sentido revolucionário, pois faz com que o comando do terceiro espaço ambivalente passe do colonizador para o colonizador. Depois desse roubo simbólico, a fronteira entre o Eu e Outro finalmente tem um novo dono.

Metáfora e catacrese sempre se referem à mesma palavra (no nosso caso, exótico), portanto, o que vai decidir se o que está sendo acionado é uma figura de linguagem ou a outra não é o termo evocado, pois este é sempre o mesmo, mas a voz que o suscita. No discurso do europeu, o exótico é um sentido metafórico imposto de fora, mas, quando dito pelo colonizado, o mesmo exótico escorrega para dentro do objeto que designava, e, assim, opera catacreticamente. A diferença entre metáfora e catacrese, então, não é de conteúdo, mas de uso, de forma de enunciação, de estratégia. A catacrese toca o tecido do exótico pelo avesso, e altera pelo lado de cá a figura que se vê pelo lado de lá.

No entanto, há um sério obstáculo histórico que o colonizado deve superar para se apropriar catacreticamente da metáfora do exótico. O problema é o seguinte: para conquistar o terceiro espaço ambivalente da fronteira, o europeu plantou a metáfora do exótico no século XIX e depois disso regou-a por muito tempo. Diante dessa antecedência, como os colonizados podem hoje virar um jogo que já estão perdendo há mais de um século? Que chance uma jovem catacrese tem contra uma experiente metáfora? Bhabha vai buscar a resposta para essas perguntas na Gramatologia de Derrida. Naquela obra, o pensador já havia afirmado: "O presente é aquilo a partir do que acredita-se poder pensar o tempo, apagando a necessidade inversa: pensar o presente a partir do tempo como diferência." (DERRIDA, 2006, p. 202). Ou seja, para Derrida, não se deve pensar o presente à luz do passado, mas pensar o passado à luz do presente. Se olharmos para hoje pela lente do ontem, a história parecerá um grande fatalismo natural, pois o ímã do telos sempre conduzirá o caminho para si; mas se trocarmos o sinal da equação e enxergamos o ontem pelo prisma do que somos hoje, o que veremos será um rastro de arbitrariedades. É inspirado por essa inversão derridiana que Bhabha se pergunta "Quem define o presente a partir do qual falamos?" (2013, p. 77).

Portanto, o primeiro passo para que a metáfora vire catacrese e o controle do terceiro espaço ambivalente saia do Eu e passe para o Outro é mudar o vetor de análise histórica. Depois de reeducado o olhar, ensina Bhabha, o que o colonizado deve fazer para 
compensar a desvantagem histórica que sua catacrese tem em relação à metáfora europeia é empregar a estratégia do presente disjuntivo, um uso bastante inovador da ideia de suplemento originário. O colonizado deve fraturar a sucessão linear do tempo colonial para liberar o presente desse fluxo. Para haver um presente disjuntivo deve-se abrir no presente uma fenda através da qual se retornará ao passado com um olhar revisionista capaz de reconstruir o percurso que nos trouxe de lá até o agora onde a cesura se operou, de maneira que possamos nos abrir para um futuro diferente daquele que teríamos caso a disjunção do presente não fosse realizada. Pela rachadura aberta no presente, nós retornamos ao oco de onde o passado partiu e refazemos o caminho até o presente quebrado. Mas não refazemos esse percurso da mesma forma com que ele foi trilhado pela primeira vez, pois, já que se recupera esse passado à luz de um presente que já passou por ele, agora essa segunda trajetória será traçada com um olhar crítico em relação à primeira, e assim emergiremos mudados pelo buraco do presente pelo qual entramos, despertando desse jeito para um futuro novo. Aliás, pode-se até dizer que a segunda trajetória propriamente dita é igual à primeira, mas a diferença é que agora somos nós, e não eles, que vamos à frente. Dessa vez são os Outros, os colonizados que lideram o caminho, dizendo o que aquele percurso foi para eles. Quer dizer: a história que se atravessa é a mesma, a diferença é que se da primeira vez ela foi protagonizada por colonizadores metafóricos, agora quem comanda a expedição são colonizados catacréticos. As metáforas que o Eu imputou ao Outro na primeira viagem não serão de jeito nenhum esquecidas, muito pelo contrário, serão lembradas para que sejam reapropriadas, ressignificadas, catacretizadas. A história da colonização não deve ser apagada, mas reescrita pelos colonizados. Reviver o passado simplesmente é reviver para fazer de novo, é nostalgia metafórica de dominadores, mas reviver o passado à luz do presente é reviver para fazer diferente, é revolução catacrética de dominados. Não se quer inventar uma outra história, mas sim uma história Outra.

A tática do presente disjuntivo de abrir uma cisão no agora para que se possa acessar o antes, refazendo criticamente o caminho de lá para cá, apropriando-se catacreticamente de metáforas para que se possa erigir um novo depois não é de forma alguma uma simples viagem no tempo, pois em nenhum momento se abandona o presente para que se chegue ao passado, pelo contrário: fratura-se a horizontalidade contínua da história colonial para que o presente se liberte desse causalidade e possa revisitar o início que o criou. Não se troca o presente pelo passado, pois é o próprio presente que vai ao 
passado ressiginificá-lo para que se ressignifique. Mas, para que isso aconteça, como comentei, é preciso que se mude a maneira com que se encara a história: não ver o hoje pelo ontem, mas o ontem pelo hoje. Como se pode ver, assim como em Derrida, há aqui a defesa de uma circularidade simultânea em detrimento de uma linearidade sucessiva: mudar a postura diante do presente para que se possa voltar ao passado para poder alterá-lo para que se possa ter um novo presente para que... Sendo assim, o que Homi Bhabha faz é criar uma espécie de modernidade pós-colonial, quer dizer, uma espacialização do presente da colônia, fazendo dele um ponto dentro e fora do tempo, equidistante a todas as épocas, uma topografia a partir da qual se pode acessar quaisquer períodos, e, principalmente, revisá-los.

"Ser parte de um tempo revisionário, um retorno ao presente para redescrever nossa contemporaneidade cultural; reinscrever nossa comunidade humana histórica; tocar o futuro em seu lado de cá. Nesse sentido, então, o espaço intermediário 'além' torna-se um espaço de intervenção no aqui e no agora" (BHABHA, 2013, p. 177)

Diante disso fica claro que o presente disjuntivo de Bhabha funciona exatamente como um suplemento originário de Derrida, pois a cisão operada no agora faz com que o presente se antecipe ao passado, sem precisar deixar de sucedê-lo. Ainda que venha depois, o presente se anexa ao passado, e assim o substitui, sendo ele mesmo a origem do percurso que o ensejou. Quando fala em criar um novo tempo, na verdade o autor se refere a criar uma nova maneira de ver o tempo, uma nova temporalidade, uma reinvenção da história a partir do presente. Para que tudo mude de agora para frente, é preciso antes que tudo mude de agora para trás, e para que essa dupla revolução se opere, primeiramente é preciso que tudo mude de agora. Em outras palavras, Bhabha nos ensina que é preciso ser póscolonial no presente para que saibamos que fomos colonizados no passado e assim possamos nos emancipar no futuro. Novamente: um rasgo no presente que o leva ao passado, mudando-o, e revoluciona o futuro. Ontem dominados, hoje pós-dominados, amanha livres. Portanto, para o autor, é justamente a nossa condição anterior de colonizado que poderá nos descolonizar. A pior coisa que podemos fazer pela nossa liberdade é esquecermos nossa herança colonial, pois só quem esteve preso nas masmorras da metáfora conhece a chave libertadora da catacrese.

"O fato de vir 'depois' do original ou como 'acréscimo' dá à questão suplementar a vantagem de introduzir um sentido de 'secundariedade' ou de atraso na estrutura do original. A estratégia suplementar sugere que o ato de acrescentar 
não necessariamente equivale a somar, mas pode, sim, alterar o cálculo. Conforme sugere sucintamente Gasché, 'os suplementos... são sinais de adição que compensam um sinal de subtração na origem.' A estratégia suplementar interrompe a serialidade sucessiva da narrativa de plurais e de pluralismo ao mudar radicalmente seu modo de articulação. Na metáfora da comunidade nacional como 'muitos-como-um', o um é agora não apenas a tendência de totalizar o social em um tempo homogêneo e vazio, mas também a repetição daquele sinal de subtração na origem, o menos-que-um que intervém com uma temporalidade metonímica, iterativa." (BHABHA, 2013, p. 251).

"O trabalho fronteiriço da cultura exige um encontro com 'o novo' que não seja parte do continuum de passado e presente. Ele cria uma ideia do novo como ato insurgente de tradução cultural. Essa arte não apenas retoma o passado como causa social ou precedente estético; ela renova o passado, refigurando-o como um 'entre-lugar' contingente, que inova e interrompe a atuação do presente. O 'passado presente' torna-se parte da necessidade, e não da nostalgia de viver." (BHABHA, 2013, p. 29)

Retomando o que se disse até aqui sobre Bhabha, o quadro que se tem é o seguinte: do contato entre o Eu e o Outro surge um terceiro espaço no meio deles, um interstício ambivalente de disputas simbólicas. O polo do binômio que definir o sentido dessa fronteira conta a história da díade, dando a tônica da relação entre os pares. Para conquistar esse terceiro espaço ambivalente, o Eu metaforizou o Outro, fixando-o como exótico. Se o metaforizado negligenciar a manobra de seu duplo, a tendência é que esse estado de coisas se perpetue. Sendo assim, para virar o jogo, o metaforizado deve lançar mão da antimetáfora da catacrese, quer dizer, apropriar-se do sentido que o Eu lhe atribuiu e ressignificá-lo à sua maneira. Para compensar sua desvantagem cronológica, o metaforizado deve usar esse efeito de atraso a seu favor, recorrendo à ideia de suplemento originário. Investido dessa missão de chegar ao rastro onde a origem arbitrariamente se situa, o metaforizado se suplementa ao fluxo que o criou, e assim o substitui. Para tal, ele abre um rasgo em seu presente que o habilita a voltar ao oco da história que o fez, e assim percorrê-la criticamente, apropriando as metáforas de maneira catacrética para abrir novas possibilidades de futuro.

Portanto, tanto um lado quanto o outro do binômio disputam esse terceiro espaço ambivalente entre eles, essa fronteira que o autor chama de "incerteza narrativa do entrelugar da cultura" ou "intervalo articulado" (BHABHA, 2013, p. 209) . A diferença é que enquanto o $\mathrm{Eu}$ opera por metáfora, o Outro procede por catacrese. Primeiramente a fronteira esteve sob controle do $\mathrm{Eu}$, que acionou a metáfora do exótico para tirar o Outro do polo do binômio que ele ocupava e fixá-lo nesse terceiro espaço ambivalente. A teoria 
de Bhabha não é de forma alguma uma tentativa de desfazer esse deslocamento, ou seja, de devolver o Outro a sua posição original, empurrando-o dessa fronteira para onde o Eu o trouxe de volta para o extremo de onde o Eu originalmente o arrancou, fazendo assim com que o Outro volte a ser o que era antes da captura metafórica, como se a arbitrariedade do Eu nunca tivesse sido cometida. Muito pelo contrário, o Outro não deve regressar à sua condição original e fingir que nunca foi sequestrado, mas sim permanecer nesse terceiro espaço ambivalente onde o Eu o fixou com a metáfora do exótico. A única diferença é que a metáfora do exótico que o Eu usou para prender o Outro nessa fronteira deve ser convertida em uma catacrese e, assim, o Outro permanecerá no terceiro espaço ambivalente não por lá ter sido aprisionado pelo $\mathrm{Eu}$, mas porque, depois de fazer a metáfora virar catacrese, agora é ele que controla esse interstício. O Outro continua no terceiro espaço ambivalente, o que muda é sua condição nessa fronteira: antes, fixado em um terreno controlado pelo Eu através da metáfora do exótico; agora, libertado em uma zona dominada por ele mesmo devido à apropriação catacrética. A passagem da metáfora para a catacrese marca a troca de comando do terceiro espaço: quando esse deslizamento ocorre, a fronteira ambivalente entre Eu e Outro sai das mãos do primeiro e passa para as do segundo.

A pergunta que surge é: depois de ser arrancado da posição que ocupava no binômio, de ser fixado arbitrariamente no terceiro espaço ambivalente entre perto e longe pela metáfora exotizante do $\mathrm{Eu}$, de disjuntar o presente, voltar ao passado, refazer o caminho e emergir catacreticamente no disjunte do presente em que mergulhou, o Outro volta a ser o que era antes de todos esses processos? Depois de passar por uma metáfora e uma catacrese, o Outro ainda é o Outro de sempre como se nada tivesse acontecido? É claro que não. Mas esse retorno e essa amnésia nunca foram a intenção de Bhabha. Apagar as marcas da metáfora do exótico e restituir o Outro à sua posição no velho binômio colonial só faria com que a história se repetisse e o Eu continuasse a dar as cartas no terceiro espaço. Ignorar dominações faz com que elas se perpetuem, por conta disso, Bhabha não quer que esqueçamos nem que regressemos, mas sim que lembremos e sigamos. Nós temos sim que deixar de ser o exótico metaforizado pelo Eu, mas isso não significa retornar à posição de Outro que ocupávamos antes da exotização metafórica, nem fingir que ela nunca aconteceu. Nem ir para um futuro sem memória nem voltar para um passado superado: há um terceiro caminho. O Outro nunca quis que o Eu o metaforizasse 
como exótico, fazendo com que esse gesto seja portanto um ato violento que não deveria pertencer à nossa história. Mas, uma vez perpetrado, essa arbitrariedade passa sim a fazer parte de nossa biografia. Já que não podemos voltar há um tempo anterior a metaforização do exótico nem fingir que ela não aconteceu, aceitemos essa condição. Mas "aceitar essa condição" não significa passivamente se deixar exotizar, pelo contrário, mas admitir que um sentido de exotização foi imposto de fora a nós, para que, reconhecido esse cenário, possamos nos apropriar desse sentido. É preciso perceber que se foi exotizado pelo Eu para que o significado desse conceito deixe de nos ser metaforicamente imposto por ele e passe a ser catacreticamente definido por nós. Para isso não podemos voltar nem esquecer, mas seguir e lembrar. Quando faz com que a metáfora do exótico que o colonizador inventou para designá-lo deslize para dentro de si em uma catacrese, o Outro evidencia para o Eu, na própria carne, as marcas da arbitrariedade de sua metaforização. A catacrese vira um espelho para a metáfora, fazendo com que ela tenha que se confrontar com a própria violência. Reza a lenda que, ao verem o quadro de Guernica, soldados espanhóis perguntaram a Picasso "quem fez isso?", ao que o pintor teria respondido "foram vocês": fazer a metáfora ver a própria monstruosidade, isso é catacrese. Ao fazer o olhar metafórico do Eu se voltar para si mesmo, o espelho catacrético do Outro faz o violento encarar a própria violência, deslegitimando-se e perdendo o controle sobre o terceiro espaço.

Que bom seria não ter sido metaforicamente exotizado, mas o fato é que fomos, e a superação desse cenário não virá nem por um retorno há um tempo anterior à exotização nem pelo esquecimento dessa captura. Fomos metaforicamente exotizados e nunca mais voltaremos a ser o que éramos, nem jamais seremos o que poderíamos ser se isso não tivesse acontecido, portanto, a saída desse cenário não está na regressão ou no recalque. Se não há volta, nem apagamento, onde fica a saída, então? A saída é arrombar a porta por dentro, abraçar o sentido que o Eu inventou para se referir a nós, não para passivamente aceitá-lo, mas para ativamente dele se apropriar, para darmos a nossa versão do que eles dizem que nós somos, transformar a metáfora em catacrese. Fazer a exterioridade da metáfora se internalizar na catacrese é inscrever em nós a história da violência que eles nos impuseram. Catacretizar a metáfora é fazer com que nós, hoje, sejamos a presentificação de todo o processo de arbitrariedade a que eles nos submeteram. $\mathrm{O}$ presente do nosso ser é a compilação dessa cruzada, todos esses séculos de violência 
exibidos hoje. Os nossos corpos atuais, mutilados, incompletos, inadequados, contam a história da barbárie que eles nos impuseram. Tudo o que temos que fazer é aparecer diante deles para que se confrontem com a própria bestialidade. Olhando-nos violentados eles têm que olhar a própria violência e, principalmente, admiti-la, deslegitimando o controle que têm sobre o terceiro espaço ambivalente.

Para acabar com a exotização metafórica, nem voltar para antes dela, nem esquecêla, mas apropriá-la catacreticamente. Eu não queria ter sido metaforizado como exótico por você, mas fui, e agora estou diante de você como tal, admita que fez isso comigo. Essa é a via da liberdade para Bhabha: o caminho da descolonização não está no regresso précolonial, nem no esquecimento a-colonial, mas na catacrese pós-colonial. O pós-colonial não nos emancipa da colonização porque nos traz para antes dela ou nos faz esquecê-la, pelo contrário, ele nos leva para depois dela e nos faz lembrá-la, ele a internaliza, conceitua-a como um corpo um dia externo que passou a ser parte constitutiva nossa, devendo portanto ser conceituado por nós, ele catacretiza a metáfora. Eu não queria ser colonizado pelo europeu, eu jamais voltarei a ser o que era antes dela nem nunca serei o que poderia ser se ela não tivesse vindo, mas o fato é que ela veio, e agora essa violência contra o que seria minha biografia passa a fazer parte da minha biografia, passa a ser a minha biografia, então deixa que eu conto. Enquanto é visto como uma interferência metafórica europeia à história da América, o episódio da colonização é tido como algo fundamentalmente da Europa, devendo portanto ser por ela narrada. Mas, se deixa de ser encarada como uma metáfora europeia para se referir a América e passa ser pensada como uma catacrese americana que ela aciona para pensar a si mesma, então a colonização não mais será conceituada como um capítulo da história europeia, mas sim como uma passagem da história da América, devendo então ser por ela contada. Um dia a colonização foi um ato externo que interferiu na nossa vida, mas, em acontecendo, ela deixou de ser só uma invasão à nossa vida e passou a ser nossa vida propriamente dita, deixou de ser uma externalidade deles e virou uma internalidade nossa, por isso somos nós, e não eles, que temos que falar sobre ela. A minha história é a história do que o europeu fez comigo, mas quem vai contar essa história sou eu. Eu não posso mudar a história, mas posso mudar a voz que narra a história, e agora é minha vez. Nem voltar, nem esquecer, seguir e lembrar: transformar a metáfora em catacrese. 
Mas que nome se dá a esse personagem catacrético? O que é esse pós-colonial que não é nem o colonizado, nem o que havia antes da colonização, nem o que haveria se a colonização não tivesse existido? A essa figura complexa, Homi Bhabha dá o nome de híbrido. O híbrido não é o que voltou nem o que esqueceu, é o que seguiu e lembrou, é o que foi metaforizado pelo $\mathrm{Eu}$, disjuntou o presente, voltou ao passado, refez o percurso e emergiu catacreticamente no presente onde mergulhou. Depois disso tudo, ele não volta a ser o que era antes, nem continua sendo o que é, nem se torna o que poderia ser: ele é o híbrido.

"O hibridismo é a reavaliação do pressuposto da identidade colonial pela repetição de efeitos de identidades discriminatórios. Ele expõe a deformação e o deslocamento inerentes a todos os espaços de discriminação ou dominação. Ele desestabiliza as demandas miméticas ou narcísicas do poder colonial, mas confere novas implicações a suas identificações em estratégias de subversão que fazem o olhar do discriminado voltar-se para o olho do poder. Isto porque o híbrido colonial é a articulação do espaço ambivalente onde o rito do poder é encenado no espaço do desejo, tornando seus objetos ao mesmo tempo disciplinares e disseminatórios - ou, em minhas metáforas mistas, uma transparência negativa." (BHABHA, 2013, p. 301)

Depois de sequestrado, metaforizado como exótico no terceiro espaço ambivalente, disjuntado o presente, retornado ao passado, caminhado de novo e reaparecer no presente catacrético, o Outro renasce como híbrido. O híbrido não é nem o que voltou nem o que esqueceu, é o que seguiu e lembrou; não é o mesmo que era antes desses deslocamentos nem o que apagou suas marcas, é uma outra coisa. O híbrido não sai do estado colonial pelo regresso pré-colonial ou pelo recalque a-colonial, mas pela catacrese pós-colonial. $\mathrm{O}$ híbrido não é mais o nativo do descobrimento, nem virou o que poderia ter sido não fosse descoberto, nem se transformou no estrangeiro que o descobriu, mas ele traz no corpo marcas de todos esses episódios, por isso é híbrido. O híbrido não mora mais na "terra à vista", mas também não conseguiu ser arrastado para metrópole, ele ficou no meio, na fronteira, no terceiro espaço ambivalente.

O terceiro espaço ambivalente que se abre depois do contato entre o Eu e o Outro é o lugar do híbrido. O híbrido não é o Eu que está no metrópole, nem o Outro que mora na colônia, mas o amálgama que habita a fronteira entre eles. Essa mesma posição limítrofe que o híbrido ocupa já foi ocupada pelo exótico, mas as circunstâncias em que cada um está lá são muito diferentes: o terceiro espaço ambivalente é o local em que o exótico é aprisionado por uma metáfora e que o híbrido é emancipado por uma catacrese. Exótico e 
híbrido moram na fronteira, mas enquanto o primeiro está subjugado nesse espaço, o outro lá reina. $\mathrm{Na}$ verdade, exótico e híbrido não são duas coisas, mas dois momentos de uma mesma trajetória, ou melhor, dois modos de ler a mesma história, um metafórico, o outro catacrético. Toda catacrese um dia foi metáfora, assim como todo híbrido liberto já foi um exótico aprisionado. Mas, operada a catacretização híbrida da metáfora exótica, o controle do terceiro espaço ambivalente finalmente muda. A conquista dessa fronteira através da catacretização híbrida da metáfora exótica encena a luta deleuziana das máquinas de guerra nômades contra os aparelhos de captura de Édipo: desterritorializar o território para reterritorializá-lo, fazer rizoma na árvore, decodificar o código e sobrecodificá-lo. No mesmo lugar onde havia a prisão metafórica do exótico será construído o palácio catacrético do híbrido: o terceiro espaço ambivalente, a fronteira. Essa fronteira é a morada do híbrido. O híbrido não é um ser nem outro, nem mora nesse ou naquele lugar; ele é um entre-ser que habita um entre-lugar, sempre livre. Estando no meio das coias ele está em casa.

\footnotetext{
"As culturas vêm a ser representadas em virtude dos processos de iteração e tradução através dos quais seus significados são endereçados de forma bastante vicária a - por meio de - um outro. Isto apaga qualquer reivindicação essencialista de uma autenticidade ou pureza inerente de culturas que, quando inscritas no signo naturalístico da consciência simbólica, frequentemente se tornam argumentos políticos a favor da hierarquia e ascendência de culturas poderosas. É nesse intervalo híbrido, em que não há distinção, que o sujeito colonial tem lugar." (BHABHA, 2013, pp. 105, 106).
}

Mas o que se hibridiza no híbrido não são culturas, geografias ou quaisquer morfologias, mas tempos, memórias e velocidades históricas. Como Bhabha espacializa temporalidades, somos levados a acreditar que o híbrido é aquele que gosta de rock e samba, mas é muito mais sofisticado que isso. Não são coisas híbridas, mas tempos híbridos, relações híbridas. O que se hibridiza é a história do nativo descoberto, com a do descobridor, com a da colonização, com a da libertação... são esses compassos e seus olhares. O híbrido reúne tudo isso dentro de si. Híbrido não é soma, é síntese. Hibridizar não é enfileirar purezas, reunir líquidos imiscíveis dentro de uma mesma garrafa, isso é multiculturalismo, mas cruzar elementos em um amálgama que não se resume a nenhum deles isoladamente, mas do qual todos participam.

Para Bhabha, esse híbrido catacrético pós-colonial habitando no terceiro espaço ambivalente é a cara do novo cosmopolitismo, a vanguarda da mundialização. Durante 
muito tempo o mundo foi pensado à luz de uma cultura nacional universal ou de uma ecumênica reunião de diferes culturas irredutíveis a um mesmo termo, agora é chegado o momento de ver o mundo pelo prisma intersticial do híbrido. A compreensão mais acurada sobre o mundo não vem de uma nação colonial que pensa reunir em sua cultura um espírito universal, nem de uma soma que acomoda todas as culturas desde que não se misturem, mas sim daquele híbrido que se apropriou catacreticamente das metáforas que o aprisionavam, daquele que foi sequestrado e se libertou não por ter voltado para casa, mas porque tomou o controle do cativeiro: o imigrante, o diaspórico, o nômade. A voz habilitada a falar do mundo já foi a do homem europeu que continha o universal, já foi a do acúmulo tribal, hoje ela é a do híbrido. O mundo não deve ser visto pelo prisma do centro, nem da periferia, mas das fronteiras híbridas entre eles, pois são nessas linhas finas de contato entre as coisas que as coisas são definidas. $\mathrm{O}$ mundo não se revela em seus espaços, mas nas frestas entre eles, e quem mora lá são os híbridos. O lugar de enunciação privilegiado para se falar do mundo hoje não é um lugar mas um entre-lugar, uma fronteira híbrida. O cosmopolita ou o mundial do nosso tempo não é aquele que mora na nação que encerra em si o universal ou que recepciona as outras culturas do mundo em claustros autocontidos, mas o híbrido que mora no terceiro espaço fronteiriço ambivalente. Bhabha deixa isso claro quando fala o que significa atualmente o projeto de uma literatura mundial:

\begin{abstract}
"O estudo da literatura mundial ser o estudo do modo pelo qual as culturas se reconhecem através de suas projeções de 'alteridade'. Talvez possamos agora sugerir que histórias transnacionais de migrantes, colonizados e refugiados políticos - essas condições de fronteira e divisas - possam ser o terreno da literatura mundial, em lugar da transmissão de tradições nacionais, antes o tema central da literatura mundial. $O$ centro de tal estudo não seria nem a 'soberania' de culturas nacionais nem o universalismo da cultura humana, mas um foco sobre aqueles 'deslocamentos sociais e culturais anômalos'" (BHABHA, 2013, p. 36)
\end{abstract}

Como se pode ver, para Bhabha o problema das coisas deve ser substituído pela questão da relação entre as coisas, quer dizer: parar de discutir o puramente nacional para que se veja a fronteira entre as nações, pois são as mediações entre as ontologias realizadas nesses perímetros que dizem o que elas são. Parar de olhar para as essências para que se preste atenção nas zonas cinzentas entre elas que as diluem.

É por olhar criticamente para substancializações de quaisquer natureza que a teoria de Bhabha ataca tanto o colonialismo quanto o multiculturalismo. As críticas ao 
colonialismo são óbvias: há no texto uma denúncia da violência do projeto imperial e das consequências nefastas que ele traz; uma rejeição da organização binomial do mundo presente na defesa da existência de um terceiro espaço fronteiriço; e, em linhas gerais, um descontentamento com as ideias universais de unidade, homogeneidade, pureza e absolutismo.

"Os próprios conceitos de culturas nacionais homogêneas, a transmissão consensual ou contígua de tradições históricas, ou comunidades étnicas 'orgânicas' - enquanto base do comparativismo cultural - estão em profundo processo de redefinição. (...) A própria ideia de uma identidade nacional pura, 'etnicamente purificada', só pode ser atingida por meio da morte literal ou figurativa, dos complexos entrelaçamentos da história e por meio das fronteiras culturalmente contingentes da nacionalidade moderna." (BHABHA, 2013, p. 25)

Mas Bhabha também se separa drasticamente do multiculturalismo, pois enquanto essa doutrina prega a soma, o fechamento e a conservação, o autor defende a síntese, a abertura e a mudança. Como se falou antes, o multiculturalismo promove a coexistência de diversas culturas diferentes, mas, embora próximas espacialmente, essas culturas se fecham em sistemas adiabáticos autocontidos invisíveis uns aos outros. As fronteiras multiculturais não são linhas borradas ou zonas conurbadas de intercâmbio, mas sólidas muralhas intransponíveis que se prestam a conservar o estado original dessas ilhas, mantendo-as como sempre foram, como se ainda vivessem em um tempo anterior à migração. Como se viu aqui, Bhabha vai para muito longe desse pensamento: para o autor, essa reunião de partes que não se misturam deve se amalgamar em uma síntese híbrida, uma terceira coisa que não é a ampliação de nenhuma delas isoladamente mas que agrega elementos de todas. Para isso, é preciso que as fronteiras entre as culturas deixem de ser superfícies blindadas e virem faces porosas que permitam o diálogo e a troca. Ao final desse diálogo, o corpo que se tem não é nem preservação da situação original da cultura, nem sua transformação na cultura com quem dialogou, mas uma síntese híbrida inédita que reúne elementos de todas as partes do diálogo, sem ser a maximização fiel de nenhuma delas.

"O reconhecimento teórico do espaço-cisão da enunciação é capaz de abrir o caminho à conceitualização de uma cultura internacional baseada não no exotismo do multiculturalismo ou na diversidade das culturas, mas na inscrição e articulação do hibridismo da cultura. Para esse fim deveríamos lembrar que é o 'inter' - o fio cortante da tradução e da negociação, o entre-lugar - que carrega o fardo do significado da cultura. Ele permite que se comecem a vislumbrar as histórias nacionais, antinacionais, do 'povo'. E, ao explorar esse terceiro espaço, 
temos a possibilidade de evitar a política de polaridade e emergir como os outros de nós mesmos." (BHABHA, 2013, p. 202)

Dito de forma definitiva, há no autor uma crítica à busca de quaisquer substancializações ou mitos originários, sejam elas coloniais ou multiculturais. Contra esse pensamento ontológico e tradicional, Bhabha volta o olhar para as fronteiras e as mudanças, para as relação ao invés das coisas, para o novo em detrimento do velho, enfim, para o híbrido. O híbrido nasce do intercâmbio entre culturas e seu espaço é a fronteira entre elas; elementos de todas essas culturas compõem o híbrido, mas ele não espelha completamente nenhuma delas. No fim das contas, a complexidade do híbrido não é algo que caiba nem no exotismo colonial nem no tribalismo multicultural.

Anteriormente falei que a estratégia dos híbridos de disjuntar o presente para transformar a metáfora colonial em uma catacrese era uma manobra para virar o jogo da dominação e conquistar o terceiro espaço ambivalente, que durante o primeiro período do mercado da diferença esteve sob controle dos europeus. Por "virar o jogo" não quis dizer que agora o Outro quer "se vingar" do seu algoz e colonizar aquele que um dia o colonizou. Claro que não. A virada de jogo diz respeito ao controle do terceiro espaço ambivalente: fazer dele uma fronteira híbrida de libertação catacrética ao invés de um perímetro exótico de prisão metafórica. Portanto, o jogo que vai ser virado não é o jogo da colonização, mas sim o da narração, o de quem conta o que esse capítulo foi, se o colonizador ou o colonizado. Aí sim haverá um destronamento: o europeu se cala e o antigo dominado começa a falar o que o branco fez com ele. Sendo assim, a conquista do terceiro espaço ambivalente através da catacretização da metáfora não é uma luta para saber quem domina quem, mas quem diz o que significa dominação, quem conta a história do poder, se o dominador ou o dominado. A única "violência" a que o Europeu será submetido é a de ter que se confrontar com a violência que nos causou, tendo que admiti-la e admitir a ilegitimidade que legitima sua posição, a arbitrariedade que naturaliza seu poder.

Como fica claro, Bhabha não tem nem o pacifismo reacionário do Professor Xavier, que acredita na natureza boa de seus algozes e neles quer se diluir, nem no revanchismo violento de Magneto, que quer tiranizar quem o tiraniza ${ }^{27}$ : há uma troca de poder em

\footnotetext{
${ }^{27}$ Não por acaso, seus poderes são, respectivamente a telepatia e o magnetismo, quer dizer: enquanto Xavier sai dele mesmo para chegar ao outro, Magneto fica onde está e traz o outro para perto de si.
} 
Bhabha, mas não do poder de mandar, mas de falar o que é o poder. O trono do colonizador será sempre dele, mas a voz que ele tinha agora será nossa. A ideia é lembrar do passado para que possamos revisá-lo e chegarmos a um futuro diferente. Submeter os europeus à colonização que eles nos impuseram seria a prova de que esquecemos o que aquele período foi. A missão de Bhabha é emancipar o colonizado, objetivo que jamais será atingido pela colonização do colonizador. Temos que nos defender, não para atacar o adversário, mas para que ele veja no espelho do nosso escudo o próprio ataque e se descubra violento. É preciso ir na contracorrente não para ser corrente um dia, mas para que, na resistência que encontramos em fluir, se evidencie que há uma corrente violenta fluindo na direção oposta ${ }^{28}$. Enfim, fazer catacrese para provar que há metáfora, lutar para mostrar que há luta e não natureza, ou, para usar a expressão do autor, para "tocar o futuro pelo lado de cá".

O fato é que, durante o segundo período do mercado da diferença, o mundo parece produzir cada vez mais híbridos, tipo fronteiriço que constrange a mesma história que o enseja, pois a obriga a olhar para a própria arbitrariedade. Forjados pela história, as feridas dos híbridos expõem as crueldades dela mesma, obrigando-a a se pensar, a se abrir para um novo período. O híbrido não encosta um dedo no mundo, apenas se coloca diante dele, cindido por ele, fazendo com que ele veja do que é capaz.

"Quanto mais nos proibimos de pensar os híbridos, mais seu cruzamento se torna possível; este é o paradoxo do modernos que esta situação excepcional em que nos encontramos nos permite enfim captar." (LATOUR, 2009, p. 32)

Chegamos às portas do século XXI e as noções até aqui vistas de mercado da diferença parecem formar um emaranhado difícil de desatar. Durante o Longo Século XIX, anos de colonização, a diferença operava com o binômio Eu/Outro e chamava para si as noções universais de unidade, homogeneidade, pureza e absolutismo; termos esses que se reuniam sob o abrigo do conceito de exótico. Conceituei essa era como período exótico-

\footnotetext{
${ }^{28}$ Um movimento já sinalizado por Said no posfácio de sua obra: "Embora ainda persistam as animosidades e iniquidades que deram origem a meu interesse pelo Orientalismo como fenômeno cultural e político, há agora pelo menos uma aceitação geral de que elas não representam uma ordem eterna, mas uma experiência histórica cujo fim - ou pelo menos correção parcial - pode estar próximo. Olhando para trás, com a distância proporcionada por quinze anos repletos de acontecimentos, e a partir de um novo e importante esforço interpretativo e acadêmico voltado contra os efeitos dos grilhões imperialistas sobre o pensamento e as relações humanas, Orientalismo teve ao menos o mérito de se alistar abertamente na luta - que continua, é claro, tanto no 'Ocidente' como no 'Oriente'." (2013, p. 440)
} 
colonial do mercado da diferença. Depois de duas guerras mundiais, com a criação da ONU, da UNESCO e dos Direitos Humanos, o mercado da diferença atravessou o que chamei de filtro da igualdade. Estabelecendo a paz e a igualdade como princípios incontornáveis da humanidade, o filtro reteve os conteúdos do período exótico-colonial do mercado da diferença, mas deixou que suas formas fluíssem para o outro lado, quer dizer: as ontologias da unidade, da homogeneidade, da pureza e do absolutismo foram contidas, mas as categorias formais de universal, de natureza humana, de estado-nação de pauta mundial localmente forjada não só foram aceitas, mas ratificadas pelas resoluções do filtro da igualdade. Dos anos 1960 em diante, a independência das antigas colônias europeias e outros acontecimentos políticos desestabilizaram o binômio Eu/Outro, criando um mundo mais fluido e instável que operava através de fluxos de intercâmbios globais: as fronteiras dos estado-nação já não eram tão rígidas, elementos externos entravam e características internas saiam. A troca do rígido binômio Eu/Outro por esses fluxos voláteis fez com que o prestígio depositado nas ideias universais de unidade, homogeneidade, pureza e absolutismo, constitutivas do período exótico-colonial do mercado da diferença, se transferisse para as noções particulares de multiplicidade, heterogeneidade, hibridismo e relativismo. A passagem do binômio para o fluxo criou um mundo mais complexo que só poderia ser explicado por essas novas ideias dinâmicas, e não por aqueles antigos conceitos engessados. As velhas formas do período exótico-colonial do mercado da diferença que passaram pelo filtro da igualdade começavam a ser preenchidas por novos conteúdos. Um segundo período do mercado da diferença ia surgindo na era global do outro lado do filtro da igualdade.

A virada do século XX para o XXI, portanto, assistia à tensa convivência entre (1) as categorias formais, oriundas do período exótico-colonial do mercado da diferença, de universalidade, natureza humana, estado-nação e pauta mundial localmente forjada, que atravessaram o filtro da igualdade; (2) os dogmas da paz e da igualdade estabelecidos pelo filtro da igualdade; (3) as ideias particulares de multiplicidade, heterogeneidade, hibridismo e relativismo que, embora fossem conteúdos de um segundo período do mercado da diferença, preenchiam aquelas categorias do primeiro que atravessavam o filtro. Vê-se aqui a delicadeza do arranjo: igualdade e diferença, universal e particular, formas antigas e novos conteúdos. Diante desse cenário, muitos acreditaram que o segundo período do mercado da diferença era idêntico ao primeiro, portanto essa passagem 
marcaria uma continuidade, mas outros diziam que os novos tempos eram o oposto dos antigos, sendo assim, a mudança representaria uma ruptura. Se por um lado, velhas soluções pareciam impensadas, por outro, novas alternativas como o multiculturalismo haviam criado problemas muito parecidos com aqueles do período exótico-colonial do mercado da diferença que o filtro da igualdade havia se encarregado de evitar. Até mesmo a própria prática da exotização sobreviveu no final do século $\mathrm{XX}$, como mostrei ao falar do problema da tribalização que a agenda multicultural trouxe. Diante dessa porosidade do filtro, muito se pergunta se os novos conceitos particulares de multiplicidade, heterogeneidade, hibridismo, relativismo são o contrário das ideias universais de unidade, homogeneidade, pureza e absolutismo ou se seriam suas meras atualizações. Enfim, posto esse cenário com tantas tensões, era preciso saber quais as continuidades e rupturas entre dos dois períodos do mercado da diferença.

Quando apresentei o primeiro período do mercado da diferença, falei que a noção de exótico funcionou como a ideia que sintetizou todas as noções constitutivas daquele período. Resta ainda saber que noção desempenha esse papel no segundo período do mercado da diferença, quer dizer, que ideia é capaz de chamar para a sua órbita todo aquele leque de signos que se envolvem e se alienam nos últimos anos do século XX. O mercado da diferença organizado pelo exótico era composto por noções fixas, estáveis e imiscíveis: o mundo estava dividido em ontologias sólidas e sedimentadas. Agora, como se viu pelo resgate dos parágrafos anteriores, se assistia à emergência de um mercado da diferença mais complexo: fluxos voláteis substituam díades canônicas e noções aparentemente inversas (igualdade/diferença, particular/universal, velhas formas/novos conteúdos, além da dúvida que paira sobre o quão "novos" os novos conteúdos são), bem ou mal, passam a coexistir nos mesmos discursos. A delicadeza desse novo arranjo escapa ao poder de síntese do exótico, acostumado a controlar noções comportadas. Para dar conta de um quadro tão complexo, era preciso acionar um conceito mais elaborado, ou melhor, mais diplomático, que conseguisse conciliar tensões antes inexistentes. Ficaria sob responsabilidade desse novo termo articular as velhas formas de universal, natureza humana, estado-nação e pauta mundial localmente forjada com os conteúdos particulares de multiplicidade, heterogeneidade, hibridismo e relativismo, mostrando como a particularidade desses conteúdos caberia naquele universal, além de fazer com que a igualdade nascida do filtro dialogue com a demanda por diferença. Como o exótico era 
pouco versátil, dever-se-ia descobrir uma ideia mais maleável que pudesse apaziguar essas tensões. A palavra que se encontrou capaz de arregimentar essas valências que rivalizavam em complementaridade foi diversidade.

"A diversidade cultural vai se tornando, com a proliferação de seu uso, um enunciado cada vez mais largo que atinge seu apogeu na contemporaneidade exatamente porque é capaz, em sua flexibilidade, de conter diversas tensões presentes nos debates sobre a diferença." (NICOLAU NETTO, 2014, p. 156)

A função de organizar o mercado da diferença, antes desempenhada pelo exótico, seria exercida agora pela diversidade. A complexidade dos novos tempos demandava um conceito mais elaborado. Nessa nova era de incerteza, a fluidez da diversidade parecia um termo mais adequado que a solidez do exótico.

Entretanto, não é porque a diversidade passou a organizar o mercado da diferença no lugar do exótico que o exótico desapareceu. Há pouco falei sobre o problema da exotização suscitado pela tribalização cultural nos anos 1990. Na verdade, o exótico só perdeu sua centralidade e deixou de desempenhar o papel de organização do marcado da diferença que desempenhava antes, mas ele ainda era um ruído audível. Como bem resume Nicolau Netto, "o exótico perde sua estabilidade semântica embasada nas clarezas de oposição entre interno e externo do século XIX. Mas seria apressado demais dizer que ele não existe" (2014, p. 97)

Mas o fato é, com a chegada de uma ideia-síntese que organize o debate, finalmente se pode dizer que o mercado da diferença entra em um segundo período. Todas aqueles conceitos que vinham sendo rascunhados desde as resoluções do filtro da igualdade podem agora se abrigar sob um mesmo termo. Com isso, o quadro se estrutura, ganha sistematicidade e se descobre como um período discernível do mercado da diferença. Como essa ideia é a diversidade e os anos são de globalização, chamarei esse segundo período do mercado da diferença de período da diversidade-global do mercado da diferença. Resta saber que relação esse segundo período do mercado da diferença estabelece com o primeiro, se de continuidade ou de ruptura.

Falei antes que, com o surgimento da agenda da globalização, o mundo deixou de ser simplesmente um corpo físico estudado pelas ciências naturais e se transformou também em uma arena cultural analisada pelas ciências sociais. Agora que a diversidade 
foi descoberta pelo mercado da diferença, algo parecido aconteceu. "Diversidade" sempre foi uma ideia cara à ecologia, à botânica e à zoologia, mas, quando a palavra passou a designar uma nova fase do mercado da diferença, o conceito entrou de vez para o glossário das ciências sociais. Assim como para a natureza, para a cultura a diversidade deveria ser mantida e buscada, pois era um indicativo de riqueza e vitalidade. Dessa forma, em todas as áreas da vida, "preservar e estimular a diversidade torna-se um imperativo" (ORTIZ, 2008, p. 32).

Durante a primeira década do século XXI, a UNESCO lançou três importantes documentos em defesa da diversidade: a Declaração Universal sobre a Diversidade (2002), a Convenção sobre a Proteção e Promoção da Diversidade e das Expressões Culturais (2005), e uma revisão do Framework for Cultural Statistics (2009), cuja primeira versão de 1986 já apresentei anteriormente. Ou seja: a mesma UNESCO que no pós-Segunda Guerra levantou a bandeira da igualdade (estribada nas categorias de universalidade, natureza humana, estado-nação e pauta mundial localmente forjada, oriundas do período exóticocolonial do mercado da diferença) e culpou a diferença pelas barbáries da colonização e do nazismo, hoje abraça a diversidade como um valor incontornável.

Olhando essa passagem da igualdade à diversidade, somos levados a crer que a UNESCO mudou, que abandou seu discurso de fundação e passou a se interessar pelas ideias opostas àqueles princípios iniciais. Se essa revolução de fato tiver acontecido, é de se esperar que as formas de universal, natureza humana, estado-nação e pauta mundial localmente forjada, vindas do período exótico-colonial do mercado da diferença, agora finalmente se extingam. Depois da Segunda Guerra, a bandeira da igualdade levantada pela UNESCO tentou neutralizar os conteúdos do primeiro período do mercado da diferença, mas aceitou suas formas. Quem sabe, a mesma UNESCO levante hoje a bandeira da diversidade para acabar com aquelas velhas formas do primeiro período do mercado da diferença que um dia aceitou. Assim, a estratégia da UNESCO para acabar com o período exótico-colonial do mercado da diferença e ensejar outro de diversidade-global que fosse o oposto do primeiro consistiria em acionar a igualdade para varrer os conteúdos daquele primeiro período e posteriormente usar a diversidade para extinguir suas formas. Desse jeito, com a igualdade se encarregando dos conteúdos e a diversidade das formas, teríamos uma ruptura completa entre os dois períodos do mercado da diferença, tanto de categorias 
quanto de substâncias, e poderíamos dizer que diversidade-global é o oposto de exóticocolonial.

Mas se abrirmos os documentos vamos ver que essa negação total não existe. $\mathrm{Na}$ verdade, os novos documentos se baseiam nos antigos. Como será apresentando adiante, a ideia de diversidade defendida nessas resoluções de 2002, 2005 e 2009 está contida na ideia de igualdade apresentada nos anos 1940 nas cartas de fundação da ONU, da UNESCO e na Declaração Universal dos Direitos Humanos. Assim, toda vez que recorre ao poroso filtro da igualdade para se afirmar, a diversidade-global banha seus novos conteúdos particulares de multiplicidade, heterogeneidade, hibridismo e relativismo nas velhas formas de universalidade, natureza humana, pauta mundial localmente forjada e centralidade do estado-nação, características do período exótico-colonial do mercado da diferença. Por se enraizar na igualdade, a diversidade acomoda conteúdos do segundo período do mercado da diferença nas formas do primeiro que a igualdade aceita. Já que os conteúdos do período da diversidade-global do mercado da diferença convivem com as formas do período exótico-colonial que o filtro da igualdade deixou passar, então todo esse apreço pelo étnico, o específico e o plural se conforma na moldura do identitário, do monolítico, do universal e do humano. Como venho insistindo, não há aqui nem uma rivalidade absoluta, nem uma perfeita comunhão, mas um equilíbrio externo que se sustenta no seu conflito interno. Analisemos cada um dos documentos:

A Declaração Universal sobre a Diversidade Cultural (2002) já mostra no título a convivência das velhas formas com os novos conteúdos, reunindo universalidade e diversidade no mesmo enunciado. No início, o texto sugere uma mudança em relação ao passado: cultura é definida de uma maneira bem mais abrangente do que no século XIX, e o conjunto de elementos que a compõem são tidos como "traços distintivos".

"Reafirmando que a cultura deve ser considerada como o conjunto dos traços distintivos espirituais e materiais, intelectuais e afetivos que caracterizam uma sociedade ou um grupo social e que abrange, além das artes e das letras, os modos de vida, as maneiras de viver juntos, os sistemas de valores, as tradições e as crenças (...)" (p.1)

Mas, seguindo com a leitura, podemos ver que o novo documento da diversidade se enraíza nos antigos da igualdade e que os conteúdos desse segundo período do mercado da 
diferença precisam dialogar com as formas do primeiro que o filtro deixou passar. Por exemplo, vemos a aproximação entre

Diversidade, universalidade dos Direitos Humanos e liberdades fundamentais:

"Reafirmando seu compromisso com a plena realização dos direitos humanos e das liberdades fundamentais proclamadas na Declaração Universal dos Direitos Humanos e em outros instrumentos universalmente reconhecidos (...)" (p. 1)

Diversidade e identidade:

"Constatando que a cultura se encontra no centro dos debates contemporâneos sobre a identidade, a coesão social e o desenvolvimento de uma economia fundada no saber (...)" (p. 1)

Diversidade, paz e nação:

"Afirmando que o respeito à diversidade das culturas, à tolerância, ao diálogo e à cooperação, em um clima de confiança e de entendimento mútuos, estão entre as melhores garantias da paz e da segurança internacionais (...)" (p. 1)

Diversidade, trocas entre culturas e unidade da natureza humana:

"Aspirando a uma maior solidariedade fundada no reconhecimento da diversidade cultural, na consciência da unidade do gênero humano e no desenvolvimento dos intercâmbios culturais (...)" (p. 1)

"Identidade, Diversidade e Pluralismo" é o título da primeira seção do documento. Como se pode ver, a ideia de identidade, que durante tanto tempo serviu à unicidade, à homogeneidade, à pureza e ao absoluto, não foi abandonada, só se adaptou à gramática da diversidade. A tensa complementaridade entre as velhas formas e os novos conteúdos fica aqui evidente: nessa seção, a diversidade é entendida como uma característica comum da humanidade. Ao unir humanidade e diversidade, a UNESCO articula o plural com o singular. Ora, "humanidade" sugere um grande grupo único e indistinto e "diversidade" é um traço que remete ao específico e ao variado. Quando atribui a ideia de diversidade à humanidade, a UNESCO afirma que a qualidade que torna esse grupo unitário e indivisível é justamente o fato de ele ser plural e multifacetário. Toda espécie tem um traço distintivo, uma característica exclusiva partilhada por todos os membros do grupo e somente por eles que faz com que sejam iguais entre si e diferentes dos membros dos outros grupos. É esse traço que funda a espécie, que faz com que seus componentes se aproximem um dos outros e se distanciem dos que não possuem aquele atributo. É assim que as coisas se dão com todas as espécies, inclusive com a humana. Mas o traço distintivo dos humanos, que congrega seus membros e os afasta dos membros das outras comunidades, é uma 
característica de outra categoria: a diversidade. O que nos animais é tautológico, nos humanos é dialógico: enquanto o traço distintivo dos animais, a característica exclusiva partilhada por todos os seus membros e somente por eles, que faz com que eles sejam iguais entre si é o fato de serem iguais entre si; o traço distintivo dos humanos, a característica exclusiva partilhada por todos os seus membros e somente por eles, que faz com que sejam iguais entre si é o fato de serem diferentes entre si. Na verdade, se quisermos ser precisos, podemos até dizer que, assim como a espécie animal, os membros da comunidade humana também são iguais entre si, mas a característica que compartilham é a dessemelhança. Os homens tem em comum o fato de serem diferentes uns dos outros, e como a família dos homens é a única cujos membros são diferentes, essa característica da diversidade passa a ser o traço distintivo desse grupo, a qualidade que organiza suas partes e faz com que se arranjem em uma espécie chamada humanidade. Por isso os homens se unem porque são diferentes e se singularizam por serem plurais.

Poder-se-ia alegar que um homem é diferente de outro como também é diferente de um cachorro; entretanto, se quisermos ser fiéis a definição da UNESCO, devemos lembrar que, esse cachorro, que é diferente do homem, é igual a outro cachorro. Ou seja, enquanto todo membro de um grupo é diferente dos membros de outros grupos mas igual aos membros do seu, o homem, além de ser diferente dos membros de outras comunidades, é diferente dos membros da sua própria; e como essa dessemelhança interna ao grupo é uma exclusividade humana, a diversidade passa a ser o traço diferencial da humanidade, quer dizer, a pluralidade dos membros da comunidade confere a singularidade dela. Vê-se aqui como fazer da diversidade a característica diferencial da humanidade é unir singularidade e pluralidade. Os membros da humanidade são diversos, diferentes uns dos outros, por isso ela é plural. Mas nenhuma outra comunidade tem membros diversos, diferentes uns dos outros, por isso ela é singular. O que nos torna singulares é o fato de sermos plurais. Somos humanos porque somos diversos e somos diversos porque somos humanos.

A frase que abre o artigo 1 desta seção é "A diversidade cultural, patrimônio comum da humanidade (...)" (p. 3), e adiante o signo multifacetário da diversidade mais uma vez é colocado ao lado da indiferenciada ontologia da natureza humana: "a diversidade se manifesta na originalidade e na pluralidade de identidades que caracterizam os grupos e as sociedades que compõem a humanidade."(p. 3). 
$\mathrm{O}$ artigo 2, contido na primeira seção, intitulado "Da diversidade cultural ao pluralismo cultural" (p. 3), revela um esforço de fazer com que toda essa diversidade se reúna em uma mesma totalidade coesa e orgânica. Quer dizer, nota-se mais uma vez aqui a tensão entre a polissemia da diversidade e um monismo da igualdade. $\mathrm{O}$ trabalho sempre oscila entre pluralidade e singularidade: todo passo na direção do diverso, do plural e do variado vem acompanhado de um trabalho de resumir essa multiplicidade em um corpo unitário e harmônico que a organize. Promove-se a diversidade, mas sempre dentro de uma fronteira. Quanto mais a humanidade se diversifica internamente, mas se solidificam os muros que contém esses elementos diversos. Ao que tudo indica, a diversidade, agora bem vinda, traz consigo um risco de dispersão que precisa ser evitado, por isso estimula-se simultaneamente a diversidade das partes que compõem o todo e a unidade do todo que contém as partes.

"Em nossas sociedades cada vez mais diversificadas, torna-se indispensável garantir uma interação harmoniosa entre pessoas e grupos com identidades culturais a um só tempo plurais, variadas e dinâmicas, assim como sua vontade de conviver. As políticas que favoreçam a inclusão e a participação de todos os cidadãos garantem a coesão social, a vitalidade da sociedade civil e a paz. Definido desta maneira, o pluralismo cultural constitui a resposta política à realidade da diversidade cultural. Inseparável de um contexto democrático, o pluralismo cultural é propício aos intercâmbios culturais e ao desenvolvimento das capacidades criadoras que alimentam a vida pública." (p. 3)

Na seção 2, o cruzamento entre os conteúdos do período da diversidade-global do período da diferença e as formas do período exótico-colonial que o filtro da igualdade aceitou se explicita no título: "Diversidade Cultural e Direitos Humanos" (p. 4). O artigo 4, contido nessa seção, intitulado "Os Direitos Humanos, Garantias da Diversidade Cultural", diz:

\footnotetext{
"A defesa da diversidade cultural é um imperativo ético, inseparável do respeito à dignidade humana. Ela implica o compromisso de respeitar os direitos humanos e as liberdades fundamentais, em particular os direitos das pessoas que pertencem a minorias e os dos povos autóctones. Ninguém pode invocar a diversidade cultural para violar os direitos humanos garantidos pelo direito internacional, nem para limitar seu alcance." (p. 4)
}

Se olharmos para a Declaração Universal dos Direitos Humanos, escrita durante o filtro da igualdade, lembraremos que lá "humanidade" foi definida como algo indiferenciado (igual), extensível às pessoas do mundo inteiro (geral) e inerente a todas esses indivíduos (natural). Ao falar em um "dignidade inerente a todos os membros da família humana" e em seus "direitos iguais e inalienáveis", o documento fazia com que toda pessoa fosse 
considerada "humana", sendo "humanidade" uma mesma e única substância que preenche todos os indivíduos e com eles já nasce, sendo-lhes imanente. Além disso, os Direitos Humanos ainda eram considerados universais. Sendo assim, vemos na Declaração Universal dos Direitos Humanos a presença daquelas velhas formas de natureza humana, universalidade, ordem mundial localmente forjada, e tudo isso centrado na figura do estado-nação. Desse modo, defender os Direitos Humanos é defender uma natureza indiferenciada, única e universal. Portanto, ao afirmar nesse documento de 2002 que os Direitos Humanos são garantia da Diversidade Cultural, a UNESCO faz com que a ideia de uma natureza indistinta, monista e universal (constitutiva dos Direitos Humanos) sirva de lastro para o contingencial, o plural, o étnico, o contextual, enfim, para os conteúdos particulares de multiplicidade, heterogeneidade, hibridismo e relativismo (constitutivos da Diversidade Cultural). Ao deixar que as formas do período exótico-colonial do mercado da diferença fluíssem para a era da diversidade-global desse conceito, o filtro da igualdade, representado aqui pelos Direitos Humanos, colocou a ideia de Diversidade Cultural em contato com a de um Monismo Natural. É verdade que se promove aqui uma diversidade cultural, mas, como ela é garantida por direitos humanos universais, há uma ressignificação das ideias de "diversidade" e de "cultural": estimula-se uma diversidade, plural e multifacetária, mas ela deve se acomodar em uma mesma, grande e única família humana. Do mesmo modo, abraça-se o cultural, essencialmente histórico, mas, por vezes, ele é tratado como um patrimônio imanente, essencialmente natural. Como falei: por se enraizar em direitos humanos indiferenciados, gerais, intrínsecos e universais, a diversidade cultural fica em sintonia com um monismo natural. Conteúdos da diversidadeglobal com formas do exótico-colonial.

$\mathrm{Na} 33^{\circ}$ Reunião da UNESCO, ocorrida em outubro de 2005, foi lançada a Convenção Sobre a Proteção e Promoção da Diversidade das Expressões Culturais. Assim como a Declaração Universal sobre a Diversidade Cultural de 2002 acima apresentada $^{29}$, esse é mais um documento que afirma a diversidade se alicerçando nas resoluções do filtro da igualdade e nas formas de universalidade, natureza-humana, pauta mundial localmente forjada e centralidade do estado-nação, que o filtro aceitou do período exótico-colonial do

\footnotetext{
${ }^{29}$ Já no início o texto explicita que se alicerça na resolução de 2002: "Referindo-se às disposições dos instrumentos internacionais adotados pela UNESCO relativos à diversidade cultural e ao exercício dos direitos culturais, em particular a Declaração Universal sobre a Diversidade Cultural, de 2002, (...)" (p. 1)
} 
mercado da diferença. No entanto, aqui estão mais explícitas as tensões entre a agenda da igualdade e a bandeira da diversidade, quer dizer: entre as formas do período exóticocolonial e os conteúdos do período da diversidade-global do mercado da diferença.

Fica claro que um dos principais objetivos da Convenção é resolver o problema da tribalização criado pelo multiculturalismo. Mirando esse alvo, o documento tenta fazer com que as comunidades culturais saiam de seu isolamento autocontido e passem a realizar intercâmbios culturais e fluxos de trocas de experiências. As palavra de ordem agora são "abrir-se" e "trocar-se".

"A definição de proteção assegura que as ações levadas a cabo e os meios utilizados pelas Partes - cujo direito soberano é reconhecido - visem preservar, salvaguardar e aprimorar a diversidade das expressões culturais, e a não limitar o seu fluxo com base em protecionismos ou isolacionismos identitários. Além disso, algumas garantias se fazem respeitar por meio da Convenção a partir do 'princípio da abertura e do equilíbrio', que assegura que as medidas tomadas pelos Estados também promovam a 'abertura para outras culturas do mundo'." (p. 29)

Para que a tribalização dê lugar ao diálogo entre as culturas, a UNESCO propõe a ideia de "interculturalidade".

"'Interculturalidade' refere-se à existência e interação eqüitativa de diversas culturas, assim como à possibilidade de geração de expressões culturais compartilhadas por meio do diálogo e respeito mútuo." (p. 6)

Estão entre os objetivos da Convenção:

"(c) Encorajar o diálogo entre culturas a fim de assegurar intercâmbios culturais mais amplos e equilibrados no mundo em favor do respeito intercultural e de uma cultura da paz; (p. 4)

(d) fomentar a interculturalidade de forma a desenvolver a interação cultural, no espírito de construir pontes entre os povos;" (p. 4)

Abraçar a "diversidade", o "diálogo", o "intercâmbio" e a "interação cultural", "construir pontes entre os povos", evitar o "protecionismo" e os "isolacionismos identitários", etc. Os termos usados não deixam dúvidas: o objetivo da Convenção é fazer com que as ilhas de culturas trancadas dentro de si mesmas criadas pelo tribalização multicultural se abram e passem a dialogar umas com as outras, trocando-se reciprocamente. Para sair da tribo multicultural e chegar à diversidade intercultural é preciso caminhar para frente.

No entanto, para chegar ao futuro, a Convenção busca noções do passado. Assim como no documento de 2002, vê-se aqui mais uma tentativa de promoção da diversidade 
que se baseia nas resoluções do filtro da igualdade e nas formas universais de natureza humana, universalidade, ordem mundial localmente forjada e centralidade do estado-nação, que foram gestadas no período exótico-colonial do mercado da diferença e atravessaram o filtro.

Novamente, os conceitos de diversidade cultural e de humanidade/direitos humanos são aproximados. Ao tomar o humano por lastro, a ideia de diversidade cultural precisa acomodar seus conteúdos particulares múltiplos, heterogêneos, híbridos e relativos, bem como seu interesse pelo contingente e pelo histórico, dentro da moldura do unívoco, do indiferenciado, do inato, do generalizado e do universal própria à condição humana. Por causa desse duplo movimento de, por um lado, estimular a diversidade das partes e, por outro, contê-las em uma mesma totalidade, observa-se aqui de novo, baseada em uma tensa harmonia, a construção de uma comunidade diversa, um monolito múltiplo, ou, como se disse, uma singularidade plural.

O texto da convenção evidencia esse paralelismo da polifonia e da historicidade da diversidade cultural com a igualdade, a universalidade monista, geral e inata dos Direitos Humanos e a imanência de uma condição humana essencial:

"Afirmando que a diversidade cultural é uma característica essencial da humanidade, ciente de que a diversidade cultural constitui patrimônio comum da humanidade, a ser valorizado e cultivado em benefício de todos, (...)" (p. 2)

"Celebrando a importância da diversidade cultural para a plena realização dos direitos humanos e das liberdades fundamentais proclamados na Declaração Universal dos Direitos do Homem e outros instrumentos universalmente reconhecidos (...)" (p. 2)

"Ao enfocar a diversidade das expressões culturais, a Convenção contribui para a 'defesa da diversidade cultural como um imperativo ético inseparável do respeito pela dignidade humana'." (p. 29)

Depois desse preâmbulo, o delicado equilíbrio entre a humanidade unívoca, indiferenciada, natural e universal e a diversidade cultural fluida e plural volta a aparecer no primeiro e no terceiro princípios da convenção:

"1.Princípio do respeito aos direitos e às liberdades fundamentais:

A diversidade cultural somente poderá ser protegida e promovida se estiverem garantidos os direitos humanos e as liberdades fundamentais, tais como a liberdade de expressão, informação e comunicação, bem como a possibilidade dos indivíduos de escolherem expressões culturais. Ninguém poderá invocar as 
disposições da presente Convenção para atentar contra os direitos do homem e as liberdades fundamentais consagrados na Declaração Universal dos Direitos Humanos e garantidos pelo direito internacional, ou para limitar o âmbito de sua aplicação." (p. 4)

"3. Princípio da igual dignidade e do respeito por todas as culturas

A proteção e a promoção da diversidade das expressões culturais pressupõem o reconhecimento da igual dignidade e o respeito por todas as culturas, incluindo as das pessoas pertencentes a minorias e as dos povos indígenas." (p. 4)

Mesmo a ideia de interculturalidade, grande inovação desse documento, carrega consigo essa tensão entre as velhas formas e os novos conteúdos. Tentando atualizar o debate, o conceito se presta a acabar com o isolamento das comunidades criado pela tribalização multiculturalista através de uma promoção de fluxos de intercâmbios culturais. Essas trocas fariam com que as culturas se abrissem umas para as outras e deixassem de ser guetos adiabáticos. O diálogo criado por essa abertura ensejaria a diversidade e suas ideias particulares de multiplicidade, heterogeneidade, hibridismo e relativismo. No entanto, a polifonia gerada pela interculturalidade deveria sempre se organizar em uma arena única e coesa onde todas as vozes recebessem um tratamento igual. Seja uma tensa afinidade ou uma harmônica disputa, a relação entre o plural e o singular pode ser vista na definição de interculturalidade que se apresentou acima, onde, resgatando, se explicita que a interculturalidade diz respeito a "interação equitativa de diversas culturas", ou seja, a um espaço de conteúdos diferentes que devem ser igualmente tratados. O caso da interculturalidade mostra que mesmo quando tenta caminhar para uma maior diversidade e para seus novos conteúdos, a UNESCO ainda precisa buscar apoio na igualdade, e nas velhas formas que ela aceitou.

O texto segue nessa oscilação entre igualdade com suas formas exótico-coloniais do mercado da diferença e diversidade com seus conteúdos da diversidade-global. Ainda que pareça buscar um equilíbrio entre os dois pratos, ora a balança pesa para um lado, ora para outro. Em uma passagem, a convenção mergulha fundo na igualdade e nas velhas formas para poder justificar a diversidade e seus novos conteúdos, criando um nó difícil de desatar:

"O respeito aos direitos humanos e às liberdades fundamentais dos indivíduos é o pano de fundo da Convenção. Juntamente com a Declaração Universal da UNESCO sobre a Diversidade Cultural, a Convenção reconhece a relação entre a diversidade cultural e a plena realização dos direitos humanos e das liberdades fundamentais, que não poderiam existir separadamente. Com relação a essa 
questão, 'não se pode invocar as disposições desta Convenção de modo a infringir os direitos humanos e as liberdades fundamentais, tais como descritas na Declaração Universal dos Direitos Humanos ou garantidas pelo direito internacional, ou de modo a limitar o seu escopo'. Assim, o risco do relativismo cultural, que em nome da diversidade reconheceria práticas culturais hostis aos princípios fundamentais dos direitos humanos, foi eliminado." (p. 23)

O trecho serpenteia freneticamente entre os dois períodos do mercado da diferença. Tentando defender tanto os princípios únicos, indiferenciados, universais e inatos dos direitos humanos quanto os valores plurais, particulares e históricos da diversidade cultural, a passagem define aqueles como "pano de fundo" desses, em seguida insiste em uma reciprocidade obrigatória entre as duas ideias, afirmando que "não podem existir separadamente", para, no final, dizer que o relativismo cultural é uma um "risco" que a diversidade representa para a igualdade e para os tão caros "princípios fundamentais dos direitos humanos", muito embora o documento objetive proteger e promover a diversidade, esforçando-se portanto para salvar do desaparecimento algo que é também uma ameaça. Talvez nenhuma passagem ilustre tão bem a complexidade do arranjo formado pelas formas do período exótico-colonial do mercado da diferença que atravessaram filtro da igualdade e os conteúdos do período da diversidade-global do mercado da diferença que foram ensejadas do outro lado do filtro. Primeiro há uma hierarquia que considera as velhas formas a base dos novos conteúdos; depois essa hierarquia desaparece, e velhas formas e novos conteúdos se nivelam, pois um não pode existir sem o outro; em seguida, o equilíbrio volta a dar lugar a uma hierarquia, mas uma hierarquia oposta à anterior, já que agora os novos conteúdos podem ameaçar as velhas formas; e, ainda que os novos conteúdos possam constranger as velhas formas (que no começo do parágrafo eram sua base e na metade sua equivalência), a Convenção intenta promovê-los e os proteger. Tudo isso no mesmo parágrafo. Como se pode ver, através da porosidade do filtro da igualdade, formas do período exótico-colonial do mercado da diferença e conteúdos da diversidadeglobal se tocam, ora envolvendo-se, ora alienando-se.

Esse tenso acordo entre formas do exótico-colonial aceitas pelo filtro da igualdade e conteúdos de diversidade-global evocados depois do filtro se revela em uma querela terminológica presente nessa Convenção. Como se viu até aqui, no corpo do texto, a UNESCO usa a todo instante o termo "Diversidade Cultural", mas, no título, a construção empregada é "Diversidade das Expressões Culturais" (grifo meu). As noções são explicitadas nessa passagem: 
"'Diversidade cultural' refere-se à multiplicidade de formas pelas quais as culturas dos grupos e sociedades encontram sua expressão. Tais expressões são transmitidas entre e dentro dos grupos e sociedades. A diversidade cultural se manifesta não apenas nas variadas formas pelas quais se expressa, se enriquece e se transmite o patrimônio cultural da humanidade mediante a variedade das expressões culturais, mas também através dos diversos modos de criação, produção, difusão, distribuição e fruição das expressões culturais, quaisquer que sejam os meios e tecnologias empregados. " (p. 5)

Como se percebe pelo trecho, "expressões culturais" são jeitos ou maneiras através das quais a cultura se expressa. Assim, a expressão passa a ser um anteparo, uma espécie de vetor ou veículo, onde a cultura se deixa ver. Quando desloca a ideia de "diversidade", fazendo com que ela deixe de se referir à "cultural" e passe a qualificar a noção de "expressão cultural", a Convenção faz um esforço de conciliar a polissemia do período da diversidade-global do mercado da diferença com o resíduo monista do período exóticocolonial que atravessou o filtro da igualdade. Como a diversidade diz respeito às expressões culturais e não à cultura que exprimem, o diálogo entre pluralidade e singularidade se dá da seguinte maneira: há muitos jeitos, maneiras e modalidades diferentes de expressar uma única e indiferenciada cultura humana universal. As expressões são diversas, mas a cultura que revelam é uma só. Resgatando termos contidos na passagem: a morada da diversidade cultural é a variedade das expressões culturais, mas o que elas expressam é esse monolito chamado "patrimônio cultural da humanidade". Se há uma diversidade cultural é porque existe uma variedade expressiva, mas essa infinidade de modos evidencia sempre uma cultura universal inerente a essa indistinta família humana. Seria incorreto afirmar um paralelismo entre modos de expressão cultural e cultura e crer que para cada jeito de exprimir existiria uma cultura correspondente. Pelo contrário: as expressões culturais são satélites que orbitam em torno de uma mesma cultura humana. São muitos jeitos de dizer a mesma coisa, muitas portas que dão para a mesma sala. Como toda expressão cultural particular aponta para a mesma cultura humana universal, cada uma dessas maneiras, por mais diferente que seja, deve ser igualmente tratada, pois se referem ao mesmo objeto.

Nesse outro trecho se repete a ideia de uma cultura singular que se apresenta sob múltiplas formas, ratificando a noção de que existem muitas "expressões culturais" de uma mesma "humanidade". 
"Considerando que a cultura assume formas diversas através do tempo e do espaço, e que esta diversidade se manifesta na originalidade e na pluralidade das identidades, assim como nas expressões culturais dos povos e das sociedades que formam a humanidade, (...)" (p. 2)

Em outros momentos do texto, quando afirma a soberania do estado-nação nesse debate acerca da diversidade (primeiro no objetivo (h) depois no segundo princípio), a convenção promove o diálogo completo entre os conteúdos do período da diversidade-global do mercado da diferença suscitados depois do filtro da igualdade e as formas do período exótico-colonial do mercado da diferença que atravessaram o filtro.

"(h) reafirmar o direito soberano dos Estados de conservar, adotar e implementar as políticas e medidas que considerem apropriadas para a proteção e promoção da diversidade das expressões culturais em seu território;" (p. 4)

"PRINCÍPIO 2: Princípio da Soberania.

De acordo com a Carta das Nações Unidas e com os princípios do direito internacional, os Estados têm o direito soberano de adotar medidas e políticas para a proteção e promoção da diversidade das expressões culturais em seus respectivos territórios." (p. 4)

Assim, com a Convenção para Proteção e Promoção da Diversidade das Expressões Culturais, a UNESCO faz os conteúdos particulares de multiplicidade, heterogeneidade, hibridismo e relativismo, próprias do período da diversidade-global do mercado da diferença, nascido depois do filtro da igualdade, encontrarem as formas de universal, natureza humana, ordem mundial localmente forjada e centralidade do estado-nação, fundantes do período exótico-colonial do mercado da diferença, anterior ao filtro. Devido à porosidade do filtro da igualdade, os conteúdos da diversidade-global devem se acomodar nas formas do exótico-colonial, por isso, mesmo que se interesse pelo étnico, o específico e o efêmero, essa polissemia da diversidade deve se fechar em uma mesma e única totalidade coesa e orgânica. Como já se disse, quanto mais se promove a proliferação de partes diferentes que compõem um todo, mais se fortalece a silhueta de todo indiferenciado que contém as partes. Para que os novos conteúdos e as velhas formas se equilibrem, estimulase simultaneamente os cortes diferenciais internos e a continuidade do perímetro externo. Muitos conteúdos diferentes podem existir, desde que uma mesma forma os arregimente, ou seja: há singularidades no plural, mas uma pluralidade no singular.

Esse balanço entre formas do exótico-colonial e conteúdos da diversidade-global não é de maneira alguma uma incoerência da UNESCO, muito pelo contrário. Com a 
Convenção, o órgão está apenas se comprometendo a fazer com que as novas demandas surgidas nesse segundo período do mercado da diferença se adaptem às categorias que ela própria se encarregou de aceitar na década de 1940. No texto, a UNESCO explicita que se vê diante de um "duplo desafio": estimular a diversidade e reuni-la na igualdade, criando simultaneamente partes diferentes e um todo adiabático, elementos que só se distinguem na medida em que se complementam e assim se fecham em um mesmo corpo orgânico. Retornando ao nosso glossário, esse esforço duplo nada mais é que o trabalho de situar os conteúdos particulares da multiplicidade, da heterogeneidade, do hibridismo e do relativismo, constitutivos do período da diversidade-global do mercado da diferença, nas formas do universal, da natureza-humana, da ordem mundial localmente forjada e da centralidade do estado-nação, categorias do período exótico-colonial do mercado da diferença que passaram pelo filtro da igualdade.

"Em consonância com a definição mais ampla de cultura, a Declaração lida com o duplo desafio da diversidade cultural: por um lado, ao assegurar a interação harmônica entre pessoas e grupos com identidades culturais plurais, variadas e dinâmicas, bem como o desejo da vida em conjunto; e, por outro, ao defender a diversidade criadora, ou seja, a grande variedade de formas pelas quais as culturas revelam as suas próprias expressões tradicionais e contemporâneas no espaço e no tempo. Durante esse período, a UNESCO buscou atender às necessidades das sociedades cujo caráter plural foi ampliado pelo acelerado processo de globalização." (p. 20)

Quando a Convenção se dedica a explicar o significado das palavras "proteção" e "promoção", presentes no título, novamente aparecem as faíscas produzidas pelo contato entre os dois período do mercado da diferença.

"É importante apontar para o fato de que, na terminologia da UNESCO, o termo "proteção" significa a adoção de medidas direcionadas à preservação, salvaguarda e valorização.(...) Quando usado em conjunto com o termo "promoção", implica o desejo de manter vivas expressões culturais ameaçadas pelo crescente ritmo de globalização. A palavra "promoção" expressa o chamado à contínua regeneração das expressões culturais, de modo a assegurar que elas não sejam confinadas em museus, folclorizadas ou reificadas. Além disso, as palavras "promoção e proteção" são inseparáveis." (p. 22)

Pelo que diz o trecho, a proteção das culturas objetiva salvá-las da extinção, mas, para que esse salvamento não vire uma monumentalização estéril, uma patrimonialização que paralisa um fluxo, descaracterizando a cultura justamente ao tentar conservá-la, a proteção vem acompanhada de uma promoção, política dedicada a fazer com que as expressões culturais continuem sendo práticas ao invés de coisas, e assim possam se reinventar 
constantemente. Desse modo, a proteção estaria encarregada de cuidar do passado das expressões, preservando sua memória e sua herança, enquanto a promoção miraria seu futuro, estimulando mudanças que manteriam as expressões sempre atuais. Unindo conservação e revolução, a UNESCO garante a vitalidade das expressões sem cair em uma objetivação meramente contemplativa, própria às práticas de musealização, folclorização e reificação citadas no trecho. Esse tratamento reificante nada mais é que um gesto de exotização, característico do primeiro período do mercado da diferença. Depois de acomodar novos conteúdos em velhas formas ao longo de todo o texto, a UNESCO, ao separar a ideia de diversidade desse engessamento folclórico exotizante, mostra as mudanças entre o primeiro e o segundo períodos do mercado da diferença. No entanto, deve-se atentar para uma questão: assim como anteriormente a Convenção apontou os riscos que o relativismo cultural da diversidade trazia para a indiferenciada humanidade, agora a globalização, outro signo desse período que a Convenção celebra, é também apontada como uma ameaça. Ao afirmar que a globalização representa um risco para a diversidade das expressões culturais, a UNESCO sugere que a globalização, ainda que seja o período que pariu a agenda da diversidade, pode sim produzir homogeneidade, um fantasma do período exótico-colonial do mercado da diferença que deveria ter sido contido pelo filtro da igualdade. O problema da diversidade, que surgiu de mãos dadas com a questão do global e com ela fundou o que chamo aqui de um período de diversidadeglobal, precisa agora se proteger desse global, pois ele pode produzir efeitos de homogeneização nocivos à diversidade, um típico perigo das políticas do período exóticocolonial do mercado da diferença que essa mesma UNESCO se dedicou a encerrar. Quando assinala um risco homogeneizante da globalização que constrangeria a diversidade das expressões culturais, a UNESCO mostra que as formas do período exótico-colonial do mercado da diferença que atravessaram o filtro da igualdade e aportaram no período da diversidade-global podem fazer com que os velhos tempos se marquem nos novos com mais intensidade do que se acreditava. Diante de um presente cada vez mais assombrado pelo passado, surgiu a pergunta: vivemos mesmo um novo período do mercado da diferença diferente do anterior?

Sobre a versão de 2009 do Framework for Cultural Statistics, atualização do documento de 1986 já debatido, não há muito o que acrescentar. Apresento-o aqui no final apenas por uma questão cronológica. Na esteira dos documentos de 2002 e 2005, esse 
segundo Framework opera com "novos conceitos que emergiram no campo da cultura desde 1986" (p. 1), quer dizer: uma visão de cultura mais abrangente e, principalmente, menos estática. Além de ser mais inclusiva e considerar a mudança, essa versão atualizada é mais enfática em tratar a cultura como um campo em contato direto com outras dimensões da vida, um elemento de uma configuração maior, e não como um corpo asséptico e absoluto distantes das demais esferas da vida. Como vimos, esse esforço já havia sido iniciado pelo documento de 1986, mas aqui essa tendência é reforçada.

"Esse Framework for Cultural Statistics substitui o de 1986. Desde o desenvolvimento do primeiro FCS, muitas abordagens diferentes de definição e medição de cultural emergiram, em paralelo a isso, mudanças sociais e tecnológicas transformaram o papel da cultura no mundo." (p. 2)

Como foi redigida nos anos do multiculturalismo, a versão original do documento traz as marca da tribalização e a sua tendência a organizar as várias culturas em comunidades fechadas em si mesmas, apartadas, diferentes uma das outras e internamente indiferenciadas. Repetindo várias vezes a ideia de "transversalidade", um termo que remete à "interculturalidade" de 2002, essa segunda versão - menos ligada às instâncias legitimadas de cultura, mais atenta a outras formas de produção cultural ${ }^{30}$, e mais interessada pelos intercâmbios e fluxos do que por formas de vida emolduradas - é, como a Convenção de 2005, um documento interessado em expressões culturais, ou melhor, em medir a diversidade das expressões culturais. Seguindo o rastro dos outros dois documentos da década aqui tematizados, o novo Framework se estabelece como um texto promovedor da diversidade, reproduzindo toda a complexidade e a delicadeza daquele tenso diálogo entre formas do período exótico-colonial do mercado da diferença e conteúdos da diversidade-global.

A própria ideia de se criar um gabarito único capaz de avaliar as culturas do mundo já mostra esse conflito. Com o Framework, a diversidade vira uma régua que se pode dizer universal justamente por ser ela capaz de medir todas as particularidades. A própria palavra "framework" remete a moldura, paradigma, quer dizer: admite-se que exista uma diversidade de partes, mas elas cabem dentro das rígidas arestas de um modelo único, de

\footnotetext{
${ }^{30} \mathrm{O}$ conceito de "performance", trazido no documento, é um bom exemplo: "A definição de performance inclui todas as performances, sejam amadoras ou profissionais, executadas em um palco profissional ou em um espaço aberto em uma vila rural." (p. 4)
} 
uma mesma escala capaz de avaliar todas elas. Por mais diferentes de sejam, as diferenças ainda conseguem ser arregimentadas por um mesmo esquema.

Eis a justificativa para a atualização:

"Padrões de análise estatística de cultura geralmente coletam dados sobre frequência nos museus, por exemplo, ou sobre o número de pessoas empregadas em um teatro ou em uma companhia de dança. Mas o que dizer dos contadores de histórias ou dos artesãos do campo tão numerosos em vários países? Essa versão revisada reflete melhor o leque de profissões e práticas culturais ao redor do mundo - desde marceneiros a artesãos de cestas até cerimônias e rituais ancestrais. Essa informação vital é importante para entender como a cultura pode contribuir para a economia e o bem estar de comunidade e de países.

Esse Framework de 2009 facilita comparações transnacionais a partir do uso de definições e classificações padronizadas. $\mathrm{O}$ documento reflete mudanças globais na tecnologia, nosso entendimento de questões culturais fundamentais, avanços em técnicas de inferência, e melhorias em políticas culturais que ocorreram desde que o Framework de 1986 foi lançado.

Com isso em mente, a UNESCO reconheceu a necessidade de atualizar seu Framework for Cultural Statistics de 1986, baseado em uma noção formal e estática de cultura que não reflete a abordagem atual mais inclusiva e as especificidades dos países em desenvolvimento. Além disso, o novo Framework fornece uma base conceitual e uma metodologia que visa permitir a produção e disseminação de estatísticas culturais que possam ser internacionalmente comparadas." (p. 2)

Chegamos aqui ao final do nosso resgate sócio-histórico e o que temos diante de nós é um quadro extremamente complexo. Primeiro, o mercado da diferença atravessou um período colonial caracterizado pela assimetria de poder entre um binômio Eu/Outro, díade cujos polos eram opostos entre si e lisos em si mesmos. Nesse primeiro momento, a ideia de diferença se relacionava com os conceitos universais de unidade, homogeneidade, pureza e absolutismo. Como a noção de exótico organizava esse debate colonial da diferença, chamei esses anos de período exótico-colonial do mercado da diferença. Mas, na segunda metade do século XX, a independência das colônias pulverizou o corpo inteiriço do Outro, fazendo com que o Eu, ao perder sua inversão simétrica, também se dissolvesse em várias partículas. Esses fragmentos começaram a operar fluxos de intercâmbios globais de pessoas, informações e mercadorias, criando assim contextos complexos em que era difícil identificar o que era interno e o que era externo. Já que o fora estava cada vez mais dentro e o dentro cada vez mais fora, aquele estável mundo binomial desapareceu e um cenário mais fluido emergiu. Com os fluxos tomando o lugar da desigual relação Eu/Outro, 
criou-se a expectativa de que os novos tempos fossem de paz e equilíbrio de poder. Diante de um cenário muito mais instável, as metas universalistas de unidade, homogeneidade, pureza e absolutismo perderam seu prestígio e as ambiciosas narrativas totalizadoras alicerçadas nesses princípios já não conseguiam explicar as sutilezas de um mundo organizado em torno de fluxos velozes. Assim, o interesse depositado naqueles valores universais se transferiu para as noções particulares de multiplicidade, heterogeneidade, hibridismo e relativismo. Com as grandes ontologias assépticas se transformando em uma nuvem de pedaços misturados, as teorias gerais que explicavam o velho mundo foram substituídas por relatos curtos que dessem conta do étnico, do contingente e do efêmero. $\mathrm{O}$ antigo conceito de exótico já não conseguia mais conciliar as tensões desse novo cenário, e assim, o mundo entrou em um segundo período do mercado da diferença. Em lugar do exótico, era preciso encontrar uma palavra que organizasse esse novo debate. A ideia capaz de abrigar o interesse particular pelo múltiplo, o heterogêneo, o híbrido e o relativo foi a ideia de diversidade. Por ser esta uma época de globalização, chamei aqui esse era de período da diversidade-global do mercado da diferença.

Mas há um interstício entre esses dois períodos do mercado da diferença complicado de definir. Seria arbitrário situar esse momento em um só dos períodos do mercado da diferença porque, a rigor, esse não é um tempo em que se fala de diferença, mas sim de igualdade. No entanto, mesmo sendo uma época de igualdade situada entre o exótico-colonial e a diversidade-global, não se pode dizer que essa membrana é um hiato entre os dois períodos do mercado da diferença, mas antes uma fronteira conurbada. A igualdade não é aqui o oposto da diferença, mas um espaço de mediação entre duas diferenças possíveis. Essas duas diferenças não simplesmente se separam por causa da igualdade, mas também se ligam através dela. A igualdade não aliena as diferenças porque, na verdade, elas a compartilham. Mais do que um vácuo, tem-se aqui uma área de triagem ou uma ilha de edição em que as duas diferenças dialogam. Se é verdade que a igualdade segurou o exótico-colonial e permitiu que a diversidade-global florescesse, também é certo que essa mesma igualdade criou problemas para a diversidade-global resolver. Como se falou, a igualdade não é um terceiro espaço, mas uma membrana porosa, uma dobradiça, ou melhor, um filtro entre os dois períodos do mercado da diferença. 
As dúvidas acerca das continuidades e rupturas entre os dois períodos do mercado da diferença se devem à seletividade inconsciente do filtro da igualdade. De fato, o imperativo da igualdade e da paz estabelecido pelo filtro abalou o estado de coisas que reinava durante o período exótico-colonial do mercado da diferença: (1) o prestígio depositado nas noções universais de unidade, homogeneidade, pureza e absolutismo se transferiu para as ideias particulares de multiplicidade, heterogeneidade, hibridismo e relativismo. (2) A natureza humana não seria mais desigual para se descobrir igualitária. (3) A ordem mundial localmente forjada deixou de ser o domínio e a violência e virou o equilíbrio e o respeito mútuo. (4) o arranjo estável entre os estados-nação e a busca por uma identidade nacional monolítica deu lugar a um modelo que desse conta dos fluxos e de identidades nacionais polissêmicas, ensejando um processo que seria conduzido não mais pelas nações europeias, mas pelos Estados Unidos. Como se pode ver, alterou-se drasticamente o diagnóstico acerca do que era o universal, qual a qualidade da natureza humana, que pauta mundial localmente forjada estaria em voga e que estado-nação guiaria os demais, mas as categorias de universal, natureza humana, pauta mundial localmente forjada e centralidade do estado-nação propriamente ditas continuavam firmes e fortes. Quer dizer, o filtro da igualdade segurou os conteúdos do período exótico-colonial do mercado da diferença que preenchiam as formas de universal, natureza humana, pauta mundial localmente forjada e centralidade do estado nação, mas permitiu que essas formas seguissem ocas para o período da diversidade-global do mercado da diferença que nascia do outro lado do filtro, fazendo com que os conteúdos dessa nova fase se acomodassem naquelas velhas formas. Desse jeito, as ideias particulares de multiplicidade, heterogeneidade, hibridismo e relativismo teriam que se adaptar na forma universal que um dia abrigou a unidade, a homogeneidade, a pureza e absolutismo. A igualdade teria que ser uma natureza humana, assim como a desigualdade o fora antes dela. A paz, o equilíbrio, o respeito e a fraternidade da família humana precisariam se assentar na moldura da pauta mundial localmente forjada, antes ocupada pela noções de tirana, violência e assimetria de poder. E todas essas qualidades da diversidade-global se encarnariam no corpo do estadonação, a mesma ontologia que abrigava os princípios do exótico-colonial. Conclusão: por causa da porosidade do filtro da igualdade, os conteúdos do período da diversidade-global do mercado da diferença deveriam ocupar as formas do período exótico-colonial do mercado da diferença. Esse arranjo formou um quadro extremamente complexo e delicado 
em que valores velhos e novos se complementavam e rivalizavam com o mesmo vigor, fazendo com que o modelo se equilibrasse na própria tensão.

Essa configuração complicada composta por velhas formas e novos conteúdos deu origem a um debate infinito acerca da relação entre o período exótico-colonial e o da diversidade-global do mercado da diferença: seriam eles iguais, opostos, complementares, rivais, partes de um mesmo todo, mutuamente obrigatórios, excludentes, indiferentes...?

Para uns, a permanência das velhas formas atestava que nada havia mudado e por isso o período da diversidade-global do mercado da diferença não passaria de uma repetição envernizada da época exótica-colonial. Ao atravessarem o filtro da igualdade, as formas do exótico-colonial faziam com que qualquer conteúdo de diversidade-global nelas encaixadas assumisse a lógica daquele primeiro período do mercado da diferença. Assim, qualquer alteração terminológica ou simbólica não passaria de uma mudança epidérmica, uma falsa inovação, pois, de um ponto de vista prático, "no fundo", tudo continuaria como sempre foi. Inclusive, diziam alguns autores, essa mudança nos nomes seria até uma etapa necessária para que a lógica do passado se perpetuasse. O exótico-colonial precisaria adaptar seu glossário aos novos tempos para que pudesse continuar exercendo sua tirana. Algo antecipado por Marx e Engels no já citado Manifesto: a velha dominação tem sempre que assumir uma nova forma para que possa continuar dominando sem que ninguém perceba a arbitrariedade desse mecanismo. Superficialmente tudo parece novo, mas, por baixo dos nomes, o sistema é o mesmo. Dessa maneira, ao se acomodarem no universal, as ideias particulares de multiplicidade, heterogeneidade, hibridismo e relativismo gerariam ondas de unidade, homogeneidade, pureza e absolutismo. Também a igualdade, por preencher a arcaica noção de natureza humana, seria apenas um caminho oblíquo que conduziria o homem de volta para a desigualdade. Seguindo essa lógica, a paz, ao aceitar ser uma pauta mundial localmente forjada, como a guerra o fora, passava a ser tão violenta quanto sua irmã mais velha e não tardaria para que ela, globalizando-se a partir de um ponto, se transformasse em uma justificativa para espoliações e invasões de povos que não compartilhavam esse valor. E a continuidade do prestígio depositado no estado-nação só fazia trocar um líder mundial por outro: saia a Europa, entravam os Estados Unidos, mas, no fundo, o mundo continuava uma reunião de territórios dominados por um mesmo centro. Se antes a colonização europeia subjugava o mundo, agora uma globalização 
americana nivelaria todos. Enfim, para esses autores havia uma continuidade entre os dois períodos do mercado da diferença: exótico-colonial e diversidade-global eram idênticos.

Por outro lado, havia aqueles que acreditavam em uma mudança verdadeira entre os dois períodos do mercado da diferença. Para esses, ainda que os conteúdos da diversidadeglobal precisassem se adaptar a formas oriundas do exótico-colonial que atravessaram o filtro da igualdade, o segundo período do mercado da diferença marcaria um tempo diferente do anterior. Aquelas mudanças terminológicas - que para os adeptos da tese da continuidade representavam apenas uma atualização de velhos mecanismos - indicavam uma revolução verdadeira nas coisas, uma mudança de direção e a apropriação de velhas formas pelos novos conteúdos era só uma estratégia para que os conteúdos de ontem fossem extintos de vez. Assim, as ideias particulares de multiplicidade, heterogeneidade, hibridismo e relativismo sepultariam as noções universais de unidade, homogeneidade, pureza e absolutismo. Da mesma forma, a natureza humana igualitária assinalaria o fim da desigualdade. A ordem mundial localmente forjada da paz construiria um mundo mais equilibrado. O novo arranjo dos estados-nação apagaria antigas assimetrias e todos os países sairiam mais empoderados. Quer dizer, os novos tempos cumpririam sua promessa e as coisas seriam diferentes do anterior. Para esses autores havia uma ruptura entre os dois períodos do mercado da diferença: exótico-colonial e diversidade-global eram opostos.

Como se pode ver, a dúvida existia por causa da convivência - a um só tempo tensa e complementar - entre as velhas formas e os novos conteúdos, quadro criado pela porosidade do filtro da igualdade. Enquanto os adeptos da continuidade acreditavam que as velhas formas se apropriavam dos novos conteúdos, inscrevendo o passado no presente, os defensores da ruptura defendiam que as os novos conteúdos revolucionariam as velhas formas, fazendo o presente sepultar o passado. Quer dizer, o debate sobre uma possível repetição ou uma suposta revolução entre os dois momentos era uma discussão para saber quem mandaria em quem: se as velhas formas engoliriam os velhos conteúdos, ou se os novos conteúdos transformariam as velhas formas; um arranjo complexo produzido pela triagem do filtro da igualdade.

Afinal, que relação existe entre o exótico-colonial e a diversidade-global? Quais são as continuidades e rupturas entre os dois períodos do mercado da diferença? No capítulo 
seguinte falarei brevemente sobre esse debate para que se possa encontrar uma saída possível. 


\section{Capítulo 4}

\section{As duas correntes}

Dois diagnósticos diferentes surgiram acerca do delicado arranjo composto por formas do período exótico-colonial do mercado da diferença e conteúdos da diversidadeglobal. Para uns a relação entre os dois momentos era de continuidade, para outros de ruptura. Trato aqui essas duas tendências como tipos ideais, à maneira de Weber (2009), pois, na complexa configuração que nos interessa, as posições não são tão nítidas assim. Logicamente, entre esses dois extremos se inscreve um gradiente de opiniões intermediárias, e mesmo se olharmos para momentos diferentes de um mesmo autor poderemos perceber uma oscilação entre a continuidade e a ruptura. Ainda assim, apresentarei aqui esses dois marcadores para que se possa ver as arestas que contêm o debate. As teorias aqui trazidas manejam suas próprias gramáticas, e não usam termos como "mercado da diferença" ou "filtro da igualdade", mas meu esforço será o de mostrar que posição esses textos ocupam no quadro analítico aqui construído.

Os autores aqui apresentados não apenas tematirazam esse assunto, mas também o instauraram, quer dizer: nessa disputa, evidenciar sentidos também é constituí-los. Por isso, não trago para a discussão apenas teóricos que assistiram todo o desenrolar do percurso aqui apresentado e, do alto de sua onisciência, deram um diagnóstico. Não, muitas obras estão inseridas em um momento específico da trajetória que nos interessa. Analisar essas teorias é importante porque elas não são apenas crônicas sobre o mercado da diferença, mas partes constitutivas dele. Esses pensadores não olharam a diferença de fora $\mathrm{e}$ passivamente a fotografaram, pelo contrário: eles são valências que compõem esse mercado, construindo-o a partir de dentro.

\section{Continuidade}

Talvez a teoria mais descrente na emancipação e na mudança seja a da Escola de Frankfurt. Não por acaso, essa desilusão no futuro lhes rendeu a alcunha de "apocalípticos" (ECO, 2008). O negativismo da Escola é tão acentuado que se torna até difícil afirmar que, para esses autores, "o passado se inscreve no presente", pois, de acordo com eles, a história nem chega a ser um fluxo, o que torna qualquer pretensa distinção entre começo e fim completamente ideológica. 
Para os frankfurtianos, o que existe é uma teleologia ao contrário: no princípio há o fim, mas ele não ruma para o começo, descrevendo uma trajetória reversa, só gira em torno de seu próprio eixo, sem sair do lugar, criando assim uma falsa sensação de deslocamento. Não é que o novo tempo ainda seja como o antigo, o passado é que já era como o presente; sendo assim, esses dois nomes não dizem absolutamente nada: se a história é um buraco e não um trajeto, se só há a simultaneidade do apocalipse e não a sucessão da aventura, então não há porque criar marcadores cronológicos ou distinções temporais, pois tudo é um agora bruto com um sentido que, por ser único, não faz sentido. Como uma mesma razão burguesa se inscreve em todos os sucessivos períodos cronológicos, submetendo-os a sua lógica técnica, então não se pode dizer que existam "sucessivos períodos cronológicos": todos os tempos são o mesmo tempo da burguesia, que não é uma classe, mas um tipo de racionalidade técnica que fagocita outras lógicas, plasmando todas nessa única engrenagem. O movimento perpétuo em um mesmo ponto gera a ilusão do progresso, mas, na verdade, esse dínamo está a serviço da permanência. Parece que damos um passo à frente, mas é só mais uma volta da máquina. A profundidade do percurso é um efeito de tridimensionalidade criado pela velocidade com que as diferentes imagens se sucedem em uma tela plana que assistimos sentados na mesma poltrona de sempre: o dinamismo da tela nos alivia o peso estático da vida e nos devolve docilmente para ela, mal sabendo nós que é nessas falsas experiências cinéticas que estaciona a história.

Ao cunharem o termo "indústria cultural", Adorno e Horkheimer (2006) mostravam como a cultura passava a assumir a lógica sistêmica do capital, abandonando assim seus velhos mecanismos internos para, a partir de então, trabalhar no compasso da indústria. Como essa lógica técnica da razão burguesa se apropria de todos os aspectos da vida, o mundo todo passa a funcionar dentro de um mesmo grande esquema. Uma só racionalidade invade todas as dimensões, fazendo com que operem de acordo com uma mesma lógica, e assim se vejam niveladas e homogeneizadas por essa ideologia. Cada elemento deixa de ser o que era para ser uma peça dessa nova máquina. Assumindo essa racionalidade, a vida é engolida por ela, e os caminhos que aparentemente levam para a fora desse pesadelo, na verdade, são rotas oblíquas que nos devolvem para dentro. A linha de chegada se inscreve em cada ponto do caminho, mas por isso mesmo nunca conseguimos cruzá-la definitivamente, pois, na verdade, não corremos em uma trilha linear, mas sim numa esteira de hamster. O slogan anuncia a si mesmo, o muro cresce conforme o escalamos e é 
por eternamente se prometer que a promessa nunca se cumpre. A razão técnica da burguesia assume, portanto, uma lógica simultaneamente pornográfica e puritana: excita e castra ao mesmo tempo, deixando-nos famintos justamente por não parar de nos alimentar, transformando as frustrações em felicidades ao nos prometer alegrias que, se por um lado nunca chegam, por outro chegam imediatamente, pois nos alegramos só de esperar por elas. Ofertas são ofertadas e desejos são desejados enquanto caminhamos sonâmbulos para o abismo.

Para esses autores, não existe qualquer afinidade entre as partes engolidas pela razão burguesa, nem delas com essa totalidade que as arregimenta. Simplesmente por ali haver uma sucessão de elementos pressupõe-se que exista uma ordem, mas esse sentimento é enganoso. As partes não são peças complementares que se articulam organicamente, formando uma totalidade harmônica, mas cacos que nunca se colam, apenas se amontoam. Por isso, no fundo, nem se pode dizer que existam partes e um todo, mas apenas um plasma, uma massa gelatinosa, amorfa e indistinta. A racionalidade técnica do capital estende a mão para as diferenças e as particularidades que estejam dispostas a abrir mão de suas especificidades dentro do plasma. Quer dizer: o preço que se paga para ter a individualidade reconhecida é justamente abdicar dela. Você é idiossincrático o suficiente para ser convidado para a festa, mas, uma vez lá dentro, tanto faz quem você seja, pois todos no salão são iguais. "Não desista, o próximo vencedor pode ser você", e "você" é qualquer um de vocês. Para o sistema, você pode ser $u m$, desde que esteja disposto a ser mais um.

No fim das contas, as partes selecionadas não se ordenam, mas se empilham, e o todo que formam não é orgânico, mas amorfo. Sendo assim, não há partes e todo, só esse engodo inexpressivo. Como se pode ver, para a Escola de Frankfurt, não há qualquer diferença entre presente e passado, aliás, não há presente e passado, só essa indistinta gosma.

Embora reconhecessem seus méritos, muitas vozes denunciaram o acento nivelador e universalista da ONU, da UNESCO e dos Direitos Humanos. Para esses críticos, as resoluções desses órgãos expulsavam velhos riscos de guerra e intolerância, mas também criavam novos. Foi uma ênfase na diferença que ensejou o colonialismo e o nazismo, mas estimular matérias únicas, indistintas e universais também poderia constranger a 
convivência pacífica entre os povos. Com o tempo, foi se cristalizando a ideia de que aqueles "princípios válidos para todas as culturas" não eram compartilhados por todas as culturas nem foram criados por elas. Quer dizer, foi ficando evidente que o mundo continuava vivendo sob uma ordem mundial localmente forjada, exatamente como no período exótico-colonial do mercado da diferença. A ortodoxia poderia ser outra, mas ainda era uma ortodoxia.

Quando a ideia de globalização começou a dominar o debate acadêmico, cultural e político, rapidamente apareceram discursos denunciando o caráter homogeneizante dessa nova onda. Como apresentado nos documentos acima, a própria UNESCO passou a tomar medidas para proteger a diversidade cultural da lâmina niveladora da globalização. Com o passar do tempo, essa ameaça de indistinção da globalização passou a ter uma cara: os Estados Unidos. O processo de globalização do mundo começou a ser encarado como um movimento de "estadosunização" do planeta. Sendo assim, ao invés de ser vista como um reconhecimento de diferenças, uma reunião de povos idiossincráticos, enfim, como uma promoção das ideias particulares de multiplicidade, heterogeneidade, hibridismo e relativismo, a globalização foi aos poucos sendo encarada como um caminho universal único, homogêneo, puro e absoluto, uma via totalitária guiada pelos americanos. Para essas vozes dissidentes, as culturas não estavam se doando reciprocamente em fluxos de intercâmbios culturais, os Estados Unidos é que estavam espalhando seus tentáculos pelos outros países, esmagando tendências nativas com sua cultura hegemônica e empurrando o mundo inteiro na direção que lhe aprouvesse. As antigas colônias ainda não escreviam suas respectivas histórias, continuavam sendo notas de rodapé de um relato que lhes escapava. Um novo processo, um novo protagonista, mas, assim como antes, uma pauta universal criada em um país específico que violentamente se espraiava pelo globo, gerando ondas de homogeneidade que atropelavam histórias locais.

Já na década de 1970, na imprensa, na política e na academia, pessoas começam a definir os Estados Unidos como um "império" e o seu governo como "imperialista", palavras usadas para se referir ao regime de poder vigente durante o período exóticocolonial do mercado da diferença. Desse modo, assim como a colonização foi o projeto imperial europeu do século XIX, a globalização seria o plano imperialista americano da 
virada do século XX para o XXI. Como disse Viveiros de Castro em uma entrevista: o "mundo global" deveria se chamar "mundo dos Estados Unidos" (2013).

Esse suposto espraiamento dos Estados Unidos pelo mundo tinha impactos nos países periféricos, logicamente, mas também incomodava outras potências mundiais, especificamente aquelas culturas que dominaram o mundo no período exótico-colonial do mercado da diferença e hoje se veem ameaçadas pelos americanos. O melhor exemplo disso é a França: durante o primeiro período do mercado da diferença, a França era o berço da civilização, o estado que encarnava os princípios universais de unicidade, homogeneidade, pureza e absolutismo. Depois da Segunda Guerra Mundial e da independência das colônias, os Estados Unidos figuraram no cenário internacional como uma grande potência, colocando-se como um referencial cultural para o resto do mundo. Desde então, a França tem acionado estratégias para proteger sua cultura da influência americana. Mesmo com a emergência da agenda diversidade e de seus valores particulares de multiplicidade, heterogeneidade, hibridismo e relativismo, a França se blinda da cultura dos Estados Unidos. O país foi um dos primeiros a criar cotas de exibição de filmes nacionais nas salas de cinema para proteger o material local da invasão de Hollywood. Em tempos em que tanto se critica o monoglotismo e se tenta construir uma nação babélica, a França ainda levanta a bandeira da francofonia e vê com maus olhos a presença do inglês em seu território. Talvez por essa proteção contra a cultura americana, a França nunca conseguiu ter - ao contrário dos Estados Unidos, da Inglaterra, da Austrália, da Irlanda ou mesmo de lugares que não falam o inglês como a América Latina e a Alemanha - uma grande banda de rock.

Como se falou, um dos pilares do período exótico colonial do mercado da diferença foi a divisão binomial do mundo. Nessa época havia o Eu, encarnando a cultura da metrópole, e o Outro, que representava a cultura da colônia. Embora fossem diametralmente opostas, cada um desses polos era indiferenciado dentro de suas fronteiras. Assim se organizava o mundo: duas grande ontologias imiscíveis, distintas uma da outra, indistintas em si mesmas, separadas por um vácuo intransponível. A chegada do período da diversidade-global do mercado da diferença fez crescer a expectativa por uma mudança desse arranjo. A independência das colônias fragmentou o bloco do Outro em várias partículas, e o Eu, tendo perdido sua unidade de referência, também acabou se diluindo. Os 
infinitos e pequenos estilhaços do que um dia foram duas grandes objetividades começaram a se trocar reciprocamente em fluxos de intercâmbios culturais, e, assim, dada a velocidade desses processos, as fronteiras que dividiam cada fragmento foram perdendo a rigidez, e então ficou difícil definir o que era próprio de um ou de outro, o que era de dentro e o que era de fora. A organização binomial do mundo cedeu lugar a fragmentação cultural e o hiato que alienava as culturas foi substituído pelos fluxos de intercâmbios culturais. Tudo parecia diferente.

Mas, como se sabe, durante o período da diversidade-global do mercado da diferença surgiu uma organização que dividia os países em primeiro, segundo e terceiro mundos. O primeiro mundo seria composto pelas economias capitalistas desenvolvidas, o segundo pelo bloco socialista e o terceiro pelos países capitalistas subdesenvolvidos. Com a queda da União Soviética e o fim do comunismo (ou pelo menos daquele que até então se praticava), essa divisão em três mundos desapareceu, mas nasceu outra que separava os países entre norte e sul, sendo o primeiro composto pelas economias desenvolvidas e o segundo pelas subdesenvolvidas. Para os que defendiam a tese da continuidade entre os dois períodos do mercado da diferença, essa divisão do mundo entre norte e sul era uma clara sobrevivência do arranjo binomial Eu/Outro, que vigorou durante o período exóticocolonial do mercado da diferença. Tanto lá como cá, tem-se duas metades indiferenciadas mas opostas entre si separadas por uma fenda. O norte capitalista desenvolvido seria uma mera atualização do Eu metropolitano, enquanto o sul capitalista subdesenvolvido encarnaria o espírito do Outro, das antigas colônias europeias. Inclusive, com raríssimas mas importantes exceções, de fato os países que compunham o Eu agora formavam o norte e as culturas niveladas no Outro hoje fazem parte do sul. Austrália, Nova Zelândia, Estados Unidos e Canadá são exemplos de países colonizados que hoje são desenvolvidos, mas, fora casos excepcionais como esses, a estrutura do passado se repete no presente: Europa no norte, África, América Latina e a maior parte da Ásia no sul.

Para os partidários da continuidade, além de ser uma organização binomial do mundo idêntica ao par Eu/Outro do exótico-colonial, a separação Norte/Sul da diversidade global ainda herdava do passado um forte acento evolucionista. Desse jeito, assim como Eu se achava superior ao Outro por acreditar que o mundo colonial estacionara em um estágio evolutivo já superado pela metrópole e por isso julgava que colonizar essas terras 
era uma missão filantrópica e civilizatória que as colocaria nos trilhos do progresso, também a globalização, alicerçada em uma hierarquia evolutiva entre desenvolvidos e subdesenvolvidos, acabou virando uma desculpa para que o norte impusesse seus valores sobre o sul. Além da influência cultural através da mídia e do consumo, os Estados Unidos interferem em outras culturas de maneira mais direta e violenta para incutir seus valores nessas terras estrangeiras: supostamente respaldados pela universalidade e pela imanência dos valores humanitários, o que para os críticos é só uma fachada, os americanos justificam suas invasões ao Oriente Médio afirmando que estão levando a paz e a democracia para países que não conhecem esses valores ocidentais, ou melhor, "universais".

Para os que acreditam em uma continuidade entre os dois períodos do mercado da diferença, há aqui um espelhamento total entre o exótico-colonial e a diversidade-global: antes, a metrópole achava que possuía uma cultura universal de riqueza autoevidente, enquanto a colônia se encontrava presa a um patamar de desenvolvimento que a Europa já havia atravessado. Devido a essa assimetria evolutiva, o Ocidente acreditava que era seu dever civilizatório levar sua cultura universal para aquele Oriente atrasado. Sendo assim, a ocupação de terras além-mar não era encarada como uma tirania, mas, pelo contrário, como um gesto filantrópico do Eu para com o Outro. Se os valores eram universais e bons em si mesmos, tudo feito em seu nome estava justificado. Enquanto doutrinava a colônia, a metrópole espoliava suas matérias primas e roubava suas riquezas. Hoje, para aqueles que acham que nada mudou, algo muito parecido acontece: os Estados Unidos se alicerçam em resoluções das Nações Unidas para afirmar a universalidade da sua cultura e assim justificar sua interferência no Oriente Médio como um ato de benevolência que tem por objetivo fazer com que aquelas culturas incompletas conheçam a paz e a democracia, valores que, mais do que americanos, são universais e devem ser adotados por todos os países. Em busca de armas de destruição em massa que representariam um risco para a paz mundial ou objetivando acabar com ditaduras que tiranizam a população local, os americanos ocupam terras estrangeiras globalizando as narrativas universais da paz e da igualdade, enquanto muitos apontam que o verdadeiro objetivo dessas missões civilizatórias é o petróleo (TODOROV, 2014). O próprio Said, autoridade em colonialismo, considera os Estados Unidos um império afeito ao discurso exotizante do Orientalismo. Para o autor, o Orientalismo americano já superou a fase do diletantismo intelectual e se encontra em sua etapa de conquista colonial e militar. Expondo suas 
filiações à tese da continuidade entre os dois períodos do mercado da diferença, Said irá afirmar em 1994: "O colonialismo reapareceu na subserviência do sul ao norte". (SAID, 2013, p. 463).

É assim que os adeptos da continuidade enxergam o problema: em ambos os períodos do mercado da diferença o mundo se dividiu em dois polos evolutivamente hierarquizados. Um dos polos encarna valores universais autoevidentes ignorados pelo outro, por isso era considerado mais evoluído. Como esses valores são tidos como universais e inerentes à natureza humana, os países que os abraçam estão alicerçados em uma verdade ahistórica, enquanto aqueles que não os compartilham passam a ser vistos como incompletos. Dada essa assimetria, os eleitos se sentem na obrigação de levar a palavra para os esquecidos, sendo assim, a ocupação desses territórios não é vista como um ato de barbárie, mas sim como uma missão civilizatória filantrópica. Sob o manto desse altruísmo, os "evoluídos" pilham recursos naturais e matérias primas dos "atrasados". Foi assim com a colonização, quando a Europa espoliou as riquezas do resto do mundo em nome dos princípios universais e naturais da civilização e de Deus; foi assim na globalização, quando os Estados Unidos saquearam o Oriente Médio em nome dos princípios universais e naturais da liberdade e da democracia. Pelo menos essa é a visão daquelas que acreditam em uma linha contínua entre os dois períodos do mercado da diferença.

Eis o cenário da continuidade: os diversos fragmentos culturais pareciam ter se reorganizado em torno de duas ontologias sólidas, opostas uma da outra mas indistintas em si mesmas: o sul e o norte. Os intercâmbios de fluxos globais construíram um mundo hierarquizado de posições fixas e estáveis. Paz, igualdade, democracia e equilíbrio acabaram virando justificativa para guerras, invasões e golpes de estado. O líder mundial poderia ter mudado, mas o resto dos países ainda continuava subserviente a um único centro. Progresso, história linear única e evolução ainda pareciam signos fortes. As ideias particulares de multiplicidade, heterogeneidade, hibridismo e relativismo, ao se deixarem acomodar na moldura do universal, da natureza humana, da agenda global localmente forjada e do estado-nação, acabaram produzindo efeitos de unidade, homogeneidade, pureza e absolutismo. Pelo visto, o particular era só mais um trilho por onde o universal deslizaria. As aparentes mudanças não representavam revoluções reais, pois eram apenas a 
atualização das velhas ideias, uma reorganização necessária para que os efeitos de sempre continuassem sendo produzidos. Enfim, para os adeptos desse pensamento, o período da diversidade-global do mercado da diferença era idêntico ao exótico-colonial, pois a relação que estabeleciam era de total continuidade.

\section{Ruptura}

Para alguns autores, a tese da continuidade completa entre os dois períodos do mercado da diferença era demasiadamente simplista e negligenciava alguns elementos importantes dessa virada de página. Esses que acreditavam em uma ruptura entre os períodos se organizavam em dois grupos: de um lado, havia alguns mais otimistas que acreditavam que tudo havia mudado, por isso celebravam os novos tempos; de outro, havia aqueles que até achavam que as assimetrias de poder do primeiro período geravam efeitos de desigualdade no segundo, mas eram justamente esses desequilíbrios que abririam possibilidades para a disseminação das ideias particulares de multiplicidade, heterogeneidade, hibridismo e relativismo.

A diferença básica entre essas duas facções que compunham a corrente da ruptura estava no tratamento que cada uma dava à história. Ambos acreditavam que o futuro seria diferente do passado, mas chegavam a essa conclusão percorrendo caminhos diferentes no que se refere ao papel da história. Os primeiros acreditavam que os novos tempos seriam diferentes dos velhos porque aquele fluxo histórico havia se interrompido, os grandes relatos e os marcadores cronológicos não funcionavam mais e tudo se confundia em um grande presente absoluto que imediatizava toda a história, transformando processo em evento. Para esses, havia liberdade porque não havia memória, só fragmentos aparecendo e sendo consumidos assim que eram suscitados, dando lugar a outros que em nada se relacionavam com o que os precedeu. Já os segundos acreditavam que tudo seria diferente justamente porque o passado se inscreve nos novos tempos e é nessa memória que nos enraizaremos para construirmos algo diferente. A emancipação viria justamente através do resgate dos abusos cometidos nas gerações anteriores. A história não deveria ser ignorada, mas revisada. Para construir um presente diferente, uns acreditavam que era preciso esquecer o passado, e outros achavam que o importante era recuperá-lo. Os primeiros são 
os pós-modernos, sendo Lyotard (2010) o membro mais representativo desse grupo ${ }^{31}$, e os segundos os pós-coloniais, rótulo que, com algum esforço, reúne nomes como Stuart Hall, Home Bhabha, Arjun Appadurai, dentre outros.

O caminho trilhado pelos pós-modernos, ou melhor, as imagens independentes que os pós-modernos sobrepuseram, escapa aos objetivos desse trabalho, portanto, olharei aqui para os pós-coloniais. As ideias principais desse grupo já foram apresentadas no capítulo anterior, quando analisei o conceito de hibridismo. Nesse caso, não pretendo me prender agora a nenhuma exegese, só mostrar em que medida o pensamento pós-colonial se filia à corrente da ruptura entre os dois períodos do mercado da diferença.

Como o próprio nome sugere, os autores do pós-colonial sabiam que a desigualdade que marcou o primeiro período do mercado da diferença gerou consequências no segundo, e que as assimetrias do mundo contemporâneo tinham raízes na dominação dos séculos passados. No entanto, para eles, seria justamente essa memória e essa inércia histórica que abririam as portas para um novo tempo. Resgatando o passado colonial, a história seria reescrita, reformulada, vista agora pelo prisma dos "debaixo", e, assim, depois desse revisionismo, uma era diferente poderia ser inaugurada, um futuro que não repetisse os erros do passado. Em linhas gerais, é isso que a catacrese do híbrido representa: disjuntar o presente para se apropriar catacreticamente das metáforas coloniais e libertar o futuro.

Sim, as assimetrias de poder ainda existem e são bastante evidentes, mas essa evidência é justamente o ponto de transição: no período exótico-colonial do mercado da diferença, essas mesmas assimetrias, ainda que gigantescas, eram naturalizadas. Naquele tempo, o que velava a dominação era justamente o seu desvelamento: por ser escancarada, defendida e até institucionalizada, a hierarquização dos povos era uma realidade sem exterior, uma verdade facilmente aceita como um dado da natureza ou uma resolução divina. Mas, depois de várias mudanças na política, na cultura e na academia, aquele sistema, antes amplamente digerido, passou a ser denunciado como uma barbárie e assim, depois que o totalitarismo apresentou sua conta, o homem teve que se confrontar com a própria monstruosidade. A violência pode até existir, mas não é mais aceita como uma natureza nem tida como uma etapa necessária de desenvolvimento, sendo antes, o retrato

\footnotetext{
${ }^{31}$ Se é que se pode chamar de "grupo" um relato que prega a fragmentação e a falência dos grandes discursos.
} 
da decadência do projeto civilizatório. Assim como no período exótico-colonial do mercado da diferença, o mundo ainda é desigual, e isso certamente é uma herança do passado, entretanto, essa desigualdade é hoje vista de uma maneira diametralmente oposta à forma com que era enxergada ontem: antes, natureza e progresso; hoje, arbítrio e atraso. Portanto, alegam os pós-coloniais, como se pode dizer que ainda vivemos no período exótico-colonial do mercado da diferença se a desigualdade, que era um pilar daquele sistema, ainda que exista, é hoje amplamente denunciada? Se a violência, antes naturalizada, é hoje combatida?

O estado de desigualdade em que as culturas hoje se encontram provoca uma assimetria em seu diálogo, já que algumas vozes falam mais alto que outras, criando-se portanto uma disputa desleal entre os povos. A assimetria desse diálogo e a deslealdade dessa luta podem até apontar para o período exótico-colonial do mercado da diferença, mas o fato de haver um diálogo e de haver uma disputa sugere que, de fato, algumas coisas mudaram. É a isso que Bhabha se refere quando fala em ir contra a corrente, não para acabar com ela, mas para denunciar que há uma corrente nos empurrando para trás. É importante que o colonial lute não apenas para derrotar seu adversário mas para que seu esforço de resistência evidencie que o mundo é sim um espaço de lutas e não de relações pacíficas. O mundo de hoje pode ser tão hierarquizado como o de ontem, mas se ontem esses gabaritos eram naturais, hoje eles são denunciados. Podemos até morrer na luta, mas teremos sido vitoriosos em evidenciar as arbitrariedades do mundo. Para os pós-coloniais, a existência de uma guerra física não implica que haja um dissenso simbólico, muito pelo contrário: o passado se alicerçava na violência, naturalizando-a e fazendo dela o único sentido em jogo. Não havia negociação, deslizamento ou risco, o mundo estava firmemente assentado na própria barbárie. Hoje, essas mesmas hegemonias, e é verdade que elas ainda existem, estão em debate, sendo seguidamente questionadas. Antes, a dominação era certeza, natureza e base de sustentação de um mundo estabilizado e sem diálogo, já que só uma voz existia. Hoje, em torno das mesmas questões, há incerteza, risco e instabilidade, pois uma variedade de vozes disputa os mesmos sentidos. A luta pode ser injusta e a injustiça pode ser um traço do passado, mas a luta é coisa do nosso tempo.

"Não se quer sugerir aqui que, numa formação sincrética, os elementos diferentes estabelecem uma relação de igualdade uns com os outros. Estes são sempre inscritos diferentemente pelas relações de poder - sobretudo as relações de dependência e subordinação sustentadas pelo próprio colonialismo. Os 
momentos de independência e pós-colonial, nos quais essas histórias imperiais continuam a ser vivamente retrabalhadas, são necessariamente, portanto, momentos de luta cultural, de revisão e de reapropriação. Contudo, essa reconfiguração não pode ser representada como uma 'volta ao lugar onde estávamos antes', já que, como nos lembra Chambers, 'sempre existe algo no meio'. Esse algo no meio é o que torna o próprio Caribe, por excelência, o exemplo de uma diáspora moderna." (HALL, 2013, p. 38).

Há uma meta-questão à qual os pós-coloniais se prendem para defender a tese da ruptura. A questão é a seguinte: o fato de haver um debate para se descobrir se a relação entre os dois períodos do mercado da diferença é de continuidade ou de ruptura não seria um indicativo de que há ruptura, posto que, se houvesse continuidade, o próprio debate seria impossível? Como se falou, no período exótico-colonial do mercado da diferença, a desigualdade era naturalizada, não havia diálogo porque só existia uma voz e os sentidos não estavam em disputa. Em um cenário como esse, um futuro diferente seria inimaginável e, mesmo que esse horizonte sorrisse para algum visionário, seu destino certamente seria a morte. Enfim, jamais se duvidaria da existência de uma era exótica-colonial do mercado da diferença se ela ainda estivesse em vigor; até porque, aqueles que viveram o período não o experimentaram como tal, como um tempo fechado, com começo, meio, fim e características autocontidas, mas como a própria natureza do universo, eterna e inquestionável. Ou seja, para os pós-coloniais, o fato de hoje podermos discutir se o período exótico-colonial do mercado da diferença acabou ou não já é um sinal que as coisas não são mais as mesmas, já que, se ele ainda estivesse vigorando, questionar sua existência seria impossível, como de fato foi.

A tese de Bhabha do presente disjuntivo está em sintonia com o meta-argumento de que discutir acerca de uma possível mudança no mercado da diferença já seria um indicativo de que ela ocorreu. Disjuntar o presente, fazer com que ele retorne ao oco em que a origem da história arbitrariamente se inscreveu, suplementar esse começo e substituílo, assumindo a anterioridade do corpo a que tardiamente se anexa e refazer o percurso à luz dos dias de hoje, apropriando-se catacreticamente das metáforas que nos impuseram, nada mais é que fazer com que o próprio espaço onde se discursa seja a fratura por onde o discurso virá fluir. Desse modo, a possibilidade da mudança já a inicia, pois a revolução passa justamente pela fresta de sua conjectura. Abre-se uma fenda no tecido contínuo do discurso para que um discurso diferente atravesse esse buraco, ressignificando no agora do corte o que até então foi discursado e criando novas possibilidades para o que ainda se 
discursará. A pergunta "o mercado da diferença mudou?" é o espaço onde essa mudança irá se dar, ou melhor, não é o espaço da mudança, mas abre o espaço para ela, opera um corte na continuidade desse mercado por onde emergirá um segundo período. A pergunta pousa na superfície lisa do mercado da diferença e gira em torno do seu próprio eixo, cavando na areia do mercado o oco onde ela mesma se situa, o buraco diferenciante que, já sendo ele próprio uma diferença, abre a possibilidade para uma nova realidade. Ora, em que contexto Said poderia ter escrito Orientalismo se não em um tempo um em que o Orientalismo estivesse em crise? Como se pode dizer que o Ocidente ainda é o único sujeito do mercado da diferença se ele é levado à condição de objeto por um palestino? É claro que Said não está apenas surfando em uma onda, ele é essa onda; seu livro não passa por uma porta escancarada, escancara a porta. Quer dizer, o autor não está chutando cachorro morto, se aproveitando da decadência do Orientalismo para criticá-lo, pois é sua própria crítica que contribui para o velório daquele pensamento totalitário. No entanto, por mais vanguardista que Said seja (e ele é muito) não se pode deslocar o autor de seu tempo. Aquele livro proporcionou uma mudança no mercado da diferença, mas também está contido nela, seguindo a seta que ele mesmo desenhou. Na verdade, isso esta(va) acontecendo por todo o debate: Bhabha, Hall e outros não estão apenas sugerindo aos periféricos que revisem a história e se apropriem catacreticamente das metáforas que lhes foram impostas, mas estão eles próprios fazendo isso ao sugerir que isso seja feito, eles são esses tais desviantes que colocam suas teorias em prática justamente no ato de escrevê-las. Quando nos manda fazer catacrese, Bhabha faz catacrese. Realmente, há uma mudança visível na biografia dos teóricos da diferença. Se, antes, orientalistas europeus brancos tinham o monopólio do discurso sobre o Outro, hoje esse debate está tomado por indianos, antilhanos, paquistaneses, latinos etc. que vaticinam uma falência dos impérios e atestam essa queda justamente por conseguirem enunciá-la. Diante disso, como não pode ter havido mudança?

Para os teóricos da ruptura, além da naturalização da violência, outro pilar do período exótico-colonial do mercado da diferença que ruiu foi a organização binomial do mundo, com seus polos indiferentes em si e diferentes entre si. Desde os pós-estruturalistas até os pós-coloniais, o que se vê é um recusa dos pares extremos e uma defesa do meio, da mediação, do intermédio. O devir de Deleuze e Guattari é uma linha de fuga que nasce entre dois pontos, perpendicular a eles, e os arrasta consigo; o rastro diferenciante de Derrida se rasga no meio da brancura da página, fazendo o texto escorregar por essa fresta; 
o híbrido de Bhabha sintetiza elementos distantes, oscilando em um terceiro espaço ambivalente entre dois pontos; a diáspora de Hall é uma história intersticial que costura culturas, passando pelo meio delas, etc. Todos essa ode ao meio produz tipos fronteiriços, nomes que passam a tomar conta do glossário das ciências sociais: híbridos, diaspóricos, creolizados, ciborgues, etc. Além disso, para esses autores, nessa nova era não se vive mais aquele tempo linear e sucessivo do período exótico-colonial, nem os elementos se articulam em um caminho de mão única; ao contrário, tudo é recursivo, circular e metalinguístico. Nada é um mero depois, mas sim uma outra leitura da mesma coisa, um avesso do que havia antes, o lado de cá do lado de lá, um suplemento originário, a catacrese de uma metáfora, etc. enfim, não se está simplesmente caminhando em linha reta, mas avançando através de uma retomada crítica do passado.

Mas, para os autores da ruptura, o grande defeito dos defensores da continuidade era uma certa miopia, uma tendência a enxergar só metade do problema. De fato, mesmo aqueles que advogavam que o mercado da diferença havia mudado não podiam negar as denúncias feitas pelos partidários da continuidade de que o mundo vivia uma supremacia econômica e cultural americana e de que hierarquias de ontem se repetiam hoje. No entanto, dizia a escola da ruptura, afirmar que essa hegemonia aponta para um cenário universalista afeito ao único, ao homogêneo, ao puro e ao absoluto (como fazia a escola da continuidade) é se ater apenas a um aspecto da questão e negligenciar outro, dito de maneira direta: é olhar só para a produção e virar as costas para a recepção. Para os póscoloniais, aqueles que pensavam que nada mudou chegavam à conclusão que o período da diversidade-global do mercado da diferença se enraizava nas ideias universais de unidade, homogeneidade, pureza e absolutismo porque encerravam sua análise quando atestavam a presença de uma centralidade americana no mundo; mas, se insistissem na observação e se perguntassem que efeitos essa centralidade gera, tais pensadores descobririam que mesmo um cenário monopolístico produz ondas particulares de multiplicidade, heterogeneidade, hibridismo e relativismo. É nesse sentido que, indo na contramão de Viveiros de Castro, Ortiz vai afirmar que "O processo de globalização tecnológica e econômica, assim como a mundialização da cultura, não é sinônimo de homogeneização, tampouco de americanização." (2008, p. 37). Ou seja, para aqueles que defendiam uma ruptura entre os dois períodos do mercado da diferença, a diversidade-global poderia até produzir um discurso universalista calcado no único, no homogêneo, no puro e no absoluto, entretanto, 
cada um ouvia essa voz monocórdia de um jeito, fazendo com que, no plano da recepção, efeitos particulares de multiplicidade, heterogeneidade, hibridismo e relativismo fossem gerados.

É exatamente a isso que Appadurai se refere quando diz que a globalização é um processo disjuntivo (2013) ou Hall quando fala das já comentadas assimetrias entre codificação e decodificação (2013). Como já comentei anteriormente, essas teorias postulam o seguinte: do ponto de vista da produção, pode até haver uma única, grande e indiferenciada voz, mas, na esfera da recepção, muitos, pequenos e diferentes ouvidos captam-na, fazendo com que aquela mensagem monolítica seja recebida das mais diversas maneiras possíveis. Mesmo que só haja um satélite, existem muitos receptores, desse modo, aquele mesmo sinal que emana dele é lido de formas variadas por essas antenas. A boca americana fala sempre a mesma coisa, mas cada ouvido do mundo escuta do seu jeito. Como já se disse, o resultado final de uma projeção depende tanto do projetor quanto da tela, portanto, mesmo que a imagem projetada se repita, se as superfícies nas quais ela se projeta forem diferentes, nenhuma exibição do filme será igual a anterior. Como disse Bohlman, "A retórica da globalização se espalhou, mas as possibilidades do que ela realmente quer dizer também se multiplicaram." (2002, p. 37). O exemplo que se usou antes foi o de uma luz refratando em líquidos variados: a luz pode até ser uma só, mas as diferentes densidades dos líquidos distorcem o facho original, fazendo com que ele se ondule de muitos jeitos. "Radicalizando o argumento, seria possível então concluir que a homogeneização do mundo sequer é possível, pois a sempre necessária recepção do interlocutor geraria por si só processos de diferenciação" (NICOLAU NETTO, 2014, p. 25)

Diante desse cenário, chega-se a um ponto extremo em que o universal (com suas ideias de unidade, homogeneidade, pureza e absolutismo) e o particular (trazendo suas noções de multiplicidade, heterogeneidade, hibridismo e relativismo) passam a ser diretamente proporcionais: quanto mais universal, mais particular. Quanto mais centralizado o mundo estiver, mais multifacetado ele será, pois quanto mais esse grande e único discurso se espalha, mais receptores diferentes ele atinge, e cada um desses o decifra à sua maneira, fraturando-o e gerando polissemia. 
Para os que acreditam na reciprocidade entre universal e particular, quanto mais um tecido cresce, mais dobras ele acumula, fazendo com que toda hegemonia seja compensada por suas infinitas apropriações. Para Ortiz é exatamente isso o que acontece com a língua. Quanto mais um idioma se alastra pelo globo, mais formas diferentes de falá-lo surgem. Elege-se uma única língua como padrão normativo para todos, desse modo, mais pessoas mundo afora passam a se comunicar nela, sendo que elas não reproduzem essa ortodoxia como ela foi nativamente concebida, mas da maneira que conseguem, e como cada uma consegue de um jeito diferente, o estabelecimento de um cânone linguístico monolítico acaba sendo responsável por uma pluralidade de vozes: produção universal escudada no único, no homogêneo, no puro e no absoluto com recepção particular dialogando com o múltiplo, o heterogêneo, o híbrido e o relativo.

É isso o que acontece com o inglês atualmente. Vivemos hoje em um mundo em que quanto mais se deve falar inglês, menos ele é falado, pois como pessoas diferentes tentam falar esse mesmo idioma, cada indivíduo imprime sua especificidade a ele, de modo que a forma original que deveria ser reproduzida nunca aparece. Quando abordei Benjamin falei que a aura pura da matriz artística só sobrevive na série de reproduções que também a macula, de modo que, como afirmou Derrida, o princípio de vida da arte também é seu princípio de morte. Resgatando Foucault, falei também que, para o autor, a literatura não existe, o que existe são os livros, ou melhor, a literatura pode até existir, subexistindo nos livros. Cada livro é uma tentativa de atingir a brancura imaculada da literatura, mas todos esses testes fracassam, e nenhum livro, sempre parcial, consegue abarcar o universo infinito e cristalino da literatura. Tentar tocar a pureza das letras já é corrompê-la, entretanto, esse mito da virgindade da literatura é forjado pelos e só sobrevive nos livros sujos que inutilmente tentam contê-la. A linha contínua da literatura é mantida pelo enfileiramento das rupturas geradas pelos livros; sua perfeição é só o amontoado dos fracassos literários que tentaram espelhá-la, mãos manchadas de tinta que garantem sua assepsia. Assim, ainda que a luz abençoada da literatura branca antecipe a escrita dos livros, iluminando-os, é essa tentativa dos livro tardia e fracassada de conter a literatura que a instaura. Dessa forma os livros funcionam como um suplemento originário em relação a literatura: anexam-se posteriormente à literatura que os influenciou e assim a criam, garantido a antecedência daquilo que secundam. Para os teóricos da ruptura, é isso que se dá entre o inglês e as tentativas de falá-lo: estabelece-se o inglês como a única 
ortodoxia possível, o único idioma que se pode falar. A partir daí, pessoas das mais diferentes línguas tentam obedecer essa resolução, mas o resultado de cada tentativa é diferente, pois a luz universal do inglês acaba refratando nos muitos idiomas particulares. No fim das contas, é justamente porque todo mundo precisa falar inglês que ninguém o fala, produzindo no máximo infinitos arremedos dele. A mesma língua deve ser falada por pessoas diferentes, mas essa continuidade da língua acaba se segmentando nas diferenças dos indivíduos, de maneira que a produção de um universal termina gerando recepções particulares. Assim como a literatura e os livros que tentam espelhá-la, o canônico e imaculado inglês universal é uma normatividade que sobrevive nos diferentes jeitos "errados" de falar inglês, nas tentativas frustradas de reproduzir essa ordem. Usando aqui o binômio de Saussure, quanto mais o inglês se universaliza enquanto língua, mais ele se particulariza enquanto fala. A estrutura pode ser monista, mas a prática é diversificada ${ }^{32}$, e se é verdade que é essa estrutura unívoca que ilumina a pluralidade das práticas, também é correto afirmar que é essa serialidade das partes que ratifica a soberania do todo. Essa tensão entre universalidade da produção e particularidade da recepção é o que leva Ortiz a afirmar que quanto mais centralizada uma língua é, mais descentralizada em sotaques ela fica, de maneira que a outra face da unidade do idioma passa a ser a diversidade dos jeitos de falá-lo:

"Ao tornar-se mundial, liberando-se de seu enraizamento anterior, ele [o inglês] torna-se também um artefato a ser 'deformado' pelos falantes dessa galáxia. Como a existência de um padrão normativo (standard) é uma quimera, qualquer indivíduo, independentemente de sua origem, tem a oportunidade e o direito de deturpá-lo. A diversidade dos sotaques é o preço pago por sua hipercentralidade". (ORTIZ, 2008, p. 129)

É exatamente a isso que Deleuze e Guattari se referem quando falam do black-english:

"Uma língua, como o inglês, o americano, não é mundialmente maior sem ser trabalhada por todas as minorias do mundo, com procedimentos de variação bastante diversos. Modo pelo qual o gaélico, o anglo-irlandês, faz variar o inglês. Modo pelo qual o black-english e tantos 'guetos' fazem variar o americano, a ponto de Nova Iorque ser quase uma cidade sem língua. (E mais: o americano não se constituiu, em suas diferenças em relação ao inglês, sem esse trabalho linguístico das minorias.)" (2011, vol. 2, p. 48).

"Os negros americanos não opõem o black ao inglês, fazem com o americano, que é sua própria língua, um black-english. As línguas menores não existem em

\footnotetext{
32 "As 'línguas' [dialetos] só existem em estado prático, ou seja, sob a forma de habitus linguísticos pelo menos parcialmente orquestrados e de produções orais desses habitus." (BOURDIEU, 2008, p. 33)
} 
si: existindo apenas em relação a uma língua maior, são igualmente investimentos dessa língua para que ela se torne, ela mesma, menor. Cada um deve encontrar a língua menor, dialeto ou antes idioleto, a partir da qual tornará menor sua própria língua maior." (2011, vol. 2, p. 51).

Segundo Deleuze e Guattari, para ser bilíngue, o indivíduo não precisa aprender uma segunda língua, fora da sua, mas apenas dar um uso diferente à seu idioma, dentro dele, tratar uma língua universal de um modo particular. Através de sugestões como essa, os teóricos da ruptura revolucionavam a relação entre universal e particular, alterando o estatuto ontológico dessas palavras. Até então, universal e particular eram vistos como territórios apartados: havia espaços universais e, fora deles, existiam outros particulares. Depois da contribuição desses autores, essa relação passou a se arranjar da seguinte maneira: o universal continuava sendo um território, já o particular deixava de ser um território, fora do universal, e passava a ser tido como um modo de usar o universal, interno a ele. O universal é uma terra, mas o particular não é outra, fora dela, mas uma estratégia de desterritorialização, uma maneira de usar o universal que, por ser muito específica, torna-o particular. Não se tem mais duas coisas, uma fora da outra, mas uma coisa e um tática de usá-la, interna a ela.

Ao fazer com que o particular deixe de ser um terreno fora do universal e se transforme em um uso interno a ele, esses autores enfraqueceram a ideia de que de um lado existiria uma matéria universal, única, homogênea, pura e absoluta, e, muito longe dela, haveria várias matérias particulares, múltiplas, heterogêneas, híbridas e relativas. Pelo contrário: uma coisa está dentro da outra, porque, na verdade, elas não são duas coisas, só o universal o é, enquanto o particular é um modo de experimentar essa coisa. O particular não deriva do universal, nascendo fora e depois dele, mas se inscreve na superfície do universal, distorcendo-o, particularizando-o. O particular surge do enrugamento do tecido liso do universal. Todo particular é a particularização de um universal, um modo particular de usá-lo. Não existe o universal e o particular, mas o universal e o universal estriado, engelhado, e isso é o particular. Para se chegar ao particular não se deve sair do universal, mas mergulhar nele, e fazer com que ele se segmente, varie internamente: fazer relevo no território plano do universal, uma depressão, um morro, isso é particular.

A relação do universal com o particular não é como a de um pai com seus filhos, exterior e hierárquica, mas de uma pele com suas manchas, interior e equilibrada. Os filhos 
estão fora do pai e o obedecem, as manchas se marcam na própria pele e com ela se mediam. As manchas precisam de uma pele para aparecer, mas elas tem a sua própria ordem, uma ordem que muda a ordem da pele, que desterritorializa a pele e a reterritorializa como mancha, de um jeito que um dia a pele precise das manchas para se deixar ver. Se no começo da doença não seria possível mancha sem pele, hoje já não existe pele sem mancha. Quem obedece a quem? Um dia só foi possível ver a mancha particular porque ela estava em uma pele universal, mas quando outras manchas particulares surgirem, tomando conta de tudo, como se verá aquela pele universal? Antes o particular se revelava no universal, hoje, adiantado o processo de particularização do universal, o universal só se deixa ver pelo particular. A brancura da pele universal não é mais uma presença bruta, mas um mito evocado pela negrura das manchas particulares. Diante desse cenário, o universal, que um dia antecedeu os particulares, passa a ser posterior a eles. A mancha que se revelava na pele se espalha por ela toda, fazendo agora com que a pele só se mostre na mancha, escondida por ela.

No filme Filadélfia (1993), quando questionada por sua chefe branca porque não está usando um brinco americano, a advogada negra que trabalha para um grande escritório de advocacia responde "mas esse é um brinco americano, é um brinco afro-americano." Essa é a tática revolucionária: não cultivar um particular longe do universal, mas marcar o particular dentro do universal, fazer um corte, uma dobra, uma rugosidade particular na pátina do universal. A relação do universal americano com o particular afro-americano é como a de uma pele com suas manchas, (e antes que se julgue absurdo comparar uma etnia com uma doença de pele, deve-se lembrar que estamos dialogando com autores que defendem a naturalidade libertária da esquizofrenia contra a violência castradora da psicanálise): é verdade que precisa haver um tipo universal americano para que haja uma forma particular afro-americana, mas quando surgirem os particulares hispano-americano, indo-americano, nativo-americano, etc. que espaço sobrará para o universal americano? Antes só era possível enxergar um particular afro-americano porque ele se situava em um universal americano, mas quando outros particulares começaram a se espalhar por todos os Estados Unidos não restou mais nenhum universal americano virgem. Se antes o particular afro-americano só aparecia porque se contrastava com o pano de fundo do universal americano, hoje, com particulares de todo tipo tomando conta desse pano, o universal americano não aparece mais sozinho, mas apenas depois do hífen, só se deixando ver 
mediado por um particular. Visível no passado, hoje a superfície da santidade imaculada do universal americano foi coberta pelas particularidades tipo-americanas que nela brotaram, de maneira que, no presente, só se pode ver o universal americano pelo filtro das particularidades hifenizadas que o velam. Se ainda se pode falar em Estados Unidos da América como se ele fosse algo único, homogêneo, puro e absoluto é porque o universal ainda constitui essa cultura, mas, por mais absurdo que isso seja, sua pureza nunca pode ser vista isoladamente, mas sempre de mãos dadas com alguma característica que antes era estrangeira, mas que hoje, por se amarrar à americanidade, passa a formá-la. Nesse caso, o universal americano, que antecedeu as particularidades, agora é segundo em relação a elas. Os particulares tipo-americano apareciam no universal americano, mas agora eles a dominaram, fazendo com que o universal é que apareça no particular, coberto por eles.

Em um mundo desejoso de produzir o universal americano, latinos, indianos e africanos devem se transformar em americanos, mas a metamorfose nunca se completa, nunca é "perfeita", produzindo sempre tipos particulares hispano-americanos, indoamericanos, afro-americanos. Dessa forma, é justamente o imperativo de que o mundo tenha cada vez mais americanos que faz com que ele tenha cada vez menos americanos, é por haver uma centralidade estadunidense que os Estados Unidos se descentralizam, é por se enfatizar o universal que se gera o particular. Todas as pessoas do mundo, por mais diferentes que sejam, devem se tornar americanas. Por causa dessa lei, os diferentes ficam um pouco americanos, mas a América também fica um pouco diferente, e é por isso que os efeitos universais de unidade, homogeneidade, pureza e absolutismo, próprios ao período exótico-colonial do mercado da diferença, não se realizam mais no presente, mesmo quando são desejados. A luz universal americana refrata nos diferentes líquidos particulares, distorcendo-se de formas infinitas. Ao invadir o líquido, a luz pode mudá-lo, mas ao ser recebida por ele, ela também se altera.

O universal americano único, homogêneo, puro e absoluto se impôs sobre todas as diferenças, é verdade. Mas, depois de ter refratado nelas, onde ele pode ser visto? Não pode. A inteireza da universalidade americana, quando se espalhou pelo mundo, deixou de ser inteira e universal. Ela não aparece mais diretamente, como universal, mas apenas depois do hífen, citada pelo particular. A americanidade universal é um discurso santo que só se materializa nas laicas particularidades do hispano-americano, do indo-americano, do 
nativo-americano, etc. Desse modo, por um lado, o universal precede o particular, pois é preciso haver o solo universal para que brote o particular, mas por outro, o particular é quem precede o universal, pois, se o particular o cita, a anterioridade do universal só se revala no particular que o sucede. A relação que um tipo universal americano, único, homogêneo, puro e absoluto estabelece com suas formas particulares múltiplas, heterogêneas, híbridas e relativas é a mesma que a aura artística original de Benjamin mantém com sua série de reproduções ou que literatura de Foucault possui com seus livros: a "perfeição" do universal é garantida pelo desastre dos particulares em espelhá-lo, assim como sua anterioridade é instaurada por essas partes que o sucedem. As particularidades existem para serem tocadas pelo universal, e o universal só sobrevive materializado nas particularidades.

Desse modo, na contemporaneidade, embora seja verdade que universal e particular sejam dois vetores diretamente proporcionais, também é certo dizer que eles rivalizam. Os dois se interpelam e um muda o outro. Por se cruzarem, universal e particular tanto se sustentam quanto competem. O particular brota no universal, e o universal se inscreve nele, de maneira que depois do processo, ambos se alteraram. $\mathrm{O}$ universal tem certa autoridade sobre o particular, pois é no espaço do universal que o particular se marca, mas, pelo mesmo motivo, o particular exerce algum controle sobre o universal, pois, florescendo em seu território, o particular distorce o universal. Os Estados Unidos podem ter mudado os imigrantes, mas os imigrantes também mudaram os Estados Unidos. O projeto universalista americano invade outros corpos, mas, uma vez dentro deles, eles o alteram. O mundo em que vivemos é sim fruto do universal americano, mas seria ele a realização desse universal? O mundo forjado pelos Estados Unidos é tipicamente estadunidense? A missão deu certo? Para esses autores não. Ao optar por se espalhar pelo mundo, o projeto imperial americano refratou nos contextos locais, e essa invasão mudou tanto esses lugares quanto esse projeto, dando origem a um híbrido que não é uma coisa nem outra, de forma que hoje, aquela missão universal americana só sobrevive enquanto um discurso suscitado pelos fracassos que teve em se estabelecer. Como a pele só aparece escondida pelas manchas e o universal só se revela coberto pelos particulares, hoje vivemos em um mundo em que o universal se faz presente enquanto ausência, só sendo viável enquanto impossibilidade, só se realizando ao se frustrar no particular. O universal invade o particular, mas, em seu interior, o particular o distorce. O mundo está meio americanizado, 
mas os Estados Unidos estão mais latinos, indianos, africanos... Deixe que a luz do universal penetre o particular e o altere, pois aqui dentro ela também não será mais a mesma.

Semelhante às passagens de Mil Platôs aqui trazidas, há uma piada que diz o seguinte: um sujeito fala para o outro "eu queria conhecer Nova Iorque, mas não sei falar inglês", ao que o amigo responde "relaxa, lá ninguém sabe falar inglês." Sim, é por causa do imperialismo americano que milhões de pessoas abandonam seus lares para tentar a sorte em Nova Iorque. Mas, uma vez lá estabelecidas, será que Nova Iorque ainda pode ser considerada uma cidade americana? Se sim, é porque ser uma nação imperialista com aspirações universais (e é isso o que os Estados Unidos são) hoje é algo muito diferente do que o era no passado. Que império é esse cuja maior cidade não fala a língua local? Façamos aqui um paralelo entre a França do período exótico-colonial do mercado da diferença e os Estados Unidos da era da diversidade-global: ambos são senhores de seus respectivos tempos e até almejam produzir um discurso universal único, homogêneo, puro e absoluto. Mas, enquanto na França daquele período, essa ambição trouxe exatamente esses efeitos, nos Estados Unidos do presente, essa busca gera o duplo dessas ideias, a saber, as noções particulares de multiplicidade, heterogeneidade, hibridismo e relativismo. A França tinha apenas uma língua, uma religião, um sangue, etc. enquanto os Estados Unidos possuem uma infinidade de dialetos, crenças e etnias. $\mathrm{O}$ valor do império francês se alicerçava no monismo de sua cultura, ele era o lastro do seu totalitarismo e motivo de orgulho nacional. Já a riqueza do império americano mora justamente na pluralidade de sua cultura; essa miscelânea é constitutiva de sua identidade e um traço distintivo desse país. Quer dizer, para exercerem seu monopólio global e proferirem um discurso universal, França e Estados Unidos abraçaram culturas e identidades nacionais opostas: enquanto a primeira ensejou as ideias universais de unidade, homogeneidade, pureza e absolutismo em seu próprio território, os segundos cultivaram os valores particulares da multiplicidade, da heterogeneidade, do hibridismo e do relativismo dentro de suas fronteiras. Durante o exótico-colonial, a França se orgulhou do seu monismo, hoje, os Estados Unidos celebram sua polissemia. Enquanto uma mandava no mundo por expulsá-lo de dentro de si, o outro o governa por reproduzi-lo em seu perímetro. Embora ambos tenham vivido seus momentos imperiais, o prisma através do qual as identidades nacionais de cada país foram encaradas são totalmente diferentes: a cultura nacional francesa é rica porque nela se encarna um 
universal, já o prestígio da americana se deve ao fato de ela conter muitos particulares. Falar da identidade nacional francesa do século XIX é lembrar do monolito de sua língua, de sua cultura, de suas raízes; já falar da identidade nacional americana do nosso tempo é falar de imigração, da comunidade hispânica, do lugar do negro na sociedade, etc. Ambas as agendas são típicas de seus países, a diferença é que, enquanto no período exóticocolonial as nações ancoravam sua identidade em um monismo cultural, na diversidadeglobal os países pensam sua identidade à luz da diversidade de suas culturas. Ser tipicamente americano hoje não é o mesmo que ser tipicamente francês ontem. Antes, o nacional estava no universal, hoje está no particular, como disse Bhabha, "cada vez mais, as culturas 'nacionais' estão sendo produzidas a partir da perspectiva de minorias destituídas." (2013, p. 26). Os países não afirmam mais sua identidade nacional em traços universais únicos, homogêneos, puros e absolutos, mas em características particulares múltiplas, heterogêneas, híbridas e relativas. Se no passado uma identidade precisava ser unicista, no presente já não é nenhuma incoerência fazer da diversidade um signo identitário. Isso não quer dizer que a diferença deixou de se referir ao outro para se referir a si, apenas que, agora, o outro faz parte de si, o estrangeiro está no nacional. Da mesma forma que, depois que as manchas tomam conta de tudo, a pele só se revela escondida por essas marcas, nos Estados Unidos do nosso tempo a universalidade do nacional só aparece coberta pelos particulares, de modo que não se pode falar de país puro sem se atravessar o filtro de alguma especificidade. Como se afirmou, paradoxalmente, a pureza da nação americana nunca aparece desacompanhada, mas sempre ladeada por outro elemento que no passado era forasteiro, mas que hoje, por se hifenizar com a americanidade, passa a ser parte constitutiva dela. Para Obama, a questão dos latinos não é só um debate sobre o Outro, como era o Oriente para o orientalista, mas uma agenda nacional, americana. Se na França do passado falar francês era algo tipicamente francês, hoje, falar espanhol é uma prática bastante americana, chegando-se a um extremo em que na maior cidade do império do nosso tempo não se fala a língua imperial. Não seria esse um indicativo de que as coisas estão mudando?

Mas não seria melhor o particular não deixar o universal não entrar de jeito nenhum? Esse foi o equívoco do multiculturalismo: fechar o étnico em comunidades isoladas e nunca sair da jaula tribal, fazendo com o universal nos cerque e nos exotize. Em seu livro, Deleuze e Guattari falam que sua estratégia é "o contrário de um regionalismo" 
(2011, vol. 2), quer dizer, não se trata de territorializar o particular, mas usar o particular para desterritorializar o universal. E por que não negar a existência do universal e acreditar que só existem particularidades sem um discurso maior que as atravesse? Essa é a saída pós-moderna, alternativa que criou um relativismo barato que mais absolve violências que suscita revoluções. O caminho encontrado por esses autores é outro: penetrar o universal, deixar que ele nos penetre, e quando nós estivermos dentro dele e ele dentro de nós, nós poderemos distorcê-lo. Ao final do processo, nós não seremos mais os mesmos, mas ele também não.

Por todos esses motivos, os teóricos da ruptura identificam uma mudança drástica entre o período exótico-colonial e o da diversidade-global do mercado da diferença. Enquanto no primeiro momento, a ênfase na produção dos valores universais de unidade, homogeneidade, pureza e absolutismo gerava exatamente esses feitos, no segundo, a busca por essas ideias enseja justamente seus duplos, quer dizer, as noções particulares de multiplicidade, heterogeneidade, hibridismo e relativismo. Ao contrário do passado, nos dias de hoje, quanto mais centralizada for a produção de um discurso, mas fragmentada é sua recepção. Erigir um cânone é fazer com que ele se dissolva, pois determinar que uma mesma luz universal penetre todos os diferentes fluidos particulares é obrigá-la a se distorcer de infinitas maneiras, sem que nenhuma delas, embora deva, reproduza a silhueta original desse facho. Por isso, para esses autores, o período da diversidade-global do mercado da diferença era oposto ao exótico-colonial, pois a relação que estabeleciam era de ruptura.

\section{Continuidades ou Rupturas?}

As posições acima apresentados dizem respeito apenas aos comentários iniciais de cada uma das duas correntes, mas, uma vez que as cartas foram colocadas à mesa, o debate se desdobrou em réplicas, tréplicas e discussões infinitas. Por exemplo: em resposta ao argumento dos teóricos da ruptura de que seria um indicativo de mudança o fato de o debate acerca da diferença ser hoje conduzido por autores nascido nas antigas colônias e não mais por orientalistas europeus, os teóricos da continuidade alegavam que tais autores, ainda que oriundos da periferia do mundo, expressavam suas ideias nos grandes centros, em universidades europeias e americanas, e por isso seu discurso ganhava alguma legitimidade. A presença de um professor indiano em Harvard, por exemplo (caso de 
Bhabha) é celebrada pela ruptura como uma indianização dos Estados Unidos e criticada pela continuidade como uma estadosunização da Índia. Como se falou, universal e particular se interpelam, mas enquanto uns julgam que esse cruzamento atesta a dominação do universal sobre o particular, como se dava no passado, outros vêem nessa intersecção uma insubordinação particular no seio do universal, como nunca se viu antes. Outro ponto polêmico dizia respeito à orientação política dos grupos: cada corrente acreditava que seu discurso era o mais crítico e acusava o outro de ineficiente. Para os defensores da tese da continuidade, esse otimismo pós-colonial afeito a possibilidades emancipatórias era visto como uma ideologia, um alegria reacionária cega aos mecanismos silenciosos da dominação. Em contrapartida, para os que se filiavam à corrente da ruptura, era justamente essa apatia dos apocalípticos que era retrógrada, já que essa falta de horizonte convidava muito mais à paralisia e ao conformismo do que à revolução.

O evento sobre o qual o dois olhares se debruçavam era o mesmo: uma coexistência entre ideias universais de unidade, homogeneidade, pureza e absolutismo e noções particulares de multiplicidade, heterogeneidade, hibridismo e relativismo. O ponto de divergência diz respeito às consequências desse cruzamento: para os que se filiam a continuidade, o universal engole o particular, como sempre; para os defensores da ruptura, o particular distorce o universal, como nunca.

Para os fins dessa pesquisa, as divergências que permeiam esse debate se devem à porosidade do filtro da igualdade, espaço de mediação entre os dois períodos do mercado da diferença que tanto os sintoniza quanto os aliena. Inscrito entre o exótico-colonial e a diversidade-global, o filtro da igualdade negou certas ideias do primeiro momento, mas afirmou outras, abrindo o mercado da diferença para uma segunda era difícil de diagnosticar. Se, por um lado, as ideias universais de unidade, homogeneidade, pureza e absolutismo foram contidas, por outra, a ideia de universal propriamente dita, destituída de seus conteúdos, foi ratificada, e com ela, a noção de uma natureza humana, de que uma agenda global pode ser afirmada de um local apenas e de que o estado-nação é uma morfologia importante. Dessa forma, do lado de lá do filtro, as noções particulares de multiplicidade, heterogeneidade, hibridismo e relativismo teriam que se conformar em molduras próprias ao momento anterior, e não havia um consenso sobre o arranjo formado por essa convivência entre velhos e novos preceitos: se o velho dominaria o novo, fazendo 
com que o passado se repetisse no presente, ou se o novo neutralizaria o velho, de maneira que o presente rompesse com o passado. Enfim, a seletividade inconsciente do filtro da igualdade reteve os conteúdos do período exótico-colonial do mercado da diferença, mas permitiu que suas formas passassem para o período da diversidade global, obrigando os conteúdos do futuro a se adaptarem às formas do passado. Esse complexo formado por formas exótico-coloniais e conteúdos da diversidade-global representava para uns, o controle do primeiro período sobre o segundo, de maneira que as novas ideias particulares de multiplicidade, heterogeneidade, hibridismo e relativismo acabariam repetindo os dogmas universais de unidade, homogeneidade, pureza e absolutismo, ensejando-se então um tempo tão violento quanto o anterior; já para outros, quando se encontrassem, o segundo período subverteria o primeiro, fazendo com que o universal deixasse de propagar seus velhos conteúdos e passasse a gerar efeitos particulares de multiplicidade, heterogeneidade, hibridismo e relativismo, inaugurando portanto uma era de emancipação. Quer dizer, depois do trabalho de mediação do filtro da igualdade, uns acreditavam que a relação entre dois períodos do mercado da diferença era de continuidade, e outros julgavam que era de ruptura. Mas afinal, o que havia acontecido?

Como se pode ver, esses dois diagnósticos sobre o mercado da diferença são respostas divergentes para aquelas perguntas que levantamos na introdução do texto:

Pergunta conceitual: A passagem do exótico-colonial para a diversidade-global significa uma mudança verdadeira das ideias universais de unidade, homogeneidade, pureza e absolutismo para as ideias particulares de multiplicidade, heterogeneidade, hibridismo e relativismo?

Pergunta política: A passagem do exótico-colonial para a diversidade-global significa a mudança de uma era de dominação e controle para um novo período de liberdade e independência?

Pergunta síntese: Afinal, quais são as continuidades e rupturas no mercado da diferença quando da passagem do exótico-colonial para a diversidade-global? Ou seja, que relação se estabelece entre colonização e globalização?

Escolher um dos dois diagnósticos é algo extremamente complicado porque ambos parecem muito coerentes. Cada escola encadeia tão bem seus respectivos enunciados que o 
leitor não consegue se decidir por uma ou outra, já que nenhuma delas apresenta pontos fracos. Diante disso, chega-se a conclusão aparentemente absurda de que, embora opostas, as duas correntes parecem estar certas!

Para sair desse impasse e optar por um dos caminhos é preciso acatar a sugestão dada por Nicolau Netto, já apresentada na introdução: antes de se fazer essas perguntas, é preciso que se elenque um índice de diferença através do qual a questão será analisada. Não raro, pesquisadores interessados nesse debate se esquecem que a diferença é um sentido histórico socialmente imputado, e por causa desse equívoco a naturalizam, fazendo com que ela pareça uma característica interna e imanente ao objeto diferente. Mas, como bem afirma o autor, "a diversidade em si não existe: ela é o discurso formulado a partir de índices de diferenciação escolhidos em uma dada condição social". (NICOLAU NETTO, 2014, p. 38). De acordo com esse enunciado, então, o fato de classificarmos algo como diferente não se deve a nada intrínseco a essa coisa, mas à razão de ela carregar consigo uma característica que é socialmente tida como um índice de diferenciação. Em um contexto em que aquele traço não fosse tido como um índice diferenciante, o mesmo artefato, que antes nos causou tanta estranheza, seria tido como familiar.

"Aquilo que foi tratado de modo afim (classificado de modo afim), um dia foi tratado de modo distinto e poderia ter sido tratado de outros modos ainda; ou melhor, a diferença ou a similitude poderia se basear em outro índice, gerando outra classificação. Portanto, a diferença entre objetos 'modernos' e 'triabis' não está neles, mas nos olhos de quem os vê e na voz de quem pode discursar sobre eles, e assim, classificá-los. Os objetos 'modernos' e 'tribais', as 'raças humanas', as cores, os sons, a cultura erudita e a popular, etc. não são diferentes de si antes de um processo determinado histórica e espacialmente que defina índices de diferenciação suficientes para tornar a diferença aceita. (...) Assim, se a definição do índice de diferenciação é social, ela não pode estar nas coisas que estão sendo distanciadas ou aproximadas. $\mathrm{O}$ diferente se funda em relação a algo e nessa relação adota-se um índice que servirá como critério para se definir a semelhança ou a diferença entre dois elementos. A determinação do índice diferencial está sempre em relação de modo a ordenar e narrar - discursar - a relação entre as coisas, mas não existe essencialmente" (NICOLAU NETTO, 2014, p. 33)

Se as duas correntes parecem estar certas é porque de fato elas estão certas, no sentido em que ambas estão de acordo com o índice de diferença que elegeram para si. Teóricos da continuidade e da ruptura elencaram seus respectivos índices e fizeram leituras acertadas deles, mantendo-se coerentes às perspectivas que escolheram. Se olharmos para o debate da diferença pelo prisma das formas do exótico-colonial que passaram pelo filtro 
da igualdade e chegaram à diversidade-global, atentando para o discurso que é produzido, os dois períodos do mercado da diferença parecerão idênticos. Mas, se deslocarmos nossa análise para os conteúdos do exótico-colonial que o filtro da igualdade reteve e que nunca chegaram à diversidade global, debruçando-nos sobre como o discurso é recebido, os dois períodos do mercado da diferença soarão opostos. Sim, assim como no passado, é verdade que o discurso da diferença produzido no presente tem aspirações universais, alicerça-se na ideia de uma natureza humana, espraia-se como uma pauta mundial localmente forjada, e toma o estado-nação como sua morfologia. Por essas razões, intelectuais nascidos no terceiro mundo precisam ir para as universidades dos grandes países para serem ouvidos, por exemplo. Em contrapartida, diferentemente do passado, também é verdade que o discurso da diferença recebido no presente dá um tratamento particular àquelas ideias universais, constrói uma ideia de natureza humana oposta à antiga, sugere uma pauta mundial localmente forjada contrária à outra, e convida estados-nação antes silenciados a participarem do debate. Por causa disso, universidades de grandes países hoje aceitam intelectuais nascidos no terceiro mundo, por exemplo. Optar por uma das correntes não é só concordar com o conteúdo de suas ideias, mas aceitar olhar o problema pelos mesmos índices de diferenciação que ela. Quando abraçamos a ontologia de um argumento, ratificamos sua metodologia, de maneira que aceitar um diagnóstico é postular que os índices em que ele se baseou para ser escrito são de fato aqueles devem ser considerados.

"Nessas perguntas estão escondidos os valores que possibilitaram a definição de diferenças sobre as quais as posições são tomadas. Em outras palavras, qualquer resposta que seja dada é insuficiente, pois na verdade ela não diz se o mundo é mais ou menos diverso, mas sim se concorda ou não com o índice de diferenciação existente para se enxergar a diferença entre as coisas culturais. Isso porque, a diferença, repito, é uma construção social e, como tal, só faz sentido em um tempo-espaço definido. Portanto, outra pergunta precisa emergir: como é definida esta diferença?" (NICOLAU NETTO, 2014, p. 28)

Escolher um índice não tem nada a ver com o truísmo do copo meio cheio ou meio vazio, mas com o cuidado metodológico de que, antes que se teçam diagnósticos sobre uma paisagem, defina-se que paisagem é essa que se está analisando; pois, se a materialidade não está evidenciada, qualquer coisa pode ser dita. Antes de dizermos se o mundo está ficando mais único, homogêneo, puro e absoluto ou múltiplo, heterogêneo, híbrido e relativo; ou mais violento ou mais liberto; ou se colonização e globalização são 
iguais ou diferentes; é necessário que se pontue sob qual índice a questão está sendo analisada.

\begin{abstract}
"Para afirmarmos se o mundo está se homogeneizando ou se diferenciando, nós temos que dizer qual critérios nós usamos para afirmar isso. Em qual materialidade esse processo está sendo observado. Como a diferença não é uma coisa em si, mas um discurso que se projeta em materialidades, a depender da materialidade que escolhemos, podemos ver homogeneização ou diferenciação." (NICOLAU NETTO, 2014, p. 20)
\end{abstract}

Fazer aquelas perguntas sem primeiro definir um índice não é nem certo nem errado, mas simplesmente irrelevante, posto que, a depender do índice, qualquer diagnóstico pode ser dado, inclusive diametralmente opostos. Todos os autores resgatados nessa primeira parte tiveram esse cuidado e produziram leituras corretas acerca da diferença, na medidas em que são coerentes aos índices que escolheram. Eu não vejo muito valor científico em dizer algo do tipo "Bhabha estava certo e Adorno errado" (ou o contrário). Podemos até dizer que temos mais afinidade com os índices escolhidos por Bhabha, que aqueles que Adorno escolheu já não organizam o debate acerca da diferença, por isso a teoria de Bhabha é mais adequada para entender nosso tempo, etc. Mas, entendidos em seus respectivos quadros analíticos, nenhum dos autores tem mais coerência interna que o outro. Se contrastarmos seus discursos com os índices que recortaram, seremos obrigados a concordar que ambos fizeram leituras finas de seus objetos. É exatamente por isso que é tão complicado escolher entre um e outro.

Cabe a esse texto agora escolher o índice com o qual trabalhará. Por isso, antes de nos fazermos aquelas três perguntas, devemos olhar para a pergunta zero que diz

Qual índice de diferença está sendo considerado e que trama sócio-histórico-cultural o investiu daquele capital de diferenciação?

O resgate histórico do conceito de diferença feito nessa primeira parte foi importante porque o meu objetivo é encontrar um índice sintético, aquele que, bem ou mal, concilie as tensões entre as duas correntes. Mas, na verdade, eu não vou escolher um índice arbitrariamente, ao acaso, mas recortar um objeto e tentar entender com qual índice ele trabalha. Para mim, o objeto cujo índice agrega valores tanto do exótico-colonial quanto da diversidade-global, ou seja, que sintetiza continuidades e rupturas do mercado da diferença, é a World Music. É dela que tratarei na segunda parte. 


\section{PARTE II}

O CASO DA WORLD MUSIC 


\section{Capítulo 5}

\section{O mundo da música e a música do mundo}

No dia 29 de junho de 1987, a Inglaterra invadiu a Rússia duas vezes para resolver problemas criados pela globalização. A primeira, na ficção mas literalmente, com a estreia nos cinemas de "007 Marcado para Morte". No filme, décimo quinto da franquia e primeiro com Timothy Dalton no papel de James Bond, o agente secreto britânico ataca a KGB para livrar o Afeganistão da ocupação soviética e salvar o mundo do comunismo. A segunda, na realidade mas metaforicamente, às sete da noite na St. John Street, quando vinte e poucos ingleses donos de gravadoras independentes se reuniram no segundo andar do pub Empress of Russia para decidir o que fazer com a produção musical dos países periféricos. Hoje, passados 28 anos desde aquele dia, pode-se dizer que as duas operações foram um sucesso. Mas o que isso significa?

Mesmo contrastado com dificuldade da missão de Bond, o desafio que aqueles donos de gravadora tinham diante de si não era fácil. Além dos empresários, estavam no pub aquele dia profissionais do rádio, do impresso e da TV especialistas em música. Segundo a ata do encontro, reuniam-se ali naquela segunda-feira de verão ${ }^{33}$ : Chris Popham, Ben Mandelson, Roger Armstrong e Ted Carroll (Global Style/Ace); Jonathan Rudnick (Crammed US); Amanda Jones, Thos Brooman e Steve Hadrell (Womad); Charlie Gillet (Oval); Mark Kidel (Canal 4); Ian Anderson e Lisa Warburton (Folk Roots/Rogue Records); Anne Hunt, Mary Farquharson e Nick Gold (Arts Worldwide/World Circuit); Scott Lund e Iain Scott (Sterns/Triple Earth); Chris Stapleton (Blues \& Soul) e Joe Boyd (Hannibal). O que unia aquelas pessoas ali era um mesmo interesse pela produção musical de fora do Ocidente. Quando se depararam com a riqueza desse material estrangeiro, os donos de gravadora perceberam que precisavam encontrar a melhor estratégia de vender aquele produto. Como mostra uma lista de tópicos a ser discutidos na reunião, o objetivo daquele encontro era pensar o marketing da jogada:

"1. O principal objetivo é tornar nosso repertório mais atrativo.

2. Quem é o nosso público alvo?

a) Os que já conhecem

\footnotetext{
${ }^{33}$ As atas das reuniões foram retiradas do site da revista Froots: www.frotsmag.com. Acessado em $01 / 05 / 2015$
} 
b) Potenciais novos consumidores

3. Como alcança-los?

a) Lojas varejistas

b) Propagandas em jornais não especializados

c) Propagando no rádio e na TV

d) Promoção em rádio

e) Imprensa" (pontos para 1)

No meio de tantas dúvidas acerca das estratégia de venda dessa nova mercadoria, havia uma certeza: o produto que se estava querendo ofertar seria um novo estilo musical. Estilos musicais, como se sabe, a despeito das diferenças entre os membros que o constituem, causam impacto porque são corpos inteiriços, únicos e de fronteiras discerníveis. Portanto, mesmo que aqueles artistas não ocidentais fossem muito diferentes uns dos outros, era preciso encontrar alguma afinidade entre eles capaz de conformá-los dentro de uma mesma moldura. Ora, todo estilo musical tem um nome e, por se referir àquilo que há de comum entre os artistas que agrupa, é justamente esse nome que garante a coesão das partes que compõem o estilo. É da necessidade de achar essa marca sintética que surge o nono ponto elencado para discussão: "Adotar um título de campanha/Mídia (e.g: World Beat/Ethnobeat/World Music)". Essa era a grande dúvida que tomava conta do segundo andar do Empress of Russia naquele dia: qual seria o nome desse novo estilo? Que categoria teria a abrangência necessária para sintetizar elementos tão diferentes?

Como ainda não havia um cabeçalho que agrupasse todos aqueles artistas de fora, as lojas de disco não possuíam uma prateleira exclusiva para expô-los. Por causa disso, esses lançamentos estrangeiros acabavam se dispersando nas várias seções dos velhos estilos ocidentais, ainda que nenhum desses rótulos canônicos representasse muito bem aqueles álbuns. Por causa dessa lacuna, cada vendedor enfiava o disco forasteiro na categoria ocidental que julgasse apropriada, e como as avaliações eram diferentes, a depender da loja, um mesmo álbum poderia estar na parte de jazz, ou blues, ou samba, mesmo que nenhuma dessas taxonomias abraçasse perfeitamente aquele som. Essa diluição dos artistas estrangeiros nas velhas categorias de sempre acabava impactando negativamente as vendas: como os donos das lojas espalhavam os discos de qualquer jeito, 
uma identidade de marca com a qual o público pudesse se identificar nunca era forjada. Em uma entrevista, Sweeney, um dos diretores da Virgin Records, afirmou:

"Um dos obstáculos para persuadir as lojas de disco a manter um grande estoque de novos produtos internacionais era a falta de uma categoria que pudesse descrevê-los. Gerentes de lojas de disco não sabiam se chamavam aquilo de 'étnico', 'folk', 'internacional' ou qualquer coisa nesse sentido, e devido a essa ausência de um nicho apropriado nas suas estantes, se inclinavam a recusar essa material" (London: Virgin Books, 1991)

Opinião corroborada por um jornal inglês daquele ano

"A demanda por discos de artistas não-ocidentais está crescendo vertiginosamente. É aí que começam os problemas para potenciais compradores desses álbuns - a loja de discos High Street não tem o disco em particular, ou nem mesmo uma seção identificável onde se possa procurá-lo, ele não aparece publicado em nenhum catálogo, e nesse ponto, tirando os mais insistentes, todos acabam desistindo - e quem pode culpá-los?" (apud FRITH, 2014) ${ }^{34}$

Dada essa dificuldade, visando a melhoria dos seus caixas, as gravadoras perceberam que era preciso acabar com essa dispersão, reunindo esses artistas sob a égide de um novo estilo musical que se deixasse reconhecer por um novo nome. Logicamente, para aglutinar músicos tão diferentes em torno de um mesmo estilo era preciso encontrar uma característica comum a todos eles, mas que característica era essa?

"Roger achou que o principal problema em vender nosso tipo de material se deve às lojas varejistas britânicas e especificamente ao fato de que elas não sabem como expor nossos discos de forma coerente. Isso fez com que nosso produto fosse guardado de forma descuidada, de maneira que ficou difícil para o comprador se familiarizar com nosso catálogo. O objetivo inicial dessa reunião foi encorajar o mercado varejista através da concentração de vários esforços" (Ata da primeira reunião)

Já naquele primeiro encontro alguns possíveis nomes foram aventados e após uma breve votação aberta elegeu-se um vencedor. E assim, no dia 29 de junho de 1987, no segundo andar do pub londrino Empress of Russia, enquanto James Bond fuzilava a cúpula da KGB sem nem despentear o cabelo, nascia o nome de um novo estilo musical que reunia praticamente toda a produção de fora do Ocidente, muito embora tenha sido forjado por ele e para ele. Como diria o agente secreto: o nome era Music, World Music.

"Concordou-se que nós devemos criar um nome genérico que abrigue nosso catálogo, com o intuito de chamar a atenção para o que fazemos. Nós discutimos vários nomes para o(s) nosso(s) tipo(s) de música(s) e por votação

\footnotetext{
${ }^{34} \mathrm{O}$ autor não dá a referência.
} 
aberta decidiu-se que 'World Music' será o rótulo com o qual trabalharemos. Outras sugestões foram 'World Beat', 'Hot...', 'Tropical...' e vários outros. Foi sugerido que todas as gravadoras presentes usariam 'World Music' na capa dos seus discos (para dar uma noção clara do 'catalogar como...') e também em todo o material de publicidade etc. Depois disso, seguiu-se uma discussão se 'World Music' deve ser como um logotipo ou simplesmente com uma fonte específica. Debateu-se se isso não poderia soar exclusivista ou elitista, o que nos levou a questionar se alguma outra gravadora poderia pertencer ao time. A discussão ficou centrada nos possíveis conflitos entre os objetivos de curto prazo dessa campanha de promover a 'World Music' (patrocinada, promovida e paga por nós), e a meta de longo prazo de estabelecer 'World Music' como o termo genérico para esse tipo de música assim como Reggae/Soul/Disco etc. (não exclusivamente e aberto a todas)" (Ata da primeira reunião)

Agora que a World Music havia nascido, seus idealizadores precisavam vendê-la. Para que as pessoas se interessassem pela marca era necessário que o nome se espalhasse o máximo possível. Visando esse fim, uma série de estratégias foram cogitadas: a primeira, já apontada na citação, seria colocar um mesmo selo "World Music" na capa dos discos daquelas gravadoras. O objetivo dessa medida era fazer com que os varejistas criassem em suas lojas uma seção específica de World Music que reunisse todos aqueles discos. Com isso, o público perceberia que aqueles artistas pertenciam a um mesmo conjunto, e assim a marca desenvolveria uma identidade própria com a qual as pessoas pudessem se identificar $^{35}$. Outras três medidas de divulgação importantes foram: fazer de outubro "O mês da World Music" ${ }^{36}$, criar um catálogo de World Music, e, a mais relevante delas, organizar uma coletânea de lançamento da World Music que reunisse dois artistas de cada gravadora ali presente.

"Roy Carr está disposto a fazer um K7 de World Music. Roger sugeriu que cada gravadora encaminhasse suas faixas escolhidas para a GlobeStyle, que preparará a produção final. Cada gravadora deve propor duas faixas (o K7 terá entre 80 e 90 minutos). O pacote do K7 também incluirá um pequeno catálogo que mostrará nossos lançamentos. A pré-produção da fita custará algo em torno de $£ 250$. Por favor, todos encaminhem um K7 contendo as faixas escolhidas o mais rápido possível." (Ata da primeira reunião)

Essas ideias foram maturadas em uma outra reunião, já com mais pessoas agregadas ao time, marcada para o dia 13 de julho, no mesmo Empress of Russia. Nesse

\footnotetext{
35 "O nome foi criado para que ficasse mais fácil encontrar o disco de Malian Kora, a música da Bulgária, o soukous do Zaire ou o Ghazal Indiano - a nova seção de World Music será o primeiro lugar na loja de discos." (jornal apud FRITH, 2014.)

${ }^{36}$ Aparentemente, a escolha pelo mês de outubro não se deu por nenhuma razão especial, apenas por uma questão de cronograma. Esse deveria ser o tempo de que precisavam para deixar tudo pronto. Como pontua a ata: "Toda essa campanha começará em setembro e continuará em outubro, que será designado como o mês da World Music" (Ata da primeira reunião)
} 
segundo encontro, os criadores começaram a perceber que a World Music já nascia marcada por tensões internas que deveriam ser contidas. A primeira já havia aparecido na reunião anterior, quando os donos de gravadora não conseguiram chegar a um acordo se o nome deveria ficar restrito àquela operação de marketing ou se tinha que ganhar vida própria, transformando-se em um estilo musical estabelecido promovido por gravadoras que não estavam no pub. Na esteira dessa dúvida, discutiu-se também se alguma das majors (nome usado para se referir às grandes gravadoras) deveria ser contatada para encampar o projeto. Como se disse, aqueles eram donos de pequenas gravadoras independentes, portanto, ter o apoio de uma gigante da indústria fonográfica levaria a coisa para um nível muito maior; mas era isso o que eles queriam? Aquelas pessoas estavam unidas para lançar uma moda, criar uma tendência, e principalmente, forjar um grande público consumidor que se identificasse com uma mesma identidade. No entanto, o produto que essa nova onda oferecia a seu compradores era a distinção e a heterodoxia. Ou seja, era preciso criar um grupo cujos membros se aproximassem pelo fato de serem diferentes. A característica que nivelava todas aquelas pessoas era o fato de elas não se deixarem nivelar por nenhuma característica, indivíduos que tinham em comum o fato de serem incomuns. Mas como se cria uma manada de idiossincráticos? Essa dúvida mostra uma balança constitutiva da World Music: a relação entre mainstream e alternativo. Seria aquele um estilo musical de massa, generalizado ou algo descolado, hipster e seleto? Nessa nova reunião decidiu-se que era preciso conciliar os dois universos: "Nós percebemos que precisamos atacar nas duas frentes: as grandes cadeias e as lojas independentes [indie]". (Ata da segunda reunião)

\footnotetext{
"As gravadoras envolvidas persuadiam os consumidores a se distinguir daqueles que compravam discos de rock ou pop mainstream, a ser diferentes. World Music não era uma categoria de vendas como as outras; essas gravadoras visavam um tipo particular de envolvimento com a música que ofereciam e prometiam uma tipo particular de experiência para seus consumidores. Como Jan Fairley pontuou, os discos de World Music eram, por um lado, vendidos como descobertas individuais, e as gravadoras eram vistas como exploradoras musicais que traziam uma pedra preciosa para compartilhar com um público especializado; e, por outro lado, esses discos eram uma moeda de troca para conectar uma comunidade de entusiastas" (FRITH, 2014, p. 306)
}

A passagem de Frith já aponta para outro ponto delicado fundante da World Music, um traço que pode ser percebido nesse trecho da ata da segunda reunião, em que se discute como será a coletânea: 
"Ele [Roy Carr, quem estava cuidando da coletânea] mencionou a 'dançabilidade' da música - então provavelmente nós devêssemos preparar a compilação com um lado para ouvir e um lado para dançar."

Essa dualidade entre ouvir e dançar sugere uma oscilação que acompanharia toda a história da World Music. Por um lado, ela é tomada como uma música reflexiva e madura que cumpre uma função quase pedagógica ao exigir do seu ouvinte uma certa atenção, um investimento mental para ouvi-la. Por outro lado, a mesma World Music é tida como uma grande brincadeira, um relaxamento ocioso, um som lúdico que nos chega espontaneamente, como o canto dos pássaros. Sendo assim, a viagem da World Music parece ser trilhada ora por um pesquisador adulto que segue um mapa rigoroso, ora por uma criança curiosa correndo num parque de diversões. Mas em nenhuma das duas acepções ela é vista como um objeto artístico propriamente dito, como a arte ocidental, mas, no primeiro caso, como um artefato etnográfico que deve instruir, e no segundo, como um brinquedo cuja função é divertir.

Uma terceira tensão pode ser percebida nos próprios nomes que foram discutidos para o novo estilo. Olhando para as possibilidades cogitadas, vemos que a World Music tanto é algo étnico, matricial, roots e tradicional como global, cosmopolita, sintético e contemporâneo. Explorando esse conflito, Erlmann afirma:

"World Music é popularmente conhecida como um fenômeno 'roots', uma expressão de identidades étnicas e nacionais e de diversidade multicultural. Entretanto, como mostra a análise de exemplos recentes, World Music também pode ser vista como um típico produto da sociedade de consumo." (ERLMANN, 1996)

Afinal, ser "do mundo" é conservar uma estrutura elementar inalterada ou agregar valor de todas as culturas? $?^{37}$

Essas valências que se cruzaram na fundação da World Music a constituem até hoje, fazendo com que no presente o estilo oscile entre o massificado e o alternativo, o reflexivo

\footnotetext{
${ }^{37}$ Para Steven Feld, a World Music teria apenas esses traços mais puristas, enquanto esse outro lado mais sincrético pertenceria ao gênero World Beat. "A oposição ou o cenário de diferenciação mútua desse padrão contrasta retoricamente apelos de 'verdade', 'tradição', 'raiz' e 'autenticidade' - sob o guarda-chuva do termo 'World Music' - com práticas de mistura, sincretismo, hibridização, blending, fusão, creolização, colaboração, todos sob o termo 'World Beat'" (2005, p. 265). No entanto, olhando para a produção contemporânea de World Music, confesso que não consigo ver essa cisão. Para mim, atualmente, essa tensão entre virgindade e cruzamento se inscreve toda na própria World Music.
} 
e o lúdico, o originário e o sincrético. Assim como "diversidade" é um conceito que concilia tensões entre formas do primeiro período do mercado da diferença e conteúdos do segundo, o nome World Music também foi escolhido porque consegue agregar forças aparentemente antagônicas.

\begin{abstract}
"Não era um nome novo, apenas um dos muitos que apareceram por aí nas décadas anteriores. Mas a lógica de Roger Armstrong era que um nome genérico estabelecido e unificado daria aos varejistas um lugar onde eles pudessem expor lançamentos que, em outra circunstância, ficariam estocados, e onde consumidores poderiam tanto procurar itens que eles ouviram no rádio (já que não sabiam soletrar o nome de um título mal pronunciado difícil de lembrar) quanto conhecer um catálogo maior. Vários títulos foram discutidos incluindo 'Worldbeat' (que deixava de fora tudo que não tivesse bateria), 'Tropical' (adeus búlgaros), 'Étnico' (chato e acadêmico), 'International Pop' (síndrome da morte-por-Johnny-e-Nana) e 'Roots' (deixa de fora Johnny e Nana). 'World Music' parecia incluir o máximo e omitir o mínimo, e por isso foi escolhido em uma votação aberta." (Revista Froots, março de 2000, p. 201.)
\end{abstract}

Voltando à segunda reunião. Naquele novo encontro as estratégias de marketing foram repisadas. Acordou-se que em outubro, o tal mês da World Music, uma série de shows seria agendado para divulgar o novo estilo.

"Charlie achou importante que houvesse algumas gigs ${ }^{38}$ ao vivo no mês da 'World Music'. John Martin levantou algumas propostas para outubro: um festival com cinco ou seis gigs no Town \& Country Club que se chamará 'Atravessando a fronteira: um festival londrino de World Music'. Ele está pensando em artistas como Ali Farka Toure, Bruce Cockburn, John Hiatt, Dembo Konte e mais uma noite extra no dia cinco e seis de outubro para 'World Music'. Algum dos 'nossos' artistas estaria disponível? Ele pediu que considerássemos buscar patrocínio para ajudar a financiar o festival." (Ata da segunda reunião.)

Como ainda havia uma grande imprecisão acerca da natureza daquele novo estilo, as atenções acabaram se voltando para a coletânea. Essa compilação seria uma espécie de disco manifesto, um ato inaugural, uma fronteira canônica que estabeleceria o que de fato era World Music. Portanto, as faixas deveriam ser escolhidas com bastante cuidado. Para diminuir a responsabilidade da coletânea e dar ao público uma ideia mais completa do que o novo estilo significava, debateu-se se não seria melhor diluir a missão de dizer o que era World Music por outros discos, distribuindo assim o peso que a coletânea carregava sozinha, além de criar listas dos melhores discos de World Music, algo que remetia a ideia de um catálogo. Como se pode ver, os inventores do novo estilo se preocupavam em deixar

\footnotetext{
${ }^{38}$ Assim como Jam Session, refere-se ao evento em que músicos tocam juntos de maneira mais descontraída, sem ensaiar e sem seguir um esquema fechado.
} 
claro para o público o que significava essa tal World Music, mas, ao que tudo indica, o nome era um mistério até para eles mesmos.

"Charlie sugeriu várias vezes que nós escolhêssemos discos específicos para a campanha: isso seria o melhor guia representativo para jornalistas e radialistas no entanto, a coletânea deve cumprir essa função. Joe propôs que nós organizássemos uma lista dos dez maiores discos de World Music de todos os tempos para que pudéssemos dizer 'isso aqui é World Music' para aqueles que ainda não perceberam que já estavam ouvindo World Music." (Ata da segunda reunião)

Uma terceira reunião foi marcada para o dia 27 de julho, na mesma hora e no mesmo lugar, para que as últimas arestas fossem aparadas. Nela ficou decidido o que segue na tabela baixo: quantos discos de cada gravadora carregariam o logotipo de World Music. Junto com a coletânea, os lançamentos que trouxessem essa insígnia ficariam responsáveis por dizer ao público o que era World Music.

\begin{tabular}{lll}
\multicolumn{1}{c}{ Gravadora } & Número de Discos & Investimento ( 550 por disco) \\
TRIPLE EARTH & 004 & $£ 200$ \\
WORLD CIRCUIT & 005 & $£ 250$ \\
EARTHWORKS & 007 & $£ 350$ \\
WOMAD & 006 & $£ 300$ \\
ROGUE RECORDS & 004 & $£ 200$ \\
N.S.A. / ROGUE & 002 & $£ 100$ \\
OVAL & 002 & $£ 100$ \\
HANNIBAL & 008 & $£ 400$ \\
COOKING VINYL & 002 & $£ 100$ \\
GLOBESTYLE & 022 & $£ 1100$ \\
STERNS & 008 & $£ 400$ \\
TOTAL & $\mathbf{0 6 8}$ & $\mathbf{\$ 3 5 0 0}$
\end{tabular}

Como é sabido, a indústria fonográfica é um espaço de grande rivalidade, mas naquele momento parecia que todos sairiam ganhando caso se unissem para lançar a World Music. Como consta na ata da primeira reunião: "Nós precisamos mudar a ideia (como disse Ian) que porque nós estamos envolvidos com o mesmo tipo de música, nós somos rivais". Foi nesse clima ecumênico que o encontro do dia 27 de julho se encerrou, e o plano foi colocado em prática. E assim, com três reuniões rápidas no segundo andar do Empress 
of Russia, nasceu, no verão londrino de 1987, o estilo musical que ficaria conhecido para sempre como World Music... mas será mesmo que as coisas aconteceram de forma tão simples assim?

Referindo-se àquelas três reuniões, Firth escreveu "'World Music' é um gênero pop não usual que teve um momento de origem preciso" (FRITH, 2014, p. 305). Ora, mas é claro que não foi desse jeito que os fatos se deram. Mitos de origem, com o intuito de parecerem de fato originários, tendem a ignorar todo o processo que os antecedeu, bem como o contexto que os circunda. O que aconteceu no Empress of Russia naquele verão de 1987 não foi o início de nenhuma história nova, mas foi sim, sem sombra de dúvida, o cruzamentos de várias histórias antigas, o ponto em que valências se interpelaram e se coagularam, formando essa figuração conhecida como World Music. Mas essas valências já vinham de muito longe, não se pode tirar o pub da história e achar que a World Music brotou da cabeça daqueles homens por geração espontânea, desenraizada de um contexto histórico. Afirmar que aquelas reuniões são o ponto de largada de uma trajetória é esquecer que houve todo um processo que forjou a configuração em que aquelas reuniões se deram. Entretanto, pode-se afirmar que esse processo deságua nos eventos do $p u b$, fazendo com que aquelas reuniões sejam a substancialização de um fluxo, a objetivação de um percurso. Não é que o pub seja a consequência presente do passado, ele é o passado presentificado. Ali não houve nenhum início, mas houve certamente uma síntese, e é por isso que o evento é relevante. Mas para descobrirmos que valências são essas que se cruzam no pub, nós temos que entender o que é World Music, uma questão que movimentou as reuniões mas que não foi respondida por elas.

A única coisa que ficou clara naqueles encontros é que World Music é o nome de um estilo musical forjado no ocidente, mas que se refere às músicas de artistas nãoocidentais que não se enquadram em nenhum estilo ocidental canônico, e que tem por objetivo justamente preencher essa lacuna, fazendo com que esses artistas se tornem reconhecíveis para o público ocidental. No entanto, já que o rótulo funda um tipo de música, é de se esperar que exista alguma afinidade propriamente musical entre os artistas reunidos por ele, e que esse título aponte para a tal característica sonora que partilham. Todavia, quando nos debruçamos sobre o acervo das gravadoras de World Music, não conseguimos encontrar nenhum traço distintivo propriamente musical, seja erudito ou 
popular, técnico ou estético, especializado ou corriqueiro. Nomes de estilos musicais são por natureza abrangentes, simplistas e vagos. Se olharmos para gêneros tradicionais como samba ou rock, por exemplo, também perceberemos que ali se reúnem artistas bastante diferentes e, da mesma forma, se procurarmos uma definição para esses estilos, encontraremos respostas diversas. Mas nada disso chega perto da envergadura e do laconismo da World Music. O nome é acionado para se referir a artistas muito distantes, musicalmente falando, e ninguém consegue dar uma definição propriamente musical do que ele seja.

Além dessa indefinição musical, o nome ainda oscila, como já se comentou, entre o massificado e o alternativo, o reflexivo e o lúdico, o originário e o sincrético. Entretanto, se a dúvida acerca das características musicais da World Music aparece porque pouco se tenta defini-la musicalmente, as interrogações sobre a posição do estilo entre os polos desses binômios se deve ao fato de que muito se fala sobre eles. No fim das contas, o vazio deixado pelo silêncio acerca das propriedades musicais da World Music é preenchido pela verborragia acerca dessas díades; de modo que o debate sobre a natureza mainstream ou hipster, matricial ou ecumênica, adulta ou divertida da World Music acaba substituindo a discussão acerca da substância estética desse gênero ${ }^{39}$. Mas de todo jeito o que se tem é uma indefinição, seja por excesso, seja por falta.

Sendo assim, o debate acerca dessas categorias acaba substituindo as propriedades estéticas da obra, de modo que os traços acessórios não musicais que deveriam apenas gravitar em torno do conteúdo musical da World Music escorregam para dentro dele, fazendo com que esses anexos virem a própria ontologia do estilo. Quanto mais procuramos uma materialidade plástica e musical interna à World Music, mais nos

\footnotetext{
${ }^{39}$ Sobre fixar o Outro entre polos aparentemente opostos que o descrevem, mas que nunca penetram na sua materialidade, Bhabha afirma "É reconhecidamente verdade que a cadeira de significação estereotipada é curiosamente misturada e dividida, polimorfa e perversa, uma articulação da crença múltipla. O negro é ao mesmo tempo selvagem (canibal) e ainda o mais obediente e digno dos servos (o que serve a comida); ele é a encarnação da sexualidade desenfreada e, todavia, inocente como uma criança; ele é o místico primitivo, simplório e, todavia, o mais escolado e acabado dos mentirosos e manipulador de forças sociais. Em cada caso, o que está sendo dramatizado é uma separação - entre raças, culturas, histórias no interior de histórias uma separação entre antes e depois que repete obsessivamente o momento ou a disjunção mítica." (BHABHA, 2013, p. 333). Ou seja, na tentativa de tecer um diagnóstico sobre a negritude, o branco jamais toca alguma questão que diga respeito a ela, limitando-se a evocar esses pares de opostos que não informam nada sobre o que é ser negro (algo que só pode ser feito por um negro ou uma negra).
} 
afogamos em um debate sobre a natureza massificada ou exclusivista, erudita ou irrefletida, originária ou misturada desse gênero. Ao contrário da música ocidental, que nos convida a mergulhar em sua interioridade musical para lá descobrirmos música, quando entramos dentro da World Music encontramos o que deveria estar fora dela, quer dizer, sentimentos de pertença ou exclusividade, aprendizado ou brincadeira, ancestralidade ou miscigenação. A música ocidental tem que ser ouvida por causa da sua riqueza estética, porque é boa e bela, traços que dizem respeito a sua musicalidade; já a World Music merece nossa atenção porque nos diverte, nos ensina, nos relaxa, nos excita, ela é "legal", "interessante", "curiosa", características não musicais cuja função seria só coroar seu conteúdo musical, mas que entram nele, e assim o substituem, tomando o lugar daquilo que deveriam apenas acompanhar.

"Fenômenos que, em termos musicalmente concretos, permanecem obscuros aos ouvintes são por estes docilmente inseridos em conceitos pré-fabricados; saber-se informado sobre tais conceitos substitui a experiência da própria música" (ADORNO, 2011, p. 282).

"No caso da maioria das exposições que apresentam objetos como etnografia, informações a respeito de funções técnicas, sociais e religiosas são elaboradas, apagando assim a noção de que a qualidade estética do objeto possa 'falar por si' - ou antes, apagando toda noção de que o objeto possua qualquer qualidade estética que mereça ser transmitida. Nesta forma de apresentação, o observador é convidado a elaborar uma compreensão do objeto com base na sua etiqueta, em lugar de reagir a ele através de uma absorção sensório-emocional das suas qualidades plásticas. Em termos da natureza do texto, a ênfase no distanciamento cultural entre observador e objeto substitui a atenção dada ao seu lugar dentro de um arcabouço histórico documentável”. (PRICE, 2000, p. 122)

Diante desse cenário, só nos resta admitir que não existe nenhum parentesco musical entre os músicos de World Music. O que dá unidade a esses artistas e faz com que se reúnam sob o abrigo do nome de um mesmo estilo de música não é nenhum traço propriamente musical, estético ou plástico, mas o fato de serem de países não-ocidentais. Mas, mesmo com essa abrangência, não se pode dizer que toda e qualquer música feita fora do Ocidente será classificada como World Music. Se um músico estrangeiro fizer um som que nitidamente se adéque a um estilo musical conhecido do Ocidente, ele será tido como um representante desse estilo e não da World Music, muito embora a indústria fonográfica dos grandes centros sempre faça questão de pontuar a origem desses artistas. Por exemplo: Titãs, Barão Vermelho e Paralamas do Sucesso não são bandas de World Music, mas obviamente de rock, porém, de "rock brasileiro" ou, como a imprensa apelidou, de Brock 
(DAPIEVE, 2000). Mas, fora esses elementos rastreáveis, há em todo país não-ocidental aquele som típico, que não é feito em nenhum outro lugar do mundo e que não se reconhece em nenhum rótulo do mercado fonográfico: é isso que será chamado de World Music. Para reunir esses sons típicos de cada lugar sob o guarda-chuva da World Music, a indústria fonográfica ignora dois pontos importantes: (1) cada país já tem uma definição nativa para seu som, mais antiga que o nome World Music; (2) como o som característico de um país não é igual ao de nenhum outro, cada lugar dá um nome diferente para sua respectiva música local, deixando claro que aqueles sons agrupados como World Music não têm nenhuma afinidade musical entre si, partilhando apenas a característica de serem músicas exclusivas de países não-ocidentais que não cabem nas velhas categorias ocidentais. Como se pode ver, pelo menos em 1987, quando o estilo foi fundado, nenhuma música foi composta para ser World Music, mas para ser outra coisa, um estilo conhecido por quem o inventou, mas desconhecido por um Ocidente que passou a chamá-lo de World Music para poder conhecê-lo de algum modo. Sendo assim, sofisticando a definição que se quer dar para o gênero, apesar de World Music ser o nome de um estilo musical inventando no Ocidente para designar músicas não-ocidentais que não se enquadram em nenhum rótulo ocidental conhecido, deve-se acrescentar que essas músicas nunca careceram de um nome, pelo contrário, sempre tiveram sua alcunha nativa, apenas não tinham um nome que o Ocidente conhecesse. O mesmo jornal da época já citado, diz o seguinte:

"A tentativa de encontrar uma definição de World Music provocou uma longa discussão até que finalmente se concordou que ele dizia respeito a praticamente qualquer música que não tivesse sua própria categoria. Talvez a o fato comum que unificasse todas aquelas gravadores de disco fosse o compromisso de todos os indivíduos com a própria música" (apud. FRITH, 2014.).

Ora, essa definição não é muito precisa. É certo que World Music é um rótulo que abarca muitas músicas, mas não é verdade que elas aguardavam uma definição, pois essas composições já tinham diferentes identidades localmente forjadas, elas apenas escapavam ao gabarito ocidental, que precisou criar uma taxonomia sua para identificá-las. A World Music surge para cumprir essa função: substituir os vários nomes de batismo desconhecidos pelo Ocidente por um único nome ocidental que o Ocidente soubesse pronunciar. Fazendo desse modo com que World Music seja um nome dado para artistas não-ocidentais não apenas inventado pelo Ocidente, mas também para apresentar esses artistas para o público ocidental, já que nenhum nome Ocidental parecia descrevê-los. O 
nome se refere aos outros, mas foi inventado por ocidentais, para ocidentais, criando-se assim um situação no mínimo engraçada em que se pode dizer que o estilo de música nãoocidental nasceu em Londres, figura de proa do Ocidente.

"Desde o começo, então, World Music é um nome que descreve o processo comercial no qual sons de outras pessoas ('diversas formas de música inclassificáveis em termos ocidentais') eram vendidas para consumidores britânicos". (FRITH, 2014, p. 305)

Contudo, é importante salientar que isso só se dá no nascimento do estilo, pois hoje já existem muitos artistas não-ocidentais que se afirmam como World Music e que trabalham sua imagem intentando ser rotulados assim; mas sobre isso se falará depois. O fato é que, diante desse quadro, deve-se admitir que a definição anteriormente dada (aquela que se achou insuficiente demais por não tocar nada propriamente musical), na verdade esgota todo o diagnóstico acerca da World Music:

World Music é o nome de um estilo musical cunhado no Ocidente para se referir às músicas de artistas não-ocidentais não contemplados por nenhum estilo ocidental canônico. $O$ objetivo desse nome é justamente suprir essa falta e tornar esses artistas estrangeiros reconhecíveis para o público ocidental.

Se essa definição for correta, então deve-se admitir que a World Music se alicerça em um conceito de diferença, pertencendo a esse mercado como uma parte constituída e constitutiva. Desse modo, podemos notar que muita coisa aconteceu antes do "mito originário" do Empress of Russia. Afirmar que o assunto discutido no pub era a diferença é ser obrigado a negar a natureza inaugural e sem passado daquelas reuniões e ter que aceitar que um longo trajeto possibilitou aqueles encontros. Em contrapartida, deve-se reconhecer também que todo esse processo deságua nos eventos realizados naquele segundo andar, e assim eles o ressignificam, dando-lhe novo fôlego. Por isso, como vimos na apresentação de Norbert Elias, não há qualquer imperialismo entre processo e evento: o percurso que passou permite o momento de agora, mas esse instante presente nada mais é que a imediatização de todo aquela caminhada passada. Desse jeito, nem o passado ficou para trás nem o presente é totalmente novo, pois ambos se fundem em um passado presentificado em que a linearidade sucessiva dos anos se transforma na tridimensionalidade simultânea do agora. Ali, no segundo andar do Empress of Russia, durante o verão inglês de 1987 , se inscreveram as tensões de séculos de mercado da 
diferença. Ainda que pareçam inofensivas opiniões pessoais, as falas daqueles donos de gravadora saem de suas bocas encharcadas de história, e as atas que trazem dúvidas sobre a melhor estratégia de marketing a ser adotada encarnam lutas ancestrais que levaram a guerras sangrentas. Todas aquelas grandes questões do mercado da diferença mostradas na Parte I se marcaram naqueles encontros, e se é verdade que o evento só existe porque foi antecedido pelo processo, também é certo que o processo só sobrevive atualizado no evento.

O "mito originário" do Empress of Russia não foi precedido apenas pela ancestral história da diferença, mas também pelo muito antigo interesse pela "música do Outro". Aqueles donos de gravadora não foram os primeiros a se debruçar sobre a produção musical estrangeira, muito pelo contrário, a vontade de encontrar sons de outro lugar é tão antiga quanto a própria música. Só para dar um rápido panorama: em 1557, o missionário huguenote Jean de Léry veio ao Brasil evangelizar os tupinambás e acabou escrevendo sobre a música de seus rituais, que para ele parecia a música da Grécia antiga. Os escritos de Léry influenciaram muito Herder, que nó século XVIII cunhou o termo Volkslied (música folclórica) e publicou dois volumes trazendo composições do gênero: Vozes do Povo nas Músicas, de 1778, e Músicas Folclóricas, de 1779. A lista de organizadores de música estrangeira influenciados por Herder é inesgotável: Louis Pinck (1873 - 1940); Robert Lachman (1890 - 1939) Erich Moritz von Hornbostel (1877 - 1935), que organizou e editou em 1934 as compilações Coletânea Demonstrativa, lançada em 1963, e Música do Oriente, publicada em 1979; Béla Bartók (1881 - 1945) e Zotlán Kodály (1882 - 1967), compositores húngaros que tentaram inventariar a música folclórica de seu país; Francis Densmore (1867 - 1935), que em 1916 cruzou os Estados Unidos para traçar um panorama da música dos nativos americanos. Na esteira de Densmore, Harry Smith lançou em 1950 a Antologia da música folclórica Americana, reeditada em 1997; gênero esse que também chamou a atenção da família Lomax, talvez os maiores curadores do patrimônio folk americano. Zvi Idelsohn (1882 - 1938) cuja pesquisa de mais de vinte anos sobre a música da diáspora judaica resultou na obra de dez volumes Tesouros das Melodias Hebraicas Orientais. Em 1932, no Cairo, Egito, ocorreu o famoso Congresso de Música Árabe, evento que reuniu os maiores pesquisadores da época. Em 1956, a Capitol Records lançou Capital of the World Series, coletânea que trazia estampada na capa a mensagem "Gravado nos países em que a música se originou. Capturado em alta fidelidade, uma série notável de 
álbuns para viajantes da música do mundo" (BOHLMAN, 2002.). No mesmo ano, a Eurovision faz um concurso de música entre os países membros da European Broadcasting Union para promover uma maior interação entre os povos da Europa. Nos anos 1960, os Beatles exploraram a música indiana e, após a dissolução da banda, George Harrison mergulhou fundo nesse universo durante a década de 1970. Enfim, a lista nunca termina. O que se pode depreender daí é que o interesse pela música estrangeira é um desejo antigo que assumiu rostos diferentes ao longo do tempo, sendo World Music a cara dessa tendência no presente, nesse período da diversidade-global do mercado da diferença. Entretanto, ainda que seja só a face nova de um projeto velho, pode-se dizer que a World Music se distingue de suas antecessoras no sentido em que almeja sintetizar as pretensões de todas essas experiências passadas, mesmo que por vezes elas apontem para direções opostas, como as já comentadas tensões entre massificado/alternativo, lúdico/erudito, étnico/cosmopolita. Ao que parece, o rótulo surge para conciliar os atritos das tentativas precedentes. Além disso, pode-se dizer que esse projeto tem uma ambição maior que a dos outros, tanto no plano conceitual quanto mercadológico, mas a isso se voltará depois. É verdade que nenhum desses nomes acima elencados fez World Music, ela só apareceu depois do Empress of Russia, no entanto, se não fossem essas experiências anteriores, aquelas reuniões jamais teriam acontecido. Dessa forma, como se pode ver, ainda que a World Music tenha nascido no verão de 1987, muitos fatos passados tiveram que acontecer para que aquela estreia fosse possível. Como disse Bohlman

"Nos princípios da história da etnomusicologia e da pesquisa em música folk,
estudiosos fazendo seus trabalhos de campo eram constantemente fotografados
organizando suas coletâneas e fazendo suas gravações. Em vários casos
exemplares, essas fotografias se tornaram ícones para coletâneas e o estudo
da World Music. Ali estão eles, os ancestrais dos etnomusicólogos e dos artistas
de World Music de hoje, encontrando-se e trocando conhecimento cultural"
(BOHLMAN, 2002, p. 23)

Situando os eventos do Empress of Russia no processo do mercado da diferença apresentado na parte I, percebemos que a World Music é fundada no período da diversidade-global do mercado da diferença, mais especificamente na fase do multiculturalismo, anterior portanto às propostas de hibridização. Além do multiculturalismo, outra tendência forte daqueles anos, que pode ser conferida nos gráficos em anexo, foi o grande aquecimento da vendas de discos. 1987, data de fundação da World Music, foi o ano em que os lucros da indústria fonográfica iniciaram uma subida 
vertiginosa, movimento conduzido principalmente pelo aparecimento do $\mathrm{CD}$, que devido a sua praticidade fez a procura por música crescer rapidamente. Essa tendência continuaria até 1999, quando a internet abateu o formato em pleno voo e fez a arrecadação das gravadoras despencar em queda livre (ver anexo). Quando CD e multiculturalismo se encontraram, o resultado foi o aparecimento das coletâneas de World Music, no entanto, enquanto essas duas tendências desapareceram, a World Music continua firme e forte, o que deve ser entendido como um sinal de que ela se emancipou das forças que a ensejaram e se adaptou às novas circunstâncias.

Por ser um típico fenômeno do segundo período do mercado da diferença, que nasceu na fase multicultural mas vive até o presente, a World Music se revela um importante laboratório para entendermos como se deu a relação entre formas universais do período exótico-colonial do mercado da diferença e conteúdos particulares da diversidadeglobal. Meu objetivo é olhar para esse fenômeno da indústria fonográfica para perceber se nele as velhas formas engoliram os novos conteúdos, assinalando a continuidade entre os dois períodos, ou se os novos conteúdos contaminaram as velhas formas, marcando a ruptura entre eles. Ao fazer a sociogênese do conceito de diferença, mostrei os modos pelos quais um centro enxerga sua exterioridade ao longo do tempo, já que a World Music é uma visão do ocidental para o ocidental sobre o mundo não-ocidental, essa figuração se revela um objeto valioso para encontrarmos pistas para responder as nossas perguntas. Afinal, como a World Music lida com seus outros? Ou melhor, qual conceito de diferença ela aciona: o exótico-colonial ou a diversidade-global? Baseado nisso poderemos tecer um comentário sobre as continuidades e rupturas entre os dois períodos do mercado da diferença.

Promovendo o cruzamento entre a sociogênese e o objeto, o que se quer aqui é olhar para aquelas perguntas pelo prisma da World Music, usando essa figuração como um anteparo onde as respostas para aquelas questões possam se projetar. Apresentando o problema preenchido pelo objeto, as dúvidas que nos movimentam agora são:

Pergunta conceitual: O fenômeno da World Music gera efeitos universais de unidade, homogeneidade, pureza e absolutismo ou efeitos particulares de multiplicidade, heterogeneidade, hibridismo e relativismo? 
Pergunta política: No fenômeno da World Music, as culturas tematizadas são empoderadas pelas gravadoras, ganhando assim maior liberdade e independência, ou seriam elas apenas usadas pela cultura das gravadoras (essa sim a verdadeira vitoriosa), caindo portanto num estado de dependência, dominação e controle?

Pergunta síntese: olhando essa mudança pelo prisma da World Music, quais são as continuidades e rupturas no mercado da diferença quando da passagem do exóticocolonial para a diversidade-global? Ou seja, que relação se estabelece entre colonização e globalização?

No entanto, para não se incorrer naquele velho erro de tecer diagnósticos sem que antes se esclareça exatamente o que se está analisando é preciso fazer aquela pergunta zero relativa ao índice de diferença, posto que, sem a marcação do índice, qualquer resposta pode ser dada, sem que nenhuma seja satisfatória.

Pergunta zero: Com qual índice de diferença a World Music opera e que configuração sócio-histórico-cultural possibilitou que ele arregimentasse tanto capital de diferenciação?

Essas são exatamente as perguntas que os autores que pesquisam World Music se fazem e que dividem o debate acerca do tema. Não é coincidência que as mesmas interrogações movimentem o estudo do mercado da diferença e da World Music, pois, na verdade, a World Music pertence a esse mercado, contida nele mas também constitutiva dele. Quando fiz o resgate histórico na parte I, falei que os estudiosos da diferença não estavam fora dela, passivamente fotografando-a, mas dentro de seu mercado, construindo-o e alterando-o ao levá-lo à condição de objeto. Agora, da mesma forma, aqueles que estudam a World Music não estão apenas tematizando seus sentidos "tal como são" (como se esse estado de virgindade existisse), mas imputando novos sentidos ao comentá-la. Nesse caso, para os fins dessa dissertação, etnomusicólogos - assim como donos de gravadora, músicos e consumidores - ocupam uma posição dentro do mercado da World Music, contidos nele, mudando-o. Olhemos então como anda o debate acerca desse fenômeno da indústria fonográfica para que possamos ensaiar um argumento nosso.

O que se seguiu aos eventos do Empress of Russia foi uma história de sucesso. Em questão de meses, o nome já estava espalhado por toda a imprensa britânica e no ano 
seguinte já havia cruzado as fronteiras do país para rivalizar na França com o Sono Mondiale, rótulo inventando pela gravadora Actuel que nunca prosperou fora de seu país de origem. Ainda em 1988, o responsável pela divisão de World Music da Tower Records, grande loja do ramo, afirmou em entrevista para a revista Newsweek que sua seção "definitivamente era a parte da loja que mais crescia" (apud. TAYLOR, 1997.). Em 1990, o mercado da música inglês, europeu ocidental e estadunidense só falava em World Music. Em maio desse mesmo ano, o rótulo conquistou uma importante vitória: a revista americana Billboard, uma das maiores publicações do mundo da música, famosa por seus catálogos de mais vendidos, criou um catálogo específico de World Music. Esse feito atesta o sucesso precoce do estilo: a World Music havia ganhado o mundo e atingido o lucrativo mercado fonográfico americano. Como diz o slogan da publicação, "não é hit até que seja hit na Billboard", de fato, depois do catálogo ficou claro que o plano deu certo, a World Music tinha "acontecido" e já não cabia mais no apertado segundo andar do Empress of Russia.

Esse primeiro catálogo, que trazia os 15 discos de World Music mais vendidos de maio de 1990, revive aquelas tensões que apareceram nos encontros em que o estilo foi "inventado". A balança massificado/alternativo se evidencia já no simples fato de uma das maiores publicações da indústria fonográfica organizar uma lista de mais vendidos de um estilo que se quer heterodoxo. Intimamente ligado com esse, o conflito reflexivo/lúdico aparece na posição em que a Billboard situa o catálogo: a lista da World Music aparece dentro da categoria maior "álbuns adultos alternativos". Era nesse ponto intersticial entre maturidade e rebeldia que a World Music se situava: nem uma reflexividade sisuda, nem uma espontaneidade irresponsável, nem um tiozão, nem uma patricinha de Ipod, mas uma brincadeira séria, um descolamento interessado, um habitus de VJ da MTV, de professor garotão por quem as alunas se apaixonam: trinta e muitos anos, barba por fazer, um tênis longilíneo parecido com All Star mas que não é All Star, etc. Os donos de gravadora relutaram muito em ter seu material incluído dentro de International, um rótulo antiquado que servia para descrever aqueles discos de canções tradicionais da Alemanha ou as tarantelas italianas; eles queriam algo mais contemporâneo, mas que não cortasse as raízes com o passado.

"Em um só gesto o rótulo velho mas ainda não abandonado 'international' (que poderia incluir tudo desde as vozes irlandesas à capela de Clancy e Makem até 
polcas) foi trocado por algo mais do momento, menos carregado, menos música-da-sua-avó, algo que contemplava tudo desde gravações que etnomusicólogos fizeram em campo até a última novidade em matéria de pop e rock fora da Europa e da América do Norte." (TAYLOR, 1997. p. 5)

Sob o mesmo guarda-chuva "adulto alternativo", ladeando a World Music, estava o catálogo de New Age, mas esse vizinho de ar contemporâneo não constrangeu a lista da World Music de trazer artistas mais tradicionais, o que nos remete à díade matricial/sincrético. No ranking que nos interessa estão reunidos artistas do mundo inteiro, mas enquanto uns carregam o signo do seu lugar de origem (como Le Mystère des Voix Bulgares, por exemplo), outros parecem ser uma colcha de retalhos, como o Gipsy Kings, banda francesa de nome inglês que canta flamenco em espanhol, que aparece com dois discos, um deles ocupado a primeira posição, não por coincidência intitulado Mosaique.

Em 1991, uma nova vitória: o Grammy, Oscar da indústria fonográfica, decidiu criar uma categoria de World Music. O prêmio foi entregue pela primeira vez na cerimônia do ano seguinte e existe até hoje. Michael Green, presidente da National Academy of Recording Arts and Sciences (NARAS), declarou à época: "Nós notamos uma movimentação ligada a essas formas específicas de música. Nós notamos que esses gêneros estavam crescendo e cada vez mais jovens artistas se envolviam com ele" (apud. TAYLOR, 1997, p.10). Era a glória: apenas quatro anos depois de ser criada, a World Music penetrava o coração da indústria fonográfica internacional, atraindo a todos como um ímã. Inclusive, a história da World Music no Grammy evidencia a já comentada tensão entre matricial e sincrético: a partir de 2004, o prêmio se dividiu entre "Melhor Disco de World Music Tradicional" e "Melhor Disco de World Music Contemporânea", mas em 2012 a academia resolveu acabar com a divisão e manter apenas um Grammy de World Music como antes. Mas voltando: meu argumento é que o interesse pela World Music é um sintoma do prestígio que algumas agendas ganharam nessa fase do mercado da diferença. Mas que agendas eram essas? Como se disse, a ascensão da World Music se dá durante o período da diversidade-global, era em que ideias particulares de multiplicidade, heterogeneidade, hibridismo e relativismo precisaram se acomodar em formas universais que, antes do filtro da igualdade, abrigavam as noções de unidade, homogeneidade, pureza e absolutismo. Desse modo, se descobrimos com qual desses glossários a World Music opera, poderemos ter uma ideia das continuidades e rupturas entre os dois períodos do mercado da diferença. Se o novo estilo abraça a multiplicidade, a heterogeneidade, o 
hibridismo e o relativismo, é porque os novos conteúdos subjugaram as velhas formas, sendo a relação entre os dois períodos de ruptura, mas se o gênero criar efeitos de unidade, homogeneidade, pureza e absolutismo, isso significa que as velhas formas sufocaram os novos conteúdos, estabelecendo uma continuidade entre os dois períodos.

Nesse mesmo ano de 1991 em que a World Music virou categoria do Grammy, o Nirvana lançou Nervemind, segundo álbum de estúdio da banda. Em uma das faixas do disco, Kurt Cobain canta "Venha como você, como você era, como eu quero que você seja". Esse convite vacilante parece traduzir a ambiguidade da oferta que a indústria fonográfica do Ocidente fazia para o resto do mundo: que imagem de estrangeiro é essa que o Ocidente quer conhecer: uma imagem nativa ou uma fabricada por ele? Que conceito de diferença está sendo acionado? Quem é o Outro desse estilo musical? Como ele deve vir: como ele é ou como eu quero que ele seja? São essas as perguntas que dividem o debate acerca da World Music. Entremos nele em busca de uma pista.

A indefinição em torno do significado desse nome, bem como as tensões que ele carrega consigo, são vistos com bons olhos por muitos autores. Para esses otimistas, a dificuldade em se definir o que é World Music só mostra como esse é de fato um nome muito includente; e se sob o abrigo dele se reúnem características tidas como opostas, isso só quer dizer que esse é um nome rico, multifacetário, um espaço onde todas as particularidades são aceitas, onde todas as diferenças são tratadas igualmente para que os atritos sejam apaziguados com diplomacia. Por conta desse ecumenismo, a World Music seria antes de tudo um lugar libertário, gregário e democrático. Enquanto as outras definições demarcam territórios e erigem muros intentando conter elementos, a World Music acaba com as fronteiras e mistura tudo. Ao contrários dos outros estilos, que aproximam partes semelhantes e afastam diferentes, a World Music junta os diferentes, tornando inútil a tarefa de defini-la, já que a única semelhança entre seus membros é o fato de serem todos dessemelhantes. Nesse sentido, definir o que é World Music não leva a nada, pois, no fim das contas, ela é tudo.

"Nesse início do século XXI é impossível definir World Music sem cair em uma tautologia. World Music é aquela música que encontramos, bem, em qualquer lugar do mundo. World Music pode ser música folk, música artística ou música popular; seus praticantes podem ser amadores ou profissionais. World Music pode ser sagrada, secular ou comercial; suas performances podem enfatizar autenticidade, enquanto ao mesmo tempo se aproximam marcadamente da 
mediação, visando disseminar o estilo para a maioria de mercados possíveis. Consumidores de World Music podem usá-la da maneira que quiserem; eles podem celebrá-la como sendo deles ou encará-la pelo prisma do estranhamento que ela causa. As definições e distinções antigas não se sustentam mais; World Music pode ser ocidental ou não-ocidental, acústica ou eletrônica. O mundo da World Music não tem fronteiras, portanto o acesso a World Music está aberto a todos. Há muitos motivos para chamar qualquer coisa de World Music." (BOHLMAN, 2002, p. 31).

Já para outros autores, a dúvida que paira sobre a World Music não faz dela um estilo includente, mas desorganizado, e as forças extremas que ela aproxima não são um indicativo de sua riqueza, mas de sua incoerência. Separando-se da definição acima dada, esse ponto de vista acredita que essa simetria e essa liberdade aparentes sejam apenas uma cortina de fumaça que secreta um jogo de papeis muito bem definidos, em que alguns atores tem bastante trânsito, enquanto outros são arbitrariamente fixados em posições periféricas. A partir daí, surge uma série de debates em torno do gênero.

Um primeiro traço que pode ser notado na narrativa do estilo é o pan-humanismo, ou seja, uma ênfase na existência de um grande parentesco humano em que todas as pessoas, embora diferentes, são iguais e estão conectadas umas às outras, compondo uma rede simétrica. Nesse sentido, a World Music seria a "música de todo mundo" e assim, esse patrimônio circularia em todas as direções dessa malha, formando uma grande ciranda de sons, como em um piquenique em que cada um leva uma comida para colocar numa toalha em que todos podem pegar tudo: sua música vem pra cá, a minha vai para aí, eu sou apresentado a você, você é apresentado mim, nós conhecemos eles, eles nos conhecem, etc.

Mas, para muitos autores, essa comunidade humana só é forjada para que dentro dela um par de opostos seja cultivado, de modo que, a continuidade do perímetro humano serviria apenas para erigir uma descontinuidade no interior dessa fronteira. De fato, olhando para as atas das reuniões e para os discursos das gravadoras que apareceram depois delas, podemos perceber que o mundo da World Music é divido em duas metades: a cultura ocidental e a cultura não-ocidental. Enquanto a primeira se encarrega da produção (gravadoras, com aparato técnico e capital) e do consumo (público comprador, também curioso e com dinheiro pra gastar em discos), a segunda fornece a matéria-prima musical, o tema a ser produzido e consumido pela primeira metade.

"Músicas do mundo exóticas sempre estarão distantes financeira e esteticamente dos lugares historicamente consolidados de gravação. O controle e a posse de 
aproximadamente $93 \%$ do mercado mundial de venda de música está concentrado na mão de seis companhias europeias-estadunidenses-japonesas: Time Warner, CBS-SONY, MCA, Thorn-EMI, BMG/RCA, e PhilipsPolygram. A integração vertical e horizontal da produção e da publicação de música, a posse da tecnologia e o controle da produção estão intimamente ligados aos centros de poder de inovação tecnológica no Ocidente e, mais recentemente, no Japão. Nos últimos 25 anos, Estrelas ocidentais da arte, do rock e do pop prosperaram nesse mercado de maneiras geralmente desconhecidas e quase impossíveis fora do Ocidente, até mesmo comparadas com uma estrela não-ocidental da estatura de Ravi Shankar." (FELD, 2005, p. 262)

O desequilíbrio do binômio já se evidencia quando olhamos para os nomes de cada um dos pares: Ocidente e não-ocidente. Quer dizer, um é um termo marcado, que é para si mesmo, enquanto o outro é um termo derivado, que é em relação ao seu duplo. O Ocidente, produtor e consumidor, tem capital de produção e consumo para adquirir uma alteridade; o não-ocidente, fornecedor de matéria prima a ser aprimorada e comprada lá fora, é essa alteridade que, por ser só dona dessa estranheza e não ter capital, precisa se vender para o Ocidente como um não-ocidente para entrar nesse mercado. Por conta disso, a simetria da comunidade pan-humana seria falaciosa, pois, uma vez reunida essa família supostamente igualitária, antigas divisões seriam afirmadas dentro dela.

"Nota-se, portanto, que se o conteúdo vendido é marcadamente global, o público consumidor é marcadamente localizado nos EUA e na Europa; a globalidade da participação nesse mercado se dá por uma desigual condição. Se World Music é um processo global, a participação dos atores norte-americanos e europeus se dá preponderantemente do ponto de vista da produção e consumo, enquanto dos outros lugares do mundo especialmente do ponto de vista de conteúdo. Com exceção de selos ou revistas do setor que se voltar para seus próprios países, a operação global da World Music tem essa característica." (NICOLAU NETTO, 2014, p. 232)

"Uma das maneiras de ver esse fato é apontar para uma mera continuação daquilo que já ocorria no século XIX, notando que tanto o turismo quanto a venda de música se voltam para um público majoritariamente concentrado nos países onde há maior poder aquisitivo. Ou seja, isso significaria que o destinatário do discurso do exótico é o mesmo do século XIX, e nada de muito novo se apresentara, além de novas técnicas. (...) De fato, o discurso do exótico é consumido majoritariamente na Europa e nos EUA." (NICOLAU NETTO, 2013, p. 103)

A ocidentalidade da produção pode ser conferida pela origem das gravadoras. Quanto ao consumo, essa pesquisa não traçou o perfil do público comprador de World Music, e eu sei que há pessoas fora do Ocidente que ouvem discos do estilo, mas, mesmo olhado para o polo da produção, pode-se perceber que o mercado alvo da Word Music é o ocidental, 
mesmo que o gênero tematize o não-ocidental: o produto é ofertado com mais abundância nos grandes centros do que nas periferias que retrata, sendo mais fácil e mais barato comprar um disco lá do que aqui. Ainda que os discos sejam vendidos na internet, justamente por serem produzidos nos grandes centros, as taxas de entrega para fora do Ocidente são muito maiores, além disso, quem tem acesso a internet e cartão de crédito? Da mesma forma, as grandes cadeias ou os comerciantes que quiserem revender o catálogo de uma gravadora encontrarão menos dificuldades para adquirir esses produtos se forem ocidentais. Como se falou, World Music é sobre não-ocidentais, mas feita por ocidentais, para ocidentais.

\footnotetext{
"Alguns etnomusicólogos estavam usando o termo World Music para descrever todas as músicas dos povos do mundo. Nenhum deles viu aquela expressão como algo potencialmente pejorativo nas entrelinhas; era apenas um atalho para separar a musica do Ocidente da música do resto" (TAYLOR, 1997, p. 51)
}

Na contramão desses críticos, há pessoas que chamam a atenção para o fato de que esses músicos não são escravos das gravadoras, pelo contrário, por terem sido contemplados pela World Music, ganharam muito dinheiro e projeção internacional, recebendo um prestígio que muitas vezes não tinham no seu próprio lugar de origem. Não por acaso, muitos artistas de World Music são infinitamente gratos a seus "descobridores", e aqueles que não entraram no radar do estilo, trabalham sua imagem para chamar a atenção desse rótulo. Além de pagarem em dinheiro o que devem aos músicos e divulgálos mundialmente, muitas gravadoras de World Music desenvolvem trabalhos filantrópicos nos países onde pinçaram seus talentos, seja enviando dinheiro e destinando uma parcela da venda de seu catálogo para projetos sociais, seja chamando a atenção do mundo para um cenário carente constantemente negligenciado. Mas essa boa vontade os livra da culpa colonial? Segundo Feld, "Projetos conduzidos com agendas políticas e estéticas progressistas e autoconscientes não são nem inocentes nem discursivamente livres da crítica pós-colonial" (2005, p. 289)

A tréplica dos que se incomodam com o rótulo é que essas características do estilo celebradas por alguns atestam ainda mais a existência de uma divisão interna àquele pretenso pan-humanismo. O que os defensores não percebem, alegam os céticos, é que na sua própria fala já está presente a assimetria de poder fundante da World Music. Para esses críticos, mesmo que o estilo insista na existência de uma mesma rede humana em que 
todos dão e recebem cultura, o que há é um binômio em que um polo fornece matéria prima cultural e o outro dinheiro, e quem dá um não dá o outro. Como, dizem, a "imagem nativa" pela qual o Ocidente está interessado é, na verdade, o que ele acha que aquela imagem nativa deva ser, então, se a figura do Outro não passa pelo crivo ocidental, a torneira fecha e o artista não pisa o solo sagrado da World Music. Portanto, nesse jogo, quem tem o dinheiro tem o poder, e assim, aquele pretenso equilíbrio pan-humano se revela, no final das contas, uma velha desigualdade. Além disso, o fato de um artista periférico precisar de uma chancela ocidental para fazer sucesso no mundo (e às vezes até no próprio país) mostra que, realmente, o Ocidente é a cultura mais poderosa que existe.

"A noção, comum entre produtores culturais, de que a banalidade é parte do preço que se paga pela exposição estabelece que músicas e músicos periféricos devem berrar para pop-stars ocidentais e para a indústria fonográfica quando quiserem participar de uma síntese musical." (FELD, 2005, p. 267)

No coração do "pan-humanismo" há um centro ocidental de triagem de culturas que decide o que o resto do mundo deve ou não deve conhecer: tudo o que ele toca vira ouro, se ele disser que é bom, é bom, se ele disser que é ruim, é ruim, e nenhum artista de fora do Ocidente conseguirá circular no espaço global sem a sua aprovação. A questão da filantropia pode até sugerir uma largueza de espírito ocidental, mas só evidencia o fato de que há uma assimetria de poder entre os dois lados do balcão da World Music, pois se o Ocidente ajuda o resto do mundo é porque está numa situação mais confortável que a dele.

Fora todas essas razões técnicas e econômicas, ainda há uma questão simbólica que aponta para uma possível desigualdade no seio dessa família. $\mathrm{O}$ discurso pan-humano da World Music afirma que há uma rede de culturas se trocando em simetria, circulando em todas as direções: minha música vai até você, sua música vem até mim e assim criamos nossos laços. Mas se isso for verdade, porque nenhuma coletânea de World Music tematiza a cultura ocidental? África, Ásia, América Latina e Caribe são constantemente retratadas pela World Music, mas nenhum lançamento traz a música de Londres ou de Nova Iorque. As gravadoras ocidentais fazem esforços hercúleos e investem grandes somas de capital para mostrar para a cultura americana um retrato supostamente fiel da África, mas não se dedicam à tarefa muito mais simples de falar de si próprios e mostrar para a África como é a cultura dos Estados Unidos. Pode-se alegar que essa cultura já se evidencia para a África de muitas maneiras, pois já preenche muitos espaços. Mas afirmar que o Ocidente está 
representado globalmente enquanto o resto do mundo está eclipsado é admitir que há um ruído na acreditada afinação do pan-humanismo. Além disso, o Ocidente não precisou da "boa-vontade" do Oriente para se globalizar, nem muito menos teve que ser embalado em uma categoria estrangeira que o aproxima de partes com quem nunca teve afinidade. É verdade que muitas coletâneas tematizam a tradição ocidental, como as raízes irlandesas, o céltico, o hebraico, etc. mas o fato de a World Music aproximar seu passado do presente dos outros confere ao seu discurso um tom evolucionista, uma sugestão de que "eles" são hoje o que "nós" fomos ontem. Também é preciso admitir que, com o aumento dos fluxos de intercâmbios globais e uma maior permeabilidade da fronteiras nacionais, a World Music acabou objetivando elementos da cultura americana e europeia, mas, mesmo nesses casos, o estilo se interessa ou pelo passado desses lugares, como foi dito, ou por uma área desses territórios marginalizada, tribalizada, tida como menos nobre: o sul negro dos Estados Unidos, os grupos minoritários europeus, a parte mais latina e o leste da Europa, etc. Ainda sobre esse tema, para os críticos do estilo, o fato de as gravadoras nunca levarem sua cultura à categoria de objeto e só tematizarem culturas não-ocidentais revela uma soberba intelectual e estética dos grandes centros, pois se só mostram o Outro para si sem nunca se mostrarem para o Outro, é porque os euro-americanos acreditam que sua inteligência e sofisticação os tornam aptos a entender a cultura estrangeira e se regozijarem com ela, enquanto a burrice e a insensibilidade dos periféricos os impediria de decifrar ou apreciar a cultura ocidental.

"O homem ocidental, em plena posse de seus processos mentais analíticos e conscientes, é capaz de olhar para a produção criativa dos seus irmãos menos civilizados e ganhar em discernimento. Mas em geral não se considera que o processo inverso poderia gerar insights valiosos.” (PRICE, 2000. p. 92)

No mundo supostamente pan-humano da World Music, a África, por exemplo, será um tema constante de coletâneas produzidas por gravadoras americanas e vendidas no mercado americano. Mas lá na África propriamente dita, não serão vendidas nem essa coletânea de música africana, nem muito menos uma coletânea retratando a cultura americana. Desse jeito, chega-se a um cenário muito parecido com o do Orientalismo, em que, segundo Said, "Não há nenhuma revista importante de estudos árabes publicada no mundo árabe atual." (2013, p. 431).

"Embora haja dezenas de organizações nos EUA para estudar o oriente árabe e islâmico, não há nenhuma no próprio Oriente para estudar os EUA, de longe a 
maior influência econômica e política na região. Pior, não há no Oriente institutos de estatura até modesta que se dediquem a estudar o Oriente." (SAID, 2013, p. 431)

Dito de maneira definitiva, para muitos céticos, essa grande família pan-humana da World Music, igualitária e simétrica, essa comunidade onde todas as diferenças teriam a mesma voz e seriam tratadas da mesma forma, é um projeto que nunca se realizou, pois, na verdade, o espaço do pan-humanismo é rasgado em duas metades muito nítidas: Ocidente e o resto. Dessa forma, contrariamente ao que se esperava, a World Music não seria um lugar de equilíbrio e diplomacia, mas um discurso em que antigas divisões seriam reafirmadas. A agenda da igualdade humana nos conduziria obliquamente para a imiscibilidade dos povos, pois, acreditam alguns, as diferentes culturas só seriam aproximadas para que se evidenciassem as diferenças entre elas ${ }^{40}$. Para esses autores, a estrutura binomial que racha o pan-humanismo pode ser notada na distribuição desigual de tarefas de cada metade: enquanto o Ocidente detém o capital e controla produção e consumo, o resto do mundo não possui esses meios, sendo obrigado a fornecer apenas a matéria prima para a indústria fonográfica ocidental. Ainda que tematizem o não-ocidental, as coletâneas de World Music são produzidas por gravadoras ocidentais e destinadas ao mercado ocidental. Como se vem repetindo: o estilo é sobre o resto do mundo, mas feito por "mim", para "mim". Olhando o tom pan-humano da World Music somos levados a crer que músicas espelhando suas respectivas culturas circulam em todas as direções, fazendo assim com que os povos conheçam uns aos outros através de elos artísticos. No entanto, como essa família é cindida em duas metades que desempenham papeis muito diferentes, esse suposto escambo de culturas com ares de feira de troca solidária se revela uma velha transação financeira, em que a matéria prima de uma periferia sem capital é comprada pelo capital de um centro sem matéria prima. A cultura africana, supostamente "tal como é", vai para os Estados Unidos, mas o que sai dos Estados Unidos para a África não é cultura, mas dinheiro. Ou seja, não há uma rede onde circulam músicas, mas uma linha reta que liga dois extremos,

\footnotetext{
${ }^{40}$ Said já havia falado sobre como a criação de uma mesma substância humana permite que hierarquias diferenciantes surjam no seu interior. "Segundo os orientalistas tradicionais, deve existir uma essência - às vezes até claramente descrita em termos metafísicos - que constitui a base comum e inalienável de todos os seres considerados; essa essência é tanto 'histórica' pois remonta à aurora da história, como fundamentalmente a-histórica, pois transfixa o ser, o 'objeto' de estudo, dentro de sua especificidade inalienável e não evolutiva, em vez de defini-lo como todos os outros seres, estados, nações, povos e culturas - como um produto, uma resultante das forças que operam no campo da evolução histórica. Assim acaba-se tendo uma tipologia - baseada numa especificidade real, mas separada da história e, consequentemente, concebida como intangível, essencial - que faz do 'objeto' estudado um outro ser, em relação ao qual o sujeito que estuda é transcendente" (2013, p. 146)
} 
um da cultura, o outro dinheiro. Não se troca cultura por cultura, mas cultura por dinheiro $^{41}$. O Ocidente não precisa da curiosidade nem do patrocínio do resto do mundo para se globalizar, mas o resto do mundo precisa do interesse e do financiamento ocidental para entrar nesse mercado global. Diante de tanta assimetria, alegam alguns autores, como se pode falar em uma mesma família pan-humana?

Essa discussão para descobrir se o pan-humanismo da World Music existe ou não reacende um antigo debate sobre as continuidades e rupturas entre os dois períodos do mercado da diferença. Aqueles que acham que o estilo promove uma comunidade panhumana identificam pelo menos duas importantes rupturas: (1) o arranjo binomial Eu/Outro do período exótico-colonial foi substituído na diversidade-global por uma rede de fluxos de intercâmbios globais simétricos. (2) A violência do período exótico-colonial, presente na dominação e no controle que o Eu exercia sobre o Outro, foi trocada pelo pacifismo da diversidade-global, evidenciada no equilíbrio com que os fluxos se trocam, no respeito, na reverência e no interesse que cada cultura tem pelas outras. Inversamente, aqueles que acham que o pan-humanismo promove uma divisão entre o Ocidente e resto do mundo diagnosticam uma continuidade nessas duas áreas: (1) o binômio Eu/Outro do período exótico-colonial, encarnado nas figuras da metrópole e da colônia, é reafirmado na diversidade-global pela bipolarização composta pelo Ocidente com capital de produção e consumo em busca de matéria prima e pelo resto do mundo fornecedor de matéria prima carente de capital. (2) A tirania do período exótico-colonial marcada na intervenção do Eu no Outro se repete na diversidade-global quando o Ocidente se apropria de matéria prima cultural do resto do mundo em troca de dinheiro. Para esses autores, as desigualdades ancestrais entre Ocidente e Oriente garantem ao primeiro um mercado produtor e consumidor rico, enquanto empurram o segundo para uma condição periférica de dependência. De acordo com esse ponto de vista, essa divisão do trabalho, essa apropriação, essa necessidade que o Oriente tem de um rubrica Ocidental para se globalizar, são só a atualização na diversidade-global da mesma violência do exóticocolonial; não por acaso, o mapa da World Music é muito parecido com o mapa do império:

\footnotetext{
${ }^{41}$ Novamente, tem-se no seio da diversidade-global uma relação típica do exótico-colonial tematizado por Said. "A minha opinião é que se trata de uma relação unilateral, sendo os EUA um cliente seletivo de uns poucos produtos (petróleo e mão de obra barata, principalmente), e os Árabes clientes altamente diversificados de uma imensa série de produtos dos EUA, materiais e ideológicos." (Said, 2013, p. 432).
} 
com algumas exceções, as gravadoras estão situadas nas antigas metrópoles e as culturas tematizadas por elas sãs as velhas colônias de ontem.

\begin{abstract}
"As práticas de comercialização e rotulação da World Music são a continuidade de um antigo binarismo constituído pelo 'Ocidente' e 'O Resto', colocando vários tipos diferentes de música dentro da mesma caixa, enquanto Gabriel, Simon $^{42}$, e outros músicos ocidentais se inscrevem em rótulos mais prestigiados como 'rock'. (...) Tais práticas de mercado apontam, mais uma vez, para as diversas maneiras que o capitalismo encontra de construir centros e margens, e para como as margens, não importa quão diversas sejam, se indiferenciem até não poderem mais ser reconhecidas. As formas com que lojas de disco divulgam, rotulam e vendem ajuda a mostra a natureza contraditória e conflituosa do capitalismo, que Lawrence Grossberg descreveu como 'máquina de fazer diferença', mas uma máquina que, como ele sabe, também busca estabilidade e previsibilidade. Nesse caso, a estabilidade é alcançada através do estabelecimento de padrões, categorias homogêneas como 'World Music' que, no final das contas, não são nem estáveis nem homogêneas" (TAYLOR, 1997, p. 14)
\end{abstract}

Usando termos mais específicos, o ponto nevrálgico em que as duas correntes divergem diz respeito à relação que se estabelece na World Music entre as gravadoras ocidentais e os músicos representativos de culturas não-ocidentais. Os que acreditam no pan-humanismo e na ruptura entre os dois períodos do mercado da diferença acham que a World Music é um ponto de inflexão em que as gravadoras, e o próprio Ocidente, abdicam de seu monopólio para repartir poder com os artistas estrangeiros, e o próprio nãoocidente. No momento dessa troca de guarda, o centro renunciaria de sua posição privilegiada em favor das periferias, encerrando um tempo de dominação e inaugurando outro de equilíbrio. Já os que acham que o pan-humanismo reproduz velhos binômios e promove uma continuidade entre os dois períodos do mercado da diferença pensam que as gravadoras e o Ocidente se apropriam vampirescamente dos artistas e do não-ocidente, inscrevendo no presente a antiga era de exploração da metrópole sobre a colônia.

Falando de uma maneira extremada e ideal-típica, o primeiro grupo diria que os artistas assinam contrato com gravadoras de World Music "porque querem", enquanto o segundo afirmaria que eles o fazem "porque não há outra opção". Para se escolher um dos lados é importante conhecer dados técnicos e contratuais relativos aos lucros de cada uma das partes, porém, mais importante ainda é atentar para algumas questões simbólicas, por exemplo: quem ganha poder, prestígio e reconhecimento com aquele trabalho: o artista ou

\footnotetext{
${ }^{42}$ Peter Gabriel e Paul Simon são dois artistas ocidentais promovedores de World Music que abordarei mais adiante.
} 
a gravadora? Qual dos dois é tido como o autor daquela obra? Mas o grande ponto é aquele antecipado por Kurt Cobain: em qual imagem de estrangeiro o Ocidente está interessado: na autoimagem do estrangeiro, independente de qual ela seja, ou na sua imagem ocidental do que aquela autoimagem estrangeira deveria ser? Nesse caso, ao invés de curioso para saber a opinião da periferia sobre si mesma, o centro estaria em busca de sua opinião sobre a periferia, ou até mais violento ainda, de sua opinião sobre a opinião da periferia sobre si mesma. Se isso for verdade, além de não revelar uma visão nativa, a World Music não chegaria nem a assumir que dá uma visão ocidental sobre o nativo, mas, tal qual o Orientalismo, cinicamente venderia sua visão ocidental como se fosse nativa. Como se falou, a World Music pode ser sobre o de fora, mas o aparato técnico de gravação e o público consumidor são ocidentais. Sendo assim cabe perguntar: será que o microfone vai continuar ligado, será que a multidão ainda vai aplaudir, não importa o que o estrangeiro cante? O que sai da sua boca é o que ele quer dizer ou o que o Ocidente quer que ele diga?

Para que o espetáculo da World Music seja possível é necessário, obviamente, que existam um artista e um público. No entanto, afora essas duas instâncias tradicionais, esse mercado precisa do trabalho de um terceiro ator para que o ciclo se feche. A necessidade desse terceiro elemento advém do seguinte fato: para o discurso da World Music, a música estrangeira não vai caminhar sozinha até o público ocidental, nem vice-versa. Ela é uma joia rara que está escondida, perdida em sua terra natal. A plateia ocidental não pode sair de casa para ver essa preciosidade na África, e essa pérola também não vai sair rolando do fundo da sua caverna até chegar em Manhattan. É aí que entra o terceiro elemento da World Music: sua função é viajar para a terra estrangeira, encontrar a tal música perdida, e trazê-la para o Ocidente. Esse terceiro elemento, portanto, se inscreve entre o artista e a plateia para encurtar a longa distância que os separa, fazendo com que a música de "lá" possa chegar "aqui". Sem ele, músico e público, trancados em seus respectivos países, jamais se conheceriam, e o fenômeno da World Music não seria possível. Essa figura pode ser chamada por muitos nomes (guia, curador, tradutor, intérprete), mas o termo que sintetiza todos esses é mediador. A World Music é um mercado de mediação, um espaço que precisa do trabalho de um mediador, que é um intermediador, um personagem que se coloca entre dois polos extremos e permite o seu diálogo. Esses dois pontos afastados que o mediador aproxima são o artista não-ocidental e a plateia ocidental ou, dito de maneira ampla, o não-ocidente e o Ocidente propriamente ditos. 
Em um sentido largo, pode-se dizer que esse personagem não é exclusivo da World Music, pois em todos os estilos musicais uma série de instâncias se coloca entre artista e público para que seu encontro seja possível: gravadoras, empresários, governantes, donos de casa de shows, organizadores de festivais, lojas de disco, etc. Mas no caso da World Music, como a distância entre os dois extremos é maior e seu encontro seria de fato impossível sem a mediação, o mediador ganha destaque: ele é o barqueiro, o diplomata, o descobridor, um Hermes contemporâneo que traz a boa nova da diversidade-global. Se hoje vivemos em um mundo em rede onde todos tem acesso a tudo sem sair de casa é porque ele saiu de casa e enredou pontos soltos. Há na World Music aquilo que Taylor descreveu como "Brought you by" feeling (1997, p.28), ou seja, o sentimento de que aquilo foi trazido exclusivamente para você. Portanto, o mediador da World Music não é como os mediadores dos outros estilos, burocratas da indústria fonográfica, seu dever é quase cívico, seu trabalho é importante para que o nosso tempo seja o que é. O músico precisa dele para ser ouvido, a plateia precisa dele para ouvir, o mundo precisa dele, e ele faz isso pelo mundo e porque gosta. Ele gosta do mundo.

O mediador da World Music pode tanto ser uma pessoa - é o caso de Mickey Hart, Paul Simon, Peter Gabriel, Ry Cooder, Steve Copeland, estrelas da música ocidental quanto uma gravadora, mas, mesmo as gravadoras tendem a antropomorfizar seu trabalho de mediação na figura do dono ou de um etnomusicólogo encarregado de rodar o mundo em busca de músicas estranhas. Uma diferença sutil é que enquanto o mediador individual geralmente procura um lugar em específico, ou mesmo só uma banda ou um artista, com o intuito de gravar um disco daquele ou com aquele nativo, as gravadoras, além de realizarem esse trabalho, se dedicam a organizar coletâneas de World Music, reunindo em um mesmo disco com tema determinado a produção, nem sempre inédita, de vários compositores e intérpretes diferentes. É justamente sobre esse ofício da mediação que pesam aquelas dúvidas sobre poder na World Music: se o estilo seria libertário ou dominador, se as gravadoras ocidentais estariam empoderando os artistas não-ocidentais ou se apropriando deles.

O terreno da mediação é movediço porque há uma imprecisão quanto a natureza do seu trabalho, e é dessa incerteza que surgem as desconfianças acerca da World Music. A grande dúvida sobre a mediação, em torno da qual gravitam as outras interrogações, nasce 
do seguinte fato: para dar credibilidade a seu trabalho, o mediador nos assegura que as músicas que capturou refletem aquela cultura "tal como ela é", em toda sua imanência crua e sua virginal concretude nativa. Aquilo que o mediador nos oferece não é a cultura como ele a vê, mas como ela se vê, como ela é. Não se tem ali uma opinião subjetiva sobre aquele povo, mas a ontologia objetiva daquele lugar. Sua íris é translúcida e sua retina é um espelho que duplica a imagem sem deformação. Para que o público não perca isso de vista, o mediador enfatiza que seu trabalho é meramente extrativista e não fabril, ou seja, em campo, ele apenas escolheria elementos de maneira livre e desinteressada para trazê-los para o Ocidente tal como são, mostrando para "nós" a realidade imaculada daquela cultura distante. A desconfiança que surge daí, abrindo a caixa de pandora para muitas outras, é: seria o trabalho de mediação esse passivo e irrefletido esforço de seleção de elementos nativos "tais como ele são" ou um ativo e reflexivo gesto de criação desses elementos, tais como o mediador acha que eles deveriam ser? Quando falou que os orientalistas inventavam o Oriente que pareciam estar só comentando, e que esse Oriente inventado no Ocidente parecia mais verdadeiro que o Oriente oriental, Said chamou nossa atenção para o fato de que mediar sentidos também é imputar sentidos, de modo que modestamente mudar símbolos de lugar também é alterá-los profundamente. Bourdieu também havia nos advertido que inocentes atos de catalogação são arbitrários gestos de criação. E, como se falou, uma instância não se dá antes da outra, pois elas são simultâneas: o habitus gera as práticas que classifica no momento em que as classifica; a mediação imputa os sentido que media, mediando-os; o arquivo escreve o texto que arquiva na hora em que o coloca na gaveta. Levando em consideração essas teorias, como fica a figura do mediador da World Music? Quando diz ser um curador que escolhe sentidos de uma cultura, investido do neutro objetivo de mostrá-la como ela é, não estaria o mediador se comportando como um autor que imputa os sentidos justamente ao escolhê-los, inventando aquela cultura tal como ele a enxerga na medida em que acredita estar somente espelhando-a da maneira como ela se vê? Ou, para usar os termos de Bauman (2010), será que os atos de interpretação não seriam também gestos de legislação? É claro que a World Music pode fazer tudo isso inconscientemente, movida por lógicas práticas e não por práticas lógicas, sem buscar fins, sem a má intenção de enganar seu público ou canibalizar seus temas, mas talvez justamente essa inocência bem intencionada possa cegar as gravadoras para o que em Said e Bourdieu é o outro lado da passividade classificatória do mediador de sentidos objetivos: 
a atividade inventiva do imputador de sentidos subjetivos. Para quem abraça esse argumento, as ideias parciais que o mediador elabora em seu juízo silenciosamente se convertem em objetos imparciais existentes na vida, sem que ninguém perceba essa transubstanciação violenta. Desse jeito, assim como acontece com a magia fetichista da mercadoria estudada por Marx, a visão de mundo do mediador se transforma no próprio mundo.

"Assim, a impressão luminosa de uma coisa sobre o nervo ótico não se apresenta como uma excitação subjetiva do próprio nervo, mas como forma objetiva de uma coisa fora do olho." (MARX, 2008. p. 71)

Para os defensores do estilo, o mediador é um homem curioso que nutre um profundo respeito pela cultura estrangeira e ajuda a dissemina-la pelo mundo. Já para os críticos, esse intermediário é um ladrão que se apropria do patrimônio cultural dos outros países. Além disso, dizem os céticos que esse guia contribui mais para o silenciamento do que para o empoderamento dos artistas. Primeiro porque reforça aquela ideia da triagem, de que um musico estrangeiro só pode circular no espaço global se tiver a benção ocidental. Segundo porque o mediador passa a impressão de que a música estrangeira é dependente, nunca se basta nem fala por si mesma, carecendo sempre de um intérprete para fazer sentido. No mundo da World Music, o artista de fora nunca aparece no espaço global sozinho, mas sempre escoltado por um mediador ocidental. $\mathrm{Na}$ sua obra referente ao período exótico-colonial, Said já havia dito que o Oriente só chega ao Ocidente domesticado pelo filtro ocidental do orientalista ${ }^{43}$. Para os críticos da World Music, o mesmo quadro se repete no período da diversidade-global: para tocar nos Estados Unidos, o cantor africano tem que passar pela terapia do mediador americano. O mediador nega a existência desse adestramento, sublinhando sempre a passividade de seu trabalho e insistindo que o produto que oferece é a verdade nativa daquela cultura, mas muitos não acreditam nisso. Não por acaso, a popularização da World Music é diretamente proporcional ao aumento de prestígio da etnomusicologia como disciplina acadêmica. "A relação entre etnomusicologia, World Music e diversidade foi se tornando cada vez mais

\footnotetext{
43 "O que é assim transmitido pela bibliothéque é uma ideia do poder e da eficácia do orientalismo, que em toda parte faz lembrar ao leitor que a partir daquele momento, para chegar ao oriente, ele terá de passar pelas grades e pelos códigos eruditos fornecidos pelo orientalista." (SAID, 2013, p. 107)
} 
clara." (NICOLAU NETTO, 2014, p. 237), ou seja: quanto maior o volume de música estrangeira, maior a necessidade de um mediador que explique e amanse esse estilo.

"Dessa forma, a música exótica só pode ocupar o espaço determinado para o campo da música erudita através da representação necessária feita pelo artista europeu, esse sim 'completo'. A música exótica só entrará nos espaços mais consagrados da música na Europa, nas casas sinfônicas e nas óperas, pelas mãos de Liszt, Mozart,Chopin, Debussy, etc. O exótico, neste espaço, é limitado à sua representação, ele nunca possui uma apresentação autônoma. Partindo do pressuposto de que toda representação é uma forma de poder, o artista ocidental tem o poder sobre a cultura exótica no momento em que ela precisa ser por ele representada." (NICOLAU NETTO, 2014, p. 78)

Se o trabalho do mediador for só uma passiva mediação, se a World Music monta um palco e deixa o estrangeiro subir nele para falar o que bem entende, então podemos dizer que as gravadoras empoderam os músicos, criando condições para que várias culturas, antes marginalizadas e retratadas por terceiros, adentrem a arena global afirmando-se tal como se enxergam. Nesse caso, como cada local irá se definir da sua respectiva maneira, o mundo será um lugar múltiplo, heterogêneo, híbrido e relativo, ideias particulares próprias ao período da diversidade-global do mercado da diferença. Entretanto, se o ofício de mediação for também uma ativa imputação, se os músicos forem bonecos de ventríloquo das gravadoras, então a suposta voz nativa não passa de um discurso ocidental sobre o estrangeiro, travestido de autobiografia do Outro. Se isso for verdade, as gravadoras estariam se apropriando dos artistas, e como imprimiriam sua mesma marca ocidental em todas as diferentes culturas tematizadas nas coletâneas, cortando as várias particularidades com a mesma lâmina euro-americana, a World Music promoveria unidade, homogeneidade, pureza e absolutismo, ideias universais nascidas no período exóticocolonial do mercado da diferença. Ali há polissemia, pois o Ocidente recua e deixa que cada parcela do mundo floresça do seu próprio jeito; aqui há monismo, pois ele avança, cultivando as várias culturas da única maneira que lhe apetece. É nesse ponto em que as opiniões se acirram.

Uma polêmica de jornal entre David Byrne, líder do Talking Heads e apreciador de música estrangeira, e Ian Anderson, um dos fundadores da World Music presente no Empress of Russia, ilustra bem essa duas perspectivas. No dia 3 de outubro de 1999, Byrne 
publicou no New York Times um artigo intitulado "Eu Odeio World Music"44. Passando pelas críticas aqui apontadas, o texto ácido traz passagens como "World Music é uma caixa de despejo na loja de discos onde estão coisas que não pertencem a nenhum outro lugar da loja". "Junta maçã com laranja", "Agrupa tudo e qualquer coisa que não é 'nós' em 'eles'", "Um rótulo para qualquer coisa que não seja cantada em inglês ou que não se encaixe no universo pop anglo-ocidental desse ano." "É uma forma não muito sutil de ratificar a hegemonia da cultura pop ocidental. Ela guetiza a maioria das músicas do mundo. Essa foi boa, Homem Branco!.", "Ver pessoas e culturas como exóticas é um mecanismo de distanciamento que quase sempre justifica a exploração e o racismo". Em resposta a esse texto, o número 201 da revista Froots, publicado em março de 2000, vem com um artigo inflamado de Ian Anderson a favor da World Music ${ }^{45}$. O cabeçalho da matéria já dava a tônica do que vinha pela frente: "Desde que a World Music apareceu em 1987 como um conceito de marketing, teóricos da conspiração gastaram energia criticando-a. 'Basta!', diz Ian Anderson." Eis algumas passagens ilustrativas:

\begin{abstract}
"Ninguém nesse projeto tinha a menor intenção de exploração, guetização, conspiração, exclusivismo, imperialismo, racismo ou qualquer -ismo sem sentido que tenha sido cacarejado geralmente por pessoas que deveriam se informar mais e fazer um pouco mais do que só expor suas próprias deficiências. Era simplesmente uma grande ideia, seguida por uma cooperação sem precedentes entre entusiastas (poucos se viam como rivais nos negócios) que queriam encontrar outros entusiastas para que tivessem mais oportunidades de partilhar seu entusiasmo. Sim, foi bom para os negócios, mas justamente por isso foi automaticamente bom para o lucro dos artistas também."
\end{abstract}

"Não há regras que impeçam Kidjo ou Youssou N'Dour ou Zap Mama de fazer uma música que eles ou os consumidores achem que cabe melhor em outra categoria, ou em categoria nenhuma até. Se eles migrarem para um gênero com o qual milhares de outros artistas já estão envolvidos é escolha deles. (...) Claro, se os artistas mudaram por uma imposição da gravadora, é outra história, mas eu não vejo isso em nenhum dos criadores da World Music."

"Não é 100\%, mas World Music (ou Musique du Monde como é conhecida em Paris) está muito na frente. Ela vende uma quantidade enorme de discos que você não conseguiria encontrar por amor ou dinheiro nenhum do mundo duas décadas atrás. Ela fez com que músicos de países muito pobres fossem respeitados (e ganhassem casas, carros e comida para suas famílias), e deu-lhes um grande público em festivais e shows. Ela nos levou a ter um novo entendimento do internacional e provocou trocas culturais - pessoas que se viram reunidas por um mesmo rótulo passaram a se ouvir e terminaram fazendo músicas incríveis juntos. Eu chamo isso de uma Coisa Boa, e sinto um pouco de

\footnotetext{
44 http://www.davidbyrne.com/archive/news/press/articles/I_hate_world_music_1999.php. Acessado em 01/05/2015.

${ }^{45}$ http://www.frootsmag.com/content/features/world_music_history/. Acessado em 01/05/2015.
} 
pena das pessoas a toa que decidiram que odeiam World Music... Evoluam, pessoal, é só uma prateleira em uma loja de discos."

"Imaginem vocês, quando The Voice [jornal] foi enganado e publicou um libelo grosseiro sugerindo que artistas como Dembo Konte \& Kausu Kuyateh estavam sendo explorados por 'Senhores de escravos da World Music' como Ian Anderson, Lucy Duran e a organização do WOMAD, Dembo ficou tão furioso que imediatamente foi bater no escritório do jornal. $\mathrm{O}$ editor quase perdeu o emprego: porque o artigo falou o que eles queriam que fosse verdade, eles o publicaram sem antes conferir se aquilo era de fato verdade."

Essa celeuma reúne de maneira desorganizada os elementos do debate que aqui nos interessa. Byrne diz que a World Music reafirma velhos binômios e fortalece antigos desequilíbrios de poder. A partir daí, o músico faz duas denúncias sérias: a primeira diz respeito ao monismo da ideia de diferença. A World Music pode até reconhecer as outras culturas como diferentes, mas como ela trabalha com uma ideia única de diferença, essas culturas acabam se nivelando ao se deixarem abraçar pelo conceito. Assumindo aqui um negativismo frankfourtiano, para Byrne, a World Music só abre as portas para culturas que ela julga diferentes e idiossincráticas, mas uma vez dentro do salão, elas se plasmam em uma mesma multidão embotada. Só poucos discos de cada país serão particulares o suficiente para se destacar dos seus conterrâneos e chamar a atenção das gravadoras ocidentais, mas uma vez percebidos, todos recebem o mesmo tratamento. Para migrar de sua prateleira original para a de World Music, o artista tem que se diferenciar de seus vizinhos, mas chegando nessa segunda estante, ele deve se igualar a seus novos companheiros, formando uma gosma indiferenciada de diferenças, um fileira de primeiros lugares. As gravadoras escolhem a dedo seus artistas, e depois enfiam todos em um mesmo pacote chamado "os diferentes". Portanto, na lógica da World Music, a sua especificidade só será reconhecida caso você esteja disposto a abrir mão dela depois desse reconhecimento: é preciso ser diferente para receber um convite, mas, no baile da diferença, todos são iguais. Aliás, todos não, há um indivíduo que se destaca dos demais: o anfitrião, o dono da gravadora, o Ocidente. Essa é a segunda denúncia de Byrne: como trabalha com um conceito único de diferença, a World Music só reconhece a diferença dos outros para nivelá-los, sendo assim, no final das contas, o estilo ratifica as idiossincrasias da própria cultura ocidental. O Ocidente junta todos os vários países do mundo sob a égide de uma mesma ideia de diferença, por isso os pavimenta, mas como ele próprio não entra no rebanho que tangeu, quem acaba se diferenciando é ele. Por isso a World Music erige um indistinto mundo distinto, um bloco diferente de tudo o que está fora dele, mas 
internamente sem fissuras. Esse conjunto agrupa particularidades para fundi-las: o resto do mundo entra e se generaliza, o Ocidente fica de fora e se especifica. Os artistas de World Music são incomuns, mas tem algo em comum: o fato de não serem ocidentais. Sendo assim, a característica sublinhada nessa brincadeira é a própria ocidentalidade. Como se pode ver, para Byrne, a World Music trabalha com dois polos diferentes entre si mas iguais em si. Além disso, um desses extremos subjuga o outro e o manipula para que ele ratifique suas idiossincrasias. Ademais, a ideia de diferença acionada pelo estilo promove as noções universais de unidade, homogeneidade, pureza e absolutismo. Se isso for verdade, para o músico, ainda que seja um fenômeno do segundo período da diversidadeglobal, a World Music cria efeitos próprios ao exótico-colonial, o que nos leva a crer que as formas do primeiro período que atravessaram o filtro contaminaram os conteúdos do segundo, estabelecendo entre as duas eras uma relação de continuidade.

Já no artigo da Froots, Anderson desmente todas as acusações de Byrne. Para o autor, a World Music é um movimento bem intencionado que surge para corrigir distorções históricas, sendo portanto uma modesta renúncia de poder do Ocidente em favor de seus Outros. No estilo, os músicos nunca foram coagidos pelas gravadoras que os contrataram, por isso mesmo podem fazer o que bem entenderem e produzir o som que quiserem. É justamente por dar essa liberdade ao artista que as coletâneas trazem aquelas culturas tais como elas são: o sujeito canta a música que quiser e a gravadora inclui no disco, independente de qual seja, simples assim. De acordo com Anderson, a afirmação de que os empresários manipulariam os artistas não passa de teoria da conspiração: que interesse eles teriam nisso? Como o próprio afirma "Ninguém achou nem pretendeu que a criação dessa definição faria esse monstro: era só uma caixa, como jazz, clássico ou rock..." Sobre a acusação de que a World Music reúne diferenças para nivelá-las dentro do estilo, o autor contra-argumenta dizendo que, ao se avizinharem na nova categoria, músicos que jamais teriam se conhecido sem a World Music descobriram uma ao outro, e assim passaram a misturar seus sons, produzindo uma terceira música completamente nova. Bohlman traz um relato etnográfico que corrobora a visão de Anderson:

"Mulçumanos americanos que entrevistei nos anos 1990 encontraram um profundo significado espiritual no qawwali da World Music, enquanto ao mesmo tempo eles estavam bastante atentos para como o qawwali estava sendo apropriado e vendido. Para os mulçumanos, o interesse pelo qawwali como 
música popular não eliminou o poder espiritual do islã. Muito pelo contrário, a popularização do qawwali lhes deu mais poder" (BOHLMAN, 2002, p. 66).

Stewart Copeland, baterista da banda britânica The Police, gravou em 1985 The Rhythmatist, disco que reúne canções de Tanzânia, Quênia, Burundi, Zaire e Congo. Quando as críticas aos mediadores de World Music chegaram a ele, Copeland respondeu algo no sentido de Anderson, mostrando que sabe o que os estrangeiros pensam:

"Recentemente eu ouvi uma expressão: garimpo cultural. É um termo
pejorativo, entretanto eu estou orgulhoso em assumir esse termo para meu
próprio trabalho. Porque eu acho que o termo propriamente dito só é usado por
jornalistas intelectuais muito ignorantes a respeito do que pensam os povos
nativos de lugares exóticos. Eles são muito abertos, gostam de compartilhar sua
cultura e sentem orgulho por ter gente do outro lado do mundo os ouvindo e os
apreciando. A ideia de que alguém vai para uma vila africana, grava suas
músicas e leva a fita embora - não é como se, de repente, 'ei, pra onde foi a
música? Deve ter sido aquele cara branco com o microfone! Ele a roubou e foi
embora com ela!' Nada pode dar-lhes maior alegria que a ideia de que algumas
pessoas numa terra distante estão dançando seu ritmo"46 Peter Gabriel, líder da também inglesa banda Genesis, foi outro que se lançou na mediação de World Music, fundando uma gravadora com o sugestivo nome de Real World e o festival World Music Arts and Dance (WOMAD), em que músicos do mundo inteiro apresentam suas composições. Na esteira dessas opiniões, Gabriel vê o WOMAD "como um veículo"

"Um artista pode vir de outro país e entrar em um circuito muito difícil de entrar se eles estivesse em outro lugar - e assim conseguir visibilidade, ser ouvido, e se tudo der certo encontrar um público que fará com que ele volte ano que vem e faça uma turnê pelas próprias pernas" 47

Portanto, na visão dessas pessoas (que sabem o que se passa na cabeça dos estrangeiros, que têm gravadoras que mostram a realidade do mundo) esse fenômeno fonográfico da diversidade-global converte assimetrias binomiais em redes equilibradas de fluxos de intercâmbios mundiais, que promovem as noções particulares de multiplicidade, heterogeneidade, hibridismo e relativismo. Se estiverem certos, então as formas do primeiro período do mercado da diferença que passaram pelo filtro da igualdade foram totalmente contraladas pelos conteúdos do segundo, de modo que a relação entre passado e presente só pode ser de ruptura.

\footnotetext{
${ }^{46}$ BLANK-ENDELMAN, D. "Stewart Copeland: The Rythmatist Returns" RMM 3 (fevereiro de 1994), 38.

${ }^{47}$ Entrevista de rádio dada a Bob Coburn.
} 
Para resolver essa querela, mudemos nosso foco dos mediadores individuais e passemos para as gravadoras que organizam coletâneas de World Music. Enquanto mediadores individuais procuram artistas estrangeiros para gravar discos inéditos quase sempre em pareceria com eles, essas gravadoras pinçam músicas de vários compositores e intérpretes diferentes, na maioria das vezes já gravadas, e simplesmente compilam essas faixas em uma coletânea com um tema determinado (que pode ser uma região do mundo, mas não necessariamente). Colocando nesses termos, o trabalho da gravadora parece ser ainda mais passivo e inocente que os dos mediadores individuais: a empresa não altera em nada o conteúdo da música, não parece imputar sentido nenhum, apenas pega a canção com a ponta dos dedos, tira de um CD e coloca em outro, fim. Alguém diria que uma mediação tão simples como essa pode ser também uma imputação violenta? Alguém seria capaz de duvidar que aquela coletânea traz a cultura estrangeira tal como ela é? Sim. Esse alguém é Roger Chartier.

Para Chartier, os sentidos de um texto não repousam apenas no conteúdo interno de seu discurso, mas também na plataforma em que ele se inscreve. Sendo assim, para entendermos o significado do que está escrito, não devemos apenas entrar no núcleo duro da palavra, mas também atentarmos para a materialidade onde aquele texto se marca. $\mathrm{Na}$ visão do historiador, o sentido de qualquer escrita se divide entre esses dois níveis: a substância do discurso e o tipo de superfície em que ele se registra. Chartier acredita nisso porque, para ele, essa autonomia do conteúdo do discurso é completamente ilusória, pois esse acreditado âmago imaculado da mensagem é condicionado pelo tipo de anteparo em que ela se projeta. Nesse caso, se quisermos ser rigorosos, não podemos nem dizer que para o historiador o sentido de um texto dependa do que é interno a ele e do meio em que ele se encontra, pois na verdade essa divisão é falsa, e as duas instâncias formam um só corpo: esse internalismo virgem não existe, pois o formato que o abraça vaza para dentro dele, e é desse amálgama entre o discurso e o seu plano de inscrição que o sentido emana. Nem os mais abissais mergulhos exegéticos conseguirão acessar um sentido exclusivo do discurso, não contaminado pelo meio em que ele está, pois aquelas palavras não foram apenas pensadas, mas pensadas para estar ali, de modo que não há uma anterioridade do conteúdo em relação ao formato, uma vez que a primeira centelha de criatividade já se media com o tipo de prancha que irá recebê-la. Quando vai escrever uma mensagem (um livro, um bilhete, um email, etc.) o escritor leva em conta o meio em que ela será escrita, 
pois essa mídia condiciona o conteúdo da mensagem. Da mesma forma, aquele que lê algo, monta um entendimento do que leu baseado não apenas no cerne do texto, mas também na plataforma em que ele se encontra. As mudanças que um livro nos provoca não derivam só das frases imaginadas pelo autor, mas do fato de elas estarem em um livro; até porque, quando decidiu escrever não apenas frases, mas frases para um livro, o escritor já deixou o conteúdo de seu pensamento ser moldado por uma forma especifica de encadernação, e se a superfície de registro fosse outra, as palavras também o seriam.

Por essas razão, Chartier acredita que a teoria de Foucault possui uma séria limitação. Ainda que tenha muita reverência pelo mestre, o autor acha que o filósofo presta muita atenção ao discurso em detrimento dos formatos nos quais ele se inscreve; e mesmo as tais "bases materiais do discurso", que Foucault tanto busca, não se referem às maneiras de registro, mas sim ao contexto sócio-histórico em que um determinado conjunto discursivo emerge para formar uma episteme. É preciso olhar para as plataformas, insiste Chartier, pois elas modelam a pretensa pureza do conteúdo discursivo que recebem. Nesse caso, um texto originalmente escrito para o rolo que é passado para o códex, por exemplo, perde bastante do seu sentido original. Seu conteúdo foi completamente preservado, mas a superfície em que se inscreve mudou radicalmente, e isso é suficiente para que o sentido do texto se altere, já que esse significado não está apenas nas palavras do papel, mas também no papel das palavras. Em resumo: um "mesmo escrito" em outra mídia já não é mais o mesmo escrito. Portanto, pode-se concluir da teoria de Chartier que: o sentido de um texto depende do discurso e da plataforma em que ele se deita. Sendo assim, por mais que nos esforcemos em conservar seu âmago discursivo, se a materialidade física onde ele está for alterada, o sentido que o texto carrega, por se alicerçar em ambos, muda drasticamente. Quer dizer, não há deslocamento inocente e ingênuo, toda vez que se transplanta um conteúdo de uma mídia para outra, adultera-se seu sentido original. Mudar a embalagem é transformar o que está dentro dela, reposicionar passivamente conteúdos é ressignificar ativamente seus significados, enfim, para Chartier, mediar sentido é imputar sentido.

Olhemos as coletâneas de World Music à luz dessa teoria. Esses lançamentos são organizados da seguinte maneira: uma composição é feita para um disco com um nome, uma capa, um autor, um contexto, um público alvo, além de trazer outras músicas. Essa composição é retirada desse disco e colocada em outro com outro nome, outra capa, outros 
autores, outros contexto, outro público alvo e com novas faixas. A substância daquela canção, forjada pelo nativo, é mantida, porém a plataforma que a recebe, criada pela gravadora ocidental, é mudada. Mas como o sentido da música não emana apenas da ontologia da faixa, conservada como o estrangeiro a deixou, mas também da superfície que a acomoda, criada pelo gravadora, então o significado original do arranjo se altera por influência do Ocidente, a substância de além-mar é contaminada por mãos euroamericanas, fazendo com que a intenção nativa perca espaço para uma significação ocidental. Portanto, de acordo com uma visão chartiana, a passiva mediação de sentido nativo das coletâneas de World Music também é uma ativa imputação de sentidos da gravadora. $\mathrm{O}$ sentido mediado é o conteúdo indígena que se conserva, mas a imputação vem da embalagem ocidental que o envolve. Por esse motivo, ali não há apenas uma cultura tal como ela se vê, mas também a visão ocidental sobre ela, vendida como sendo uma autoimagem. O conteúdo remete ao sentido estrangeiro, mas o modo de registro é branco, como o sentido vem de ambos, a mudança na mídia destrói a ideia de que a coletânea espelha a inteireza da cultura estrangeira. Músicas que são arrancadas de seu disco original e posicionadas em outro já não são mais a mesma música. O mesmo problema das faixas com o disco se repete em maior grau entre o disco e a prateleira: tirar um álbum de sua estante e colocá-lo em outra de World Music é ressignificá-lo. O conteúdo do disco pode ser o mesmo, mas a maneira de classificá-lo muda. Como o entendimento que se faz acerca dele se baseia nessas duas instâncias, mudar sua posição é mexer no seu sentido. Chartier nos ensina que nenhum nome é inocente, toda vez que um símbolo é remanejado seu sentido se altera. Portanto, na visão do autor, a justificativa de Anderson de que a World Music seria uma mediação passiva que conserva sentidos originais porque "é só uma caixa" ou "só uma prateleira numa loja de discos" não cabe. Para Chartier, uma caixa nunca é só uma caixa.

Retomando o que foi dito no capítulo 1, pode-se perceber que esses autores enxergam uma forte semelhança entre os dois períodos do mercado da diferença. Assim como Nicolau Netto se referiu ao período exótico-colonial em que os dicionários universais apareceram ${ }^{48}$ como sendo uma época tomada por um "afã classificatório" (p.

\footnotetext{
48 "Tanto as histórias universais da música como os dicionários universais ou enciclopédicos se inserem em um momento no qual se buscava reunir em obras singulares todo o conhecimento humano." (NICOLAU NETTO, 2014, p. 65)
} 
67), Bohlman falou que o período da diversidade-global que ensejou a World Music trouxe uma forte "vontade de antologia" (2002, p. 38), de produzir apanhados que "reuniam a diversidade em disco com o objetivo de representar a World Music de uma maneira holística" (2002, P. 26). Se para Said o Orientalismo "é uma disciplina sistemática de acumulação" (2013, p. 178) e "toda a obra de Sacy [organizador de crestomatias] é essencialmente uma compilação" (2013, p. 181), para os críticos da World Music, o estilo também é um empilhamento de cacos culturais desordenados, mas que tem uma ordem arbitrariamente inventada pelo mediador, que a oferta ao público ocidental como se aquilo fosse uma sistematicidade indígena. Realmente, pode-se notar um paralelo entre as crestomatias do Orientalismo e as coletâneas de World Music. As duas intentam apresentar uma cultura estrangeira para um público ocidental. Para isso, recorrem a um mediador da terra para onde o produto se destina, no primeiro caso um pesquisador orientalista, no segundo um artista, um etnomusicólogo ou uma gravadora, sempre ocidentais. Ambos os mediadores, para cumprir esse objetivo de mostrar os de fora para o Ocidente, recorrem ao mesmo método: selecionar partes dispersas da cultura estrangeira, retirá-las de seus contextos originais e reuni-las em uma compilação que é oferecida ao público ocidental como sendo uma autoimagem nativa, como sendo a cultura do Outro tal como ela é. Para que essas compilações - seja a crestomatia, seja a coletânea - produzam esse feito de verdade, os mediadores - tanto o orientalista quanto a gravadora - devem insistir que seus trabalhos de mediação são passivos gestos de seleção. Entretanto, para Said, Chartier e outros, esse ofício traz consigo uma ativa marca de instauração. Classificar é instaurar, escolher é fazer, enfim, para essa corrente, mediar sentido é imputar sentido.

"Sempre selecionamos ativamente elementos pertencentes a tempos diferentes. Ainda podemos selecionar. É a seleção que faz o tempo, e não o tempo que faz a seleção. O modernismo - e seus corolários anti e pós-modernos - era apenas uma seleção feita por alguns em nome de muitos." (LATOUR, 2009, p. 75).

Se esses autores estiverem certos, se o mediador imputa os sentidos que acredita apenas mediar, então as compilações não trazem a cultura nativa tal como ela é, mas como o Ocidente a vê, embora elas sejam vendidas como uma autobiografia estrangeira. O Outro não está sendo apenas mostrado, como a World Music afirma, mas inventado pelo estilo. Se isso for verdade, o suposto pan-humanismo ecumênico da World Music não é uma história contada por todos nós, mas sobre todos nós, contada por um de nós. O resto do mundo não fala por si, o Ocidente é que legisla em nome de todos, embora se comporte 
como se estivesse passando a palavra para seus vizinhos. Nesse caso, a rede pan-humana repetiria o binômio Eu/Outro, em que o primeiro domina o segundo porque define a si mesmo e a seu duplo e, justamente porque no mundo só haveria uma voz, a World Music produziria efeitos universais de unidade, homogeneidade, pureza e absolutismo. Quer dizer, na visão desses céticos, as formas universais oriundas do primeiro período do mercado da diferença teriam estrangulado os conteúdos do segundo do outro lado do filtro, de maneira que a relação entre exótico-colonial e diversidade-global seria de continuidade.

"É apenas o artista genial que pode suplementar esse outro, dono de uma cultura sempre incompleta aos olhos europeus do século XIX. A cultura do outro, presa à natureza e à tradição não é apenas substituída, mas acrescentada, na ideia de que seus déficits, suas falhas aos olhos europeus, serão preenchidos e 'corrigidos' por aquele que atingiu o ideal artístico. (...) Não basta, portanto, um artista ocidental reproduzir a música do outro, mas sim suplementá-la, acrescer a ela todos os ingredientes que justamente a diferenciam da música autônoma europeia (...).Por necessitar ser representada - pelo compositor/artista ocidental e suplementada por esse, segundo as regras geradas naquele campo, ela é, portanto, sempre um discurso do eu em relação ao outro, sua voz nunca é autônoma. O suplemento, que para Rousseau seria perigoso, funda a relação entre a música erudita e a música exótica em um momento no qual o universal da música é o quadro de referência." (NICOLAU NETTO, 2014, pp. 79, 80).

Nesse debate sobre World Music, discute-se com muito afinco se as gravadoras reproduzem a cultura estrangeira tal como ela é ou se a produzem tal como acreditam que ela seja. Mas, antes de sabermos se o Ocidente espelha nativamente ou inventa ocidentalmente essa coisa chamada "cultura estrangeira", deveríamos nos perguntar: seria a cultura estrangeira uma coisa? Aceitamos de maneira tão acrítica essa briga entre entusiastas e detratores da World Music acerca da capacidade das gravadoras de dar conta da realidade nativa do Outro, que nunca duvidamos da existência dessa ontologia. Mas é preciso questionar esse ponto que subjaz à polêmica. Quando discutem se a World Music repete ou inventa a cultura indígena, essas facções já tomam como dado a existência desse corpo monolítico, plano e indiferenciado, restando apenas descobrir se essa rocha é forjada pelo Ocidente ou pelo locais. Mas será que essa cultura existe assim, como coisa? Esse consenso sobre a continuidade da superfície e a consistência morfológica do nativo, pressuposto por partes dos dois grupos, dá ao Outro uma feição estanque e inteiriça, o que, em linhas gerais, significa que sua cultura é tratada como uma natureza. Feld já havia falado desse "ponto de transição que simultaneamente faz a natureza soar tão musical e a música tão natural" (2005, p. 280). Essa tendência pode ser percebida nos próprio nomes de gravadoras de World Music: City of Tribes, EarthBeat!, Earthworks, Original Music, 
Real World, Redwood Cultural Work, Rhythm Safari, Roots Records, Soundings of the

Planet, Erdenklang, dentre outros.

"A música exótica - não apenas aquela dos ciganos - era vista como natural, que não se aprende. O oposto da música ocidental, espaço dos especialistas, cujo aprendizado pressupõe um mestre e cujo esforço requerido é maior 'do que escalar uma alta montanha', como já ensinava uma léxica de 1732." (NICOLAU NETTO, 2014, p. 88)

Encarar as culturas não-ocidentais como natureza traz sérias implicações: a primeira é que, como a cosmologia ocidental só reconhece uma natureza possível, as culturas do mundo não são convertidas em diferentes naturezas, mas em uma mesma massa natural indiferenciada e constante; o que, no fim das contas, significa que a World Music promove as ideias universais de unidade, homogeneidade, pureza e absolutismo. Segundo que, se é natural, além de pavimentada, a cultura do Outro não é histórica, não muda, sendo antes um corpo eterno, preso em um passado absoluto que o Ocidente já superou ${ }^{49}$. Terceiro, para o Ocidente, natural é sinônimo de pré-reflexivo, espontâneo, portanto, por ter sido composta em uma cultura natural, a música estrangeira, ao contrário da Ocidental, não parece um fruto do pensamento, mas algo instintivo, automático ${ }^{50}$.

"Mais do que em qualquer arte das grandes civilizações do mundo (sejam ocidentais ou orientais), a arte primitiva emerge direta e espontaneamente de impulsos psicológicos. Da mesma forma como uma criança chora quando tem fome e emite sons de contentamento quando está satisfeita, imagina-se que os artistas primitivos expressem seus sentimentos livres da capa impositiva do comportamento aprendido e das limitações conscientes que moldam o trabalho do artista civilizado." (PRICE, 2000, p. 57)

Não é o nativo que faz a música, a música é que faz o nativo. Enquanto a arte do Ocidente tem um vínculo metalinguístico consigo, é uma arte que sabe que é arte, que desde o começo quis ser o que é, a arte dos trópicos carece desse giro sobre si própria. O nativo

\footnotetext{
49 "A tradição histórica da World Music contrasta radicalmente com a história teleológica da música ocidental - na verdade, do mainstream euro-americano em geral - uma história que passa por desenvolvimentos estilísticos e pela genealogia dos "Grandes Homens", cada um deles passando a tocha da tradição para um sucessor." (BOLHMAN). O que nos remete novamente ao Orientalismo: "A própria possibilidade de desenvolvimento, transformação, movimento humano - no sentido mais profundo da palavra - é negada ao Oriente e ao oriental. Como uma qualidade e, em última análise, imobilizada ou improdutiva, eles vêm a ser identificados com um tipo ruim de eternidade." (SAID, 2013, p. 282).

${ }^{50}$ Sobre o festival WOMAD de Adelaide, Austrália em 1992, Taylor comenta que uma das palavras mais usadas era "sentimento" [feeling]. As músicas tinham muito "sentimento", as letras eram carregadas de "sentimento", nos shows os artistas tocavam com "sentimento", etc. Para o autor, essa ênfase da World Music no lado "sentimental" da música faz parecer que ela não tem nada de "racional". "Os sentimentos presentes e evocados pareciam tão reais, talvez deveriam ser também profundos, ou espirituais" (TAYILOR, 1997, p. 25)
} 
sabe, mas não sabe que sabe, fez, mas não sabe o que fez. Como a arte precisa dessa dobra reflexiva sobre si para ser arte, a música dos outros, ao falhar nessa quesito, ainda não pode ser considerada arte, é uma quase arte, uma arte em potencial. Para que o espetáculo se complete, é preciso que algum ocidental consciente junte as pontas da reta natural da música nativa e feche o círculo da reflexividade artística. Isso coloca o músico estrangeiro em uma posição de dependência em relação ao Ocidente, pois sua arte só será assim considerada depois de ganhar a chancela ocidental.

"Existe uma linha de raciocínio segundo a qual objetos de produção primitiva
não constituem objetos de arte até que conhecedores ocidentais estabeleçam o
seu mérito artístico. (...) O olho discriminante do observador ocidental é
geralmente tratado como se fosse o único meio pelo qual um objeto etnográfico
poderia ser alçado ao status de obra de arte. (...) Conhecedores ocidentais
atribuem a si mesmos a tarefa de interpretar o significado e a significância de
objetos de arte por pessoas que, argumentam eles, estão menos equipadas para
tal. (...) Os membros do mundo ocidental são aqueles que, mais uma vez, por
seu acesso à riqueza material e à comunicação, estão, nas últimas décadas do
século XX, assumindo a responsabilidade de determinar a natureza da produção
artística em praticamente todos os cantos do mundo. (...) Os ocidentais
assumiram a responsabilidade da definição, conservação, interpretação,
comercialização e existência futura das artes mundiais." (PRICE, 2000, pp. 102,
103)

Quarto, considerar a música estrangeira resultado de uma natureza espontânea e não de uma cultura reflexiva é inocentar o Ocidente de qualquer acusação de apropriação ou espoliação colonial. Se a cultura estrangeira é uma natureza, quando pega a música desse lugar e a leva para casa, o Ocidente não está roubando uma obra de arte, mas tirando um fruto do pé, e não há nada de errado nisso. Paul Simon, que formou com Art Garfunkel a maior dupla de música folk dos Estados Unidos, lançou em 1986 Graceland, disco que contou com a contribuição de vários artistas africanos, incluindo o grupo vocal Ladysmith Black Mambazo, que ganhou fama internacional depois do lançamento. Quando acusado de estar explorando aqueles artistas, Simon afirmou que "cultura flui como água" ${ }^{51}$. Se estiver certo, que crime o artista americano cometeu? Ninguém pode ser preso por beber a água de um rio. Inclusive, um dos maiores sucessos do artista é a canção "Bridge Over Trouble Water", que no Brasil ganhou uma versão de Guilherme Arantes intitulada "Rio das Inquietas Água" (sic). Para muitos críticos, o músico de fato se enxerga como uma cartesiana ponte ocidental que nos ajuda a atravessar esse indisciplinado rio caudaloso de músicas selvagens.

\footnotetext{
${ }^{51}$ HERBSTEIN D. "The Hazards of Cultural Deprivation" Africa Report 32 (julho - agosto 1987), 35.
} 
"Ocidentais - incluindo músicos - agora permitem que outros tenham uma cultura, mas uma cultura no sentido antropológico. A cultura ocidental ainda é uma cultura no sentido 'casa de ópera', civilização. Então a intenção retórica/discursiva/imperialista ainda prevalece. Essas culturas de outras pessoas são culturas naturais, e naturalizar culturas significa que ela pode ser tomada. (...) Peter Gabriel pode usar uma gravação de dez anos sem compensar ou creditar os músicos, mas se tentarem fazer o mesmo com a música de Gabriel, eles teriam que pagar direitos autorais. O sucesso da cultura antropológica é meramente semântico" (TAYLOR, 1997, p. 126)

Quinto, como se viu, tudo que apresenta o imediatismo instintivo da natureza é tido como bom, normal e saudável, portanto, qualquer traço da cultura do Outro que fuja dessa estabilidade natural será visto como uma desnaturalização ou como uma antinatureza, consequentemente como uma queda, uma corrupção ou um perigo. O estado de natureza da cultura estrangeira faz dela um todo indiferenciado e imutável; aquilo que escapar a esse padrão será uma nota fora do tom, um relevo mau na planície boa, uma cicatriz cultural na pele da natureza. É dessa noção de que precisa se conformar dentro do paradigma de sua natureza que surge a ideia de que o nativo deve se manter "fiel" ao que é, e não "trair" sua cultura. A culutura-natureza é um bem constante e monolítico, se o nativo mudou é porque abandonou esse terreno sagrado e se degenerou, se contaminou, esqueceu quem era. Mais do que se trair, ele traiu sua cultura-natureza, e pior, traiu o público ocidental e o mediador, comeu o fruto que o dono da gravadora havia proibido, e agora, com o contrato recindido, terá que ganhar o pão com o suor da sua testa, fora do jardim da indústria fonográfica ocidental. Artistas ocidentais que buscam a música estrangeira dão mostras de sua riqueza e versatilidade, mas artistas estrangeiros que se aproximam da música ocidental estão se traindo e perdendo sua cultura. Paul Simon pode se lambuzar à vontade de África, mas um africano desrespeita sua "essência" e "deixa de ser quem ele é" quando liga uma guitarra elétrica. Enfim, os globais podem se etnicizar, mas os étnicos não podem se globalizar. Como tem que se manter fiel a ela, a cultura-natureza não libera o nativo, mas o restringe como um camisa de força. Aquele espaço não é uma ponte que mostra tudo o que ele poderia ser, mas um limite que diz até onde ele pode ir.

O senegaleses Youssou N'Dour teve essa "ousadia" e pagou o preço, saindo de queridinho da World Music para rebelde mal agradecido. Depois de ter gravado com Paul Simon e Peter Gabriel, N'Dour se mudou para Londres e resolveu dar um novo rumo à sua carreira. Michael Brook, seu produtor artístico, descreveu assim a virada do músico: 
"O que é excitante para mim é que a banda está prestes a estabelecer uma música pessoal. Há elementos tradicionais africanos e senegaleses nela, e há também elementos pop, mas parece que eles estão chegando a um novo estágio de maturidade cultural, onde a influência se torna menos importante. Eles são africanos fazendo música, mas você não os classificaria exatamente como Música Africana: é algo completamente novo" 52

A mudança de N'Dour não foi bem recebida por seus fãs, que começaram a achá-lo "ocidental demais". Sobre isso, o artista comentou o seguinte:

"Bem, primeiro minha música foi senegalesa e então se abriu para mostrar o lado da África moderna, das cidades como Dakar e Abidjan. Eu acho que minha música realmente evoluiu. É verdade que para pessoas mais velhas ela perdeu algo, mas em compensação ganhou popularidade com os mais jovens. É a vida. Eu não faço música para essa ou aquela pessoa; eu faço porque sou eu, o que eu sinto. Em Dakar, nós ouvimos muitos discos diferentes. Nós estamos abertos para esses sons. As pessoas que dizem que minha música está muito ocidental precisam lembrar que nós também ouvimos esse tipo de música por aqui. Nós ouvimos a música africana com a moderna. É muito simples, sério. Quando eu era jovem, crescendo em Dakar sem viajar para canto nenhum, minha música tinha uma pegada diferente. Mas quando eu comecei a viajar e a excursionar pela Europa, América e o resto do mundo, obviamente eu comecei a ouvir novos sons e a misturar novas ideias musicais, o que trouxe esse tipo de crítica. Eu não gostaria de me definir, mas eu me vejo de duas maneiras. Uma diz respeito a meu lado africano, a segunda se abre para outras influências e outras culturas" $^{\prime 53}$

N'Dour até hoje é um músico muito prestigiado (inclusive ganhou um Grammy depois de toda essa celeuma), mas na época em que resolveu alçar novos voos, o artista foi duramente criticado por estar "traindo sua essência" e "perdendo suas origens", ou seja, por pisar fora do cercado de cultura-natureza. O crítico Brooke Wentz, fazendo referência a Shaking Tree [árvore que balança], música que N'Dour gravou em parceria com Peter Gabriel, escreveu uma resenha sobre a virada de página do artista intitulada "Youssou N'Dour: ele está balançando a árvore ou a derrubando?"54. Ninguém achou que Simon e Gabriel estavam perdendo sua cultura quando gravaram com N'Dour, mas N'Dour esqueceu suas origens quando se aproximou da música europeia. Por isso, dizem os críticos, a World Music aprisiona o estrangeiro a uma tradição e libera o ocidental para conhecer o mundo, pois o mesmo interesse pela diferença, no primeiro é tido como infidelidade, e no segundo como enriquecimento.

\footnotetext{
${ }^{52}$ CULLMAN, "Wolrd Music's Hope", 174.

${ }^{53}$ Em entrevista para Kwaku.

${ }^{54}$ Rythim Music (maio - junho 1994, 58)
} 
"Gabriel e Simon estão liberados a trabalhar com N'Dour e 'africanizar' suas músicas, mas, ao que parece, N'Dour não pode trabalhar com eles e 'ocidentalizar' sua música. Sua cultua é conceituada por críticos ocidentais como pura, enquanto a deles já foi tocada pelo artifício, voraz por natureza. Uma postura pós-colonial/pós-moderna (sic) permite que N'Dour tenha uma cultura, algo que a ideologia colonialista não fez, mas é uma cultura natural, enquanto a cultura ocidental é uma cultura civilizada, tecnológica, comprometida com desenvolvimento, expansão, progresso e artifício" (TAYLOR, 1997, p. 135)

O verbete da Wikipedia sobre o artista se encerra dizendo que "Youssou N'Dour sempre se manteve fiel às suas origens e continua morando em sua cidade natal." Há muitos músicos ocidentais que moram nas cidades em que nasceram, e tantos outros que se mudaram para outros lugares, mas no caso deles isso não é um indicativo de fidelidade ou de traição, é só a vida que segue.

A mesma coisa aconteceu com Angélique Kidjo, cantora do Benin nascida em 1960, ano em que o país ficou independente da França. Criada em um período em que seu país se abria para o mundo, Kidjo aprendeu várias línguas, conheceu outras culturas e em 1983 se mudou para França, onde estudou jazz, música clássica e canto. Em 1989 lançou seu primeiro disco, Parakou, que não causou grande impacto. A consagração viria dois anos depois com o segundo disco, Logozo, que ficou 47 semanas no catálogo da Billboard. A Mango, divisão da gravadora Island responsável por música do resto do mundo, disse que Kidjo era "a diva africana funk da World Music". O título do disco, que significa "tartaruga", se refere aos franceses: um povo que, segundo a cantora, se esconde dentro de seu casco quando algum estranho se aproxima. Esse retraimento causou muita estranheza em Kidjo, uma filha da independência cosmopolita e curiosa sempre interessada pelo que estava do lado de fora do casco.

Mas, assim como N'Dour, Kidjo quis desbravar novos sons, sons que ela considerava tão seus quanto aqueles de sua terra natal. Investida desse espírito cosmopolita, em 1994 foi lançado Ayé, terceiro álbum da cantora. Entretanto, aquela mudança de direção, que atestaria a inventividade de um músico ocidental, foi recebida como um gesto de traição da artista do Benin. As resenhas, além de cobrarem da cantora maior fidelidade à sua cultura-natureza, ainda sugeriam uma imaturidade, ou até uma falta de reflexividade, da artista, pois, na visão dos críticos, Kidjo estava sendo manipulada por produtores europeus que queria ocidentalizar sua música, e ela teria se deixado enganar, trocando ouro por espelhinhos. Mal sabem esses jornalistas que a iniciativa partiu da 
própria cantora e contrariou a vontade da gravadora. Também erraram aqueles que disseram que Kidjo estava em busca de sons de "outras culturas". De forma alguma: aquela sonoridade pop rock fez parte de sua formação tanto quanto a música tradicional africana, era isso o que tocava nas rádios do Benin independente e na França dos anos 1980, onde a cantora morou. Ao contrário de Simon e Gabriel, que se atiraram para o outro lado do mundo em busca de músicas que nunca tinham ouvido, Kidjo não estava interessada pelo Outro quando fez um som mais pop: aquele estilo também dizia respeito a ela.

Uma crítica da época afirmou:

"A diva funk beninesa mais ou menos dispensou o estilo peculiar de músicas que fez seus últimos CDs, Logozo e particularmente o primeiro, Parakou, interessantes. Em Parakou, as canções vão de faixas dançantes até lamentos à capela e há uma percussão dramática e intrigante muito rica. Em compensação, Ayé é um rock-divertido quadrado, sorrateiramente empacotado por um produtor pop e, de qualquer jeito que você olhe para o disco - não necessariamente com uma lente purista - as canções dele soam menos atraentes" (BROUGHTON et. al., 1994)

O saxofonista americano Branford Masrsalis, que tocou em duas faixas de Logozo, afirmou que produtores ocidentais "estão tentando transformar sua música [de Kidjo] em ocidental. A produção é boa, mas não é ela. Quando os maiores ritmos do mundo estão em seu quintal, porque usar baterias eletrônicas e sequências de bases?" Bom, ninguém perguntou isso para Peter Gabriel quando ele saiu da Inglaterra em busca de música africana.

Em entrevista, Kidjo rebateu as críticas de forma semelhante a N'Dour:

"Não há muita coisa na música africana hoje que seja pura. Nós todos temos maneiras diferentes de expressar nossa música. Há um tipo de racismo cultural acontecendo em que as pessoas pensam que músicos africanos devem fazer um certo tipo de música. Ninguém perguntou a Paul Simon 'Por que você usa músicos africanos negros? Por que não usa americanos? Por que não faz a sua música? O que Paul Simon deveria fazer?' Eu não faço minha música para agradar gente que quer ver algo muito tradicional. A música que eu escrevo sou eu, é como eu me sinto: se você quiser ver música tradicional e exotismo, pegue um avião e vá para África. Eles tocam essas músicas nas ruas. Eu não vou tocar tambores tradicionais e me vestir como gente que mora no mato. Eu não vou mostrar minha bunda para porra de americano nenhum. Se eles quiserem ver isso, vão ter que viajar. Eu não estou aqui para isso. Eu não peço aos americanos que toquem música country. Eu não estou aqui para alimentar as fantasias de ninguém. Se eles querem ver mulheres africanas exóticas, eles vão 
ter que voar para a África; e se não prestarem atenção, quando chegarem lá vão levar um murro na cara." ${ }^{55}$

Insistindo no mesmo caminho, em 1996 Kidjo lançou Fifa, seu quarto álbum. Embora traga músicas em inglês (na verdade, por isso mesmo), esse foi o disco da cantora que menos vendeu nos Estados Unidos. O que nós podemos perceber olhando a trajetória de Kidjo é que quanto mais se distanciou da ideia que os ocidentais faziam da sua cultura, menos ela vendeu: Logozo ficou 47 semanas na lista da Billboard, nove delas em primeiro lugar; Ayé 33, nunca em primeiro, mas 16 semanas em segundo; Fifa aguentou cinco bravas semanas e sumiu sem nunca ter entrado nem nas dez mais.

É difícil tomar partido na briga entre defensores e críticos da World Music olhando para os casos de N'Dour e Kidjo. Os defensores acham que o estilo é um fenômeno da diversidade-global que rompe com o exótico-colonial, insistindo numa rede simétrica de fluxos ao invés de um binômio desequilibrado e apostando nas ideias particulares de multiplicidade, heterogeneidade, hibridismo e relativismo. Já os críticos acreditam que a World Music traz as práticas exótico-coloniais para os nossos dias, reafirmando a velha díade de poder e propagando ideias universais de unidade, homogeneidade, purismo e absolutismo. Vestindo esses enunciados de empiria, pode-se dizer que a grande divergência entre as facções diz respeito ao fato de que os defensores julgam que os mediadores ocidentais revelam passivamente a cultura estrangeira tal como ela é, independente de como ela seja, enquanto os críticos dizem que esses mediadores ativamente instauram uma imagem de como queriam que aquela cultura fosse e aprisionam o Outro nesse paradigma, embora vendam essa narrativa sua como se ela fosse um discurso nativo. Para refutar a crítica de que a World Music amarraria o artista a uma caricatura préfabricada no Ocidente, Ian Anderson, na sua já citada entrevista, afirma que os músicos estrangeiros selecionados pelos mediadores ocidentais (e faz referência especificamente a N'Dour e Kidjo) tem toda a liberdade para fazer o som que bem entenderem, inclusive o prestígio que o estilo lhes trouxe até os respaldaria a dar esse salto. Olhando a biografia de N'Dour e Kidjo somos obrigados a reconhecer que Anderson estava certo: houve um momento da carreira em que os músicos quiseram mudar seu estilo e, de fato, mudaram completamente. Entretanto, desmentindo a ideia de Anderson de que haveria uma equivalência de poder entre mediador e artista, os músicos pagaram um altíssimo preço por

${ }^{55}$ WENTZ. "No Kids Stuff", 43 
seu "atrevimento". É verdade que ambos venceram o Grammy, N'Dour em 2005 e Kidjo em 2008; mas, como falei, entre 2004 e 2011, o Grammy de World Music se bifurcou entre "tradicional" e "contemporâneo", e os artistas foram agraciados com esse segundo, ou seja: foram reconhecidos como World Music, mas como um tipo específico de World Music, distante de suas tradições. Em 2012, como já dito, o prêmio voltou a ser apenas de World Music, e Kidjo venceu nessa categoria em 2015. De fato, a divisão fazia cada vez menos sentido, o Ladysmith Black Mambazo, contemporâneo desses dois artistas, ganhou na categoria tradicional, por exemplo. Ao que tudo indica então, a resposta para nossas perguntas está em um ponto intermediário entre essas duas alternativas extremas. A própria Kidjo, na mesma entrevista em que destila toda a sua raiva contra a exotização que sofre, reconhece que World Music é uma categoria complicada, um faca de dois gumes que, do mesmo jeito que a incomoda, também a sensibiliza.

"Eu gosto de World Music. Ela dá um panorama aberto, sem sectarismo
musical. World Music não é um gênero, como funk ou reggae. Ela é tocada por
músicos que acham que artistas - principalmente os do terceiro mundo, onde a
mídia não se faz tão presente - podem se expressar de uma maneira
contemporânea e original, graças à riqueza de suas culturas. O único perigo do
rótulo World Music é ele te deixar fora do mainstream, porque a importância
dada a essa música no mercado é a mesma que é dada ao terceiro mundo no
tabuleiro da economia global" A opiniões aqui trazidas quase sempre são bastante parciais, pois só olham para metade do problema e por isso se entregam completamente ou a defesa cega ou a crítica incondicional da World Music. Mas nessa passagem Kidjo é bastante sensata, pois deixa as paixões de lado e analisa o problema de forma racional. A artista recusa os extremos e admite que existe uma tensão interna à World Music: através do estilo, o Ocidente aceita a entrada das outras culturas em uma comunidade mundial que antes as excluía, mas, em compensação, uma vez dentro da rede, esses povos estrangeiros são fixados em uma posição periférica do arranjo. Eu deixo você entrar, mas, como você só está entrando porque eu deixei, então me obedeça aqui dentro. Kidjo percebe que a World Music empodera o resto do mundo através do estabelecimento de uma rede múltipla, heterogênea, híbrida e relativa de particularidades, mas, ao mesmo tempo, esse gesto filantrópico viola o estrangeiro, pois é um aceite condicional, por isso ainda há um ruído universal único, homogêneo, puro e absoluto. 
Mas, para os críticos hard-core, por ser indiferenciada, imutável, espontânea, disponível e limitar seus membros, a cultura-natureza do Outro se distingue completamente da cultura ocidental, que não apresenta nenhuma dessas características. Portanto, uma sexta consequência desse tratamento natural que a World Music dá às culturas que tematiza seria uma reafirmação da distância que separa o Ocidente do resto do mundo.

Já que tem uma cultura propriamente cultural, o Ocidente está sempre mudando, avançando, fazendo e se reinventando; e, nessa mitologia, os responsáveis por tais transformações brancas são as pessoas, homens e mulheres de ação com cabeças pensantes que criam, fazem coisas, empurram a história para frente e mudam o mundo. Já as outras culturas, por serem naturais, estão terminadas, na verdade já nasceram prontas, ou melhor, nem nasceram, não foram inventadas, sempre estiveram aí, existindo em sua perenidade. $\mathrm{O}$ natural é a imagem do incriado, do eterno, do matricial e da autossuficiência. Ele não avança, dura em sua eternidade, permanece, é o que é, uma natureza. Além de incriada, a natureza é plana; reina nela um parentesco simpático, uma continuidade xamânica, entre todas as coisas. Tudo se dá ao mesmo tempo e colado, formando uma massa natural sem cortes diferenciais, um bloco de imanência que só entende o imediatismo e a simultaneidade. Nesse mundo nivelado e já pronto, não há espaço para criadores ou inventores, pois tudo já foi feito. O ocidental não pertence ao seu mundo, seu mundo é que pertence a ele, pois ele o inventou. Com o estrangeiro, pensa o ocidental, o oposto se dá: ele não é dono de seu universo, pois esse universo o contém, ele é parte desse cosmos, é só mais uma coisa dentro dele, como os astros e os animais. O ocidental acredita na existência de um hiato entre ele o mundo, tendo ele aparecido antes do mundo, mas em contrapartida crê em uma contiguidade entre o estrangeiro e o contexto no qual ele habita. Eu mudo meu ambiente, e assim marco a diferença entre nós dois; o Outro é mudado pelo seu ambiente, por isso passa a fazer parte dele.

\footnotetext{
"Nas culturas Deles, a natureza e a sociedade, os signos e as coisas são quase que coextensivos. Em nossa cultura, ninguém mais deve poder misturar as preocupações sociais e o acesso às coisas em si." (LATOUR, 2009, p. 99).

"O valor exagerado atribuído à língua árabe permite que o orientalista equipare a linguagem à mente, à sociedade, à história e à natureza. Para o Orientalista, a linguagem fala o oriental árabe, e não vice-versa." (SAID, 2013, p. 428).
} 
A a-historicidade e indiferenciação lisa desse estado de natureza em que o Ocidente atira as culturas estrangeiras exercem um duplo impacto na questão da autoria das músicas compiladas em uma coletânea de World Music. Analisemos as duas características.

A a-historicidade interfere na autoria da seguinte maneira: como as culturas distantes são naturezas em que tudo está terminado, nada precisa ser feito e não há necessidade de inventores, então nem as músicas são criações, nem os compositores são criadores. As músicas, como já se comentou, não são consideradas pelos mediadores como bens simbólicos nascidos do pensamento indígena, mas pedacinhos de natureza que surgem espontaneamente, como frutos de uma árvore, ou, como Paul Simon falou, como uma água corrente. Por consequência, os músicos não podem se proclamar inventores de músicas que, por serem perenes e inconscientes, nunca foram inventadas. Se as músicas não são culturais, criadas e reflexivas, mas naturais, eternas e espontâneas, então os músicos não são inventores ou compositores, e nem mesmo podem dizer que a música lhes pertence. Já que é natureza, então a canção já nasceu pronta e não é de ninguém, por causa disso, o artista não a fez nem a possui, apenas a descobriu e a evidencia. Como não a criou, o mais correto seria dizer que o estrangeiro apenas dá vazão àquela música que sempre existiu, ou seja, ele é um cabide de história, alguém que faz do seu corpo um receptáculo, um instrumento dessa alma tradicional, dessa natureza indistinta que mais o significa do que é significada por ele. Dito de maneira definitiva, o músico nativo não é autor, mas vetor da World Music, ela não é dele, passa por ele, atravessa-o, já vem de antes, e vai para mais muito longe ${ }^{56}$. Conclui-se então que músico e música não são criador e criatura, mas vetor e essência.

"Na compreensão ocidental das coisas, uma obra originada fora das grandes tradições deve ter sido criada por uma personagem sem nome que representa a sua comunidade e cuja arte respeita os ditames de tradições antiquíssimas." (PRICE, 2000, p. 87)

Já a indiferenciação da cultura impacta a autoria pelo seguinte: como a cultura é uma natureza, um todo indivisível e monocromático, a música que o artista-vetor está

\footnotetext{
${ }^{56}$ SongCatchers [algo como "apanhadores de canção"] é uma banda fundada em 1991 que misturava integrantes de Seattle e outros nativo-americanos que já excursionou com Peter Gabriel e se apresentou em mais de um WOMAD. O nome "se refere à crença de algumas tribos, particularmente os Pima do sudoeste, de que a música não é 'composta' no sentido europeu-ocidental do termo, pois ela já existia, só foi capturada ou assimilada pelo músico" (TAYLOR, 1997, p. 184)
} 
veiculando representa toda a cultura, todo esse grande e homogêneo monolito. Aquela canção não é um aspecto da paisagem local, um bem simbólico que, aliado a vários outro elementos, formaria um grande acervo cultural. Não. Como tudo se funde numa cultura nivelada, aquela música encerra todos os aspectos do local, ela é esse local. Ainda que não seja o autor, mas apenas o transmissor da canção, o artista poderia cantar uma faixa que dissesse respeito a algo em específico, a um recorte que, por ser bem delimitado, passaria a pertencê-lo e a ele nos remeteria, mas não. Músicos ocidentais expressam algo tão próprio a eles que parece que aquilo não poderia ser transmitido por mais ninguém, há uma assinatura ali; mas cantores brasileiros cantam o Brasil, pedaços do país saem da sua boca quando ele começa a cantar. Ouvir Paul Simon é ouvir Paul Simon, um artista diferente de todos os outros, mas ouvir Ladysmith Black Mambazo é deixar a África entrar no nosso ouvido. Eu sou eu, mas ele é o Oriente Médio. Há na World Music um arranjo metonímico que faz com que o artista estrangeiro represente toda aquela cultura-natureza indiferenciada. Como bem disse Said, "uma voz se torna uma história inteira" (2013, p. $328)$.

"O indivíduo para se investir de autenticidade, o que legitima sua voz, deve ser percebido como o representante de uma etnia ou cultura; ou melhor, ele deve ser percebido propriamente como uma cultura." (NICOLAU NETTO, 2014, p. 321)

Essa metonímia, assim como aquele traço vetorial, corrói a autoria porque o indivíduo acaba se diluindo nessa tradição que carrega nas costas. Da mesma forma que "o Oriente é o palco sobre o qual todo o leste está confinado e nesse palco aparecerão figuras cujo papel é representar o conjunto maior do qual elas emanam" (SAID, 2013, p. 102), o autor é engolido pela própria cultura ${ }^{57}$. Como falei, aquele mundo não pertence a ele, ele é que pertence ao mundo. Por esse motivo, quando compram um disco de World Music, os fãs do estilo tem mais interesse na região de onde aquela música vem do que no artista propriamente dito: aquele álbum é "da cultura", é de "música brasileira", e não do fulano

\footnotetext{
57 "Em primeiro lugar, a representação se transmuta em uma autorrepresentação, quando esses atores se tornam signos de si mesmos. Em segundo lugar, esses atores, se agora tem suas vozes, antes inaudíveis, percebidas no espaço global, não são condicionados à própria diferença e, portanto, apenas discursam enquanto se mostram atrelados ao índice de diferenciação que o legitimam. Tanto um artista quanto um acadêmico, que antes pouco espaço teriam para suas músicas ou seus textos, hoje o encontram pela valorização da diferença. Mas, para tanto, é necessário que se mantenham fiéis a discursos ligados a essa diferença, de modo que suas vozes se tornam presentes, mas condicionadas. É nessa complexidade que o discurso da diversidade é compreendido." (NICOLAU NETTO, 2014, p. 22)
} 
que está cantando. Tanto é que, no cartão promocional organizado no Empress of Russia, os discos apareciam na ordem alfabética do país do artista, e só depois vinha seu nome e o título do álbum.

"A arte nas sociedades primitivas geralmente tem sido considerada como representando ideias coletivas comunicadas através de modos de expressão coletivamente desenvolvidos. Esta crença é a pedra fundamental no mundo que marca a fronteira entre a arte ocidental e a primitiva. (...) [A arte primitiva] envolve a comunidade como um todo, e não indivíduos selecionados, no processo de expressão artística." (PRICE, 2000. p. 55)

"Cada partícula do Oriente falava de seu caráter oriental, tanto assim que o atributo de ser oriental atropelava todo exemplo contrário. Um homem oriental era primeiro um oriental, e só em segundo lugar um homem." (SAID, 2013, p. 329)

Juntos, os traços vetorial e metonímico do artista estrangeiro reforçam a ideia de que ele deve se manter fiel à cultura-natureza que propaga e resume, mostrando uma obra que espelhe apenas ela e nada mais. Para os críticos da World Music, essa visão de cultura restringe os movimentos do artista indígena e libera a circulação do mediador ocidental, pois, quando se aproximam de outras culturas, o primeiro é taxado de traidor, enquanto o segundo é aplaudido como inventivo.

Há ainda uma terceira característica da World Music que abala a autoria nativa, essa mais recorrente nas coletâneas. Esse traço é o seguinte: como a maioria dessas compilações traz uma variedade de músicos estrangeiros, fica difícil precisar de quem é aquela peça afinal. Cada artista acaba se afogando no mar formado por todos, pois um nome vai puxando o outro para baixo até que todos se nivelam nas profundezes da própria pluralidade.

Como é muito importante para a arte ocidental, a posição do autor não pode nunca ficar vaga. Mas se o nativo é desacreditado como criador da obra, quem é que ocupa esse lugar? Para os críticos da World Music, na falta de um indígena que assine a composição, o mediador ocidental, que teve o trabalho de encontrá-la, acaba assumindo sua autoria. $\mathrm{Na}$ visão desses detratores, o estilo desloca o estrangeiro da condição de autor, insistindo na sua natureza vetorial e metonímica, para depois assumir esse papel, cumprindo assim o arco de imputar os sentidos que media ou, para falar à maneira de Bourdieu, de gerar os significados que classifica. 
Em A Literatura em Perigo, Todorov (2009) diz que os estudos literários nos colégios e nas universidades francesas enfatizam demasiadamente as categorias analíticas internas à teoria literária em detrimento da leitura e da fruição das obras propriamente ditas. Por abraçar o fisiologismo cientificista dos conceitos literários, o ensino francês fecha os olhos para o objeto que essa teoria analisa, a saber, os livros e o mundo humano que eles tematizam. Devido a essa assimetria, na visão do autor, o que ocorre é uma inversão de prioridades pedagógicas, uma vez que as categorias ganham uma prevalência em relação às coisas por elas categorizadas: os princípios de organização e análise das obras passam a ser mais importantes que as obras propriamente ditas, e assim a ferramenta rouba o protagonismo do trabalho que ela deveria estar só auxiliando. Por travarem um duelo armados com a bainha ao invés da espada, os professores franceses acabam dando relevância a um instrumento que tradicionalmente tinha uma função apenas secundária. Como o meio se transforma em um fim, a citação eclipsa a fala, criando um cenário em que se torna mais relevante empreender uma pesquisa oblíqua sobre a coisa do que um estudo direto na coisa propriamente dita. Como o próprio Todorov afirma, o andaime fica mais importante que o prédio; o que em termos práticos quer dizer que a crítica e a teoria literária tomam um lugar antes ocupado pela literatura. Ao analisar esse cenário, o diagnóstico do autor é categórico: faz-se necessário inverter essa relação, colocando a crítica na posição auxiliar que lhe cabia para que os livros e os mundos que eles ensejam voltem a ter a relevância que tinham antes. Para os descontentes com a World Music, esse problema apontado por Todorov ilustra bem o caso do estilo: tradicionalmente, o músico é um autor que protagoniza, e a gravadora ou o descobridor são simples mediadores coadjuvantes, entretanto, assim como ocorre entre literatura e crítica, o protagonismo da autoria está se transferindo do músico para aquele que o lançou. Quando falei das díades massificado/alternativo, reflexivo/lúdico, originário/sincrético, disse que essas características são satélites de composições ocidentais, mas desempenham um papel importante na World Music, pois ao invés de gravitarem em torno dela, deslizam para dentro do conteúdo de cada faixa. Ou seja, o público está mais interessado em uma sistematicidade que deveria ser secundária do que na composição propriamente dita, e como quem sistematiza a World Music é o mediador ocidental, o objeto de interesse dos consumidores é algo forjado pela gravadora ou pelo descobridor mesmo, e não pelo músico. 
Na história da World Music não são raros os exemplos de mediadores que acabaram chamando mais atenção do que os autores estrangeiros por eles lançados. Por exemplo: em 1991, Michael Hart, o já citado baterista da banda americana Greatful Dead, lançou Planet Drum, disco em que o músico aparece tocando com percussionistas de Índia, Nigéria, Brasil e Porto Rico. O álbum foi um sucesso de vendas tão grande que atingiu a primeira posição do catálogo de World Music da Billboard. No Grammy de 1992, concorreram na estreante categoria "World Music" os discos Txai do brasileiro Milton Nascimento, Brazilian Serenata do também brasileiro Dori Caymmi, Este Mundo dos franceses "ciganos" do Gipsy Kings, Amen do malinês Salif Keita, e Planet Drum. Mas quem era o autor de Planet Drum mesmo? Embora seja uma coletânea que reúne percussionistas de várias partes do mundo, apenas o baterista americano do Greatful Dead é creditado como autor da obra. O único nome que aparece na capa do disco, que traz desenhos em traço rupestre da Terra rodeada por animais e homens batendo tambor, é "Michael Hart". Sendo assim, a Academia entendeu que Hart era o autor do álbum, devendo ele, portanto, concorrer ao prêmio. Resultado: Planet Drum venceu o Grammy de World Music daquele ano, e assim, a primeira edição do prêmio criado para prestigiar a produção musical de artistas não-ocidentais ignorados pelos rótulos tradicionais da indústria fonográfica não foi nem para o negro líder do Clube da Esquina agora compondo sobre índios, nem para o filho de Dorival Caymmi que passeou pela Bossa Nova, nem para os franceses que tocam música cigana em espanhol, nem para o malinês albino radicado em Paris que misturava djembê com guitarra elétrica, mas para um roqueiro americano mesmo. Em 1993, o segundo premiado foi o disco Brasileiro de Sergio Mendes, mas depois o cenário voltou a se repetir: Ry Cooder, outro músico americano, venceu o terceiro e o quarto Grammys de World Music, respectivamente em 1994 e 1995. Justiça seja feita, Cooder não ficou com o reconhecimento só para ele: A Meeting by the River, da terceira edição, é creditado a Cooder e ao indiano Vishwa Mohan Bhatt, e Talking Timbuktu, da quarta, é assinado por Cooder e pelo malinês Ali Farka Touré, e nos dois anos o americano subiu ao palco para pegar o prêmio acompanho de seus parceiros estrangeiros.

O caso de Cooder divide opiniões: para os defensores do estilo, a parceria do americano com os estrangeiros atestaria que hoje se vive em um mundo sem fronteiras e igualitário. Sem fronteiras porque no presente culturas diferentes podem se reunir em um mesmo disco, e igualitário porque se antes os centros dominavam as periferias, atualmente 
eles se interessam pela sua produção cultural, e até ajudam a evidenciá-la. Já os críticos da World Music acreditam que esse episódio ratifica os limites e a assimetria do mundo. Os limites se vêem aqui fortalecidos porque, embora reunidas em um mesmo disco, as culturas não se misturam, de modo que essa proximidade atestaria mais sua imiscibilidade do que seu parentesco. Já o desequilíbrio de poder se vê duplamente representado: primeiro porque premiar a parceria entre um americano e músicos estrangeiros é deixar claro que esses artistas de fora jamais teriam seu talento reconhecido se não estivessem acompanhados de um músico ocidental. Se isso for verdade, mais uma vez, a cultura ocidental se firma como chancela de qualidade global, estabelecendo que nada no mundo pode florescer se não tiver seu beneplácito. Embora já fizessem aquele som há muito tempo, Bhatt e Touré só foram ouvidos e premiados depois de receberem a benção de Cooder. O segundo indicador de assimetria de poder está intimamente ligado ao primeiro: como a fama do estrangeiro se deve à boa vontade do ocidental, não é considerado abusivo que esse desfrute de um pouquinho do prestígio que ele mesmo proporcionou àquele. $\mathrm{A}$ música de Bhatt e Touré precisa ser ciceroneada por Cooder para entrar no mercado fonográfico americano e, como pagamento, esse mediador vai aparecer um pouco como autor daquelas músicas que ele apresenta, como uma pequena comissão que o ocidente ganha por ter tido a gentileza de deixar o resto do mundo pisar seu chão abençoado. Por esse motivo, Cooder não estaria apenas mostrando a Índia e o Mali tal como são, mas se apropriando deles, construindo sua carreira musical nos Estados Unidos explorando artistas daqueles países. Ainda que se considere essa tese exagerada, não se pode negar que três dos quatro primeiros Grammys de World Music foram vencidos pelos Estados Unidos, dois deles pelo mesmo americano; quadro no mínimo curioso se lembrarmos que a World Music é uma categoria que nasceu para se referir à músicas não-ocidentais que não cabiam em nenhum rótulo tradicional do Ocidente.

O mesmo se deu com Graceland: embora diversos músicos africanos tenham participado do disco, o único nome que aparece na capa é o do americano que os reuniu, Paul Simon. Em 1987, Graceland ganhou o Grammy de Disco do Ano (o de World Music só foi criado em 1992, como já dito), mérito que é atribuído apenas a Paul Simon. Na edição de abril de 1987 da revista Musician, Cesar Rosas e Louis Perez, da banda Los Lobos, falaram sobre a experiência de trabalhar com (para?) Paul Simon no projeto All Around the World; or, The Myth of Fingerprints: 
"Nós chegamos no estúdio e não havia nenhuma música. Depois de um tempo, começamos a nos sentir como idiotas: 'quando ele vai mostras as músicas?'... Nós esperávamos que ele tivesse uma música pronta para interpretarmos quando encontrássemos com ele em Los Angeles, mas ele disse 'vocês aí, só toquem' e a gente disse 'tocar o que?'. Nós só arranhamos qualquer coisa e disso ele tirou uma música, e foi isso... Nós nos sentimos um pouco alienados da obra final; nós não tivemos nenhum envolvimento real naquilo."

O depoimento do Los Lobos ratifica o argumento de Feld de que Simon usa os músicos estrangeiros apenas como "trabalhadores braçais" (2005b, p. 242). Rhythmatist seguiu o mesmo caminho: uma reunião de músicos não-ocidentais assinada pelo músico ocidental que os reuniu, Stewart Copeland, único nome e único rosto na capa.

"Em Rhythmatist, como é comum nesse tipo de álbum, nenhum músico é creditado pelo nome, exceto os ocidentais (ou não-ocidentais famosos); músicos africanos são creditados apenas com o nome das suas tribos. A capa do álbum diz 'Todas as músicas compostas por Stewart Copeland'." (FRITH, 2014, p. 310)

O mesmo ocorre com as coletâneas organizadas por gravadoras de World Music: cada faixa é de um músico estrangeiro diferente, mas quem assina a compilação é a gravadora ocidental que os arregimentou.

No debate para saber se a World Music dá poderes ao músico ou chupa seu sangue, os defensores do estilo sempre fazem referência à questão econômica para provar a tese do empoderamento e refutar a do vampirismo. De fato, se olharmos para o aspecto estritamente financeiro do negócio, veremos que a World Music é o que se chama de um ganha-ganha: é bom para os músicos e para os mediadores. Nenhum artista assinou contrato com uma major e saiu de lá pobre, e Paul Simon e Peter Gabriel nunca roubaram dinheiro de ninguém. Entretanto, se recusarmos o filtro financeiro e olharmos a balança ajuda/apropriação pelo prisma da autoria, aí o jogo já não parecerá mais tão equilibrado assim. Os estrangeiros são muito bem pagos por suas parcerias com ocidentais, e também ganham bastante reconhecimento. Mas quem é o centro das atenções? Quem assina o trabalho? É verdade que, se não fosse Paul Simon, hoje o Ladysmith Black Mambazo ainda seria uma desconhecida banda africana perdida em sua terra natal; mas, vale perguntar: o que seria hoje Paul Simon se não fosse o Ladysmith Black Mambazo? Certamente estaria em melhores lençóis que a banda, mas seria um dos maiores artistas da segunda metade do século XX, famoso por sua versatilidade e inquietação musical? Teria ganho o Grammy na categoria Disco do Ano "sozinho"? Para os que acreditam que toda a 
sua fama se deve aos anos de parceria com Art Garfunkel, cabe a pergunta: por onde anda Art Garfunkel? Enfim, olhando para a questão do poder pelo aspecto da autoria e da fama ao invés do financeiro, a World Music não parece um universo tão justo. E mesmo se nos prendermos à questão monetária, retomando o que já se falou antes, se o Ocidente está em posição de mandar dinheiro para o resto do mundo sem que o contrário seja possível, então é porque, de fato, as balança global não está muito equilibrada. Além de tudo isso, é preciso reconhecer que essa divisão entre fama e dinheiro é completamente ilusória, pois fama é dinheiro; não só subjetivamente falando, mas contratualmente também: refiro-me aqui à questão dos direitos autorais. Essa pesquisa não entrou nessas tecnicalidades jurídicas (até porque as gravadoras são muito lacônicas nesse ponto), mas os iniciados na investigação em World Music dizem que os ocidentais quase sempre são os donos desses direitos. Especificamente sobre Simon, Feld afirma que o artista cultiva profundo respeito pelo música não-ocidental, o que se reflete no pagamento generoso que faz a esses músicos. Entretanto, o americano assina sozinho todos os projetos feitos em parceria, e o copyright desses trabalhos também é todo dele. Os valores não estão disponíveis, mas eu não duvidaria que Simon tenha pago "informalmente" aos músicos um montante equivalente ao que ele ganhou com os direitos autorais da obra, no entanto, desses direitos e dessa assinatura ele não abre mão. Ao que tudo indica, na lógica da World Music, mais vale o velho ditado "é melhor dar dinheiro do que dar intimidade".

"Artistas pop de elite se encontram na melhor posição artística e econômica do mundo para se apropriar do que os apetece na diversidade da música humana, com todo o apoio das gravadoras e até com a completa gratidão do músico cujo trabalho agora aparecerá sob um novo nome" FELD, 2005b, p. 245)

Em todos esses casos, os críticos do estilo identificam uma mesma tendência: ocidentais que desempenham o trabalho secundário de organizar a produção de músicos não-ocidentais, esse sim os verdadeiros protagonistas, acabam tendo mais evidência que esses estrangeiros que supostamente deveriam estar divulgando. Toda vez que se dedicam a passivamente reunir elementos indígenas tais como são, os ocidentais terminam ativamente construindo esses traços culturais tal como acreditam que eles sejam, embora os ofertem a seu público como se aqueles fossem discursos nativos.

Esse debate para saber se a World Music espelha o estrangeiro tal como é ou o inventa tal como gostaria que ele fosse é o lado empírico do nosso problema teórico. Pois, 
no fundo, o estilo é um encontro do Ocidente (representado pelos mediadores individuais e pelas as gravadoras) com o resto do mundo (os músicos de fora). Caso se limite a passivamente mostrar as culturas estrangeiras tais como são, a World Music representa um transferência de poder do Ocidente para o resto do mundo, pois se antes a Europa representava o Outro, hoje, ao que tudo indica, o Outro conquistou o direito de representar a si mesmo. Se isso estiver em curso, então a World Music evidencia um mundo marcado pelas ideias particulares de multiplicidade, heterogeneidade, hibridismo e relativismo, pois, como cada cultura que os mediadores revelam se afirma de uma maneira diferente da outra, o todo que compõem é um arranjo plural e multifacetário. Nesse cenário, as formas do período exótico-colonial do mercado da diferença que atravessaram o filtro da igualdade se renderam aos conteúdos particulares da diversidade-global, estabelecendo entre as duas metades desse mercado uma relação de ruptura. Mas se o estilo se dedica a ativamente construir essas culturas de fora tal como acredita que elas sejam, então o Ocidente continua monopolizando o poder, pois, assim como no passado, ele representa tanto a si mesmo quanto aos outros. Da mesma forma, já que a imagem de todas as culturas, por mais que sejam vendidas como autoimagens, foi silenciosamente forjada pelas mesmas mãos ocidentais, então uma única assinatura se imprime em todos as particularidades da Terra, aproximando-as, nivelando-as, de modo que o mundo erigido pela World Music só pode ser uma arena universal tomada pelo único, o homogêneo, o puro e o absoluto. Nesse cenário, as formas do exótico-colonial que passaram pelo filtro da igualdade estrangularam os conteúdos da diversidade-global, fazendo com que os dois períodos desse mercado mantenham uma relação de continuidade.

"Elas [as coletâneas] ilustram algum tipo igualdade partilhada por pesquisador de campo e nativo? Será que o dispositivo de gravação que os separa nos garante autenticidade? O que a presença de uma mediação tecnológica nos diz sobre o 'campo' em que esse encontro etnográfico aconteceu? Nós estamos testemunhando uma transferência de propriedade, do músico para a gravação e transcrição? Finalmente, não seria esse um caso claro de distribuição desigual de poder, em outras palavras, não estaríamos aqui vendo o uso de meios tecnológicos de representação que tiram o nativo da musica para que ela seja apreciada, estudada e consumida por aqueles que não tem a música mas tem a tecnologia de possuí-la? (...) O que acontece quando uma transcrição ou uma gravação da música de alguém impressa ou em disco como World Music? Quem ganha poder com o ato de representar? Quem perde? (BOHLMAN, 2002, p. 25) 
No extremo que acredita que a World Music promove a emancipação e a pluralização do mundo estão os próprios mediadores ocidentais envolvidos no estilo. Já na ponta que considera o rótulo uma estratégia de apropriação e ocidentalização da Terra se situam críticos como Erlmann. Revisitando o pós-moderno, o autor acredita que a World Music seja não só um estilo musical, mas uma estética contemporânea do global, autonomizada de qualquer referente. Mesmo que pareça se mediar com uma empiria (o mundo não-ocidental), essa estética cortou raízes com esse significante e hoje paira independente sobre a Terra, assumindo a forma que quiser, sem espelhar nenhuma essência. Para o autor, a World Music é um sistema classificatório que, por tentar classificar algo inclassificável, se distanciou de qualquer lógica de classificação, e assim descobriu que sua razão de ser não era o objeto a ser classificado, mas a própria vontade intransitiva de classificar. Em outras palavra: para Erlmann, a World Music não passa de uma superfície autorreferente, um sentido único que não anuncia nada a não ser a si mesmo, uma máquina petrificada que gira sem sair do canto cuja única função de existência é se perpetuar.

"Meu argumento parte da hipótese de que World Music é mais que um novo estilo, mais que uma prateleira nas lojas de disco. World Music é uma nova estética da imaginação global, uma maneira emergente de capturar o momento histórico presente e a reconfiguração total do espaço e da identidade cultural que caracterizam sociedades ao redor do globo." (ERLMANN, 1996, p. 468)

"World Music, então, não é a música do 'mundo não-ocidental' (...). Ao invés disso, World Music parece ser a figura estética mais próxima daquilo que Baudrillard chamou de 'estágio fractal do valor', um momento histórico em que o valor não depende mais do uso natural do mundo, nem de uma lógica de troca de bens ou de uma rede estrutural de sentidos. Valor, no estágio viral, se desenvolve da pura contiguidade, da proliferação cancerosa de valores sem nenhuma referência a qualquer ponto que seja. Nesse estágio, as forças e processos de produção cultural se vêem dispersas e desenraizadas de qualquer tempo ou lugar em particular, mesmo que 'tradição local' e 'autenticidade' sejam o foco dos produtos do entretenimento global. Por esse prisma, World Music parece ser o horizonte sonoro de um universo que, por detrás de toda essa retórica de 'raiz', esqueceu suas origens." (ERLMANN, 1996, p. 475)

Portanto, para o autor, as imagens do estrangeiro que o estilo suscita não estão em sintonia com esse estranho que tematizam, mas apenas consigo mesmas. Já que só dialoga consigo e não com o Outro que retrata, então essa estética não reproduz o nativo tal como ele é, mas o inventa como acredita que ele seja. Dada essa estrutura autocontida da World Music, para Erlmann o estilo não leva o Ocidente para fora de si, mas o fixa dentro dele mesmo. 
De modo que essa aparente busca pelo Outro no fim das contas se revela um reencontro do Ocidente com sua própria natureza. Assim como o Orientalismo, a construção do Outro operada pela World Music tem por função ratificar as idiossincrasias do Eu. Elabora-se uma alteridade que seja o simétrico invertido do que somos para que esse negativo se contraste conosco e saliente nossa especificidade. Assim como um pau de selfie, que se distancia de nós para captar nossa melhor imagem, a World Music se afastaria do centro apenas para emoldurá-lo ${ }^{58}$.

"Se, como eu argumento, a World Music representa uma tentativa do Ocidente de remodelar sua imagem localizando-se e se diversificando através de uma associação com uma alteridade, uma análise séria da música global só pode ser escrita de uma posição de sujeito ocidental." (ERLMANN, 1996, p. 474)

Todavia, entre os que acham que a World Music é um mergulho no Outro, como os donos das gravadoras, e os que dizem que o estilo é uma âncora no Eu, como Erlmann, há algumas propostas intermediárias, mais preocupadas com o problema dos índices, que podem ser úteis para desatarmos esse nó.

Uma delas é a de Frith. Para o autor, a World Music não simplesmente leva o ocidental para fora, nem apenas o fixa dentro, mas promove um turismo, ou seja, leva-o para passear pelo resto do mundo, mantendo a promessa de que depois ele será entregue seguro na porta de casa. Opinião corroborada por Nicolau Netto, para quem a World Music "permite que a definição do local [estrangeiro] não se dê simplesmente por suas relações endógenas, mas também pelo condicionamento ligado à experiência da casa". (NICOLAU NETTO, 2014 p. 262).

"A pessoa que visita um festival, um museu etnográfico ou ouve um disco o faz da posição de um turista; ao contrário do etnógrafo que leva sua casa para outro lugar (...) e ali permanece, a casa do turista é mantida intacta, para onde ele sempre retorna após curtos períodos fora, quando manteve uma relação regulada e ponderada com o outro. Dessa forma, o consumidor de World Music está atrás

\footnotetext{
${ }^{58}$ Opinião corroborada por Born, "Talvez seja um truísmo pontuar que esses compositores modernistas e pós-modernistas que recorrem ou fazem referência a outros estilos (não-ocidental, folk, ou popular urbano) não estão produzindo essa música, mas se utilizando dela para enriquecer seu próprio paradigma de composição. Eles estão transformando essa música ao incorporá-la à sua própria estética: apropriando-a e representando-a. Ao fazer isso, eles não intentam apenas evocar essa música do outro, mas criar uma distância em relação a ela e transcendê-la. O que se deve descobrir é se a estrutura de representação do outro constrói um relação desigual entre sujeito estético (o compositor, e depois o público) e objeto (a música ou cultura sendo representada); isso é, se essa relação de representação musical deve inevitavelmente envolver a tentativa estética e discursiva de subsumir e controlar o outro." (BORN, 2014, p. 16)
} 
de uma diferença que não negue ou desmonte a familiaridade do lar e que, portanto, tenha nessa familiaridade sua referência; a diferença (...) deve ser calibrada a partir da casa, sendo tal progresso empreendido especialmente pelas instâncias como museus, festivais e selos de World Music. Passa-se aqui algo como um suplemento à casa, segundo o qual a experiência turística deve reproduzir a casa, acrescentando algo de diferente nela, mas controlado." (NICOLAU NETTO, 2014, p. 261)

Dessas teorias sobre World Music que recusam os extremos da crítica irrefletida ou do elogio cego - ou seja, que não acreditam nem que o estilo apenas se comprometa com o Outro, espelhe-o passivamente tal como é, transfira poder para ele e promova as ideias particulares de multiplicidade, heterogeneidade, hibridismo e relativismo, nem que seja fiel só ao $\mathrm{Eu}$, crie o Outro tal como acredita que ele seja, monopolize o poder e gere efeitos universais de unidade, homogeneidade, purismo e absolutismo - a proposta que me parece mais interessante é a de Kassabian (2005) ${ }^{59}$. Assim como Frith e Nicolau Netto, a autora também considera a World Music uma forma de turismo que põe em diálogo o doméstico e o estrangeiro, mas sua teoria traz um insight valioso. Analisando especificamente a Putumayo, uma gravadora nova-iorquina de coletâneas de World Music, Kassabian estabelece uma diferença entre "turismo pós-moderno" e "turismo distributivo". Enquanto o primeiro dilui as noções de "aqui" e "lá", o segundo ratifica essas ontologias e as aproxima, promovendo uma viagem quântica em que se pode estar simultaneamente tanto "aqui" quanto "lá". O objetivo do turismo distributivo em juntar o "aqui" e o "lá" não é apagar suas fronteiras e fundi-los em um mesmo corpo contínuo, mas justamente reafirmar a separação das duas metades ao deixar mais evidente a assimetria de suas silhuetas. Ao reconhecer que as duas partes são conectáveis, o turismo distributivo confirma que elas não são uma só.

"O turismo distributivo que a Putumayo vende, no entanto, oferece um efeito quântico: envolvimento [entanglement]. Assim como o gato de Schrödinger está simultaneamente vivo e morto, e a luz é tanto uma partícula quanto uma onda, então também eu, como ouvinte da Putumayo, estou tanto aqui quanto lá, onde quer que 'lá' possa ser. Enquanto muitos autores do pós-moderno alegam que a distinção entre 'aqui' e 'lá' ruiu e não significa mais nada, eu argumento exatamente o contrário. Por ser uma atividade cultural pós-moderna, o turismo distributivo precisa que a diferença entre 'aqui' e 'lá' seja mantida para que seja possível habitar simultaneamente os dois espaços. (...) A metáfora das subjetividades distributivas oferece a possibilidade do que eu anteriormente chamei de efeito quântico. Se eu sou um nó denso em uma rede rugosa, eu estou de fato tanto aqui quanto lá ao mesmo tempo. Não sem-espaço, mas em dois espaços envolvidos [entangled]. Eu considero isso a pedra de toque da

\footnotetext{
${ }^{59}$ Agradeço ao professor Anderson da Mata pela sugestão desse artigo.
} 
Putumayo. A arte das capas de Heindl [artista plástica que ilustra as capas das coletâneas da gravadora], sua engenharia e a escolha da ordem das faixas nos guiam através de um aparente reconhecimento naïf para um senso de estar 'aqui/lá' [t/here]". (KASSABIAN, 2005, p. 219)

Até aqui não há muita novidade em relação a Firth e Nicolau Netto: as três teorias recusam os extremos do estudo da World Music; para eles, o estilo nem só se filia ao Outro, à mediação, à liberdade e às ideias particulares, mas também não é totalmente fiel ao Eu, à imputação, ao controle e às ideias universais. Ao invés desse maniqueísmo, os autores adotam a saída intermediária do turismo, postulando que a World Music sintoniza essas duas metades. Usando a gramática dos autores: contra a dualidade permanecer/ir, sugere-se a saída intermediária do turismo, que une os dois movimentos. Mas, embora os três turismos aproximem os dois extremos, há uma diferença básica entre eles: no caso de Frith e Nicolau Netto, a casa e o exterior são dois espaços extremos ligados pela World Music, que funciona como um veículo que tira o ocidental de casa, leva para o exterior, depois o deixa em casa novamente, costurando os dois lugares com a linha do seu rastro. No caso de Kassabian, nem a casa e o exterior são dois espaços, nem a World Music é uma nave que os liga com seu itinerário. Para a autora, a própria World Music é um terceiro espaço intermediário que reúne em si as experiências extremas da casa e do exterior. Dito de outro modo, enquanto no primeiro caso há dois espaços unidos por uma temporalidade, no segundo há duas temporalidades unidas por um espaço. Em Frith e Nicolau Netto, a casa e o exterior são lugares conectados pelo elo temporal da World Music. O turista estava em casa, o estilo o trouxe para o exterior, depois o devolveu para casa. $\mathrm{O}$ fato de ter estado em casa no passado e a promessa de voltar para lá no futuro colocam essa metade ocidental do mundo em contato com a banda não-ocidental onde ele está agora. Em Kassabian, a casa e o exterior são dois tempos unidos pelo espaço da World Music. O turista vai para ela e vivencia essas duas dimensões simultaneamente.

O doméstico é seguro, mas monótono; o mundo é excitante, mas perigoso. A World Music cruza os dois, aproveitando o melhor de cada lado: no cerne do estilo, a segurança doméstica acaba com o risco do mundo e a excitação do mundo corta a monotonia doméstica, criando-se assim o equilíbrio perfeito entre segurança e excitação, como uma lua de mel no útero materno. 
Analisando o consumo de moda brasileira na França - objeto esse que, ao lado do turismo e da World Music, forma uma espécie de triunvirato do período da diversidadeglobal do mercado da diferença - Leitão (2013) chega a uma conclusão semelhante a de Kassabian. De acordo com a autora, para que seja vendida como estrangeira, a peça não pode nem ser familiar demais, pois se confundiria com algo doméstico, nem muito estranha, porque nesse caso a referência ao Brasil não será percebida. Sendo assim, o lugar ideal da diferença é um ponto equidistante entre perto e longe, posição que reúne o nacional e o estrangeiro ao evocar uma imagem já conhecida do desconhecido.

"O exótico está sempre situado, não no absoluto desconhecimento, mas na tensão entre conhecido e desconhecido, entre próximo e distante. Aquilo que é estranho demais ou absolutamente desconhecido dificilmente poderá ser fonte de exotismo já que, para que a elaboração de representações a respeito do outro aconteça, são necessárias pistas mínimas que conduzam o pensamento." (LEITÃ̃, 2007. p. 213).

Seja unindo dois espaços com uma temporalidade ou duas temporalidades com um espaço, o que as análises de Frith, Nicolau Netto e Kassabian sobre World Music (e de Leitão sobre moda) têm em comum é que todas são propostas de síntese entre dois diagnósticos extremos. Juntando aqui o glossário do problema e do objeto, pode-se perceber esses dois diagnósticos extremos acerca desse fenômeno da indústria cultural: o primeiro diagnóstico acredita que as formas do período exótico-colonial do mercado da diferença que passaram pelo filtro da igualdade engoliram os conteúdos da diversidadeglobal, fazendo do presente um tempo igual ao passado, ou seja, uma era binomial em que um lado do mundo domina o outro e propaga as ideias universais de unidade, homogeneidade, pureza e absolutismo. Para essa corrente, a relação entre os dois períodos do mercado da diferença é de continuidade. Os que se filiam a esse pensamento acreditam que a World Music diz respeito apenas ao Ocidente, que através do estilo concentra poder e ativamente inventa o estrangeiro tal como acredita que ele deveria ser, embora venda seu produto como se ele fosse um discurso nativo. O segundo diagnóstico acredita que as formas do período exótico-colonial do mercado da diferença que passaram pelo filtro da igualdade foram neutralizadas pelos conteúdos da diversidade-global, fazendo do presente o inverso do passado, quer dizer, um mundo equilibrado e pacífico em que ideias particulares de multiplicidade, heterogeneidade, hibridismo e relativismo são defendidas. Para essa escola, a relação entre os dois períodos do mercado da diferença é de ruptura. De acordo com esses autores, a World Music é uma abertura para o mundo não-ocidental, que 
assim se vê empoderado e capaz de se autoafirmar pela World Music, que passivamente mostra essa imagem nativa tal como ela é.

As propostas de síntese de Frith, Nicolau Netto e Kassabian recusam o maniqueísmo dessa díade, e entre os dois polos desse par inscrevem um terceiro diagnóstico que agrega elementos de ambos. Já que sintetiza traços de duas leituras opostas, esse diagnóstico intermediário é tenso, complexo. Para ele, o lugar da World Music não é nem aqui nem lá, mas uma zona intersticial no meio dessas duas, que articula esses polos. Ela equilibra o conhecido e o desconhecido, o doméstico e o estrangeiro, o Eu e o Outro, como falou Taylor, "Você (quase) já ouviu isso antes, mas você nunca ouviu nada como isso antes" (TAYLOR, 1997, p. 28). Por oscilar nesse tênue terceiro espaço intermediário, pode-se dizer que o lugar da World Music é a ambivalência.

Essa palavra apareceu em dois momentos da dissertação, para se referir a dois usos diferentes do espaço intersticial entre o Ocidente e seus Outros. Primeiro para designar a ambivalência metafórica de captura do período exótico-colonial, ou seja, a ambivalência do Orientalismo acionada pelo Eu para fixar o Outro, que gera efeitos universais de unidade, homogeneidade, pureza e absolutismo. Depois, o conceito foi usado para a ambivalência catacrética de redenção do período da diversidade-global, quer dizer, a ambivalência de Homi Bhabha, acionada pelo Outro para se emancipar do Eu, criando ondas particulares de multiplicidade, heterogeneidade, hibridismo e relativismo.

Mas qual dessas duas é a ambivalência acionada pela World Music? Ou seja, quem manda no terceiro espaço intersticial ambivalente da World Music? Seria o Eu ocidental, que usaria uma metáfora exótica-colonial para prender o Outro não-ocidental; ou seria esse Outro não-ocidental, que se libertaria do Eu através de uma catacrese da diversidadeglobal?

De qual período é a ambivalência acionada? Quem é o dono do terceiro espaço? Quem é o dono da World Music?

Por ser um fenômeno que aparece nos dois períodos do mercado da diferença, a ambivalência se mostra um bom parâmetro para compará-los. Se observarmos de que maneira o fenômeno se manifesta na World Music, como uma régua ou um grupo-controle, podemos dizer se ela está mais próxima dos sentidos do primeiro período do mercado da 
diferença ou do segundo. A partir daí poderemos ver o que desapareceu e o que ficou de um período para o outro, enfim, poderemos saber quais as continuidades e rupturas entre os dois períodos do mercado da diferença. A ambivalência é o termo marcador da diferença nos dois períodos desse mercado, sendo portanto um conceito que causa diferença. Ela foi o parâmetro a partir do qual a diferença foi buscada tanto no passado quanto no presente: aquilo é ambivalente é diferente. Desse modo, deve-se admitir que a ambivalência é a resposta para a nossa pergunta zero, quer dizer, é o índice a partir do qual responderemos as outras perguntas. É o que será feito na conclusão. 


\section{Conclusão}

\section{Duas ambivalências ambivalentes}

Recorri a Gregory Bateson para poder iniciar esse texto. Agora, chegado o final do percurso, volto ao autor para tentar fechar meu argumento.

Falando de maneira abrangente, Bateson quer entender como se conciliam duas ideias aparentemente opostas: permanência e mudança. No seio das sociedades, esses conceitos teóricos se traduzem empiricamente como coesão e evolução. A coesão dos indivíduos e das diferentes esferas de uma sociedade diz respeito à sua permanência, ou seja, àquilo que fica, que dura cristalizado. Para se manter coesa, a sociedade precisa resistir à ação do tempo, e quem sabe até negá-lo. Já a evolução se relaciona com a mudança, com um projeto de mutação comprometido com a variância e o movimento. Como pode então uma sociedade desejar simultaneamente a permanência coesiva e a mudança evolutiva, essas duas forças contrárias?

Essas vontades aparentemente imiscíveis que as sociedades tentam conciliar não têm nada a ver com "passado" e "futuro" ou "tradição" e "modernidade". Não se tem aqui um conflito geracional entre dois períodos do fluxo, mas, o problema muito mais sério de promover um fluxo sem ser completamente arrastado por ele. Por permanência coesa e mudança evolutiva Bateson entende, respectivamente, a tensão entre a harmonia sistêmica do funcionamento da sociedade e o seu desenvolvimento. Os elos de solidariedade sistêmicos e funcionais que ligam as partes da sociedade garantem a permanência coesa, mas atrapalham a mudança evolutiva. Já o desenvolvimento e a variância promovem essa mudança evolutiva, mas ameaçam a permanência coesa. Sendo assim, esses laços devem ser sólidos o bastante para unir a sociedade, mas não a ponto de petrificá-la; da mesma forma, a torrente do progresso precisa ser forte o suficiente para empurrar a sociedade para frente, mas tendo o cuidado de não desatar seus nós. Há que se achar a balança perfeita entre a dureza dos vínculos e a vazão do fluxo. Equilibradas a permanência coesiva e a mutação evolutiva, a sociedade se padroniza e melhora, ou seja, funciona e se desenvolve: dogmas da vida comunitária ostentados tanto no sermão de tios Iatmul quanto na bandeira brasileira. Mas como chegar ao equilíbrio desses opostos? 
Ora, ideias opostas nunca deixarão de ser opostas. O que é inversamente proporcional, inversamente proporcional é. Já que antinomias não podem ser apagadas, então a saída para conciliar forças conflitantes não é fazer que parem de conflitar para que se conciliem, mas que se conciliem ainda se conflitando. Os vetores não devem parar de brigar e começar a se fortalecer, mas se fortalecer reciprocamente através da briga. A rivalidade não deixa de ser rivalidade e se transforma em companheirismo, o companheirismo é que se funda na rivalidade, e vice-versa. Ideias concorrentes se aliam, e ao invés de formar um paradoxo, esse cenário enseja um paradigma, pois as forças não concorrem apesar de se aliarem ou se aliam apesar de concorrerem, mas fazem uma coisa porque fazem a outra: o equilíbrio tenso ou a tensão equilibrada entre sua concorrência e sua aliança permitem que o arranjo dure e progrida. Assim, tal modelo garante tanto a união quanto o desenvolvimento da configuração, ou seja, tanto a permanência coesiva quanto a mudança evolutiva, até porque "o próprio funcionamento da sociedade tem algo de evolutivo" (GEIGER, 2008, p. 32). À noção capaz de juntar forças disjuntivas que promovem a manutenção e o desenvolvimento de uma sociedade, Bateson dá o nome de Cismogênese: a "criação da separação" (2008).

"Bateson adota uma perspectiva sincrônica e dinâmica, em que a integração da
sociedade é determinado estado de equilíbrio entre tendências agregadoras e
desagregadoras (ou, melhor: em que efeitos potencialmente desagregadores da
recorrência de certos elementos de coesão são contrabalançados por vínculos
transversais, desagregadores das cristalizações daqueles). A isso está ligada a
noção de cismogênese. (...) [Cismogênese] traz a ideia de que integridade e
ruptura não são distintos e opostos, mas faces do mesmo processo e que não
existem por si mesmas, mas em contexto - rupturas podem ser reequilíbrio em
outro plano; estabilidade pode estar associada a variações." (GEIGER, 2008, pp.
34, 35)
"Ordem e desordem não são estados ou condições da matéria, mas
classificações dela. Coesão ou desagregação são feitas dos mesmos elementos,
são determinadas disposições dos processos vitais, sociais ou mentais."
(GEIGER, 2008, p. 52)

Uma sociedade que se funda cruzando narrativas disruptivas, como permanência coesiva e mudança evolutiva, deve cultivar relações de mesma natureza entre seus indivíduos, e é exatamente assim que os Iatmul se relacionam: por ciclos cumulativos de sucessões de rupturas. A relação entre duas pessoas se funda no corte, é ele que as enlaça. A dimensão cíclica da cismogênese é muito importante, porque a natureza cumulativa do circuito permite tanto a solidez quanto a mudança. O próprio autor define o mecanismo 
como "um processo de diferenciação nas normas de comportamento individual, resultante da interação cumulativa dos indivíduos", um "estudo das reações dos indivíduos às reações dos indivíduos" (BATESON, 2008, p.223).

O ciclo cismogênico trabalha assim: um indivíduo exibe um comportamento para outro; esse outro devolve um comportamento para o primeiro baseado naquela conduta que ele anteriormente mostrou; na tréplica do primeiro estarão contidas tanto seu gesto inicial quanto a réplica do segundo, e tudo isso será levado em consideração quando a bola voltar para o outro, e assim infinitamente. Ou seja: na cismogênese, cada novo enunciado traz em seu bojo todos os anteriores. Cada revolução do sistema carrega todas as precedentes e mais aquela nova. Os momentos passados da interação não passaram, pois se inscrevem no momento presente, fazendo com que a interação vá engordando de si mesma.

"Quando nossa disciplina é definida em termos das reações de um indivíduo às reações de outros indivíduos, torna-se imediatamente evidente que precisamos considerar a relação entre dois indivíduos como passível de alterar-se no tempo, mesmo na ausência de perturbações externas. Temos não apenas de considerar as reações de $\mathrm{A}$ ao comportamento de $\mathrm{B}$, mas ir adiante e considerar como estas afetam o comportamento posterior de B e o efeito disso sobre A." (BATESON, 2008, p. 223)

Vê-se aqui como a dimensão cíclica da cismogênese garante permanência coesiva e mudança evolutiva: nenhuma volta da máquina é uma mera repetição do que já passou, mas também não é um momento completamente inédito. Já que cada ciclo carrega os anteriores e acrescenta um novo, essa memória dos antigos garante a permanência coesiva do sistema, enquanto a novidade recém-chegada promove a mudança evolutiva. Como a maioria das díades analíticas mostradas nesse texto, essa divisão é apenas discursiva, porque no objeto elas são uma coisa só: a nova contribuição que enseja o progresso nada mais é que o amálgama das revoluções passadas encarregadas da fixidez. A cismogênese funciona como um dínamo de um motor que acumula energia a cada nova volta: quando estava acontecendo, aquela revolução era um momento-diferença que amontoava todas os outras em um processo-igual, mas sempre vem mais um corte diferenciante que atira aquele anterior na pilha de igualdades para onde ele próprio irá em breve. Cada novo comportamento é diferente dos precedentes porque, à luz dele, todos os passados foram iguais, mas quando mais um chega, aquele desempenho que se acreditava um talhe diferenciante passa a se acumular na memória indiferenciada, e é esse último que vai se enxergar como diferente, até que um próximo apareça no instante seguinte. Sucedendo-se, 
as rupturas geram continuidade, mas uma continuidade de rupturas: cada momento do circuito chega para interrompê-lo, mas imediatamente outro aporta investido da mesma missão, de maneira que cada novo corte promove a continuidade do que o antecedeu, que foram outros cortes, tornados linha pelo que acabou de aparecer. Há uma série de rasgos chegando sem parar, e o recém-chegado - que sempre pensa que é o último, mas nunca é transforma os hiatos diferenciantes que o precederam em uma pátina indiferenciada. O que cria um acervo homogêneo são as sucessivas alterações heterogêneas. Esse entrelaçamento de cortes ou vínculo de separações gera um padrão, mas um padrão de mudanças. A serialidade das cisões forja uma superfície, e assim o modelo não cessa nunca, porque cessa sempre. Uma fenda vai sendo colocada atrás da outra, formando um ladrilho de faltas. Tudo segue interrompendo-se, novidade atrás de novidade, promovendo memória, diferença atrás de diferença, gerando mesmidade. Parando sem parar, a cismogênese repousa na própria continuidade: a mudança é constante, o que configura tanto um progresso diferenciante, como um funcionamento indiferenciado, permanência coesa e mudança evolutiva. A arte de Benjamin e o platô de Deleuze e Guattari são cismogêneses. É com Bateson que estamos dialogando desde o princípio.

"Inclino-me a ver o status quo como um equilíbrio dinâmico, no qual mudanças estão continuamente tendo lugar. De um lado, processos de diferenciação tendendo a um incremento do contraste etológico e, de outro, processos que continuamente contrariam essa tendência à diferenciação." (BATESON, 2008, p. 222)

A cismogênese pode ser de dois tipos: complementar ou simétrica, mas ambas se assentam no padrão indiferenciado da diferença desagregadora que geram. A diferença complementar é um ciclo de côncavos e convexos. Por exemplo: quanto mais A manda, mais B obedece. A dá uma ordem; B a segue. A dá uma segunda ordem, alicerçada na primeira que deu e na obediência de B; B obedece novamente, carregando a ordem original de A, sua obediência anterior e essa nova ordem... e assim sucessivamente. Há aqui tanto padronização como mudança, ou seja, tanto permanência coesiva quanto mudança evolutiva. O que permanece são os papeis (A manda, B obedece), o que muda é a ênfase de cada desempenho (A manda cada vez mais, B obedece cada vez mais). A cada novo ciclo ambas as instâncias se fortalecem, quer dizer: em toda nova rotação do circuito cismogênico os papeis ficam mais fixos e os desempenhos mais desenvolvido. À medida que o tempo passa, fica mais claro, mais sólido, mais indiscutível a permanência coesiva 
(A manda, B obedece), e mais exagerada, mais elevada a mudança evolutiva (A manda cada vez mais, B obedece cada vez mais). No futuro, A estará mandando e B estará obedecendo como sempre, e como nunca. A mesma coesão permanente, gerando linearidade e mesmidade, com a mudança evolutiva em grau inédito, promovendo ruptura e diferença. Ordem e progresso se fortalecendo mutuamente.

"Fica evidente que muitos sistemas de relacionamento, seja entre indivíduos, seja entre grupos de indivíduos, contêm uma tendência para a mudança progressiva. Se, por exemplo, um dos padrões de comportamento cultural, considerado apropriado no indivíduo A, é culturalmente rotulado como assertivo, enquanto de $\mathrm{B}$ se espera que responda a isso com o que é culturalmente visto como submissão, é provável que esta submissão encoraje uma nova asserção, e que essa asserção vá requerer ainda mais submissão. Temos então um estado de coisas potencialmente progresso, e, a não ser que outros fatores estejam presentes para conter os excessos de comportamento assertivo e submisso, A necessariamente se tornará mais e mais assertivo, e B deverá se tornar mais e mais submisso; e essa mudança progressiva ocorrerá, sejam A e B indivíduos separados ou membros de grupos complementares." (BATESON, 2008, p. 223)

Já na cismogênese simétrica há um paralelismo. Ao contrário da complementar, que opera por encaixe, a simétrica trabalha com espelhamento. Por exemplo: A manda B para o inferno, B manda A para o inferno em resposta, e assim sucessivamente. Cada nova mandada para o inferno traz consigo todas as outras anteriores, de modo que quando $\mathrm{A}$ manda B para o inferno pela centésima vez, na verdade ele manda B para o inferno, com uma única frase, duzentas vezes. Assim como no exemplo anterior, há aqui a fixação de um padrão e uma variação infinita. A cada revolução da máquina, cristaliza-se que A e B se odeiam, gerando assim linearidade e mesmidade, mas o grau do ódio está sempre aumentando, promovendo ruptura e diferença. A permanência coesiva, o chão firme e indiscutível onde a interação se dá, é o ódio, e a mudança evolutiva, o corte inédito progressivo, é o grau desse ódio. Os dois sempre se odiaram, mas nunca se odiaram tanto. Todo dia se odeiam, mas hoje mais do que ontem, e menos que amanhã: padrões estáveis com variações infinitas reciprocamente se ajudando.

"Se, por exemplo, encontramos a bazófia como padrão cultural de comportamento em um grupo, e o outro grupo responde a isso com mais bazófia, uma situação competitiva pode se desenvolver na qual a bazófia leva a mais bazófia, e assim por diante. Esse tipo de mudança progressiva pode ser chamado cismogênese simétrica." (BATESON, 2008, p. 223)

Na cismogênese, as oposições são também possibilitadoras, pois onde parece haver contradição, o que se tem é complementaridade. Assim como a ciranda dos planetas no 
universo é harmonicamente mantida pela mútua anulação de forças gravitacionais contrárias, a simetria da cismogênese é assegurada pela repelência que, por ser mutuamente exercida, se conforma enquanto união. $\mathrm{O}$ modelo precisa estar rigorosamente desenhado para que as duas partes gravitem uma ao redor da outra, unindo-se e se afastando com a mesma força, que assim se invalida. Se o envolvimento superar a negação, os conceitos colidem; se o contrário ocorrer, o arranjo se dissolve e as noções vagam à deriva no oceano infinito dos sentidos. Sendo assim, o que se observa no fenômeno da cismogênese não é nem uma fusão nem uma exclusão de ideias - ou são ambas com a mesma intensidade -, mas um tenso equilíbrio entre esses dois momentos. O modelo converge na sua divergência espelhada, equilibrando-se na própria tensão ao conseguir a proeza de repousar em seu conflito. Na cismogênese, as "coisas" não são só elas mesmas, mas também anteparos onde se projetam suas inversões simétricas; e não há nada que seja apenas tela ou apenas imagem, todos são as duas coisas: dizer é criar as condições para que mais daquilo seja dito; criar as condições para que mais daquilo seja dito é dizer. O que temos é uma mola infinita de formação recíproca: cada polo da díade analítica se faz ao fazer o outro e faz o outro ao se fazer. Rivalizar também é um companheirismo de construção mútua que se projeta numa subida espiralada sem fim. Para que uma constelação de sentidos sobreviva não se pode aproximar os elementos favoráveis e expulsar aqueles aparentemente perigosos. Muitas vezes, o que garante a continuidade do arranjo é o simétrico alinhamento das forças atrativas e repelentes que fazem com que os vetores se anulem ao se envolverem e alienarem com a mesma intensidade. "Não se trata de opostos ou estranhos absolutos, mas de reforços mútuos: uma unidade em dois tempos, uma oscilação lógica e epistemológica." (BATESON, 2008, p. 57). Embora pareça, um cenário em que possíveis contradições se revelaram fortes complementaridades não é ambíguo, mas ambivalente.

"É possível que, em uma cismogênese, os padrões de comportamento entre os dois grupos envolvidos seja tal que, enquanto cada grupo diverge mais e mais do outro, os membros de cada um também se tornam mais e mais dependentes do comportamento complementar dos membros do outro grupo, de modo que, em algum momento do progresso da cismogênese, um equilíbrio seja atingido quando as forças da dependência mútua igualarem a tendência cismogênica." (BATESON, 2008, p. 239) 
O papel da cismogênese é recorrer à ambivalência para harmonizar vetores rivais. Através da ambivalência, a cismogênese promove conciliações tensas ou tensões conciliadas, arranjos a um só tempo harmônicos e disruptivos que constroem elos a partir de cortes. Quando viu a necessidade de juntar permanência coesiva e mudança evolutiva, a sociedade Iatmul usou a ambivalência da cismogênese para unir essas duas forças antagônicas. Entre os dois polos dessa díade, a ambivalência da cismogênese estabeleceu uma relação delicada entre vínculo e cisma. $\mathrm{Na}$ sociedade Iatmul há uma rivalidade recíproca entre permanência coesiva e mudança evolutiva, duas forças que se aproximam e se distanciam com a mesma intensidade, e no centro dessa luta repousa aquela cultura, durando e progredindo em um modelo ambivalente criado pela cismogênese. A World Music se encontra em uma situação parecida com a dos Iatmul: assim como aquele povo, o estilo precisa conciliar forças antagônicas. No seio da World Music se encontram as formas universais do período exótico-colonial e os conteúdos particulares da diversidade-global. Essas formas universais historicamente abrigavam as ideias de unidade, homogeneidade, pureza e absolutismo; noções que, assim como a permanência coesiva, promoviam mesmidade e fixidez. Já os conteúdos particulares geravam efeitos de multiplicidade, heterogeneidade, hibridismo e relativismo; valores que, assim como a mudança evolutiva, estavam comprometidos com a polissemia e a variância. Para os fins dessa pesquisa, a World Music resolveu a querela entre o universal único, homogêneo, puro e absoluto do exótico-colonial e o particular múltiplo, heterogêneo, hibrido e relativo da diversidadeglobal da mesma forma que os Iatmul lidaram com a balança permanência coesiva/mudança evolutiva, ou seja: através de uma cismogênese ambivalente. No caso Iatmul, a natureza ambivalente da cismogênese entre permanência coesiva e mudança evolutiva não deixou que nenhum conceito eclipsasse o outro. Pelo contrário, por criar uma ambivalência, a cismogênese se funda na reciprocidade e na interdependência, ainda que seja um mutualismo de oposições. Entre permanência coesiva e mudança evolutiva há uma simbiose de inimigos, por isso ninguém subjuga ninguém e ambos se nivelam, harmonizando-se em sua recíproca negação. O mesmo ocorre na World Music: ao promover uma cismogênese ambivalente entre o universal do exótico-colonial e o particular da diversidade-global nenhum dos lados estrangula o outro. Ao invés disso, a ambivalência cismogênica se encarrega de construir uma rivalidade equilibrada entre os dois, de modo que os ideias universais de unidade, homogeneidade, pureza e absolutismo 
do exótico-colonial se entrelaçam nos valores particulares de multiplicidade, heterogeneidade, hibridismo e relativismo da diversidade-global. A World Music é justamente o amálgama dessas duas tendências, tendências que rivalizam e se harmonizam porque repousam ao apontar para direções opostas, enfim, forças ambivalentes, cismogênicas.

Infelizmente, eu não sou o primeiro a dar um tratamento cismogênico à World Music. Antes dessa dissertação, Steven Feld (2005) já havia feito essa leitura, por isso, é acompanhado dessa que considero a voz mais sensata sobre o estilo que me debruço sobre nossas questões. Reformulo-as aqui cruzando teoria e objeto para que uma resposta satisfatória possa ser dada.

Pergunta zero: Com qual índice de diferença a World Music opera e que configuração sócio-histórico-cultural possibilitou que ele arregimentasse tanto capital de diferenciação?

O índice para o qual se escolheu olhar foi a ambivalência. Cada um dos períodos do mercado da diferença opera com sua respectiva ambivalência: o exótico-colonial com uma metáfora controladora e a diversidade-global dom uma catacrese libertária. Ambas as ambivalências são maneiras de tratar o terceiro espaço que se abre entre o Eu e Outro: na primeira, esse interstício está sob controle do $\mathrm{Eu}$ e gera efeitos universais de unidade, homogeneidade, pureza e absolutismo; na segunda, o Outro controla essa membrana, que assim propaga as ideias particulares de multiplicidade, heterogeneidade, hibridismo e relativismo.

No entanto, afirmei que a World Music é uma cismogênese, ou seja, um mecanismo que concilia ideias opostas de maneira ambivalente. Sendo assim, pode-se dizer que há no estilo uma ambivalência de ambivalências, ou seja: a World Music é um terceiro espaço entre o Eu e o Outro em que forças metafóricas de captura, geradoras das ideias universais de unidade, homogeneidade, pureza e absolutismo e estratégias catacréticas de emancipação, enredadas nas noções particulares de multiplicidade, heterogeneidade, hibridismo e relativismo lutam, e assim se acomodam, montando uma arranjo cismogênico ambivalente a um só tempo disruptivo e harmônico. A cismogênese, investida da missão de conciliar oposições, dá um tratamento ambivalente a duas ambivalências contrárias. 
Mas não se está dizendo aqui que as gravadoras assumiriam o papel dos universais metafóricos controladores enquanto os artistas fariam as vezes de particulares catacréticos libertários. Não: esse conflito é todo interno ao próprio discurso da World Music. Dentro do texto do estilo há uma luta entre essas duas forças, e é justamente nesse embate que a World Music se enraíza. As próprias gravadoras oscilam entre as duas posições. A continuidade da silhueta externa da narrativa é mantida pelas descontinuidades internas a esse perímetro.

Ao adotar o caminho da cismogênese, a ambivalência passa a ser a resposta para todas as nossas perguntas.

Pergunta conceitual: A passagem do exótico-colonial para a diversidade-global significa uma mudança verdadeira das ideias universais de unidade, homogeneidade, pureza e absolutismo para as ideias particulares de multiplicidade, heterogeneidade, hibridismo e relativismo? No caso da World Music, o estilo gera efeitos universais de unidade, homogeneidade, pureza e absolutismo ou ondas particulares de multiplicidade, heterogeneidade, hibridismo e relativismo?

Quando universal e particular se encontram, nenhuma das tendências subjuga a outra, pois a cismogênese se encarrega de desenvolver entre elas uma relação ambivalente que funda um elo baseado em sua repelência, ou uma harmonia que se alicerça na própria tensão do modelo.

Nem o universal domina o particular nem o particular domina o universal, o que ocorre entre ambos é uma reciprocidade antagônica ou uma rivalidade mútua, ou seja, um arranjo que cria vínculos baseados na separação. Como bem resumiram Deleuze e Guattari (escudados em Bateson, diga-se): "Há exatamente uma história universal, mas é a da contingência" (2011, vol. 1, p. 10).

É exatamente isso o que acontece na World Music. No estilo, vemos uma "rearticulação do universal com os particulares." (NICOLAU NETTO, 2014, p. 212). Em sintonia com o vaticínio de Mil Platôs, há na World Music um estímulo à proliferação de particulares, mas desde que essa polissemia se conforme dentro da moldura monolítica do universal. 
"A diferença não nega necessariamente o universal na contemporaneidade. No discurso da diversidade, ocorre uma relação complexa em que, se há uma continuidade - justamente a manutenção da relação - há a novidade na inversão das intenções do século XIX, quando hoje o universal não será afirmado de antemão, mas sim embasado na soma das diferenças." (NICOLAU NETTO, 2014, p. 203).

"O universal da música é afirmado, mas apenas na soma das diversas visões que as sociedades possuem sobre suas músicas (...). A humanidade (o universal) é, portanto, definida pela diversidade; o discurso da diversidade não nega necessariamente o universal, mas recoloca sua relação com o particular, partindo desse último em suas formulações." (NICOLAU NETTO, 2014, pp. $215,216)$

Portanto, erram aqueles que, falando de World Music ou tecendo um diagnóstico mais abrangente, dizem apocalipticamente que o universal nunca esteve tão forte; mas também se equivocam os otimistas pós-modernos que decretam seu fim. $\mathrm{O}$ universal ainda existe, mas comprometido com essa missão de gerir particularidades em seu interior ${ }^{60}$. Essa é a opinião que o próprio Said expressa em 1994, ao se debruçar sobre o primeiro período da diferença do cerne do segundo:

\begin{abstract}
"Mas enquanto os pós-modernos, numa de suas afirmações programáticas mais famosas (de Jean-françois Lyotard), enfatizam o desaparecimento das grandes narrativas de emancipação e esclarecimento, a ênfase por trás de grande parte da obra realizada pela primeira geração de artistas e eruditos pós-coloniais é exatamente oposta: as grandes narrativas permanecem (...) Seria errado sugerir que em grande parte das melhores obras pós-coloniais, que proliferaram tão dramaticamente a partir do início da década de 1980, não haja uma forte ênfase no local, no regional e no contingente: ela existe, mas me parece estar conectada de forma muito interessante, na sua abordagem geral, a um conjunto universal de interesses, todos relativos à emancipação, a atitudes revisionistas para com a história e a cultura, e a um emprego difundido de modelos e estilos teóricos recorrentes." (SAID, 2013, pp. 463, 464).
\end{abstract}

\footnotetext{
${ }^{60}$ Sobre isso, Bhabha comenta: "A diversidade cultural é um objeto epistemológico - a cultura como objeto de conhecimento empírico - enquanto a diferença cultural é o processo de enunciação da cultura como 'conhecível', legítimo, adequado à construção de sistemas de identificação cultural. Se a diversidade é uma categoria da ética, estética ou etnologia comparativas, a diferença cultural é um processo de significação através do qual afirmações da cultura ou sobre a cultura diferenciam, discriminam e autorizam a produção de campos de força, referência, aplicabilidade e capacidade. A diversidade cultural é o reconhecimento de conteúdos e costumes culturais pré-dados; mantida em um enquadramento temporal relativista, ela dá origem a noções liberais de multiculturalismo, de intercâmbio ou da cultura da humanidade. A diversidade cultural é também a representação de uma retórica radical da separação de culturas totalizadas que existem intocadas pela intertextualidade de seus locais históricos, protegidas na utopia de uma memória mítica de uma identidade coletiva única. A diversidade cultural pode inclusive emergir como um sistema de articulação e intercâmbio de signos culturais em certos relatos antropológicos do início do estruturalismo." (BHABHA, 2013, p. 69)
} 
A Declaração Universal sobre a Diversidade Cultural, lançada em 2002, não deixa dúvidas sobre o ímpeto cismogênico do presente de conciliar a tensão entre universal e particular de maneira ambivalente. Como falei ao cotejar o documento, o próprio título do texto já é esclarecedor: nos nossos dias, a diversidade é celebrada como um valor universal. O artigo seis da declaração afirma:

"Artigo 6 - Rumo a uma diversidade cultural accessível a todos:

Enquanto se garanta a livre circulação das ideias mediante a palavra e a imagem, deve-se cuidar para que todas as culturas possam se expressar e se fazer conhecidas. A liberdade de expressão, o pluralismo dos meios de comunicação, o multilinguismo, a igualdade de acesso às expressões artísticas, ao conhecimento científico e tecnológico - inclusive em formato digital - e a possibilidade, para todas as culturas, de estar presentes nos meios de expressão e de difusão, são garantias da diversidade cultural." (p. 3)

Ou seja, a diversidade é o que nos faz únicos. Toda polissemia aponta para a riqueza dessa grande e indistinta família humana. Retomando Nicolau Netto,

"Em verdade, a própria hegemonia do discurso da diversidade revela: ele também se propõe como um discurso universal. Se sua base é a valorização da diferença, essa precisa ser assumida como valor por todas as culturas, em qualquer tempo e espaço." (2014, p. 302).

Nos dias de hoje, o universal e o particular existem, ou melhor, o particular é um valor universal. Embora opostas, não há antecedência de uma ideia sobre a outra. Ao se encontrarem no nosso tempo, universal e particular formam uma cismogênese ambivalente, uma união fundada em sua rivalidade. Vejamos como esse arranjo se manifesta em cada uma das díades que nos interessam:

\section{Unidade/Multiplicidade:}

Quando olha para a cultura Iatmul, Bateson afirma:

"De um lado, temos o tipo de material que já mencionei, isto é, a distribuição de milhares de nomes pessoais para as coisas e as pessoas do mundo e para as diferentes facetas de suas personalidades; de outro, temos a insistência em que tudo é realmente um. (...) Outro exemplo desse monismo místico pode ser visto na teoria segundo a qual todas as cosias do mundo não passam de padrões de ondas. Mas, à percepção da unidade de todas as coisas, podemos contrapor a confusão que resultou talvez da rivalidade entre os clãs e da ênfase no orgulho. Todos acreditam no monismo fundamental e nele insistem, mas cada grupo tem sua própria teoria mitológica segundo a qual seus próprios ancestrais ocupam as posições-chave na origem unitária do mundo. Daí sucede que não há uma teoria monista, mas toda uma série de teorias conflitantes, todas elas enfatizando a sua 
unidade fundamental do mundo. (...) E assim oscila a cultura entre monismo e pluralismo." (2008, pp. 273, 274)

Essa descrição da cultura Iatmul parece se encaixar perfeitamente na nossa sociedade presente. Hoje, nosso mundo também oscila entre unidade e multiplicidade. Como já falei, há um estímulo à polissemia, mas todas essas partes diferentes devem se acomodar dentro de um mesmo corpo. Uma variedade de partes dentro de um mesmo todo: a variedade das partes polissemiza o todo, e o monismo do todo nivela as partes. Ou seja, no presente tanto a unidade quanto a multiplicidade são cultivadas, de maneira que não seria incorreto afirmar que a unidade é um conceito múltiplo, ou a multiplicidade uma ideia única.

"A globalização, assim, exige uma fragmentação dos conceitos, mas exige certo consenso que possa gerar um discurso sobre o mundo capaz de propô-lo como espaço único. Os domínios culturais e o elenco das atividades da UNESCO vivem essa dicotomia. (...) Em qualquer indicador que a UNESCO vier a propor, tais seleções estarão presentes, o que significa dizer que mesmo na fragmentação certa ordem mundial começa a ser gerada: a novidade é que ela precisa dar conta de uma ideia de diversidade." (NICOLAU NETTO, 2014, p. 45)

É exatamente esse o conflito presente no Framework: um gabarito único que quer entender a multiplicidade das culturas. Tanto os que vêem nisso um retrato da colonização quanto aqueles que celebram aqui uma pulverização pós-moderna estão errados. É verdade que o Orientalismo era um gabarito único, mas não media a diversidade. Também é certo que a fragmentação pós-moderna prega o plural, mas não para medi-la com uma mesma régua. Assim como entre os Iatmul, há aqui uma oscilação ambivalente entre as duas ideias: promove-se a multiplicidade para que ela possa ser contida em uma mesma unidade.

"Embora haja a necessidade de um quadro de referência internacional, os elementos que o preencherão certamente serão locais, respeitando as atividades culturais específicas. A definição de atividades culturais é complexa quando a diversidade das culturas precisa entrar em jogo: noções mundiais e especificidades locais estão em debate". (NICOLAU NETTO, 2014, p. 42).

A World Music é o palco onde essas forças lutam, e se harmonizam. No etilo, unidade e multiplicidade formam uma cismogênese ambivalente, pois concorrendo, reciprocamente se adéquam. Embora use um tom e um glossário bem distante dos nossos, Erlmann comenta esse fenômeno.

"O apelo contemporâneo por imagens do "mundo" comercialmente produzidas mantém uma relação inversamente proporcional com a impopularidade dos 
conceitos totalizantes no discurso teórico da atualidade. A nostalgia por totalidade na produção artística popular parece derivar precisamente do fato de que, numa era sem síntese, coo Roberto Musil certa vez chamou a modernidade, essas imagens respondem aos desejos residuais e fora de moda por unidade e coerência. (...) Uma das expressões ideológicas mai intensas dessas mitologias totalizantes são os rituais públicos de World Music tais como os festivais WOMAD. Como tais, os festivais WOMAD são lições da ideologia da produção universal de commodities. Os shows celebram a diversidade das expressões artísticas nas culturas do mundo, essa celebração da diferença mascara uma mesmidade, assim como repousa nela" (ERLMANN, 1996, p. 477)

"World Music oferece o espectro panorâmico de um ecumenismo global, de uma longa totalidade considerada perdida pelo pensamento crítico contemporâneo. Sob a proliferação exponencial de sentidos e toda a celebração da diferença, World Music parece articular esse prosaico sentimento expressado pelo comercial da AT\&T de 1990: 'Nós estamos todos conectados'." (ERLMANN, 1996, p. 468).

Erlmann usa um acento meio marxista para sugerir que a multiplicidade seria uma ideologia que vela uma unidade concreta. Ou seja, para o autor, a polissemia seria uma cortina de fumaça mentirosa que nos cegaria para uma verdade monista. Esse não foi o caminho que escolhemos aqui quando optamos pela cismogênese. Para os fins desse texto, não há qualquer hierarquia de realidade entre a unidade e a multiplicidade; para nós, esses são dois vetores que se harmonizam em sua oposição, formando uma cismogênese ambivalente. Trouxe o autor apenas para ilustrar a presença dessa tensão na World Music. Esse sentimento está bem evidenciado no título daquela coletânea pensada no Empress of Russia: The World Music at One. Outro disco cujo nome ilustra bem essa tensão é a coletânea da Putumayo One World, Many Cultures. Em ambos os casos se vê a ambivalência que nos interessa: estúmulo da multiplicidade, contido dentro de uma unidade.

\section{$\underline{\text { Homogeneidade/Heterogeneidade }}$}

O mesmo padrão cismogênico de ambivalência aparece no par homogeneidade/heterogeneidade. Cultiva-se o heterogêneo, mas o que deriva dele é a homogeneidade. Assim como a mistura de todas as cores diferentes resulta no branco, na diversidade contemporânea, estimula-se o surgimento de várias culturas idiossincráticas, mas todas são igualmente tratadas e, unidas, formam uma grande cultura lisa e monocromática. "A tendência atual parece ser a percepção de que a homogeneização e heterogeneização da cultura são dois processos mutuamente presentes na atualidade" 
(NICOLAU NETTO, 2014, p. 222). Os vários povos heterogêneos forjam um único povo homogêneo.

Essa ambivalência se evidencia na World Music, onde tendências opostas de homogeneização e heterogeneização se envolvem e se alienam com a mesma intensidade; fenômeno cismogênico que Erlmann sarcasticamente define como "Síndrome de Benetton".

"Primeiro, eu vejo homogeneização e diferenciação não como características da globalização musical mutuamente excludentes que devessem ser lamentadas, denunciadas, ou demandadas como necessárias, mas como partes constitutivas da estética musical do capitalismo tardio. (...) Homogeneidade e diversidade são dois sintomas do que se pode chamar de Síndrome de Benetton: quanto mais pessoas ao redor do mundo usam o mesmo traje, mais o comercial celebra a diferença." (ERLMANN, 1996, P. 469)

Mas, novamente, não se pode achar que a heterogeneidade seja uma mentira que esconde a verdadeira homogeneidade, nem o contrário. Em uma ambivalência cismogênica, as instâncias se nivelam, conciliando-se em uma luta simétrica. Esse é exatamente o tratamento que Feld dá para a questão quando fala da World Music. "Ao mesmo tempo em que World Music é homogeneizante, a excitação, a revitalização, a 'chamada de longa distância', ilustrada na World Music pela África, ainda é a marca de alteridade" (2005b, p.245). Nesse mundo em que homogeneidade e heterogeneidade ambivalem, a única coisa igual em todas as culturas do mundo é que elas são diferenças. Ou seja, o que nos homogeneíza é a heterogeneidade.

\section{$\underline{\text { Pureza/hibridismo }}$}

O nosso tempo afirma simultaneamente tanto a pureza quanto o hibridismo. Através de uma ambivalência cismogênica, essas forças contrárias se enlaçam, compartilhando uma cesura. Mas aqui a relação entre parte e todo se altera: antes falei que a multiplicidade deve se conformar dentro da unidade, e a heterogeneidade resulta em homogeneidade. Mas nessa balança cismogênica, o híbrido é que contém o puro, e assim, mesmo se opondo, esses vetores se afinam.

Hoje é possível afirmar simultaneamente as duas narrativas porque o híbrido que se defende é uma reunião de puros. Celebra-se uma totalidade híbrida, mas as partes reunidas para forjá-la são purezas que não se misturam, apenas se enfileiram uma ao lado da outra. 
Como disse Latour, "Todos os híbridos eram concebidos como uma mistura de formas puras" (2009, p. 76). O híbrido não é uma síntese de formas puras que abriram mão de sua pureza e se deixaram misturar nessa massa híbrida, mas uma soma de elementos imiscíveis. Não há fusão, mas empilhamento. Ao contrário do fato social de Durkheim, a união das purezas não enseja uma síntese híbrida externa de natureza sui generis, o híbrido é só a sucessão de purezas que se aproximam, mas não se trocam.

"Se hibridismo e autenticidade eram termos tomados como opostos até menos da primeira metade do século XX, hoje eles convêm pelo fato de o hibridismo se valorizar pela enumeração e não pela síntese, na qual elementos são colocados lado a lado, sendo cada um percebido como puro. Assim, pela enumeração, que pode ser mais bem vista pela tendência à hifenização nas descrições das coisas culturais, o hibridismo não nega a pureza necessária para a percepção da autenticidade." (NICOLAU NETTO, 2014, p. 15).

"Com esse entendimento, se de um lado é possível aceitar que de fato não existem formas puras e que todo processo de hibridismo se dá a partir de mistura de formas já misturadas, consegue-se entender que em todo processo de hibridismo é presente a suposição, ainda que momentânea, de formas puras. Com isso, o hibridismo não se opõe às formas puras, na verdade, mas de alguma forma as afirma. Se entre os autores póscoloniais a afirmação da forma pura é momentânea, sendo apenas um instante da análise, na World Music ela se mantém, razão pela qual o híbrido gira no mesmo contexto do autêntico." (NICOLAU NETTO, 2014, p. 278).

Por isso na World Music se valoriza tanto a parte como o todo. No estilo, buscamse sons virgens e intocados, que ainda não foram contaminados por outras influências, para que cada um deles se reúna em um todo misturado. $\mathrm{O}$ híbrido não é uma qualidade dos elementos, que são puros, mas da totalidade que formam. Mas essa síntese só pode ser feita pelo mediador, nunca pelo músico. $\mathrm{O}$ artista se conserva puro, e a gravadora promove o híbrido ao reunir essas purezas. Mas se o estrangeiro se antecipar ao ocidental e cultivar dentro de si a mistura, ele pode ser descartado. Mesmo os músicos que se definem como híbridos, o fazem pelo enfileiramento de purezas, elencando os ingredientes insolúveis que o compõem. Pois aqueles que se colocam como o terceiro vértice de uma triangulação, ou seja, a resultante misturada de vetores puros, acabam recebendo as críticas que N'Dour e Kidjo tiveram que ouvir. 
Por isso, no campo da World Music a cismogênese ambivalente entre pureza e hibridismo se revela. As duas ideias são estimuladas, mas cada uma precisa do seu oposto para que ela mesma possa se afirmar. Ambiciona-se criar um mundo híbrido, mas para fazê-lo as purezas devem ser reunidas, sempre somadas, nunca sintetizadas.

\section{$\underline{\text { Absolutismo/Relativismo }}$}

Pouco resta a ser dito sobre esse último par. Assim como todas as díades aqui apresentadas, o absoluto e o relativo estabelecem entre si uma relação ambivalente de cismogênese. Ambos os conceitos são valorizadas, e para se ter um é preciso passar pelo outro, ainda que se oponham. Nesse mutualismo de contrários, prega-se o relativismo, que por sua vez é tido como uma agenda global absoluta. No seio da World Music, a relatividade é recebida como um princípio inquestionável, que paira sobre qualquer outro. Característica própria a um mundo onde a diferença é o traço que nos iguala.

Pergunta política: A passagem do exótico-colonial para a diversidade-global significa a mudança de uma era de dominação e controle para um novo período de liberdade e independência? No caso da World Music, as culturas tematizadas são espelhadas tal como são, sendo portanto empoderadas, ou inventadas tal como a gravadora acredita que elas sejam, sendo então apropriadas?

Uma coisa que a trajetória aqui trazida nos ensinou é que representar é poder. Definir significados, imputar sentidos ou quaisquer atos de fala são, fundamentalmente, gestos de poder, reservados àqueles que dele dispõem. Diante disso, se hoje as culturas se definem tal como são é porque elas se emanciparam do jugo ocidental, mas se continuam sendo retratadas como o Ocidente acredita que elas sejam, é porque ainda são dominadas por ele.

Esse debate sempre é evocado quando se fala da relação dos mediadores ocidentais com os artistas de World Music. Há quem afirme que os intermediários passivamente retratam os músicos tal como esses se enxergam, deixando que livremente se afirmem; já outros acreditam que os mediadores ativamente constroem uma imagem desses músicos tão como queriam que eles fossem, inventado esse retrato e violentamente se apropriando dele. Os que pertencem à primeira corrente justificam seu ponto de vista afirmando que os próprios artistas buscam a World Music e são gratos a seus padrinhos ocidentais; enquanto 
aqueles que se filiam à segunda corrente dizem que isso só evidencia o estado de dependência em que esses músicos se encontram em relação às gravadoras. Para esses críticos, os artistas não enxergam a natureza predatória dessa relação, que se esconderia sob o verniz dessa aparente alforria.

Mas o que uma análise cismogênica da World Music revela é que não se pode adotar essa postura maniqueísta. No estilo, não há a pura liberdade, nem o absoluto controle, mas uma tensa harmonia entre essas forças antagônicas, quer dizer, uma oscilação ambivalente que une ideias contrárias, estabelecendo entre elas um elo enraizado em seu antagonismo. Da rivalidade simétrica entre dominação e independência, surge um conceito que vem sendo cada vez mais utilizado para definir o contemporâneo: gerenciamento.

Não se vive mais no tempo do Orientalismo, em que a imagem do Outro era inventada pelo Eu a partir do zero, sem qualquer diálogo com ele, atendendo apenas ao bel prazer do Ocidente. Em compensação, a promessa pós-moderna de uma liberdade total não se cumpriu. Não se pode crer que o Eu se retirou completamente do mercado dos sentidos e entregou um microfone para o Outro falar o que bem entende. Nem há um ventriloquismo nem uma palestra, mas uma espécie de carpintaria do discurso estrangeiro. Colocando de outro modo, pode-se dizer que a voz nativa não é nem falada nem dublada, mas editada. No passado, a diferença era execrada, hoje ela é valorizada, o que sugere liberdade; em compensação, esse conceito de diferença tão prestigiado não é definido apenas pelo nativo, mas por uma sintonia fina entre ele o mediador ocidental.

"Na contemporaneidade abrem-se espaços para vozes antes caladas, mas que apenas se manifestam sob condições específicas. (...) A valorização da diferença, se abre espaço para novas vozes operarem no espaço global, pode levar a um tipo de controle que se acumula em poucos atores" (NICOLAU NETTO, 2014, p. 14)

É dessa forma que esses atores se legitimam para operar no cenário global. Mas é também dessa forma que suas vozes são condicionadas na negociação que necessitam fazer. Um ator que opera no cenário global a partir da valorização de sua suposta proximidade com uma cultura, o que o torna uma representação dela, deve em troca oferecer uma fidelidade a tal aproximação que o reduz à própria representação. Ele deve se tornar um ator fixo, no sentido em que apenas poderá operar no cenário global enquanto se mostrar um legítimo representante da diferença. Assim, se pelo discurso da diversidade há uma libertação da diferença, que passa a ter valor, e uma distribuição da presença de vozes no cenário global, o que é dizer distribuição de poderes, há também um 
condicionamento de algumas vozes a essa diferença." (NICOLAU NETTO, 2014, p. 14)

Na World Music, há tanto um interesse legítimo pelo que o Outro tem a dizer quanto uma expectativa sobre o que ele deve falar, e o que aparece na coletânea é a resultante dessas duas forças, ou seja, são os enunciados nativos aprovados pelo crivo ocidental. Portanto, o estilo media e imputa sentido; mas não há uma falsa mediação escondendo uma verdadeira imputação, pois no fundo esses não são dois gestos, mas um só: a mediação de sentido da World Music é uma imputação de sentido. Aqueles que acreditam que o fenômeno passivamente mostra o músico como ele é, libertando-o, negligenciam a pauta ocidental presente no processo. Já os que dizem que a World Music ativamente inventa esse artista da maneira que lhe apraz, dele se apropriando, à revalia da alegria que o músico sente em pertencer ao estilo, incorrem no erro que atribuem às gravadoras: negligenciar a voz nativa, tratar o outro como uma marionete incapaz de saber o que se passa com ele.

Recusando essas posições extremadas, a ideia de gerenciamento constrói uma síntese ambivalente entre liberdade e controle, reunindo essas forças opostas em um mesmo arranjo. Com o tempo, a tendência é que essas forças contrárias se afinem reciprocamente em sua tensão, burilando-se mutuamente na medida em que rivalizam, até que se chega ao ponto em que o que o artista "é" corresponde exatamente ao que o mediador "quer que ele seja", e vice-versa. Por exemplo: se olharmos o caso de Carlinhos Brown, um nome recorrente nas coletâneas de World Music, podemos perceber a cismogênese do gerenciamento. No tom de Brown, fica claro que o artista se sente livre e acredita que sua música retrata não só o que pensa mas, metonimicamente, representa também a cultura em que ele está inserido. Quando está compondo ou se apresentado, o músico não está "se traindo", desempenhando um papel que não gosta, que contraria sua vontade, só para agradar as gravadoras estrangeiras. O trabalho de Brown é o que ele quis que ele fosse, e por isso mostra sua verdadeira intenção. Em paralelo a isso, seria ingênuo pensar que na autoimagem do artista não está incutida uma demanda estrangeira; mas essa expectativa ocidental, por sua vez, também se media com o que Brown tem a dizer; uma voz que leva em conta os ouvidos americanos que em compensação.... enfim, há entre músicos estrangeiros e mediadores ocidentais uma mola recursiva cismogênica em que as duas forças vão sempre negociando e assim caminham para um acordo, mesmo que 
rivalizem. Muito antes de conhecer Paul Simon, o Ladysmith Black Mambazo decidiu cantar em inglês para chamar a atenção do público internacional (tática também adotada por muitas bandas latinas de metal). Essa foi uma decisão que o conjunto tomou "por conta própria", sem a pressão direta de ninguém. No entanto, inscrita nessa estratégia, já estava presente uma agenda ocidental. Quando Paul Simon chegou na África "desinteressadamente", dentre todos os grupos vocais, foi o Ladysmith Black Mambazo que chamou sua atenção. Ou seja, muito antes de se conhecerem, um já estava no horizonte do outro, e assim o encontro dos dois pareceu um fatalismo incontornável, uma coincidência que só poderia ser proporcionada pelos deuses da música, quando na verdade a história já estava burilando esse encontro. Simon tinha uma demanda específica e o Ladysmith tinha algo muito próprio a ofertar; a cismogênese do gerenciamento foi afinando essas forças opostas, transformando-as numa vontade só. Se não fosse a World Music, Ladysmith Black Mambazo jamais seria conhecido, portanto é correto dizer que o estilo empoderou e libertou a banda. Mas se não precisasse da World Music para ficar conhecido, certamente a banda teria uma sonoridade diferente. Em todo o caso essa sonoridade seria "fiel" e "verdadeira", mas os ingredientes compondo essa autenticidade seriam outros. É por isso que, para Nicolau Netto, o presente é um tempo em que a diferença é simultaneamente estimulada e contida. Vivemos em um tempo dedicado a fomentar a diferença e a situá-la em padrões específicos. Antes acorrentado pelo Ocidente, hoje o outro está livre, porém não para sair, mas para entrar no esquema do Eu.

"A descentralização ocorrida na globalização não pode ser confundida com o descontrole. Controle e fragmentação não são termos antagônicos, como muitos mecenas da desregulamentação do mercado nos querem fazer crer. (...) A maleabilidade do campo discursivo deve ser entendida como uma abertura para uma nova série de controles (...) O gerenciamento da diversidade é um modo de escolher, entre as mais diversas possíveis expressões, aquelas que podem prosperar, de acordo com interesses." (NICOLAU NETTO, 2014, p. 163).

$\mathrm{Na}$ esteira do conceito de gerenciamento, e em diálogo direto com Bateson, Feld cunha a noção de "patronagem". O autor identifica "uma espiral ascendente no padrão ajuda-dependência" entre mediadores e artistas, o que gera o fenômeno da patronagem:

"Esse processo tem o efeito positivo de validar músicos e músicas historicamente marginalizados, mas simultaneamente reproduz a instituição da patronagem e seus direitos de validação, assim como antigos padrões de elitismo cultural de vanguarda. (...) Com os mesmos pop-stars cada vez mais investidos dos papéis de curadoria, promoção e colaboração, é compreensível 
que enunciados de altruísmo e generosidade sejam tão frequentes quanto acusações de canibalismo e colonialismo" (FELD, 2005, pp. 270, 271)

"Apropriação musical canta uma linha dupla com uma mesma voz. Ela tanto é uma melodia de admiração, até homenagem e respeito, uma fonte fundamental de conexão, criatividade e inovação. Isso está situado em um discurso de 'raiz', de reproduzir e expandir 'a tradição'. No entanto, essa voz se harmoniza com uma contramelodia de poder, até controle e dominação, uma fonte fundamental de assimetria no que diz respeito à posse da música. Isso se situa em um discurso de espoliação" (FELD, 2005, p. 280)

Quando perguntei a um DJ brasileiro que discoteca coletâneas de World Music o que ele achava dessa tensão entre liberdade e controle presente no estilo, ele me respondeu que considerava World Music "um mal necessário". Essa saída intermediária parece resumir a cismogênese do gerenciamento: é lamentável que os músicos precisem desse controle para se emancipar. É ruim precisar da World Music, mas já que precisamos dela, que bom que ela existe. No mundo gerenciado da World Music, liberta-se aquele que se mediar com a gravadora. Nos discos, ouvimos tanto os artistas como são, como quanto as gravadoras queriam que eles fossem, só não sabíamos que essas vontades antagônicas caminhavam ciclicamente para uma adversa conciliação.

Pergunta síntese: olhando essa mudança pelo prisma da World Music, quais são as continuidades e rupturas no mercado da diferença quando da passagem do exóticocolonial para a diversidade-global? Ou seja, que relação se estabelece entre colonização e globalização?

$\mathrm{Na}$ trajetória descrita pelo conceito de diferença, formas universais oriundas do período exótico-colonial desse mercado atravessaram o filtro da igualdade e passaram a abrigar conteúdos particulares da diversidade-global, criando a tensa harmonia descrita nessa conclusão. Diante desse cenário, que diagnóstico podemos dar sobre esse percurso? Entre os dois períodos do mercado da diferença há continuidade ou ruptura?

Desde o começo do texto, essa foi a lente pela da olhamos nosso recorte. Mas afirmar que se fez uma análise através dessa pergunta é admitir que não se fez um estudo dessa interrogação propriamente dita. Ao fazer a díade continuidade/ruptura sempre de olhar e nunca de olhado, acabamos naturalizando a ideia desses conceitos. Para resolver esse problema, é necessário aqui tirar o binômio de sua condição de lente, e levá-lo à 
categoria de objeto. Afinal, que relação se estabelece entre essas duas palavras, ou melhor: quais são as continuidades e rupturas entre os conceitos de continuidade e ruptura?

Para um pensamento tradicional, têm-se aqui duas ideias opostas e antagônicas, mas o que a perspectiva cismogênica nos ensina é que forças contrárias podem ensejar também um tipo de união. Por estarmos mergulhados numa lógica canônica, pensávamos que teríamos que escolher entre uma saída e outra, mas o que a cismogênese nos mostrou é que podemos ficar com as duas. Porque para o pensamento cismogênico, é justamente a oposição entre continuidade e ruptura que permite que esses conceitos se entrelacem, construindo uma instável segurança.

Portanto, para a saída cismogênica que aqui escolhemos, a relação entre os dois períodos do mercado da diferença é de continuidade $e$ de ruptura. O espaço que compartilham é justamente o hiato que os separa. O corte que se abre entre os dois é o vínculo que estabelecem. Colonização e globalização são contrários, por isso se fortalecem mutuamente. A ruptura as envolve, e a continuidade as aliena. O exótico-colonial e a diversidade-global se opõem, por isso estarão sempre juntos.

$$
* * *
$$

Respondidas as perguntas, esse deveria ser o momento de encerrar a dissertação, mas depois de ler tantos críticos do monismo e do fechamento, talvez o mais correto seja terminar o texto abrindo e não fechando. Feita essa leitura provisória do estado atual do mercado da diferença, cabe agora perguntar: a que novas sínteses podemos ambicionar ascender?

Conciliando um universal único, homogêneo, puro e absoluto a um particular múltiplo, heterogêneo, híbrido e relativo, nosso tempo lida muito bem com o fato de que existem muitas singularidades, mas nunca abriu mão da ideia de que só há uma única pluralidade que arregimenta todas aqueles elementos. Ou seja: as singularidades estão no plural, mas a pluralidade está no singular. Ainda que outros agentes tenham sua existência reconhecida, parece que só um pode ensejar o modelo que organiza todos. Os tipos, as especificidades e as idiossincrasias são contempladas, mas desde que se conformem dentro do conjunto forjado pela diversidade que as enxergou. Com isso, desenvolveu-se uma visão de relativismo mais avançada que as anteriores, mas ainda assim limitada, pois 
outros são vistos, mas nunca podem ver; ou seja: os outros são reconhecidos, mas reconhecidos como "outros objetos" e nunca como "outros sujeitos". Como muitas singularidades existem mas só uma delas se faz apta a montar o arranjo que sistematiza todas, o que se tem é uma globalidade localmente forjada; quer dizer, uma diversidade derivada de um único centro.

Hoje temos uma multiplicidade unicista, uma heterogeneidade homogênea, um hibridismo puro, um relativismo absoluto, um universal particular e uma liberdade controlada. Mas que novos saltos podemos dar? Talvez seja chegado o momento em que o debate sobre "Os outros" atingiu a um nível em que não basta que as culturas "sejam vistas", é preciso também que elas "vejam". Essa nova agenda surge quando as "outras culturas" deixam de se alegrar em ser mais um elemento contemplado por um único discurso e começam a questionar o monopólio dessa narrativa unívoca que parece ser a única habilitada a reunir todas as variedades em uma mesmo sistema por ela construído. A partir daí, vai sendo elaborada um nova ideia de polissemia em que as singularidades não se conformam mais em se espremer em uma pluralidade única ensejada por uma delas e começam a tentar criar suas respectivas generalizações. Ao invés de adentrarem em um esquema engendrado por outros, essas culturas passam a forjar seus próprios esquemas. Para que se contentar em ser mais um elemento contemplado por um conjunto que a todos nivela se você pode sugerir seu próprio conjunto? Para que se alegrar em ser mais um ponto visto por um único ponto de vista se cada um pode ser dono de seu respectivo pontos de vista? "Você" concebe uma diversidade que me olha como um "outro", mas poderia você ser o "outro" da diversidade que tem a mim como um "eu"? Como falei, exigir um novo nível de simetria cultural em que não basta que todos sejam vistos, mas sim que todos possam ver. Para que o debate adentre essa nova era, vê-se que é necessário abandonar um estágio em que uma única localidade propõe a globalidade que reúne todas para que se atinja o nível em que cada localidade possa construir sua respectiva globalidade. Nem deixar que contem a nossa história nem agradecer quando "deixam" que contemos o nosso relato de uma história protagonizada por eles, mas sim darmos a nossa versão dos fatos construindo as generalizações que são próprias a nossa singularidade. A diversidade até deixa que falemos de nós mesmos, mas isso é pouco, queremos ter os nossos Outro's e falarmos sobre todos também. Não só exibir nosso nativismo, nossas idiossincrasias mas nossa globalidade, nosso cosmopolitismo. Há muito tempo se diz que existem muitas 
singularidades, mas a questão é: quantas pluralidades podem existir? Ao invés de músicos africanos dentro de uma gravadora de World Music americana, é possível haver uma gravadora de World Music africana com músicos americanos? A África pode mostrar sua visão de mundo e não só sua visão de África? Aparentemente o presente não nos dará essa resposta. Só quando pararmos de festejar o crescimento dos vários galhos diferentes e começarmos a olhar criticamente para o tronco único que os sustenta, deixaremos de ter um polo irradiador de polissemia e aí então cada ponto poderá ser o centro da sua respectiva onda polissêmica. Para que a multiplicidade possa ser contada pelo prisma dos múltiplos e os diversos se vejam habilitados a diversificar é preciso seguir a sugestão de Home Bhabha (2013) e "tocar o futuro pelo lado de cá".

Estudando a diferença percebemos como é comum a prática de se distanciar de si mesmo para que se possa retornar ao Eu com maior vigor. Ao longo da história, o homem procurou alteridades para que de maneira oblíqua pudesse entender melhor a si mesmo. Adotando aqui essa estratégia, depois de dedicarmos tantas páginas a um objeto externo, talvez esse seja o momento de voltarmos para o seio da sociologia para tentarmos entender melhor o que tudo isso tem a ver conosco. Indubitavelmente, as ciências sociais fazem parte do mercado da diferença, e, assim como a World Music, vivem um conflito entre ideias universais de unidade, homogeneidade, pureza e absolutismo e noções particulares de multiplicidade, heterogeneidade, hibridismo e relativismo, além, é claro, dá eterna balança liberdade/controle. Diante disso, cabe perguntar: até que ponto o pesquisador não se relaciona com seus interlocutores como uma gravadora de World Music com seus artistas?

Há muito tempo Geertz nos ensinou que a cultura é um texto. Se isso for verdade, quem teria escrito esse texto: nós ou os nativos? Mesmo quando essa querela se resolver, uma nova interrogação pode surgir: quem está lendo esse texto: nós? O nativo? Nós estamos lendo para ele? Ele está lendo para nós? Tem quem se sinta livre da culpa objetivista e dominadora do nosso ofício afirmando que se está em busca de captar uma "teoria nativa" ao invés de inventar ou aplicar uma sua. Mas será que isso é suficiente? Existe uma velha piada que diz que os chineses se referem a "comida chinesa" simplesmente como "comida". Tendo isso em vista é lícito perguntar: até que ponto as "teorias nativas" são vistas como tais pelos nativos? Não seriam elas apenas "teorias", o 
que faria a caçada por "teorias" com esse apêndice "nativas" um problema fundamentalmente nosso? Ou menos ainda, além de os nativos não a verem como "nativas", será que eles também não se recusam a encará-las como "teorias"? Quem sabe elas sejam simplesmente o fluxo vital se desenrolando com toda a sua naturalidade sem que "o Outro" formate essa fluidez nas sólidas arestas de uma problematização teórica. Se isso for correto, não se está sendo menos cientista social e mais "índio" ao se propor essa missão. Por esse prisma, a busca por uma teoria nativa não parece menos encastelada do que os ambiciosos sistemas parsonianos. Ainda que tudo isso esteja resolvido, deve-se perguntar se o "Outro" precisa mesmo disso tudo e se aquilo vai causar alguma mudança em sua vida. Há quem acredite que nossas canetas funcionam como a cauda do Avatar de James Cameron e que, através delas, nos conectamos ao nosso campo, agindo em perfeita simbiose com "os Outros" a espera do dia em que fecharemos pela última vez nossos claros olhos ocidentais para que eles se abram definitivamente amarelados e vejam nossos novos corpos azuis. Mas enquanto nossas canetas forem apenas canetas, a única possibilidade de ficarmos azuis é se nos riscarmos com elas.

Se tudo isso tiver algum sentido, talvez nós até estejamos habilitados a falar "dos Outros", mas jamais "em nome dos Outros". Para os momentos fáusticos em que esquecemos as fronteiras da profissão, é bom lembrar: nós pertencemos ao mundo, mas, infelizmente, o mundo não nos pertence. 
Anexo 


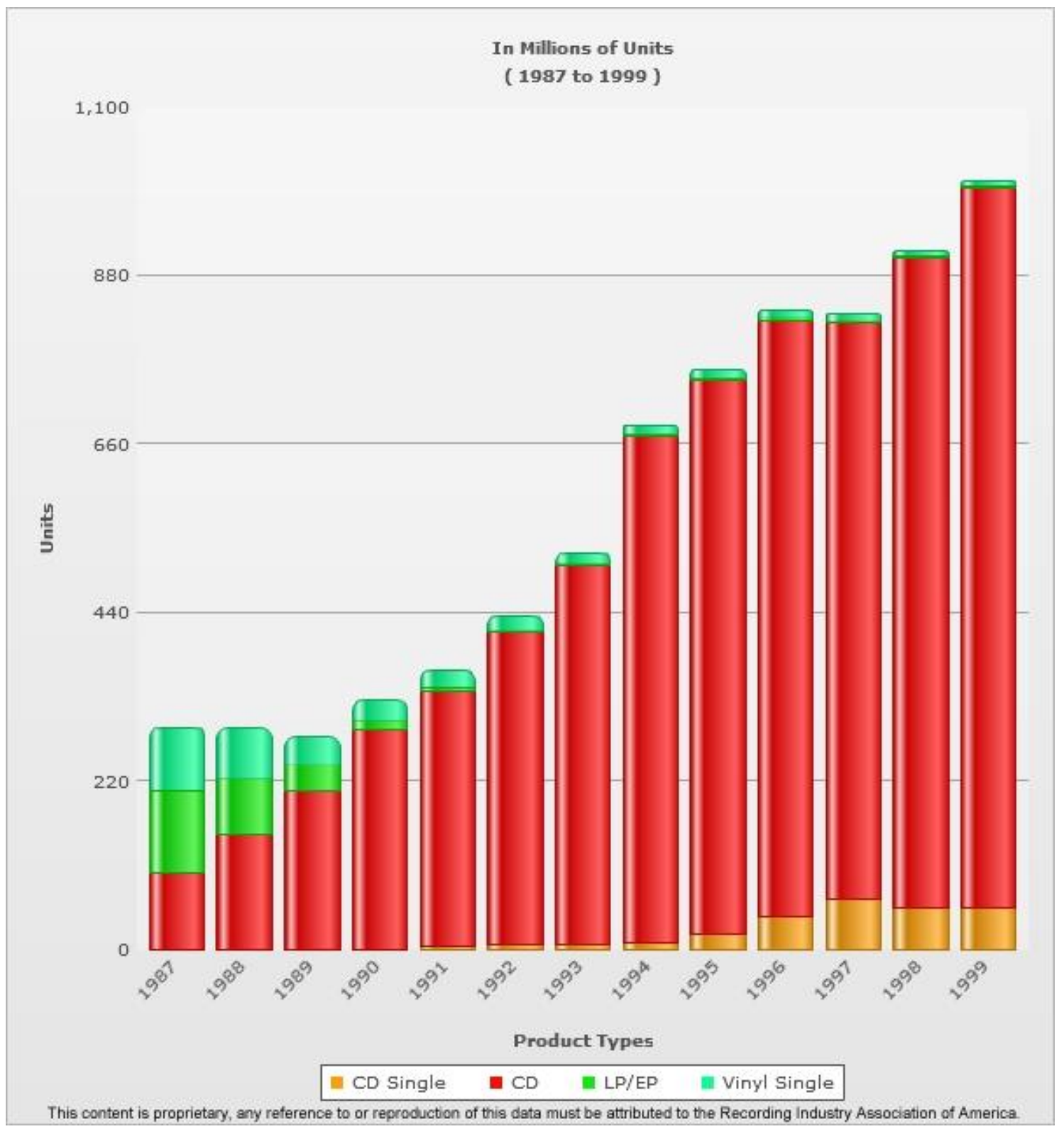

Gráfico 1: Unidades de discos vendidas nos Estados Unidos entre 1987 e 1999. Fonte: Record Industry Association of America (RIAA) 


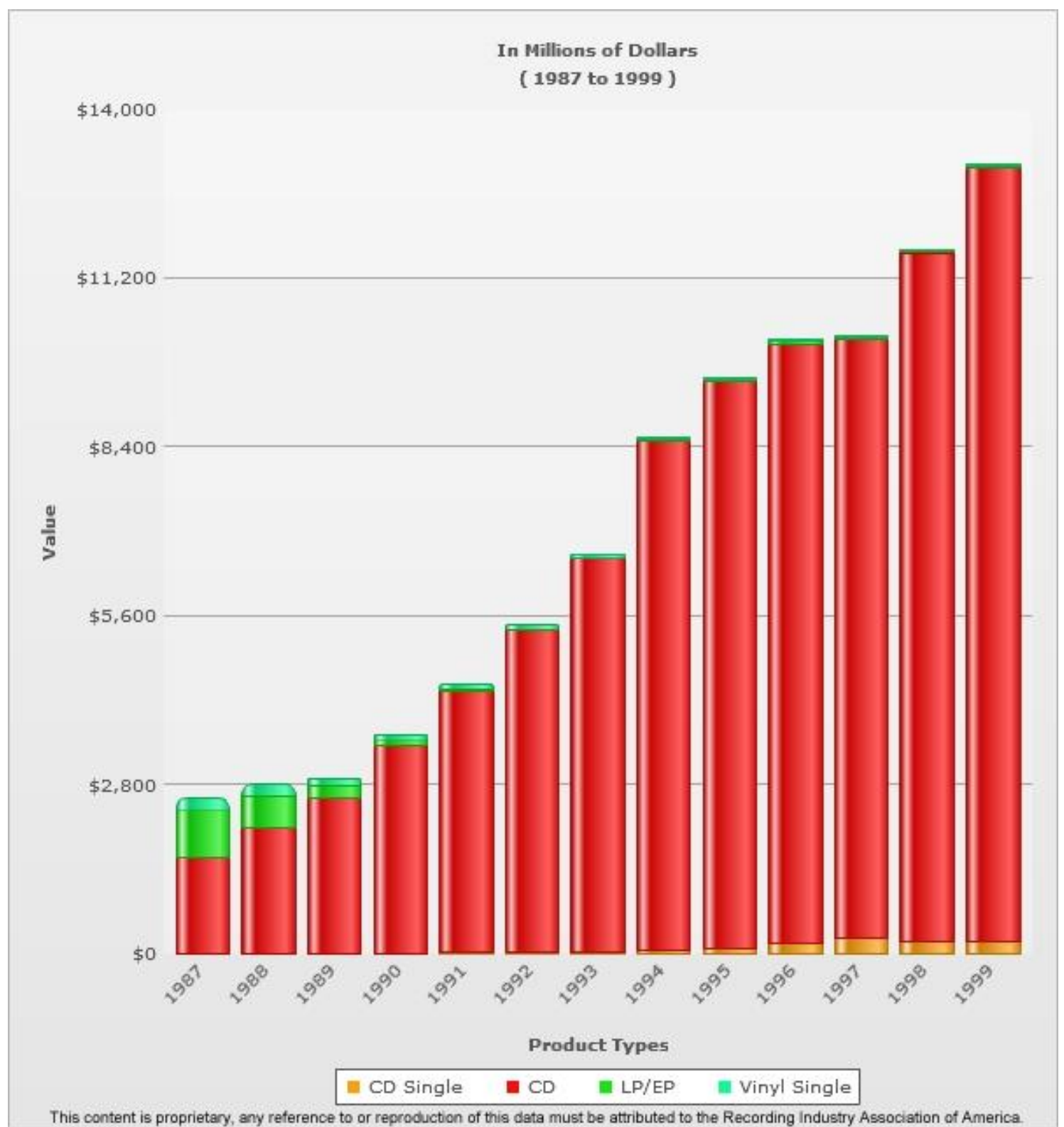

Gráfico 2: Lucro com a venda de discos nos Estados Unidos entre 1987 e 1999. Fonte: Record Industry Association of America (RIAA) 


\section{Bibliografia}

ADORNO, T. Introdução à Sociologia da Música. São Paulo: Unesp. 2011.

ADORNO, T. \& HORKHEIMER, M. Dialética do Esclarecimento. Rio de Janeiro: Zahar, 2006.

APPADURAI, A. The Social Life of Things. Cambridge: Cambridge University Press, 2013.

BARTHES, R. Aula. São Paulo: Cultrix, 2008.

BATESON, G. Naven. São Paulo: Edusp, 2008.

BAUMAN, Z. Legisladores e Intérpretes. Rio de Janeiro: Zahar, 2010.

BENJAMIN, W. A Obra de Arte na Era de sua Reprodutibilidade Técnica. Porto Alegre: Zouk, 2012.

BHABHA, H. O Local da Cultura. Belo Horizonte: UFMG, 2013.

BOHLMAN, P. World Music: a very short introduction. Oxford: Oxford University Press, 2002.

BORGES, J. Outras Inquisições. São Paulo: Cia das Letras, 2007. O Aleph. São Paulo: Cia das Letras, 2008.

BORN, G. Musical Modernism, Post-Modernism and Others. In: In: Western Music and its Others. BORN \& HESMONDHALGH. Berkley: University of California Press, 2014.

BORSTELMANN, T. The 1970s: A new global history from civil rights to economic inequality. Princeton: Princeton University Press, 2012.

BOURDIEU, P. Coisas Ditas. São Paulo: Brasiliense, 1990.

A Distinção. São Paulo: Edusp. Porto Alegre: Zouk, 2007. Economia das Trocas Linguísticas. São Paulo: Edusp, 2008. O Senso Prático. Petrópolis: Vozes, 2009.

BROUGHTON, S et al. World Music: The Rough Guide. Londres: Rough Guides, 1994.

CHARTIER, R. A Ordem dos Livros. Brasília: UnB, 1994.

DAPIEVE, A. Brock: o rock brasileiro dos anos 80. São Paulo: 34, 2000.

DARWIN, C. A Origem das Espécies. São Paulo: Hemus, 2013.

DELEUZE, G. \& GUATTARI, F. O que é a Filosofia? São Paulo: 34, 2000. O Antí-Édipo. São Paulo: 34, 2010 Mil Platôs. (5 vols). São Paulo: 34, 2011. 
DERRIDA, J. Gramatologia. São Paulo: Perspectiva, 2006.

DURKHEIM, E. As Formas Elementares da Vida Religiosa. São Paulo: Martins Fontes, 2003. As Regras do Método Sociológico. São Paulo: Martins Fontes, 2007.

ECO, U. Apocalípticos e Integrados. São Paulo: Perspectiva, 2008.

ELIAS, N. O Processo Civilizador. Rio de Janeiro: Zahar, 1990. Mozart: sociologia de um gênio. Rio de Janeiro: Zahar, 1995.

ENGELS, F. \& MARX, K. Manifesto do Partido Comunista. Porto Alegre: LP\&M, 2006.

ERLMANN, V. The Aesthetics of Global Imagination: reflections on World Music in the 1990s. In: Public Culture 1996 - 8. 467-487. Chicago: University of Chicago, 1996.

FEATHERSTONE, M. Archiving Cultures. In: British Journal of Sociology. Vol. 51. Issue n. 1. (January - March 2000) pp. 161 - 184. ISSN 00071315. London School of Economics, 2000.

FELD, S. From Schizophonia to Schismogenesis: on the discourse of commodification practices of "World Music" and "World Beat". In: Music Grooves. KEIL \& FELD. Tucson: Fenestra, 2005.

$2005 b$.

Notes on World Beat. In: In: Music Grooves. KEIL \& FELD. Tucson: Fenestra,

FOUCALT, M. O que é um Autor? In: Ditos e Escritos: Estética - literatura e pintura, música e cinema (vol. III). Rio de Janeiro: Forense Universitária, 2001.

Conferência. In: Foucault, a Filosofia e a Literatura. MACHADO, R. Rio de Janeiro: Zahar, 2005.

A Ordem do Discurso. São Paulo: Loyola, 2007

As Palavras e as Coisas. São Paulo: Martins Fontes 2007b.

FRITH, S. The Discourse of World Music. In: Western Music and its Others. BORN \& HESMONDHALGH. Berkley: University of California Press, 2014.

GEERTZ, Clifford. A interpretação das culturas. Rio de Janeiro: LTC, 2010

GEIGER, A. Apresentação de Naven. In: Naven. São Paulo: Edusp, 2008.

HALL, S. Da Diáspora. Belo Horizonte: UFMG, 2013.

KASSABIAN, A. Would You Like Some World Music in Your Latte? Starbucks, Putumayo and Distributed Tourism. In: Twentieth century music / Volume 1 / Issue 02 / September 2004, pp 209 - 223 DOI: 10.1017/S1478572205000125, Published online: 22 April 2005.

KROEBER, A. A Natureza da Cultura. Lisboa: 70, 1993. 
LATOUR, B. Jamais Fomos Modernos. São Paulo: 34, 2009.

LEITÃO, D. Nós, os outros: construção do exótico e consumo de moda brasileira na França. In: Horizontes Antropológicos, v.13, n. 28, 2007.

LÉVI-STRAUSS, C. As Estruturas Elementares do Parentesco. Petrópolis: Vozes, 2003. Introdução à Obra de Marcel Mauss. In: Sociologia e Antropologia. MAUSS, M. São Paulo: 2007. . O Pensamento Selvagem. São Paulo: 2011.

LYOTARD, J. Condição Pós-moderna. Rio de Janeiro: Jose Olympio, 2010

MARX, K. O Capital. São Paulo: Boitempo, 2008.

MOORE, A. \& GIBBONS, D. Watchmen. DC Comics, 2014.

NICOLAU NETTO, M. O Discurso da Diversidade e a World Music. São Paulo: Anna Blume, 2014.

ORTIZ, R. A Diversidade dos Sotaques. São Paulo: Brasiliense, 2008.

PRICE, S. Arte Primitiva em Centros Civilizados. Rio de Janeiro: UFRJ, 2000.

PYNCHON, T. Vineland. São Paulo: Cia. das Letras, 1990. Vício Inerente. São Paulo: Cia. das Letras, 2010.

ROTH, P. O Animal Moribundo. Alfragide: Leya, 2013.

SAID, E. Orientalismo: o Oriente como invenção do Ocidente. São Paulo: Cia das Letras, 2013.

SAUSSURE, F. Curso de Linguística Geral. São Paulo: Cultrix, 2006.

TAYLOR, T. World Music, World Markets. New York: Routledge, 1997.

TODOROV, T. A Literatura em Perigo. São Paulo: Difel, 2009. Os Inimigos Íntimos da Democracia. São Paulo: Cia. das Letras, 2014.

VIVEIROS DE CASTRO, E. O Nativo Relativo. In: Mana; 8(1); 113-148; 2002-04 A Inconstância da Alma Selvagem. São Paulo: Cosac Naify, 2013.

WALLACE, D. Breves Entrevistas com Homens Hediondos. São Paulo: Cia das Letras, 2005 .

WEBER, M. Economia e Sociedade. Brasília: UnB, 2009.

WOLF, T. A Fogueira das Vaidades. Rio de Janeiro: Rocco, 1988.

DOCUMENTOS: 
Atas das Reuniões do Empress of Russia, 1987:

http://www.frootsmag.com/content/features/world_music_history/minutes/

Carta das Nações Unidas e Estatuto da Corte Internacional de Justiça. 1945.

Constituição da Organização das Nações Unidas para Educação, Ciência e Cultura, 1945.

Declaração Universal dos Direitos Humanos, 1948.

Framework for Cultural Statistics. Primeira versão: 1987. Segunda versão: 2009.

Declaração Universal Sobre Diversidade Cultural, 2002.

Convenção Sobre a Proteção e Promoção das Diversidade das Expressões Culturais, 2005. 